\title{
THERMAL WATERS OF UTAH TOPICAL REPORT
}

November 1978

\section{MASTER}

by

Utah Geological and Mineral Survey

606 Black Hawk Way

Salt Lake City, Utah 84108

\section{U.S. DEPARTMENT OF ENERGY IDAHO OPERATIONS OFFICE}

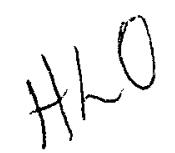

DISTRIBUTION TF THE Rarnexp IS HMTEQ To DOE Offices and BOE Contractors $\& b$ 


\section{DISCLAIMER}

This report was prepared as an account of work sponsored by an agency of the United States Government. Neither the United States Government nor any agency Thereof, nor any of their employees, makes any warranty, express or implied, or assumes any legal liability or responsibility for the accuracy, completeness, or usefulness of any information, apparatus, product, or process disclosed, or represents that its use would not infringe privately owned rights. Reference herein to any specific commercial product, process, or service by trade name, trademark, manufacturer, or otherwise does not necessarily constitute or imply its endorsement, recommendation, or favoring by the United States Government or any agency thereof. The views and opinions of authors expressed herein do not necessarily state or reflect those of the United States Government or any agency thereof. 


\section{DISCLAIMER}

Portions of this document may be illegible in electronic image products. Images are produced from the best available original document. 
Printed in the United States of America Available from

National Technical Information Service

U.S. Department of Commerce

5285 Port Royal Road

Springfield, Virginia 22161

Price: Printed Copy $\$ 9.00$; Microfiche $\$ 3.00$

This report was prepared as an account of work sponsored by the United States Government. Neither the United States nor the Department of Energy, nor any of their employees, nor any of their contractors, subcontractors, or their employees, makes any warranty, express or implied, or assumes any legal liability or responsibility for the accuracy, completeness or usefulness of any information, apparatus, product or process disclosed, or represents that its use would not infringe privately owned rights. 
THERMAL WATERS OF UTAH

\section{Topical Report}

by

\author{
Harry D. Goode
}

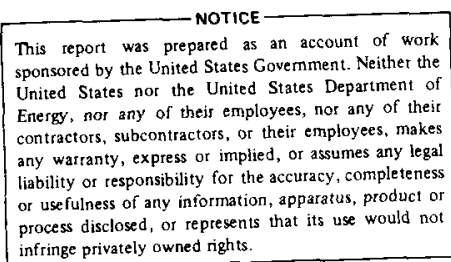

process disclosed, or represents
infringe privately owned rights.

\section{Utah Geological and Mineral Survey 606 Black Hawk Way \\ Salt Lake City, Utah 84108}

November 1978

Prepared for the

U.S. Department of Energy

Under Contract No. DE-ASO7-77ET28393 
CONTENTS

$\begin{array}{ll}\text { ABSTRACT } & 1\end{array}$

INTRODUCTION 3

Summary of Occurrences of Thermal Waters 3

Purpose and Scope 6

Evaluation of Temperature Measurements 6

Origin of the Thermal Waters 7

Hot Springs along the Wasatch Fault Zone 8

Known Geothermal Resource Areas (KGRAs) 10

Possible Uses for the Thermal Waters of Utah 11

Recommendations for Future Work 12

Acknowledgments 12

Cited References 13

DESCRIPTIONS OF ARFAS OF THERMAL WATERS 15

Areas That Have Hot, Warm, and Slightly Warm Water 15

Lower Bear River Area 16

Bonneville Salt Flats 18

Cove Fort-Sulphurdale $\quad 19$

Southern Curlew Valley 21

East Shore Area 23

Escalante Desert 27

Escalante Valley (Roosevelt, Thermo) 29

Fish Springs 34

Grouse Creek Valley $\quad 35$

Heber Valley (Midway) 36

Jordan Valley $\quad 37$

Pavant Valley - Black Rock Desert 44

Sevier Desert $\quad 47$

Sevier Valley $\quad 49$

Uinta Basin 53

Utah and Goshen Valley 58

Central Virgin River Basin $\quad 65$

Areas That Have Warm and Slightly Warm Water 68

Beaver Valley 68

Blue Creek Valley $\quad 68$

Cache Valley 69

Canyon Lands 70

Cedar City Valley - Parowan $\quad 74$

Cedar Valley $\quad 74$

Northern Juab Valley $\quad 74$

Park Valley $\quad 75$

Promontory Mountains $\quad 75$

Rush Valley $\quad 76$

Skull Valley 76

Snake Valley $\quad 77$

Tooele Valley 78

Tule Valley 80

Wah Wah Valley $\quad 82$ 
Areas That Have Slightly Warm Water

Grand Staircase $\quad 83$

Hansel Valley $\quad 84$

Pilot Valley $\quad 84$

Pine Valley 85

Sink Valley 85

Yuba Dam - Leamington Canyon 85

Other Occurrences of Hot and Warm Water: Castille. Hot Spring, Como Springs, Diamond Fork Spring, Patio Spring, and a well in Great Salt Lake Desert 86

RECORD OF THERMAI SPRINGS AND WELLS 88

Explanation for Tables in This Report 88

Areas That Have Hot, Warm, and Slightly Warm Water 92 Tables 1-A to 23-B

Areas That Have Warm and Slightly Warm Water 145 Tables 24 to 39

Areas That Have Slightly Warm Water 168 Tables 40 to 45

Other Occurrences of Hot and Warm Water 171 Table 46 


\section{ILLUSTRATIONS}

Figure 1 - Map of Utah summarizing occurrence of thermal water. 2

Figure 2 - Ideal sections of progressive dislocation of valley block. 9

Figure 3 - Map of East Shore Area showing thermal wells and springs. 24

Figure 4 - Map of Newcastle area showing geothermal test holes. 27

Figure 5 - Map of Thermo area showing geothermal test holes. 31

Figure 6 - Map of Jordan Valley showing thermal wells and springs. 38

Figure 7 - Map showing selected faults and temperatures of ground water in the Jordan Valley, Utah 42

Figure 8 - Map showing areal distribution of water temperature in the principal aquifer in Jordan Valley.

Figure 9 - Map of Ashley Valley Oil Field showing oil well locations and water temperature measurement sites.

Figure 10 - Map of Utah Valley, Utah, showing wells and springs that yield hot, warm, and slightly warm water.

Figure 11 - Well-numbering system used in Utah.

\section{TABLES}

Table 1-A Lower Bear River Area. Springs and Wells with Water Temperatures of $20^{\circ}$ to $105^{\circ} \mathrm{C}$. 92

Table 1-B Lower Bear River Area. Springs and Wells with Water Temperatures of $15.5^{\circ}$ to $19.5^{\circ} \mathrm{C}$.

Table 2 Bonneville Salt Flats. Wells and one spring with Water Temperatures of $20^{\circ}$ to $88^{\circ} \mathrm{C}$.

Table 3 Cove Fort-Sulphurdale. Measured temperatures and computed geothermal gradients in 13 drill holes.

Table 4-A Southern Curlew Valley. Springs and wells with water temperatures of $20^{\circ}$ to $43^{\circ} \mathrm{C}$.

Table 4-B Southern Curlew Valley. Springs and wells with water temperatures of $15.5^{\circ}$ to $19.5^{\circ} \mathrm{C}$.

Table 5-A East Shore Area. Springs and wells with water temperatures of $20^{\circ}$ to $60^{\circ} \mathrm{C}$.

Table 5-B East Shore Area. Springs and wells with water temperatures of $15.5^{\circ}$ to $19.5^{\circ} \mathrm{C}$. 
Table 6 Escalante Desert (Beryl, Lund, Newcastle). Selected. wells with water temperatures of $15.5^{\circ}$ to $149^{\circ} \mathrm{C}$. 102

Table 7-A Escalante Valley. Springs and wells with water temperatures of $20^{\circ}$ to $99^{\circ} \mathrm{C}$.

Table 7-B Escalante Valley. Springs and Wells with Water Temperatures of $15.5^{\circ}$ to $19.5^{\circ} \mathrm{C}$.

104

Table 8 Fish Springs Group. Three Springs with water temperatures of $17.5^{\circ}$ to $38^{\circ} \mathrm{C}$.

106

Table 9 Grouse Creek Valley. Springs and wells with water temperatures of $16^{\circ}$ to $42^{\circ} \mathrm{C}$.

106

Table 10 Heber Valley. Springs and wells with water temperatures of $16^{\circ}$ to $45^{\circ} \mathrm{C}$.

106

Table 11-A Jordan Valley. Springs and wells with water temperatures of $20^{\circ}$ to $58.5^{\circ} \mathrm{C}$.

106

Table 1l-B Jordan Valley. Springs and wells with water temperatures of $15.5^{\circ}$ to $19.5^{\circ} \mathrm{C}$.

Table 12-A Pavant Valley - Black Rock Desert. Springs and

Wells with Water Temperatures of $20^{\circ}$ to $67^{\circ} \mathrm{C}$.

Table 12-B Pavant Valley. Black Rock Desert. Springs and Wells with Water Temperatures of $15.5^{\circ}$ to $19.5^{\circ} \mathrm{C}$. 116

Table 13-A Sevier Desert. Wells that Yield Water of $20^{\circ}$ to $29^{\circ} \mathrm{C}$ and One Spring at $82^{\circ} \mathrm{C}$.

120

Table 13-B Sevier Desert. Wells with Water Temperatures of $15.5^{\circ}$ to $19.5^{\circ} \mathrm{C}$.

Table 14 Upper Sevier River Valley. Wells and Springs with Water Temperatures of $15.5^{\circ}$ to $32^{\circ} \mathrm{C}$.

124

Table 15-A Central Sevier River Valley. Wells and Springs with Water Temperatures of $20^{\circ}$ to $76.5^{\circ} \mathrm{C}$.

Table 15-B Central Sevier River Valley. Wells and Springs with Water Temperatures of $15.5^{\circ}$ to $19.5^{\circ} \mathrm{C}$.

Table 16-A San Pitch Valley. One Well and Two Springs with Water Temperatures of $20^{\circ}$ to $55^{\circ} \mathrm{C}$.

Table 16-B San Pitch Valley. Wells and Springs with Water

$$
\text { Temperatures of } 15.5^{\circ} \text { to } 19.5^{\circ} \mathrm{C} \text {. }
$$


Table 17 Uinta Basin-Ashley Valley. Temperature of Water from Oil Wells, an Irrigation Ditch, and Ashley Creek.

Table 18 EXPLANATION for Figure 7 and records of water temperature and conductance in the Ashley Valley oil field.

Table 19-A Uinta Basin. Wells and Springs with Water Temperatures of $20^{\circ}$ to $57.5^{\circ} \mathrm{C}$.

Table 19-B Uinta Basin. Wells and Springs with Water Temperatures of $15.5^{\circ}$ to $19.5^{\circ} \mathrm{C}$.

Table 19-C Uinta Basin. Gas and Water Wells with Temperatures of $17^{\circ}$ to $34^{\circ} \mathrm{C}$.

Table 20-A Northern Utah Valley. Wells and Springs with

Water Temperatures of $20^{\circ}$ to $46^{\circ} \mathrm{C}$.

Table 20-B Northern Utah Valley. Wells with Water Temperatures of $15.5^{\circ}$ to $19.5^{\circ} \mathrm{C}$.

Table 2l-A Southern Utah and Goshen Valleys. Wells with Water Temperatures of $20^{\circ}$ to $34^{\circ} \mathrm{C}$.

Table 21-B Southern Utah Valley. Wells with Water Temperatures of $15.5^{\circ}$ to $19.5^{\circ} \mathrm{C}$.

Table 22-A Southern Utah and Goshen Valleys. Springs with Water Temperatures of $15.5^{\circ}$ to $31.5^{\circ} \mathrm{C}$, , and a Mine with Water Temperature of $54.5^{\circ} \mathrm{C}$.

Table 22-B Goshen Valley. Wells with Water Temperatures of $15.5^{\circ}$ to $19.5^{\circ} \mathrm{C}$.

Table 23-A Central Virgin River Basin. Wells and Springs with Water Temperatures of $20^{\circ}$ to $42^{\circ} \mathrm{C}$.

Table 23-B Central Virgin River Basin. Wells and Springs with Water Temperatures of $15.5^{\circ}$ to $19.5^{\circ} \mathrm{C}$.

144

Table 24 Beaver Valley. Wells and Springs with Water Temperatures of $15.5^{\circ}$ to $23.5^{\circ} \mathrm{C}$.

Table 25-A Blue Creek Valley. Wells and Springs with Water Temperatures of $20^{\circ}$ to $28^{\circ} \mathrm{C}$.

Table 25-B Blue Creek Valley. Wells and Springs with Water Temperatures of $15.5^{\circ}$ to $19.5^{\circ} \mathrm{C}$. 
Table 26-A Cache Valley. Wells and One Spring with Water Temperature of $20^{\circ}$ to $49^{\circ} \mathrm{C}$.

Table 26-B Cache Valley. Wells and One Spring with Water Temperatures of $16^{\circ}$ to $19^{\circ} \mathrm{C}$.

Table 27-A Canyon Lands. Wells with Water Temperatures of $15.5^{\circ}$ to $28^{\circ} \mathrm{C}$.

Table 27-B Canyon Lands. Springs with Temperatures of $15.5^{\circ}$ to $31^{\circ} \mathrm{C}$.

Table 28... Cedar City Valley. Wells with Water Temperatures of $15.5^{\circ}$ to $21^{\circ} \mathrm{C}$.

Table 29 Parowan. Spring and Wells with Water Temperatures of $14.5^{\circ}$ to $20^{\circ} \mathrm{C}$.

Table 30 Cedar Valley. Wells with Water Temperatures of $15.5^{\circ}$ to $27^{\circ} \mathrm{C}$.

Table 31 Northern Juab Valley. Records of a Spring with Temperature of $20^{\circ} \mathrm{C}$ and a Well with Water Temperature of $15.5^{\circ} \mathrm{C}$, and Chemical Analyses of Water from Both.

Table 32 Park Valley. Records of Springs with Water Temperatures of $16^{\circ}$ to $26.5^{\circ} \mathrm{C}$ and Chemical Anlayses of Water from Those Springs

Table 33 Promontory Mountains. Records of Wells and Springs with Water Temperatures of $15.5^{\circ}$ to $25^{\circ} \mathrm{C}$ and Chemical Analyses of Water from those Wells and Springs.

Table 34 Rush Valley. Records of One Well and Three Springs with Water Temperatures of $16^{\circ}$ to $26.5^{\circ} \mathrm{C}$ and Chemical Analyses of Water from the WeIl and Springs

Table 35-A Skull Valley. Records of Wells and Springs with Water Temperatures of $20^{\circ}$ to $26.5^{\circ} \mathrm{C}$ and Chemical Analyses of Water from Some of Those Wells and Springs.

Table 35-B Skull Valley. Records of Wells and Springs with Water Temperatures of $15.5^{\circ}$ to $19.5^{\circ} \mathrm{C}$ and Chemical Analyses of Water from Some of the Wells and Springs.

Table 36 Snake Valley. Records of Springs and Wells with Water Temperatures of $15.5^{\circ}$ to $27^{\circ} \mathrm{C}$. 
Table 37-A Tooele Valley. Wells and One Spring with Water Temperatures of $20^{\circ}$ to $30^{\circ} \mathrm{C}$.

Table 37-B Tooele Valley. Wells and One Spring with Water Temperatures of $15.5^{\circ}$ to $19.5^{\circ} \mathrm{C}$.

Table 38 Tule Valley. Wells and Springs with Water Temperatures of $16^{\circ}$ to $31^{\circ} \mathrm{C}$.

Table 39 Wah Wah Valley. Wells and Springs with Water Temperatures of $15.5^{\circ}$ to $24.5^{\circ} \mathrm{C}$.

Table 40 Grand Staircase. Springs with Water Temperatures of $15.5^{\circ}$ to $35.5^{\circ} \mathrm{C}$.

Table 41 Hansel Valley. Spring and Wells with Water Temperatures of $16^{\circ}$ to $18^{\circ} \mathrm{C}$.

Table 42 Pilot Valley. Well and Springs with Temperatures $15.5^{\circ}$ to $16^{\circ} \mathrm{C}$.

Table 43 Pine Valley. Well with a Water Temperature of $16^{\circ} \mathrm{C}$

Table 44 Sink Valley. Wells with Water Temperatures of $15^{\circ}$ to $18^{\circ} \mathrm{C}$.

Table 45 Yuba Dam to Leamington Canyon. Springs in Mills Valley with Temperatures of $16.5^{\circ}$ to $17^{\circ} \mathrm{C}$.

Table 46 Records of Castilla, Como, Diamond Fork, and Patio thermal springs and of a well in the Great Salt Lake Desert. 


\section{ABSTRACT}

Western and central Utah has 16 areas whose wells or springs yield hot water $\left(35^{\circ} \mathrm{C}\right.$ or higher $)$, warm water $\left(20^{\circ}-34.5^{\circ} \mathrm{C}\right)$, and slightly warm water $\left(15.5^{\circ}-19.5^{\circ} \mathrm{C}\right)$. These areas and the highest recorded water temperature for each are: Lower Bear River Area, 105\% ; Bonneville Salt Flats, $88^{\circ}$; Cove FortSulphurdale, $77^{\circ}$; Curlew Valley, 43; East Shore Area, $60^{\circ}$; Escalante Desert, $149^{\circ}$; Escalante Valley (Roosevelt, 269 , and Thermo, $85^{\circ}$ ); Fish Springs, $60.5^{\circ}$;

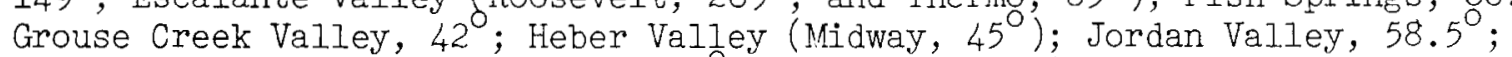
Pavant Valley-Black Rock Desert, $67^{\circ}$; Sevier Desert (Abraham-Crater Hot Springs,

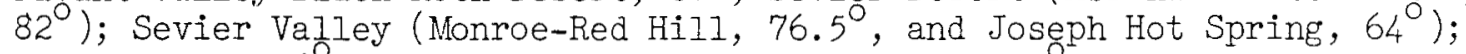
Utah Valley, $46^{\circ}$; and Central Virgin River Basin, $42^{\circ}$. The only hot water in eastem Utah comes from the oil wells of the Ashley Valley Oil Field, which in 1977 yielded 4400 acre-feet of water at $43^{\circ}$ to $55^{\circ} \mathrm{C}$. Many other areas yield warm water $\left(20^{\circ}\right.$ to $\left.34.5^{\circ} \mathrm{C}\right)$ and slightly warm water $\left(15.5^{\circ}\right.$ to $\left.19.5^{\circ} \mathrm{C}\right)$. With the possible exception of the Roosevelt KGRA, Crater Hot Springs in the Sevier Desert, Escalante Desert, Pavant-Black Rock, Cove Fort-Sulphurdale, and Coyote Spring in Curlew Valley, which may derive their heat from buried igneous bodies, the heat that warms the thermal water is derived from the geothermal gradient. Meteoric water circulates through fractures or permeable rocks deep within the earth, where it is warmed; it then rises by convection or artesian pressure and issues at the surface as springs or is tapped by wells. Most thermal springs thus rise along faults, but some thermal water is trapped in confined aquifers so that it spreads laterally as it mixes with and warms cooler near-surface water. This spreading of thermal waters is evident in Cache Valley, in Jordan Valley, and in southern Utah Valley; likely the spreading occurs in many other artesian basins where it has not yet been recognized. In the East Shore Area thermal water trapped in confined aquifers warms water in overlying aquifers.

Some of the areas of hot water, such as Roosevelt, Pavant-Black Rock, and Cove Fort-Sulphurdale, probably have a potential to produce electricity; the estimated potential at Roosevelt is 300 megawatts. But the many areas of warm and hot water whose temperatures are too low to produce electricity may still have their waters utilized for space heating, as is planned for Monroe, for greenhouses, and for the processing of farm produce.

In this report are tables that give records of about 1500 thermal springs and wells, 66 yield hot water, more than 400 yield warm water, and more than 1000 yield slightly warm water. The records include location, ownership, temperature, yield, depth (of wells), geologic unit, and some chemical analyses.

In this report temperatures are recorded in ${ }^{\circ} \mathrm{C}$. To convert ${ }^{\circ} \mathrm{C}$ to ${ }_{F}$ multiply by 2 , subtract $10 \%$, and add 32 . For example: $22^{\circ} \mathrm{C}=44-4.4+32=71.6^{\circ}$ or $72^{\circ} \mathrm{F}$

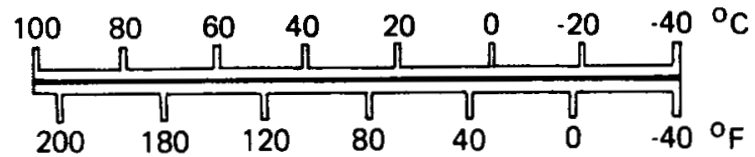




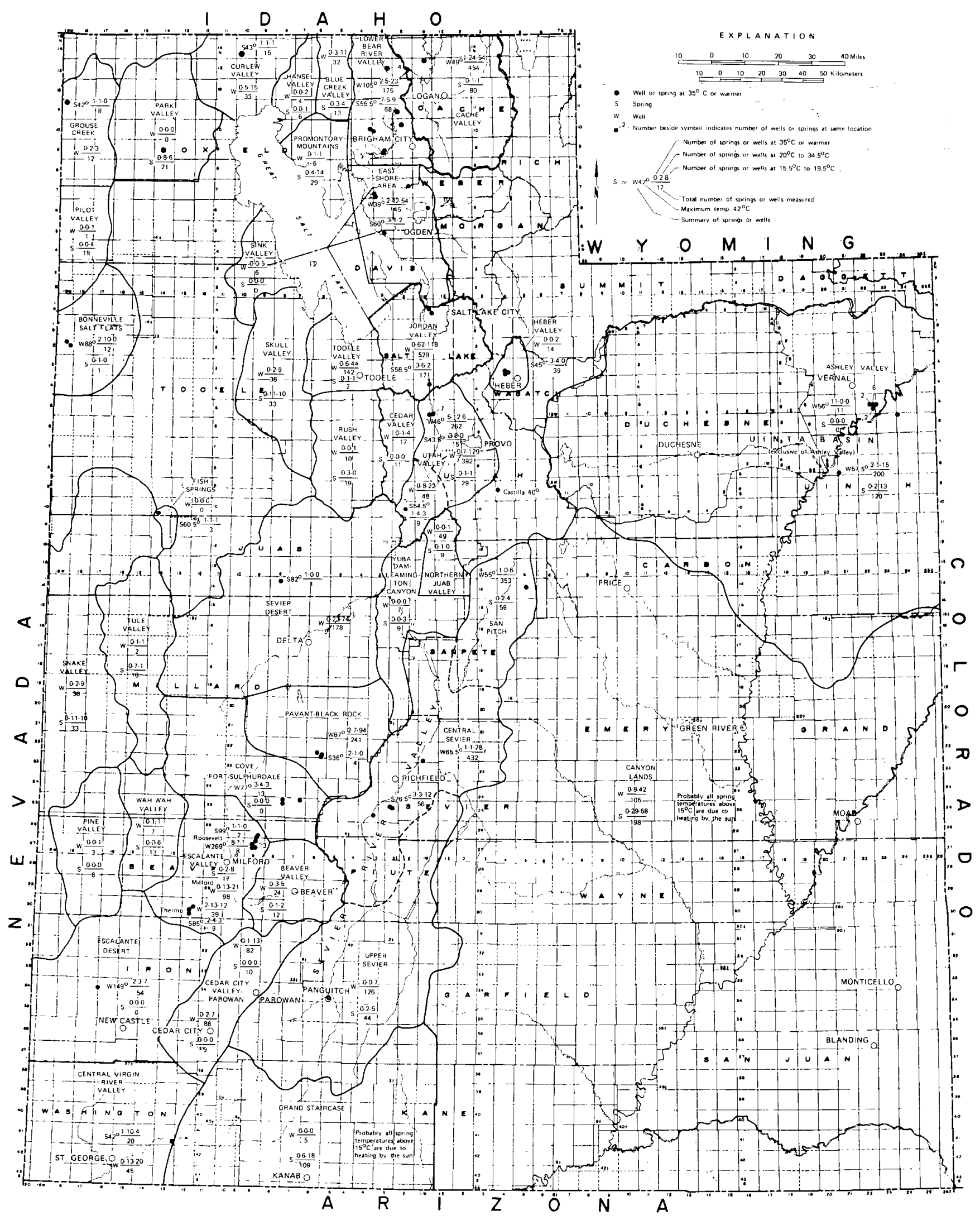

Figure 1. Map of Utah summarizing occurrence of thermal water. 


\title{
INTRODUCTION
}

\author{
Summary of Occurrences of Thermal Water in Utah
}

Thermal waters are defined as those waters whose temperature is "appreciably above the mean annual temperature of the atmosphere" (Meinzer, 1923, p. 54). In this report, all water of $15.5^{\circ} \mathrm{C}$ or higher is considered to be thermal water. Thermal waters are here divided into three categories: hot water is $35^{\circ} \mathrm{C}$ or higher, warm water is $20^{\circ}$ to $34.5^{\circ} \mathrm{C}$, and slightly warm water is $15.5^{\circ}$ to $19.5^{\circ} \mathrm{C}$.

In western and central Utah there are 16 areas that have hot, warm, and slightly warm waters. In eastern Utah the only hot water comes from the oil wells of the Ashley Valley Oil Field. Warm and slightly warm water is discharged by wells or springs in 15 additional areas, scattered over the State, and slightly warm water occurs in 6 other areas. In addition, one isolated spring (Castilla) yields hot water of $40^{\circ}$, and three other springs and a well yield warm water of $20^{\circ}$ to $16.5^{\circ}$. These areas and the number of springs and wells in each temperature range are shown on the map ( $f i g .1$ ), and wells and springs that yield hot water are plotted on the map. Brief summaries of 16 significant areas are given here and all areas are discussed at greater length in the body of the report.

Lower Bear River Area -

Several hot springs $\left(42^{\circ}\right.$ to $55.5^{\circ} \mathrm{C}$ ) have high yields of $450-5000$ gallons per minute $(\mathrm{gpm})$ but the water is moderately saline to briny (7,850 to 43,500 milligrams per liter (mg/l) dissolved solids).

In a geothermal test well near Brigham City a bottom-hole temperature of $105^{\circ} \mathrm{C}$ was measured at 11,005 feet.

Bonneville Salt Flats -

Wells drilled in connection with salt recovery have temperatures that range between $21^{\circ}$ and $35^{\circ} \mathrm{C}$; two deep wells have temperatures of $43^{\circ}$ at $1200 \mathrm{ft}$ and $88^{\circ}$ at $1636 \mathrm{ft}$ respectively.

Cove Fort-Sulphurdale -

There are no records of water wells or springs in the Cove Fort-Sulphurdale area, but Rush (1977) measured temperatures in 13 drill holes and the three highest were $77^{\circ}, 49^{\circ}$, and $43^{\circ} \mathrm{C}$ in holes from 1000 to 400 feet deep. The computed geothermal gradients for those holes were $5.8^{\circ}, 7.7^{\circ}$, and $7.1^{\circ} \mathrm{C}$ per 100 feet, respectively.

\section{East Shore Area -}

Temperatures $\left(21^{\circ}\right.$ to $\left.39^{\circ}\right)$ and chemical analyses of water from wells drilled by Great Salt Lake Minerals and Chenicals Corp. north of Little Mountain suggest that heat from a fault zone rises through aquifers and confining beds and warms water at shallow depths without circulation of the hotter saltier water from the fault zone itself.

Three hot springs, Hooper, Ogden, and Utah, yield moderately to very saline water at $60^{\circ}, 57^{\circ}$, and $58.5^{\circ}$ respectively. 
Escalante Desert -

Two wells yield large quantities of slightly to moderately saline hot water: one 500 feet deep near Newcastle yields $1700 \mathrm{gpm}$ (pumped) of $35^{\circ} \mathrm{C}$ water, and one near Beryl Junction yields $1000 \mathrm{gpm}$ (flow) of $149^{\mathrm{C}}$ water from 7000 feet.

\section{Escalante Valley -}

The two Known Geothermal Resource Areas, Roosevelt and Thermo, with high temperatures of $269^{\circ}$ and $85^{\circ} \mathrm{C}$ respectively, appear to have the potential to produce electricity, and Dotsons Warm Springs should be satisfactory for recreation. In addition, about 15 irrigation and domestic wells have water temperatures between $20^{\circ}$ and $26.5^{\circ} \mathrm{C}$.

If a 50-megawatt generating plant is put into operation at Roosevelt, a "spin-off" benefit probably will result because such a plant will have available about 500,000 gallons of waste water per hour at $116^{\circ} \mathrm{C}$. Heat from this water could be used before the water is injected back into the geothermal reservoir (Val Finlayson, pers. commun., 1978).

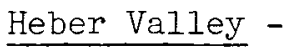

Three springs near Midway yield slightly saline water at $39^{\circ}$ to $45^{\circ}$; several others yield warm water at $21^{\circ}$ to $30^{\circ}$. Waters from several of the Midway Hot Springs are used in swimming pools.

Jordan Valley -

Three hot spring areas, Becks and Wasatch at the north end of the valley and Crystal near the south end, yield water of $40.5-58.5^{\circ} \mathrm{C}$. Becks and Wasatch have been used for recreation in the past, and the area around Crystal is being investigated to determine the feasibility of using some of the water for space heating in the Utah State Prison.

Warm water appears to move laterally in some of the artesian aquifers. Warm water of $20^{\circ}-31^{\circ} \mathrm{C}$ is reported in about 60 wells and slightly warm water of $15.5^{\circ}-19.5^{\circ} \mathrm{C}$ in another 120 wells. The areas of greatest concentration of warm water are a fan-shaped area in the north part of the valley and a northsouth elongate area in the south-central part.

An area of possible interest for further exploration is about $3 \frac{1}{2}$ miles east of Magna where 5 wells show anomalously high silica contents of 71 to $82 \mathrm{mg} / 1$. Water temperatures in these wells range from $17^{\circ}$ to $21.5^{\circ} \mathrm{C}$, well depths from 105 to 156 feet, and dissolved solids from 976 to $1220 \mathrm{mg} / 1$.

$\underline{\text { Pavant Valley - Black Rock Desert }}$

Meadow and Hatton Hot Springs yield moderately saline water of $35^{\circ}-36^{\circ} \mathrm{C}$ and a 90-ft well near Hatton Hot Springs yielded water to $67^{\circ} \mathrm{C}$. Studies of chemical temperatures of these waters by Parry and Cleary (1978, p.46) and by Rush (1978, written commun.) suggest that this area should be explored further for potential geothermal energy.

Sevier Desert -

Abraham (Crater) Hot Springs yields water at temperatures up to $82^{\circ} \mathrm{C}$ with 3200 to $3800 \mathrm{mg} / 1$ dissolved solids. Although it has been designated a Known Geothermal Resource Area (KGRA), chemical thermometer temperatures of $165^{\circ} \mathrm{C}$ $(\mathrm{Na}-\mathrm{K}-\mathrm{Ca})$ and $11 \mathrm{C}^{\circ} \mathrm{C}\left(\mathrm{SiO}_{2}\right)$ reported by Parry and Cleary (1978, p.8) suggest that the area has litile potential as 2 high-temperature resource. 
All 175 wells for which water temperatures have been reported have temperatures of $11.5^{\circ} \mathrm{C}$ or higher, $2^{\circ} \mathrm{C}$ above the mean annual air temperature. Seventyfour of those wells have water temperatures between $15.5^{\circ}$ and $19.5^{\circ} \mathrm{C}$ and 20 have water temperatures between $20^{\circ}$ and $28^{\circ} \mathrm{C}$.

Sevier River Valley -

In the Central Sevier Valley, Monroe and Red Hill Hot Springs ( $76^{\circ}$ and $76.5^{\circ}$ ) probably will soon be developed to provide space heating for schools and other buildings in Monroe. If that development is successful, it is likely that the water from Joseph Hot Spring $\left(64^{\circ}\right.$ ) could be similarly used.

In the San Pitch Valley, Crystal and Peacock Warm Springs yield fresh water at $22^{\circ} \mathrm{C}$ which is used for irrigation. A 5800 -ft-deep well flows $300 \mathrm{gpm}$ of fresh water at $55^{\circ} \mathrm{C}$.

Uinta Basin -

Only oil wells yield hot water $\left(44.5^{\circ}\right.$ to $56^{\circ}$ ) in the Uinta Basin and only gas wells and two springs yield warm water $\left(20^{\circ}-34.5^{\circ} \mathrm{C}\right)$.

In 1977 the Ashley Valley oil field produced more than 4400 acre-feet of hot water that was used for irrigation downstream from the field.

Utah Valley (Northern and Southern) and Goshen Valley -

The only hot springs in the area are at Saratoga $\left(46^{\circ} \mathrm{C}\right)$, but water from the Burgin mine west of Goshen Valley yields moderately saline water at $54.5^{\circ} \mathrm{C}$.

Despite the lack of hot water in southem Utah Valley there appears to be a heat source which heats water that then spreads laterally in the confined aquifers so that the median temperature of well water in southern Utah Valley is $14^{\circ} \mathrm{C}$, $2 \frac{1}{2}^{\circ} \mathrm{C}$ higher than the median temperature of well water in northern Utah Valley.

Central Virgin River Valley -

The median temperature of well waters in the Central Virgin River Valley is $18^{\circ} \mathrm{C}$ and of springs $20.5^{\circ} \mathrm{C}$, both above the average annual air temperature of $16^{\circ} \mathrm{C}$. The only hot water $\left(42^{\circ} \mathrm{C}\right)$ is at LaVerkin Hot Springs which discharge about $10 \mathrm{cfs}$ of moderately saline water ( $9500 \mathrm{mg} / 1$ dissolved solids) into the Virgin River.

Cache Valley -

The north-south faults that bound the graben of Cache Valley apparantly permit warm water to rise from depth, but confining beds that overlie the artesian aquifers divert the water so that the heated water moves laterally away from the faults. Thus most of the warm and slightly warm water is concentrated in two tabular bodies, one on either side of the valley. One deep well (5,208 ft) that bottomed in Paleozoic rock yields moderately saline water at $49^{\circ}$. Eighty other wells yield water at $15.5^{\circ}$ to $31^{\circ}$.

Canyon Lands -

Most of the warm water in the springs of Canyon Lands can be attributed to solar heating. Several "warm" springs of the Henry Mountains were remeasured in December 1977 and found to be definitely cool. 
Purpose and Scope

This report is intended to provide information about the occurrence, geologic control, and potential for use of natural thermal waters of the State of Utah at $15.5^{\circ} \mathrm{C}$ or higher. Much of the information about thermal springs has come from J. C. Mundorff's report Major Thermal Springs of Utah, published in 1970 by Utah Geological and Mineralogical Survey as Water-Resources Bulletin 13 (in 1978 out of print). Information about wells that produce warm water and also additional information about warm-water springs have come from Technical Publications of the Utah Division of Water Rights, from other Water-Resources Bulletins of the Utah Geological and Mineral Survey, from Water-Supply Papers, Basic-Data Reports, Basic-Data Releases, Professional Papers, and Bulletins of the U.S. Geological Survey, and from unpublished records by the author.

The study consisted largely of compiling and evaluating information in published reports; one four-day field trip was made to remeasure temperatures of water from oil wells in the Ashley Valley oil field and to remeasure temperatures of a few springs in the Henry Mountains area. The study began on November 1, 1977, and the report was completed on May 31, 1978.

Al1 work was done under Contract 78-5146 between the Utah Geological and Mineral Survey and the Contractor, Harry D. Goode, author of this report.

\section{Evaluation of Temperature Measurements of Water in Springs and Wells}

This study has considered all published occurrences of spring and well waters in Utah that have temperatures of $15.5^{\circ} \mathrm{C}$ or higher. These occurrences are listed in the tables that accompany each discussion of the thermal areas. Although it is recognized that a temperature of $16^{\circ}$ recorded for a well 1000 feet deep is not as significant as the same temperature in a well 100 feet deep, the criterion used here is temperature and not depth of well, and the reader is left to evaluate the significance of the temperature/depth relationship.

Spring temperatures also must be evaluated not only because many springs issue from near-surface aquifers, such as thin pediments, that may be warmed by the sun, but also because spring temperatures are commonly measured where there is sufficient flow to make a conductance measurement or to collect a sample for chemical analysis rather than at actual points of seepage. Thus many above-normal temperatures of spring water are simply the result of excessive warming by the sun, and since most sampling and testing of spring waters is done during the warm-weather months, temperatures of $16^{\circ}$ to as much as $30^{\circ} \mathrm{C}$ may not indicate an anomalous deep heat source.

During my studies of the Henry Mountains (Goode and Olson, 1977) in the sumners of 1975-76-77, I measured temperatures of 150 springs, of which 50 had temperatures of $15.5^{\circ} \mathrm{C}$ or higher. Where possible these temperatures were measured where the water issued from the ground but many of the springs yield water by seepage so these temperatures were measured where the flow became concentrated enough for a conductance measurement or for sample collection. A few developed springs were measured where the water flowed from a pipe. Obviously the temperatures measured in the summertime some distance from point of issue will be anomalously high. To verify this explanation, in December 1977 I measured temperatures of about 10 springs in the Henry Mountains that had showed temperatures of $15.5^{\circ}$ or higher during summertime measurements. All the remeasurements were cooler; one spring that had been measured at $23^{\circ}$ in summer was frozen in winter.

My experience with measurements of spring temperatures seems to be confirmed by repeated measurements recently published for five springs in the south-eastern 
Uinta Basin (Conroy and Fields, 1977, p. 211). At each spring, temperatures were measured 9 to 14 times at approximately monthly intervals between December 1974 and September 1976.

\begin{tabular}{|c|c|c|c|c|}
\hline Spring & Range & $\begin{array}{l}\text { gpm } \\
\text { in yield }\end{array}$ & $\begin{array}{c}{ }^{\circ} \mathrm{C} \\
\text { Range in temp. }\end{array}$ & $\begin{array}{l}{ }^{\circ} \mathrm{C} \text { Total } \\
\text { Fluctuation }\end{array}$ \\
\hline$(D-15-20) 15 b b d$ & 0.7 & $5-3$ & $3-12.5$ & 9.5 \\
\hline$(D-15-23) 36 d d d$ & 2.5 & -17 & $1-17$ & 16 \\
\hline$(D-15-24) 10 b c d$ & 75 & -170 & $7-11$ & 4 \\
\hline$(\mathrm{D}-15-25) 13 \mathrm{bad}$ & 24 & -60 & $5-12$ & 7 \\
\hline$(D-15-25) 18 \mathrm{cda}$ & 1 & -3.5 & $2-10$ & 8 \\
\hline
\end{tabular}

Although none of these springs has a particularly high temperature, all the highest temperatures were measured between the end of May and mid-September, suggesting some warming by the sun.

On Bonneville Salt Flats the U.S. Geological Survey in 1976 augered 119 test holes 1 to $19 \mathrm{ft}$ deep (Lines, 1978). Water levels ranged from 1 inch above land surface to 11 feet below land surface, but most were within $2 \mathrm{ft}$ of land surface. Temperatures measured in 60 of those holes between March 31 and April 7, 1976, ranged from $5^{\circ}$ to $13^{\circ} \mathrm{C}$ with a median of $8^{\circ}$; temperatures measured in 40 of those holes between August 31 and September 28,1976 , ranged from $16^{\circ}$ to $23^{\circ}$ with a median of $21^{\circ}$. These measurements not only confirm the effect of the sun's heat on water temperatures but also indicate a magnitude of $13^{\circ}$ for summer warming. Additional temperature measurements could refine the indicated magnitude of solar heating.

From the evidence above, I feeI that many, probably most, of the temperature measurements of springs in the $16^{\circ}$ to $30^{\circ} \mathrm{C}$ range are not indicators of a subsurface heat source, although I have included them in the tables.

Origin of the Thermal Waters

Essentially all the thermal waters of Utah have originated as meteoric water that has circulated deep below the surface of the earth and has been warmed by the normal or slightly elevated geothermal gradient. In some places, deeply circulating waters have warmed overlying bodies of water that now yield thermal water to wells by conduction. In some places, such as Roosevelt Hot Springs, Abraham (Crater) Hot Springs, Coyote Spring in Curlew Valley, Escalante Desert, PavantBlack Rock Desert, and Cove Fort-Sulphurdale heating may result from a still-hot intrusive body or from adjacent volcanic rocks. It is unlikely that any of the thermal water is magmatic water (water derived from the cooling of magma as it solidifies).

Mundorff (1970, p. 6) has said that "nearly all thermal springs in Utah are in or very near fault zones that serve as escape routes for deeply circulated waters under artesian pressure." Meteoric water penetrates cracks and fissures in the bedrock of the mountains, moves deep within the earth and becomes heated, then seeks to escape back to the surface by the shortest possible route. Commonly, such a route is the fault that separates the mountain mass from the adjacent valley. Examples of this idealized system occur in many places in the Basin-Range Province in the western part of Utah, but the hot springs along the Wasatch Fault Zone present a special case because the bounding fault has only a shallow dip of about $35^{\circ}$ (see discussion of Wasatch Fault Zone below). Where the meteoric water of the mountains penetrates only to moderate depths, it does not become heated but it may still return to the surface as cold springs along the bounding faults 
Many of the wells that produce thermal water are located on or near faults, some of which also have nearby thermal springs, such as those at Saratoga near the Utah Lake Fault Zone. But many areas in the artesian basins of the BasinRange Province have thermal wells that are not near thermal springs and the water presumably is warmed by conduction from deeper circulating hot water. For example, two areas in Cache Valley yield warm water to wells and are near buried faults that separate the valley from the adjacent mountain; a large warm-water area in the north-central part of Jordan Valley is apparently related to a buried fault; and in the western part of the East Shore area several wells near Little Mountain yield warm water from an area that may be near a buried fault. In such areas it appears that heated water rises along the fault but its vertical movement is finally stopped by a relatively impermeable confining bed that overlies the fault. The heated water then moves laterally and mixes with other water in the permeable zone, but the constant supply of heat warms the water in permeable zones that overlie the confining bed above the fault and that water, generally appreciably fresher than the water that rises along the fault, becomes available to be withdrawn by wells. This system might be described as a natural heat-exchanging system whereby deeply circulating, commonly saline water transfers its heat by conduction to an overlying fresher-water aquifer from which it is separated by a relatively impermeable confining bed.

\section{Hot Springs along the Wasatch Fault Zone}

Four of the five hot spring areas along the Wasatch Front occur on faults that bound the distal ends of spurs that project from the front, and only one of the spring areas is on the main Wasatch frontal fault. In addition, the Cutler Warm Springs, temperature $21^{\circ}-26.5^{\circ} \mathrm{C}$, "issue from limestones of Paleozoic age along the bed and banks of the Bear River...about one mile east of the main Wasatch fault" (Mundorff, 1970, p. 50). The discussion below will suggest that the main deep conduit for hot water is the frontal fault, but that most of the readily visible hot and warm water finds shorter routes to the surface along the faults that bound the spurs than along the frontal fault itself. Furthermore, the frontal fault may, through buried splinter faults, transmit heat to many areas of warm water of $15^{\circ}-20^{\circ} \mathrm{C}$ whose sources cannot be directly identified.

From north to south the five hot spring areas are:

\begin{tabular}{|c|c|c|c|c|c|}
\hline & Spur & $\begin{array}{l}\text { Distance in miles } \\
\text { from main fault }\end{array}$ & ${ }^{\circ} \mathrm{C}$ & $\begin{array}{c}\text { gpm } \\
\text { Discharge } \\
\end{array}$ & $\begin{array}{l}\text { Total } \\
\text { solids } \mathrm{mg} / \mathrm{I}\end{array}$ \\
\hline $\begin{array}{l}\text { Madsens (Crystal) } \\
(B-11-2) 29 \mathrm{da}\end{array}$ & Madsen & $1 \frac{1}{2}$ & $51-55.5$ & $500-1800$ & $\begin{array}{l}38,500 \\
45,500\end{array}$ \\
\hline $\begin{array}{l}\text { Utah } \\
(B-7-2) 14 \mathrm{dca}\end{array}$ & $\begin{array}{l}\text { Pleasant } \\
\text { View }\end{array}$ & $2 \frac{1}{2}$ & $57-58$ & $250-700$ & $\begin{array}{l}18,900 \\
25,200\end{array}$ \\
\hline $\begin{array}{l}\text { Ogden } \\
(B-6-1) 23 \operatorname{ccd}\end{array}$ & & $\begin{array}{l}\text { On frontal } \\
\text { fault }\end{array}$ & $49-65$ & $35-100$ & $\begin{array}{l}8,650 \\
8,820\end{array}$ \\
\hline $\begin{array}{l}\text { Becks-Wasatch } \\
(\mathrm{B}-1-1) 14 \mathrm{dcb} \\
(\mathrm{B}-1-1) 25 \mathrm{db}\end{array}$ & City Creek & $4-5$ & $\begin{array}{l}52-56 \\
40-42\end{array}$ & $\begin{array}{l}60-450 \\
310-1020\end{array}$ & $\begin{array}{r}13,100 \\
13,900 \\
5,590 \\
12,800\end{array}$ \\
\hline $\begin{array}{l}\text { Crystal } \\
(\mathrm{C}-4-1) \text { and }\end{array}$ & $\begin{array}{c}\text { Traverse } \\
\text { Range }\end{array}$ & 4 & $.50-58$ & $45-60$ & $\begin{array}{l}1,300 \\
1,700\end{array}$ \\
\hline
\end{tabular}


Although Crystal Springs are included among these five hot spring areas in this group, it should be pointed out that Mundorff (1970, p. 34) attributes the source of heat for these springs to the Tertiary volcanic rocks that are about 700 feet deep, as well as the geothermal gradient.

Gilbert (1928, p. 22) in his report on basin-range structure, mentions these five springs in part of his discussion of the Wasatch fault, which is excerpted below. First, Gilbert points out that the plane of the "frontal fault of the range," as measured at about 10 places, generally dips about $35^{\circ}$, with one measurement of $20^{\circ}$ and another of $45^{\circ}$ (1928, p. 22). Then he describes how the spurs are created as successive movements occur on the frontal fault:

The local dip line is assumed to be straight except at a single place, low down, where a firmly fixed knob of strong rock projects from the footwall. During early stages of the movement (A) (fig. 2) weaker rocks of the valley block make the necessary adjustment by flow. At some later stage the knob punches out a piece of the valley block, creating a spur block. If the spur block were merely severed and the valley block moved away from it a chasm would be created (B) like the crevasse of a glacier, but the parts are too heavy to permit this, and their settling yields a condition like that shown in (C) (1928, p. 32).

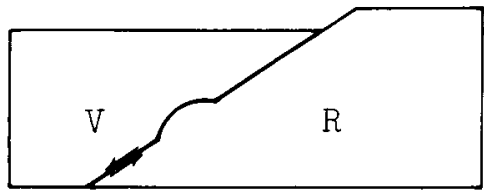

A

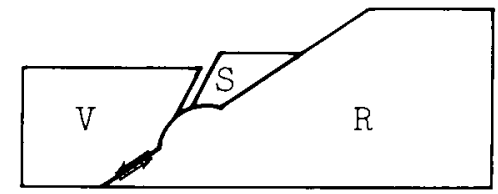

B

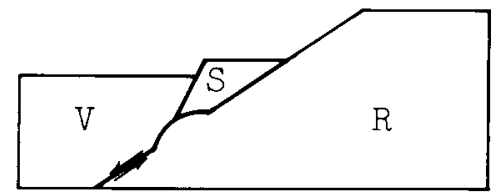

C

Figure 2. Ideal sections of progressive dislocation of valley block, $V$. and range block, $R$, to illustrate hypothetical derivation of spur block, S. (Source: Gilbert, 1928, fig. 27)

Gilbert continues:

all four of the fault-block spurs are accompanied by thermal springs, whose waters rise along their bases.. The spur base is lower than adjacent parts of the range base, and the point of issue at each spur locality may be determined by that fact, but that conclusion does not explain the scarcity of thermal waters on the long line of the frontal fault. It may be that the outer faults of the spurs are peculiarly favorable for the conveyance of deep penetrating circulation because of the conveyance of the less perfect adjustment there of the fault walls (p. 32).

Gilbert then estimates that where the mean annual air temperature is $52^{\circ}\left(11^{\circ} \mathrm{C}\right)$, as at Salt Lake City, and where the temperature gradient is $1^{\circ} \mathrm{F}$ for each 75 feet, rock temperature of $134^{\circ}\left(56.5^{\circ} \mathrm{C}\right)$ is reached at depth of 6,150 feet. 
This may be accepted as an underestimate of the depth to which water circulates on the faults that limit the spurs (p. 33).

When we realize that Gilbert also attributed the fluctuations of temperatures of some thermal springs to "the dilution of a practically constant discharge of uniformly hot water rising from the depths with a variable discharge of cool ground water," and that "in localities that show no indications of recent volcanism the heat of waters rising along the fault is presumably derived from the inner earth's store" ( $p$. 33), we have to admit that Gilbert did a magnificent job of interpreting the geologic environment of the hot springs near the Wasatch fault zone. But I should like to expand on his interpretation of the reason for the concentration of hot springs on the faults bounding the spurs rather than on the main frontal fault. In addition to the "less perfect adjustment... of the fault walls" of the bounding faults, the steep bounding faults provide shorter conduits to the surface than does the frontal fault. From this we can infer that meteoric water circulates at great depth and is heated along the frontal fault, then rises to the surface by the shortest routes. The best exposed of these short routes are at the distal ends of the spurs, but it is likely that there are many similar small faults, now buried by surficial deposits, that act as escape routes for warm water that rises along the frontal fault elsewhere. These hidden escape routes may permit the rising of hot waters in many places that cannot be pinpointed, but instead effect a general warming of the subsurface water. This phenomenon could be the explanation for areas that produce water of $15^{\circ}$ to $20^{\circ} \mathrm{C}$, about $4^{\circ}$ to $9^{\circ}$ above the mean annual air temperature.

Marseli (Milligan and others, 1966, p. 4) suggests that "Commonly the heated water finds freer avenues of escape to the surface along the more open fissures in the 'footwall' of the fault than along the major fault plane itself'. Thus many thermal springs issue at points several hundred feet back from the associated fault zone. Examples are: Cutler Thermal Springs, where Bear River breaches the Wasatch Range; the hot springs at the mouth of Ogden Canyon; and the LaVerkin Hot Springs along the Virgin River just east of the Hurricane Fault Zone."

\section{Known Geothermal Resource Areas (KGRAs)}

The Energy Resources Map of Utah (Utah Geol. \& Mineral Survey, 1975) classifies geothermal areas into three categories, Original KGRA, Known Geothermal Resource Area defined by geologic criteria; Administrative KGRA, Known Geothermal Resource Area defined by competitive interest; and Area Potentially Valuable for Geothermal Resources (PVGRA). These areas and the areas under lease are listed here (Rush, 1978).

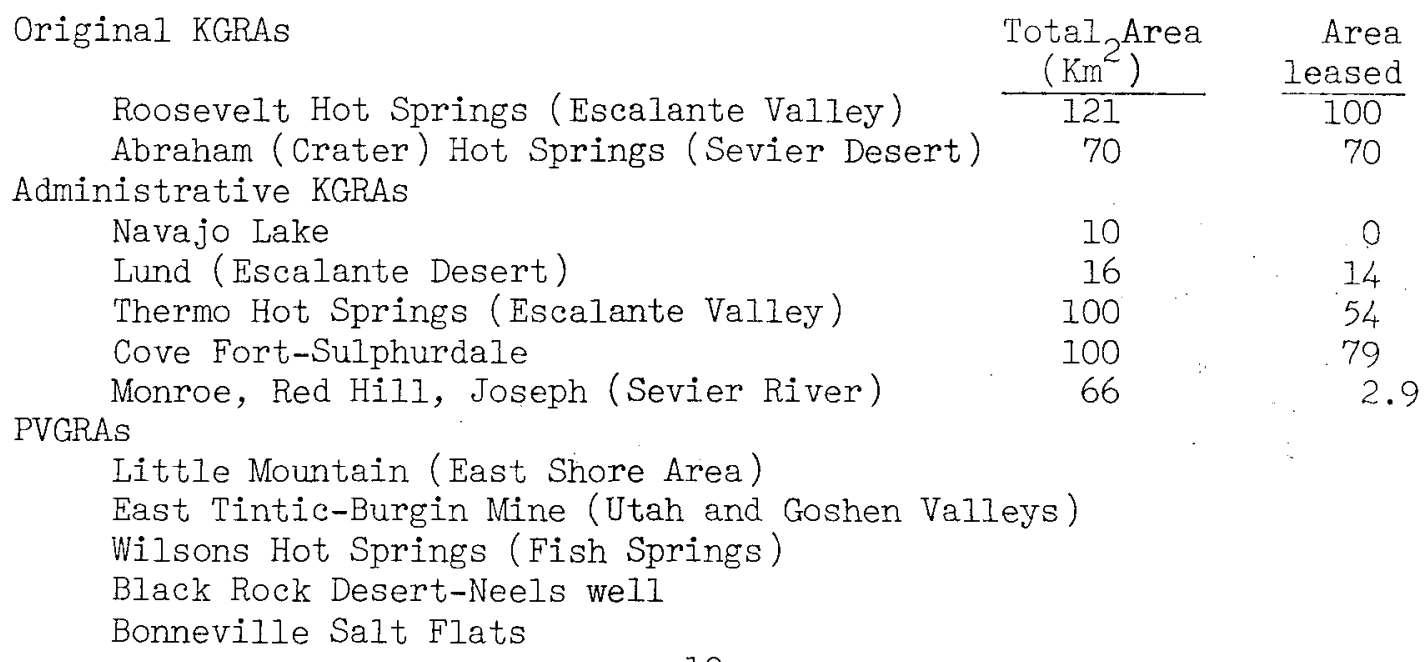


Presumably these areas were classified on their apparent potential to yield geothermal energy that could be used to generate electricity.

Since the publication of the map, Navajo Lake has been dropped from the list, and the Roosevelt, Thermo, and Cove Fort-Sulphurdale areas have been identified by Rush of the U.S. Geological Survey as having potential for generating electric power. The Earth Science Laboratory at the University of Utah Research Institute has also recommended that the hot springs at Monroe be used for space heating in two schools and other municipal buildings in Monroe. These geothermal areas are discussed in more detail in the appropriate sections on individual areas.

Exploration near Beryl (see Escalante Desert) located $149^{\circ} \mathrm{C}$ water at 7000 feet, and exploration by Great Salt Lake Minerals and Chemicals Corp. near Little Mountain (see East Shore Area) located hot water at about 900 feet. No other exploration in those areas has been reported.

Further information about history and problems of developing the geothermal resources of Utah are contained in Utah Energy, Research Report No. 8 of the Office of Legislative Research (Millar and Searle, 1976).

\section{Possible Uses for the Thermal Waters of Utah}

This study originally set as its limit waters in the temperature range $15.5^{\circ}-90^{\circ} \mathrm{C}$, but this report has also included reported temperatures appreciably higher (such as the genthermal-test well near Beryl whose water temperature was reported as $\left.300^{\circ} \mathrm{F}, 149^{\circ} \mathrm{C}\right)$. Therefore, we shall begin this section on utilization of thermal waters by removing from consideration all geothermal systems that may have a potential to produce electrical energy, say those above $200^{\circ} \mathrm{C}$. Thus all thermal waters not used to generate power and all geothermal waters discarded after generation of power can be considered to be available for other uses.

The areas that have thermal waters are shown on figure 1 ; some of the possible uses are considered below.

Uses for thermal waters can be divided into three categories: domestic, in which the waters come into contact with human beings; agricultural, in which the waters come into contact with crops; and industrial, in which the waters are kept within the industrial system. For many of the specific uses within each category there are limitations about the chemical quality of the water that may be used. These limitations are complex and therefore no attempt will be made here to define the quality of water required for each use. Rather, some of the possible uses and the minimum temperatures needed for each use are listed here. (The interested reader is referred to a short discussion. Relationship of quality of water to use, in Hem, 1970, or to a more complete discussion in Water Quality Criteria by McKee and Wolf, 1963).

Domestic

Heating swimming pools Therapeutic bathing Home hot-water Public hot-water supplies $95^{\circ}$ at campgrounds, resorts, etc. $\underline{\text { Agricultural }}$

$30^{\circ}$
$40^{\circ}$
$90^{\circ}$
$95^{\circ}$

\section{Industrial}

$\begin{array}{lc}\text { Space heating } & 15^{\circ}-25^{\circ} \\ \text { (with pumps) } & \\ \text { All-year mining } & 30^{\circ} \\ \text { Deicing } & 30^{\circ} \\ \text { Space heating } & 60^{\circ}-90^{\circ} \\ \text { (optimum) } & \\ \text { Refrigeration } & 70^{\circ} \\ \text { Drying cement } & 110^{\circ} \\ \text { Air conditioning } & 110^{\circ} \\ \text { ( }{ }_{2} \text { O+Li+Br system) }\end{array}$


(Industrial uses continued)

$\begin{array}{lc}\text { Fresh water by } & 120^{\circ} \\ \text { distillation } & \\ \text { Sugar refining } & 120^{\circ} \\ \text { Evaporation of } & 120^{\circ} \\ \text { saline solutions } \\ \text { Food canning }\end{array}$

Many more uses of thermal waters and the problems of such utilization are given in the papers presented at a symposium held in San Diego, California, January 31 - February 2, 1978. The papers were published by Geothermal Resources Council, P.0. Box 98, Davis, California 95616, under the title Direct Utilization of Geothermal Energy: a Symposium.

Obviously the warm and hot waters of Utah could be put to many uses. So far, utilization has been minimal, a few greenhouses and swimming pools; but as other sources of energy become more costly we can expect appreciable development of thermal waters for space heating, greenhouses for year-round production of highvalue crops, food processing, and many of the other uses listed above.

\section{Recommendations for Future Work}

Periodic Up-Dating of Thermal Data

This study has confined itself principally to data in published reports, supplemented by small amounts of information collected by the author in prior investigations of water resources. Thus, descriptions of some areas, such as Tooele Valley and Northern Utah Valley, depend on information collected more than 15 years ago. Therefore, there should be added to the tables presented here information collected since the last publication of data, and a program of periodically updating the file on thermal waters should be instituted.

Use of Thermal Water-Temperature and Quality Requirements

Some areas in Utah, such as the lower Bear River area and Ashley Valley, annually discharge thousands of acre-feet of hot water, and, if a 50-megawatt generating plant is put into operation at Roosevelt Hot Springs, many million gallons of water above the boiling point will be discharged each day as waste water from the plant.

This study has presented a short list of possible direct uses for thermal water. A fuller study could equate the amounts, temperature, and quality of thermal waters with the specific requirements of various uses.

\section{Acknowledgments}

This report on thermal water in Utah is the result of a study of the literature on ground water in Utah. The more than 1500 well and spring records that are included in the report were culled from about 6000 records of wells and springs on which water temperatures were measured and published by hydrologists of the U.S. Geological Survey over a period of many decades. Without this large amount of basic data, the records of water temperatures included here would have been appreciably less complete. Similarly, most of the discussions of geology have been taken from reports by geologists of the U.S. Geological Survey. Thus I owe a deep debt of gratitude to all whose material I have used. 
Val Finalyson of Utah Power and Light Co. supplied me with information about geothermal test wells drilled near Brigham City and in the Escalante Desert, and Richard Peterson of Equity Oil Co. discussed the wells of the Ashley Valley Oil Field with me. To both I am grateful.

This report was prepared under contract \#78-5146 between the Utah Geological and Mineral Survey and me. During the preparation of the report I received excellent cooperation from the drafting and clerical staff of the Utah Survey, and I am especially grateful to Donald T. McMillan, Director, for editing the manuscript and to Brad Taylor for preparing most of the tables of wells and springs that have slightly warm water. Wallace Gwynn and Peter Murphy contributed reports and made suggestions that were extremely helpful as the work progressed.

\section{Cited References}

The references listed here apply only to the foregoing introductory material. References that apply to the individual areas of Utah that are discussed in the next section are listed at the end of each sub-section. A selected bibliography at the end of this report lists other works that were consulted but not listed.

Conroy, L.S., and F.K. Fields, 1977, Climatologic and hydrologic data, southeastern Uinta Basin, Utah and Colorado, water years 1975 and 1976: U.S. Geol. Survey Utah Basic-Data Release No. 29, 244 p.

Geothermal Resources Council, 1978, Direct utilization of geothermal energy: a symposium at San Diego, California, Jan. 31 - Feb. 2, 1978, 133 p.

Gilbert, G.K., 1928, Studies of Basin-Range structure: U.S. Geol. Survey Prof. Paper 153, $92 \mathrm{p}$.

Goode, H.D., and Eric Olson, 1977, Reconnaissance appraisal of the water resources of the Henry Mountains coal field, Wayne and Garfield Counties, Utah. Univ. of Utah, College of Mines and Mineral Industries, $85 \mathrm{p}$.

Hem, J.D., 1970, Study and interpretation of the chemical characteristics of natural water: U.S. Geol. Survey Water-Supply Paper 1473, 363 p.

Lines, G.C., 1978, Selected ground-water data, Bonneville Salt Flats and Pilot Valley, western Utah: U.S. Geol. Survey Basic-Data Release No. 30, $14 \mathrm{p}$.

McKee, J.E., and H.W. Wolf, 1963, Water Quality Criteria: California State Water Quality Control Board Publ. 3-A, $548 \mathrm{p}$.

Meinzer, O.E., 1923, Outline of ground-water hydrology with definitions: U.S. Geol. Survey Water-Supply Paper 494, 71 p.

Millar, R.D., and R.T. Searle, 1976, Utah Energy - a staff report to the Joint Legislative Committee on Energy Policy: Utah Office of Legislative Research, Research Rept. 8, 115 p.

Milligan, J.H., R.E. Marsell, and J.M. Bagley, 1966, Mineralized springs in Utah and their effect on manageable water supplies: Utah State Univ., Logan, Utah, Water Research Lab. Rept. WG23-6, $50 \mathrm{p}$. 
Mundorff, J..C., 1970, Major thermal springs of Utah: Utah Geol. and.Mineralog. Survey, Water-Resources Bull. 13, $60 \mathrm{p}$.

Parry, W.T., and M. Cleary, 1978, Na-K-Ca and $\mathrm{SiO}_{2}$ temperature estimates for Utah spring and well waters: U.S. Geol. Survey, Geothermal Research.

Rush, F.E., 1977, Subsurface temperature data for some wells in western Utah: U.S. Geol. Survey Open-File Report 77-132, 84 p. 


\section{DESCRIPTIONS OF AREAS OF THERMAL WATERS}

The thermal waters of Utah are divided into three categories: hot at $25^{\circ} \mathrm{C}$ and higher, warm at $20^{\circ}$ to $34.5^{\circ} \mathrm{C}$, and slightly warm at $15.5^{\circ}$ to $19.5^{\circ} \mathrm{C}$. The seventeen areas of Utah that have hot water also have warm and slightly warm water. They will be discussed first, in alphabetical order. Then the areas that have warm and slightly warm water will be discussed followed by the areas that have only slightly warm water. Finally, a few isolated thermal springs and a well will be discussed.

The discussions of each area refer to tables of records of thermal springs and wells and of chemical analyses where they are available. These tables follow the text of the report.

References for the discussions and records of the individual areas follow each discussion. Additional but uncited references appear in the selected Bibliography.

\section{Areas That Have Hot, Warm and SIightly Warm Water}

Sixteen areas in the western and central part of Utah and the Ashley Valley oil field in the Uinta Basin in the eastern part of Utah yield hot, warm and slightly warm water to wells or springs. The hottest water at $269^{\circ} \mathrm{C}$ has been measured in a geothermal test well in the Roosevelt KGRA in the Escalante Valley. That area probably has potential to generate electricity, perhaps as much as 300 megawatts (Ward and others, 1978). Another area, Monroe-Red Hill Hot Springs in the Sevier River Valley, is being developed to provide space heating. It is likely that the hot and warm waters of some of the other of these seventeen areas could be utilized for space heating, greenhouses, or food processing. Descriptions of these seventeen areas follow.

\section{Cited References}

Ward, S.H., W.T. Parry, W.P. Nash, W.R. Sill, K.L. Cook, R.B. Smith, D.S. Chapman, F.H. Brown, J.A. Whelan, and J.R. Bowman, 1978, A summary of the geology, geochemistry, and geophysics of the Roosevelt Hot Springs thermal area, Utah: Geophysics, v. 43, p. 1515-1542. 


\section{Lower Bear River Area}

\section{INTRODUCTION}

The lower Bear River area includes the eastermmost portion of Box Elder County. It encompasses about 700 square miles in the valleys of the Lower Bear River and its principal tributary, the Malad River.

\section{SUMMARY Of OCCURRENCES of HOT and WARM WATER}

The hot- and warm-water springs of the Lower Bear River Valley yield water that is slightly saline to briny ( 2120 to $43,500 \mathrm{mg} / 1$ dissolved solids), and the hot springs above $42^{\circ} \mathrm{C}$ generally have high yields of 450 to $5000 \mathrm{gpm}$. Despite this seeming evidence for a subsurface source of high heat, the only geothermal test well in the area, $(\mathrm{B}-10-2) \mathrm{bcc}$, reported a temperature of only $105^{\circ} \mathrm{C}$ at 11,005 feet.

\section{GEOLOGIC and HYDROLOGIC ENVIRONMENT}

Precambrian and Paleozoic rocks form the mountains that bound the area on the east and west, and Cenozoic rocks fill the valleys. No rocks of Mesozoic age are exposed in the area, probably because the area was a highland of the Sevier Orogenic belt in late Mesozoic time and therefore early Mesozoic rocks that may have been deposited were eroded away.

Today the dominant structure is a narrow north-trending graben, or series of grabens, that is a continuation of the graben structure along the Wasatch Front farther south. Little Mountain, west of the main part of the graben, is a horst bounded by north-trending faults.

Cenozoic deposits fill the graben to thicknesses that may reach 8000 feet (Bjorklund and McGreevy, 1974, p. 11). These deposits are principally deltaic and lake-bottom deposits except around the margins of the valleys where there are alluvial, colluvial, and landslide deposits. The great bulk of the deltaic and lacustrine deposits consists of silt and clay with interbedded alluvial sand and sparse gravel. Except where this valley fill has been drained by streams that have dissected it, it is so saturated that Bjorklund and McGreevy have mapped most of the valley fill, perhaps half of the total area, as areas of natural discharge (1974, plate 2). About 190,000 acre-feet of the natural discharge of 295,000 acre-feet per year is by springs and drains (figures adjusted from Bjorklund and McGreevy, 1974, p. 21). Springs near West Hills, Blue Springs Hills, and Little Mountain discharge about 30,000 acre-feet annually from Paleozoic limestone or from unconsolidated sediments nearby. Another 30,000 acre-feet is discharged by "springs along the west side of the Wasatch Range and Clarkston Mountain." And "at least 140,000 acre-feet of water is discharged annually from springs and drains on the valley floor" (Bjorklund and McGreevy, 1974 , p. $23-24)$.

OCCURRENCES Of WARM and HOT WATER

A now abandoned geothermal-test well had a reported bottom-hole temperature of $105^{\circ} \mathrm{C}$ from a depth of 11,005 feet (Val Finlayson, Utah Power \& Light Co., pers. commun. 1978), and twelve springs and six water wells have reported water 
temperatures of $20^{\circ}$ to $74^{\circ} \mathrm{C}$ (table $\mathrm{AA}$ ). Of the latter 18 , nine are between $20^{\circ}$ and $34^{\circ}$, six between $35^{\circ}$ and $49^{\circ}$, and three others are at $51^{\circ}, 53.5^{\circ}$, and $74^{\circ}$ respectively. The highest temperature, $74^{\circ}$, was measured in a well, (B-9-3)27cba, 502 feet deep. This well produced gas and was plugged and abandoned. A companion well, (B-9-3)27cba2, 500 feet deep, also produced gas. Its water temperature, $43^{\circ}$, was measured in a pool, so it is probably appreciably lower than if measured at the discharge point. The geologic map of Bjorklund and McGreevy (1974, plate 1) shows a northwest-trending normal fault in the immediate vicinity of the two wells. Likely the fault is the source of the heat. Four wells (table IA) have reported water temperatures of $20^{\circ}$ to $29^{\circ}$. Two of these, (B-10-3) 4add and (B-10-3)33dac, are nearly on a N-S line with the two wells above. If the inferred N-S fault that is shown on the Bjorklund-McGreevy geologic map were plotted about one mile to the west, all four of these wells would be close to that plot. The remaining two wells obtain their water from Paleozoic limestone and the Tertiary Salt Lake Formation, respectively. The source of the heat is unknown.

of the dozen springs, five have temperatures of $21^{\circ}$ to $26^{\circ}$ and seven have temperatures from $42^{\circ}$ to $53.5^{\circ}$. The five with the lower temperatures rise from the Oquirrh Formation or other Paleozoic rocks, and at least Cutler Warm Springs and the two near Little Mountain are controlled by faults; probably the other two are also. Stinking Hot Spring, Little Mountain Hot Spring, and Crystal Hot Spring are all controlled by faults. (See discussion of Hot Springs along the Wasatch Fault Zone for further information about Crystal Hot Spring and Cutler Warm Springs). The four springs that rise in (B-13-2)23 probably are those called Uddy Hot Springs by Mundorff. He says that they "issue from Paleozoic limestones at the small escarpment between the flood plain and the higher levels of the Malad River valley... The springs may issue in the vicinity of a fault concealed beneath the valley fill of Quaternary age" (1970, p. 32).

Only one of the warm-water wells, (B-12-3)15cde, yields water of even passable quality, probably about $1000 \mathrm{mg} / \mathrm{l}$ dissolved solids; the other five apparently yield or did yield water that is too salty for use. Similarly, all the warm- and hot-water springs yield water that is slightly saline to briny (2120 to 43,500 mg/l dissolved solids). In general the hot springs above $42^{\circ} \mathrm{C}$ have high yields of 450 to $5000 \mathrm{gpm}$. Only Stinking Hot Spring yields less, an estimated $45 \mathrm{gpm}$. The five springs that have temperatures from $21^{\circ}$ to $26^{\circ}$ have appreciably lower yields of 2 to $15 \mathrm{gpm}$.

T'wenty-two wells and eight springs yield water at temperatures from $15.5^{\circ}$ to $19.5^{\circ} \mathrm{C}$ (table $\left.1 \mathrm{~B}\right)$. Conductance measurments show that the quality of this cooler water is appreciably better than the quality of the warmer water, but even several of these springs and wells yield slightly to moderately saline water of up to about $10,000 \mathrm{mg} / \mathrm{l}$.

Cited References

Bjorklund, L.J., and L.J. McGreevy, 1973, Selected hydrologic data, lower Bear River drainage basin, Box Elder County, Utah: U.S. Geol. Survey Basic-Data Release No. 23, $22 \mathrm{p}$.

, 1974, Cround-water jesources of the lower Bear River drainage basin, Box Elder County, Utah: Utah Dept. Nat. Resources Tech. Publ. No. $44,58 \mathrm{p}$.

Mundorff, J.C., 1970, Major thermal springs of Utah: Utah Geol. and Mineralog. Survey, Water-Resources Bull. 13, $60 \mathrm{p}$. 


\section{Bonneville Salt Flats}

\section{INTRODUCTION}

The Bonneville Salt Flats are in western Tooele County adjacent to the Nevada border. Wendover is the only town, and the principal industry is the extraction of salt from brines that underlie the salt flats. The wells drilled to explore for and recover the brines provide the principal information about subsurface temperature.

\section{SUMMARY Of OCCURRENCES Of HOT and WARM WATER}

Many shallow and deep wells drilled to extract brines from the Bonneville Salt Flats have reported warm and hot water. Two deep wells that seem to straddle a northeast-trending fault reached water of $43^{\circ}$ at 1200 feet and $88^{\circ} \mathrm{C}$ at 1636 feet, respectively.

\section{GEOLOGIC and HYDROLOGIC ENVIRONMENT}

The Bonneville Salt Flats are in an asymmetric two-step graben whose axis trends about ${ }^{\circ} 50^{\circ}$ (Turk, 1973, fig. 3). The northwestern boundary of the graben is the Silver Island Mountains formed largely of Paleozoic sedimentary rocks, but "intruded by five stocks of unknown age, ranging in comoosition from quartz monzonite to granodiorite (Whelan and Petersen, 1974, p. 75). In addition, there are dikes of various compositions and "seven volcanic flows of rhyolite or andesitic composition in the southern Silver Island Pange" (Whelan and Petersen, 1974, p. 77). The southeastern flank of the graben probably is composed of volcanic rock but it has no surface expression and is hidden by the valley fill.

"The basin overlying the volcanic rocks was filled with fluvial and later lacustrine sediments of Plio-Pleistocene age" (Turk, 1973, p. 1). The youngest deposits form the salt crust which underlies about 150 square miles "and ranges in thickness from a feather edge to nearly 5 feet in the center... The sediments underlying the salt crust are saturated with sodium chloride brine" (Turk, 1973, p. I).

Turk (1973, p. 1) has identified three aquifers: 1) an alluvial fan aquifer off the southeast slope of the Silver Island Mountains that supplies brackish water to 27 wells, 2) "a deep stratified aquifer holding low-grade brine recoverable by deep wells, and 3) a shallow aquifer of lacustrine sediments containing high-grade brine which is harvested for its potassium chloride content."

\section{OCCURRENCE of HOT and WARM WATERS}

Turk (1973, p. 5) reports one spring, Blue Lake Spring, (C-4-19)6d, about 15 miles south of Wendover, that yields moderately saline water at a temperature of $29^{\circ} \mathrm{C}\left(84^{\circ} \mathrm{F}\right)$. All other temperature data come from wells, of which only a few records are givenhere in table 2. Most of the wells, even one, (c-1-19)23cbc, that is 1496 feet deep, have water temperatures that range from $21^{\circ} \mathrm{C}$ to $35^{\circ} \dot{C}$, but deep wells 1 and 3 reached water of $43^{\circ} \mathrm{C}$ at 1200 feet and $88^{\circ} \mathrm{C}$ at 1636 feet, respectively. These last two wells seem to straddle a southwestward extension of the inner fault on the southeast side of the graben.

Whelan and Petersen have computed reservoir temperatures using the $\mathrm{Na}-\mathrm{K}-\mathrm{Ca}$ method of Fournier and Treusdell, and have determined that the temperature for well $\# 5$ is $270^{\circ} \mathrm{C}$, for DBW13, $199^{\circ} \mathrm{C}$, and for DBW8, $285^{\circ} \mathrm{C}$. Because the waters of DBW 8 and 13 are so briny, Whelan and Petersen feel that the temperature at well $\# 5,270^{\circ} \mathrm{C}$, may be the best indicator of the reservoir temperature (1974, p. 77 ). 
Whelan and Petersen (1974, p. 78) conclude that "Bonneville Salt Flats just south of Wendover, Utah, possibly contain a geothermal reservoir. AlI of the theoretical requirements for the system could be present. There is a buried intrusive which could be the heat source; water in the form of brines appears to be present; the faulting of the Wendover Graben could provide the required permeability; and buried volcanics could provide the cap rock."

Although Turk (1973, p. 74) doesn't specifically deny the existence of a thermal reservoir, in his short discussion on the Great Salt Lake Desert he suggests that the warmth of the water may be due to a high geothermal gradient which results from a hindering of heat flow by the thick porous clay beds that underlie the desert. "The implication is that areas of thick clay accumulation, like the Great Salt Lake Desert, may have a low-temperature geothermal potential without a near-surface source of heat..."

\section{Cited References}

Lines, G.C., 1978, Selected groundwater data, Bonneville Salt Flats and Pilot Valley, western Utah: U.S. Geol. Survey Basic-Data Release No. 30, 14 p.

Stephens, J.C., 1974, Hydrologic reconnaissance of the northern Great Salt Lake Desert and summary hydrologic reconnaissance of northwestern Utah: Utah Dept. Nat. Resources Tech. Pub. No. 42, $48 \mathrm{p}$.

Turk, L.J., 1973, Hydrology of the Bonneville Salt Flats, Utah: Utah Geol. and Mineral Survey Water-Resources Bull. 19, $81 \mathrm{p}$.

Whelan, J.A., and Petersen, C.A., 1974, Bonneville Salt Flats - a possible goethermal area?: Utah Geology, vo.1, n. 1, p. 71-82.

$$
\text { Cove Fort - Sulphurdale }
$$

Cove Fort-Sulphurdale, in an area of Quaternary volcanic rocks, is listed as an Administrative KGRA in the section on Known Geothermal Resource Areas, above. No records of water wells in the area were found in the literature, and Mundorff (1970, p. 50) reported an unsuccessful search for "Sulphurdale Hot Springs" that may have been related to the mining of sulfur deposits in the area.

Rush (1977) reported temperature measurements that he made in 13 wells or drill holes in the Cove Fort-Sulphurdale area, and I have computed geothermal gradients from his reported measurements: 
Table 3. - Cove Fort-Sulphurdale. Measured temperatures and computed geothermal gradients in 13 drill holes. Data from Rush, 1977.

\begin{tabular}{|c|c|c|c|c|c|}
\hline $\begin{array}{l}\text { Coordinate of } \\
\text { drill hole }\end{array}$ & $\begin{array}{r}\text { Bottom } \\
\text { depth }\end{array}$ & $\begin{array}{l}\text { Bottom } \\
\text { temp. }{ }^{\circ} \mathrm{C} \\
\end{array}$ & $\begin{array}{l}\text { Reference } \\
\text { depth } \\
\end{array}$ & $\begin{array}{c}\text { Reference } \\
\text { temp. }{ }^{\circ} \mathrm{C} \\
\end{array}$ & $\begin{array}{l}\text { Gradient } \\
{ }^{\circ} \mathrm{C} / \mathrm{km}\end{array}$ \\
\hline $\begin{array}{r}(\mathrm{c}-23-8) 28 \mathrm{ba} \\
33 \mathrm{~cd} \\
(\mathrm{c}-23-9) 34 \mathrm{~cd} \\
(\mathrm{c}-24-8) 2 \mathrm{ac} \\
9 \mathrm{a}\end{array}$ & $\begin{array}{l}104 \\
295 \\
293 \\
377 \\
487\end{array}$ & $\begin{array}{l}18.94 \\
22.34 \\
18.96 \\
19.64 \\
20.32\end{array}$ & $\begin{array}{r}20 \\
105 \\
105 \\
105 \\
100\end{array}$ & $\begin{array}{l}15.34 \\
15.89 \\
15.84 \\
17.10 \\
14.77\end{array}$ & $\begin{array}{r}141 \\
116 \\
56 \\
30 \\
46\end{array}$ \\
\hline $\begin{array}{r}(c-24-9) 12 c c \\
25 b a\end{array}$ & $\begin{array}{l}493 \\
168\end{array}$ & $\begin{array}{l}21.00 \\
13.20\end{array}$ & $\begin{array}{l}100 \\
100\end{array}$ & $\begin{array}{l}16.14 \\
12.84\end{array}$ & $\begin{array}{l}39 \\
16\end{array}$ \\
\hline$(c-25-7) 2 \mathrm{cc}$ & 1000 & 77.20 & 100 & 25.10 & 190 \\
\hline $\begin{array}{r}(c-25-9) 1 c c \\
7 c c \\
12 d c \\
(c-26-7) 18 c c \\
(c-26-8) 27 b c\end{array}$ & $\begin{array}{l}400 \\
206 \\
437 \\
112 \\
289\end{array}$ & $\begin{array}{l}43.00 \\
17.83 \\
49.30 \\
12.62 \\
14.80\end{array}$ & $\begin{array}{r}100 \\
105 \\
100 \\
20 \\
105\end{array}$ & $\begin{array}{l}21.85 \\
16.60 \\
23.47 \\
11.02 \\
12.82\end{array}$ & $\begin{array}{r}232 \\
39 \\
252 \\
56 \\
36\end{array}$ \\
\hline
\end{tabular}

Three of those holes show very high geothermal gradients of 190, 232, and 252, but only further exploration will reveal the potential of the area.

Cited References

Mundorff, J.C., 1970, Major thermal springs of Utah: Utah Geol. and Mineralog. Survey, Water-Resources Bull. 13, $60 \mathrm{p}$.

Rush. F.E., 1977, Subsurface-temperature data for some wells in western Utah: U.S. Geol. Survey Open-File Report 77-132, 84 p. 
Southern Curlew Valley, Utah

\section{INTRODUCTION}

Curlew Valley heads in southern Idaho, crosses into Utah, and drains into the northern part of Great Salt Lake. The Utah (southern) part of Curlew Valley encompasses about 550 square miles (Bolke and Price, 1969, p. I). Probably fewer than 300 people live in the Utah portion of the valley and essentially all of them are engaged in agriculture, principally the raising of livestock.

\section{SUMMARY Of OCCURRENCES Of HOT and WARM WATER}

Coyote Spring, (B-14-10)33bcc, yields about $20 \mathrm{gpm}$ of hot $\left(43^{\circ} \mathrm{C}\right)$ moderately saline $(3240 \mathrm{mg} / \mathrm{l}$ ) water. Volcanic rocks crop out a mile or two from the spring and probably underlie the spring area at depth. Although only two wells, both about 10 miles southwest of the spring have reported warm saline water, the spring area would seem to be a likely place to explore for hotter water at depth. Another area, between Rose Ranch and the Idaho border, has five wells with water of $20^{\circ}-24^{\circ} \mathrm{C}$; three of these appear to line up with an inferred $\mathrm{N}-\mathrm{S}$ fault. One of these wells, (B-15-9)28cbb, yields slightly saline water that has $77 \mathrm{mg} / 1$ silica and $2640 \mathrm{mg} / 1$ dissolved solids; two others yield fresh water. Probably water in this temperature range could be expected in the vicinity.

\section{GEOLOGIC and HYDROLOGIC ENVIRONMENT}

The Utah portion of Curlew Valley is flanked on the west by the Raft River Range and on the east by the Hansel Mountains. Northward the Utah portion receives drainage "from Idaho and southward it opens toward Great Salt Lake. Within the Utah portion of the valley are hills of Tertiary and Quatemary felsic volcanic rocks and basalt that cap a gravity high which occupies the central and eastern portions of the valley (Baker, 1974, plate 2). Thus the valley fill in the central and eastern portions is probably less than 1000 feet thick whereas in the western portion there is a trough at least 3000 feet deep between the Raft River Range and the Wildcat Hills.

"The consolidated rocks surrounding Curlew Valley and underlying it at deptn have been distorted by repeated episodes of structural deformation... The abundant faults, fractures, and associated solution openings form the principal conduits through which water moves in the older consolidated rocks in the Curlew Valley drainage basin. Major structural features probably exerted considerable influence on the distribution of the basaltic lava flows, which are an important element of the ground-water flow systems in the valley fill...(and provide) the principal source of water to many wells in the area" (Baker, 1974, p. 12-13).

Because the hydrology of the valley is complex, Baker (1974, p. 1) has distinguished three major ground-water flow systems "that contain water of suitable chemical quality for irrigation. A fourth flow system, which contains hot, saline water, is present at depth in the western part of the valley." 
OCCURRENCES Of HOT and WARM WATER

Hot $\left(45^{\circ} \mathrm{C}\right)$ moderately saline water $(3240 \mathrm{mg} / \mathrm{l}$ dissolved solids) is yielded by Coyote Spring, ( $B-14-10) 33 b c c$ (table 4-A). "Although no other source in Curlew Valley produces thermal water, two wells in the Kelton area (about 10 miles southwest of Coyote Spring) reportedly encountered hot saline water at depth (probably below 500 feet)... These data suggest that hot saline water may underlie at least part of the western half of Curlew Valley."

"The high temperatures of water in the system probably indicate the presence in the subsurface of a relatively young intrusive body that is still hot, or relatively deep circulation of the water" (Baker, 1974, p. 34). A mile long outcrop (dike?) of basalt that Baker has mapped about a mile west of coyote Spring suggests that there may be a hydrologic barrier between the source of Coyote Spring and the thermal waters encountered in the two wells cited above, but the presence of volcanics in the Wildcat Hills that also lie between the spring and the wells and the gravity high in the same area are strong evidence for a deep volcanic source for the heat for both the spring and the wells.

A temperature of $25^{\circ}$ is reported for a spring (B-13-12)30caas that discharges near several presumably cooler springs that are near the base of an alluvial fan at the southeast corner of the Raft River Range. Other springs with temperatures of $21^{\circ}$ to $23^{\circ}$ are reported a few miles to the west in the Park Valley area.

Five wells in Ts. 14 and 15 N., R. 9 W. between the Rose Ranch and the Idaho border have reported temperatures of $20^{\circ}$ to $24^{\circ} \mathrm{C}$. In the vicinity are other wells $15.5^{\circ}-19^{\circ} \mathrm{C}$. Baker's geologic map (1974, plate 2) shows an inferred $\mathrm{N}-\mathrm{S}$ fault about on line with three of the wells $\left(20.5^{\circ}-249\right.$; he makes no specific mention of the wells or the fault, but if there is a fault it could be the source of heat for the warmer water.

The very saline Black Butte Spring, 20,300 mg/l dissolved solids, yields slightly warm water of $19^{\circ}$ near a basalt outcrop (table $4-B$ ).

\section{Cited References}

Baker, C.H., Jr., 1974, Water resources of the Curlew Valley drainage basin, Utah and Idaho: Utah Dept. Nat. Resources Tech. Pub. No. 45, $83 \mathrm{p}$.

Bolke, E.L., and Don Price, 1969, Hydrologic reconnaissance of Curlew Valley, Utah and Idaho: Utah Dept. Nat. Resources Tech. Pub. No.25, 35 p.

Hood, J.W., 1971, Hydrologic reconnaissance of the Park Valley area, Box Elder County, Utah: Utah Dept. Nat. Resources Tech. Pub. No. 30, 46 p. 
East Shore Area

INTRODUCTION

The East Shore Area lies between Great Salt Lake on the west and the foot of the Wasatch Range on the east (fig. 3). It includes the portions of Weber and Davis Counties that are west of the mountains and a small part of southern Box Elder County, in township 7 north. This area with a population of about 250,000 is second in Utah only to Salt Lake County which has about 508,000 people (Bur. of Econ. And Business Research, March 1976). It is the site of Weber State College, Hill Air Force Base, and the Clearfield Depot as' well as other military and governmental agencies. The Weber County portion produces beef, dairy products, and poultry and has processing facilities to make them ready for market. The Davis County portion also is partly agricultural and industrial but much of its expansion in the last two decades has been to provide homes for people who work in Salt Lake Valley.

SUMMARY of PRINCIPAL OCCURRENCES, USE, and POTENTIAL for USE

Temperature measurements on 145 wells in the East Shore area (Bolke and Waddell, 1972, p. 40-51) suggest that in most areas west of Ogden wells of depths of a few hundred feet are likely to reach water of $15 \frac{1}{2}^{8} \mathrm{C}$ or warmer, 4 or more degrees above the mean annual air temperature. Of the 145 wells, 45 that have temperatures of $20^{\circ}$ or higher are listed in table $5-\mathrm{A}$ and are discussed in some detail, 54 others that have temperatures of $15 \frac{1}{2}^{\circ}$ to $19 \frac{1}{2}^{\circ}$ are listed in table 5-B and only 47 have temperatures of $15^{\circ}$ or lower. The highest well water temperatures, $25^{\circ}$ and $39^{\circ}$, are in a cluster of 13 wells drilled by Great Salt Lake Minerals and Chemicals Corp. to depths of 412 to 920 feet. The waters from all except the deepest of these wells have conductances that suggest the dissolved minerals content is $500 \mathrm{mg} / \mathrm{l}$ or less. So far, no use has been made of the heat from these well waters, but those wells reporting the higher temperatures would certainly have potential to provide space heating.

Three spring areas, Ogden, Utah, and Hooper Hot Springs, yield highly saline water of $57^{\circ}$ to $60^{\circ} \mathrm{C}$ and another, Southwest Hooper Warm Springs, yields brine at about $32^{\circ} \mathrm{C}$. The water from Utah Hot Springs is used to heat nearby buildings (Mundorff, 1970, p. 29); the water from the other springs is unused. The discharge of Ogden Hot Springs has been reported as 35 to $100 \mathrm{gpm}$, but the discharges of the other springs have not been reported. The waters from all these springs probably could be used for space heating.

\section{GEOLOGIC and HYDROLOGIC ENVIRONMENT}

The East Shore Area, like other areas along the Wasatch Front, is a structural graben whose eastern side is marked by the Wasatch fault and by the scarps along the face of the mountains. The western side is probably marked by buried faults east of Little Mountain and Antelope Island. Feth and others (1966, p. 26) say "that in general the bedrock surface (of the graben) is in the shape of an elongated trough, the deepest part of which is in the eastcentral part of T.6 N., R.2 W., about 3 miles north of the Ogden Municipal Airport and about 5 miles west of the Wasatch front. The gravity anomalies indicate that the unconsolidated or poorly consolidated rock in the trough has a maximum thickness of 6,000 - 9,000 feet." South of this area is another elongate gravity low that Cook and Berg (1961, p. 79) describe as the Farmington graben where "the thickness of the valley fill... is unknown..but exceeds 3500 feet." 


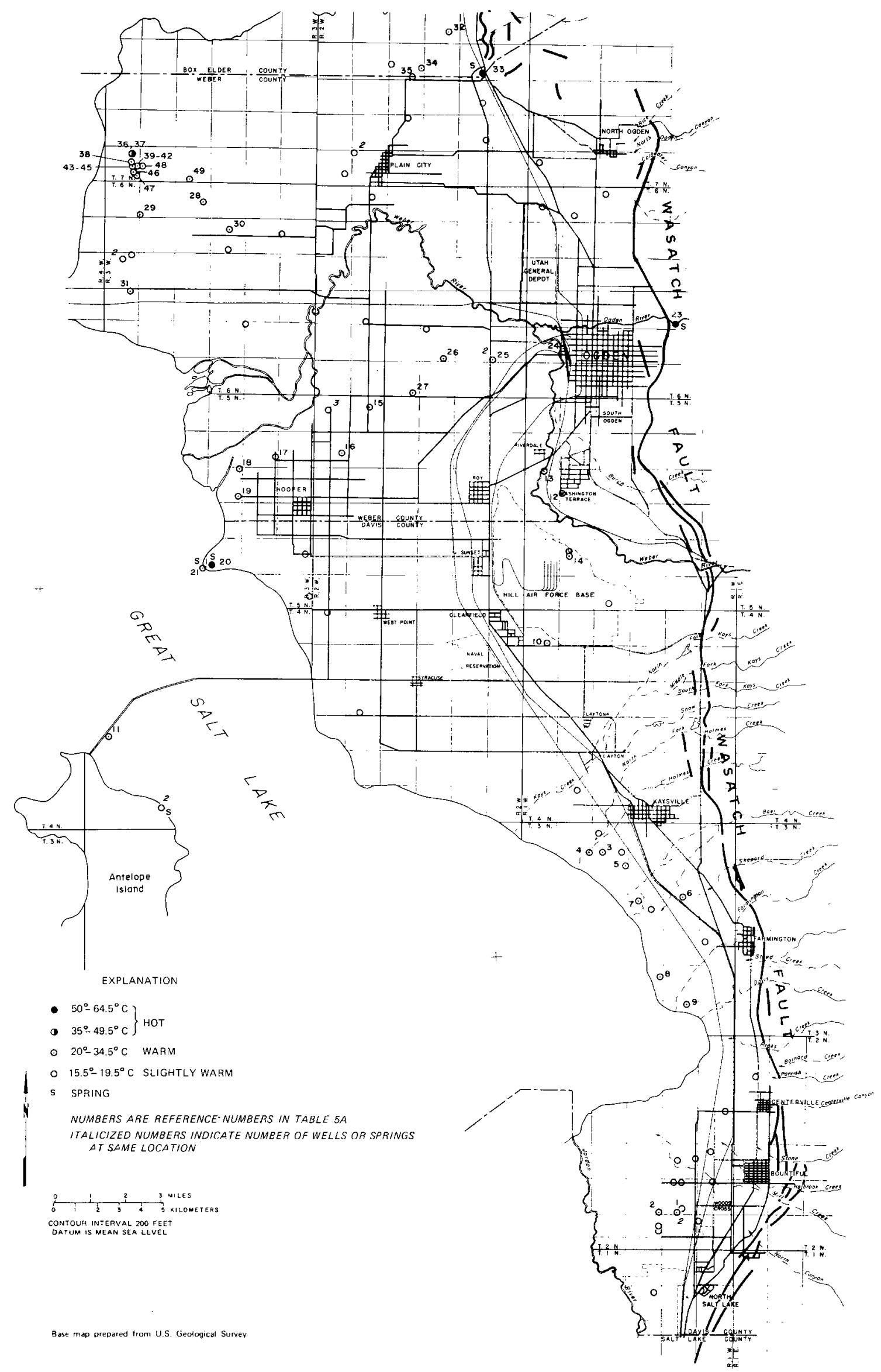

Figure 3. Map of East Shore Area showing thermal wells and springs. 
The valley fill consists of detritus derived from the nearby Wasatch and from the Uinta Mountains to the east, and brought into the valley principally by the Weber and Ogden Rivers. During the high cycles of Lake Bonneville the rivers formed huge deltas that make up the bulk of the near-surface deposits, which today near the mountains provide relief of nearly a thousand feet above the flat lake plain near the shore of Great Salt Lake.

The character of the deep sediments in the valley fill is not known, but they are probably similar to the intertonguing alluvial and lacustrine deposits that make up the upper 1200 feet. These deposits are gravel and sand near the mountain front and largely sand, silt, and clay in the lower parts of the valley. Eiven the delta deposits laid down in Lake Bonneville have large proportions of silt and clay because the outflows from the Weber and Ogden Rivers traveled through estuaries before they reached the mountain front.

The unconsolidated deposits form extensive aquifers that are largely artesian so that there is a constant tendency toward upward movement of water. The widespread lacustrine clay beds that act as confining layers inhibit this tendency, but undoubtedly some upward movement occurs. Whether or not the hydraulic environment promotes the upward transfer of heat is not known, but only 6 of the 137 wells for which temperatures have been reported (Bolke and Waddell, 1972, p. 40-51) show temperatures as low as $11^{\circ}$, which is about the mean annual air temperature. In addition to the 45 wells that have temperatures of $20^{\circ}$ or higher and are discussed in the section on occurrences of warm and hot water, about 60 wells report temperatures of $15^{\circ}$ to $19^{\circ}$ and about 25 others temperatures of $12^{\circ}$ to $14^{\circ}$.

OCCURRENCES and CONTROL Of WARM and HOT WATER

About 6 miles west of Plain City 14 wells (table 5-A) that range in depth from 399 to 806 feet yield water of good quality (260 to $531 \mathrm{mg} / \mathrm{l}$ dissolved solids) at temperatures from $21^{\circ}$ to $39^{\circ} \mathrm{C}$ (Bolke and Waddell, 1972, plate 3). Another well in the same cluster reaches bedrock at 920 feet and produces $38^{\circ}$ water of poorer quality ( $980 \mathrm{mg} / 1$ dissolved solids). For a full discussion of the findings of Bolke and Waddell the reader is referred to their report, Technical Publication No. 35, p. 16, but, briefly, they concluded that in that area there are "at least four distinct water-bearing zones...delineated on the basis of drillers' logs and water quality, water temperature, and water-level data obtained from 12 wells perforated at various depths." They further say that "the source of heat causing the abnormally high ground-water temperatures is unknown, but it may be an underlying hot body or warm water that is moving upward along a fault." However, because the water in the upper zones is not highly saline as is water of $32^{\circ}$ to $60^{\circ}$ that comes from Hooper Springs about 11 miles south, they believe that "the higher than normal temperatures probably result from conductive vertical heat transfer rather than from mixing with warm saline water." The higher silica content, $67 \mathrm{mg} / \mathrm{l}$, of the water from the 920-foot well may indicate that some mixing occurs at about 900 feet.

Thirteen of the wells mentioned above were drilled by Great Salt Lake Minerals and Chemicals Corp. to obtain hot process water of $82^{\circ} \mathrm{C}$ or higher for their plant at Little Mountain.

Two highly saline springs, Hooper Hot Springs and Southwest Hooper Warm Springs, on the shore of Great Salt Lake about 2 miles southwest of Hooper, yield water of $60^{\circ}$ and $32^{\circ}$. This hot and warm water is probably rising along the same fault that is believed to supply the heat for the GSLM\&C Corp. wells mentioned above. (The geologic map of Feth and others (1966) shows a N-S trending fault that goes through Hooper Springs and extends nearly to the vicinity of GSLM\&C Corp. wells. ) 
Two other hot springs, Ogden and Utah Hot Springs, have been mentioned in many reports, probably the first of which was Hayden's (1871, p. 175) observation on the spring near the mouth of Ogden Canyon, for which he reported a temperature of $121^{\mathrm{O}} \mathrm{F}\left(49.5^{\circ} \mathrm{C}\right)$. Most authors assign the geothermal gradient as the source of the heat for these springs, both of which are on major faults (see discussion on springs along the Wasatch fault zone), but Pack (Pack and Carrington, 1921, p. 26-27) contended that, except in volcanic areas, surface waters cannot descend to depths great enough to supply hot springs, and therefore "most of such springs have their origin at very great depths, in other words, that the water issuing from them is coming to the surface for the first time... and is, therefore, known as 'magmatic' water."

In addition to the wells of Great Salt Lake Minerals and Chemicals Corp. and the warm and hot springs mentioned above, 30 wells whose depths range from less than 200 to about 1000 feet report temperatures of $20^{\circ}$ to $25^{\circ} \mathrm{C}$ and one well in the Farmington Bay Refuge, 1220 feet deep, reports temperatures as high as $33^{\circ} \mathrm{C}$. These wells generally seem to have a random distribution from Bountiful on the south nearly to Willard and from Ogden on the east to Antelope Island. The only pattern that can be discerned in their distribution is formed by the group of nine wells that stretches southwestward from Ogden to Hooper. Parallel to and partly coincident with this band of wells, Feth and others (1966, plate 3), show a band where the content of silt and clay below 200 feet is less ( 20 to $40 \%$ and 40 to $60 \%$ ) than it is in adjacent areas (60-80\%). The same map also suggests, although its coverage doesn't quite extend to that area, that the GSLM\&C Corp. wells may be in an area where the subsurface sediments are slightly coarser (less than 40\% silt and clay) than the surrounding sediments (40-60\%). The connection between higher temperature and coarser texture, if indeed there is a connection, does not seem to occur in other areas where Feth and others have mapped low silt and clay contents.

\section{Cited References}

Berge, C.W., G.W. Crosby, and R.C. Lenzer, 1976, Geothermal exploration of Roosevelt KGRA, Utah (abs.): Rocky Mtn. Section, AAPG and SEPM 25th Ann. Mtg., Billings Montana, Program, p. 52-53.

Bolke, E.L., and K.M. Waddel, 1972, Ground water conditions in the East Shore area, Box Elder, Davis, and Weber Counties, Utah 1960-1969: Utah Dept. Nat. Resources Tech. Pub. No. 35, $53 \mathrm{p}$.

Bureau of Economic and Business Research, 1969, Statistical abstract of Utah: University of Utah, $231 \mathrm{p}$.

Cook, K.L., and J.W. Berg, Jr., 1961, Regional gravity survey along the central and southern Wasatch Front, Utah: U.S. Geol. Survey Prof. Paper 316E, p.75-89.

Feth, J.H., D.A. Barker, L.C. Moore, R.J. Brown, and C.E. Veirs, 1966, Lake Bonneville: Geology and hydrology of the Weber Delta district, including Ogden, Utah: U.S. Geol. Survey Prof. Paper 518, 76 p.

Greider, B. 1976, Geothermal energy, Cordilleran hingeline-West, in Hill, J.G., ed., Geology of the Cordilleran hingeline: Denver, Rocky Mtn. Assn. Geologists, p. $351-362$.

Hayden, F.V., 1871, Preliminary report (fourth annual) of the United States Geological Survey of Wyoming and portions of contiguous Territories, $511 \mathrm{p}$. 
Mundorff, J.C., 1970, Major thermal springs of Utah: Utah Geol. and Mineralog. Survey, Water-Resources Bull. 13, 60 p.

Pack, F.J., and A.C. Carrington, 1921, Geologic and economic resources, Weber County, Utah: University of Utah Bull. v. 11, no. 19, 61 p.

Smith, R.E., 1961, Records and water-level measurements of selected wells and chemical analyses of ground water, East Shore area, Davis, Weber, and Box Elder Counties, Utah: U.S. Geol. Survey Basic-Data Report No. 1, 35 p.

Thomas, H.E., W.B. Nelson, 1948, Ground water in the East Shore area, Utah: Part I, Bountiful district, Davis County: Utah State Engineer Tech. Pub. No.5, 152 p.

\section{Escalante Desert}

\section{INTRODUCTION}

The Escalante Desert occupies about 400 square miles in Iron and Washington Counties about 25 miles west and northwest of Cedar City. The principal comulnities are Enterprise, Newcastle, and Modena, with Beryl Junction in a cross-roads community near the center of the area. The economy depends on agriculture, which in turn depends on nearly 80,000 acre-feet of ground water for irrigation each year (Sandberg, 1977, p. 14).

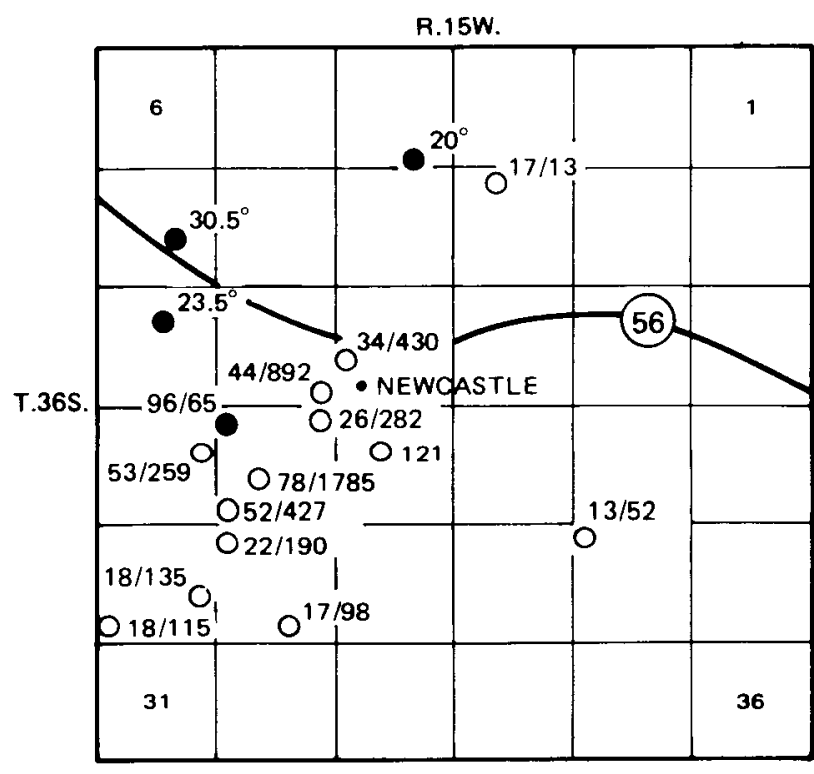

$$
0^{16 / 79}
$$

Figure 4 - Map of Newcastle area showing geothermal test holes (Rush, 1977).

- water well with temperature

o geothermal test well

34/430 temperature at

about 100 feet ${ }_{\mathrm{C}}^{\mathrm{C}}$ per kilometer 
SUMMARY Of OCCURRENCES and POTENTIAL fOr USE

In the Newcastle area, one well ( $\mathrm{C}-36-15) 20 \mathrm{bbd}$, has produced boiling water, and three others have yielded warm water of $20^{\circ}$ to $31^{\circ} \mathrm{C}$ (table 6). Rush (1977) measured temperatures on 15 wells in the vicinity of Newcastle and I have plotted those wells on figure 4. Also shown are temperatures at about 100 feet and the geothermal gradient in each well. The ultimate potential of this area is not known but the waters are satisfactory for irrigation and certainly could be used for greenhouses or space heating.

Near Beryl, a geothermal test wêll, drilled to a depth of 12,295 feet between April 8 and July 15, 1976, yielded a flow of 1000 gpm from a depth of 7000 feet. This water was at a temperature of $149^{\circ} \mathrm{C}$ and contained less than $4000 \mathrm{ppm}$ dissolved solids. Although the temperature is too low for efficient production of electricity (Val Finlayson, Utah Power \& Light Co. pers. commun. 1978) such a yield without pumping should be useful for crop processing.

\section{GEOLOGIC and HYDROLOGIC ENVIRONMENT}

The hills and low mountains that nearly surround the Escalante Desert are composed principally of Tertiary volcanic rocks with a few exposures of Cretaceous and Tertiary sedimentary rocks south and southwest of Newcastle. Crosby (1973, p. 31) has interpreted the Escalante Desert as a probable caldera. "The eastern rim of this probable caldera is downfaulted and covered by valley fill deposits of the Escalante Desert." The generally circular shape of this desert and the annular drainage of Shoal Creek west of Enterprise support the caldera hypothesis.

The desert itself is one of the most highly developed ground-water basins in Utah. Pumpage in the Beryl-Enterprise district has risen from about 50,000 acre-feet per year in the 1950's to nearly 80,000 acre-feet in the 1970's. (Sandberg, 1977, p. 57). Although there are no firm estimates of recharge to the ground-water reservoir, it has been generally believed that most of the water pumped comes from storage. Between 1950 and 1977 the water level in an observation well, (c-35-17)25ded, in the area of high pumping, declined about 40 feet (Sandberg, 1977, p. 57). Much of this period, 1950 to 1964, was also a period of lower-than-normal precipitation, so the lowering of the water levels in response to pumpage from storage is hardly excessive.

OCCURRENCES Of HOT and WARM WATER

Hot water of $149^{\circ}$ and $95.5^{\circ} \mathrm{C}$ has been reported from a depth of 7000 feet in a 12,295-ft-deep geothermal-test well about 4 miles southwest of the Beryl siding on the Union Pacific Railroad and from a 500-foot-deep water well near Newcastle (table 5). The geothermal-test well flowed $1000 \mathrm{gpm}$ and the water contained less than 4000 ppm dissolved solids (Val Finlayson, pers. comm. 1978). Ten other wells in the Newcastle area produce water at temperatures ranging from $20^{\circ}$ to $78^{\circ} \mathrm{C}$ (fig. 4). Eleven other wells, six near Newcastle, four west of the main Beryl-Enterprise pumping area, and one about 12 miles southeast of Lund, yield slightly warm water of $15.5^{\circ}$ to $19^{\circ} \mathrm{C}$.

The temperature of the water from the geothermal test well was lower than $260^{\circ}$ that Utah Power and Light Co. required for generating electricity but a free flow of $1000 \mathrm{gpm}$ at $149^{\circ} \mathrm{C}$ should make the water valuable for crop processing. Although Sandberg in $1966(\mathrm{p} .34)$ said that local residents reported hot water near Newcastle, it wasn't until the Christensen Bros. well was drilled in December 1975 that boiling water was encountered (Rush, 1978, written commun.). Rush reports 
a temperature log was run on January 20, 1976 after the well had been idle for several weeks. That log shows a hot-water aquifer between depths of 230 and 360 feet.

Rush (1978, written commun.) computed the "reservoir temperature of the hydrothermal system to be $117^{\circ} \mathrm{C}$ and $293^{\circ} \mathrm{C}$, using two geothermometers. The difference in estimates may result from either the mixing of thermal and nonthermal water or to misapplication of a geothermometer. If the higher temperature is valid, this would be a very hot hydrothermal reservoir. The depth of groundwater circulation to produce this upper limit without a shallow heat source would be about $7 \mathrm{~km}$ (23,000 feet) computed on the basis of a regional heat flow of 2 HFU" (heat flow units).

Crosby's map (1973, p. 28) shows a northeast-trending (buried?) normal fault very close to the Christensen well. Probably the hot water rises along the fault up to a confined permeable bed which permits it to move laterally.

only further exploration can determine the potential of the Newcastle area as a source of geothermal energy, but meanwhile the hot water in the area of the Christensen well is of good enough quality for irrigation and it is certainly hot enough for use in greenhouses or for space heating.

\section{Cited References}

Crosby, G.W., 1973, Regional structure in southwestern Utah in Geology of the Milford Area, 1973, Utah Geol. Assn. Pub. 3, p. 27-32.

Rush, F.E., 1977, Subsurface temperature data for some wells in western Utah: U.S. Geol. Survey Open-File Rept. 77-132, 36 p.

Sandberg, G. W., 1963, Ground-water data, Beaver, Escalante, Cedar City, and Parowan Valleys, parts of Washington, Iron, Beaver, and Millard Counties, Utah: U.S. Geol. Survey Basin-Data Report No. 6, 26 p.

, 1966, Ground-water resources of selected basins in southwestern Utah: Utah State Engineer Tech. Pub. No. 13, 43 p.

, 1977, Beryl-Enterprise area, in Bolke, E.L., and others, Groundwater conditions in Utah, Spring of 1977: Utah Dept. Nat. Resources Coop. Inv. Rept. No. 16, p. 14 and 56-58.

\section{Escalante Valley}

\section{INTRODUCTION}

Escalante Valley is in eastern Millard, Beaver, and Iron Counties. The Milford pumping district within the valley is one of the most heavily irrigated areas in Utah: from 1966 to 1975 irrigators pumped an average of 55,000 acrefeet of water each year; in 1976 they pumped 65,000 acre-feet. The valley is also the locale of two Known Geothermal Resource Areas (KGRA), Roosevelt and Thermo Hot Springs. 
SUMMARY of OCCURRENCES and POTENTIAL for USE

Roosevelt Hot Springs and Thermo Hot Springs have been designated as KGRAs, and the extensive continuing exploration at Roosevelt strongly suggests that at least that area has potential to produce electricity, perhaps as much as $300 \mathrm{MW}$ (megawatts). The potential at Thermo has yet to be tested.

Dotsons Warm Springs are warm enough $\left(36^{\circ} \mathrm{C}\right)$ and of satisfactory chemical quality to be used in swimming pools or greenhouses.

GEOLOGIC and HYDROLOGIC ENVIRONMENT

The mountains that essentially surround the Escalante Valley are geologically complex, and it can be presumed that the bedrock that underlies the valley fill of alluvium and lake deposits also is complex. Crosby (1973, p. 27-32) has described some of the structural complexities in more detail than will be covered here.

To the east are the Mineral Mountains which consist largely of a Tertiary granite "plutgn, which is the largest exposed intrusive body in Utah, covering nearly $150 \mathrm{~km}^{2}$ (Lipman and others, 1978, p. 134). The center of the range was also the site of extensive Pleistocene volcanic activity including rhyolite domes, obsidian-rich lava flows, and pyroclastics of ash-flow tuffs. "Potassium argon ages indicate that all the rhyolite of the Mineral Mountains was erupted between 0.8 and $0.5 \mathrm{~m} . \mathrm{y}$.ago" (Lipman and others, 1978, p. 133). The Roosevelt KGRA is on a north-south fault along the west flank of the Mineral Mountains and probably was affected by the Pleistocene volcanism.

To the west are the San Francisco Mountains consisting of Precambrian and Paleozoic rocks, largely metamorphosed, and Tertiary volcanics. To the southeast, also, are extensive Tertiary volcanics.

The mountain blocks are separated from the valley by fault zones that are largely hidden by overlying alluvium.

The valley fill consists of alluvium derived from the flanking mountains and brought in by the Beaver River, and lake deposits laid down in Pleistocene Lake Bonneville. The intertonguing of coarse-grained deposits of high permeability with fine-grained deposits of low permeability has resulted in three zones of high permeability separated by three zones of low permeability. The zones of high permeability make up the principal aquifer, which Mower and Cordova (1974, p.1) estimate to be as much as 840 feet thick.

Because of the high pumpage in the valley, the estimated discharge of 81,000 acre-feet exceeds the estimated recharge of 58,000 acre-feet, and has resulted not only in lowering water levels by as much as 30 feet since 1950, but also in compaction of the valley fill and subsidence of the land surface in an area about 1 mile wide and 11 miles long south of Milford (Mower and Cordova, 1974, p. 1-2).

OCCURRENCE Of HOT and WARM WATER

Two hot springs, Roosevelt and Thermo, and one warm spring, Dodsons (Radium) (table 7-A), have been discussed rather extensively by Mundorff (1970) and I shall include his descriptions below. Since Mundorff completed his study, several workers have studied the Roosevelt area, among them Petersen (1973, 1974, 1975a, $1975 \mathrm{~b}$ ), who computed a $\mathrm{Na}-\mathrm{K}-\mathrm{Ca}$ reservoir temperature of $292^{\circ}$ to $298^{\circ} \mathrm{C}$, Rush ( 1978 , written commun.), and Iipman and others (1978), and there has been extensive drilling. "Phillips Petroleum Co., the successful bidder on the KGRA in 1974, is continuing exploration on the property. Nunerous test wells so far drilled in the KGRA have documented the presence of a low-salinity liquid dominated geothermal system (Berge, Crosby, and Lenzer, 1976; Greider, 1976). The thermal anomaly covers approxi- 
mately $32 \mathrm{~km}^{2}$, and reservoir temperatures exceed $250^{\circ} \mathrm{C} "$ (Lipman and others, 1978, p. 134). Rush (1978, written commun.) says the "reservoir temperature is equal to or greater than $260^{\circ} \mathrm{C}$. A recent report on the area (Ward and others, 1978) says that 7 productive wells and 4 "dry holes" have been drilled in the Roosevelt area (in T.26 and 27S., R.9 W.) and the highest temperature recorded was $269^{\circ} \mathrm{C}$. The authors further make "a conservative estimate of $10 \mathrm{~km}^{2}$ for the size of the region that may be brought into production. This area will support about 60 production wells ( 1 well per 40 acres) which at $5 \mathrm{MN} /$ well will yield $300 \mathrm{MW}$ (megawatts) electricity" ( $p, 1538)$.

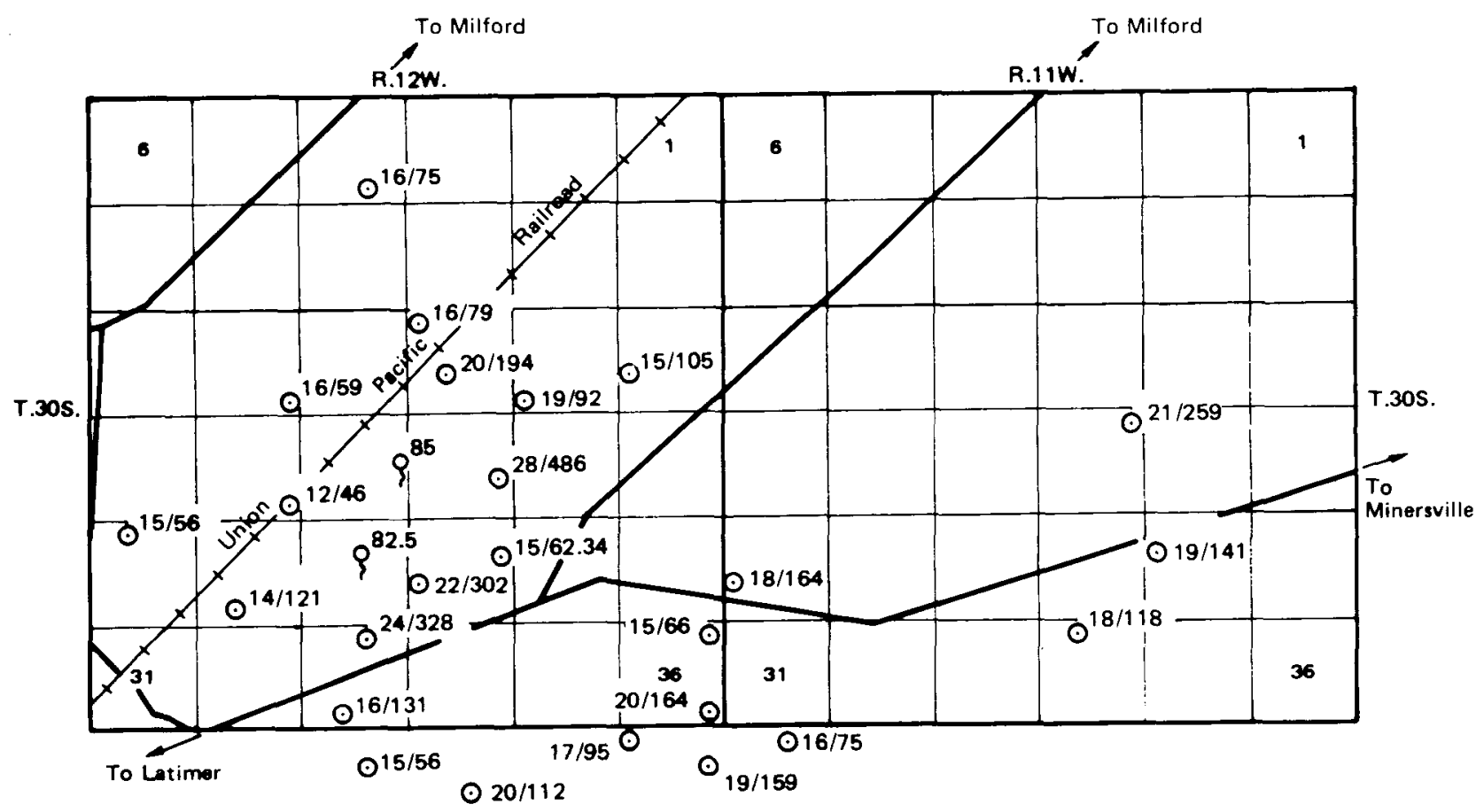

Figure 5 - Map of Thermo area showing geothermal test holes (Rush, 1977).

Q spring with temperature

$\odot$ geothermal test we11

16/75 temperature at $/ o_{\mathrm{C}}^{\text {gradient in }}$
about 100 feet

Rush (1978, written commun.) also studied the Thermo area and concluded that, the hydrothermal reservoir is less than $4 \mathrm{~km}$ deep and has a temperature "equal to or less than $200^{\circ} \mathrm{C} . "$ The holes that Rush used for his temperature measurements are shown on figure 5; also shown are temperatures at depth of 100 feet in each hole and the computed geothermal gradients.

In addition to the springs mentioned above, warm water at $21^{\circ}$ to $33^{\circ} \mathrm{C}$ also occurs in three springs in the volcanics south of Minersville, in Salt Spring about one-quarter mile northwest of Roosevelt Hot Spring, and in Woodhouse Spring about 10 miles southwest of Milford. 
About six wells near Milford and two wells southwest of Minersville yield water of $20^{\circ}$ to $27^{\circ} \mathrm{C}$. The Minersville town well drilled near Dotsons Spring yields water at $33.5^{\circ} \mathrm{C}$ that is essentially identical in chemical quality to the water from Dotsons Spring.

The follwing excerpts from Mundorff (1970, p. 42-43) give: his interpretations of Dotsons Warm Springs and Thermo and Roosevelt Hot Springs.

Roosevelt (McKeans) Hot Springs

Roosevelt (McKeans) Hot Springs, (C-26-9)34dcb-S1, are in Beaver County, about 12 miles northeast of Milford and about 20 miles northwest of Beaver. Lee $(1908$, p. 20) reported that the largest of the springs in Roosevelt Hot Springs had a discharge of about $10 \mathrm{gpm}$, and that the temperature at the pipe leading from the spring was $190^{\circ} \mathrm{F}$. He also stated that much of the silica contained in solution as the boiling water issued from the rocks was deposited as the water cooled. U. S. Geological Survey personnel reported a discharge of $1 \mathrm{gpm}$ and a temperature of $185^{\circ} \mathrm{F}$ in November 1950 and reported a temperature of $131^{\circ} \mathrm{F}$ in September 1957. In May 1966 the spring was dry and appeared not to have discharged for several years.

Intrusive rocks of Tertiary age crop out immediately east of the former springs, and volcanic rocks of late Tertiary age crop out less than two miles southeast of the springs (figure 18). The springs issued from a fault zone along the west side of the Mineral Mountains. The heating of the water, probably of meteoric origin, may have been caused by contact with volcanic rocks or by an abnormally high geothermal gradient in the area where both intrusive and extrusive rocks of Tertiary age are common.

Lee (1908, p. 20 and 50) reported a dissolvedsolids content of only $645 \mathrm{ppm}$ and a discharge of $10 \mathrm{gpm}$. In 1950 the dissolved-solids content was $7,040 \mathrm{ppm}$ at a measured discharge of $1 \mathrm{gpm}$. In 1957 the dissolved-solids content was $7,800 \mathrm{ppm}$. Lee's data show that the water was of the sodium sulfate chloride type; silica concentration (101 ppm) exceeded that of any single ion. In 1950 and 1957, the highly mineralized water was sodium chloride in type; silica content was very high (405 and 313 ppm). The analysis of a sample obtained in 1957 shows fairly high concentrations of boron and fluoride. The source of the dissolved solids is not known. If Lee's data are reliable, the spring discharge showed about a tenfold increase in dissolved-solids content with a tenfold decrease in discharge during a 50-year period. Lee (1908, p. 20) states that "the water contains a large amount of mineral in solution, as shown by the analysis in table 9"; but the data in table 9 of Lee's report do not show an especially "large amount of mineral in solution."
The very high silica concentrations indicate a possibility of marked increase in temperature with depth: The lack of spring flow during the past 10 years and the lack of information on the possible presence of a reservoir rock indicate that the geothermal potential of the area can be evaluated only by intensive: subsurface exploration.

\section{Radium (Dotsons) Warm Springs}

Radium (Dotsons) Warm Springs, (C-30-9) 7aca-S1, issue from a seepage zone about 300 feet long: along the south bank of the Beaver River about one mile east of Minersville in Beaver County. The springs issue from alluvium, but the source of the water probably is the faulted sedimentary rocks of Paleozoic age immediately northeast of the springs. Large areas of pyroclastic rocks of late Tertiary age are within one mile of the springs (figure 18).

Lee $(1908$, p. 21$)$ reported that the discharge of the springs was $57 \mathrm{gpm}$ and the temperature of the water was $97^{\circ}$ F. On July 11, 1967, U. S. Geological Survey personnel measured a water temperature of $89^{\circ} \mathrm{F}$ and estimated that the total discharge from the spring zone was $100 \mathrm{gpm}$.

Chemical data obtained during 1963-67 show that the dissolved-solids content ranged from 956 to $1,020 \mathrm{ppm}$, that the water was of the sodium calcium sulfate type, that fluoride concentrations were moderately high, and that silica concentrations were low.

The altitude of the faulted mountains within a few miles of the springs is 2,000-3,000 feet higher than that of the springs. The presence of volcanic rocks of late Tertiary age in the vicinity of the springs suggests that the source of heat may be either volcanic or an abnormally high geothermal gradient in the zone of faulted sedimentary rocks adjacent to the volcanics. The spring discharge undoubtedly is meteoric water that infiltrates the faulted or porous rocks at higher altitudes a few miles from the springs; the water descends 2,000-3,000 feet through these rocks, is warmed, and issues along a fault zone in the immediate vicinity of the springs.

Thermo Hot Springs

Gilbert (in Howell, 1875, p. 257) stated that "Another group of hot springs, ... is located... sixteen miles west of Minersville [Beaver County]. 
These springs, [(C-30-12)21-S and (C-30-12)28-S], are situated in the open desert, on two parallel ridges having a north and south trend, placed en echelon, about twenty rods apart, each eight or ten rods in width and 20 feet high, with a total length of about one and a half miles. These ridges have been formed mainly by the drifting sand, held together by the moisture and consequent vegetation, as no sinter nor tufa seems to be deposited by the springs. The highest temperature noted was $185^{\circ}[\mathrm{F}] . "$ In contrast to Gilbert's report of sand ridges and the absence of tufa, Lee $(1908$, p. 22) reported that "The springs occur in two conspicuous mounds built up from the surface of the plain by silica deposited from the spring waters." U. S. Geological Survey personnel reported in July 1967 that the springs issue along the sides and top of calcareous travertine mounds. The southern mound, which has the most active spring, is about half a mile long, 200-250 feet wide, and 10-20 feet higher than the desert floor. The southern mound is mainly clay covered and has travertine along the sides. The hottest spring was on the south mound and had a temperature of $170^{\circ} \mathrm{F}$. The, two sets of observations, which were made nearly a century apart, indicate that the sand ridges observed by Gilbert have become partly indurated by calcium carbonate or silica that precipitated from the spring water. The observations of Lee (1908), however, indi- cate that appreciable chemical precipitation must have occurred by 1908. Perhaps older travertine deposits had been buried by drifting sand shortly before Gilbert's observations.

The springs issue from the alluvium in Escalante Valley, but the source of the water probably is rainfall on the faulted mountains northwest or southeast of the springs. A fault buried beneath the alluvium may control the location of the springs. Volcanic rocks of late Tertiary age crop out in the mountains within a few miles south of the springs (figure 18). The source of the heat probably is an abnormally high geothermal gradient that results from late Tertiary volcanism.

The dissolved-solids content of the water ranged from 1,470 to $1,500 \mathrm{ppm}$. The water is sodium sulfate in type although both bicarbonate and chloride anions are present in significant amounts. Silica concentration was fairly high-100 to $108 \mathrm{ppm}$. Results of spectrographic analyses were somewhat erratic; one sample showed unusual concentrations of aluminum, copper, and lead, but another sample obtained a year later at the same spring showed nothing unusual.

Discharge from the entire spring area was estimated to be about $200 \mathrm{gpm}$ in July 1967.

\section{Cited References}

Crosby, G.W., 1973, Regional structure in southwestern Utah in Geology of the Milford Area, Utah Geol. Assn. Pub. 3, p. 27-32.

Howell, E.E., 1875, Report on the geology of portions of Utah, Nevada, Arizona, and New Mexico, examined in the years 1872 and 1873 in Report upon geographical and geological explorations and surveys west of the $\overline{100 t h}$ Meridian, v. 3(3) (Wheeler): Washington, U.S. Govt. Printing Office, p. 256-257.

Lee, W.T., 1908, Water resources of Beaver Valley, Utah: U.S. Geol. Survey WaterSupply Paper 217, $57 \mathrm{p}$.

Lipman, P.W., P.D. Rowley, H.H. Menert, S.H. Evans, Jr., W.P. Nash, and F.H. Brown, 1978, Pleistocene rhyolite of the Mineral Mountains, Utah - geothermal and archeological significance, with sections by G.A. Izett and C.W. Naeser and by Irving Friedman: U.S. Geol. Survey Jour. Research, v.6, no.1, p. 133-147.

Mower, R.W., and R.M. Cordova, 1974, Water resources of the Milford area, Utah, with emphasis on ground water: Utah Dept. Nat. Resources Tech. Pub. No. 43,99 p.

Mundorff, J.C., 1970, Major thermal springs of Utah: Utah Geol. and Mineralog. Survey, Water-Resources Bull. 13, $60 \mathrm{p}$.

Petersen, C.A., 1973, Roosevelt and Thermo Hot Springs, Beaver County, Utah: Utah Geol. Assn. Pub. 3, p. 73-74. 
Petersen, C.A., 1974, Summary of Stratigraphy in the Mineral Range, Beaver and Millard Counties, Utah: Utah Geology, v. 1, p. 45-54.

, 1975a, Geology and goethermal potential of the Roosevelt Hot Springs area, Beaver County, Utah: Unpublished M.S. Thesis, Univ. of Utah, 50 p.

, 1975b, Geology of the Roosevelt Hot Springs area, Beaver County, Utah: Uta.h Geology, v.2, no.2, p. 109-116.

Rush, F.E., 1977, Subsurface temperature data for some wells in western Utah: U.S. Geol. Survey Open-File Rept. 77-132, 36 D.

Sandberg, G.W., 1963, Ground-water data, Beaver, Escalante, Cedar City, and Parowan Valleys, parts of Washington, Iron, Beaver, and Millard Counties, Utah:

U.S. Geol. Survey Basic-Data Report No. 6, 26 p.

Ward, S.H., W.T. Parry, W.P. Nash, W.R. Sill, K.L. Cook, R.B. Smith, D.S. Chapman, F.H. Brown, J.A. Whelan, and J.R. Bowman, 1978, A summary of the geology, geochemistry, and geophysics of the Roosevelt Hot Springs thermal area, Utah: Geophysics, v. 43, p. 1515-1542.

\section{Fish Springs Group}

"The Fish Springs group is in Juab and Tooele Counties, about 55 miles northwest of Delta" (Mundorff, 1970, p.27). The springs rise from three general areas at the north end and northeast flank of the Fish Springs Range (see Table 8). Wilsons Hot (Health) Springs are principally in section 33, T.10 S., R.14 W., in Tooele County. Big Spring (North Springs) is in Juab County about a mile to the southeast of Wilsons Hot Spring at (C-11-14)3d, and Fish Springs are about 3 miles south of Big Spring in the eastern halves of sections 23 and 26, T.11 S., R.14 W.

The working "Wilson Health Springs" on the Fish Springs NW quadrangle and Meinzer's reference to a bathhouse (1911, p. 125) indicate that at one time a resort existed at the hot springs, but Mundorff does not mention it so it probably no. longer exists.

Mundorff's (1970, p. 37) interpretation of the group is given here:

Wilson Hot Springs consist of several springs that issue along a northeast-trending line that extends ahout half a mile into the Great Salt Lake Desert from the base of the Fish Springs Range. The springs issue from soft 1 ufa mounds formed on valley fill of Quaternary age. The springs probably rise along a fault buried beneath the valley fill. Fish Springs Rangc, which is composed of faulted sedimentary rocks of Paleozoic age (figure 15). extends southward from Wilson Hot Springs and has altitudes more than 4.000 feet higher than those of the springs along the noutheast base of the mountains. In July 1967, the iemperature of the hottest measured spring in the group was $141^{\circ} \mathrm{F}$ at the edge of the pool and $168^{\circ}$ $F$ in the center of the pool: the estimated discharge was $100 \mathrm{gpm}$. The dissolved-solids content of these springs, which issue at the southern margin of Great Sialt Like Desert. is about 22,000 ppm; about 83 percent of the dissolved solids. by weight, is sodium chloride.
The discharge of Wilson Hot Springs probably is meleoric water that has circulated to depths of several thousand feet through the fault system of the Fish Springs Range. As the heated water moves up through highly saline lakebed sediments, either large quantities of salts are dissolved or relatively dilute hot water mixes with concentrated interstitial brines of the sediments. If a geothermal gradient of $1^{\circ} \mathrm{F}$ for cach 100 feet of depth is assumed, circulation to it depth of about two miles would be required if the water does not cool as it moves upward and does not mix with cool shallow water. In this area, however, the geothermal gradient may be abnormally high. Volcanic rocks of late Tertiary age crop out about eight miles southeast and about 10 miles southwest of the springs, and a large intrusive igneous body of late Tertiary age crops out about 15 miles northeast of the springs. Although these igncolis rocks probabiy are not the direct source of the heat. they may indicate the possibility that the geothermal 
gradient is as high as $1^{\circ} \mathrm{F}$ for each 50 feet or less of depth in the area surrounding the springs.

Both Big Spring, (C.11-14)3-S, and Fish Springs, (C-11-14)23-26.S, appear to be associated with the same fault zone, but not necessarily the same fault, that results in Wilson Hot Springs. The discharges of Big and Fish Springs have much lower temperatures than those for Wilson Hot Springs. Temperatures of these two springs range from about $65^{\circ}$ to $82^{\circ} \mathrm{F}$, and the dissolved-solids content is about 1,800 ppm for Fish Springs. The water is of the sodium chloride type; only about 60 percent of the dissolved solids, by weight, is sodium chloride compared to about 83 percent sodium chloride in Widson Hot Springs. The total discharge of all springs in the Fish Springs group probably varies from less than $40 \mathrm{cfs}$ to mure than $60 \mathrm{cfs}$ seasonally and from year to year. The relatively low temperature and dissolved-solids content of Fish Springs indicate that the water does not circulate to great depths and that the water does not have appreciable exposure to a saline environment, as compared to the water issuing from Wilson Hot Springs.

The discharge from Big Spring and the many Fish Springs supplies water to the Fish Springs National Wildlife Refuge where there are extensive pools and marshy areas that are inhabited by waterfowl.

\section{Cited References}

Meinzer, O. E., 1911, Ground water in Juab, Millard, and Iron Counties, Utah: U.S. Geol. Survey Water-Supply Paper 277, 162 p.

Mundorff, J. C., 1970, Major thermal springs of Utah: Utah Geol. and Mineralog. Survey Water-Resources Bul1. 13, $60 \mathrm{p}$.

\section{Grouse Creek Valley}

Grouse Creek Valley is in Box Elder County near the northwest corner of Utah. Grouse Creek and its drainage basin include about 430 square miles. Probably fewer than 500 people live in the valley, most of them in Grouse Creek and Etna (Hood and Price, 1970, p. 3).

A hot spring $\left(42^{\circ} \mathrm{C}\right.$ ) that yields $225 \mathrm{gpm}$ of fresh water ( $248 \mathrm{mg} / \mathrm{l}$ dissolved solids) from Paleozoic rocks in the valley of Death Creek and a warm spring $\left(20^{\circ} \mathrm{C}\right)$ that yields $215 \mathrm{gpm}$ of fresh water $(304 \mathrm{mg} / \mathrm{l})$ from volcanic rocks near Kimber Ranch are the only thermal springs in Grouse Creek Valley (Table 9). The hot spring may derive its heat from nearby volcanic rocks, but it has only half as much silica ( 24 vs $47 \mathrm{mg} / \mathrm{l}$ ) as the warm spring which does come from the volcanics. Both springs have low contents of dissolved solids; in fact the water from the hot spring probably contains less dissolved mineral matter than any other hot spring in Utah.

Two shallow wells, 62 and 92 feet deep, have water temperatures of $20^{\circ}$, and three other wells (60,232, and 605 feet deep) have water temperatures of $16^{\circ}$ and $18^{\circ}$.

\section{Cited References}

Hood, J. W., and Don Price, 1970, Hydrologic reconnaissance of Grouse Creek Valley, Box Elder County, Utah: Utah Dept. Nat. Resources Tech. Pub. No. 29, 49 p. 
Heber Valley

Heber Valley, in Wasatch County, is a small (valley floor about 44 square miles) triangular-shaped "back valley" between the Wasatch Mountains on the west and the volcanic hills of the Wasatch-Uinta transition zone on the east. The upper plate of the great Charleston thrust fault forms a highland south of the valley.

Warm and hot water, $29^{\circ}$ to $45^{\circ} \mathrm{C}$, occurs as springs and in "hot pots" in the vicinity of Midway in the western part of the valley (see Table 10). These hot pots and springs were investigated rather thoroughly by Baker (1968) who also studied the ground water of the whole of Heber Valley (1970); therefore, I shall mention only briefly some of the pertinent points, for the most part, paraphrasing or quoting from Baker (1968), but with my additions in brackets.

"The hot pots are surrounded by a deposit of calcareous tufa that covers an area of about 4.5 square miles and locally is at least 70 feet thick. The tufa deposit forms a low terrace that is underlain by alluvium; water apparently rises through the alluvium from a bedrock source" (p. D63). Chemical analyses show that the water is not highly mineralized, about 1600 to $2050 \mathrm{mg} / \mathrm{l}$ dissolved solids, "but it is much more mineralized than other ground water in the area... which rarely exceeds, $1000 \mathrm{mg} / 1^{\prime \prime}$ ( p. D65).

The geologic map of the Heber quadrangle (Bromfield, Baker, and Crittenden, 1970) gives clues to the possible sources of heat for the thermal water. "Carbonate rocks of Mississippian and Pennsylvanian age crop out extensively in the high mountains north and west of Midway and are overlain by younger (Triassic) sedimentary rocks of low permeability. The sedimentary rocks dip steeply toward the valley [and apparently are folded into a buried anticline whose crest is near the hot springs in the southwest quarter of section 26 (Bromfield and others, 1970) j. An intrusive body of Tertiary age crops out a short distance north of Midway, and the sedimentary rocks surrounding the intrusive are intensely fractured and faulted [along the Dutch Hollow and Pine Creek thrust faults]. According to C. S. Bromfield (oral commun. 1966), magnetic anomalies near Midway suggest that the intrusive body extends southeastward under the hot pots. If this is so, the fracturing of the sedimentary rocks in the vicinity of the intrusive body [and along the crest of the anticline] would provide the necessary break in the confining layers to permit water that is under artesian pressure in the carbonate rocks to escape to the surface" (p. D69).

"The following theory of the origin and continued existence of the hot pots is proposed. Meteoric water enters the carbonate rocks in the Wasatch Range, descends along fractures [probably principally the thrust planes] and solution openings, and dissolves minerals from the rocks through which it passes. This mineralized water is heated at depth and, under artesian pressure, returns to the surface through fractures in the rocks [such as the strong fault that cuts Triassic rocks on the south slope of Burgi Hill, a fault whose extension would go through the hot spring area near Mound City I. When the hot mineralized water nears the surface, the drop in confining pressure causes loss of dissolved carbon dioxide and resultant deposition of calcium carbonate (tufa)" ( $\mathrm{p}$. D69).

Two wells, one at the northern tip of the valley and the other near the southeast corner, yield slightly warm water of good quality (less than $450 \mathrm{mg} / 1$ dissolved solids) at $16^{\circ} \mathrm{C}$. These wells are distant from the hot pots and cannot be related to them. 
Cited References

Baker, C.H., Jr., 1968, Thermal Springs near Midway, Utah: U.S. Geol. Survey Prof. Paper 600-D, p. D63-D70.

1970, Water resources of the Heber-Kanas-Park City area northcentral Utah, with a section on a gravity and aeromagnetic survey of Heber and Rhodes Valieys by D.L. Peterson: Utah Dept. Nat. Resources Tech. Pub. No. $27,74 \mathrm{p}$.

Bromfield, C.S., A.A. Baker, and M.D. Crittenden, Jr., 1970, Geologic map of the Heber quadrangle, Wasatch and Summit Counties, Utah: U.S. Geol. Survey Geologic Quadrangle Map GQ-864.

$$
\text { Jordan Valley }
$$

\section{INTRODUCTION}

Location

Jordan Valley encompasses about 400 square miles in Salt Lake County, Utah (figure 6). Except for the small number of people who live in Emigration, Mill Creek, Big Cottonwood, and Little Cottonwood Canyons, essentially all the 508,000 (1975 estimate) people of Salt Lake County live in Jordan Valley. Salt Lake City, the capital of Utah, is a center for light and heavy industry, oil refining, and tourism, and is the home of the University of Utah. Salt Lake County is one of the leading agricultural counties of the state.

\section{Previous Work}

The waters of Jordan Valley have been studied more intensively than those of any other area in Utah. In addition to early mention of thermal waters by the King report (1878), the other principal studies are by Richardson, Underground water in the valleys of Utah Lake and Jordan River, Utah (1906); Taylor and Leggette, Ground water in the Jordan Valley, Utah (1949); Marine and Price, Geology and ground-water resources of the Jordan Valley (1964); and Hely, Mower, and Harr, Water resources of Salt Lake County, Utah (1971a). Records of wells, springs, streamflow, and water chemistry have been published by the U.S. Geological Survey as Basic-Data Reports No. 4 (1963), No. 11 (1966), No. 12 (1966), No. 13 (1967), No. 15 (1968), and No. 17 (1969).

SUMMARY Of OCCURRENCES, USES, and POTENTIAL for USE

Hot water occurs at Becks $\left(55^{\circ} \mathrm{C}\right)$ and Wasatch $\left(42^{\circ} \mathrm{C}\right)$ Hot Springs at the west end of the Salt Lake salient in the northern part of Jordan Valley and at

Crystal $\left(58.5^{\circ} \mathrm{C}\right)$ Hot Springs in the southern part of the valley. These waters are now unused but Becks and Wasatch have been used for recreation in the past and could be so used in the future; Crystal Hot Springs is being investigated for possible use by the nearby Utah State Prison.

Warm water $\left(20-31^{\circ} \mathrm{C}\right.$ ) has been recorded for about 60 wells (Table $11-\mathrm{A}$ ) and slightly warm water $\left(15.5^{\circ}-19.5^{\circ} \mathrm{C}\right)$ has been recorded for about 120 wells (Table 11-B). Some of these wells are in the southern part of the valley and are probably related to the same heat source as Crystal Hot Springs. The other wells form a large fan-shaped pattern in the northern part of the valley. The warmest water is in the center of the fan and the heat is probably supplied by a north-trending buried fault zone, from which it spreads laterally through the horizontal artesian aquifers. Figures 7 and 8 show the patterns of warm ground water as plotted by Marine and Price (1964) and by Hely, Mower, and Harr, 1971a. 


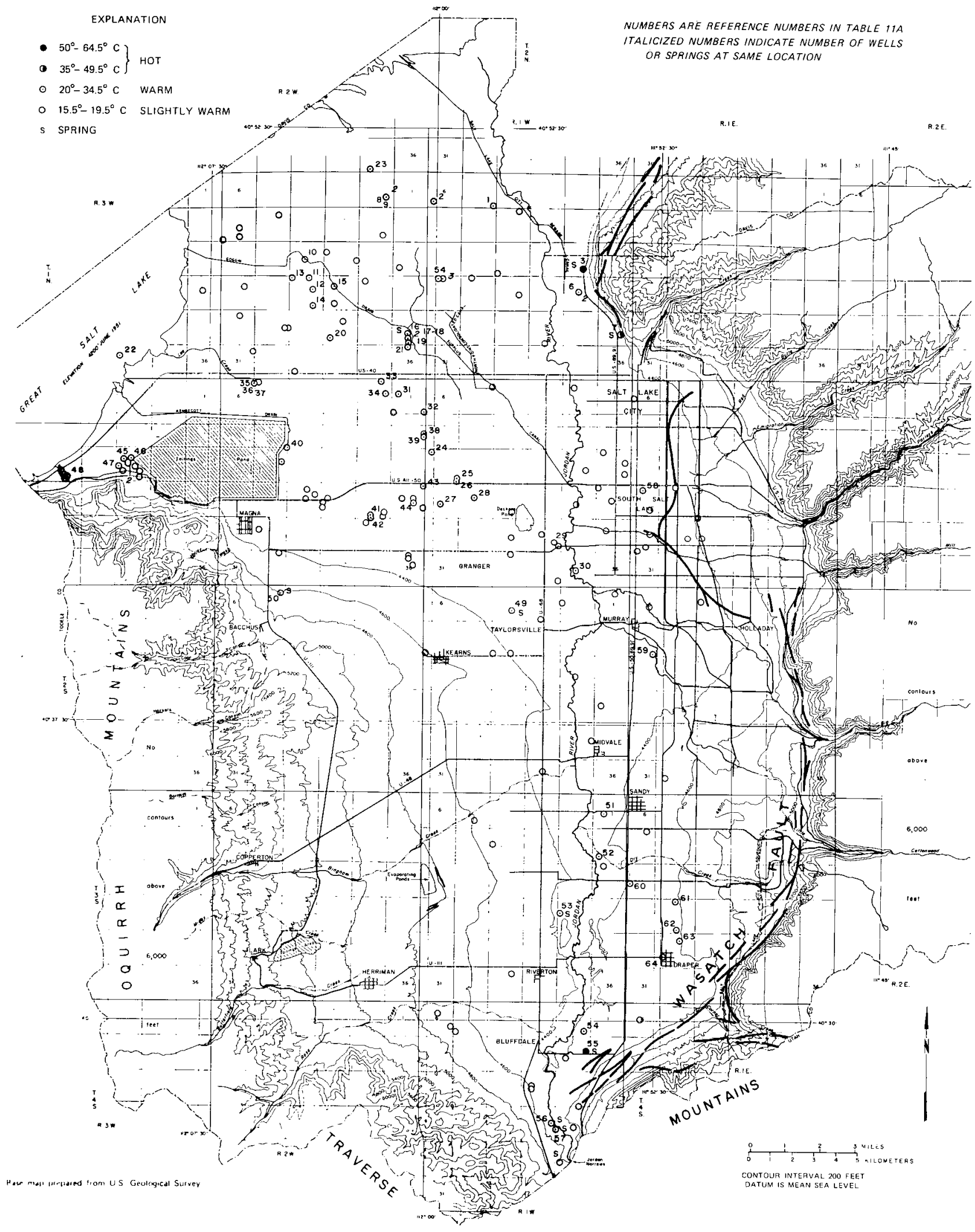

Figure 6. Map of Jordan Valley showing thermal wells and springs. 
The warm water in the southern part of the valley should have a potential use for space heating and greenhouses. The warm water in the north is now being used with heat pumps, and it has a good potential for such use as industry expands in that area.

Five wells whose water temperatures range from $17^{\circ}$ to $21.5^{\circ} \mathrm{C}$, and whose dissolved solids range from 976 to $1220 \mathrm{mg} / \mathrm{l}$, show anomalously high silica of 71 to $82 \mathrm{mg} / \mathrm{l}$. The wells range in depth from 105 to 156 feet and all are within an area of less than half a square mile about $3 \frac{1}{2}$ miles east of Magna. There is no ready explanation for the high silica content, but the anomaly is worthy of further investigation.

\section{GEOLOGIC and FYDROLOGIC ENVIRONMENT}

The Jordan Valley is a north-trending graben, bounded on the east by the Wasatch fault zone and on the west by exposed faults and by buried faults whose existence is based on geophysical data. Jordan Valley is separated from the Utah Valley graben on the south by the Traverse Range spur and from the East Shore graben on the north by the Salt Lake salient. The deepest part of the graben is a bowl-shaped depression in the southern part of the valley in the area of (clockwise from the northeast) Sandy, Draper, Bluffdale, Herriman, and South Jordan. The northwestern portion of the valley, including Granger, Taylorsvilie, and Magna, is underlain by a pediment that extends eastward from the foot of the Oquirrh Mountains almost to the center of the valley. The eastern edge of that pediment is bounded by a largely buried north trending fault zone that probably marks the western boundary of the graben in that area (Cook and Berg, 1961, p. 79, 80, 83, and plate 13).

The rocks of the Wasatch Range are largely metasediments of Precambrian age and marine sedimentary rocks of Paleozoic and Mesozoic age. The Oquirrh Mountains to the west are principally composed of the Oquirrh Formation of Pennsylvanian age.

The valley fill is composed of alluvial deposits brought in by streams from the mountains and of lacustrine deposits laid down along the shores and on the bottom of Pleistocene Lake Bonneville. The deposits near the mountains on the east, south, and southwest sides of the valley are predominantly thick gravel and sand, but those on the pediment in the northwest portion are thinner silt and clay. The lower portions of the valley are underlain by lake-bottom clay and silt.

The interbedded alluvial and lacustrine deposits have produced excellent aquifers separated by confining layers so that ground water occurs under artesian conditions in most areas of the valley, and in the lowest portions the aquifers supply flowing wells. The aquifers have been developed extensively; almost 12,000 wells were on record through 1969 (Hely, Mower, and Harr, 1971, p. 138), yet the area of flowing wells has changed little since G.B. Richardson published a map showing the area of artesian flow in 1904 (1906, plate VII). (See also Hely, Mower, and Harr, 1971a, plate 1).

Recharge to the aquifers amounts to about 367,000 acre-feet per year and according to Hely, Mower, and Harr (1971a, p. 119 and 135), comes from:

Seepage f
$" 1$
$"$
$"$
$"$

rom bedrock

irrigated fields

precipitation on valley floor

major canals

creek channels

lawns and gardens

Underflow from channel fill \& Jordan Narrows

Seepage from tailings pond
135,000

81,000

60,000

48,000

20,000

17,000

4, 000

2,400

367,000 
This recharge is matched by discharge:

$\begin{array}{lr}\text { Into Jordan River } & 170,000 \\ \text { By wells } & 107,000 \\ \text { Evapotranspiration } & 60,000 \\ \text { Springs diverted for use } & 19,000 \\ \text { Other } & 11,000 \\ & 367,000\end{array}$

An appreciable but unmeasured part of this discharge is warm to hot water supplied by springs and wells.

OCCURRENCES Of HOT and WARM WATERS

The hottest waters in Jordan Valley are yielded by Becks $\left(55^{\circ} \mathrm{C}\right)$ and Wasatch $\left(40^{\circ} \mathrm{C}\right)$ Hot Springs at the west end of the Salt Lake salient and by Crystal ( $55^{\circ}$ $\left.58^{\circ} \mathrm{C}\right)$ Hot Springs along the Steep Mountain fault on the north side of the Traverse Range salient. These springs are discussed in more detail in the section on Hot Springs along the Wasatch Fault Zone.

On Table 11-A are listed about 60 wells with temperatures of $20^{\circ}$ to $31^{\circ} \mathrm{C}$. Most of these wells have been plotted on maps by Marine and Price and by Hely, Mower, and Harr that appear at the end of this discussion (figure 7 \& 8). Despite the differences in categories of temperature used for plotting, there is general agreement between the two maps. In the southern part of Jordan Valley there are areas of warm water that are probably related to the Crystal Hot Springs area. Some of the heat from the spring area may spread out northward in favorable confined aquifers. In the northern part of the valley there may be some heat that spreads laterally from the Warm Springs fault at the west end of the Salt Lake salient, but the principal warming apparently comes from the largely buried Granger-Taylorsville fault zone that trends slightly west of north in the valley center. The fan-shaped pattern of the area of warm water, with the warmest water near the center of the fan and with expansion of the fan northwestward in the same direction as ground water moves toward Great Salt take, strongly suggests that there is an upwelling of heat along the fault and lateral spreading of that heat in favorable confined aquifers.

Cited References

Cook, K.L., and J.W. Berg, Jr., 1961, Regional gravity survey along the central and southern Wasatch Front, Utah: U.S. Geol. Survey Prof. Paper 316E, p. 75-89.

Hely, A.G., R.W. Mower, and C.A. Horr, 1967, Hydrologic and climateologic data 1966, Salt Lake County, Utah: U.S. Geol. Survey Basic-Data Release No. 13, $85 \mathrm{p}$.

, 1968, Hydrologic and climatologic data 1967, Salt Lake County, Utah: U.S. Geol. Survey Basic-Data Release No. 15, 74 p.

, 1969, Hydrologic and climateologic data 1968, Salt Lake County, Utah: U.S. Geol. Survey Basic-Data Release No. 17, 70 p. 
Hely, A.G., R.W. Mower, and C.A. Harr, 197la, Water resources of Salt Lake County, Utah: Utah Dept. Nat. Resources Tech. Pub. No. 31, 239 p. , 1971b, Sumnary of water resources of Salt Lake County, Utah: Utah Dept. Nat. Resources Tech. Pub. No. 34, 25 p. Sunnary of 1971a above.

Iorns, W.V., R.W. Mower, and C.A. Horr, 1966, Hydrologic and climatologic data collected through 1964, Salt Lake County, Utah: U.S. Geol. Survey BasicData Release No. 11, 91 p.

, 1966, Hydrologic and climatologic data 1965, Salt Lake County, Utah: U.S. Geol. Survey Basic-Data Release No. 12, 84 p.

Marine, I.W., 1960, Geology and ground-water resources of Jordan Valley, Utah: Univ. of Utah PhD Thesis, $202 \mathrm{p}$.

Marine, I.W., and Don Price, 1964, Geology and ground-water resources of the Jordan Valley, Utah: Utah Geol. and Mineralog. Survey Water-Resources Bull. 7, $67 \mathrm{p}$.

, 1963, Selected hydrologic data, Jordan Valley, Salt Lake County, Utah: U.S. Geol. Survey Basic-Data Report No. 4, 30 p.

Richardson, G.B., 1906, Underground water in the valleys of Utah Lake and Jordan River, Utah: U.S. Geol. Survey Water-Supply Paper 157, 81. p.

Taylor, G.H., R.M. Leggette, 1949, Ground water in the Hordan Valley, Utah: U.S. Geol. Sruvey Water-Supply Paper 1029, 257 p. 


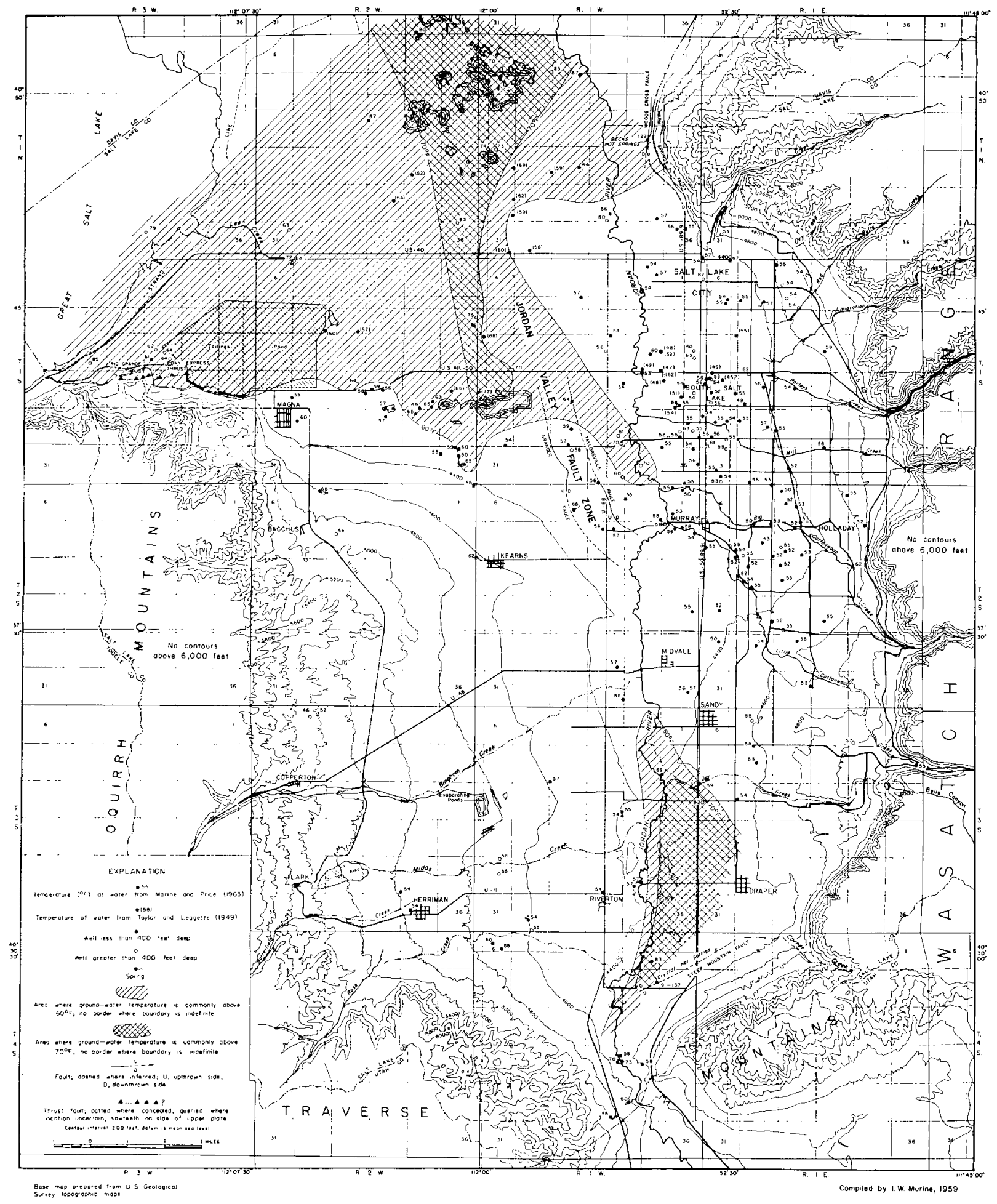

Figure 7. Map showing selected faults and temperatures of ground water in the Jordan Valley, Utah. (Reprinted from figure 30 of Marine and Price, 1964) 


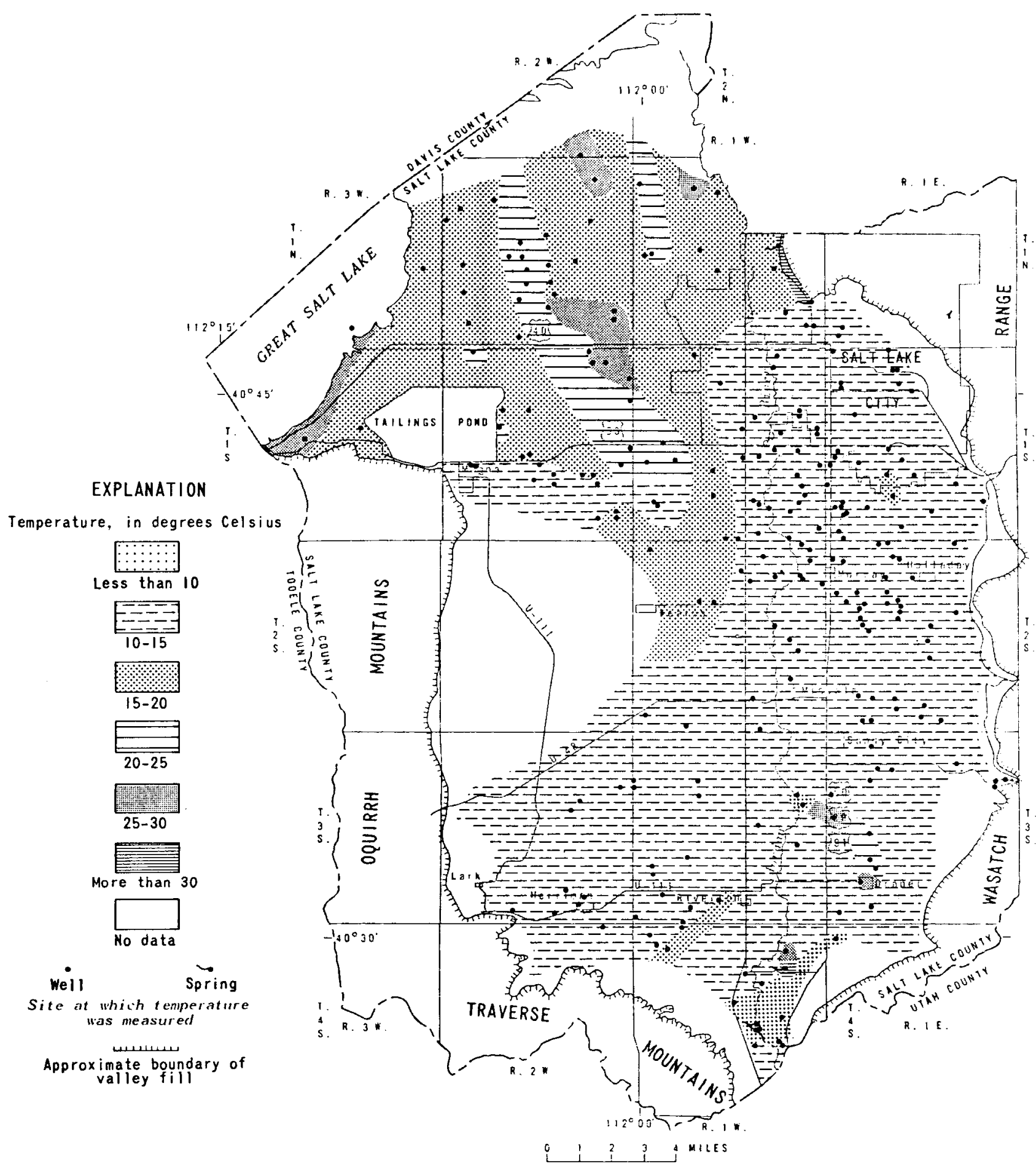

Figure 8. Map showing areal distribution of water temperature in the principal aquifer in Jordan Valley. (Reprinted from figure 78 of Hely, Mower, and Harr, 1971a) 
Pavant Valley - Black Rock Desert

\section{INTRODUCTION}

Pavant Valley is in eastem Millard County, in west-central Utah. The area considered covers about 300 square miles and includes the towns of Holden, Fillmore, Meadow, and Kanosh, whose total population is about 4000. The economy depends on agriculture, but tourism and mining of volcanic cinders contribute to the economy (Mower, 1965).

SUMMARY Of OCCURRENCES and POTENTIAL of the HOT and WARM WATERS

Warm to hot springs about 5 miles southwest of Meadow yield water of $30^{\circ}$ $41^{\circ} \mathrm{C}$, and water in a nearby 90 -foot well is $67^{\circ} \mathrm{C}$. Mundorff (1970) concluded that although some heat may be contributed to the spring by nearby late Tertiary or Quaternary volcanics it is likely that the heating is due to the normal geothermal gradient and therefore the area has "questionable geothermal potential." Later workers, Parry and Cleary, and Rush, have used geothermometers to conclude that deep water temperatures may range from $180^{\circ}$ to $230^{\circ} \mathrm{C}$, and Parry and Cleary have stated that Pavant Valley is "a prime target for further exploration." Most well waters in the valley are in the range of $11^{\circ}-22^{\circ} \mathrm{C}$, and the median temperature is $15^{\circ} \mathrm{C}$. Thus in most areas where there now are wells, the chance of reaching water of $15.5^{\circ} \mathrm{C}$ or higher is almost 1 in 2 .

\section{GEOLOGIC and HYDROLOGIC ENVIRONMENT}

Pavant Valley is at the eastern border of the Basin and Range Physiographic Province and is bounded on the east and south by the Pavant Range, which is in the Colorado Plateau Province. A low ridge of extinct volcanoes and flowsseparate the valley from the main part of the Sevier Desert to the west (Mower, 1965, p. 10).

The valley fill consists of the Sevier River(?) Formation, more than 800 feet thick, pre-Lake Bonneville lake beds, from 0 to nearly 800 feet in thickness, basalt flows from two extinct volcanoes in parts of the area, and intertonguing alluvial fans and lacustrine deposits of Lake Bonneville (Mower, 1965, p. 19). Water flows from the creeks of the Pavant Range into the valley-fill deposits and has saturated them so thoroughly that extensive evapotranspiration occurs over an area of about 35,000 acres in the lower western parts of the valley (Mower, 1965).

Irrigation wells pumped about 82,000 acre-feet each year from 1966-75, with general declines in water levels of less than 1 foot per year.

OCCURRENCE Of WARM and HOT WATERS

Warm to hot water occurs in two spring areas and in a well about 5 miles southwest of Meadow, and warm water occurs in 7 wells scattered around the valley (Table 12-A), but these occurrences can be appreciated better from the background of Mower's interpretation (1965, p. 72).

"TEMPERATURE

The temperature of water from 178 wells in Pavant Valley ranged from $52^{\circ}$ to $85^{\circ} \mathrm{F}\left(11^{\circ}-29.5^{\circ} \mathrm{C}\right)$. The temperature of the shallowest water is about the same as the mean annual air temperature of $52^{\circ} \mathrm{F}$ $\left(11^{\circ} \mathrm{C}\right)$. Ground-water temperature increases an average of $1 \mathrm{~F}$ for each 80 feet of depth in the sediments in the valley. The temperature also increases westward from the mountains toward areas of 
recent volcanic activity. Near the mountains along the east side of the valley, the temperature of the ground water ranges from $52^{\circ}$ to $57^{\circ} \mathrm{F}\left(11^{\circ}-14^{\circ} \mathrm{C}\right)$; along the west side of the valley, the temperature ranges from about $60^{\circ}$ to $85^{\circ} \mathrm{F}\left(15.5^{\circ}-29.5^{\circ} \mathrm{C}\right)$, except that the temperature of water from wells in the basalt aquifer ranges from $54^{\circ}$ to $57^{\circ}\left(12^{\circ}-14^{\circ} \mathrm{C}\right)$. A temperature of $143^{\circ} \mathrm{F}\left(61.5^{\circ} \mathrm{C}\right)$ was measured for springs along Devil's Ridge west of Hatton, but the rate of flow is only 1 or $2 \mathrm{gpm}$. Wells in Pavant Valley have not been known to tap water warmer than $85^{\circ} \mathrm{F}\left(29.5^{\circ} \mathrm{C}\right)$. (Well (C-22-6)35ddb, was drilled after Mower wrote his report).

"The temperature of ground water, in general, increases $1^{\circ}-3^{\circ} \mathrm{F}$ $\left(0.5^{\circ}-1.5^{\circ} \mathrm{C}\right)$ through the irrigation season. This temperature rise is caused principally by excess irrigation water that has been warmed at the land surface and has returned to the aquifer and by upward migration of warmer water from lower depths."

Next, a comment on and a couple of additions to Mower's interpretation by making reference to his Basic-Data Report No.5 (1963) which records temperatures of 239 wells. As Mower says above, the temperatures range from $11^{\circ}-29.5^{\circ} \mathrm{C}$, but only one is at $29.5^{\circ} \mathrm{C}$ and the rest range from $11^{\circ}-22^{\circ} \mathrm{C}$. The median temperature is $15.5^{\circ}$, 94 wells have slightly warm water with temperatures between $15.5^{\circ}-19.5^{\circ} \mathrm{C}$, and 7 have warm water with temperatures of $20^{\circ}-29^{\circ} \mathrm{C}$. The pattern formed by plotting the slightly warm to warm water simply shows a scattering among the other wells that yield slightly cooler water. Appreciably warmer water occurs in the warm or hot springs and hot-water wells southwest of Meadow (Table 12-A), but conflicting reports of the temperatures require some explanation. Meadow "Hot" Spring was measured in the summer of 1970 by Rush (1978) at $30^{\circ} \mathrm{C}$. Dennis, Maxey, and Thomas (1946) report a temperature of $35^{\circ} \mathrm{C}$ from "Warm Spjing" which they locate on a map in the same place, (C-22-6)27ddc, as the Meadow spring measured by Rush.

Hatton Hot Spring, (c-22-6)35ddc, was measured in the summer of 1976 by Rush (1978) at $36^{\circ} \mathrm{C}$. Dennis, Maxey, and Thomas (1946) show a Winepa Hot Spring at (C-22-6)35dca, but do not give a temperature. As quoted above, Mower (1965) reports a temperature of $63^{\circ} \mathrm{C}$ for Devil's Ridge Spring, for which Dennis, Maxey, and Thomas give a temperature of $13^{\circ} \mathrm{C}$, and Rush also reports a temperature of $13{ }^{\circ} \mathrm{C}$ at the site, (C-22-6)34baa, where Dennis, Maxey, and Thomas plotted Devil's Ridge Spring. Probably Mower measured a temperature at Hatton Hot Spring and erroneously reported it as Devil's Ridge. This explanation seems to be confirmed by the $67^{\circ} \mathrm{C}$ temperature that Rush measured in a 90-foot well, (c-22-6)35ddb, close to Hatton Hot Spring.

Mundorff (1970, p. 40-41) also has reported on Meadow and Hatton Hot Springs and his statements are worth repeating:

"Meadow... and Hatton...Hot Springs....issue from valley-fill deposits of Tertiary or Quaternary age. Basalt flows of Quaternary age are only about three miles north of the springs; basalt flows of late Tertiary age are about three miles west of the springs and in the vicinity of Black Rock Volcano about three miles south of the springs...

"Temperature of the water of Meadow Hot Springs was $84^{\circ} \mathrm{F}\left(29^{\circ} \mathrm{C}\right.$ ) in May 1966 and was $106^{\circ} \mathrm{F}$ ( $41^{\circ} \mathrm{C}$ ) in May 1967; a discharge of $60 \mathrm{gpm}$ was estimated in 1957. Hatton Hot Springs have not flowed for several years; the temperature of the water was $100^{\circ} \mathrm{F}\left(38^{\circ} \mathrm{C}\right)$ in 1957.

"Chemical data obtained during the past 25 years at Meadow Hot Springs show that the dissolved-solids content has ranged from 4,690 to 4,900 ppm and that the water is of the sodium chloride type. In equivalents per million, calcium is about half that of sodium, and sulfate is about half that of chloride. 
The germanium content of a sample obtained in May 1966 was fairly high ( 571 $\mathrm{mg} / 1$ ) but the germanium content of two other samples obtained during 1966 and 1967 was not especially high in a sample obtained in May 1967. Silica concentration did not exceed $50,000 \mathrm{mg} / 1$ in any sample analyzed.

"Some heat undoubtedly is furnished by the nearby volcanic flows of later Tertiary and Quaternary age. The dissolved solids content of water at Meadow and Hatton Hot Springs (4,670-4,900 ppm) is somewhat similar to that of the ground water in the general area of the springs. Water from a well about five miles northeast of the springs has dissolved-solids content of 8,050 ppm. The depths of these wells range from 100 to 527 feet. If ground water similar to that found in the described wells were in contact with the volcanic flows or were circulated to a depth of 3,000 feet, water having the chemical and thermal characteristics of the hot springs would result.

"Despite the proximity of volcanic rocks of late Tertiary and Quaternary age, the immediate area of the springs appears to be of questionable geothermal potential. The relatively low temperature of the spring water, the low silica content, and the similarity in chemical quality of the spring water and the ground water in a fairly large surrounding area are not favorable indicators of a large increase in temperature at fairly shallow dpeth."

In contrast to Mundorff's opinion (1970, p. 41) that the Meadow and Hatton spring areas have "questionable geothermal potential," Parry and Cleary (1978, p. I), who computed $\mathrm{Na}-\mathrm{K}-\mathrm{Ca}$ and $\mathrm{SiO}_{2}$ temperatures for many springs and wells in the Pavant Valley, conclude that "the combination of water chemistry, young silicic volcanics, and proximity to known geothermal areas make Pavant Valley a prime target for further exploration". They computed mixing models to explain the low silica content of the water from Meadow Hot Spring; "those models suggest a hot water temperature of $190^{\circ}$ to $230^{\circ} \mathrm{C}$ and a cold water fraction of $86 \%$ to $90 \%$ (Parry and Cleary, 1978, p. 26).

Rush also studied Meadow and Hatton Hot Springs and concluded that "the temperature of the hydrothermal reservoir, estimated with geothermometers is about $180^{\circ} \mathrm{C}$ or less" (1978, written commun.). Rush outlined an elongate area of about $3 \mathrm{sq}$. mi. surrounding Hatton Hot Spring where he reports that high heat flow results in rapid snowmelt, and goes on to say that "subsurface temperatures of $70^{\circ} \mathrm{C}$ can be expected at depths of as little as $10 \mathrm{~m}$ under these snownelt areas" (1978, written commun.).

Cited References

Dennis, P.E., G.B. Maxey, and H.F. Thomas, 1946, Ground water in Pavant Valley, Millard County, Utah: Utah State Engineer Tech. Pub. No. 3, 96 p.

Lee, W.T., 1908, Water resources of Beaver Valley, Utah: U.S. Geol. Survey Water-Supply Paper 217, 57 p.

Mower, R.W., 1965, Ground-water resources of Pavant Valley, Utah: U.S. Geol. Survey Water-Supply Paper 1794, 78 p.

, 1963, Selected hydrologic data, Pavant Valley, Millard County, Utah: U.S. Geol. Survey Basic-Data Report No. 5, 20 p.

Mundorff, J.C., 1970, Major thermal springs of Utah: Utah Geol. and Mineralog. Survey, Water-Resources Bull. 13, 60 p. 
Parry, W.T., and M. Cleary, 1978, Na-K-Ca and $\mathrm{SiO}_{2}$ temperature estimates for Utah spring and well waters: U.S. Geol. Survey, Geothermal Research Program, Contract 14-08-0001-G-341, $51 \mathrm{p}$.

\section{Sevier Desert}

\section{INTRODUCTION}

The Sevier Desert occupies about 3000 square miles in Juab, Millard, and Tooele counties in central Utah. The center of population is Delta, and the principal activities are agriculture and raising of livestock. Beryllium ore that is mined in Juab County west of the Sevier Desert is processed at a plant near Lynndyl. Probably about 10,000 people live in the area under consideration.

\section{SUMMARY Of OCCURRENCES Of HOT and WARM WATER}

The only hot water in the area is reported from Abraham (Crater) Hot Springs, which issue from a tufa mound near a Quaternary basalt flow. Temperatures to $82^{\circ} \mathrm{C}$ have been measured and total solids content ranges from 3200 to $3800 \mathrm{ppm}$. The area has been designated as a KGRA (Energy Resources Map of Utah, 1975) and thus is deemed to be worthy of further investigation.

All well water in the Sevier Desert is in the $11^{\circ}-28^{\circ} \mathrm{C}$ range (Table 12-A and $\mathrm{B}$ ). The lowest reported temperature is $1^{\circ}$ above the reported mean annual air temperature of $10^{\circ} \mathrm{C}$ (Mower and Feltis, 1968, p. 10). Water south of Delta is apparently slightly warmer than water north of Delta. Although no strong pattern can be developed from the occurrences, a well south of Delta appears to have 5 chances in 6 of reaching water of $15.5^{\circ}$ or higher, whereas a well north of Delta has only 1 chance in 3 .

\section{GEOLOGIC and HYDROLOGIC ENVIRONMENT}

The Sevier Desert of this report includes Tintic Valley and the northern portion of a huge closed intermontane structuralbasin that extends southward into the Sevier Lake basin and Pavant Valley. The Sevier River drains the High Plateaus to the southeast of the basin and would flow, if not fully diverted in the vicinity of Delta, into the Sevier Lake basin. The Sevier Desert is bounded by, clockwise from the southwest, the Cricket, Little Drum, Drum, and McDowe11 Mountains on the west, Simpson, Sheeprock, and West Tintic Mountains on the north, and East Tintic, Gilson, and Canyon Mountains on the east. All are typical fault-block ranges of the Basin-range Physiographic Province.

The valley floor is underlain principally by lake-bottom deposits of silt and clay that were laid down in Pleistocene Lake Bonneville. The continuity of the lake-bottom deposits in several places is interrupted by Plio-Pleistocene volcanic rocks that stand above the lake plain. Along the eastern side of the valley are extensive sand dunes. Interfingering with the lake deposits are stream-laid deposits brought in by the Sevier River and by streams from the surrounding mountains during dry climatic cycles when the basin was not filled with a lake. Altogether, the valley-fill deposits probably aggregate more than 6000 feet.

The complex interfingering of fine-grained and coarser-grained deposits has formed two principal artesian aquifers in much of the basin and multiaquifer artesian system "from the Leamington-Oak City area west and southwest toward Sevier Lake" (Mower and Feltis, 1968, p. 15). The unconsolidated deposits of the basin are probably more than 1000 feet thick in much of the 
basin and "in excess of 8000 feet near the center of the basin" (Mower and Feltis, 1968, p. 35). By using an average saturated thickness of 775 feet for the main part of the desert and 300 feet for the Old River Bed area, Mower and Feltis (p. 36) have computed the volume of ground water in storage at more than 400 million acre-feet. Water is discharged from this closed basin by natural evapotranspiration and by pumpage from wells; recharge comes from streams, irrigation ditches, and irrigated fields and probably by underflow from the mountains that border the basin.

\section{OCCURRENCE of HOT and WARM WATER}

The only hot water in the Sevier Desert occurs at Abraham(Crater) Hot Springs ( $\mathrm{C}-14-8) 10 \mathrm{~S}$ and $15 \mathrm{~S}$ which are about 16 miles north-northwest of Delta (Table 13-A). According to Mundorff (1970, p. 37-40), "these springs issue from a tufa mound about 15 feet high and several hundred feet in diameter on the floor of the Sevier Desert along the east side of a Quaternary basalt flow (Fumarole Butte)... Water temperatures near the center of the spring area are about $180^{\circ} \mathrm{F}\left(82^{\circ} \mathrm{D}\right)$... In July 1967, the total discharge from all springs was estimated to be about $250 \mathrm{gpm}$ " although other estimates have ranged from 700 to $5000 \mathrm{gpm}$. "Dissolved solids content ranges from about 3,200 to 3,800 ppm... (hence) the water is unsuitable for most uses... The absence of boiling temperatures, the low silica concentrations, and the large water discharge during some periods indicate that test drilling would be necessary to determine if temperature increase with depth is sufficient to sustain an economically feasible geothermal development."

Rush (1978, written commun.) inventoried about 40 orifices at Crater Hot Springs and estimated total flow at about $1400 \mathrm{gpm}$ with additional seepage of about $700 \mathrm{gpm}$. He believes the water rises along a north northwest-trending fault from a reservoir about $1.3 \mathrm{~km}$ deep or "only $200 \mathrm{~m}$ deeper than the estimated base of the alluvial valley fill...The estimated temperature of the hydrothermal reservoir is only $110^{\circ} \mathrm{C} "(\mathrm{p} .63)$.

Slightly warm $\left(15.5^{\circ}-19.5^{\circ} \mathrm{C}\right)$ and warm $\left(20^{\circ}-34.5^{\circ} \mathrm{C}\right)$ water up to $28^{\circ}$ is common in the wells whose temperatures are recorded by Mower and Feltis (1964) (Table 13-B). Basic-Data Report No. 9 lists about 600 wells. Of these, temperatures were measured on 171 . The lowest temperature of $11^{\circ} \mathrm{C}, 1^{\circ}$ above mean annual air temperature, was recorded on only one well. Eighty other wells
have reported temperatures of $12^{\circ}$ to $15^{\circ}$, 70 wells of $15.5^{\circ}$ to $19.5^{\circ}$, and 20 of $20^{\circ}$ to $28^{\circ}$. The wells of $15.5^{\circ}$ to $19.5^{\circ}$ are scattered all over the mapped area; all eleven wells measured in Juab County are in that temperature range. The wells whose temperatures are $20^{\circ}$ to $28^{\circ}$ fit no apparent pattern, but 11 of the 20 are south of Delta as are 33 of the 70 that are between $15.5^{\circ}$ and $19.5^{\circ}$. Furthermore, only 8 other wells were measured in the area south of Delta: all were $14.5^{\circ}$ to $15^{\circ}$.

It therefore appears that a well south of Delta has about 5 chances in 6 of penetrating water above $15.5^{\circ}$, and a well elsewhere about 1 chance in 3 .

There is no ready explanation why the water of the Sevier Desert has abovenormal temperature. Possibly there is deep-seated heat near Pavant Butte to the south and certainly there is heat near Funarole Butte, the source of heat for Abraham Springs; but there is no indication of increase in water temperature toward those possible sources, so the mystery remains.

\section{Cited References}

Mower, R.W., 1964, Ground-water data Sevier Desert, Utah: U.S. Geol. Survey Basic-Data Report No. 9, 34 p. 
Mower, R. W., and R.D. Feltis, 1968, Ground-water hydrology of the Sevier Desert, Utah: U.S. Geol. Survey Water-Supply Paper 1854, 75 p.

Mundorff, J.C., 1970, Major thermal springs of Utah: Utah Geol. and Mineralog. Survey, Water-Resources Bul1. 13, $60 \mathrm{p}$.

Sevier River Valley

\section{INTRODUCTION}

The Sevier River heads on the Markagunt Plateau, and its principal tributary, the East Fork Sevier River, heads on the Pausaugunt Plateau, both in south-central Utah. The two northeastward-dipping plateaus are separated by the north-trending Sevier fault which has raised the Pausaugunt on the east above the Markagunt on the west. Both streams flow generally northward, and the East Fork is joined near Antimony by Otter Creek, which flows southward from the Fish Lake Plateau. The East Fork then flows westward to meet the main Sevier River at Kingston. Beyond Kingston, the Sevier continues northward, past Marysvale, Sevier, Joseph, Richfield, Salina, and Redmond to Gunnison where it is joined by the San Pitch River, which drains the east flank of the Wasatch Plateau and flows southward to meet the Sevier. The river then flows northwestward through Sevier Bridge Reservoir which holds the flow of the river behind Yuba Dam. After passing Yuba Dam, the river continues northwestward to the Canyon Range where it makes a right-angle turn to the southwest, then goes through Leamington Canyon to the Sevier Desert.

SUMMARY of OCCURRENCES Of HOT and WARM WATER and POTENTIAL for USE

Three hot springs, Monroe $\left(76^{\circ} \mathrm{C}\right)$, Red Hill $\left(76.5^{\circ} \mathrm{C}\right)$, and Joseph $\left(64^{\circ} \mathrm{C}\right)$, yield water that is hot enough for direct space heating and plans are underway by the town of Monroe to develop the nearby hot springs for heating schools and other buildings.

LeFevre spring 10 miles north of Panguitch yields $15 \mathrm{gpm}$ of water at $26^{\circ}$ $32^{\circ} \mathrm{C}$. Possibly development of the spring area could increase the yield for heating a greenhouse. The nearby Tebbs spring yields a greater quantity, 280 gpm, of cooler but still warm water at $20^{\circ} \mathrm{C}$.

The heat from the fresh waters of Johnson Warm Spring, $25^{\circ} \mathrm{C}, 10 \mathrm{gpm}, 418 \mathrm{mg} / \mathrm{I}$ dissolved solids, and of Richfield Warm Springs, $22^{\circ} \mathrm{C}, 700 \mathrm{gpm}, 307 \mathrm{mg} / 1$ dissolved solids, is going to waste but might have potential for the future.

The yields and quality of waters of the two warm springs in the San Pitch Valley, Crystal, $22^{\circ} \mathrm{C}, 360-425 \mathrm{gpm}$, about $600 \mathrm{mg} / 1$ dissolved solids, and Peacock $22^{\circ} \mathrm{C}, 346-1260 \mathrm{gpm}, 466 \mathrm{mg} / \mathrm{l}$ dissolved solids, are adequate for irrigation. These waters could be used to warm greenhouses.

The 5800-ft deep well, (D-14-5)16bdd, that flows nearly $300 \mathrm{gpm}$ of fresh water at $55^{\circ} \mathrm{C}$ from the Masuk-Emery could be an indicator of a valuable resource. The depth involves a high first cost, but the freshness, temperature, and artesian flow might offset that cost over a long period.

\section{GEOLOGIC and HYDROLOGIC ENVIRONMENT}

Both main branches of the Sevier River begin as spring flow from the Tertiary Wasatch Formation. They flow northward and traverse broad exposures of Tertiary volcanics into which they have cut steep canyons, some of the steepest downstream from their confluence at Kingston. Near Richfield the valley is flanked by Tertiary and Mesozoic sedimentary rocks, which contain the river until it reaches the Canyon Range. There the river has cut through Paleozoic and Precambrian rocks as well as Mesozoic rocks. The tributary San Pitch River Valley is flanked 
principally by Cretaceous and Tertiary sedimentary rocks from the headwaters to the confluence with the Sevier.

The northward course of the Sevier River probably is fault controlled, because many faults are parallel to or sub-parallel to the trend of the valley. The faults are most evident in the Central Sevier area from Sevier to Gunnison where the river valley is a graben and Monroe and Red Hill Hot Springs rise on the eastern flanking fault.

In its course from the High Plateaus to the Sevier Desert, the river flows through many small alluvium-filled basins that are separated by buried bedrock barriers or by exposed bedrock barriers through which the river has cut canyons. These basins are essentially saturated with water, which is drawn on by wells to supplement irrigation water supplied by the river.

The Sevier River is the most highly appropriated river in Utah and, perhaps, in the United States. Much of its flow is probably used for irrigation several times before it finally reaches its last use in the Sevier Desert, about 200 miles from its sources in the High Plateaus.

In the discussions that follow, the warm and hot waters that occur in the Sevier River drainage will be considered under three headings:

Upper Sevier: Headwaters of Sevier River, East Fork Sevier River, and Otter Creek to Kingston

Central Sevier: Mainstem of the Sevier River from Kingston to Yuba Dam

San Pitch: San Pitch River drainage to its junction with the Sevier

OCCURRENCES Of WARM and HOT WATER

Upper Sevier - Headwaters to Kingston

Two springs about 10 miles north of Panguitch yield warm water (Table 14 ). The LeFevre spring yields about $15 \mathrm{gpm}$ of water that ranges from $26^{\circ}-32^{\circ} \mathrm{C}$. It rises from a fault zone that cuts the Tertiary Wasatch Formation. The nearby Tebbs spring, (c-33-5)16cde, yields $280 \mathrm{gpm}$ of water of excellent quality, 218 $\mathrm{mg} / \mathrm{I}$ dissolved solids, at temperatures from $10^{\circ}-20^{\circ} \mathrm{C}$. It rises from alluvium. Five other springs and two wells yield water of $15.5^{\circ}-18^{\circ} \mathrm{C}$. One of these springs is in Panquitch Valley, one in Circle Valley, two in East Fork Valley, and one in Grass Valley. Both wells are in Grass Valley.

Central Sevier - Kingston to Yuba Dam

One deep ( $9638 \mathrm{ft}$ ) oil-test well and three spring areas report hot water (Table 15-A). Two other springs and one well yield warm water between $20^{\circ}-25^{\circ} \mathrm{C}$. Because the oil-test well is so deep its water temperature of $65^{\circ} \mathrm{C}$ can hardly be considered an asset, but the three hot spring areas, Monroe, (C-25-3)Indda, at $76^{\circ}$, Red Hill, (C-25-3)licac, at 76.5 , and Joseph, (C-25-4)23aac, at $64^{\circ}$ are significant. All three springs rise on faults: Monroe and Red Hill on the Sevier Fault on the east side of the valley and Joseph on the Dry Wash Fault which is west of outcrops of volcanic rock near the center of the valley.

Rush (1978, written commun.) has studied Monroe, Red Hill, and Joseph Hot Springs. He concludes that Monroe and Red Hill are part of the same spring system and are fed by a hydrothermal reservoir about $4 \mathrm{~km}$ deep and having a temperature as high as $160^{\circ} \mathrm{C}$. He also believes that Joseph Hot Spring is related to a hydrothermal reservoir about $4 \mathrm{~km}$ deep at a temperature of about $160^{\circ} \mathrm{C}$.

Johnson Warm Springs, (C-25-3)27aba, at $25^{\circ} \mathrm{C}$, also issue from the Sevier Fault about 2 miles south of Monroe Hot Springs, and Richfield Warm Springs, ( C-23-3)26aca, $20^{\circ}$ to $22^{\circ} \mathrm{C}$, issues from the Elsinore Fault zone on the west side of the valley about half a mile west of Richfield. 
Monroe Hot Springs issue from a single tufa mound that extends for about half a mile along the mountain front; the width of the mound is about 600 feet from the mountain front to the base, and the height is 75-100 feet. The springs issue from seepage zones and from fissures and cracks that have been enlarged by Jocal residents to increase the spring yield. Discharge is at two major points-one near the center of the mound and the other at the base. The largest spring on the mound discharges about 50 gpm; water temperature was $148^{\circ} \mathrm{F}$ on February 13 , 1967. The other large spring discharges about $40 \mathrm{gpm}$ from the base of the mound; water temperature was $106^{\circ}$ F. Several small springs discharge from the surface of the mound. The total discharge of Monroe Hot Springs was about 150-200 gpm on February 13, 1967. In addition to the visible discharge from the springs, some water evaporates directly from the mound surface; saturated arcas high on the mound above the spring areas and extending to the mountain front indicate that artesian pressure is forcing water to the surface of the mound.

Red Hill Hot Spring issues from a tufa mound about 600 feet long, 200-300 feet wide, and about 50 feet high. The only spring that issues from the mound discharges as much as 150 gpm from a crevice in the north-central part of the mound. The water temperature was $167^{\circ} \mathrm{F}$ on February 13 . 1967; a temperature of $169^{\circ} \mathrm{F}$ was reported for "Monroe Hot Springs" (Carpenter and Young, 1963. p. 17), but this temperature actually was for Red Hill Hot Spring.

Johnson Warm Spring issues along the Scvier fault about two miles south of Monroe Hot Springs. Richardson (1907, p. 58) reported a hlow of 180 gpm and a temperature of $80^{\circ} \mathrm{F}$. In April 1967, U.S. Geological Survey personnel reported a flow of 10 gpon and a lemperature of $77^{\circ} \mathrm{F}$.

Both Monroe and Red Hill Hot Springs have dissolved-solids contents ranging from about 2,600 io 2,900 ppm and are of the sodium sulfate chloride type. Johnson Warm Spring has a much lower dis. solved-solids content and is of the calcium sulfate type. One of the small springs in the Monroe Hot Springs showed a high manganese content $(346 \mu \mathrm{g} / \mathrm{l})$. Johnson Warm Spring had one of the highest molyb. denum contents $(18 \mu \mathrm{g} / 1)$ of all themal springs in Uiah.

Joseph Hot Springs issue from tuta deposited by the springs over the Dry Wash fault. Extensive areas of volcanic rocks crop out immediately east of the fault. Water temperatures of $145^{\circ}$ and $148^{\circ} \mathrm{F}$ were measured in 1966 and 1967. Discharge of the springs probably averages 30 gpm. Dissolved-solids content of Joseph flot Springs ranges between about
5,000 and 5,200 ppm-nearly double that of Monroc and Red Hill Hot Springs. The water is of the sodium chloride type. The concentration of calcium is about the same for Monroe, Red Hill, and Joseph Hot Springs; sulfate is somewhat greater in Joseph Hot Springs than in Monroe and Red Hill Hot Springs. In Juseph Hot Springs, chloride (in equivalents per miltion) is nearly double that of sulfate; but in Monroe and Red Hill llot Springs, chloride and sulfate are about equal (in equivalents per million).

The presence of volcanic rocks of late Tertiary age along the faults from which Monroe, Red Hill and Joseph Hot Springs issue indicates that these rocks probably contribute 10 the healing of the water. They may be a direca source of heat for some of the water, and the volcanic activity that resulted in these rocks may have resulted in an abnomally high geothermal gradient. The depth of circulation and the amount of dilution by cool shallow ground water are not known. The major faults certainly furnish the avenues of escape for the water that enters the earth's surface at altitudes much higher than those of the springs, but the depth of circulation in the fault zone is unknown.

Richfield Warm Springs, (C-23-3)26aca-S1, are about half a mile west of Richfield in Sevier County. These springs issue at a fault contact between alluvium and sandstones of Tertiary age in the Elsinore fault zone along the west side of the Sevier River valley (figure 17). Numerous faults occur in the eastcrn part of the Pavant Range. which is immediately west of the springs. Volcanic rocks of late Tertiary age crop out about two miles south of the springs and extend for many miles southwestward along the west side of the Sevier River valley; similar outcrops are common along the east side of the valley.

Richardson (1907. p. 58) reported that spring discharge was $1.440 \mathrm{gpm}$ and that water temperature was $74^{\circ} \mathrm{F}$. In June 1966, discharge was $700 \mathrm{gpm}$ and water temperature was $72^{\circ} \mathrm{F}$. Dissolved-solids content of the springs is low-about $300 \mathrm{ppm}$; the water is of the magnesium calcium bicarbonate type.

The presence of numerous faults in the mountains one to five miles west of the springs, the large discharge of the springs and the low dissolved-solids content indicate that the spring discharge is meteoric water that descends not more than 2,000-3,000 feet and is heated slightly by the geothermal gradient. The altitude in some areas of possible infiltration is more than 2,000 feet higher than that of the springs. The geothermal gradient within the mountains is sufficient to raise the temperature of the water $15^{\circ}-20^{\circ}$ 
Recent investigations (continuing into 1978) at Monroe Hot Springs by the Department of Geology and Geophysics of the University of Utah probably will lead to the developing of those springs for heating of schools and several other buildings in Monroe (S. H. Ward, pers. commun. 1978).

Slightly warm water $\left(15.5^{\circ}-19.5^{\circ} \mathrm{C}\right)$ has been reported in 29 wells and 11 springs (Table 14-B). Two of these springs yield large quantities of water: Fayette Spring, $1900 \mathrm{gpm}$ at $18^{\circ} \mathrm{C}$, and Redmond town spring, $6000 \mathrm{gpm}$ at $19^{\circ} \mathrm{C}$. Richardson (1907, p. 58) reported a temperature as high as $70^{\circ} \mathrm{F}\left(21^{\circ} \mathrm{C}\right)$ and a flow of 13.5 cf's for Redmond Springs.

San Pitch River - Headwaters to confluence with Sevier River

Two springs, Crystal (Livingston Warm Spring), (D-18-2)13cad, and Peacock (Nine Mile Warm Spring), (D-19-2)4dea, consistently yield water at $22^{\circ}-22.5^{\circ} \mathrm{C}$, and one deep well, (D-14-5)l6bdd, yields fresh artesian water of $55^{\circ} \mathrm{C}$ from the Masuk and Emery Sandstone members of the Mancos Shale between the bottom of the casing at 5588 and the plug at 5800-5900 (Table 16-A). Both springs rise along faults so it is likely that they and the deep well derive their heat from the geothermal gradient.

Six wells yield slightly warm water of $15.5^{\circ}-19^{\circ} \mathrm{C}$ and four springs and a mine tunnel yield water of $15.5^{\circ}-18.5^{\circ} \mathrm{C}$ (Table 15-B).

Robinson (1968, Tables 1 and 2) measured temperatures of about 350 wells and 51 springs. Except for the deep well that yields water of $131^{\circ} \mathrm{F}\left(55^{\circ} \mathrm{C}\right)$, temperatures ranged from $46^{\circ} \mathrm{F}\left(8^{\circ} \mathrm{C}\right)$ to $66^{\circ} \mathrm{F}\left(19^{\circ} \mathrm{C}\right)$ and averaged $52^{\circ} \mathrm{F}\left(11^{\circ} \mathrm{C}\right)$. Temperatures of water from the springs ranged from $37^{\circ} \mathrm{F}\left(3^{\circ} \mathrm{C}\right)$ to $73^{\circ} \mathrm{F}\left(22^{\circ} \mathrm{C}\right)$ and averaged $52^{\circ} \mathrm{F}\left(11^{\circ} \mathrm{C}\right)$.

\section{Cited References}

Carpenter, C.H., G.B. Robinson, Jr., and I.J. Bjorklund, 1964, Selected hydrologic data, upper Sevier River basin, Utah: U.S. Geol. Survey Basic-Data Report No. 8, 29 p.

Carpenter, C.H., and R.A. Young, 1963, Ground-water data central Sevier Valley parts of Sanpete, Sevier, and Piute Counties, Utah: U.S. Geo1. Survey Basic-Data Report No. 3, 34 p.

Mundorff, J.C., 1970, Major thermal springs of Utah: Utah Geol. and Mineralog. Survey, Water-Resources Bull. 13, $60 \mathrm{p}$.

Robinson, G.B., Jr., 1968, Selected hydrologic data San Pitch River Basin, Utah: U.S. Geol. Survey Basic-Data Release No. 14, 44 p.

Richardson, G.B., 1907, Underground water in Sanpete and Central Sevier Valleys, Utah: U.S. Geol. Survey Water-Supply Paper 199, 63 p. 
Uinta Basin

\section{INTRODUCTION}

The Uinta Basin includes most of northeastern Utah south of the crest of the Uinta Mountains. It encompasses more than 10,000 square miles including nearly all of Uintah and Duchesne Counties as well as parts of Carbon, Emery, Grand, Utah, and Wasatch Counties. Many oil fields have been developed in the Uinta Basin, beginning with the Ashley Valley field in 1949.

SUMMARY Of PRINCIPAL OCCURRENCES, USE, and POTENTIAL

Warm to hot water between $20^{\circ}$ and $55^{\circ} \mathrm{C}$ is yielded in quantity by wells in the Ashley Valley oil field $\left(43^{\circ}-55^{\circ}\right.$, 4400 acre-feet per year, approximately $1500 \mathrm{ppm}$ dissolved solids), by a spring in Split Mountain Canyon (30 , $2700 \mathrm{gpm}$, $942 \mathrm{ppm})$, by a water well converted from an oil-test well about 5 miles southeast of Jensen $\left(43^{\circ}-46^{\circ}, 200 \mathrm{gpm}, 2000 \mathrm{ppm}\right)$ (this well apparently abandoned December 1977), and by springs that rise along a fault or faults in the Duchesne River valley about 2 miles northwest of Hanna (26 $, 2250 \mathrm{gpm}, 454 \mathrm{ppm}$ ). All the water except that from the spring in Split Mountain is used for irrigation, but without any attempt to make use of the heat.

The water that rises with the oil in Ashley Valley is run through settling tanks that separate the oil and water. The water is then disposed of into ponds and ultimately into ditches by which it enters the irrigation system east of the field. Such water could be used for space heating in the inmediate vicinity, perhaps even in Naples or Jensen, or for extending the growing season by using large greenhouses.

The warm water from the springs northwest of Hanna similarly might be used in greenhouses.

Slightly warm water, $15.5^{\circ}-19.5^{\circ} \mathrm{C}$, is yielded by 13 springs and 7 shallow wells that are between 12 and 160 feet deep. One spring yields $117 \mathrm{gpm}$ and another $40 \mathrm{gpm}$ but the rest of the springs and wells all yield $20 \mathrm{gpm}$ or less. These waters are in the temperature range suitable for use in heat pumps, but only the water from the wells might be so used for the springs are generally remote from human habitations. Most of the springs and wells yield water containing less than $1000 \mathrm{ppm}$ dissolved solids but four springs and two wells yield water containing 1000 to $2770 \mathrm{ppm}$.

\section{GEOLOGIC ENVIRONMENT}

"The Uinta Basin is an asymmetric syncline with an axis that is concave southward and generally parallel to the eastward-trending Uinta Mountains that lie to the north. Beds that form the north flank of the basin dip steeply southward away from the Uinta Mountains. Beds that form the south flank dip up to $5^{\circ}$ northward toward the axis of the syncline. Rocks of Precambrian, Cambrian, and Mississippian through Tertiary ages are exposed" along the steep north flank of the basin and have been identified in oil wells (Feltis, 1966, p. 9). Only Tertiary rocks are exposed over the rest of the basin; they extend from the foot of the Uinta Mountains to the crest of the Book Cliffs where they have been cut off by the erosion that has exposed Cretaceous rocks at the base of the cliffs. 
Significant faults parallel the east-west trend of the basin axis along the south flanks of the mountains. In the northeastern part of the basin is the Deep Creek fault zone which trends northwest-southeast about where the trend of the axis of the basin turns southeastward. All these faults cut the Paleozoic as well as Tertiary rocks and therefore probably provide conduits for water from the mountains to get into the deep subsurface. In addition, the rocks along the flank of the mountains have joints that may also act as conduits for water.

Although warm and hot waters are reported in several localities in the Uinta Basin, there appears to be no significant source of heat other than the normal geothermal gradient. A few springs, whose temperatures are all below $32^{\circ} \mathrm{C}$, rise along faults and one rises on the Split Mountain anticline. Wells in the Ashley Valley oil field yield water of $43^{\circ}$ to $53^{\circ} \mathrm{C}$ from depths of about 4200 feet, but the water itself may be coming from formations 1000 to 2000 feet below the well bottoms.

\section{OCCURRENCES Of HOT tO WARM WATER}

\section{Ashley Valley Oil Field}

The principal occurrence of hot water in the Uinta Basin is in the Ashley Valley oil field in township 5 south, range 22 east, where several wells yield water of $43^{\circ}$ to $53^{\circ} \mathrm{C}$ from depths of about 4200 feet below the land surface (Table 17). Probably all the other wells in the 28-well field yield water of about the same temperature but temperature information on them has not been reported. Total water yield of the oil field in 1963 was nearly 29 million

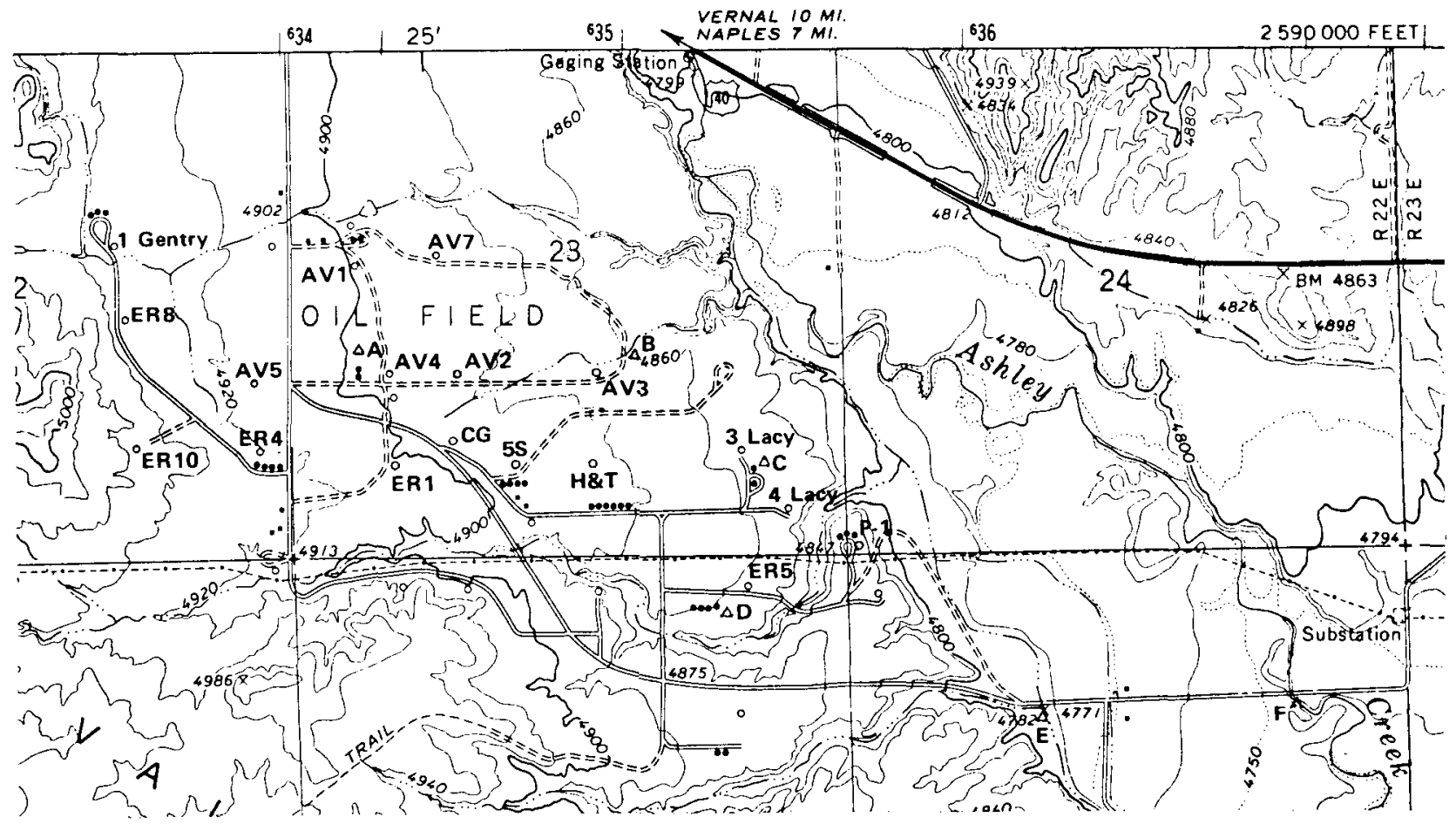

Figure 9. Map of Ashley Valiey Oil Field showing oil well locations and water temperature measurement sites.

scale: $1: 24,000$ 
Table 18 - EXPLANATION for Figure 9 and records of water temperature and conductance in the Ashley Valley oil field

Symbols \&

points

$\mathrm{AV}-2,3,4,5,7$

$E R-1,2,4,5$, $6,8,10$

$\mathrm{H} \& \mathrm{~T}$

$3 \& 4$ Lacy

$\mathrm{P}-1$

CG

$5 \mathrm{~S}$

$\because \quad A$

B

C

D

E

F

\section{Ownership or description}

Equity Oil Co.

Energy Reserves (Formerly Pan American)

Hollandsworth and Travis

R. Lacy

Polumbus Corp.

Crain and Griffith T.E.Hall \#1

Thomas E. Hall $5 \mathrm{~S}$

Composite of Equity wells $\mathrm{AV}-2,3,4,5,7$

Composite of Equity wells $\mathrm{AV}-2,3,4,5,7$ below settling ponds; half a mile below $A$

Composite of Lacy 3 and 4

Composite of ER-1,2,4,5,6,8

Composite of ditch water and outflow from oil field

Ashley Creek

\begin{tabular}{ccc}
$\begin{array}{c}\text { Temperature } \\
{ }^{\circ} \mathrm{C}\end{array}$ & $\begin{array}{c}\text { Conductance } \\
\text { mmho }\end{array}$ & Date \\
\hline & & \\
& & \\
$56^{\circ}$ & 2400 & $12 / 7 / 77$ \\
& & \\
45 & 2500 & do \\
50 & 1600 & do \\
47 & 1620 & do \\
49 & 1580 & do \\
16 & 1150 & do \\
53 & 2700 & do \\
50 & 1800 & $12 / 6 / 77$ \\
20 & 2900 & $12 / 7 / 77$ \\
2 & 3700 & $11 / 4 / 60$ \\
& & $12 / 7 / 77$
\end{tabular}

1590

1330

1860

2460

829
$11 / 3 / 59$

do

do

do

do 
barrels or 3700 acre-feet of water having about $1500 \mathrm{ppm}$ dissolved solids. In 1977 the yield was 34.6 million barrels or more than 4400 acre-feet. It would seem that so long as pumping continues in the field, water production will remain high; if pumping stops, water production would cease for a while, but artesian pressures would be restored and ultimately, perhaps in a year or less, the wells would begin to flow, although at a rate appreciably less than the present 4400 acre-feet a year. Richard Peterson, of Equity Oil Co., told me that the top-hole pressure on the discovery well, Equity \#1AV, was between 500 and 600 pounds when the well was first put into production in 1948. Restoration of that pressure should produce appreciable flow.

By 1952, 30 wells were producing about 900,000 barrels of oil and 600,000 barrels of water. From 1952 to 1960 oil production averaged about 950,000 bbls a year and reached a peak of 1,400,000 bbls in 1960. During the same period, water production steadily increased to about $18,700,000$ bbls in 1960 . Since 1962, oil production has declined and water production has increased: in the year ending December 1977, about 180,000 bbls of oil and 34,634,000 bbls of water were produced by 28 wells.

In Table 18 are given water temperatures and conductances measured on some wells, a ditch, and a creek on December 6 and 7, 1977, and, where available, reasonably comparable measurements taken in 1959 and 1960 (all temperature measurements were made by Goode, the 1977 conductances were measured by Goode, and the 1959 and 1960 conductances were reported by laboratory personne1).

The 1977 temperatures of the Equity and Energy Reserves wells, although not comparable to the 1959-60 temperatures on a well-to-well basis, suggest that the water may be as much as 2 or $3^{\circ} \mathrm{C}$ higher now than it was in 1959-60. This rise could be the result of a greater volume of water moving through the plumbing system ( 34.6 million bbls vs 18.7 million) or it may be due to a general warming of the system by the long-term movement of the hot water through it.

As reported by Goode and Feltis (1962, p. 12) the water "is probably sustained by surface recharge in outcrop areas north and east of the field. Possibly the water comes not only from the oil-bearing strata (the Weber-Phosphoria) but also from a sequence of underlying limestones of Pennsylvanian and Mississippian age." The water probably moves up into the oil-bearing rocks along normal faults that are known to cut those rocks (Peterson, 1957, map).

\section{Other Occurrences}

About 7 miles southeast of the Ashley Valley oilfield, in sec. 1, T.6 S., R.23 E., is an oil-test well that was reported as converted to a water well (Table 19-A). It was reported to yield $200 \mathrm{gpm}$ of water containing about $2000 \mathrm{ppm}$ total solids at temperatures of $43^{\circ}-46^{\circ} \mathrm{C}$ from a depth of 2650 feet. In December 1977 it appeared that this well was not longer being used.

In Split Mountain Canyon, one or more springs at (D-4-24)16eddS yield $2700 \mathrm{~g} 7 \mathrm{~m}$ of water containing $942 \mathrm{ppm}$ total solids at $30^{\circ} \mathrm{C}$. This water probably gains its heat from the geothermal gradient as it moves through the subsurface before rising near the center of the Split Mountain anticline.

About $3 \frac{1}{2}$ miles east of Ouray an oil-test well, Shell \#1 State, (D-8-30)36baa, has recorded temperatures of $43^{\circ}, 52^{\circ}$, and $57^{\circ} \mathrm{C}$ from depths of about 3390,4550 , and 4790 respectively. The water is briny and has chloride contents of 11,500 , 20,000 , and 31,000, respectively, at the above depths. The temperatures suggest a geothermal gradient of $1^{\circ} \mathrm{C}$ per hundred feet.

In the valley of the Duchesne River about 2 miles northwest of Hanna, a group of warm springs produces about $2250 \mathrm{gpm}$ of water containing $454 \mathrm{ppm}$ total solids at a temperature of $26^{\circ}$. This water evidently is controlled by a cluster of normal faults that trend generally east-west. 
In the southeastern part of the Uinta Basin, the U.S. Geological Survey has been monitoring wells and springs as part of a special ground-water study. Information on wells that have reported temperatures of $17^{\circ}$ to about $34^{\circ}$ are included in Table 19-C. Most of the wells are gas wells or water wells converted from gas wells and are deeper than 5600 feet. Considering that the gas wells are 5600 to $7000 \mathrm{ft}$ deep, the reported temperatures appear to be anomalously low.

\section{OCCURRENCES Of SLIGHTLY WARM WATER}

Slightly warm water, 15.5 to $19.5^{\circ} \mathrm{C}$ is yielded by 13 springs and 7 shallow wells that are between 12 and 160 feet deep (Table 19-B). Four of the springs are in Dinosaur National Monument. Another, the one with the highest yield in the group ( $117 \mathrm{gpm}$ ), is just beyond the southerm boundary of the monument. Two springs and a well are in the valley of the Duchesne River about 12 miles northwest of Duchesne. Two shallow wells are about a mile southwest of Roosevelt, another is about 9 miles southeast of Roosevelt, and a fourth is about 12 miles southwest of Roosevelt.

In the southern part of the basin, south of the Duchesne and White Rivers, are two very shallow wells, only 22 and 12 feet deep, whose waters likely were warmed to the reported $17^{\circ}$ and $18^{\circ}$ respectively by the heat of the sun. Similarly, a spring on Flat Rock Mesa, which apparently yields 0.2 gpm from flat-iying rocks, probably has its water warmed by the sun. Other temperature measurements at Flat Rock Mesa spring show among others $3^{\circ} \mathrm{C}$ on $2-11-75$ and $12^{\circ} \mathrm{C}$ on $7-23-75$ (Conroy and Fields, 1977, p. 211). Sulphur Spring was plotted by Hood, Mundorff, and Price (1976, Plate IB) about a quarter mile from a fault shown on the Geologic Map of Utah (Stokes and others, 1963, southeast quarter). Probably there is a relation between the fault and the spring.

\section{Cited Iicerences}

Conroy, L.S., and F.K. Fields, 1977, Climatologic and hydrologic data, southeastern Uinta Basin, Utah and Colorado, water years 1975 and 1976: U.S. Geol. Survey Utah Basic-Data Release No. 29, 244 p.

Feltis, R.D., 1966, Water from bedrock in the Colorado Plateau of Utah: Utah State Engineer Tech. Publ. No. 15, 79 p.

Goode, H.D., and R.D. Feltis, 1962, Water production from oil wells of the Uinta Basin, Uintah and Duchesne Counties, Utah: Utah Geol. and Mineralog. Survey Water-Resources Bull.1, 31 p.

Hood, J. W., J.D. Mundorff, and Don Price, 1976, Selected hydrologic data, Uinta Basin area, Utah and Colorado: U.S. Geol. Survey Basic-Data Release No. $26,321 \mathrm{p}$.

Peterson, V.E., 1957, The Ashley Valley oil field, in Intermountain Assoc. Petroleum Geologists Guidebook 8th Ann. Field Conf., 1957, p. 191-192.

Price, Don, and L.L. Miller, 1975, Hydrologic reconnaissance of the southern Uinta Basin, Utah and Colorado: Utah Dept. Nat. Resources Tech. Pub. No. $49,59 \mathrm{p}$.

Stokes, W.I., L.F. Hintze, and J.H. Madsen Jr., 1961-1963, Geologic Map of Utah: Univ. of Utah. 
Utah and Goshen Valley

\section{INTRODUCTION}

Utah Valley and its neighbor to the southwest, Goshen Valley, encompass about 600 square miles between latitudes $39^{\circ} 50^{\prime}$ and $40^{\circ} 30^{\prime}$ north and between longitudes $111^{\circ} 32^{\prime}$ and $112^{\circ} 01^{\prime}$ west. Both valleys are wholly within Utah County (figure 10).

Northern Utah Valley sustains both heavy industry and agriculture whereas southern Utah Valley and Goshen Valley are principally agricultural areas. Provo, the principal city, is the home of Brigham Young University, the largest university in the State.

SUMMARY of OCCURRENCES, USES, and POTENTIAL for USE

Waters of temperatures from $15.5^{\circ}$ to $46^{\circ} \mathrm{C}$ are yielded by springs and wells near Saratoga Springs in northern Utah Valley, and waters of temperatures from $15.5^{\circ}$ to $34 \mathrm{C}$ are yielded from wells and springs in southern Utah Valley and in Goshen Valley. In northerm Utah Valley the warm and hot water in wells is confined to the area near Saratoga Hot Springs, but in southern Utah Valley water of $20^{\circ}$ to $34^{\circ} \mathrm{C}$ apparently is related to a N-S fault in the Payson area and slightly warm $\left(15.5^{\circ}-19.5^{\circ} \mathrm{C}\right)$ water has been measured in about 30 percent of the wells in the low valley floor.

In other areas outside Utah, waters in these temperature ranges and of the low salinity of most of the waters of these two valleys are used for space heating, for heating greenhouses, and for extending the growing seasons of certain crops. At present, the only known use of the thermal properties of the waters of the Utah Valley and Goshen Valley is at Saratoga Springs where the moderately saline ( 1050 to $1600 \mathrm{ppm}$ dissolved solids) warm water from the springs and wells is used to supply swimming pools at the resort.

Some of the wells near Saratoga Springs supply irrigation water, but apparently no attempt is made to use the heat of the water to extend the growing season or to heat greenhouses, a use for which this water would seem to be ideally suited. This water could also be used for space heating, for its fairly low salinity should cause few problems with such use.

With the exception of the springs at Bird Island and at Lincoln Point, whose waters contain 6140 and $6650 \mathrm{ppm}$ total solids, essentially all the warm water so far reported from wells and springs in southern Utah Valley and in Goshen Valley might be used for space heating, for heating greenhouses, or for extending the growing season.

In Utah Valley, neither the chemistry of the warm waters nor the geophysical studies, which provide information to help in the interpretation of the sources of heat, suggest that any source is capable of providing water or steam hot enough to generate electricity.

In Goshen Valley, however, recent studies of the $\mathrm{Na}-\mathrm{K}-\mathrm{Ca}$ and $\mathrm{SiO}_{2}$ content of the waters of wells and springs by Parry and Cleary (1978) lead them to conclude that hot water as high as $180^{\circ} \mathrm{C}$ may exist at depth, and therefore the area is worthy of further investigation.

The findings of Parry and Cleary in Goshen Valley may relate that area to the nearby East Tintic district, whose Burgin mine yields saline water of about $60^{\circ} \mathrm{C}$. In 1965, Lovering and Morris, after comprehensive studies of geothermal gradients in the Latite Ridge area of the East Tintic mining district suggested that the area "should be explored as a possible source of geothermal power" (p. $\mathrm{F}-1$ ). 


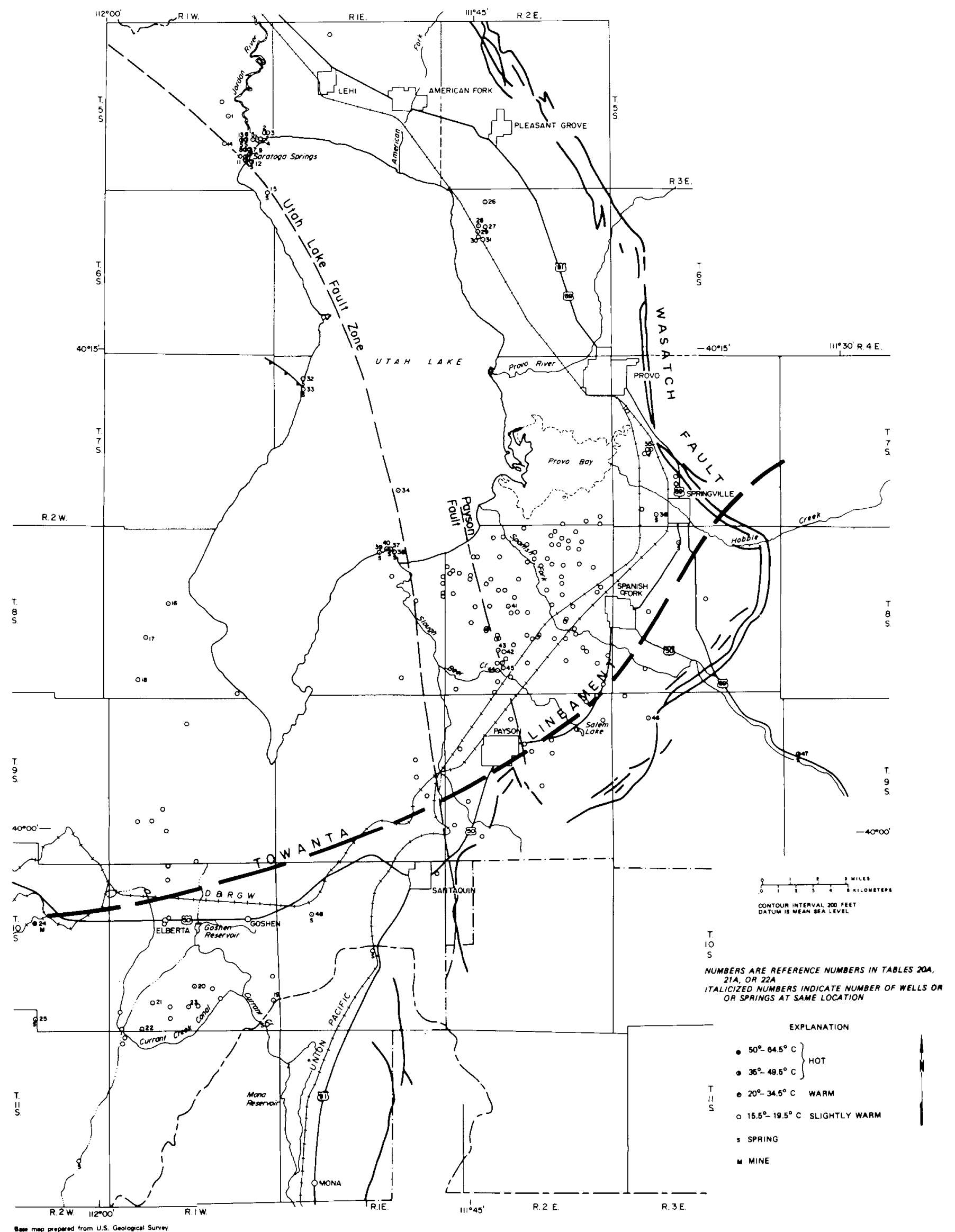

Figure 10. Map of Utah Valley, Utah, showing wells and springs that yield hot, warm, and slightly warm water. 


\section{GEOLOGIC and HYDROLOGIC ENVIRONMENT}

The major structure of Utah Valley is a NNW-trending graben, bounded on the east by the Wasatch fault zone and on the west by the Utah Lake fault zone (Cook and Berg, 1961, plate 13). The northern end of the graben is marked by faults along the southern margin of the Traverse Range, and the southern end by NEtrending splinter faults of the Wasatch fault zone.

Southern Utah Valley is characterized structurally not only as the southern termination of the Utah Valley graben, but also, as Ritzma (1976, p. 119) points out, Southern Utah Valley is the place where the Wasatch fault is offset to the southwest and his $\mathrm{W} 72^{\mathrm{O}} \mathrm{W}$-trending Towanta lineament bends to the south and crosses from Utah Valley to Goshen Valley in the gap between West Mountain and Long Ridge. Perhaps the bending of the Towanta lineament between Santaquin and Goshen Valley is the reason for the southwestward-trending magnetic nose that is shown on the aeromagnetic map of north-central Utah (Mabey and others, 1964). Certainly southern Utah Valley is disturbed enough to provide conduits for water to circulate deeply enough to become moderately warm.

Goshen Valley is shaped like an arrowhead that points to the SSW and which is bounded on the southeast by a series of NE-trending faults and on the west side by probable faults that separate the valley from the East Tintic Mountains to the west. Northeastward, Goshen Valley merges into Utah Valley.

Utah Lake occupies about 150 square miles in parts of both valleys, and the other parts of the valleys are underlain at the surface by unconsolidated fluvial and lacustrine deposits of Quaternary age. In most of Utah Valley the Quaternary deposits are about 250 to 600 feet in thickness, but are nearly 900 feet thick just east of Long Ridge, and are about 1300 feet thick at West Mountain; in Goshen Valley the Quaternary deposits are 300 feet to more than 500 feet thick (Cordova, 1970, figs. 4 to 11). Below the Quaternary deposits is an unknown thickness of Tertiary deposits. Cook and Berg (1961, p. 82) believe that the Tertiary and Quaternary rocks in the center of the Utah Valley graben "extend to a depth of at least several thousand feet."

The rocks of the mountains surrounding Utah and Goshen Valleys are principally Paleozoic marine sediments with early Tertiary volcanics surrounding the southern tip of the arrowhead of Goshen Valley. Presumably the bedrock underneath the Cenozic deposits of both valleys is of Paleozoic age.

The interbedding of the alluvial sands and gravels from the mountains with the silt and clay deposits that were laid down during the lake cycles provides an artesian environment that is typical of the graben valleys along the Wasatch Front. Thomas (Hunt, Varnes, and Thomas, 1953) identified three artesian (confined) aquifers in northern Utah Valley: A Tertiary(?), a deep Pleistocene, and a shallow Pleistocene. They underlie deposits of the Lake Bonneville Group which contain ground water under water-table or unconfined conditions. Cordova (1970) recognized the same three artesian aquifers in southerm Utah Valley, but only the shallow and deep Pleistocene aquifers in Goshen Valley.

OCCURRENCE Of THERMAL WATER

Thermal water is reported in several areas in the two valleys (Tables 20-A and $B, 21-A$ and $B, 22-A$ and $B$ ), grouped here according to their presumed geologic control, which for each is a fault or fault zone. 
Utah Lake Fault Zone

The Utah Lake fault zone parallels the northern portion of the west shore of Utah Lake, probably about a quarter mile offshore. Northward, it passes through Saratoga Springs and probably continues northwestward beneath the volcanics of the Traverse Range. Southward it goes near Bird Island and then east of Lincoln Point at the north end of West Mountain. From there it goes through Holladay Springs and meets the main Wasatch fault zone about one mile northeast of Santaquin. In the vicinity of Lake Mountain and West Mountain, the west side of the fault is up, and near Santaquin the east side is up, which "suggests either a hinge action or east-west cross faulting" north of Santaquin (Cook and Berg, 1961, p. 82).

Along this fault zone in the vicinity of Saratoga Springs are shallow wells 90 to 198 feet deep that produce water from $21^{\circ}$ to $46^{\circ} \mathrm{C}$. In the same area are two springs at $43.5^{\circ} \mathrm{C}$. In the lake southeast of Saratoga Springs are springs that have been measured at $41.5^{\circ}$ and $32^{\circ} \mathrm{C}$.

"In the summer of 1904, during the survey of Utah Lake by G.L. Swendsen of the Reclamation Service, three groups of springs were found beneath the water of the lake. Their existence was shown by the presence of depressions occupying areas of 100 square feet to 3 acres in extent and having depths of 20 to 80 feet. Since the prevailing depth of the lake is much less and the bottom is composed of slimy mud, a considerable discharge is thus indicated"(Richardson, 1906, p. 49). During the winter when most of Utah Lake freezes over a band of open water marks the location of these springs in the lake.

Farther south, a spring on Bird Island yields water of $21^{\circ}$, and springs on the tip of Lincoln Point have been measured at $31.5^{\circ} \mathrm{C}$. About ten miles south of Lincoln Point, east of West Mountain are shallow wells, 55 to 125 feet deep, that yield water of $16.5^{\circ}$ to $18.5^{\circ}$. Finally, about two miles west of Spring Lake are the Holladay Springs, which are described as having "warm waters" by Cook and Berg (1961, p.28). I measured the temperature of one of the Holladay Springs at $11^{\circ}$ on December 9, 1972.

Chemical Quality and Source of the Warm Water

The warm waters that come from springs and wells along the Utah Lake fault zone can be separated into three groups based on the concentration of dissolved solids. Springs and wells in the northern reach of the Utah Lake fault zone near Saratoga Springs range in total dissolved solids from about 1050 to 1600 ppm. The springs on Lincoln Point and the one on Bird Island range from 6140 to 6650 $\mathrm{ppm}$ in total solids. The slightly warm (about $15.5^{\circ} \mathrm{C}$ ) waters in some of the wells that are near the south end of the east face of West Mountain contain less than $500 \mathrm{ppm}$ total solids.

It thus appears that although the Utah Lake fault zone probably is the main conduit by which the water comes to the surface, it is likely that the sources of water, the sources of heat, or both are different in the different parts of the fault zone. Therefore they should be examined separately.

The springs that rise in the lake near Saratoga Springs and the nearby warm springs and warm-water wells are similar chemically and probably therefore are all supplied by a common source. Likely that source is Cedar Valley, west of Lake Mountain, where there are sinks and no surface drainage out of the valley. Feltis (1967, p. 13), in his report on Cedar Valley, suggested that 
ground water from Cedar Valley might discharge in the bottom of' Utah Lake. 'l'he principal structure of Lake Mountain is a syncline which, according to cross sections by Bullock (1951, p. 24), would drop the tops of two possible aquifers, the Great Blue Limestone and the Pinyon Peak Limestone, to about 500 feet above sea level and about 3000 feet below sea level, respectively. Either or both of these aquifers could bring water to the fault zone. Probably the normal geothermal gradient is more than sufficient to warm the waters to the $32^{\circ}$ to $46^{\circ}$ that are reported near Saratoga Springs.

The highly mineralized waters of Bird Island and Lincoln Point must be derived from a different source from the one that supplies the warm water at Saratoga Springs. The salinity of these waters suggests that they are supplied by some deep-seated heat source such as has been postulated for many of the warm and hot springs of Utah that rise along faults or near volcanic area. No known volcanic rocks are close enough to be the source of heat, and the aeromagnetic map that includes the area of the springs (Mabey and others, 1964) shows no anomaly in the area, so it is likely that water penetrates the fault zone to a great depth and then rises to supply the springs.

In contrast to the saline waters of Bird Island and Lincoln Point the warm waters in the wells east of West Mountain are fresh and therefore they probably derive their heat from the normal geothermal gradient, and at rather shallow depth.

\section{Payson Fault}

Cock and Berg (1961, p. 82) recognize a "second concealed northward-striking fault, 2 to 3 miles east of" the Utah Lake fault zone, which "apparently begins near Payson and extends north past the mouth of Spanish Fork." Aligned along or close to that fault in the vicinity of Benjamin are five wells, 117 to 675 feet deep, that yield water of $20^{\circ}, 20^{\circ}, 26.5^{\circ}, 31.5^{\circ}$ and $34^{\circ}$, including the warmest water in southern Utah Valley. Chemical analyses of the water from two of the wells show 450 or less total solids, so it is likely that the other wells yield water of good quality. Likely the fault is the conduit for the heat, but it is likely that heat rather than hot water is rising from the fault, for the quality of the water is better than it would be if rising from great depth. Futhermore, wells nearly everywhere in southern Utah Valley yield warmer-than-normal water, so it is likely that there is horizontal spreading of warm water through the confined aquifers.

One way to evaluate the occurrence of warm water in southern Utah is to compare temperature measurements of well water in northern Utah Valley with those of southern Utah Valley, as below:

Total wells measured $11.1^{\circ} \mathrm{C}$ to $15.4^{\circ} \mathrm{C}$ $11^{\circ} \mathrm{C}$ or less ( $\mathrm{coO}$ ) $15.5^{\circ} \mathrm{C}$ or higher (warm)

$\begin{array}{cc}\text { Northern. Utah Valley } & \text { Southerm Utah Valley } \\ 262 & 392 \\ 23 & 136 \\ 141 & 218 \\ 98 & 38\end{array}$

When we recognize that 11 of the wells of $15.5^{\circ}$ or higher water temperature in northern Utah Valley are near the Saratoga Hot Springs and that only one of those in southern Utah Valley is near a warm spring, and when we see that 6 
of the wells in the north are ones at Geneva that go more than 800 feet to reach $20.5^{\circ}$ and $21^{\circ}$ water, whereas most wells in the south are much shallower, the high proportion (more than one third of the total) of warm-water wells in southern Utah Valley becomes significant. Evidently, expectable temperatures are $2 \mathrm{C}$ higher in southern than in northern Utah Valley - except for the hot spring areas.

Certainly the Payson fault is a control for some of the heat in southern Utah Valley, but perhaps also the crossing of the Wasatch fault zone by the Towanta lineament has caused an even larger region of disturbance that may permit more water to circulate to great depths. Whatever the control, it is likely that the heat rises and then spreads laterally through the confined aquifers, with the result that pin-pointing the control becomes difficult.

Other areas in southern Utah Valley

Several wells at seattered places in the southeast portion of Utah Valley yield slightly warm water, apparently of good quality.

\begin{tabular}{|c|c|c|c|c|c|}
\hline Coordinates & Location & Temp ${ }^{\circ} \mathrm{C}$ & $\begin{array}{l}\text { Depth } \\
\text { in } \\
\text { feet }\end{array}$ & $\begin{array}{l}\text { Total } \\
\text { Solids } \\
\text { in } \mathrm{mg} / \mathrm{l}\end{array}$ & $\begin{array}{l}\mathrm{Cl} \\
\text { in } \mathrm{mg} / \mathrm{l}\end{array}$ \\
\hline$(\mathrm{D}-7-3) 20 \mathrm{bda}$ & Ironton & 22 & 337 & 259 & 12 \\
\hline$(D-8-2) 2 c d a$ & NW of Spanish Fork & 16 & 140 & & \\
\hline $11 \mathrm{adb}$ & " & 17 & 204 & & \\
\hline $12 \mathrm{bdc}$ & $"$ & 17 & 199 & 404 & 49 \\
\hline $26 c a c$ & SW of Spanish Fork & 18.5 & 357 & & \\
\hline $36 \mathrm{dbd}$ & South of Spanish Fork & 16.5 & 38 & & \\
\hline$(D-9-3) 19 d d b$ & East of Salem & 16.5 & 112 & & \\
\hline
\end{tabular}

Southern Goshen Valley

The springs and principal wells that produce warm water of $18.5^{\circ}$ to $22^{\circ}$ in southern GQshen Valley Iine up as a band that trends about $\mathrm{N} 45^{\circ} \mathrm{E}$ along the southeast flank of the valley. The wells range in depth from 335 feet to 862 feet and yield waters that contain 491 to $1780 \mathrm{ppm}$ total solids. Warm Springs yield $21^{\circ}-$ 22 water with $1320 \mathrm{ppm}$ total solids, and the spring in the canyon of Currant Creek yields $19^{\circ}$ water with $1017 \mathrm{ppm}$ total solids.

The volcanic rocks in the vicinity are of Eocene age and therefore probably too old to be the source of heat. It appears more likely that heat for these moderately warm waters is related to a NE-SW-trending fault system, which may be an expression of the Towanta lineament of Ritzma (1976, p. 119).

\section{Northern Goshen Valley}

In northern Goshen Valley, in Township 8 South, Range 1 West, warm water, up to $20.5^{\circ} \mathrm{C}$, is reported from four wells 205 to 392 feet deep, but in three of those wells temperatures of $14^{\circ}$ and $14.5^{\circ}$ have also been reported. There are also inconsistencies in chemical analyses of water collected at different times from two of the wells, ( $C-8-1) 32 \mathrm{bdb}-1$ and $(\mathrm{C}-8-1) 35 \mathrm{dcb}-1$ (B-D 16, p. 25), so it is difficult to speculate on the origin of the water or the source of the heat in these waters. 


\section{Springs south of Pelican Point}

Two springs on the west shore of Utah Lake about two miles south of Pelican Point yield water of $24^{\circ}$ to $25^{\circ} \mathrm{C}$. The water contains 1430 to $1570 \mathrm{ppm}$ total solids of which about $500 \mathrm{ppm}$ is chloride. These springs appear to be on line with a northwest-trending thrust fault mapped by Bullock (1951, p. 12) in the Great Blue Limestone on the east side of Lake Mountain. Probably meteoric water sinks deep enough along the fault to be heated to the observed temperature.

\section{Cited References}

Bullock, K.C., 1951, Geology of Lake Mountain, Utah: Utah Geol. and Mineralog. Survey Bull. 41, $46 \mathrm{p}$.

Cook, K.L., and J.W. Berg, Jr., 1961, Regional gravity survey along the central and southern Wasatch Front, Utah: U.S. Geol. Survey Prof. Paper 316E, p. $75-89$.

Cordova, R.M., 1969, Selected hydrologic data southern Utah and Goshen Valleys, Utah: U.S. Geol. Survey Basic-Data Release No. 16, 35 p.

, 1970, Ground-water conditions in southern Utah Valley and Goshen Valley, Utah: Utah Dept. Nat. Resources Tech. Pub. No. 28, 74 p.

Feltis, R.D., 1967, Ground-water conditions in Cedar Valley, Utah County, Utah: Utah State Engineer Tech. Pub. No. 16, 31 p.

Hunt, C.B., H.D. Varnes, and H.E. Thomas, 1953, Lake Bonneville: Geology of northern Utah Valley, Utah: U.S. Geol. Survey Prof. Paper 257-A, 99 p.

Lovering, T.S., and H.T. Morris, 1965, Underground temperatures and heat flow in the East Tintic District, Utah: U.S. Geol. Survey Prof. Paper 504-F, p. F1-F28.

Mabey, D.R., M.D. Crittenden Jr., H.T. Morris, R.J. Roberts, and E.W. Tooker, 1964, Aeromagnetic and generalized geologic map of part of north-central

Utah: U.S. Geol. Survey Geophysical Investigations Map GP422.

Parry, W.T., and M. Cleary, 1978, Na-K-Ca and $\mathrm{SiO}_{2}$ temperature estimates for Utah spring and well waters: Final Volume 78-1, U.S. Geol. Survey

Contract 14-08-0001-G-341.

Richardson, G.B., 1906, Underground water in the valleys of Utah Lake and Jordan River, Utah: U.S. Geol. Survey Water-Supply Paper 157, 81 p.

Ritzma, H.R. 1976, Towanta lineament, northern Utah: Proceedings of the First International Conference on the New Basement Tectonics, Utah Geol. Assn. Pub. 5, p. 118-125.

Subitzky, Seymour, 1962, Records of selected wells and springs, selected drillers' logs of wells, and chemical analyses of ground and surface waters, northern Utah Valley, Utah County, Utah: U.S. Geol. Survey Basic-Data Report No. 2. 
Central Virgin River Basin

\section{INTRODUCTION}

The drainage area of the Central Virgin River includes most of Washington County, and one of the Virgin's tributaries, Ash Creek, heads in Iron County just south of Cedar City. The two principal tributaries, the Santa Clara River and Ash Creek, drain most of the Pine Valley Mountains, and the mainstem of the Virgin comes into the area by breaching the Hurricane Cliffs on the eastern margin of the area.

St. George, in the south-central part of the area, is the Hub of "Utah's Dixie," a recreation area that capitalizes on the warm climate in the southwest corner of Utah; in St. George the average annual temperature is $61^{\mathrm{O}} \mathrm{F}$ $\left(16^{\circ} \mathrm{C}\right.$ ) (Cordova and others, 1972, p. 6).

SUMMARY Of OCCURRENCES and POTENTIAL FOR USE

The mean annual air temperature in the vicinity of St. George, in the central Virgin River valley, is $16^{\circ} \mathrm{C}$, thus many springs and wells yield slightly warm or warm water of $15.5^{\circ} \mathrm{C}$ to $24^{\circ} \mathrm{C}$. Out of 69 wells and springs whose water temperatures were measured, 23 had temperatures of $15.5^{\circ} \mathrm{C}$ to $19.5^{\circ} \mathrm{C}$ and 23 had temperatures of $20^{\circ} \mathrm{C}$ or higher.

The waters of two spring areas, Veyo Warm Springs, $32^{\circ} \mathrm{C}$, and LaVerkin Hot Springs, $38^{\circ}-42^{\circ} \mathrm{C}$, have been used for bathing but only Veyo continues to be so used. The water at Veyo is of good quality, about $400 \mathrm{mg} / \mathrm{l}$ dissolved solids, and may owe its heat to the young basalt from which it issues. The water of LaVerkin Hot Springs, on the other hand, is highly mineralized, about $9,500 \mathrm{mg} / 1$ dissolved solids, which makes it unsuitable for most uses; and its high rate of discharge, about $4500 \mathrm{gpm}$, results in excessive contamination of the Virgin River. The spring probably derives its heat from the geothermal gradient.

\section{GEOLOGIC and HYDROLOGIC ENVIRONMENT}

The central Virgin River and its tributaries drain an area west of the Hurricane Fault, hence most authorities, such as Hunt (1974), would put the area in the Basin and Range Physiographic Province, but Stokes (1977, p. 13) puts the St. George Basin, which includes most of the area considered here, in the Colorado Plateau Province. Probably the area should be considered transitional between the two provinces.

The topographically lower, southern portions of the area are underlain by gently northward-dipping Mesozoic rocks capped over wide areas by Quaternary and Tertiary volcanics. The northerm part of the area is dominated by the laccolith of the Pine Valley Mountains. Lateral spreading by the laccolith intruded the Tertiary Claron Formation, and later erosion has removed whatever sediments may have overlain the Claron (Cook, 1960, map).

The hydrology of such a geologically complex area must also be complex. The river valleys and adjacent low areas, comprising about 20 percent of the total area, are underlain by unconsolidated deposits of variable thickness that are saturated enough to supply 80 percent of the water withdrawn by wells. The other 20 percent of water withdrawn by wells comes from aquifers in consolidated rocks, principally the Navajo Sandstone (Cordova and others, 1972, p. 8). 
As might be expected in an area where the mean annual air temperature is as high as $16^{\circ} \mathrm{C}$, water obtained from many wells and springs is also slightly warm to warm, as is shown in the attached tables (Tables 23-A and B). Most of the slightly warm to warm springs rise along faults and thus owe some or all of their heat to the normal geothermal gradient at moderate depths.

Two spring areas, Veyo Warm Spring at $32^{\circ} \mathrm{C}$ and LaVerkin Hot Springs at $38^{\circ}-42^{\circ} \mathrm{C}$, are worthy of the discussion given them by Mundorff (1970, p. 44 and 46).

"Veyo Hot Spring, (C-40-16)6cb-S1, is about 18 miles north-northwest of St. George in Washington County. This spring. is no longer accessible to direct observation; a swimming pool has been constructed over the spring. In July 1967, the owner reported that the spring discharge was $120 \mathrm{gpm}$ and the water temperature was $90^{\circ} \mathrm{F}\left(32^{\circ} \mathrm{C}\right)$. He also reported that when he started to develop the spring, it discharged horizonatally from sand and gravel. The spring issues along the base of a nearly vertical canyon incised in basalts of Quaternary age and in sedimentary rocks of Cretaceous age that underlie the basalt. The vicinity of the spring is nearly surrounded by basalt flows of Quaternary age...

"The source of the spring discharge may be meteoric water that infiltrates the intensely fractured and thus permeable basalt. The water may be heated by the residual heat of the basalt as it descends to the contact of the basalt with underlying rocks of Cretaceous age. The source of the water also could be meteoric water that infiltrates the cretaceous rocks beyond the area of basalt flow. The water may be heated as it moves from the Cretaceous rocks through the Quaternary basalt from which it ultimately discharges.

"In 1966 and 1967, two samples of water were obtained that are believed to represent actual spring discharge; the dissolved-solids content was only about $400 \mathrm{ppm}$, and the water was calcium magnesium bicarbonate in type.

"LaVerkin (Dixie) Hot Springs, (C-42-12)25-S, are about 18 miles eastnortheast of St. George in Washington County. These springs issue from the bed and banks of the Virgin River near the mouth of a canyon. The springs issue from the limestone of Paleozoic age along the Hurricane fault... Basalt flows of Quaternary age are exposed over an area of several square miles west, southwest and southeast of the springs... Gregory (1950, p. 197) reports that LaVerkin Hot Springs 'are related genetically to the nearby Hurricane fault and possibly also to the concealed igneous masses that gave rise to the lavas on the adjoining cliffs. These springs issue from cavities in the Kaibab limestone in the canyon wall and in the stream bed of the Virgin River at places where strong joints and faults of small throw provide outlet for deep-seated water. The water from the several springs ranges in temperature from $108^{\circ}$ to $132^{\mathrm{O}} \mathrm{F}$ ( $42^{\mathrm{O}}$ to $55.5^{\circ} \mathrm{C}$ ) and flows at the rate of about 1,000 gallons per minute.' The water probably is meteoric in origin.

"On August 1, 1963, the Virgin River was dry immediately upstream from the springs; U.S. Geological Survey personnel measured the water discharge of the Virgin River immediately downstream from the short reach in which the springs issue at $10.2 \mathrm{cfs}$ or about $4,600 \mathrm{gpm}$. Survey personnel reported discharges of $10.0 \mathrm{cfs}$ in September 1956. Miligan and others (1966, Table 1) reported a discharge of $11.6 \mathrm{cfs}$ on August 21,1964 . The discharge of the springs apparently is much greater than that reported by Gregory (1950).

"Measured temperatures during the period 1960-66 ranged from $100^{\circ}$ to $108^{\circ} \mathrm{F}$ $\left(38^{\circ}-42^{\circ} \mathrm{C}\right)$. Gregory (1950) reported a temperature range of $108^{\circ}-132^{\circ}\left(42^{\circ}-\right.$ $\left.55.5^{\circ} \mathrm{C}\right)$. Thus the minimum temperature reported by Gregory is the maximum temperature observed during 1960-66. The source of the temperature range reported by Gregory is not known, but that range is the same as that reported by Stearns 
and others (1937, p. 183). The observations that resulted in a reported temperature of $132^{\circ} \mathrm{F}\left(55.5^{\circ} \mathrm{C}\right)$ may have been made as early as the $1880^{\prime} \mathrm{s}$. Either the original temperature observations were inaccurate or the springs have cooled significantly during the past 80 years. If the interest in the springs were assumed to be restricted to the potential for generation of electric power, however, the difference between $100^{\circ}$ and $132^{\circ} \mathrm{F}\left(38^{\circ}-55.5^{\circ} \mathrm{C}\right)$ is of no significance. The large discharge ( $10 \mathrm{cfs}$ or more), the high dissolvedsolids content (9,000-10,000 ppm), and the very low silica content (about 10$30 \mathrm{ppm}$ ) indicate a poor potential for geothermal development despite the presence of basalt flows within a few miles of the springs. The source of the heat that warms the water probably is an abnormally high geothermal gradient that resulted from volcanic activity during Quaternary time.

"The major significance of the springs is their adverse effect on the quality of water in the Virgin River, especially during periods of low flow in the stream. The spring discharge has a high dissolved-solids content, is of the sodium chloride type, and has a fairly high boron concentration (about 5 ppm); the source of the dissolved solids is not known. In equivalents per million, calcium and magnesium combined are less than half that of sodium, and sulfate is less than half that of chloride. At the gaging station on the Virgin River at Virgin, which is about five miles upstream from LaVerkin Hot Springs, the average discharge during a 57-year period of record is about $200 \mathrm{cfs}$; during many years, daily mean discharges of less than 100 cf's are common. Data on the chemical quality of the Virgin River at Virgin indicate that the annual weightedaverage dissolved-solids content is in the 400-600 ppm range. If LaVerkin Hot Springs contribute about $10 \mathrm{cfs}$ of water having a dissolved-solids content of about 10,000 ppm to the Virgin River when the stream has a discharge of 100 cfs and a dissolved-solids content of $500 \mathrm{ppm}$, the dissolved-solids content of the stream is almost tripled. The average annual dissolved-solids discharge of LaVerkin Hot Springs is about the same as that for the entire Virgin River basin upstream from the springs (a drainage area of about 950 square miles)."

Cited References

Cook, E.F., 1960, Geologic Atlas of Utah, Washington County: Utah Geol. and Mineralog. Survey Bull. 70, 119 p.

Cordova, R.M., G.W. Sandberg, and Wilson McConkie, 1972, Ground-water conditions in the central Virgin River basin, Utah: Utah Dept. Nat. Resources Tech. Pub. no. 40, $59 \mathrm{p}$.

Gregory, H.E., 1950, Geology and geography of the Zion Park region, Utah and Arizona: U.S. Geol. Survey Prof. Paper 220,200 p.

Hunt, C.B., 1974, Natural Regions of the United States and Canada: W.H. Greeman and Co., San Francisco, 725 p.

Milligan, J.H., R.E. Marell and J.M. Bagley, 1966, Mineralized springs in Utah and their effect on manageable water supplies: Utah State Univ., Logan, Utah Water Research Lab. Rept. WG23-6.

Mundoff, J.C. 1970, Major thermal springs of Utah: Utah Geol. and Mineralog. Survey, Water-Resources Bull. 13, 60 p.

Stearns, N.D., H.T. Stearns and G.A. Waring, 1937, Thermal springs in the United States: U.S. Geol. Survey Water-Supply Paper 679-B.

Stokes, W.L., 1977, Subdivision of the major physiographic provinces in Utah: Utah Geology, v. 4, no. 1, p. 1-17. 
Areas That Have Warm and Slightly Warm Water

Fifteen areas, all in western or central Utah, yield warm and slightly warm water to wells or springs. One well, more than 5200 feet deep, in Cache Valley, yields $15 \mathrm{gpm}$ of hot water at $49^{\circ} \mathrm{C}$. But it is not likely that such a small yield from such a great depth represents an economic resource or an unusual heat source so Cache Valley has been put into this lower category, for the highest temperature recorded for any other well is $28^{\circ} \mathrm{C}$, and that from a well 1473 feet deep. Descriptions of these 15 areas follow.

\section{Beaver Valley}

Beaver Valley lies wholly within the eastern part of Beaver County. Surface water principally from the Beaver River supplies most of the agricultural water in the valley, so that only about 4000 to 5000 acre-feet of water is pumped from wells (Sandberg, 1966, p. 22).

Three wells, in or near Greenvilie, (c-29-8)25cac 1 and 2, and (c-29-8)36aab, report water of $20^{\circ}, 20^{\circ}$, and $23.5^{\circ} \mathrm{C}$ respectively (Table 24 ). The chemical analysis for (C-29-8)25cac 2 shows $69 \mathrm{mg} / \mathrm{l}$ silica, but only $254 \mathrm{mg} / \mathrm{l}$ dissolved solids.

Five other wells and three springs have reported water temperatures of

\section{Cited References}

Lee, W.T., 1908, Water resources of Beaver Valley, Utah: U.T. Geol. Survey Water-Supply Paper 217, 57 p.

Sandberg, G.W., 1963, Ground-water data, Beaver, Escalante, Cedar City, and Parowan Valleys, parts of Washington, Iron, Beaver, and Millard Counties, Utah: U.S. Geol. Survey Basic-Data Report No. 6, 26 p.

, 1966, Ground-water resources of selected basins in south-western Utah: Utah State Engineer Tech. Pub. No. 13, 43 p.

\section{Blue Creek Valley}

Blue Creek Valley is in eastern Box Elder County and it heads at the north border of Utah; it drains southward toward Bear River Bay of Great Salt Lake. The drainage area of the valley includes about 250 square miles and is sparsely populated. Most of the land is used for livestock grazing and the growing of small grains and alfalfa. "The only community center in the area is Howell, which had a population of about 200 in 1970. A chemical and rocket-motor plant for the Thiokol Chemical Corp. is located in the southern part of the area" (Bolke and Price, 1972, p. 3)

Three springs and three wells yield warm water of $20^{\circ}-28^{\circ} \mathrm{C}$ (Table 25-A) Two of the wells and two of the springs yield fresh water of less than $1000 \mathrm{mg} / \mathrm{l}$; but the warmest $\left(28^{\circ}\right)$ spring, Blue Springs, yields about $10 \mathrm{cf}$ s of water containing about $1900 \mathrm{mg} / \mathrm{l}$. "Blue springs is the largest source of irrigation water in the Valley" (Bolke and Price, 1972, p. 16) but apparently no direct use is made of its warmth.

Fifteen additional wells and springs yield fresh to moderately saline water ( 405 to $4860 \mathrm{mg} / 1$ dissolved solids). (Table 25-B). 
Cited Reference

Bolke, E.I., and Don Price, 1972, Hydrologic reconnaissance of the Blue Creek Valley area, Box Elder County, Utah: Utah Dept. of Nat. Resources Tech. Pub. No. 37, $31 \mathrm{p}$.

Cache Valley

\section{INTRODUCTION}

The Utah portion of Cache Valley occupies about 365 square miles of the total 1175 square miles of Cache County in northeastern Utah. Nearly all of the total population of 48,500 (1975 estimate) of Cache County live in the valley. "Agriculture, the principal industry, is devoted mostly to livestock, poultry, dairy products, alfalfa, small grains, corn, sugar beets, potatoes, fruits, and garden vegetables" (Bjorklund and McGreevy, 1971, p. 7). Logan, the principal city, is also the site of Utah State University.

SUMMARY Of OCCURRENCES, USES and POTENTIAL

In the Utah portion of Cache Valley, temperatures of $20^{\circ}$ to $28^{\circ}$ are reported from 23 wells, 48 to 1473 feet deep, that have been drilled in three areas: 1) northwest of Logan, 2) west of Benson and Riverside, and 3) south of Amalga (Table 26-A). One oil and gas test well is reported to have water of $49^{\circ} \mathrm{C}$ from a depth of 5208 feet, a rather low temperature for such a depth; an even deeper well $\left(5,500 \mathrm{ft}\right.$ ) has a reported temperature of $21^{\circ} \mathrm{C}$. In addition, temperatures of $16^{\circ}$ to $19^{\circ} \mathrm{C}$ are reported from about 50 wells in the same general areas of 1 and 2 mentioned above, and also between Lewiston and Cornish (Table 26-B).

Two wells, (A-12-1)28baa 3 and $28 \mathrm{baa}_{5}$, about $24-25^{\circ} \mathrm{C}$, apparently supply water for a svimming pool, for their owner is listed as Logana Plunge. That appears to be the only use made of the warnth of waters in the valley.

Presumably the heat for the warm water comes from the major N-S faults in the valley, but the low temperatures suggest that these sources have but little potential. Probably some of the water could be used in heat pumps, or for water supply in greenhouses, as well as for swimming pools.

\section{GEOLOGIC and HYDROLOGIC ENVIRONMENT}

Cache Valley is a north-trending complex graben the easternmost valley in its part of the Basin and Range physiographic province. The valley floor is underlain by alluvial deposits from the mountains to the east and west, and by lacustrine deposits laid down in Pleistocene Lake Bonneville. Underlying the Quaternary surficial deposits are Tertiary sedimentary rocks and, at depths of about 5000 feet, are pre-Cenozoic rocks of probable Precambrian, Paleozoic, and Mesozoic age.

"Uplifted blocks [of Precambian and Paleozoic rocks] surrounding the valley form mountain ranges. Maximum vertical displacement probably exceeds 10,000 feet in parts of the valley. The Bear River Range [to the east] contains large folds that predate the block faulting. Thrust faults that also predate the block faulting lie east and south of the area, and possibly underlie the area at great depth. Faults with minor displacement are common in the mountain ranges and probably exist in the blocks underlying the valley" (Bjorklund and McGreevey, 1971, p. 12). 
"Deposits related to Lake Bonneville and earlier lakes play an important role in the occurrence of ground water in Cache Valley. The major aquifers are composed of sand and gravel in fans and deltas; interbedded layers of lakebottom clays and silts confine the aquifers and sause widespread artesian conditions" (Bjorklund and McGreevy, 1971, p. 14).

"Most wells in the area derive water from units of Quaternary c:ge; a few wells tap the Salt Lake Formation of Tertiary age...Most of the Salt Lake Formation is fine grained and well indurated and yields little water; however, some sandstone, conglomerate, and fanglomerate are water bearing." The few wells and springs that tap the formation are mostly in or near outcrops along the margins of the valley (Bjorklund and McGreevy, 1971, p. 15).

Cache Valley is well watered. The water budget of Bjorklund and McGreevy (1971, p. 54) for 1960-68 indicates that each year 1,700,000 acre-feet moves into the valley and 1,700,000 moves out. Ground water in the amount of 280,000 acre-feet per year is discharged by wells, springs, seeps, and drains, and by evapotranspiration. The ground-water discharge that is not consumed in the valley leaves the valley as surface water.

OCCURRENCE Of HOT and WARM WATER

The only hot water in the Utah portion of Cache Valley was reported from an oil and gas test well (B-13-1)lOacb, "which was drilled to a depth of 5,208 feet and yielded water with a temperature of $49^{\circ} \mathrm{C}\left(120^{\circ} \mathrm{F}\right) "$ (Bjorklund and McGreevy, 1971, p. 43). Warm water between $20^{\circ}$ and $28^{\circ} \mathrm{C}$ or slightly warm water between $16^{\circ}$ and $19^{\circ} \mathrm{C}$ is reached by wells, generally at depths of 150 to 200 feet, in four areas: 1) northwest of Logan, 2) west of Benson and Riverside, 3) south of Amalga, and 4) between Lewiston and Cornish. The warm water of the areas near Logan and Benson may be related to the major faults in the valley but, if so, it is desseminated horizontally from the faults, for in those three areas no warm springs rise along the faults. The only warm spring (B-14-I) $33 \mathrm{acaS}, 31^{\circ} \mathrm{C}$, rises along the Dayton fault zone about one mile southwest of Trenton.

Cited References

Bjorklund, L.J., and .L.J. McGreevy, 1971, Ground-water resources of Cache Valley, Utah and Idaho: Utah Dept. Nat. Resources Tech. Pub. No. 36, 66 p.

McGreevy, L.J., and L. J. Bjorklund, 1970, Selected hydrologic data Cache Valley, Utah and Idano: U.S. Geol. Survey Basic-Data Release No. 21, 51 p.

Canyon Lands

\section{INTRODUCTION}

The Canyon Lands Section of the Colorado Plateau includes all of southeastern Utah south of the Uinta Basin. The section encompasses about 25,000 square miles including all of Grand and San Juan Counties, more than half of Emery, Wayne, Garfield, and Kane Counties, as well as parts of Carbon and Sevier Counties.

SUMMARY Of OCCURRENCES Of WARM WATER

If the 38 occurrences of warm water $\left(20^{\circ}-31^{\circ}\right)$ and the 98 occurrences of slightly warm water $\left(15.5^{\circ}-19.5^{\circ}\right)$ are plotted on a map, it becomes apparent that most plots are in bunches: near Moab, near Loa, in the Henry Mountains, 
and in the Navajo Indian Reservation principally south of the San Juan River. This bunching is due to the fact that the areas named above are the principal areas where spring and well temperatures have been measured: by the U.S. Geological Survey near Moab and in the Indian Reservation and by me in the Henry Mountains and in the Indian Reservation. The absence of water warmer than $31^{\circ} \mathrm{C}$ is probably due to the fact that in the whole of the Canyon Lands so far investigated there are no discernable sources of anomalous subsurface heat; rather it is the sun that raises temperatures of near-surface waters as high as $31^{\circ}$.

Probably there is only limited use for the heat reported in waters in the Canyon Lands. The springs and shallow wells that yield water whose temperature fluctuates with the seasons are certainly not dependable sources of heat. The few reported wells that are deep enough to yield water of reasonably uniform temperature are in the Indian Reservation and near the Henry Mountains. Although it is not likely that these waters will be used in heat pumps, the temperatures of $15.5^{\circ} \mathrm{C}$ to $24^{\circ} \mathrm{C}$ from moderate depths of 500 to 800 feet suggest that similar temperatures might be reached at moderate depths elsewhere in the Canyon Lands.

\section{GEOLOGIC ENVIRONMENT}

As befits its name, the Canyon Lands Section of the Colorado Plateau is characterized by deep canyons cut into generally flat-lying sedimentary rocks of Mesozoic age. But these generally flat-lying Mesozoic rocks have been upwarped in Utah by the San Rafael Swell, the Momument Upwarp, and the Circle Cliffs Upwarp so that now the Mesozoic rocks that were in the centers of the upwarps have been removed and Paleozoic rocks are exposed. Furthermore, in some places, the originally flat-lying rocks have been domed up by the now well-exposed laccolithic intrusions of the LaSal 24 million years before present (M.Y.B.P.), Henry (44 M.Y.B.P.), and Abajo Mountains (28 M.Y.B.P.) (radiometric ages from Hintze, 1973, p. 81), as well as by the unexposed intrusion that presumably underlies Navajo Mountain. Probably partly as a result of the igneous activity but mostly as a result of epeirogenic uplift, the whole area has been raised as much as 3 miles since Cretaceous time, so that now the Canyon Lands Section is a highland with plateau surfaces at about 5,000 feet and with several peaks above 11,000 feet (Hunt, 1974, p. 425).

The generally high altitude of the Canyon Lands Section has promoted the extensive erosion that has resulted in deep dissection by the Colorado River and its many tributaries. Most of the debris removed from the uplands has been carried away by those streams, but surrounding the LaSal, Henry, and Abajo Mountains are vast pedimented areas that are covered by gravels close to the mountains and by finer alluvial and colluvial deposits away from the mountains. Except for the generally narrow flood plains that fill many valleys, these pedimented areas are the only ones that have unconsolidated surficial materials that can be cultivated.

No water so far reported in the Canyon Lands Section is warmer than $31^{\circ} \mathrm{C}$ and there is nothing in the geologic environment to suggest that there is any appreciably warmer water that has not been reported. The principal igneous activities occurred about 24 or more million years before present, and, although there must be residual heat at depth, no surface manifestation of hot or warm water around the intrusions has been reported. 
The attached table (Tables $27-A$ and $B$ ) list 136 reported occurrences of warm or slightly warm water in the Canyon Lands:

$\begin{aligned} 29 \text { springs } & 20^{\circ}-31^{\circ} \mathrm{C} \\ 8 \text { wells } & 20^{\circ}-28^{\circ} \mathrm{C} \\ 56 \text { springs } & 15.5^{\circ}-19.5^{\circ} \mathrm{C} \\ 43 \text { wells } & 15.5^{\circ}-19.5^{\circ} \mathrm{C}\end{aligned}$

Of the 29 springs with reported temperatures of $20^{\circ}-31^{\circ}$ I measured 20; of the 56 springs with reported temperatures of $15.5^{\circ}-19.5^{\circ}$, I measured 41 . Most of my reported temperatures were measured during the months of July and August, some of them tens or hundreds of feet below the actual places of issuance. Where water seeps from rocks temperatures normally are measured where there is concentrated flow, commonly at the points where samples are measured for conductance and/or are collected for analyses. This water is warmed by the sun. In addition, springs that rise from thin near-surface aquifers may yield warm water right at the points of issuance, for the aquifers and their contained water are also warmed by the sun. Even the water that comes from high-yield springs such as the one that yields $7300 \mathrm{gpm}$ near Loa may show fluctuations of temperature; it has been measured $11^{\circ}$ to $16.5^{\circ} \mathrm{C}$.

To test the idea that many of the reported water temperatures are the result of warming of the water by the sun before or after it issues from the ground, I rechecked on December 8, 1977, ten springs and seeps that I had measured in the summers of 1975, 76, or 77. The comparative temperatures for these springs show that all are cold-water springs.

\begin{tabular}{|c|c|c|c|c|}
\hline Spring name & Date & $\begin{array}{l}\text { Temp } \\
{ }_{\mathrm{C}} \\
\end{array}$ & $\begin{array}{c}\text { Conductance } \\
\text { mmho } \\
\end{array}$ & Flow* \\
\hline $\begin{array}{l}\text { Cow Wash - fed } \\
\text { by return flow } \\
\text { from irrigation }\end{array}$ & $\begin{array}{r}8-3-76 \\
12-8-77\end{array}$ & 21 & 680 & $\begin{array}{l}100 \mathrm{M} \\
\text { Dry }\end{array}$ \\
\hline Little Meadow & $\begin{array}{c}7-11-75 \\
12-8-77\end{array}$ & $\begin{array}{l}16 \\
13\end{array}$ & $\begin{array}{l}595 \\
540\end{array}$ & $\begin{array}{l}2 \mathrm{E} \\
2 \mathrm{E}\end{array}$ \\
\hline Poison & $\begin{array}{r}8-1-75 \\
12-8-77\end{array}$ & $\begin{array}{c}15.5 \\
8\end{array}$ & $\begin{array}{r}1000 \\
980\end{array}$ & $\begin{array}{l}\text { Drip } \\
\text { Drip }\end{array}$ \\
\hline Poison Trib & $\begin{array}{r}8-1-75 \\
12-8-77\end{array}$ & $\begin{array}{r}19 \\
3\end{array}$ & $\begin{array}{l}1500 \\
2300\end{array}$ & $\begin{array}{l}1-2 E \\
1-2 E\end{array}$ \\
\hline Drinking Cup & $\begin{array}{r}8-9-76 \\
12-8-77\end{array}$ & 23 & 625 & $\begin{array}{c}3 \mathrm{E} \\
\text { Frozen }\end{array}$ \\
\hline Maidenwater & $\begin{array}{c}7-25-76 \\
12-8-77\end{array}$ & $\begin{array}{r}19 \\
8\end{array}$ & $\begin{array}{l}580 \\
590\end{array}$ & $1-2 \mathrm{E}$ \\
\hline South Hog & $\begin{array}{r}7-6-77 \\
12-8-77\end{array}$ & $\begin{array}{l}19 \\
11.5\end{array}$ & $\begin{array}{l}625 \\
670\end{array}$ & $\begin{array}{r}5 \mathrm{E} \\
15-20 \mathrm{E}\end{array}$ \\
\hline Middle Hog & $\begin{array}{r}7-6-77 \\
12-8-77\end{array}$ & $\begin{array}{l}31 \\
\text { Couldn't } \\
\text { too much }\end{array}$ & $\begin{array}{l}\quad 620 \\
\text { ecover seepage } \\
\text { low in channel }\end{array}$ & $\begin{array}{l}\text { Seep } \\
\text { area- }\end{array}$ \\
\hline Saleratus & $\begin{array}{c}8-19-75 \\
12-8-77\end{array}$ & $\begin{array}{l}20 . \\
6.5\end{array}$ & $\begin{array}{l}2100 \\
1700\end{array}$ & $\begin{array}{l}I E \\
I E\end{array}$ \\
\hline Mill Race & $\begin{array}{r}8-7-75 \\
12-8-77\end{array}$ & 25 & 4000 & $\begin{array}{l}\text { 5E } \\
\text { Dry }\end{array}$ \\
\hline
\end{tabular}

*Flow in gallons per minute; $E=$ estimated, $M=$ measured 
On the basis of these remeasurements of temperature and of personal knowledge of more than half of the springs, I feel that all the temperatures of the warm spring waters recorded in the table are the result of warming by the sun of thin alluvial, colluvial, pediment, and even some sandstone aquifers, or are the result of the temperature being measured at a point other than the point of actual issue of the water from the rock. In sumnary, then, it is not likely that any of these spring temperatures are indicators of perennially warm subsurface water.

The Garkane Power well that yields $3110 \mathrm{gpm}$ of $24^{\circ} \mathrm{C}$ water from the Navajo Sandstone at a depth of 761 feet would seem to be getting heat because the Navajo Sandstone probably plunges several thousand feet between its recharge area west of the Waterpocket Fold and the well site on the Caineville Anticline, yet two other wells that get water from the Navajo on the Caineville Anticline from depths of 1250 and 1350 feet produce water that is only $18^{\circ} \mathrm{C}$. There is no ready answer for the difference in temperatures.

The well that produces the warmest water, $28^{\circ} \mathrm{C}$, the Roadside Geyser, is probably driven by $\mathrm{CO}_{2}$ gas, but the source of the heat is unknown.

A group of four flowing wells in the Navajo Sandstone north of Hovenweep National Monument produce water of $16.5^{\circ}$ to $18^{\circ}$ from depths of about 300 feet. The wells penetrate a small dome on the eastern edge of the Blanding Basin (Goode, 1958, fig. 8).

Three springs and eight wells a few miles north and west of Loa yield water of $15.5^{\circ}$ to $17^{\circ} \mathrm{C}$ from Tertiary volcanic rocks. The water is of excellent quality, generally about $150 \mathrm{mg} / 1$ or less of dissolved solids, and yields are abundant: two wells flow 1150 and $1750 \mathrm{gpm}$ and the largest warm-water spring yields $7300 \mathrm{gpm}$ But even such large yields are no guarantee of constant temperatures for temperatures of $15^{\circ}, 16^{\circ}$, and $16.5^{\circ}$ have been measured at an even higher volume spring, Pine Creek Spring, which flows $7900 \mathrm{gpm}$.

\section{Cited References}

Bjorklund, L.J., 1969, Reconnaissance of the ground-water resources of the upper Fremont River Valley, Wayne County, Utah: Utah Dept. Nat. Resources Tech. Pub. No. 22, $49 \mathrm{p}$.

Feltis, R.D., 1966, Water from bedrock in the Colorado Plateau of Utah: Utah State Engineer Tech. Pub. No. 15, 79 p.

Goode, H.D., 1958 The geology and distribution of aquifers in the southeastern part of San Juan County, Utah: U.S. Geol. Survey Open-file Rept., 9 p., 9 figs.

, 1969, Reconnaissance appraisal of the water resources near Escalante, Garfield County, Utah: Utah Geol. and Mineralog. Survey Water-Resources Bull. 11, $38 \mathrm{p}$.

Goode, H.D., and Eric Olson, 1977, Reconnaissance appraisal of the water resources of the Henry Mountains coal field, Wayne and Garfield Counties, Utah: Univ. of Utah, College of Mines and Mineral Industries, $85 \mathrm{p}$.

Hunt, C.B., 1974, Natural Regions of the United States and Canada: W.H. Freeman and Co., San Francisco, 725 p. 
Sumsion, C.T., 1971, Geology and water resources of the Spanish Valley area, Grand and San Juan Counties, Utah: Utah Dept. Nat. Resources Tech. Pub. No. $32,40 \mathrm{p}$.

\section{Cedar City and Parowan Valleys}

Cedar City and Parowan Valleys are in the eastern part of Iron County at the foot of the Hurricane Cliffs. Both valleys are largely agricultural and depend largely on ground water for their irrigation supplies. Cedar City is the largest community and is also the home of Southern Utah State University. In Cedar City Valley, two wells yield warm water: (C-37-13) llaaa ( $\left.21^{\circ} \mathrm{C}\right)$. and $(\mathrm{C}-23-13) 36 \mathrm{abb}\left(20^{\circ} \mathrm{C}\right)$. Seven other wells yield slightly warm water at $15.5^{\circ}-19.5^{\circ} \mathrm{C}$ ( Table 28$)$.

In Parowan Valley, one well, $(\mathrm{C}-32-8) 12 \mathrm{bac}$, yields water of $20^{\circ} \mathrm{C}$, and 13 wells yield water of $15.5^{\circ}-18.5^{\circ} \mathrm{C}$ ( Table 29 ).

\section{Cited References}

Bjorklund, L.J., C.T. Sumsion, and G.W. Sandberg, 1977, Selected hydrologic data, Parowan Valley and Cedar City Valley drainage basins, Iron County, Utah:

U.S. Geol. Survey Basic-Data Release No. 28, 55 p.

Sandberg, G.W., 1963, Ground-water data, Beaver, Escalante, Cedar City, and Parowan Valleys, parts of Washington, Iron, Beaver, and Milland Counties, Utah: U.S. Geol. Survey Basic-Data Report No. 6, 26 p.

\section{Cedar Valley}

Cedar Valley is in a small structural intermontane basin in the northwest corner of Utah County, southeast of the Oquirrh Mountains. The valley portion occupies about 140 square miles of the 300-square-mile basin. The basin is topographically closed except in the northern portion where there is drainage to Utah Valley to the east (Feltis, 1967, p. 6).

One well produced fresh warm water of $27^{\circ} \mathrm{C}$, and four others produce fresh or slightly saline water of $15.5^{\circ}$ to $18^{\circ} \mathrm{C}$ (Table 30 ).

\section{Cited Reference}

Feltis, R. D., 1967, Ground-water conditions in Cedar Valley, Utah County, Utah: Utah State Engineer Tech. Pub. No. 16, $31 \mathrm{p}$.

\section{Northern Juab Valley}

Northern Juab Valley lies wholly within the eastern part of Juab County in Central Utah. Northern Juab Valley occupies about 120 square miles of Juab Valley north of Levan. The valley is a structural trough bounded on the east by the Wasatch fault at the base of Mt. Nebo, the southernmost mountain of the Wasatch Range, and at the base of the San Pitch Mountains south of Mt. Nebo. The west side of the valley is bounded by an inferred fault at the base of the West Hills and Long Ridge. The valley fill, consisting of detritus from the mountains and lake deposits of Pleistocene Lake Bonneville, is probably more than 2000 feet thick (Cook and Berg, 1.961, p. 82). 
One spring in Juab Valley about 2 miles southwest of Mona yields $1.3 \mathrm{gpm}$ of fresh water at $20^{\circ} \mathrm{C}$ (Table 31). One well near the western margin of the valley about 4 miles southwest of Nephi yields fresh water at $15.5^{\circ} \mathrm{C}$. All other springs and wells yield cooler water.

\section{Cited References}

Cook, K.L., and J.W. Berg, Jr., 1961, Regional gravity survey along the central and southern Wasatch Front, Utah: U.S. Geol. Survey Prof. Paper 316E, p. $75-89$.

\section{Park Valley}

The Park Valley area is in northwestern Box Elder County, in the northernmost part of the Great Salt Lake Desert. The drainage basin occupies about 1050 square miles and is the home of about 250 people, principally in the communities of Park Valley and Rosette (Hood, 1971, p. 3).

Six springs yield small quantities of fresh water in the $21^{\circ}$ to $25^{\circ} \mathrm{C}$ range from the south flank of the Raft River Range, and two others, Warm Spring No. 1, $26.5^{\circ} \mathrm{C}$ and Warm Spring No. 2, 20 $0^{\circ}$ yield 340 and $385 \mathrm{gpm}$ of fresh water from the east flank of the Grouse Creek Mountains (Table 32). Six other springs yield slightly warm water, $16^{\circ}$ to $19.5^{\circ}$, from the same general areas.

No temperatures have been reported from the few wells in the valley. Potential for any development of warm water appears small.

\section{Cited References}

Hood, J. W., 1971, Hydrologic reconnaissance of the Park Valley area, Box Elder County, Utah: Utah Dept. Nat. Resources Tech. Pub. No. 30, 46 p.

\section{Promontory Mountains Area}

The Promontory Mountains area of Box Elder County occupies the peninsula between Bear River Bay and the north arm of Great Salt Lake. The land includes about 357 square miles and is used principally for grazing and some dryland agriculture. Few people live in the area, but Thiokol Chemical Corp. withdraws water from wells for use in the plant in Blue Springs Valley to the northeast.

Four springs on the east side of the Promontory range yield saline or slightly saline warm water in the $20^{\circ}-25^{\circ} \mathrm{C}$ range (Table 33 ). They probably are controlled by faults.

Ten saline springs yield slightly warm water $\left(15.5^{\circ}-19.5^{\circ} \mathrm{C}\right)$ along the east side of the Promontory Range in T.7 N. Nine of these springs are near or on a concealed fault (Hood, 1972, plate 1). Two other saline springs yield water of $16.5^{\circ}$ and $17.0^{\circ} \mathrm{C}$ in $\mathrm{T} .7 \mathrm{~N}$. on the west side of the range.

One well at Promontory yields fresh water of $21.5^{\circ}$ or $22.5^{\circ} \mathrm{C}$ from a depth of 423 feet.

The springs along the mountains probably are fed by water that moves through fractures in the carbonate rocks, is heated by the geothermal gradient, and returns to the surface through the faults.

\section{Cited Reference}

Hood, J. W., 1972, Hydrologic reconnaissance of the Promontory Mountains area, Box Elder County, Utah: Utah Dept. Nat. Resources Tech. Pub. No. 38,35 p. 


\section{Rush Valley}

Rush Valley is a large (about 400 square miles) complex structrual valley in eastern Tooele County that apparently has very little warm water.

The warmest water comes from Morgans Warm Spring $\left(24^{\circ}-26.5^{\circ} \mathrm{C}\right)$ and from Russels Warm Spring $\left(21.5^{\circ} \mathrm{C}\right)$, both of which issue from alluvium near an inselberge of Paleozoic rock in the northern part of the valley (Table 34). As Mundorff (1970, p. 36 reports, "a fault buried beneath the valley fill in the vicinity of the springs probably is the channel through which the water moves upward into the fill." Morgan Warm Spring yields as much as $1000 \mathrm{gpm}$ of water containing $594 \mathrm{mg} / 1$ dissolved solids and Russels Warm Spring yields about 450 gpm of water with about $44 \mathrm{mg} / \mathrm{l}$ dissolved solids. Another spring, in the valley of Faust Creek, yields about $600 \mathrm{gpm}$ of fresh water at $20^{\circ} \mathrm{C}$. And a well about 2 miles southwest of the latter spring yields $4100 \mathrm{gpm}$ of fresh water at $16^{\circ} \mathrm{C}$ from a depth of 534 feet.

Cited References

Hood, J.W., Don Price, and K.M. Wadde11, 1969, Hydrologic reconnaissance of Rush Valley, Tooele County, Utah: Utah Dept. Nat. Resources Tech. Pub. No. $23,58 \mathrm{p}$.

Mundorff, J.C., 1970, Major thermal springs of Utah: Utah Geol. and Mineralog. Survey Water-Resources Bull. 13, $60 \mathrm{p}$.

\section{Skull Valley}

\section{INTRODUCTION}

Skull Valley is in the eastern portion of Tooele County, southwest of Great Salt Lake and west of Tooele Valley. The valley includes about 400 square miles of the total 880 square miles that is in the Skull Valley drainage basin. The Dugway Proving Grounds, a U.S. Army facility, is in the southwest corner of the valley. Except for those stationed at the Proving Grounds, few people live in the valley. Those who do live there are engaged in agriculture, principally raising livestock.

SUMMARY Of OCCURRENCES, USE, and POTENTIAL

Warm and slightly warm water, mostly moderately saline, rises as springs along a fault on the northwest flank of the Stansbury Range or along a presumed fault on the north end of the range. The salinity of much of the warm water is too high for use for agriculture but the water probably is useful for wildlife. The temperature at the surface is generally less than $24^{\circ} \mathrm{C}$ but probably indicates that higher temperatures would be encountered by drilling.

\section{GEOLOGIC and HYDROLOGIC ENVIRONMENT}

Skull Valley is a complex graben that is boomerang-shaped, with the north arm trending about $\mathrm{N} 20^{\circ}$ E and with the south arms trending about $\mathrm{N} 35-40 \mathrm{~W}$. The graben is flanked on each side by at least two sub-parallel faults that not only separate the valley from the low Cedar Mountains on the west and from the high Stansbury Mountains on the east but also, to some degree, shatter the rocks of the mountains. 
The rocks of the bounding mountains include a Paleozoic sedimentary sequence of quartzite, limestone, sandstone, and shale and a few exposures of Tertiary volcanics. Probably the Paleozoic rocks also underlie the valley at depths of 1200 or more feet in the southern part of the valley and to 6000 or 7000 feet in the northern portion (Hood and Waddell, 1968, p. 17). The valley fill consists of thick Tertiary sedimentary and volcanic rocks overlain by thin Quaternary alluvial deposits from the mountains and lacustrine deposits laid down in Pleistocene Lake Bonneville. The Quaternary alluvium provides the principal aquifers of the valley.

Above the valley and covering the bedrock at the base of the flanking mountains are extensive stony alluvial and colluvial deposits that act as a recharge area for the alluvial aquifers in the valley. Faults along the northwestern and northern flanks of the Stansbury Mountains provide conduits for warm saline springs that presumably derive their recharge from the bedrock of the mountains and, to some degree, from the stony alluvium-colluvium.

\section{OCCURRENCES Of WARM WATER}

About 11 springs or spring areas yield water of temperatures from $20^{\circ}$ to $24^{\circ} \mathrm{C}$ (Table 35-A). All but two of these rise from a fault along the northwest flank of the Stansbury Range or along a presumed fault at the north end of the Stansburys. Most of the water along the northwest flank is moderately saline (about 3500 to $6000 \mathrm{mg} / 1$ dissolved solids), but one spring, (c-3-8)2lddbs yields about $10 \mathrm{gpm}$ of $24^{\circ}$ water that contains only $137 \mathrm{mg} / 1$ dissolved solids. The three warm springs that rise along the north end of the range are probably very saline (more than 10,000 $\mathrm{mg} / \mathrm{l}$ ) but there are only partial chemical analyses to verify this.

About ten slightly warm springs $\left(15.5^{\circ}\right.$ to $\left.19.5^{\circ} \mathrm{C}\right)$ also rise along the fault on the northwest flank of the Stansburys and these too are moderately or slightly saline (Table 35-B).

Two wells, both near Delle, have water temperatures of $24^{\circ}$ and $26.5^{\circ} \mathrm{C}$. The water of both is saline but there is no obvious source for the warmth of the water.

In contrast to the moderate temperatures measured at the surface in Skull Valley, Parry and Cleary (1978, p. 26) have computed for 28 wells and springs $\mathrm{Na}-\mathrm{K}-\mathrm{Ca}$ temperatures that range from $12^{\circ} \mathrm{C}$ to $179^{\circ} \mathrm{C}$, with the highest 20 temperatures averaging $150^{\circ} \mathrm{C}$. From their mixing models they concluded, however, that probably "cold water fractions of $90 \%$... prevent accurate estimate of the temperature of any hot water component present."

Cited References

Hood, J.W., and K.M. Waddell, 1968, Hydrologic reconnaissance of Skull Valley, Tooele County, Utah: Utah Dept. Nat. Resources Tech. Pub. No. 18, 54 p.

Parry, W.T., and M. Cleary, 1978, Na-K-Ca and $\mathrm{SiO}_{2}$ temperature estimates for Utah spring and well waters: U.S. Geol. Sruvey, Geothermal Research Program, Contract 14-08-0001-G-341, 51 p.

\section{Snake Valley}

Snake Valley is a long (about 135 miles) north-trending well-watered intermontane valley that straddles the Nevada-Utah border. It includes parts of the western portions of Tooele, Juab, Millard, Beaver, and Iron Counties. 
The unconsolidated valley-fill desposits underlie about 1.2 million acres and form the principal groundwater reservoir, which has an estimated 12 million acre-feet of recoverable water in the upper most 100 feet of saturated alluvium (Hood and Rush, 1965, p. 1 ).

Many springs rise from the valley floor and three areas, Warm Springs, Twin Springs, and Knoll Springs, produce water of $19.5^{\circ}$ to $27^{\circ} \mathrm{C}$ ( Table 36 ). Two wells on the west side of the valley produce water of $22^{\circ}$. Although the generalized map of Hood and Rush does not show faults directly related to these areas of warm water it is likely that the warming comes from the geothermal gradient along faults.

\section{Cited References}

Hood, J.W., and F.E. Rush, 1965, Water-resources appraisal of the Snake Valley area, Utah and Nevada: Utah State Engineer Tech. Pub. No. 14, $40 \mathrm{p}$.

Tooele Valley

\section{INTRODUCTION}

"Tooele Valley is at the eastern edge of Tooele County in northwestern Utah... and is about 30 miles southwest of Salt Lake City. The valley proper includes approximately 250 square miles bounded by Great Salt Lake" on the north, the Oquirrh Mountains on the east, South Mountain to the south, and the Stansbury Island on the west (Gates, 1965, p. 10). Tooele Valley is the site of the Tooele Army Depot which occupies about 37 square miles in the southern part of the valley. Most of the rest of the valley is devoted to agriculture. Probably about 25,000 people were living in the valley in 1975.

SUMMARY of OCCURRENCES and POTENTIAL fOr USE

One well, 687 feet deep, produces slightly saline water, 2780 ppm dissolved solids, at $30^{\circ} \mathrm{C}$, near Mills Junction. Granstville Warm Springs produces highly saline water, about $25,000 \mathrm{ppm}$ dissolved solids, at $24^{\circ}$ to $32^{\circ} \mathrm{C}$. Four other wells produce water of $20^{\circ}$ to $23^{\circ} \mathrm{C}$ (Table $37-\mathrm{A}$ ).

With only two occurrences of significantly warm water it is not likely that there is a source of high heat at moderate depths, yet a concentration of wells with water of nearly $20^{\circ}$ between Grantsville and Erda suggests that in that area there may be heat that is spread laterally through the principal aquifer.

This slightly warm water of good quality could be used in heat pumps. 


\section{GEOLOGIC and HYDROLOGIC ENVIRONMENT}

The mountains that border Tooele Valley on the east, south, and west "are formed by Paleozoic rocks ranging in age from Lower Cambrian to Pennsylvanian [and Permian] but with the Ordovician and Silurian periods unrenresented. There is no sedimentary record of the interval between Pennsylvanian [Permian] and Tertiary times, and the Tertiary, Quaternary, and Recent sediments are of continental origin. These continental deposits play the dominant role in the groundwater hydrology of the basin,... and give rise to the conditions which yield water by artesian flow in the lower part of the valley" (Thomas, 1945, p. 97).

The topographic axis through the center of Tooele Valley is nearly south to north with a slight turn to the northeast near Great Salt Lake, but the structural axis of the Tooele Valley graben is about N35E through Grantsville. (Cook and others, 1966, fig. 2). "As a result of step faulting of great magnitude, the central part of the [three-step] graben [near the south shore of Great Salt Lake] forms a deep trench whose bottom lies many thousands of feet below the shallower flanks of the graben, so that the total thickness of the Cenozoic rocks is at least 8000 feet" (Cook and others, 1966, p. 65). To emphasize the minimum of 8000 feet, Cook and others (1966, fig. 3) show a cross section in which the deepest part of the graben, about 3 miles wide, is about 12,000 feet below the surface. Possibly the deep inner fault on the southeast side of the central graben is the Box Elder Canyon Fault of Thomas, which is projected from the mouth of Box Elder Canyon in the southwest comer of the valley about N4OE (Thomas, 1946, p. 150 and Plate 1). The Box Elder Canyon Fault of Thomas may be an extension of the Sixmile Creek fault which Gates (1965, fig. 5) has plotted from the same deep well information that cook and others used to confirm their geophysical evidence for the boundary of the deep inner graben. At any rate the center part of the graben is very deep and the overall pattern of faulting is very complex.

Superposed on these deep faults are thick Tertiary deposits and thin Quaternary alluvium and lake deposits. Some of the deep faults have had movement since the Quaternary deposits were laid down, for springs rise along them Fishing Creek fault, Warm Springs fault, and Mill Pond fault - or there is a discernable scarp - Occidental(?) fault.

The intertonguing of coarse alluvial and fine lacustrine deposits has produced artesian (confined) conditions in most of the valley, and there are flowing wells in the lower parts of the valley, below about 4400 feet. "A zone of coarse sediments 60 to 125 feet thick, encountered at depths of 90 to 210 feet in the western and 180 to 300 feet in the eastern part of the Grantsville district and at depths of 170 to 230 feet in the western and 100 to 160 feet in the eastern part of the Erda district, constitutes the principal aquifer in the valley. Several flowing wells yield water from strata above this principal aquifer and some wells reach deeper aquifers. In all cases the deeper wells have a greater head than the shallow wells and some differential head has been observed in wells reaching different parts of the principal aquifer" (Thomas, 1946, p. 98 ).

\section{OCCURRENCE OF WARM WATER}

Water in the warm range $\left(20^{\circ}\right.$ to $\left.34.5^{\circ} \mathrm{C}\right)$ has been reported from six wells (out of 142) and one spring, Grantsville Warm Spring, in Tooele Valley (Table 
37-A), and water in the slightly warm range $\left(1.5 .5^{\circ}\right.$ to $\left.19.5^{\circ} \mathrm{C}\right)$ has been reported from 44 wells (Table 37-B); and the median temperature from all 142 wells whose temperatures have been recorded is $14.5^{\circ} \mathrm{C}$, appreciably above the mean annual air temperature of $11^{\circ} \mathrm{C}$ a.t Tooele (Gates, 1965, p. 12).

The warmest water of $30^{\circ} \mathrm{C}$ comes from a well 687 feet deep in sec. 9, T.2 S., R.3 W. Four other wells produce warm water from moderate depths: two east of Grantsville, $21^{\circ}$ and $23^{\circ}$ from depths of 380 and 320 respectively, one northwest of Grantsvilie, $20^{\circ}$ from 210 feet, and one near Toaele., 21.. $5^{\circ}$ from 710 feet. An oil test we11, (c-2-5)13bca, 3540 feet deep, produces $23^{\circ}$ water.

The water of Grantsville Warm Springs is highly saline with 25.,800 ppmo dissolved solids. Its temperature "ranges from about $75^{\circ}$ to about $90^{\circ} \mathrm{F}\left(24^{\circ}-\right.$ $\left.32^{\circ} \mathrm{C}\right)$. Volcanic rocks of Tertiary age crop out about five miles southwest of the springs but probably are not directly related to the source of heat for the water; the source of heat probably is the geothermal gradient. A buried fault in the vicinity of the springs probably is the escape route of water that infiltrates the faulted rocks of Paleozoic age at altitudes of 5,000 8,000 feet in the Stansbury mountains. If the water descends to depths of 3,000 - 5,000 feet below the upland surface before moving upward along a fault, the observed temperatures would result" (Mundorff, 1970, p. 34).

Slightly warm water $\left(15.5-19.5^{\circ} \mathrm{C}\right)$ is common in wells between Grantsville and Erda, and nearly all the other wells in that area record temperatures of $14^{\circ}-15^{\circ} \mathrm{C}$. Although only two wells in this area report temperatures of $21^{\circ}$ and $23^{\circ}$, the virtual absence of water below $14^{\circ}$ and the abundance of slightly warm water suggest that there may be a source of moderate heat that is warming the water of the principal aquifer.

Cited References

Cook, K.L., J.W. Berg, W.W. Johnson, and R.T. Novotny, 1966, Some Cenozoic structural basins in the Great Salt Lake area, Utah, indicated by regional studies in The Great Salt Lake: Utah Geol. Soc. Guidebook No. 20, p. 57-75.

Gates, J.S., 1963, Selected hydrologic data, Tooele Valley, Tooele County, Utah: U.S. Geol. Survey Basic-Data Report No. 7, 23 p.

- 1965, Reevaluation of the ground-water resources of Tooele Valley, Utah: Utah State Engineer Tech. Pub. No. 12, 65 p.

Mundorff, J.C., 1970, Major thermal springs of Utah: Utah Geol. and Mineralog. Survey Water-Resources Bul1. 13, 60 p.

Thomas, H.E., 1946, Ground water in Tooele Valley, Tooele County, Utah: Utah State Engineer Tech. Pub. No. 4, $241 \mathrm{p}$.

Tule Valley

INTRODUCTION

Tule Valley and its tributary drainage area includes about 940 square miles in western Juab and Millard Counties, Utah. The valley has no permanent inhabitants and "the land is used mainly for seasonal livestock grazing... About 530,000 acres... or 88 percent of the land is Federally owned. About 68,000 acres...or 11 percent is owned by the State of Utah. About 1,1000 acres ...or less than I percent is privately owned" (Stephens, 1977, p. 2). 
"The Tule Valley drainage basin is a topographically closed basin bounded in part by drainage divides in the House and Fish Springs Ranges on the east and the Confusion Range on the west... The northern boundary is a broad, Iow divide conneoting the Fish Springs and Middle Ranges, Granite Mountain, and the Confusion Range. The southern boundary is likewise a broad, low divide that connects the House and Confusion Ranges" (Stephens, 1977, p. 2).

Tule Valley is a structural basin that is the result of block faulting on the east and eastward tilting and faulting on the west. A rather sinuous fault or fault zone separates the valley from the House Range on the east and a major fault separates the southern part of the valley from the Confusion Range on the west. A branch of this fault trends northward through the middle of the broad northern portion of the valley and is the conduit by which major springs rise.

The valley floor is underlain by alluvium from the adjacent mountains and by lacustrine deposits laid down in Pleistocene Lake Bonneville. These deposits are probably only a few hundred feet thick but are saturated essentially to the surface of the land in the central portion of the valley. Stephens has estimated that the annual recharge from precipitation is about 7,600 acre-feet (1977, p. 10), but he has also estimated that annual discharge by evapotranspiration is 40,000 acre-feet. He believes that the difference between discharge and recharge from precipitation is made up by interbasin underflow, principally from Wah Wah Valley to the south but perhaps also from other sources (1977, p.21). He also feels that some water may move northward out of the valley through the subsurface in Sand Pass (1977, p. 16).

\section{OCCURRENCES OF WARM WATER}

All springs that discharge on the valley floor - Coyote Spring, Tule Spring, and others - have water temperatures of $19.5^{\circ}$ to $28^{\circ} \mathrm{C}$ (Table 38 ), or about $8.5-17^{\circ} \mathrm{C}$ higher than the mean annual air temperature of $11^{\circ} \mathrm{C}$ on the valley floor (Stephens, 1977, p. 22). These springs undoubtedly gain their heat from the geothermal gradient. Probably recharge from the Confusion Range goes several thousand feet below the surface and then rises along the fault in the middle of the valley.

In addition, a well, ( $-17-15) 25 \mathrm{cbb}$, and a nearby spring also yield warm water a mile or so east of the fault mentioned above. This warm water probably rises along an as yet unidentified fault.

There are few discharge measurements for the warm springs but the abundant evapotranspiration suggests that wells in the vicinity of the springs could pump large quantities of warm water, probably containing less than $1500 \mathrm{mg} / \mathrm{l}$ dissolved solids.

Cited Reference

Stephens, J.C., 1977, Hydrologic reconnaissance of the Tule Valley drainage basin, Juab and Millard Counties, Utah: Utah Dept. Nat. Resources Tech. Pub. No. 56, $26 \mathrm{p}$. 
Wah Wah Valley

\section{INTRODUCTION}

Wah Wah Valley and its tributary drainage area encompass "about 600 square miles in Millard and Beaver Counties in southwestern Utah.... Except for a small tract of irrigated land at Wah Wah Ranch, the land in the drainage basin is used mainly for livestock grazing. More than 87 percent -- about 332,000 acres.... -- of the land is in Federal ownership, about 11 percent -- 43,000 acres....is owned by the State of Utah, and the remainder -- about 9,000 acres....-- is privately owned" (Stephens, 1.974, p. 2).

\section{GEOLOGIC and HYDROLOGIC ENVIRONMENT}

"The Wah Wah Valley drainage basin is a closed basin bounded by drainage divides in the Wah Wah Mountains on the west and southwest, the Confusion and House Ranges on the north, and the San Francisco Mountains on the east. The northeastern boundary of the basin is a broad, low ridge, which connects the northern end of the San Francisco Mountains with the southern end of the House Range. The ridge rises about 25 feet $(7.6 \mathrm{~m})$ above the floor of the Wah Wah Valley hardpan and divides the surface drainage of Wah Wah Valley from that of the Sevier Lake basin" (Stephens, 1974, p.5).

"Wah Wah Valley is part of an eastward-tilted fault block that is bounded on the west by a fault along the western side of the Wah Wah Mountains and on the east by a series of faults along the western side of the San Francisco Mountains... In addition to the major structural features, minor folding and extensive faulting, fracturing, and brecciation have accompanied the emplacement of igneous intrusives, especially in the San Francisco Mountains" (Stephens, 1974, p. 7 ).

The alluvial fill in the Wah Wah Valley is estimated to be more than 2000 feet thick, but the water table is more than 200 feet below the surface. Although there is no surface discharge from the valley, subsurface discharge, perhaps toward Tule Valley to the north, is apparently able to remove the estimated annual recharge of 7,000 acre-feet (Stephens, 1974, p. 12,18,19).

The principal source of water in the valley is Wah Wah Springs which discharges about $500 \mathrm{gpm}$ of $\mathrm{cool}$ and slightly warm water from many openings. The source of this water is Paleozoic rocks in the Wah Wah Mountains.

\section{OCCURRENCES Of WARM and SLIGHTLY WARM WATER}

Warm water, at $24.5^{\circ} \mathrm{C}$, has been reported from only one source, a test well, (c-28-14) $11 \mathrm{abb}$, which was deepened to 1472 feet after the original drilling failed to reach water at 660 feet (Table 39). A temperature log run on this well after deepening showed a nearly straight-line increase in temperature from about $22.3^{\circ} \mathrm{C}$ at 700 feet to about $28.8^{\circ} \mathrm{C}$ at 1480 feet, for a geothermal gradient of about $24.6^{\circ} \mathrm{C} / \mathrm{km}$ (St,ephens, 1974. D. 17). This oradient is perhaps lower than the general geothermal gradient of $40^{\circ}-50^{\circ} \mathrm{C} / \mathrm{Km}$ in the Basin and Range Province as reported by Chapman (oral commun. 1978).

Slightly warm water of $16.5^{\circ}$ to $19.5^{\circ} \mathrm{C}$ is reported for Wah Wah Springs, a group of springs that has produced extensive calcareous tufa deposits about 
3 miles west of Wah Wah Ranch. The water discharges through the tufa from the limestone of the underlying Orr Formation. Recharge is undoubtedly from the crest of the Wah Wah Mountains and, according to Stephens (1974, p. 22), the water is directed to the discharge area by a northeast-plunging flexure in the limestone.

\section{Cited Reference}

Stepehns, J.C., 1974, Hydrologic reconnaissance of the Wah Wah Valley drainage basin, Millard and Beaver Counties, Utah: Utah Dept. Nat. Resources Tech. Pub. No. $47,45 \mathrm{p}$.

Areas That Have Slightly Warm Water

Six areas of Utah have springs and wells that yield water that is no hotter than slightly warm, $15.5^{\circ}$ to $19.5^{\circ} \mathrm{C}$. Such water can be used in heat pumps for space heating, so brief descriptions of these areas follow.

Grand Staircase

The Grand Staircase includes all the area from the Pink Cliffs south to the Arizona border. The western boundary is the Hurricane Fault and the eastern boundary is the Coxcomb, the northern extension of the East Kaibab Monocline. The area encompasses most of western Kane County, a part of eastern Washington County, and a small part of Garfield County.

The rocks of the Grand Staircase consist of a great thickness of Mesozoic marine and non-marine shales, sandstones, limestones, and conglomerates exposed as treads and risers of a "staircase" that dips $2^{0}$ to $3^{0}$ to the north-northeast. Capping the Mesozoic sequence is the Eocene Wasatch Formation whose pink cliffs form the northern boundary of the area. The treads of the staircase are formed of the more resistant sandstones or limestones and the risers are commonly shales or soft sandstone or siltstone. The treads are generally rather porous so that they absorb an appreciable portion of the moderate rainfall of 12 to 25 inches. This water tends to move downward until it reaches a less permeable bed where it begins to move downdip toward the north. Presumably the down-dip storage areas are now essentially saturated so that some part of the recharge is rejected and returns to the surface as springs that rise above many slightly permeable horizons, such as clay or siltstone. The springs supply water for the mainstems and tributaries of the Virgin River and Kanab Creek that flow southward toward the Colorado.

The water that issues from the springs normally penetrates only to shallow depths so the only warming of the water is from the heat of the sun (Table 40 ). Although several spring temperatures are recorded as higher than $20^{\circ} \mathrm{C}$, all were measured as discharge from pipes, in a pond, or in a shallow seep. None represents heating by deep circulation.

Cited References

Goode, H. D., 1964, Reconnaissance of water resources of a part of western Kane County, Utah: Utah Geol. and Mineralog. Survey Water-Resources Bull. 5, 62 p. 
Goode, H. D., 1966, Second reconnaissance of water resources in western Kane County, Utah: Utah Geol. and Mineralog. Survey Water Resources Bull. 8, $44 \mathrm{p}$.

\section{Hansel Valley}

Hansel Valley is in northeastern Box Elder County and its drainage area of about 240 square miles drains southward into the north arm of Great Salt Lake. The valley is used for grazing and dryland cultivation of small grains, principally by farmers who commute from nearby towns (Hood, 1971, p. 2).

Two wells, 125 and 286 feet deep, produce saline: water with 1630 and 7060 $\mathrm{mg} / \mathrm{l}$ dissolved solids, at temperatures of $16^{\circ}$ and $18^{\circ} \mathrm{C}$ respectively (Table 41 ). One spring at Monument Point produces about $45 \mathrm{gpm}$ of brine, about 52,000

$\mathrm{mg} / \mathrm{l}$ dissolved solids, at $17.5^{\circ} \mathrm{C}$ from the Oquirrh Formation.

Cited Reference

Hood, J. W., 1971, Hydrologic reconnaissance of Hansel Valley and northern Rozel Flat, Box Elder County, Utah: Utah Dept. Nat. Resources Tech. Pub. No. 33, $35 \mathrm{p}$.

Pilot Valley

The Utah portion of Pilot Valley (which extends across the border into Nevada) is an area of about 420 square miles in southwestern Box Elder County and northwestern Tooele County. Pilot Valley is bordered on the west by the Pilot Range and on the east and south by the Silver Island Range. About 85,000 acres of the valley bottom is covered with salt deposits, and less than 300 acres of the valley is cultivated. "The present population of the valley consists of a single family" (Stephens and Hood, 1973, p. 3 and 7).

Four springs and one well yield slightly warm water $\left(15.5^{\circ}\right.$ and $\left.16.0^{\circ} \mathrm{C}\right)$ in the NE $\frac{1}{4} \sec .36, \mathrm{~T} .4 \mathrm{~N} ., \mathrm{R} .19 \mathrm{~W}$. (Table 42). One of the springs, Donner spring, yields about 200 gpm of water that contains about $370 \mathrm{mg} / \mathrm{l}$ dissolved solids, and the well also yields fresh water. The other three springs yield slightly saline water.

In 1976 the U.S. Ceological Survey put in 14 four-foot test wells along three east-west lines across the floor of Pilot Valley. These wells were spaced 1 to 2 miles apart and water temperatures were measured on September 30 and October I, 1976. The lowest temperature measured was $18^{\circ} \mathrm{C}$ at $4.57 \mathrm{ft}$ (or more) below land surface (in a 4-ft well), and the highest temperature, $21.5^{\circ} \mathrm{C}$, was measured in two wells at 0.69 and $1.34 \mathrm{ft}$ (or more) below land surface (Iines, 1978, p. 5). Obviously all temperatures were the result of warming by the sun during the previous summer.

Cited References

Lines, G.C., 1978, Selected ground-water data, Bonneville Salt Flats and Pilot Valley, western Utah: U.S. Geol. Survey Basic-Data Release No. 30, 14 p.

Stephens, J.C., and J.W. Hood, 1973, Hydrologic reconnaissance of Pilot Valley, Utah and Nevada: Utah Dept. Nat. Resources Tech. Pub. No. 4I, 33 p. 
Pine Valley

Pine Valley is a topographically closed basin principally in western Millard and Beaver Counties. One well in the northern part of the valley, (C-15-16)18bdd, yields water of $204 \mathrm{mg} / 1$ dissolved solids at a temperature of $16 \mathrm{C}$ from a depth of about 340 feet (Stephens, 1976)(Table 43). All other wells and springs yield appreciably cooler water.

Cited Reference

Stephens, J. C., 1976, Hydrologic reconnaissance of the Pine Valley drainage basin, Millard, Beaver, and Iron Counties, Utah: Utah Dept. Nat. Resources Tech. Pub. No. 51, $31 \mathrm{p}$.

The Sink Valley Area

The Sink Valley area lies west of Great Salt Lake in Tooele and Box Elder Counties. The area occupies about 330 square miles and includes not only Sink Valley but also a portion of the west shore of Great Salt Lake that is separated from Sink Valley by the Lakeside Mountains. "Most of the land in the Sink Valley area is owned by the Federal Government and is used partly as a military reservation (Hill Air Force Range) and partly as a winter range for sheep. The only residents are the families of several railroad workers at Lakeside and a small detachment of civilian and U.S. Air Force personnel (generally less than 100 men) at the Hill Range test facility about 12 miles southwest of Lakeside" (Price and Bolke, 1970, p. 3-4).

Five wells scattered on the valley floor encountered water of $16^{\circ}-17^{\circ} \mathrm{C}$ at depths from about 125 to 400 feet (Table 44). This water was slightly to moderately saline, about 1750 to $4500 \mathrm{mg} / 1$ dissolved solids. One of these wells, (B-4-10)25bac, had been drilled to 739 feet and sampled during drilling. It reached very saline water below 400 feet and near-brine $(29,900 \mathrm{mg} / \mathrm{l}$ dissolved solids) at 600 feet.

Cited Reference

Price, Don, and E. I. Bolke, 1970, Hydrologic reconnaissance of the Sink Valley area, Tooele and Box Elder Counties, Utah: Utah Dept. Nat. Resources Tech. Pub. No. 26, 28 p.

Yuba Dam-Leamington Canyon

(Including southern Juab, Scipio, Round, and Mill Valleys)

No warm water has been reported from wells or springs between Yuba Dam and Leamington Canyon. However, three prominent springs in Mills Valley yield slightly warm water of $17^{\circ} \mathrm{C}$ (Table 45). Blue Springs and Molten Springs yield waters of good quality that contain $334 \mathrm{mg} / 1$ and $410 \mathrm{mg} / 1$ dissolved solids respectively. Chase Springs yields about $3 \mathrm{cfs}$ of $16^{\circ} \mathrm{C}$ water that contains 1190 $\mathrm{mg} / \mathrm{l}$ dissolved solids.

\section{Cited Reference}

Bjorklund, L. J., and G. B. Robinson, Jr., 1968, Ground-water resources of the Sevier River basin between Yuba Dam and Leamington Canyon, Utah: U.S. Geol. Survey Water-Supply Paper 1848, 79 p. 
Other Occurrences of Hot and Warm Water

Castilla Hot Springs

Castilla Hot Springs, (D-9-4)lobaaS, in Spanish Fork Canyon two miles: below Diamond Fork, yields moderately saline water of $6360 \mathrm{ppm}$ dissolved solids at a temperature of $40^{\circ} \mathrm{C}$. The springs rise near a fault that cuts sandstone of Paleozoic age. Because the spring area is flanked by mountains that rise about 5000 feet above the 4900-foot altitude of the spring, Mundorff ( 1970, p. 49) believes that water descending "from altitudes of 7,000 to 10,000 feet could be heated (by the geothermal gradient) to the observed temperatures at the altitude of the springs."

A concrete shelter has been built over the orifices of the springs, but its appearance in 1977 suggested that the waters were seldom used.

Como Warm Springs

Como Warm Springs is the only source of warm water in Morgan Valley. According to Mundorff (1970, p. 9, 11):

"Como Warm Springs,(A-4-3)31cab-S1, rise along a concealed fault that crosses Weber River valley about one mile east of Morgan, Morgan County... The fault cuts limestones of Middle Paleozoic age, and the springs issue from near the base of carbonate rocks of Mississippian age. The source of the water is not known, but the relatively low temperature of the water $\left(25^{\circ} \mathrm{C}\right)$, the low dissolved-solids content (about $600 \mathrm{ppm}$ ), and the point of discharge suggest that the water is of meteoric origin and is brought to the surface along a conduit formed by the fault.

"The water is calcium sulfate bicarbonate in type; spectrographic analysis for 17 minor elements indicates no high concentrations of any of these elements.

"Part of the water is temporarily used in a swimming pool near the springs, but all the water ultimately enters the Weber River in the vicinity of the springs. Discharges ranging from about 2 to $20 \mathrm{cfs}$ ( 900 to 9,000 gpm) have been measured or estimated at different times.

"The source of the heat probably is the normal geothermal gradient. Circulation of water to a depth of $1,500-2,000$ feet could result in temperatures that are $20^{\circ} \mathrm{F}\left(10^{\circ} \mathrm{C}\right)$ higher than temperatures of shallow ground water in the area. These warm springs, like most other thermal springs in Utah, have no potential for geothermal development for power generation."

Diamond Fork Warm Springs

Mundorff (1970, p. 49) reports:

"Diamond Fork Warm Springs, (D-8-5)14d-S, are about 17 miles east of Spanish Fork in Utah County. These springs issue from conglomerates of Mesozoic age along Diamond Fork... Temperature of the water was $68^{\circ} \mathrm{F}\left(20^{\circ} \mathrm{C}\right)$ and dissolved-solids content was about $837 \mathrm{ppm}$ on October 20, 1967. The water is of the calcium sodium sulfate type; the odor of hydrogen sulfide is noticeable: The relatively low temperature and dissolved-solids content of these springs suggest that meteoric water enters the surface in the mountains at altitudes 2,000-3,000 feet higher than that of the springs, descends through fractures or voids to about the altifude of the springs, and issues from fissures in the conglomerate along Diamond Fork. The normal geothermal gradient causes the temperature of the spring discharge to be $10^{\circ}-15^{\circ} \mathrm{F}\left(5^{\circ}-8^{\circ} \mathrm{C}\right)$ warmer than that of shallow ground water in the vicinity.

"Reported discharge of the springs has ranged from about 350 to $700 \mathrm{gpm}$. On October 20, 1967, the discharge of the largest spring was about $450 \mathrm{gpm} . "$ 


\section{Patio Spring}

Patio Spring, (A-7-1)22caas, is described as rising from Quaternary lake beds 12 miles northeast of Ogden (Waring, 1965, p. 42). Actually the spring is in Ogden Valley about 10 miles northeast of Ogden, and it probably rises from alluvium above exposures of lake beds. The spring "discharges about 220 acre-feet of water per year. Some of the water is used for the swimming pool in the Patio Springs Lodge and the rest is diverted for irrigation" (Doyuran, 1972 , p. 71 ).

Keller Corp. Well \#2

The Keller well, (B-5-13)3lacd, yields moderately saline water of 4050 $\mathrm{mg} / \mathrm{l}$ dissolved solids at a temperature of $22^{\circ} \mathrm{C}$. The well taps water that is fresher than the surrounding brine of the Great Salt Lake Desert. Probably the freshness is due to recharge that comes from the nearby Newfoundland Mountains.

Cited References

Cordova, R. M., 1969, Selected hydrologic data, southern Utah and Goshen Valleys, Utah: U.S. Geol. Survey Basic-Data Release No. 16, 35 p.

Doyuran, Vedat, 1972, Geology and ground-water resources of Ogden Valley, Utah: Univ. of Utah PhD Dissertation, $134 \mathrm{p}$.

Mundorff, J. C., 1970, Major thermal springs of Utah: Utah Geol. and Mineralog. Survey Water-Resources Bull. 13, $60 \mathrm{p}$.

Saxon, F. C., 1972, Water-resource evaluation of Morgan Valley, Morgan County, Utah: Unpub. M.S. Thesis, Univ. Of Utah, $116 \mathrm{p}$.

Stephens, J. C., 1973, Hydrologic reconnaissance of the northern Great Salt Lake Desert and sunmary hydrologic reconnaissance of northwestern Utah: Utah Dept. Natural Resources Tech. Pub. No. $42,48 \mathrm{p}$.

Waring, G. A. (Revised by R. R. Blankenship and Ray Bental1), 1965, Thermal springs of the United States and other countries of the world: U.S. Geol. Survey Prof. Paper 492, 383 p. 


\section{RECORDS OF THERMAL SPRINGS AND WELLS}

The tables of records of thermal springs and wells are presented here in the same order as the discussions of the areas in the text: tables of areas that have hot, warm, and slightly warm water are presented first, followed by those that have warm and slightly warm water and then by those that have only slightly warm water. For most areas the records of wells and springs that have hot and warm water (above $20^{\circ} \mathrm{C}$ ) are combined in a table whose number is followed by the letter $\mathrm{A}$, and the records of slightly warm water $\left(15.5^{\circ}\right.$ to $19.5^{\circ} \mathrm{C}$ ) are in tables whose numbers are followed by the letter $B$.

\section{Explanation for Tables in This Report}

\section{COORDINATES}

The system of numbering springs and wells in this report is based on the cadastral land-survey system of the United States. By this system, Utah is divided into four quadrants by the Salt Lake base line and meridian and these quadrants are designated by the upper case letters A, B, C, and D, indicating the northeast, northwest, southwest, and southeast quadrants, respectively. Numbers designating the township and range (in that order) follow the quadrant letter, and all three are enclosed in parentheses. The number after the parentheses indicates the section, and is followed by three letters indicating the quarter section, the quarter-quarter section, and the quarter-quarter-quartersection - (10 acres); the letters a, b, c, and d indicate, respectively, the northeast, northwest, southwest, and southeast quarters of each subdivision. The number after the letters is the serial number of the well or spring in the 10-acre tract; the letter $S$ preceding the serial number denotes a spring. Thus (B-13-3)23acbs, indicates the first spring in the northwest quarter of the southwest quarter of the northeast quarter of section 23, TI3W, R3N, Salt Lake base and meridian. In the Uinta Basin a Uinta baseline and meridian is used (see fig. 1) and these coordinates are preceded by $U$ in this report.

\section{SOURCE}

$$
\begin{array}{ll}
G-\text { gas well } & M \text { - mine } \\
O-\text { oil well } & S \text { - spring } \\
\text { O/W - oil and water well } & \text { W - water well }
\end{array}
$$

\section{GEOLOGIC FORMATION}

110 PTOD

111 ALVM

111 CLVIN

111 LCST

112 PLCN

112 PVNT

120 TRTR

121 SLIK

200 MNCS

\author{
Quaternary pediment, terrace, or outwash deposit \\ Holocene alluvium \\ Holocene colluvium \\ Holocene Lacustrine deposits \\ Pleistocene series \\ Pleistocene Pavant Flow \\ Tertiary system \\ Pliocene Salt Lake Formation \\ Mesozoic Mancos Shale
}



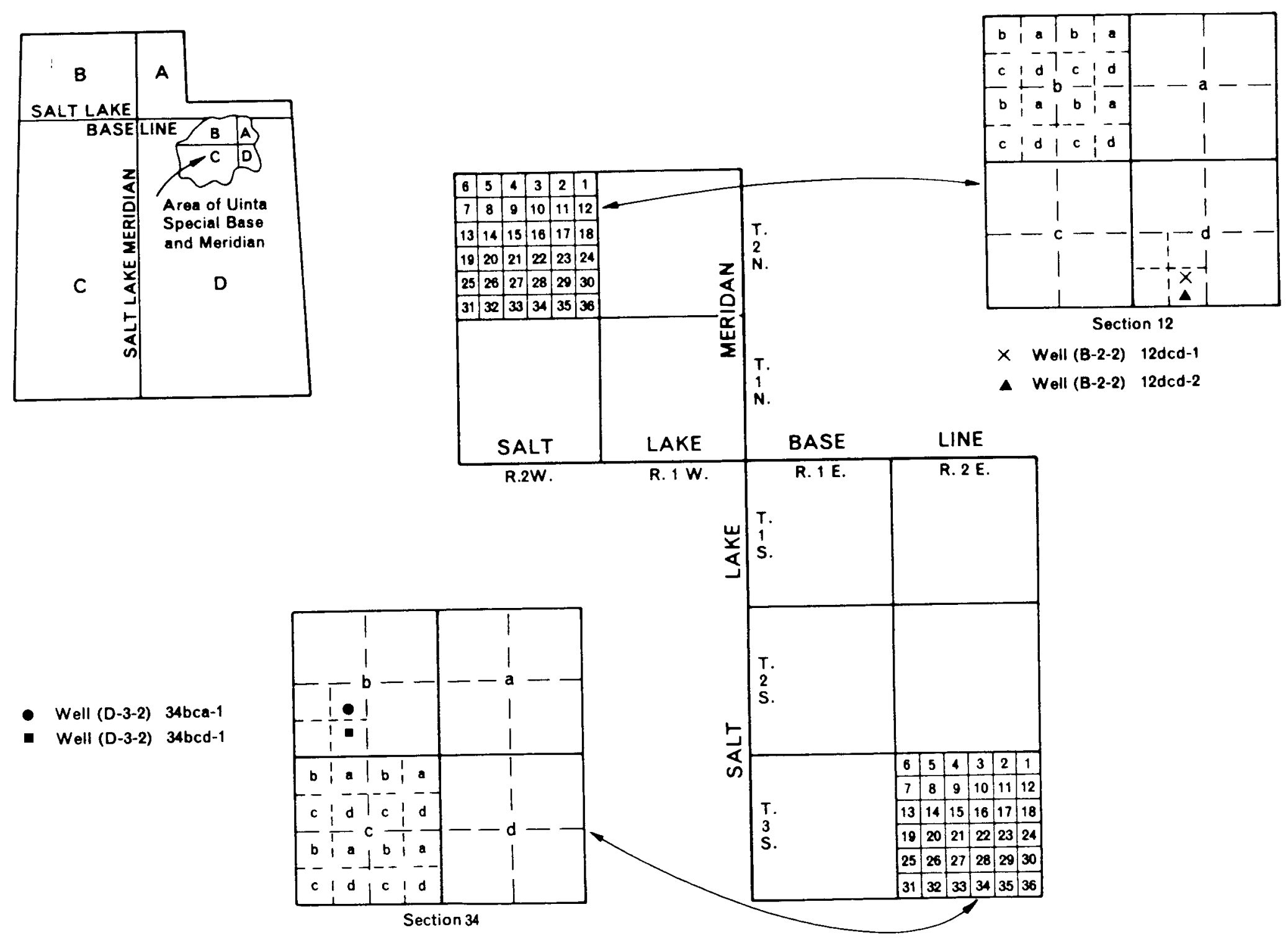

Figure 11. Well-numbering system used in Utah. 
200 SGCF

210 DKOT

211 EMRY

211 FRRN

211 KPRS

217 BRCN

220 GLCN

220 NVJO

221 BLFF

221 CRML

221 ENRD

221 SMVL

230 MNKP

$231 \mathrm{CHNL}$.

231 KYNT

231 MONV

231 SRMP

231 WNGT

300 PLZC

310 CDRM

310 HLGT

$310 \mathrm{KIBB}$

310 OGRK

310 OQRR

310 PRKC

310 WEBR

324 HRMS

370 CMBR

400 ABRG

400 PCMB
Mesozoic Straight Cliffs Sandstone

Cretaceous Dakota Sandstone

Cretaceous Emery Sandstone Member of Mancos Shale

Cretaceous Ferron Sandstone Member of Mancos Shale Cretaceous Kaiparowits Formation

Lower Cretaceous Burro Canyon Formation

Jurassic-Triassic Glen Canyon Formation or Group

Jurassic-Triassic Navajo Sandistone

Upper Jurassic Bluff Sandstone of San Rafael Group

Upper Jurassic Carmel Formation of San Rafael Group

Upper Jurassic Entrada Sandstone of San Rafael Group

Upper Jurassic Summerville Formation of San Rafael Group

Triassic Moenkopi Formation

Upper Triassic Chinle Formation

Upper Triassic Kayenta Formation of Glen Canyon Group

Upper Triassic Moenave Formation of Glen Canyon Group

Upper Triassic Shinarump Member of Chinle Formation

Upper Triassic Wingate Sandstone of Glen Canyon Group Paleozoic Erathem

Permian Cedar Mesa Sandstone Member of Cutler Formation

Permian Halgaito Tongue of Cutler Formation

Permian Kaibab Limestone

Permian Organ Rock Tongue of Cutler Formation

Perm.-Penna-Miss. Oquirrh Group

Permian Park City Formation

Perm-Penna. Weber Quartzite or Sandstone

Middle Pennsylvanian Hermosa Formation

Cambrian System

Precambrian Albion Range Group

Precambrian Eratherm

\section{YIELD}
d - Reported by driller
$R$ - reported
E - estimated
$\mathrm{M}$ - measured 
REFERENCES

References listed in the tables refer to the following:

BD-U.S. Geological Survey Basic-Data Release

Doyuran, Vedat, 1972, Geology and ground-water resources of Ogden Valley, Utah: Univ. of Utah PhD Dissertation, $134 \mathrm{p}$.

HG - Harry D. Goode, unpublished data.

H Mtn - Goode, H.D., and Eric Olson, 1977, Reconnaissance appraisal of the water resources of the Henry Mountains coal field, Wayne and Garfield Counties, Utah: Univ. of Utah, College of Mines and Mineral Industries, $44 \mathrm{p}$.

IWM - U.S. Geological Survey, Basic-Data Report No. 4.

Petersen, C.A., 1975, Geology and geothermal potential of the Roosevelt Hot Springs area, Beaver County, Utah: Unpublished M.S. Thesis, Univ. of Utah, $50 \mathrm{p}$.

PP - U.S. Geological Survey Professional Paper.

Rush, F.E., 1977, Subsurface-temperature data for some wells in western Utah: U.S. Geol. Survey Open-File Report 77-132, 84 p.

Saxon, F.C., 1972, Water-resource evaluation of Morgan Valley, Morgan County, Utah: Unpub. M.S. Thesis, Univ. of Utah, $116 \mathrm{p}$.

TP - Utah Department of Natural Resources Technical Publication.

Turk, L.J., 1973, Hydrology of the Bonneville Salt Flats, Utah: Utah Geol. and Mineral Survey Water-Res. Bull. 19, $81 \mathrm{p}$.

UP\&L - Utah Power and Light Co.

WRB - Utah Geol. and Mineralog. Survey Water Resources Bulletin.

WSP - U.S. Geological Survey Water Supply Paper.

ANALYSIS

Where the $\mathrm{Na}$ value is given and no $\mathrm{K}$ value appears then the $\mathrm{Na}$ value represents the sum of $\mathrm{Na}$ plus $\mathrm{K}$. 
TABLE 1-A. Lower BeaL Bdver Area. Sordngs and Walls with Water Temperatures of $20^{\circ} 10105^{\circ} \mathrm{C}$

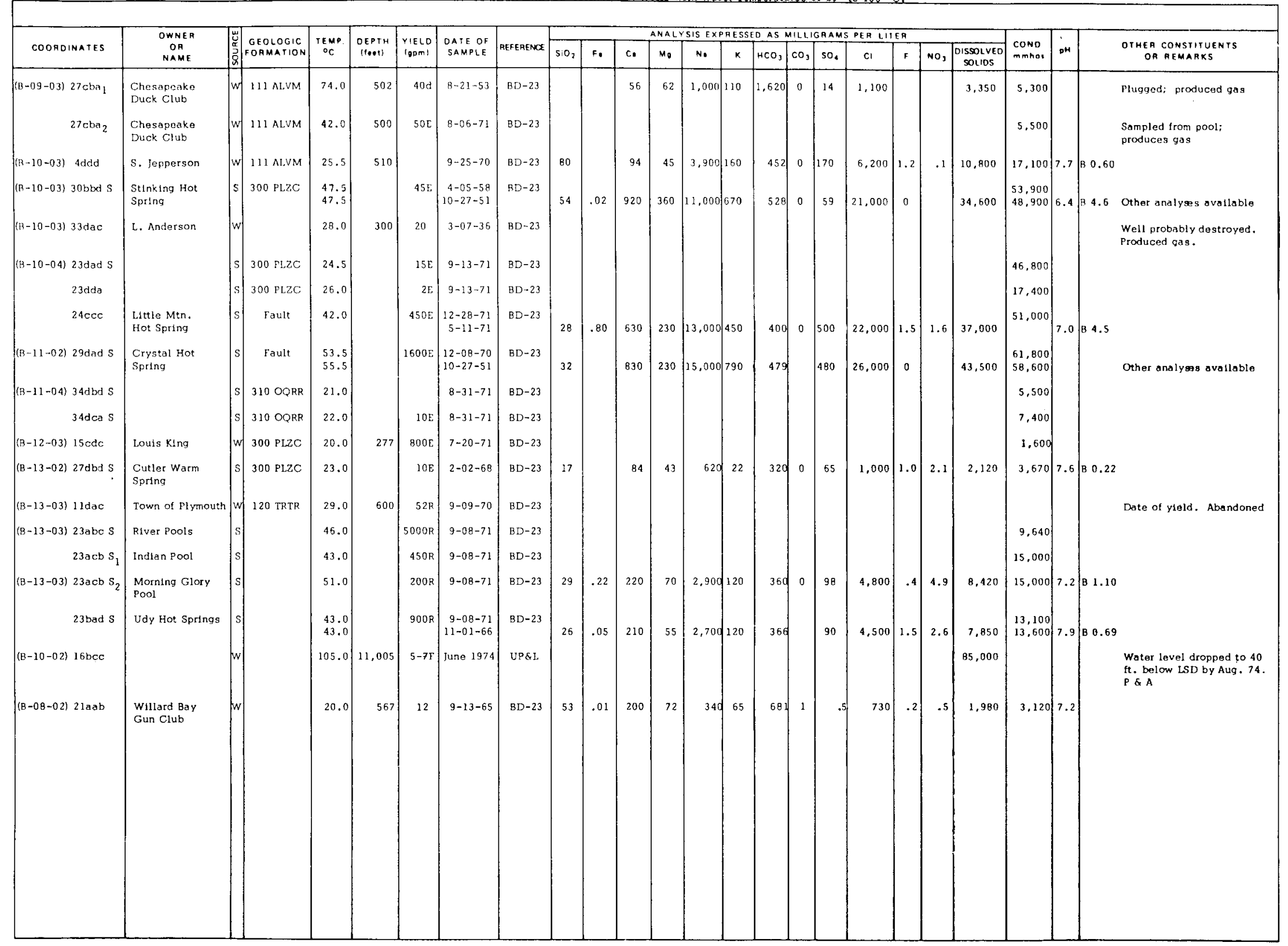




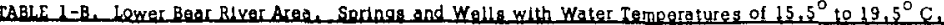

\begin{tabular}{|c|c|c|c|c|c|c|c|c|c|c|c|c|c|c|c|c|c|c|c|c|c|c|c|c|c|c|}
\hline \multirow{2}{*}{\multicolumn{2}{|c|}{ COORDINATES }} & \multirow{2}{*}{$\begin{array}{c}\text { OWNEA } \\
\text { OP } \\
\text { NAME }\end{array}$} & \multirow{2}{*}{\multicolumn{2}{|c|}{ 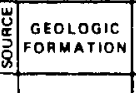 }} & \multirow{2}{*}{ TEMP. } & \multirow{2}{*}{$\begin{array}{l}\text { DEPPH } \\
\text { (teat) }\end{array}$} & \multirow{2}{*}{\begin{tabular}{|l|} 
YYELLO \\
igpm
\end{tabular}} & \multirow{2}{*}{$\begin{array}{l}\text { DATE OF } \\
\text { SAMPLE }\end{array}$} & \multirow[b]{2}{*}{ REFERENCE } & \multicolumn{13}{|c|}{ ANALYSIS EXPRESSED AS MILLIGAAMS PEA LITER } & \multirow{2}{*}{\begin{tabular}{|c|} 
COND \\
mmtoor \\
\end{tabular}} & \multirow[b]{2}{*}{$\mathrm{pH}$} & \multirow{2}{*}{\multicolumn{2}{|c|}{$\begin{array}{c}\text { OTHER CONSTITUENTS } \\
\text { OA REMARKS } \\
\end{array}$}} \\
\hline & & & & & & & & & & $\mathrm{SiO}_{2}$ & $\mathrm{Fe}$ & c. & $m_{0}$ & N. & ${ }^{k}$ & $\mathrm{HCO}_{3}$ & $\mathrm{Co}_{3}$ & so. & c & $\mathrm{F}$ & $\mathrm{NO}_{3}$ & \begin{tabular}{|c} 
Dissolved \\
soLIOS
\end{tabular} & & & & \\
\hline$(B-09-02)$ & 11 eda & D. L. Bunderson & w & 111 ALVM & 16.5 & 626 & $10 \mathrm{E}$ & $9-17-70$ & $B D-23$ & & & & & & & & & & & & & & 900 & & & Amber water. \\
\hline & $15 \mathrm{daa}$ & Harold Reeder & w & 111 ALVM & 16.5 & 465 & 10 & $\begin{array}{l}7-30-70 \\
5-17-71\end{array}$ & BD-23 & 19 & .28 & 2 & 1.2 & 150 & 1.8 & 351 & 22 & 5.5 & 16 & .7 & .1 & 395 & $\begin{array}{l}620 \\
593\end{array}$ & 8.7 & & $\begin{array}{l}\text { Amber water; lowest hard- } \\
\text { ness in area: } 10 \mathrm{mg} / 1 \text {. }\end{array}$ \\
\hline & $26 a a b_{2}$ & p. O. Jensen & $w \mid$ & 111 ALVM & 15.5 & 330 & 3500 & $8-2 \theta-70$ & $B D-23$ & & & & & & & & & & & & & & 400 & & & \\
\hline & $26 \mathrm{adb}$ & P. R. Parker & $|w|$ & 111 ALVM & 15.5 & 400 & $2000 \mathrm{~d}$ & $8-04-70$ & BD-23 & & & & & & & & & & & & & & 420 & & & \\
\hline & $26 a d d$ & Norman Nelson & $w \mid$ & 111 ALVM & 15.5 & 353 & 250d & $9-04-70$ & $B D-23$ & & & & & & & & & & & & & & 400 & & & \\
\hline & 35bad & Farl Francla & $|w|$ & \# ALVM & 16.5 & 369 & 23 & $5-26-70$ & $\mathrm{BD}-23$ & & & & & & & & & & & & & & 420 & & & \\
\hline & $35 \mathrm{cdb} s$ & Porter Spring & $\mathrm{s}$ & 111 ALVM & 16.0 & & $900 \varepsilon$ & $5-03-72$ & $\mathrm{BD}-23$ & & & & & & & & & & & & & & 660 & & & \\
\hline$(B-10-03) 3$ & 32000 & B. E. Stallings & $|w|$ & 111 ALVM & 18.0 & & & $8-06-71$ & $B D-23$ & & & & & & & & & & & & & & 1,400 & & & \\
\hline$(B-10-04)$ & 1 labab 5 & & $s$ & $300 \mathrm{PLZC}$ & 18.5 & & $2 \mathrm{E}$ & $9-18-70$ & BD-23 & & & & & & & & & & & & & & 10,300 & & & \\
\hline$(B-10-05)$ & 1ldas 3 & & $s$ & 310 OQRR & 18.0 & & 180E & $4-21-71$ & $B D-23$ & & & & & & & & & & & & & & 8,930 & & & \\
\hline$(B-11-02)$ & $5 \mathrm{dcb}$ & Jaa a Earl & $w$ & 111 ALVM & 16.0 & 25 & $25 \mathrm{R}$ & $8-30-71$ & $B D-23$ & & & & & & & & & & & & & & 290 & & & \\
\hline & 29dac 8 & $\begin{array}{l}\text { Crystal Cold } \\
\text { Springs }\end{array}$ & $s$ & 111 ALVM & $\begin{array}{l}16.5 \\
17.0\end{array}$ & & $2600 \mathrm{E}$ & $\begin{array}{r}12-08-70 \\
9-11-64\end{array}$ & $B D-23$ & & 1.1 & 76 & 46 & 420 & 31 & 253 & 0 & 57 & 660 & & & 1,920 & 2,900 & & B. 2 & \\
\hline$(B-11-03)$ & lcbc & Calvin Kay & $w$ & & 15.5 & 12 & 20 & $8-12-71$ & BD-23 & & & & & & & & & & & & & & & & & \\
\hline$(B-11-03)$ & $5 b b b_{2}$ & rohn Lawg & $w$ & $111 \mathrm{ALVM}$ & 15.5 & 238 & $10 \mathrm{~d}$ & $6-18-71$ & $\mathrm{BD}-23$ & & & & & & & & & & & & & & 600 & & & \\
\hline$\{\mathrm{B}-11-0,03)$ & $6 a c b$ & B. Y. Westmoraland & $w$ & $300 \mathrm{PLZC}$ & 16.0 & 198 & 100 & $9-03-36$ & $B D-23$ & & & & & & & & & & & & & & & & & Date of report of yleld. \\
\hline & $6 \mathrm{dbd}$ & B. Y. Westmorelanc & $w$ & 300 PLZC & 15.5 & 92 & & $6-18-71$ & $8 D-23$ & & & & & & & & & & & & & & 1,100 & & & \\
\hline$(B-11-03)$ & $6 \mathrm{dcc}$ & $\begin{array}{l}\text { Salt Creak } \\
\text { Springe }\end{array}$ & $\mathrm{s}$ & 310 OQRR & 19.5 & & paooom & $6-25-71$ & BD -23 & 20 & .07 & 52 & 21 & 660 & 29 & 350 & & 67 & 960 & .2 & 5.8 & 1,990 & 3,700 & 8.1 & & \\
\hline$(8-11-03)$ & 20dad & Kelth Barfuss & $w$ & $111 \mathrm{ALVM}$ & 16.0 & 410 & 1 & $9-15-70$ & BD-23 & & & & & & & & & & & & & & 5,400 & & & \\
\hline$(B-11-04)$ & $4 d d d$ & Town of Bothwall & $\mathrm{w}$ & 111 ALVM & 15.5 & 166 & 300 & $12-10-53$ & BD -23 & 42 & & 130 & 57 & 170 & & $25 \mathrm{~s}$ & 02 & 280 & 370 & .2 & 6.0 & 1,310 & 2,200 & 7.6 & & \\
\hline & $23 \mathrm{bcc}$ & D. Woodward & $w$ & $111 \mathrm{ALVM}$ & 16.5 & 393 & 2 & $9-17-70$ & BD -23 & & & & & & & & & & & & & & 1.300 & & & \\
\hline & $34 \mathrm{bdb} S$ & & $s$ & 310 OQRR & 18.0 & & 10E & $8-31-71$ & $\mathrm{BD}-23$ & & & & & & & & & & & & & & 4,100 & & & \\
\hline & 34cdd $S$ & & $s$ & $3100 Q R R$ & 18.5 & & $2 \mathrm{E}$ & $8-31-71$ & BD-23 & & & & & & & & & & & & & & 14,700 & & & \\
\hline & $34 \mathrm{dcc} S$ & & $s \mid$ & 310 OQRR & 18.5 & & $200 \varepsilon$ & $5-14-71$ & $\mathrm{BD}-23$ & 37 & .01 & 130 & 74 & 1,700 & 67 & 329 & 02 & 250 & 2,800 & .5 & 8.4 & 5,280 & 8,840 & 7.8 & & \\
\hline$(B-12-02)$ & $7 \mathrm{dbb} \mathrm{s}$ & & $s$ & & 15.5 & & & $8-27-71$ & BD -23 & & & & & & & & & & & & & & 1,400 & & & \\
\hline$(B-12-02)$ & $12 \mathrm{cbc}$ & D. D. Erickson & $w$ & $111 \mathrm{ALVM}$ & 16.5 & 65 & $20 \mathrm{~d}$ & $8-15-71$ & $\mathrm{BD}-23$ & & & & & & & & & & & & & & & & & Date of yleld. \\
\hline$(B-12-04) 2$ & $22 a a c$ & Ralph Udy & $w$ & $300 \mathrm{PLZC}$ & 16.5 & 680 & $2450 \mathrm{~d}$ & $\begin{array}{r}3-31-71 \\
7-20-71\end{array}$ & $B D-23$ & 23 & .05 & 78 & 35 & 110 & 3.6 & 209 & 0 & 52 & 240 & .1 & 8.0 & 653 & $\begin{array}{l}1,100 \\
1,120\end{array}$ & 8.0 F & 8.06 & \\
\hline & $27 a d d$ & X. H. Frdal & $w$ & 111 ALVM & 15.5 & 500 & L350d & $8-09-71$ & $B D-23$ & & & & & & & & & & & & & & 1,400 & & & \\
\hline & $33 \mathrm{dbb}$ & R. Anders on & $w$ & $300 \mathrm{PLZC}$ & 16.5 & 460 & $4 d$ & $8-31-53$ & $\mathrm{BD}-23$ & & & & & & & & & & & & & & & & & Date of yield. \\
\hline & $36 \mathrm{~d} 00$ & R. Holdoway & $w$ & $300 \mathrm{PLZC}$ & 18.0 & 118 & 100 & $9-15-70$ & BD-23 & & & & & & & & & & & & & & 1,700 & & & \\
\hline$(8-13-02) 3$ & 33add & Don Stubbs & $w$ & $300 \mathrm{PLZC}$ & 18.0 & 85 & 40 & $7-21-70$ & $B D-23$ & & & & & & & & & & & & & & 1,000 & & & \\
\hline$(8-13-03)^{3}$ & $35 \mathrm{dd}$ & $\begin{array}{l}\text { L D S Bolmont } \\
\text { Word }\end{array}$ & $w$ & 111 ALVM & $\begin{array}{l}15.5 \\
13.5 \\
\end{array}$ & $\begin{array}{l}237 \\
130 \mathrm{~s}\end{array}$ & 4700 & $\begin{array}{l}8-25-64 \\
2-\quad-63\end{array}$ & $8 D-23$ & 47 & .18 & 66 & 35 & $\begin{array}{l}440 \\
700 \\
\end{array}$ & $\begin{array}{l}28 \\
65\end{array}$ & $\begin{array}{r}485 \\
, 240 \\
\end{array}$ & & 220 & $\begin{array}{l}470 \\
510\end{array}$ & .9 & 2.2 & 1,560 & $\begin{array}{l}2,390 \mathrm{0} \\
3,020\end{array}$ & $\left|\begin{array}{l}7.8 \\
8.0\end{array}\right|$ & B.44 & S=Somplo depth. \\
\hline
\end{tabular}


TABLE $1-B$, Lower Bogr River Ared. Springs and Wells with water Temperatures of $15,5^{\circ}$ to $19.5^{\circ} \mathrm{C}$.

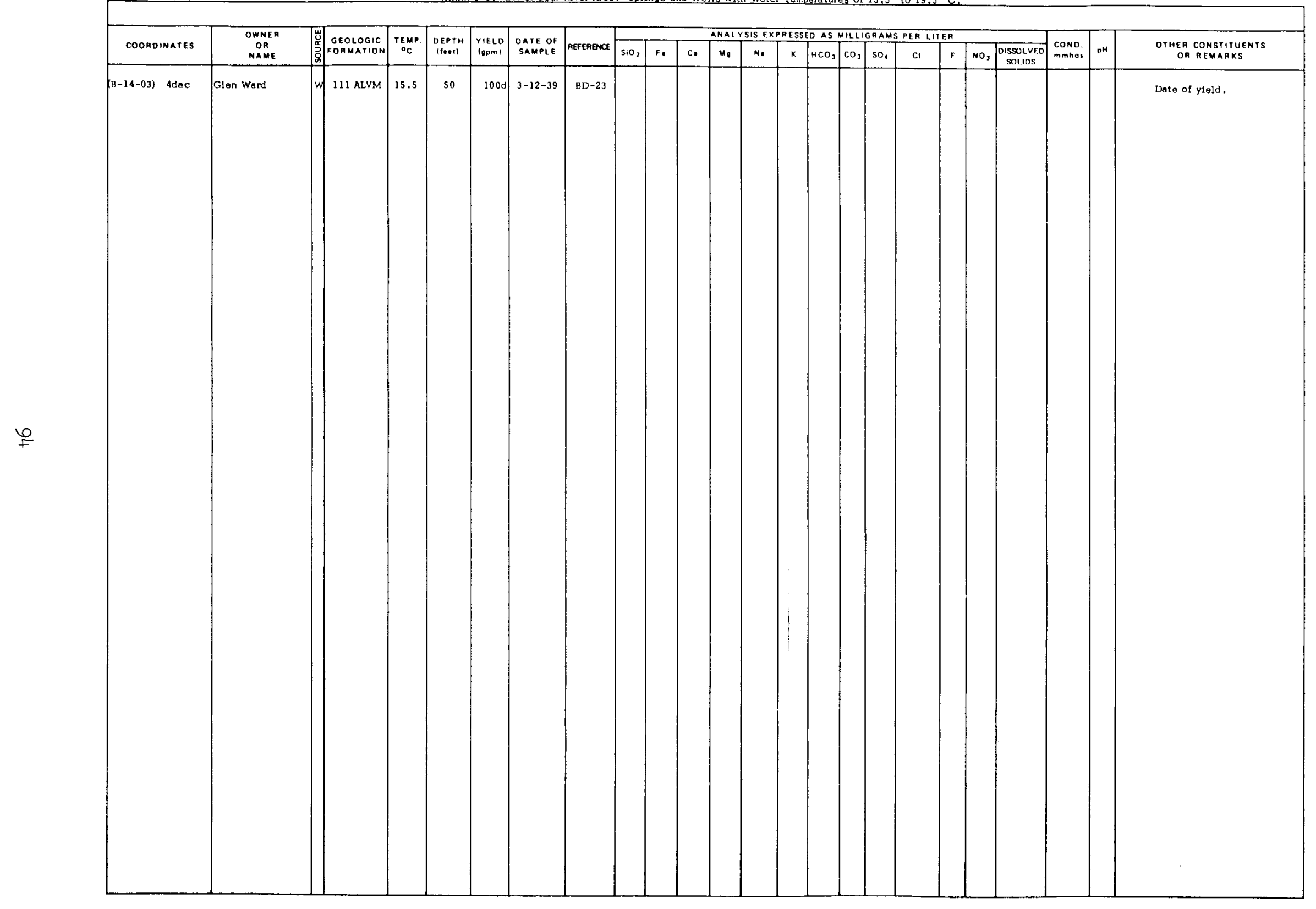

(1) 
TABIE 2. Bonneville Salt Flats. Wells and one spring with water temperatures of $20^{\circ}$ to $88^{\circ} \mathrm{C}$

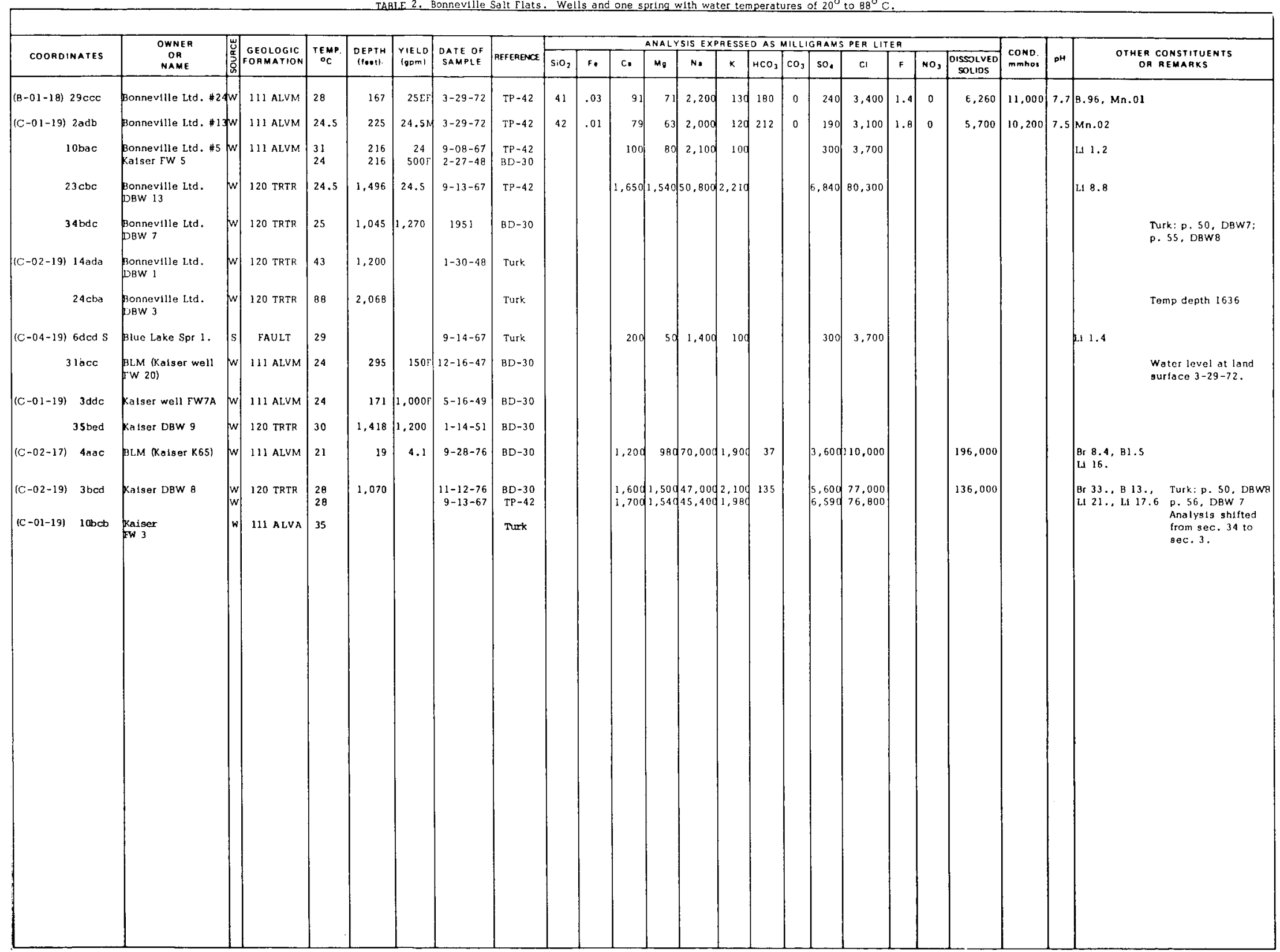


TABLE 4-A, Southern Curlew Valleg, Springs and wolls with water tempgroturgg of $20^{\circ}$ i $43^{\circ} \mathrm{C}$

\begin{tabular}{|c|c|c|c|c|c|c|c|c|c|c|c|c|c|c|c|c|c|c|c|c|c|c|c|c|}
\hline \multirow{2}{*}{ COORDINATES } & \multirow{2}{*}{$\begin{array}{c}\text { OWMEE } \\
\text { OR } \\
\text { NAME }\end{array}$} & \multirow{2}{*}{\multicolumn{2}{|c|}{ 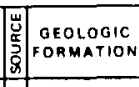 }} & \multirow{2}{*}{ TEMP. } & \multirow{2}{*}{$\begin{array}{l}\text { DEPTH } \\
\text { (loot) }\end{array}$} & \multirow{2}{*}{\begin{tabular}{|l|} 
YIELLO \\
lopml \\
\end{tabular}} & \multirow{2}{*}{\begin{tabular}{|l} 
DATE OF \\
SAMPLE
\end{tabular}} & \multirow{2}{*}{ REFERENCE } & \multicolumn{13}{|c|}{ ANALYSIS EXPAESSEO AS MILLLGRAMS PER LITER } & \multirow{2}{*}{$\begin{array}{l}\text { CONo } \\
\text { mmhor }\end{array}$} & \multirow[b]{2}{*}{ DH } & \multirow{2}{*}{$\begin{array}{l}\text { OTHER CONSTITUENTS } \\
\text { OR AEMARKS }\end{array}$} \\
\hline & & & & & & & & & $\mathrm{SiO}_{2}$ & $\mathrm{Fo}$ & c. & $M_{0}$ & N. & $k$ & $\mathrm{HCO}_{3}$ & $\mathrm{cos}_{3}$ & so. & $\mathrm{c}_{1}$ & $F$ & No, & $\begin{array}{l}\text { DISSOLVED } \\
\text { SOLIOS }\end{array}$ & & & \\
\hline$(\mathrm{B}-13-12) 30 \mathrm{CaOS}$ & L. G. Carter & 5 & & 25 & & $5 \mathrm{E}$ & $6-17-66$ & $T P-45$ & 10 & & 39 & 11 & 44 & .6 & 156 & 0 & 19 & 65 & .2 & 1.4 & 274 & 482 & $8.0 \mathrm{~B}$ & 8.01 \\
\hline$(B-14-09) \quad 4 b b b$ & C. Taylor & $|w|$ & 112 PLCN & 22 & 350 & & 5-24-56 & $T P-45$ & 61 & & 146 & 35 & 123 & & 186 & 0 & 34 & 426 & & 3.6 & 921 & 1.680 & 7.2 & \\
\hline & Gary Hanna & $|w|$ & $112 \mathrm{PLCN}$ & 20,5 & 360 & k,000M & $1970-72$ & $T P-45$ & & & & & & & & & & & & & & & & $\begin{array}{l}\text { Thlo well apparently shown } \\
\text { as } 9 b b b \text { in } T P-23\end{array}$ \\
\hline$(B-14-10) 33 \mathrm{bcc} \mathrm{S}$ & Coyote Spr. & $s$ & & $\begin{array}{l}43 \\
43.5\end{array}$ & & $20 \mathrm{R}$ & $5-28-68$ & $\begin{array}{l}\mathrm{TP}-45 \\
\mathrm{TP}-45\end{array}$ & 29 & & 87 & 19 & 1,070 & 56 & 352 & 0 & 70 & 1,620 & 2.7 & 4.8 & 3,240 & 5,590 & 7.6 & B. 8 \\
\hline$(8-15-09) 28 \mathrm{cbb}$ & J. E. Le8 & $w$ & & 24 & 400 & 2,340 & $\begin{array}{l}8-08-67 \\
8-12-70\end{array}$ & $\begin{array}{l}T P-45 \\
T P-45\end{array}$ & $m$ & & 369 & 92 & 452 & 32 & 144 & 0 & 35 & $\begin{array}{l}1,500 \\
1,550\end{array}$ & & 12 & 2,640 & $\begin{array}{l}4,700 \\
4,730\end{array}$ & 7.3 & \\
\hline $29 \mathrm{dbc}$ & C. Taylor & $\mathrm{w}$ & $112 \mathrm{PLCN}$ & 20 & 480 & 1.585 & $1970-72$ & $T P-45$ & & & & & & & & & & & & & & & & \\
\hline 3 labc & Ethel Taylor & $\mathrm{w}$ & & $\begin{array}{l}21.5 \\
16\end{array}$ & 407 & $k, 300$ & $\begin{array}{c}9-69 \\
9-30-69\end{array}$ & $\begin{array}{l}\text { TP- } 45 \\
\text { TP-45 }\end{array}$ & 63 & & 70 & 17 & 31 & & 181 & 0 & 20 & 99 & & 1.6 & 432 & 626 & 7.8 & \\
\hline
\end{tabular}

TABIE 4-8. Southern Curlew valley. Springs and wells with water temperatures of $15.5^{\circ}$ to $19.5^{\circ} \mathrm{C}$

\begin{tabular}{|c|c|c|c|c|c|c|c|c|c|c|c|c|c|c|c|c|c|c|c|c|c|c|c|c|c|}
\hline \multirow[b]{2}{*}{ COORDINATES } & \multirow{3}{*}{$\begin{array}{c}\text { OWNER } \\
\text { OR } \\
\text { NAME } \\
\text { Black Butte }\end{array}$} & \multirow{3}{*}{\multicolumn{2}{|c|}{ 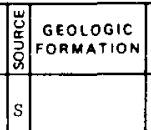 }} & \multirow{3}{*}{\begin{tabular}{|c|}
\multicolumn{1}{|c|}{$\begin{array}{c}\text { TEMP. } \\
\text { OC }\end{array}$} \\
19 \\
\end{tabular}} & \multirow{2}{*}{$\begin{array}{l}\text { DEPTH } \\
\text { (foet) }\end{array}$} & \multirow{2}{*}{$\begin{array}{l}\text { YIELD } \\
\operatorname{lgpml}\end{array}$} & \multirow[b]{2}{*}{$\begin{array}{l}\text { DATE OF } \\
\text { SAMPLE }\end{array}$} & \multirow[b]{2}{*}{ REEERENCE } & \multicolumn{13}{|c|}{ ANALYSIS EXPRESSED AS MILLIGAAMS PER LITER } & \multirow{2}{*}{$\begin{array}{l}\text { CONO. } \\
\text { mmnos }\end{array}$} & \multirow[b]{2}{*}{$\mathrm{DH}$} & \multirow{2}{*}{\multicolumn{2}{|c|}{$\begin{array}{l}\text { OTHER CONSTITUENTS } \\
\text { OR REMARKS }\end{array}$}} \\
\hline & & & & & & & & & $\mathrm{SiO}_{2}$ & $\mathrm{~F}$. & $c_{1}$ & $M_{8}$ & N. & $x$ & $\mathrm{HCO}_{3}$ & $\mathrm{Co}_{3}$ & $\mathrm{so}_{4}$ & $\mathrm{cl}$ & $F$ & $\mathrm{NO}_{3}$ & $\begin{array}{c}\text { Dissolved } \\
\text { SOLIDS }\end{array}$ & & & & \\
\hline$(B-11-11) \quad 6 d b b s$ & & & & & & $18 \mathrm{R}$ & $9-23-60$ & $T P-30$ & 14 & & 520 & 124 & $6,\left.670\right|^{2}$ & 276 & 206 & 0 & 224 & $11,600 \mid$ & & 15 & 20,300 & 30,400 & 7.2 & & \\
\hline$(B-12-09) 30$ cda & Test hole 3 & w & $112 \mathrm{PLCN}$ & $\begin{array}{l}14 \\
15.5\end{array}$ & 162 & & $\begin{array}{l}7-07-72 \\
9-25-72\end{array}$ & $\begin{array}{l}\mathrm{TP}-45 \\
\mathrm{TP}-45\end{array}$ & & & $\begin{array}{l}200 \\
120\end{array}$ & $\begin{array}{r}120 \\
66\end{array}$ & $\begin{array}{l}660 \\
740\end{array}$ & ${ }_{46}^{1.8}$ & $\begin{array}{l}223 \\
173\end{array}$ & $\begin{array}{l}0 \\
0\end{array}$ & $\begin{array}{l}170 \\
100\end{array}$ & $\begin{array}{l}1,500 \\
1,500\end{array}$ & & & $\begin{array}{l}2,760 \\
2,660\end{array}$ & $\begin{array}{l}5,190 \\
4,890\end{array}$ & $\begin{array}{l}7.4 \\
7.5\end{array}$ & & \\
\hline$(B-12-11) \quad 5 a b b$ & A. Fehlman & $|w|$ & & 17 & 230 & 250 & 4-29-72 & $T P-45$ & & & 150 & 76 & 460 & 30 & 206 & 0 & 160 & 960 & & & 1,940 & 3,540 & 7.3 & & \\
\hline$(B-12-11) \quad 5 b b a$ & A. Fehlman & w & 111 ALVM & $\begin{array}{l}15.5 \\
15\end{array}$ & 300 & 1,610 & $\begin{array}{r}7-12-67 \\
3-14-72\end{array}$ & $\begin{array}{l}\mathrm{TP}-45 \\
\mathrm{TP}-45\end{array}$ & 40 & & $\begin{array}{r}72 \\
130\end{array}$ & $\begin{array}{l}39 \\
58\end{array}$ & $\begin{array}{l}112 \\
150\end{array}$ & $\begin{array}{l}14 \\
18\end{array}$ & $\begin{array}{l}222 \\
231\end{array}$ & $\begin{array}{l}0 \\
0\end{array}$ & $\begin{array}{l}51 \\
54\end{array}$ & $\begin{array}{l}255 \\
450\end{array}$ & .4 & 2.5 & $\begin{array}{l}756 \\
974\end{array}$ & $\begin{array}{l}1,210 \\
1,870\end{array}$ & $\begin{array}{l}7.5 \\
7.5\end{array}$ & B. 09 & $\begin{array}{l}\text { Reported drilled to } 700 \\
\text { plugged back to about } 300 \text {. }\end{array}$ \\
\hline$(8-13-08) 10 d c c$ & E. Deak!n & $|w|$ & 111 ALVM & 15.5 & 408 & & $9-25-72$ & $\mathrm{TP}-45$ & & & 210 & 70 & 260 & 15 & 167 & 0 & 50 & 890 & & & 1,580 & 3,000 & 7.8 & & \\
\hline$(B-13-09) 35 \mathrm{bbd}$ & Don Rigby & $|w|$ & $112 \mathrm{PLCN}$ & 19.5 & 428 & 550 & $12-11-70$ & TP-45 & 37 & .09 & 180 & 140 & $3,300 \mid 1$ & 180 & 164 & 0 & 460 & 5,800 & .5 & .4 & 10,000 & 15,600 & 7.7 & 31.07 & \\
\hline$(B-13-10) 11 d \propto d$ & Test hole 1 & $|w|$ & $112 \mathrm{PLCN}$ & 15.5 & 128 & & $6-16-72$ & TP-45 & & & 72 & 32 & 590 & & 255 & 0 & 93 & 970 & & & 1,880 & 3,540 & 7.5 & & \\
\hline $34 d d c$ & Test hole 2 & $|w|$ & 112 PLCN & 19.5 & 95 & & $6-28-72$ & TP -45 & 47 & .02 & 76 & 48 & 9в० & 66 & 193 & 0 & 120 & 1,600 & .6 & .9 & 3.040 & 5,420 & 7.7 & & \\
\hline$(\mathrm{B}-13-11) 10 \mathrm{CdC}$ & Test hole 4 & $w$ & 111 ALVM & 17 & 283 & & $9-25-72$ & TP-45 & & & 56 & 28 & 74 & 11 & 222 & 0 & 31 & 150 & & & 459 & 901 & 7.5 & & \\
\hline$(B-14-07) \quad 7 \mathrm{~A} A 0$ & Bert Ellagon & $w$ & $111 \mathrm{ALVM}$ & 15.5 & 100 & & 2- -69 & $T P-45$ & & & & & & & & & & & & & & & & & \\
\hline$(8-14-08) \quad 5 \mathrm{dcc}$ & Chas Taylor & $|w|$ & $300 \mathrm{PLZC}$ & 17.5 & 400 & 2,050 & $10--65$ & TP-45 & & & & & & & & & & & & & & & & & \\
\hline $5 \mathrm{cod}$ & Ches Taylor & $w$ & $111 \mathrm{ALVM}$ & 16 & 400 & 2,420 & $7-13-67$ & $T P-45$ & 51 & & 85 & 20 & 53 & 11 & 176 & 0 & 24 & 180 & .3 & 3.1 & 587 & 889 & 7.4 & B. 04 & \\
\hline $7 \mathrm{bbb}$ & LDS Church & $w$ & & 19 & 608 & 2,530 & $10-15-58$ & $\begin{array}{l}\text { TP-45 } \\
\text { TP-45 }\end{array}$ & 65 & & 77 & 20 & 45 & & 174 & 0 & 22 & 145 & & 2.2 & 462 & & 7.9 & & \\
\hline$(B-14-10) \quad 16 b b$ & Chas taylor & $|w|$ & 111 ALVM & $\begin{array}{l}16 \\
15.5\end{array}$ & 120 & 1,435 & $\begin{array}{l}5-24-56 \\
8-08-67\end{array}$ & $\begin{array}{l}\text { TP-45 } \\
\text { TP-45 }\end{array}$ & $\begin{array}{l}60 \\
52\end{array}$ & & $\begin{array}{l}46 \\
65\end{array}$ & $\begin{array}{l}24 \\
15\end{array}$ & $\begin{array}{l}28 \\
28\end{array}$ & 6.8 & $\begin{array}{l}194 \\
188\end{array}$ & $\begin{array}{l}0 \\
0\end{array}$ & $\begin{array}{l}31 \\
27\end{array}$ & $\begin{array}{l}66 \\
82\end{array}$ & .4 & $\begin{array}{l}.9 \\
.3\end{array}$ & $\begin{array}{l}352 \\
391\end{array}$ & $\begin{array}{l}558 \\
583\end{array}$ & $\begin{array}{r}7.6 \\
7.4\end{array}$ & 8.03 & \\
\hline$(B-15-10) 36 \mathrm{bbb}$ & Pater Mayo & $w$ & $112 \mathrm{PLCN}$ & $\begin{array}{l}16.5 \\
10.5\end{array}$ & 613 & 2,140 & $\begin{array}{l}5-24-56 \\
5-\quad-56\end{array}$ & $\begin{array}{l}\mathrm{TP}-45 \\
\mathrm{TP}-45\end{array}$ & 56 & & 59 & 17 & 18 & & 198 & 0 & 23 & 51 & & 2.2 & 324 & 502 & 7.4 & & \\
\hline
\end{tabular}


TABLE 5-A. East Shore Area. Springs and Wells with Water Temperatures of $20^{\circ}$ to $60^{\circ} \mathrm{C}$

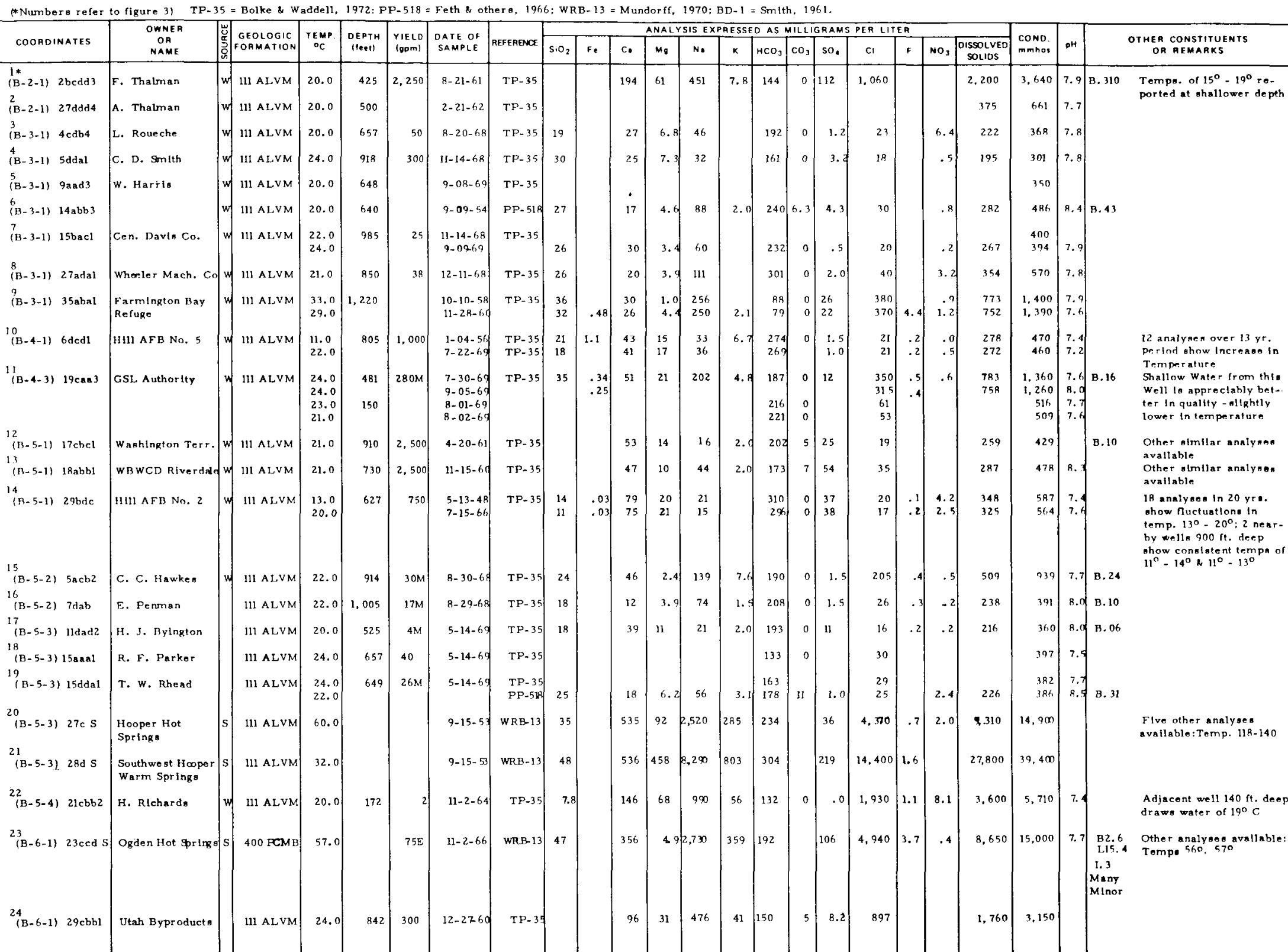


TABLE 5-A. East Shore Area. Springs and Wells with Water Temperatures of $20^{\circ}$ to $60^{\circ} \mathrm{C}$.

\begin{tabular}{|c|c|c|c|c|c|c|c|c|c|c|c|c|c|c|c|c|c|c|c|c|c|c|c|c|}
\hline \\
\hline & OWNER & GEOLOGIC & TEMP. & & & & & \multicolumn{14}{|c|}{ mNumbors refer to nguro $31^{\text {OWNE }}$} & & & \\
\hline COOADINATES & $\begin{array}{l}\text { OR } \\
\text { NAME }\end{array}$ & b. GORMATION & of & (1+oet) & topml & SAMPLE & REFEREACE & $\mathrm{SiO}_{2}$ & $\mathrm{Fe}$ & c. & $M_{0}$ & N. & \begin{tabular}{l|l}
$K$ & HC \\
\end{tabular} & $\mathrm{HCO}_{3} \mathrm{C}$ & \begin{tabular}{|l|l|}
$\cos _{3}$ & $\mathrm{~s}$ \\
\end{tabular} & so, & ci & $F$ & No, & $\begin{array}{l}\text { DISSOLVED } \\
\text { SOLIDS }\end{array}$ & $\begin{array}{l}\text { Cono. } \\
\text { mmmas }\end{array}$ & $\mathrm{DH}$ & & $\begin{array}{l}\text { OTMER CONSTIIUENTS } \\
\text { OA REMARKS }\end{array}$ \\
\hline $\begin{array}{l}25^{*} \\
(\mathrm{~B}-6-2)\end{array}$ & G. E. Stratford & 111 ALVM & $\begin{array}{l}22.0 \\
20.0\end{array}$ & 690 & & $\begin{array}{r}5-13-43 \\
11-18-59\end{array}$ & $\begin{array}{l}\text { TP-35 } \\
\text { BD-1 }\end{array}$ & 18 & & \begin{tabular}{l|l}
178 & 4 \\
180 & 4
\end{tabular} & 42 & $\begin{array}{l}233 \\
231\end{array}$ & $\begin{array}{l}172 \\
163\end{array}$ & & & $\begin{array}{r}.0 \\
3.7\end{array}$ & $\begin{array}{c}700 \\
700\end{array}$ & & $\begin{array}{l}.2 \\
.3\end{array}$ & $\begin{array}{l}1,240 \\
1,260\end{array}$ & 2,400, & 7.3 & & $\begin{array}{l}\text { Two omliar analysea show } \\
\text { temperatures of } 20^{\circ}\end{array}$ \\
\hline$(\mathrm{B}-2-2) 27 \mathrm{ded} 2$ & L. Defrieo & $111 \mathrm{ALVM}$ & 20.0 & 625 & & $11-18-59$ & TP- 35 & 19 & & $42 \mathrm{po}$ & .0 & 41 & & 193 & $\begin{array}{lll}0 & 9\end{array}$ & 9.1 & 48 & & .4 & 266 & 459 & 7.8 & & $\begin{array}{l}\text { Four similar analyses show } \\
\text { temperatures } 18^{\circ}-22^{\circ}\end{array}$ \\
\hline$(\mathrm{B}-6-2) \quad 33 \mathrm{ddc} 2$ & D. Provedol & 111 ALVM & 20.0 & 682 & & $5-07-69$ & TP- 35 & 17 & & 42 & 12 & 20 & & 197 & 099 & 9.5 & 18 & & .0 & 216 & 377 & 7.7 & & \\
\hline $2_{(\mathrm{B}-6-3)}^{28} 4 \mathrm{dabl}$ & E. J. Waymont & 111 ALVM & 21.0 & 540 & $6 \mathrm{M}$ & $10-9-68$ & TP- 35 & 25 & & 4.0 & 3.4 & 197 & 48 5 & 502 & \begin{tabular}{l|l}
0 & 4 \\
\end{tabular} & 4.2 & 28 & 2.0 & .9 & 531 & 816 & $8.0 \mathrm{~B}$ & B. 70 & \\
\hline$(B-6-3) \quad 10 \times a c b 2$ & R. M. Jacob & MI ALVM & 22.0 & 752 & $14 \mathrm{M}$ & $5-14-69$ & $T P-35$ & 19 & & 8.0 & 2.9 & 159 & & 324 & $\begin{array}{lll}0 & 1\end{array}$ & 1.2 & 84 & .6 & .4 & 453 & 741 & $8.0 \mathrm{~B}$ & B. 40 & \\
\hline (B-6-3) $\quad 19 \mathbf{z a b l}$ & Marguardt ACFT & III ALVM & 22.0 & 229 & 150 & $11-05-59$ & TP-35 & 35 & & 96 & 18 & 340 & & 146 & 018 & 18 & 645 & & 10 & 1,230 & 2,290 & 7.5 & & Stm llar analyols a year \\
\hline (3-7-2) LodbdI & Welle \& Larkln & 111 ALVM & 24.0 & 782 & 943 & $18-20-68$ & TP-35 & 16 & & 75 & 10 & 216 & & 169 & 08 & 8.5 & 390 & & .3 & 866 & 1,480 & 7.9 & & \\
\hline $\begin{array}{l}33 \\
(\mathrm{~B}-7-2) \\
34\end{array}$ & Utah Hot Springs & $370 \mathrm{CMBR}$ & 58.5 & & & $11-13-66$ & WRB-13 & 35 & &, 000 & 39 & 6.580 & $\begin{array}{lll}935 & 18\end{array}$ & 182 & & $\infty$ & 12,700 & 4. 3 & .8 & 21.600 & 34800 & 7.5 & B. 3.1, & 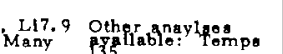 \\
\hline $\begin{array}{l}(B-7-2) \text { l6dadI } \\
35\end{array}$ & LDS Church & W 11 ALVM & 24.0 & 1,021 & & $5-07-69$ & TP-35 & 61 & & 18 & 1.5 & 90 & & 279 & 0 & .8 & 12 & & .2 & 327 & 460 & $\left.7.8\right|^{N}$ & & \\
\hline $\begin{array}{l}(\mathrm{B}-7-2) 16 \mathrm{dcd} 2 \\
36\end{array}$ & R. G. Ponton & W III ALVM & $\left.25.0\right|^{1}$ & 1,176 & $42 \mathrm{M}$ & |5-07-69 & TP-35 & 28 & & 21 & 4.4 & 49 & 681 & 193 & \begin{tabular}{l|l}
0 & 4 \\
\end{tabular} & 4.5 & 10 & .5 & .2 & 221 & 333 & $7.8 \mathrm{~B}$ & 8.08 & $\begin{array}{l}\text { A elmlaer enalyale } \\
\text { avallable }\end{array}$ \\
\hline $\begin{array}{l}(\mathrm{B}-7-3) 3 \text { inacl } \\
37\end{array}$ & $\begin{array}{l}\text { GSLM \& C Corp. } \\
\text { No. } 14\end{array}$ & W 111 ALVM & 39.0 & 806 & $56 \mathrm{M}$ & $\mid 9=27.68$ & TP-35 & 24 & & 15 & 4.4 & 148 & \begin{tabular}{l|l}
9.4 & 3 \\
\end{tabular} & 305 & $\begin{array}{lll}0 & 1 .\end{array}$ & 1.0 & 104 & .7 & .3 & 462 & 785 & $8.1 \mid 1$ & B.20 & \\
\hline $\begin{array}{l}(\mathrm{B}-7-3) \quad 31 \mathrm{adcl} \\
39\end{array}$ & $\begin{array}{l}\text { GSLM \& C Corp. } \\
\text { No. } 11\end{array}$ & $w$ II ALVM & 34.0 & 712 & $53 \mathrm{M}$ & $9-05-68$ & TP-35 & & & & & & & & & & & & & 650 & & & & \\
\hline $\begin{array}{l}\text { (B-7-3) 31daal } \\
40\end{array}$ & $\begin{array}{l}\text { GSLM \& C Corp. } \\
\text { No. } 3\end{array}$ & $W 111$ ALVM & 25.0 & 412 & $29 \mathrm{M}$ & $9-05-68$ & TP-35 & & & & & & & & & & & & & 580 & & & & \\
\hline $\int_{41}^{(B-7-3) 31 \text { daa2 }}$ & $\begin{array}{l}\text { CSLM \& C Corp. } \\
\text { No. } 4\end{array}$ & $\mathrm{w} 111$ ALVM & 25.0 & 415 & $30 \mathrm{M}$ & $\mid$\begin{tabular}{|l|}
$9-05-68$ \\
\end{tabular} & TP-35 & & & & & & & & & & & & & 500 & & & & \\
\hline $\int_{42}^{(B-7-3)} \quad 31 \mathrm{dag} 3$ & $\begin{array}{l}\text { GSLM \& C Corp. } \\
\text { No. } 5\end{array}$ & w 111 ALVM & 30.0 & 575 & $40 \mathrm{M}$ & $9-05-68$ & TP-35 & & & & & & & & & & & & & 725 & & & & \\
\hline$(B-7-3) 31$ daa4 & $\begin{array}{l}\text { GSLM \& C Corp. } \\
\text { No. } 12\end{array}$ & $w$ In ALVM & 34.0 & 717 & $69 \mathrm{M}$ & $9-05-68$ & TP. 35 & & & & & & & & & & & & & 650 & & & & \\
\hline${ }_{4}^{43}(\mathrm{~B}-7-3) 31 \mathrm{dab} 1$ & $\begin{array}{l}\text { GSLM \& C Corp } \\
\text { No. } 6\end{array}$ & $w 111$ ALVM & $3 a .0$ & 590 & $29 \mathrm{M}$ & $\mid \begin{array}{r}9-05-68 \\
12-17-69\end{array}$ & TP-35 & 44 & & 14 & 1.9 & 157 & \begin{tabular}{ll|l} 
& 7.6 & 3 \\
\end{tabular} & 339 & $0^{0}$. & .0 & 89 & .9 & .2 & 491 & $\begin{array}{l}710 \\
772\end{array}$ & 7.7 & в. 19 & \\
\hline $\begin{array}{l}{ }_{(B-7-3)}^{4} 31 \mathrm{dab} 2 \\
45\end{array}$ & $\begin{array}{l}\text { GSLM \& C Corp } \\
\text { No. } 7\end{array}$ & W.111 ALVM & 340 & 710 & $72 \mathrm{M}$ & $9-05-68$ & & & & & & & & & & & & & & & 690 & & & \\
\hline $\begin{array}{l}\begin{array}{l}45 \\
(\mathrm{~B}-7-3)\end{array} 31 \mathrm{dab} 3 \\
\text { ? }\end{array}$ & $\begin{array}{l}\text { GSLM \& C Corp }\} \\
\text { No. } 10\end{array}$ & W III ALVM & 34.9 & 705 & $65 \mathrm{M}$ & $9-05-68$ & TP-35 & & & & & & & & & & & & & & 680 & & & \\
\hline $\begin{array}{l}46 \\
(\mathrm{~B}-7-3) 31 \mathrm{dacl}\end{array}$ & $\begin{array}{l}\text { GSLM } \& \text { Corp } \\
\text { No. } 8\end{array}$ & WIII ALVM & 30.9 & 621 & $28 \mathrm{M}$ & $9-05-68$ & TP-35 & & & & & & & & & & & & & & 750 & & & \\
\hline (B-7.3) 31ddal & $\begin{array}{l}\text { GSLM } \& \text { Corp } \\
\text { No. } 9\end{array}$ & $w 111$ ALVM & $30 \oint$ & 597 & $28 \mathrm{M}$ & \begin{tabular}{|l|}
$9-05-68$ \\
$9-10-69$
\end{tabular} & T P-35 & 33 & & 14 & 8.8 & 147 & & 310 & 0 & .8 & 96 & & .0 & 478 & $\begin{array}{l}925 \\
750\end{array}$ & $|7.9|$ & & \\
\hline$(B-7-3) 33 \mathrm{cdd}$ & Goorge Eest \#1 $_{1}$ & $w 111$ ALYM & 20.0 & 399 & $18 \mathrm{M}$ & $1-2-2-60$ & BD-1 & 24 & .05 & 10 & 3.9 & 76 & 8 & 228 & & 1.4 & 23 & .4 & .3 & 259 & 409 & 7.5 & & $\begin{array}{l}\text { Towo Other Analyeed } \\
\text { Avallable }\end{array}$ \\
\hline
\end{tabular}


TABLE 5-B. East Shore Area. Springs ond wells with water temperatures of $15.5^{\circ}$ to $19.5^{\circ} \mathrm{C}$.

\begin{tabular}{|c|c|c|c|c|c|c|c|c|c|c|c|c|c|c|c|c|c|c|c|c|c|c|c|c|}
\hline COOADIN & mates & $\begin{array}{c}\text { OWNER } \\
\text { OA } \\
\text { NAME }\end{array}$ & 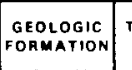 & 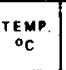 & 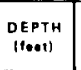 & 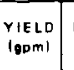 & $\begin{array}{l}\text { DAFE OF } \\
\text { SAMPLE }\end{array}$ & REERERSOX & sion & r. & c. & 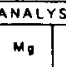 & Ne & AESSEO & HCOS & 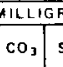 & so. & EA LIT & $\begin{array}{l}\mathrm{ER} \\
\mathrm{ER}\end{array}$ & $\left.\mathrm{N}_{0}\right\}^{0}$ & 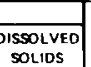 & $\begin{array}{l}\text { cono } \\
\text { manos }\end{array}$ & $\mathrm{OH}$ & $\begin{array}{l}\text { OTHER CONSITUENTS } \\
\text { OR REMARKS }\end{array}$ \\
\hline$(A-02-01)$ & $7 a b a a_{1}$ & J. gradshow & & 18 & 450 & & $10-15-64$ & $\mathrm{TP}-3 \mathrm{~S}$ & 20 & & 16 & 7.9 & 31 & & 129 & 0 & 12 & 14 & & 2.3 & 162 & 264 & 7.4 & \\
\hline & $7 a b a$ & J. Bradshaw & & 18 & 450 & & $\mid 10-01-68$ & TP-35 & & & & & & & 126 & 0 & & 17 & & & & 272 & 7.5 & \\
\hline$(B-01-01) 1$ & $10 a a c$ & D. B. Holbrook & & 16 & 231 & $10 \mathrm{~d}$ & $12-20-65$ & TP-35 & 50 & & 51 & 17 & 577 & & 429 & 0 & 1.2 & 778 & & 1.3 & 1,720 & 3.080 & 7.7 & \\
\hline & $10 \mathrm{aac}$ & D. B. Holbrook & & 16 & 231 & $18 \mathrm{~d}$ & $11-13-68$ & TP-35 & 48 & & 45 & 20 & 570 & & 433 & 0 & 6.2 & 760 & & .7 & 1,700 & 2.970 & 8.0 & \\
\hline$(B-02-01) 1$ & $130 a \mathrm{~b}$ & L. Nopoll & & 16 & 264 & & $10-10-58$ & TP-35 & 21 & & 9.6 & 2.9 & 80 & & 192 & 0 & 9.5 & 30 & & .5 & 248 & 395 & 7.8 & \\
\hline & $13 a \mathrm{ab}$ & L. Napol1 & & 15 & 264 & & $|5-05-69|$ & TP-35 & 19 & & 9.6 & 1.9 & 80 & & 193 & 0 & 8.2 & 28 & & .2 & 236 & 393 & 7.7 & \\
\hline$(B-02-01) 2$ & 23add 6 & A. V. Eldredge & & 17 & 331 & $6 \mathrm{AN}$ & $8-20-68$ & TP-35 & & & & & & & & & & & & & & 464 & & \\
\hline & 23bdd & L. Hepworth & & 18 & 600 & 6ad & $|8-29-68|$ & TP-35 & & & & & & & 220 & 12 & & 48 & & & & 522 & 8.5 & \\
\hline & 24bad 3 & C. Jeppson & & 16 & 386 & sans & $|\theta-20-68|$ & TP-35 & & & & & & & 186 & 5 & & 32 & & & & 415 & 8.4 & \\
\hline & 25baa 15 & Pht111ps pot. & & 16 & 570 & 650 & $12-12-5 \theta$ & TP-35 & 15 & & 55 & 16 & 34 & & 208 & \begin{tabular}{l|l}
0 & 3 \\
\end{tabular} & 38 & 42 & & 7.2 & 309 & 542 & 7.8 & \\
\hline & $26 a b b$ & D. C. Wingegar & & 19 & 273 & $20 \mathrm{al}$ & 8-21-68 & TP-35 & 15 & & 18 & 6.3 & 113 & & 218 & \begin{tabular}{l|l}
0 & 3 \\
\end{tabular} & 32 & 72 & & 5.7 & 373 & 622 & 8.1 & \\
\hline & $26 \mathrm{bab}$ 日 & W. R. Smith & & 16 & 584 & 65 & $4-17-62$ & TP-35 & & & 23 & 7.7 & 119 & 2.0 & 145 & \begin{tabular}{l|l}
11 & 6 \\
\end{tabular} & 62 & 103 & & & 388 & 696 & $8.9 \mathrm{~B}$ & \\
\hline & $260 d \mathrm{~d}$ | & F. Thalman & & 18 & 84 & & $|5-07-63|$ & TP-35 & & & & & ${ }^{73}$ & & 292 & \begin{tabular}{l|l}
0 & 4 \\
\end{tabular} & 49 & 12 & & & & 753 & 7.5 & \\
\hline & 260 dd 4 & F. Thalman & & 17 & 200 & & 5-07-63 & TP-35 & & & & & 88 & & 282 & \begin{tabular}{l|l}
0 & 14 \\
\end{tabular} & 147 & 131 & & & & 1,120 & 7.4 & \\
\hline & $26 \mathrm{dcb}$ & P. ᄃ. Burnham & & 17 & 400 & $120 \mathrm{~m}$ & $8-20-6 \theta$ & $T^{P-35}$ & & & & & & & 222 & 0 & & 121 & & & & 820 & 7.9 & \\
\hline & 348da 3 & D. Hart & & 16 & 270 & & $|5-09-47|$ & TP-3S & 8.9 & & 30 & 10 & 161 & & 264 & \begin{tabular}{l|l}
0 & 5 \\
\end{tabular} & 55 & 141 & & 10 & 552 & 958 & & \\
\hline & 348do 3 & D. Hart & & 17 & 270 & & $\mid 10-10-64$ & TP-35 & 17 & & 42 & 27 & 242 & & 213 & \begin{tabular}{l|l}
0 & 8 \\
0
\end{tabular} & 8в & 334 & & 5.3 & 859 & 1,510 & 7.8 & \\
\hline & 34add 2 & D. M. Hunter & & 19 & 410 & $7 \mathrm{~m}$ & $8-20-68$ & TP-35 & 15 & & 143 & 47 & 456 & & 136 & 03 & 36 & 988 & & .3 & 1,910 & 3,130 & 7.7 & \\
\hline & 34add 2 & D. M. Hunter & & 19 & 410 & $7 \mathrm{mg}$ & $9-08-69$ & TP-35 & & & & & & & 140 & 0 & & 925 & & & & 3,100 & 7.9 & \\
\hline & $\begin{array}{lll}36 \mathrm{bbc} & 2\end{array}$ & Petro flex & & 16 & 501 & & $\mid 10-10-58$ & TP-35 & 17 & & 93 & 27 & 96 & & 314 & \begin{tabular}{l|l}
0 & 8 \\
\end{tabular} & 86 & 140 & & 11 & 624 & 1.070 & 7.5 & \\
\hline & $36 \mathrm{bbc} \quad 2$ & Petro Flex & & 15 & s01 & & $11-10-60$ & TP-35 & 15 & 0 & 87 & 29 & 105 & 3.3 & 310 & \begin{tabular}{l|l}
0 & 9
\end{tabular} & 91 & 152 & .1 & 11 & 645 & 1,100 & 8.0 & \\
\hline$(B-03-01)$ & $\begin{array}{lll}4 \mathrm{~b} c \mathrm{C} & 2\end{array}$ & G. W. Webster & & 16 & 250 & 190 & $8-20-68$ & TP-35 & & & & & & & & & & & & & & 341 & & \\
\hline & tddb 5 & E. W. Bradley & & 18 & 485 & $10 \mathrm{ar}$ & $11-14-68$ & TP-35 & & & & & & & & & & & & & & 332 & & \\
\hline & $15 \mathrm{acd} \quad 1$ & L.D.s. Church & & 16 & 260 & $3 \mathrm{M}$ & $\mid 9-11-69$ & TP-35 & 41 & & 36 & 18 & 68 & & 320 & 0 & & ${ }^{33}$ & & 1.8 & 349 & 571 & 7.4 & \\
\hline & $24 \mathrm{bca}$ & F. Richards & & 16 & 176 & & $\mid 0-10-58$ & TP-35 & 21 & & 67 & 15 & 120 & & 510 & 0 & 2.3 & ${ }^{48}$ & & .5 & 509 & 872 & 7.6 & \\
\hline & $24 \mathrm{bca}$ & F. Richards & & 12 & 176 & & $11-09-60$ & TP- -35 & 20 & 20 & 30 & 14 & 123 & 1.3 & 380 & в & 2.1 & 48 & .2 & .3 & 434 & 711 & 8.3 & \\
\hline$(B-04-01) 3$ & $32 \mathrm{bb}$ & P. D. Robins & & 17 & 770 & $1 \mathrm{ad}$ & $11-14-68$ & TP-35 & & & & & & & 194 & 0 & & 31 & & & & 345 & 7.7 & \\
\hline$(B-04-02)$ & 6bas 2 & в. Thurgood & & 16 & 609 & sad & $9-08-69$ & TP-35 & & & & & & & 233 & 0 & & 20 & & & & 428 & 7.8 & \\
\hline & $17 \mathrm{cdd}$ & D. H. W1100x & & 16 & 583 & 1an & 8-21-68 & TP-35 & & & & & & & 222 & 0 & & 22 & & & & 385 & 8.2 & \\
\hline$(B-05-01) 2$ & 29bdb 3 & HHII AFB & & 18 & 800 & 740 & $\mid 11-19-51$ & TP-35 & 13 & & 71 & 18 & 18 & 2.4 & 278 & $0=3$ & 32 & 18 & .1 & 4.7 & 314 & 521 & 7.7 & \\
\hline & 29bdb 3 & HIII AFB & & 12 & 800 & 740 & 4-14-52 & TP-35 & 12 & .03 & 73 & 19 & 20 & 1.7 & 296 & 0 & 30 & 18 & .1 & 2.2 & 322 & 556 & 7.5 & \\
\hline & $29 \mathrm{bdb} \quad 3$ & HHII AFB & & 19 & 800 & 740 & $7-15-66$ & TP-35 & 10 & .02 & 68 & 21 & 14 & & 274 & 0 & 33 & 17 & .2 & 2.9 & 305 & 525 & 7.8 & \\
\hline & 29bdb 3 & BIII AFB & & 16 & 800 & 740 & $7-24-69 \mid$ & TP-35 & 11 & & 71 & 27 & 2.5 & & 286 & 0 & 31 & 30 & .3 & .4 & 314 & 535 & 7.7 & \\
\hline & 33cda & HIII AFB & & 11 & 730 & 1,080 & $10-04-51$ & $\mathrm{TP}-35$ & 22 & & 5) 51 & 16 & 36 & 8.2 & 298 & 0 & 1.9 & 22 & .1 & .1 & 304 & 500 & 7.6 & \\
\hline
\end{tabular}


TABLE 5-B. Last Shore Area. Springs and wells with water temperatures of $15.5^{\circ}$ to $19.5^{\circ} \mathrm{C}$

\begin{tabular}{|c|c|c|c|c|c|c|c|c|c|c|c|c|c|c|c|c|c|c|c|c|c|c|c|c|}
\hline \multicolumn{2}{|c|}{ COORDINATES } & $\begin{array}{l}\text { OWNEA } \\
\text { OMN } \\
\text { OAME }\end{array}$ & $\begin{array}{l}\text { LoO1c } \\
\text { AnTín }\end{array}$ & TEMP. & DEPTM & 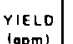 & DATE OF, & R REFEAENOE & & & & rALYS & $515 \mathrm{E}$ & RESSED & $D A S M$ & L & GAMAS & PER L & & & & vo. & 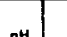 & TUEATS \\
\hline \multirow{2}{*}{\multicolumn{2}{|c|}{$(B-05-01) 33 \mathrm{cda}$}} & & & & & & & & & 1 & 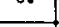 & 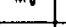 & N. & ${ }^{\mathrm{k}}$ & $\mathrm{HCO}_{3}$ & $\mathrm{cos}^{\mathrm{O}}$ & so. & $c_{1}$ & $F$ & No, & $\begin{array}{l}0 \\
\text { solos } \\
\end{array}$ & \begin{tabular}{c|c} 
mmmoos \\
\end{tabular} & on & OR REMAAKI \\
\hline & & HIII AFB & & 19 & 730 & 1,080 & $7-23-69$ & \begin{tabular}{|l|l|} 
TP-35 \\
\end{tabular} & 22 & & 60 & 22 & 38 & & 348 & 0 & 2.2 & 26 & .2 & .8 & 347 & 586 & 7.7 & \\
\hline \multirow{6}{*}{$\begin{array}{r}6 \\
6 \\
6\end{array}$} & sbdd & J. V. Stoddard & $y$ & 16 & 304 & & $12-10-58$ & TP-35 & 33 & & 38 & 16 & 45 & & 282 & 0 & .0 & 18 & .2 & .1 & 289 & 471 & 7.8 & \\
\hline & 6bdd & J. v. Stoddard & | & 16 & 304 & & $11-16-60$ & TP-35 & 29 & & 38 & 15 & 36 & 6.7 & 268 & 0 & 2.7 & 19 & .3 & .2 & 279 & 452 & 7.9 & \\
\hline & 6bdd 3 & I. v. Stoddard & w & 19 & 609 & 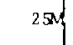 & 8-29-68 & TP-35 & 16 & & 36 & 9.7 & 23 & 3.1 & 190 & 0 & $8.2 \mid$ & 18 & .3 & .8 & 206 & 359 & $8.11^{3}=$ & .04 \\
\hline & 6bdd 3 & I. v. stoddard & & 19 & 609 & 230 & $9-09-69$ & TP-35 & & & & & & & 192 & 0 & & 17 & & & 134 & 362 & 7.8 & \\
\hline & 6bda 4 & I. v. Stoddard & $w$ & 16 & 303 & $7 a y$ & $8-29-68$ & TP-35 & & & & & & & 254 & 0 & & 20 & & & & 455 & 7.8 & \\
\hline & 6bdd 4 & J. v. Stoddard & w & 16 & 303 & ram & $9-09-68$ & TP-35 & & & & & & & 262 & 0 & & 18 & & & & 444 & 7.8 & \\
\hline \multirow{2}{*}{\multicolumn{2}{|c|}{$\begin{array}{rr}(\mathrm{B}-05-03) \text { 25adc } & 2 \\
35 \mathrm{dad} & 2\end{array}$}} & J. J. Frew & & 16 & 616 & & 5-14-69 & TP-35 & 15 & & 45 & 14 & 16 & 1.7 & 203 & & 17 & 18 & .2 & .4 & 240 & 389 & $8.0 \mathrm{~B}=\mathrm{B}-3(-3$ & .05 \\
\hline & & c. w. Stoddard & & 17 & 785 & 20ad & 7-05-69 & TP-35 & 19 & & 40 & 12 & 21 & 2.3 & 202 & 0 & 8.5 & 18 & & & & & & \\
\hline \multirow{4}{*}{$(B-05-04)$} & $21 \mathrm{cbb}$ & H. Richards & & 19 & 140 & 2 & $11-\quad-64$ & TP-35 & 12 & & 184 & 80 & 1140 & 60 & 112 & 0 & $.22^{2}$ & 2,240 & .7 & 17 & 4,360 & 6,870 & 7.5 & \\
\hline & $\begin{array}{lll}4 b b d & 5\end{array}$ & WBWCD & & 15 & 1,133 & 750 & $9-19-67$ & TP- -35 & & & 9.4 & 4.6 & 25 & \begin{tabular}{|c|}
6.5 \\
\end{tabular} & 75 & & 19 & 12 & & & 138 & 194 & 8.5 & \\
\hline & $4 \mathrm{bbd} 5$ & wBWCD & & 16 & 1,133 & 750 & $8-26-68$ & TP-35 & & & & & & & 148 & 0 & & & & & & 243 & 7.8 & \\
\hline & $5 \mathrm{cdb}$ & H. R. Parker & & 18 & 1,000 & 4000 & $8-30-68$ & TP-35 & 16 & & 30 & 11 & 9.6 & 1.6 & 160 & 0 & 6.5 & 8.5 & .1 & .7 & 154 & 265 & $7.9 \mathrm{~B}=$ & $=03$ \\
\hline \multirow[t]{2}{*}{$8-06-01)$} & бсаa & M. Harts & & 16 & 640 & & $10-08-58$ & TP-35 & 20 & & 34 & 8.5 & 13 & & 159 & 0 & 6.6 & 7.5 & & .6 & 168 & 269 & 7.8 & \\
\hline & 6саa & M. Harris & & 15 & 640 & & $10-16-64$ & TP-35 & 19 & & 31 & 9.1 & 15 & & 161 & 0 & 5.4 & 6.6 & & .0 & 156 & 266 & 7.7 & \\
\hline \multirow{6}{*}{$\begin{array}{rr}(B-06-02) & 5 \\
& 5 \\
20 \\
25 \\
27 \\
27 \\
27\end{array}$} & $\begin{array}{llll}5 a c b & 2\end{array}$ & т. Knnght & & 16 & 850 & 120 & $11-04-59$ & $\mathrm{TP}^{\mathrm{P}-35}$ & 20 & & 19 & 5.8 & 92 & & 270 & 0 & 2.3 & 28 & & 1.5 & 300 & 493 & 8.1 & \\
\hline & $\begin{array}{lll}5 \mathrm{acb} & 2\end{array}$ & T. Knıght & & 20 & 850 & 124 & $9-29-66$ & TP-35 & & & & & & & 266 & 0 & & 29 & & & & 495 & 7.8 & \\
\hline & $20 \mathrm{cdd} \quad 3$ & A. Segna & & 16 & 540 & 4 & $11-21-68$ & TP-35 & 21 & & 33 & 8.3 & 36 & & 195 & 0 & 3.2 & 21 & & 1.0 & 215 & 352 & 7.9 & \\
\hline & 250003 & G. E. Strattor & of & 16 & 302 & & $11-04-58$ & TP-35 & 20 & & 36 & 17 & 68 & & 336 & 0 & .6 & 24 & & .3 & 331 & 558 & 7.7 & \\
\hline & 27 bba 2 & D. Lucla & 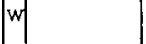 & 17 & 536 & 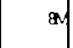 & $11-04-58$ & TP-35 & 24 & & 95 & 22 & 105 & & 193 & 0 & 3.3 & 278 & & 3.4 & 626 & 1.180 & 7.6 & \\
\hline & $27 b$ ba 2 & D. Lucla & & 19 & 536 & of & $9-09-69$ & TP-35 & 19 & & & & & & 200 & 0 & & 275 & & & & 1,190 & 7.8 & \\
\hline \multirow{8}{*}{ (B-06-03) 12} & $12 \mathrm{bcc}$ & Warren Cemetens & & 18 & 550 & & 5-14-69 & TP-35 & 20 & & 14 & 5.8 & 79 & 3. & 240 & 0 & 1.8 & 28 & .3 & .3 & 275 & 445 & $\left.7.9\right|^{8}=$ & $=.21$ \\
\hline & 14dec 2 & L.D. S. Church & & 17 & 604 & af & $8-28-68$ & TP-35 & 19 & & 20 & 9.2 & 47 & & 198 & ${ }^{0}$ & .2 & 20 & & & 220 & 351 & 7.9 & \\
\hline & $19 a a b$ & Marquart ACFT & & 17 & 229 & 150 & $12-10-58$ & TP-35 & 40 & 10 & 104 & 17 & 332 & & 146 & 0 & .0 & 660 & .4 & 1.5 & $\mid 1,230$ & 2,330 & 7.3 & \\
\hline & $19 a b c$ & Marquart ACFT & & 19 & 220 & 1 & $10-09-58$ & TP-35 & 23 & & 9.6 & 3.9 & 123 & & 284 & 0 & 1.4 & 52 & & & 353 & 588 & 7.8 & \\
\hline & $19 a b c$ & Marquart ACFT & & 16 & 220 & 1 & $10-21-66$ & TP-35 & 24 & & 7.0 & 4.9 & 114 & & 285 & 0 & .7 & 35 & & 3.0 & 321 & 517 & $7.7 \mid$ & \\
\hline & 19abc 2 & Marquart ACFT & & 19 & 295 & 25 & $10-09-58$ & TP-35 & 32 & & 42 & 7.8 & 210 & & 182 & 0 & 3.7 & 310 & & 1.9 & 096 & 1,270 & 7.5 & \\
\hline & 19abc 2 & Marquart ACFT & & 18 & 295 & 25 & $11-16-60$ & TP-35 & 33 & .01 & 41 & 9.2 & 207 & 5.5 & 172 & 0 & 3.3 & 310 & .7 & 5.1 & 700 & 1,270 & 7.5 & \\
\hline & 26bbb & D. wilson & & 18 & 512 & a) & $8-28-68$ & TP-35 & 18 & & 19 & 9.2 & 47 & 3.0 & 190 & 0 & .8 & 22 & $|.4|$ & 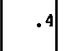 & 210 & 354 & $7.28 \mathrm{~B}$ & $=.11$ \\
\hline \multirow{5}{*}{$\begin{array}{r}(B-07-01) \\
3 \\
3 \\
3 \\
2 \\
2 \\
2\end{array}$} & $31 \mathrm{bdb}$ & Ranah Inn & & 18 & 482 & & $10-07-58$ & TP -35 & 19 & & 41 & 6.8 & 11 & & \begin{tabular}{|l|}
164 \\
\end{tabular} & 0 & 7.6 & 8.9 & & 1.3 & 176 & 288 & 7.8 & \\
\hline & 31bda & Ranch Inn & & 13 & 482 & & $11-08-60$ & TP-35 & 18 & .01 & 39 & 8.8 & 10 & 1.5 & 168 & 0 & 7.6 & 7.5 & .1 & 1.9 & 177 & ${ }^{283}$ & 7.6 & \\
\hline & $16 \mathrm{cbb}$ & & & 16 & & 1 & $\mid 5-06-69$ & TP-35 & 34 & & 19 & 10 & 840 & & 452 & 0 & 8.2 & 1,090 & & & 2,220 & 3,900 & 7.6 & \\
\hline & 23abd & v. Hough & $m$ & 17 & 315 & $2 \mathrm{an}$ & $10-02-68$ & TP-35 & 22 & & 34 & 10 & 35 & 4.5 & 193 & 0 & 22 & 24 & .5 & .1 & 245 & 404 & & $=.03$ \\
\hline & $26 \mathrm{dac}$ & I. W. Randall & 11 & 18 & 510 & & $10-19-64$ & TP-35 & 50 & & 30 & 7.9 & 52 & & 248 & 0 & 5.4 & 8.2 & & 1 & 256 & 379 & 8.0 & \\
\hline
\end{tabular}


JABLE.5-B, East Shore Aree. Springs and wells with water temperatures of $15.5^{\circ}$ to $19.5^{\circ} \mathrm{C}$

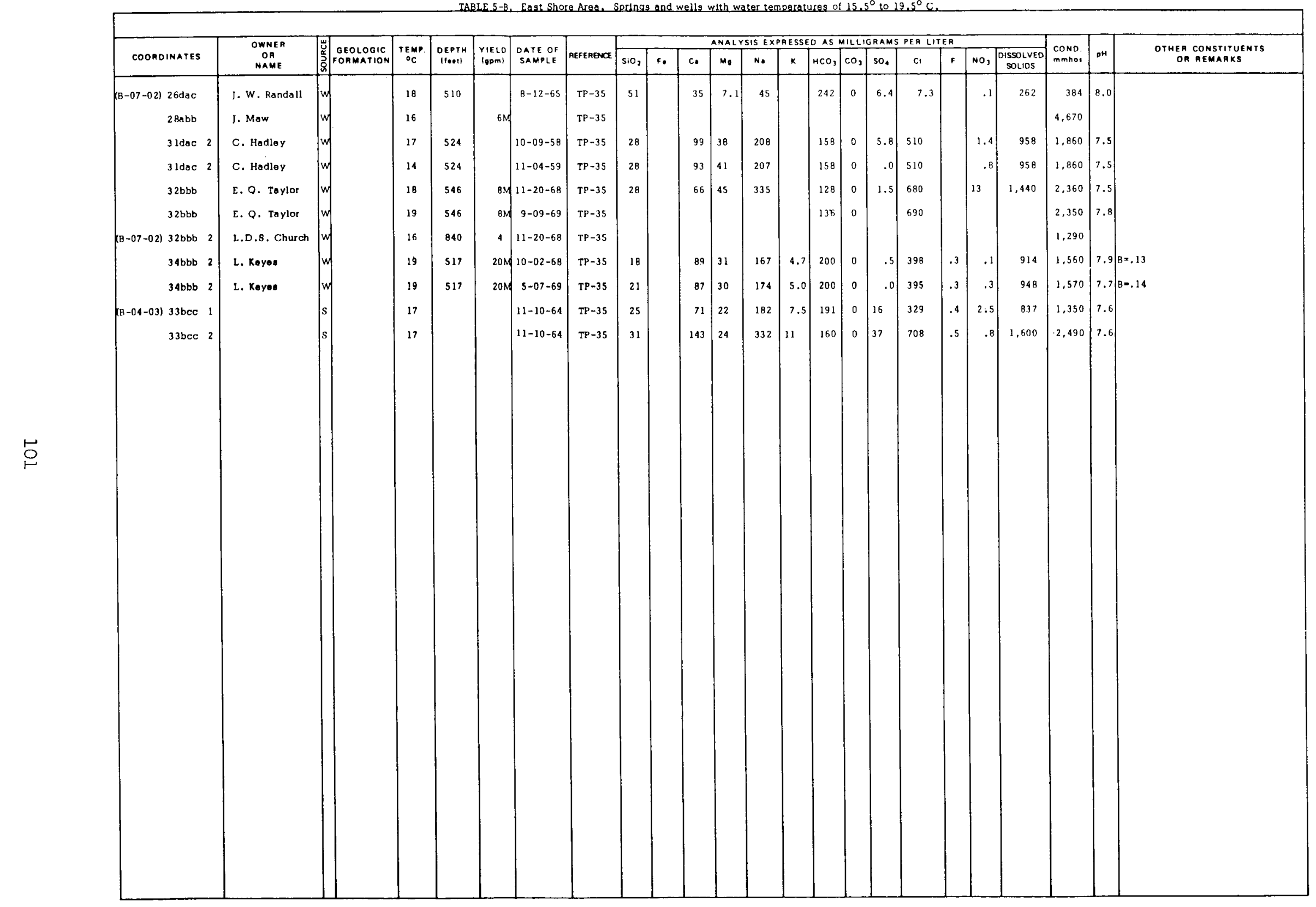




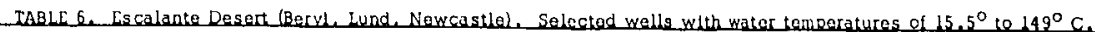

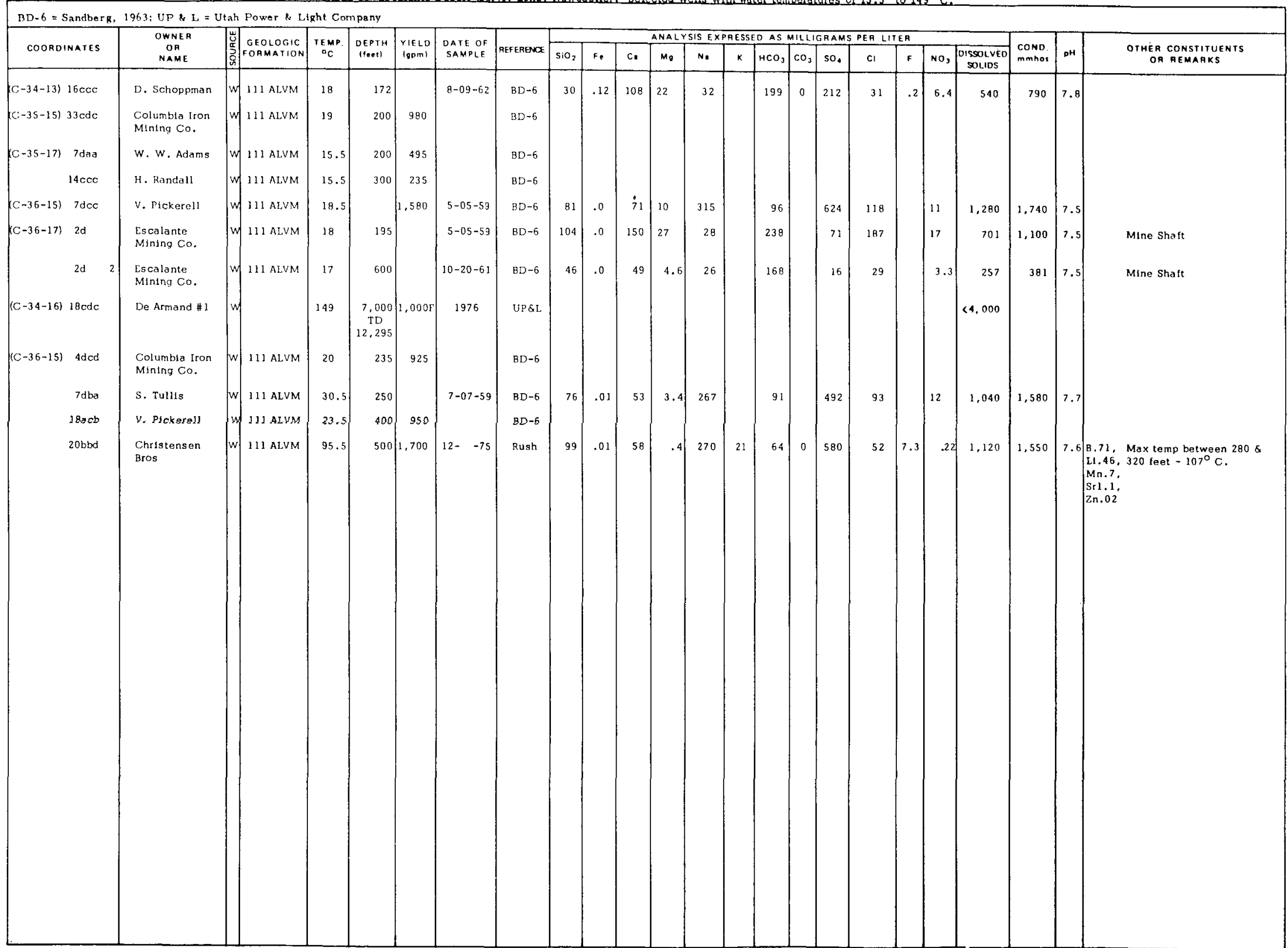


TABLE 7-A. Escalante valley, Springs and wells with water temperatures of $20^{\circ}$ to $99^{\circ} \mathrm{C}$.

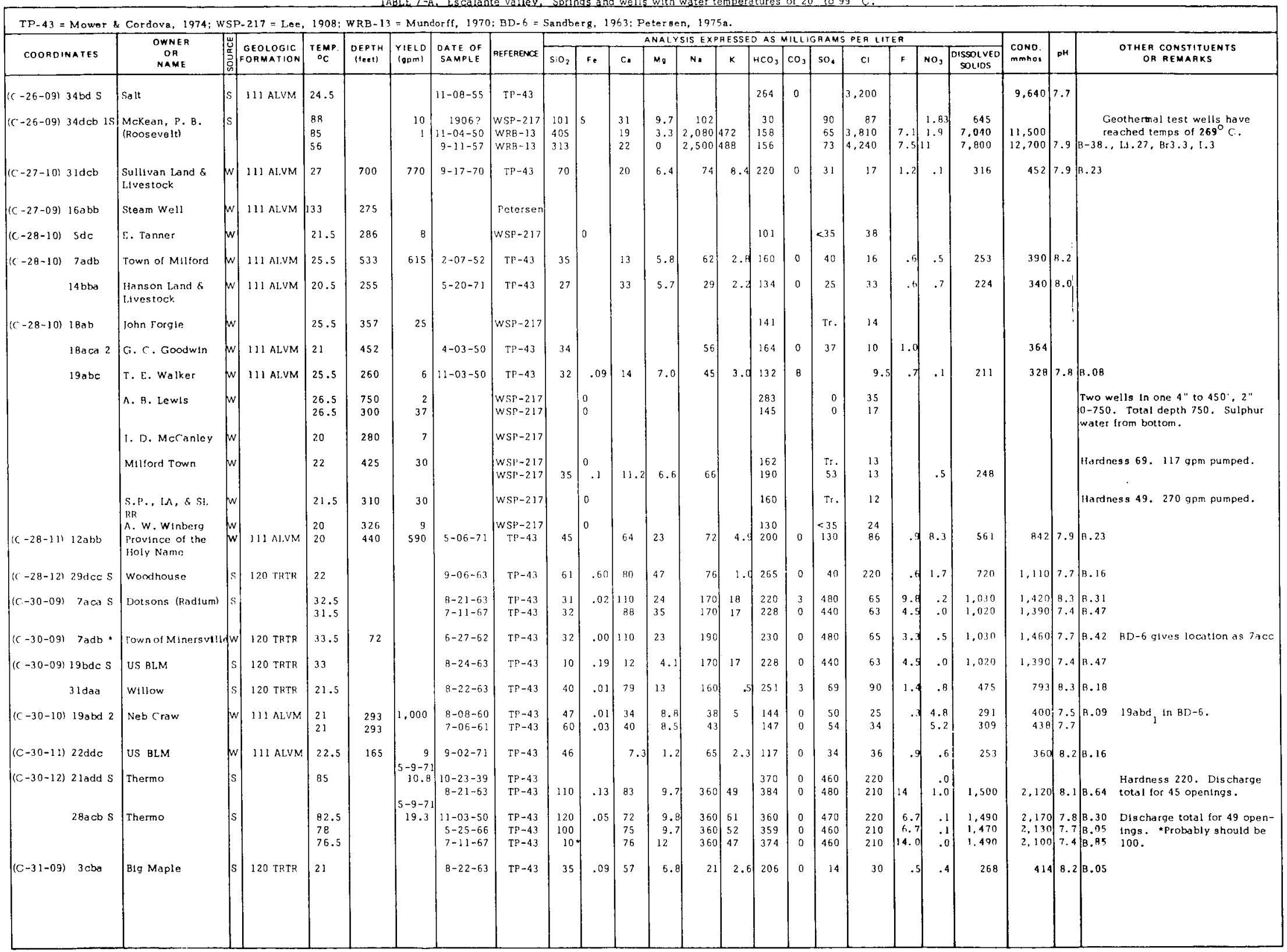


Table 7-B. Encalanto Valley. Springs and Wolle with Water Tomporatures $15,5^{\circ}$ to $19,5^{\circ} \mathrm{C}$.

\begin{tabular}{|c|c|c|c|c|c|c|c|c|c|c|c|c|c|c|c|c|c|c|c|c|c|c|c|}
\hline & & & & & & & & & & & & & Det & $A S$ & & & $P$ & & & & & & \\
\hline COOADINATES & NAME & $\begin{array}{l}0 \\
\vdots \\
a\end{array}$ & 等 & (1+eet) & (logmi & SAMPLE & REEFERACS & $\mathrm{SiO}_{2}$ & F. & c. & $\mu_{0}$ & N. & $k$ & $\mathrm{HCO}_{3} \mathrm{CO}$ & $c_{3}$ & so. & $\mathrm{c}_{1}$ & $F$ & No, & \begin{tabular}{|l} 
Oissolved \\
solitis
\end{tabular} & 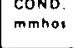 & ${ }^{p H}$ & 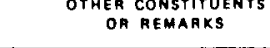 \\
\hline$(C-28-10) 8_{\mathbf{a n d}}$ & Sullivan L \& L & W 111 ALVM & 16.0 & 185 & 960 & $9.18-70$ & TP-43 & 38 & & 71 & 22 & 36 & 3.2 & 133 & 0 & $\mid 110$ & 80 & .9 & 1.5 & 449 & 682 & 7.4 & $B=04$ \\
\hline$(\mathrm{C}-28-10) \quad 16 \mathrm{cda}$ & J. Mayar & $111 \mathrm{ALVM}$ & 19.0 & 440 & 900 & $5-09-71$ & TP-43 & 26 & & 65 & 23 & 50 & 2.6 & 158 & 0 & 160 & 59 & .6 & 2.7 & 476 & 712 & 7.9 & $B=.01$ \\
\hline$(\mathrm{C}-28-10) 19 \mathrm{bcd}$ & D. M. Yardley & W 111 ALVM & 17.0 & 210 & 1,200 & $5-07-71$ & TP-43 & 42 & & 160 & 60 & 51 & 6.d & 147 & 0 & 370 & 190 & & .6 & 954 & 1,350 & 7.9 & $B=.04$ \\
\hline$(\mathrm{C}-28-10) 19 \mathrm{ccd}_{4}$ & D. M. Yardloy & w 111 ALVM & 15.5 & 102 & 1,120 & 5-07-71 & TP- 43 & 49 & & 260 & 75 & 66 & 8.9 & 170 & 0 & $560 \mid$ & 290 & & 3.2 & 1,410 & 2,100 & 7.9 & $B \times .11$ \\
\hline$(C-28-10) 20$ ddd & C. R. Wtsoman & $\mathrm{W} 111 \mathrm{ALVM}$ & 16.5 & 410 & 837 & & $\mathrm{BD}-6$ & & & & & & & & & & & & & & & & \\
\hline$(\mathrm{C}-28-10) 28 \mathrm{cdd}$ & Mayer Bros. & w 111 ALVM & $\begin{array}{l}16.0 \\
16.0\end{array}$ & $\begin{array}{l}355 \\
355\end{array}$ & 800 & $\begin{array}{l}8-26-69 \\
5-15-71\end{array}$ & $\begin{array}{l}\text { TP-43 } \\
\text { TP-43 }\end{array}$ & 34 & & $\begin{array}{r}99 \\
120\end{array}$ & $\begin{array}{l}39 \\
67\end{array}$ & $\begin{array}{l}51 \\
63\end{array}$ & 3. & $\begin{array}{l}192 \\
186\end{array}$ & $\begin{array}{l}0 \\
0 \\
\end{array}$ & $\mid \begin{array}{l}190 \\
330\end{array}$ & $\begin{array}{l}110 \\
170\end{array}$ & & $4=2$ & 673 & $\begin{array}{r}990 \\
1,300\end{array}$ & $\begin{array}{l}7.7 \\
8.0\end{array}$ & \\
\hline$(\mathrm{C}-28-10) 29 \mathrm{bcd} z$ & O. R. willtems & W 111 ALVM & 17.5 & 143 & & $5-20-65$ & тP-43 & 38 & & 56 & 17 & 51 & & 158 & 0 & 100 & 56 & & 1.9 & 414 & 616 & 7.2 & \\
\hline$(\mathrm{C}-28-10) 30 \mathrm{bdc}_{3}$ & J. Baldwin & w 111 ALVM & 19.0 & 290 & 1,100 & $8-08.68$ & тP-43 & 38 & & 120 & 39 & 48 & & 132 & 0 & 230 & 150 & & 4.6 & 773 & 1.080 & 7.6 & \\
\hline & & W 111 ALVM & 16.0 & 290 & & $6.25-70$ & TP- 43 & & & & & & & & & & 83 & & & & ${ }^{731}$ & & \\
\hline & & w 111 ALVM & 16.5 & 290 & & 6-10-71 & TP-43 & 42 & & 91 & 24 & 33 & 4.4 & 137 & 0 & 160 & 92 & & 1.6 & 522 & 779 & 7.7 & $B=.01$ \\
\hline (C.28-10) 30bdd 2 & J. Baldwin & W 111 ALVM & 16.0 & 186 & & 5-19-65 & TP-43 & 39 & & 44 & 11 & 18 & & 122 & 0 & 35 & 38 & & 2.3 & 263 & 385 & 7.5 & \\
\hline (C-28-11) 10acd & U.S. E.L.M. & W 111 ALVM & 16.5 & 227 & 1 & $11-03-50$ & $T P-43$ & 48 & .05 & 54 & 40 & 99 & 4.2 & 285 & 0 & 170 & 82 & & & 642 & 988 & 8.0 & $B=09$ \\
\hline$(\mathrm{C}-28-11)$ l2dbc & M. Persons & \begin{tabular}{l|l}
$\mathrm{w}$ & $111 \mathrm{ALVM}$ \\
\end{tabular} & 17.0 & 460 & 784 & & $B D-6$ & & & & & & & & & & & & & & & & \\
\hline (C-28-11) 13dca & F. Brinkman & $\mathrm{w} 111 \mathrm{ALVM}$ & 15.5 & 600 & 1 & $4.03-50$ & TP- 43 & & & & & & & 152 & 0 & & 30 & & & & 466 & & \\
\hline (C-28-11) 25ded, & Green Dlamond & $w 111 \mathrm{ALVM}$ & 17.0 & 431 & 2,500 & $9-04-57$ & TP- 43 & 40 & & 100 & 24 & 36 & & 154 & 0 & 160 & 100 & & 1.5 & 538 & 872 & 7.4 & \\
\hline & & & 20.5 & 431 & & $5-02-59$ & TP-43 & 38 & .00 & 27 & 9 & 40 & & & 0 & 44 & 19 & & .6 & 249 & 373 & 7.7 & \\
\hline (C-28-10) 20तdd & C. R. Wlsoman & w & 16.5 & 410 & 837 & & BD-6 & & & & & & & & & & & & & & & & \\
\hline$(C-28-11) 25 \mathrm{CCA}_{\mathrm{l}}$ & $\begin{array}{l}\text { Green Diamond } \\
\text { Ranch }\end{array}$ & W. 111 ALVM & 19.5 & 431 & & $5-18-62$ & TP-43 & 36 & .12 & 71 & 16 & 36 & 4. & 144 & 0 & 120 & 60 & & & 445 & 668 & 7.7 & $B=.08$ \\
\hline & & 111 ALVM & 17.5 & 431 & & $8-10-67$ & TP- 43 & & & 220 & 48 & 70 & & 186 & 0 & $460 \mid$ & 190 & & & 1,230 & 1.540 & 7.6 & \\
\hline$(C-28-10) 35 \mathrm{cad}_{1}$ & H. Cook & w) $111 \mathrm{ALVM}$ & 15.5 & & 1 & $5-14-71$ & TP. 43 & 54 & & 30 & 88 & 16 & 3.9 & 131 & 0 & 25 & 19 & .7 & & 226 & 310 & 7.8 & $B=02$ \\
\hline$(\mathrm{C}-29-10)$ bbaa $_{2}$ & J. A. Mayer & W 111 ALVM & 16.8 & 190 & 560 & 5.20 .65 & TP-43 & 37 & & 34 & 6.2 & 19 & & 123 & 0 & 21 & 19 & & .7 & 195 & 283 & 7.5 & \\
\hline$(\mathrm{C}-29-10) 8 \mathrm{add}$ & Milford Farme & $w 111 \mathrm{ALVM}$ & 15.5 & & & & BD-6 & & & & & & & & & & & & & & & & \\
\hline (C-29-11) 4baa & w. H. Child & w 111 ALVM & 15.5 & 68 & & $6-27-62$ & BD- 6 & 17 & .01 & 120 & 81 & 356 & & 169 & & 712 & 372 & 1.4 & 3.2 & 1,750 & 2,710 & 7.4 & $B=.63$ \\
\hline (C-29-11) 11acc & T. R. RImper & W/ 111 ALVM & 16.0 & 53 & & $5-19-65$ & TP- 43 & 41 & & 34 & 9.7 & 19 & & 118 & 0 & 27 & 23 & .7 & 9.4 & 240 & 329 & 7.6 & \\
\hline$(\mathrm{C}-29-11) 19 \mathrm{cas}_{2}$ & Cook Bros. & Wf 111 ALVM & 16.0 & 75 & & $6-10-70$ & $\mathrm{TP}^{\mathrm{A}}-43$ & 60 & & 45 & 28 & 120 & 4.4 & 215 & 0 & 160 & 110 & .7 & 3.8 & 651 & 949 & 8.0 & $B=.23$ \\
\hline$(C-30-13)$ Bces & J. Guymon & W/ 111 ALVM & 18.0 & 263 & 7 & $6-09-71$ & TP-43 & 43 & & 32 & 11 & 47 & I. 8 & 158 & 0 & 59 & 36 & .6 & 2.3 & 318 & 444 & 7.5 & $B=.08$ \\
\hline$(\mathrm{C}-25-12) 35 \mathrm{ccc}$ & Armotrong & \begin{tabular}{l|l}
$\mathrm{S}$ & $120 \mathrm{TRTA}$
\end{tabular} & 17.5 & & & $9-07-63$ & TP-43 & 56 & .13 & 43 & 9.0 & 100 & 7.2 & 154 & 0 & 51 & 140 & .4 & 3.8 & 496 & 797 & 7.8 & $B=.21$ \\
\hline$(C-26-11) 19 d b b$ & woot & \begin{tabular}{l|l|l|}
$\mathrm{S}$ & $120 \mathrm{TR}$ TR
\end{tabular} & 17.0 & & & $9-07-63$ & TP. 43 & 13 & & 42 & 28 & 120 & 8.7. & 207 & 0 & 50 & 190 & .9 & .5 & 547 & 987 & 8.0 & $8=.25$ \\
\hline$(\mathrm{C}-26-11) 29 \mathrm{eac}$ & Smith & \begin{tabular}{l|l}
$S$ & 120 TRTR
\end{tabular} & 17.5 & & 1 & $9-07-63$ & TP-43 & 30 & .31 & 66 & 23 & 10 & $" 1$ & 219 & 0 & 57 & 150 & 7 & 1.6 & 545 & 907 & 7.8 & $B=.18$ \\
\hline (C-26-12) 10bdb & Three Kilne & $120 \mathrm{TRTR}$ & 17.0 & & .83 & $9-07-63$ & TP- 43 & 41 & & 120 & 50 & 69 & 3.0 & 197 & 0 & 79 & 290 & & 2.3 & 948 & 1,330 & 7.3 & $B=10$ \\
\hline$(C-26-12) 30 \mathrm{~d}=\mathrm{b}$ & South Soop & $120 \mathrm{TRTR}$ & 17.5 & & & $9-09-63$ & TP-43 & 53 & & 110 & 25 & 84 & 1.7 & 364 & 12 & 51 & 150 & 4 & .6 & 671 & 1,100 & 3.4 & $B=.16$ \\
\hline$(C-27-12)$ bCac & Coyoto & $120 \mathrm{TRTR}$ & 18.5 & & & $9-09-63$ & TP-43 & 25 & .223 & 190 & 67 & 87 & 6.2 & 150 & 0 & 460 & 250 & .3 & 1.5 & 1,290 & 1,720 & 7.8 & $B=.17$ \\
\hline
\end{tabular}


Table 7-B. Escalente Valley. Springs and Welle with Water Temper aturee $15.5^{\circ}$ to $19.5^{\circ} \mathrm{C}$

\begin{tabular}{|c|c|c|c|c|c|c|c|c|c|c|c|c|c|c|c|c|c|c|c|c|c|c|c|}
\hline COORDIMATES & $\begin{array}{c}\text { OWNER } \\
\text { ONR } \\
\text { MAME }\end{array}$ & 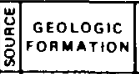 & TEMP. & \begin{tabular}{|l|} 
DEPTH \\
(towe $)$ \\
\end{tabular} & 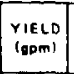 & $\begin{array}{c}\text { OATE of } \\
\text { sAMMPDE }\end{array}$ & arterenex & $\mathrm{siO}_{2}$ & f. & c. & $\frac{\text { NAL }}{M_{0}}$ & $\frac{S 15 \in X}{N .}$ & FESSEE & $\begin{array}{l}\mathrm{EOAS} \\
\mathrm{HCO}\end{array}$ & MILLI & $\begin{array}{l}\text { So. } \\
\text { So. }\end{array}$ & $\frac{P E R T}{\mathrm{Cr}}$ & ER & ${ }_{N},{ }_{10}$ & 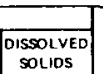 & \begin{tabular}{|l|}
$\begin{array}{c}\text { cono } \\
\text { mmhoi }\end{array}$ \\
\end{tabular} & ${ }^{\prime}$ & $\begin{array}{l}\text { OTHEA ConstiTUENTS } \\
\text { OR REMARKS }\end{array}$ \\
\hline $\begin{array}{l}(C-29-9) \quad 17 b c b \\
(C-29-9) \quad 19 b b b \\
(C-29-13) 2 b d c \\
(C-31-9) 5 b b a \\
(C-31-10) \text { Bbda }\end{array}$ & $\begin{array}{l}\text { Guyo } \\
\text { Oak } \\
\text { Wire Gra.. } \\
\text { Dry wrilow }\end{array}$ & 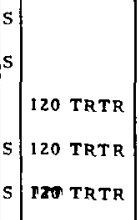 & $\begin{array}{l}17.5 \\
17.0 \\
18.5 \\
19.5 \\
17.5\end{array}$ & & & \begin{tabular}{l|}
$8-23-63$ \\
$8-23-63$ \\
$8-31-63$ \\
$8-22-63$ \\
$8-22-63$
\end{tabular} & $\begin{array}{c}T P-43 \\
T P-43 \\
T P-43 \\
T P=43 \\
T P-43\end{array}$ & $\begin{array}{l}23 \\
21 \\
18 \\
39 \\
50\end{array}$ & $\begin{array}{l}.07 \\
.04 \\
.82 \\
.52 \\
.61\end{array}$ & $\begin{array}{r}100 \\
67 \\
440 \\
7.2 \\
73\end{array}$ & $\begin{array}{l}58 \\
29 \\
110\end{array}$ & $\begin{array}{r}39 \\
18 \\
98 \\
125 \\
35\end{array}$ & $\mid \begin{array}{l}2.0 \\
2.6 \\
7.4 \\
1.1 \\
16\end{array}$ & $\begin{array}{l}388 \\
284 \\
256 \\
256 \\
244\end{array}$ & $\begin{array}{l}0 \\
0 \\
0 \\
0 \\
0\end{array}$ & $\begin{array}{r}200 \\
45 \\
1,200 \\
17 \\
24\end{array}$ & $\begin{array}{l}46 \\
37 \\
260 \\
42 \\
74\end{array}$ & $\begin{array}{l}.2 \\
.3 \\
.5 \\
.3 \\
.5\end{array}$ & $\begin{array}{l}1.8 \\
.7 \\
.8 \\
.7 \\
2.7\end{array}$ & \begin{tabular}{|c|}
673 \\
352 \\
2.480 \\
337 \\
430
\end{tabular} & \begin{tabular}{|r|}
996 \\
592 \\
2.760 \\
514 \\
635 \\
\end{tabular} & $\begin{array}{l}7.9 \\
8.0 \\
7.8 \\
8.0 \\
7.7\end{array}$ & $\begin{array}{l}B=09 \\
B=05 \\
B=.22 \\
B=08 \\
B=.11\end{array}$ \\
\hline
\end{tabular}




\begin{tabular}{|c|c|c|c|c|c|c|c|c|c|c|c|c|c|c|c|c|c|c|c|c|c|c|c|c|}
\hline \multirow[b]{2}{*}{ COOHOINATES } & \multirow{2}{*}{$\begin{array}{l}\text { OWNER } \\
\text { OP } \\
\text { NAME }\end{array}$} & \multirow{2}{*}{\multicolumn{2}{|c|}{ 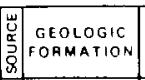 }} & \multirow{2}{*}{$\begin{array}{ll}T \in M P \\
{ }^{\circ} \mathrm{C} \\
\end{array}$} & \multirow{2}{*}{$\begin{array}{l}\text { OEPTH } \\
\text { 1"eet1 }\end{array}$} & \multirow{2}{*}{$\begin{array}{rl}Y & Y E L O \\
\text { Y } & \\
\end{array}$} & \multirow{2}{*}{$\begin{array}{l}\text { DAIE OF } \\
\text { SAMPLE }\end{array}$} & \multirow[b]{2}{*}{ REFERENCE. } & \multicolumn{13}{|c|}{ ANALYSSIS EXPAESSEO AS MILLIGAAMS PER LIIEA } & \multirow{2}{*}{$\begin{array}{l}\text { COND } \\
\text { mathor }\end{array}$} & \multirow[b]{2}{*}{$\mathrm{PH}$} & \multirow{2}{*}{$\begin{array}{l}\text { OTHER CONSTITUENTS } \\
\text { OA AEMAAKS }\end{array}$} \\
\hline & & & & & & & & & $\mathrm{SiO}_{2}$ & $\mathrm{Fe}$ & c. & $M_{0}$ & N. & k & $\mathrm{HCO}_{3}$ & $\mathrm{CO}_{3}$ & so. & $\mathrm{cl}$ & $\mathrm{F}$ & No, & $\begin{array}{c}\text { Dissolved } \\
\text { solios }\end{array}$ & & & \\
\hline $\begin{array}{l}(C-10-14) \quad 33 \\
(C-11-14) \\
(-14)\end{array}$ & $\begin{array}{l}\text { Wilson Hot } \\
\text { Spritras }\end{array}$ & $s$ & Fault & 60.5 & & 38 & $7-12-67$ & $W_{R B}-13$ & 33 & & 741 & 224 & 7.090 & 18 & 178 & & 1,560 & 11,900 & 4.0 & 0 & 21, во0 & 31,200 & 7.4 & 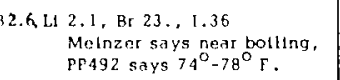 \\
\hline$(C-11-14) \quad 3 d$ & Big Sprs & $s$ & Fault & & & 17.5 & & $\begin{array}{l}\text { WRE }-13 \\
\text { WSP }-277\end{array}$ & & & & & & & & & & & & & & & & PP492 says $85^{\circ} \mathrm{F}$. \\
\hline $\begin{array}{r}(c-11-14) 23 \\
26\end{array}$ & rish Sprs & $s$ & rautt & 28 & & 24 & $7-12-67$ & WRB-13 & 20 & & 136 & 26 & 470 & 36 & 312 & & 340 & 630 & 2.0 & 0 & 1,820 & 3.050 & 7.7 & $\begin{array}{l}\text { 3.79. Li. } 33, \text { Br } 1.3,1.02 \\
\text { Other orfices range } 65^{\circ}-72^{\circ} \\
\text { comparable quallty. }\end{array}$ \\
\hline
\end{tabular}

TABLE 9. Grouse Creek Valley. Springs and wells with water temperatures of $16^{\circ} 1042^{\circ} \mathrm{C}$

\begin{tabular}{|c|c|c|c|c|c|c|c|c|c|c|c|c|c|c|c|c|c|c|c|c|c|c|c|c|}
\hline \multirow{2}{*}{ COORDINATES } & \multirow{2}{*}{$\begin{array}{l}\text { OWNEA } \\
\text { OA } \\
\text { NAME }\end{array}$} & \multirow{2}{*}{ 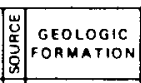 } & \multirow{2}{*}{$\begin{array}{l}\text { TEMP. } \\
{ }^{\circ} \mathrm{C}\end{array}$} & \multirow{2}{*}{$\begin{array}{l}\text { DEPTH } \\
\text { DENO+1 }\end{array}$} & \multirow{2}{*}{$\begin{array}{l}Y \quad Y \in L D \\
\text { igpm) } \\
\end{array}$} & \multirow{2}{*}{$\begin{array}{c}\text { DATE OF } \\
\text { SAMPLE } \\
\end{array}$} & \multirow[b]{2}{*}{ REFEREACE } & \multicolumn{13}{|c|}{ ANALYSIS EXPRESSED AS MILLIG RAMS PER LITER } & \multirow[b]{2}{*}{$\begin{array}{l}\text { CONo. } \\
\text { mmhos }\end{array}$} & \multirow[b]{2}{*}{$\mathrm{pH}$} & \multirow{2}{*}{\multicolumn{2}{|c|}{$\begin{array}{l}\text { OTHER CONSTITUENTS } \\
\text { OR AEMARKS }\end{array}$}} \\
\hline & & & & & & & & $\mathrm{SiO}_{2}$ & F. & $c_{1}$ & $M_{0}$ & No & $k$ & $\mathrm{HCO}_{3}$ & $\mathrm{CO}_{3}$ & $\mathrm{so}_{4}$ & $\mathrm{cl}_{1}$ & $\mathrm{~F}$ & No, $_{3}$ & $\begin{array}{l}\text { DISSOLVEED } \\
\text { SOLIDS }\end{array}$ & & & & \\
\hline$(\mathrm{B}-10-18) 16 \mathrm{dac}$ & J. B. \& D. KItt & $w$ & 18 & 60 & & $9-01-56$ & $\mathrm{TP}-29$ & & & & & & & & & & & & & & & & & \\
\hline $2100 \mathrm{~b}$ & Merlin Tannar & Wf 111 ALVM & 20 & 62 & $350 \mathrm{M}$ & $9-05-56$ & $\mathrm{TP}-29$ & & & & & & & & & & & & & & & & & \\
\hline 30bad $s$ & $\begin{array}{l}\text { Kimber (Rose) } \\
\text { Spring }\end{array}$ & \begin{tabular}{|l|l|}
$\mathrm{S}$ & $120 \mathrm{TRTR}$ \\
\end{tabular} & 20 & & 215M- & $4-11-68$ & TP-29 & 47 & & so & 8.3 & 25 & 5.7 & 154 & 0 & 18 & 50 & .4 & 2.5 & 304 & 441 & 7.6 & 8.02 & \\
\hline $33 \mathrm{sba}$ & B. C. Kimber & $w$ & 20 & 92 & $1,130 \mathrm{M}$ & $9-20-56$ & $T P-29$ & & & & & & & & & & & & & & & & & \\
\hline$(B-11-1 \theta) \quad 2 \operatorname{cod} 2$ & H. Paskett & Wf 120 TRTR & 16 & 605 & 25R & $4-12-68$ & TP-29 & 55 & & 37 & 5.8 & 36 & & 192 & 0 & 22 & 10 & & .4 & 263 & 367 & 7.7 & & Perf 280-310. \\
\hline $33 \mathrm{bdc}$ & R. D. 'Worburton & $W \mid 120$ TRTR & 16 & 232 & $\begin{array}{l}220- \\
705 \mathrm{M}\end{array}$ & $5-17-68$ & $T P-29$ & 64 & & 128 & 37 & 61 & 17 & 321 & 0 & 152 & 141 & & .3 & 844 & 1,170 & 7.5 & & Perf $60-225$ \\
\hline$(B-11-19)$ 11dad $s$ & M. Warburton & \begin{tabular}{|l|l|}
$S$ & 300 PLZC
\end{tabular} & 42 & & $225 \mathrm{R}$ & $5-16-68$ & $T P-29$ & 24 & & 44 & 14 & 13 & & 184 & 0 & 29 & 9.1 & & .2 & 248 & 373 & 7.5 & & \\
\hline
\end{tabular}

\begin{tabular}{|c|c|c|c|c|c|c|c|c|c|c|c|c|c|c|c|c|c|c|c|c|c|c|c|c|}
\hline \multirow{2}{*}{ COOROINATES } & \multirow{2}{*}{$\begin{array}{c}\text { OWNER } \\
\text { OR } \\
\text { NAME } \\
\end{array}$} & \multirow{2}{*}{ 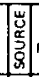 } & \multirow{2}{*}{\begin{tabular}{|l|} 
GEOLOGIC \\
FOAMATION
\end{tabular}} & \multirow{2}{*}{ TEMP } & \multirow{2}{*}{$\begin{array}{l}\text { DEPTH } \\
(1 \oplus 0,1)\end{array}$} & \multirow{2}{*}{$\begin{array}{l}\text { YIELO } \\
\text { Ysom) }\end{array}$} & \multirow{2}{*}{$\begin{array}{l}\text { DATE OF } \\
\text { SAMPLE }\end{array}$} & \multirow[b]{2}{*}{ REFEREACE } & \multicolumn{13}{|c|}{ ANALYSIS EXPRESSED AS MILLIGAAMS PER LITER } & \multirow{2}{*}{$\begin{array}{l}\text { COND. } \\
\text { mmhor }\end{array}$} & \multirow[b]{2}{*}{ pH } & \multirow{2}{*}{$\begin{array}{l}\text { OTHER CONSTITUENTS } \\
\text { OR REMAGKS }\end{array}$} \\
\hline & & & & & & & & & $\mathrm{SiO}_{2}$ & $\mathrm{Fe}$ & $\mathrm{ca}$ & $m_{0}$ & N. & ${ }^{k}$ & $\mathrm{HCO}_{3}$ & $\mathrm{CO}_{3}$ & so. & 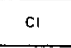 & $F$ & No, & \begin{tabular}{|c|} 
DissolvED \\
SOLIOS
\end{tabular} & & & \\
\hline (D-01-04) з3ааa $S$ & & $\mathrm{~s}$ & 120 TRTR & 21 & & sos & $6-\quad-68$ & $\mathrm{TP}-27$ & & & & & & & & & & & & & & & & \\
\hline$(\mathrm{D}-03-04) 26 \mathrm{ccas}$ & Eugene Payne & $\mathrm{s}$ & & 39 & & SOE & $9-28-66$ & TP -27 & 23 & & 331 & 68 & 114 & 25 & 674 & 0 & 661 & 108 & 2.2 & .1 & 1,730 & 2,200 & $7.3=$ & B. 67 \\
\hline 27 baa $S$ & & $s$ & & 45 & & $3 \mathrm{M}$ & $9-13-67$ & TP-27 & 27 & & 345 & 83 & 148 & 16 & 644 & 0 & 742 & 132 & 2.5 & .4 & 1,910 & 2.410 & $7.5 \mathrm{E}$ & B. 64 \\
\hline 27 bad $S$ & & $s$ & & $\begin{array}{l}39 \\
40\end{array}$ & & $150 \mathrm{E}$ & $\begin{array}{l}9-28-66 \\
5-16-67\end{array}$ & $\begin{array}{l}\text { TP-27 } \\
\text { TP-27 }\end{array}$ & $\begin{array}{l}28 \\
28\end{array}$ & & $\begin{array}{l}389 \\
361\end{array}$ & $\begin{array}{l}73 \\
88\end{array}$ & $\begin{array}{l}151 \\
152\end{array}$ & $\begin{array}{l}31 \\
32\end{array}$ & $\begin{array}{l}728 \\
696\end{array}$ & $\begin{array}{l}0 \\
0\end{array}$ & $\begin{array}{l}820 \\
853\end{array}$ & $\begin{array}{l}138 \\
140\end{array}$ & $\begin{array}{l}2.5 \\
3.1\end{array}$ & .1 & $\begin{array}{l}2,040 \\
2,060\end{array}$ & $\begin{array}{l}2,560 \\
2,490\end{array}$ & $\begin{array}{r}7.3 \\
7.8\end{array}$ & $\beta .79$ \\
\hline $27 \mathrm{cbd} S 1$ & & $\mathrm{~s}$ & & $\begin{array}{l}29 \\
29 \\
30\end{array}$ & & & $\begin{array}{l}9-28-66 \\
5-16-67 \\
5-23-67\end{array}$ & $\begin{array}{l}\text { TP-27 } \\
\text { TP-27 } \\
\text { TP-27 }\end{array}$ & $\begin{array}{l}21 \\
22\end{array}$ & & $\begin{array}{l}353 \\
228\end{array}$ & $\begin{array}{l}72 \\
95\end{array}$ & $\begin{array}{l}125 \\
130\end{array}$ & $\begin{array}{l}28 \\
28\end{array}$ & $\begin{array}{l}716 \\
476\end{array}$ & $\begin{array}{l}0 \\
0\end{array}$ & $\begin{array}{l}702 \\
719\end{array}$ & $\begin{array}{l}115 \\
115\end{array}$ & $\begin{array}{l}2.1 \\
2.3\end{array}$ & .1 & $\begin{array}{l}1.840 \\
1,650\end{array}$ & $\begin{array}{l}2,330 \\
2,280 \\
2,280\end{array}$ & $\mid \begin{array}{l}7.4 \\
7.8\end{array}$ & $\begin{array}{l}3.70 \\
3.71\end{array}$ \\
\hline $27 \mathrm{cbd} s 2$ & & $s$ & & $\begin{array}{l}29 \\
32\end{array}$ & & & $\begin{array}{l}9-28-66 \\
5-15-67\end{array}$ & $\begin{array}{l}\mathrm{TP}-27 \\
\mathrm{TP}-27\end{array}$ & $\begin{array}{l}19 \\
17\end{array}$ & & $\begin{array}{l}329 \\
279\end{array}$ & $\begin{array}{l}70 \\
74\end{array}$ & $\begin{array}{l}111 \\
114\end{array}$ & $\begin{array}{l}25 \\
26\end{array}$ & $\begin{array}{l}686 \\
572\end{array}$ & $\begin{array}{l}0 \\
0\end{array}$ & $\begin{array}{l}643 \\
611\end{array}$ & $\begin{array}{l}103 \\
105\end{array}$ & $\begin{array}{l}2.2 \\
2.4\end{array}$ & .10 & $\begin{array}{l}1,710 \\
1.630\end{array}$ & $\begin{array}{l}2,180 \\
2,220\end{array}$ & \begin{tabular}{|l|}
7.7 \\
7.9
\end{tabular} & $\begin{array}{l}3.64 \\
8.64\end{array}$ \\
\hline $27 \mathrm{cbd} 83$ & & $s$ & & 28 & & $1 E$ & $5-16-67$ & $\mathrm{TP}-27$ & 21 & & 329 & 88 & 163 & 33 & 584 & 0 & 805 & 150 & 2.7 & .0 & 1.980 & 2,610 & 7.7 & 3.80 \\
\hline$|(D-03-05) \quad 6 b a b \quad 2|$ & Howard Jensen & $|\mathrm{w}|$ & 111 ALVM & 16 & 53 & & $8-15-67$ & TP-27 & 14 & & 42 & 9.7 & 4.4 & 1.5 & 128 & 0 & 44 & 5.2 & .3 & .1 & 187 & 303 & $7: 1$ & B.03 \\
\hline$(\mathrm{D}-04-05) 14 a a c$ & Robert Clyde & $w$ & 111 ALVM & 16 & 104 & $20 \mathrm{R}$ & $8-17-67$ & TP-27 & 43 & & 89 & 26 & 31 & 3.7 & 376 & 0 & 38 & 35 & .5 & 4.0 & 446 & 705 & 7.9 & $B .05$ \\
\hline
\end{tabular}




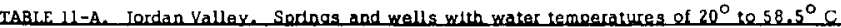

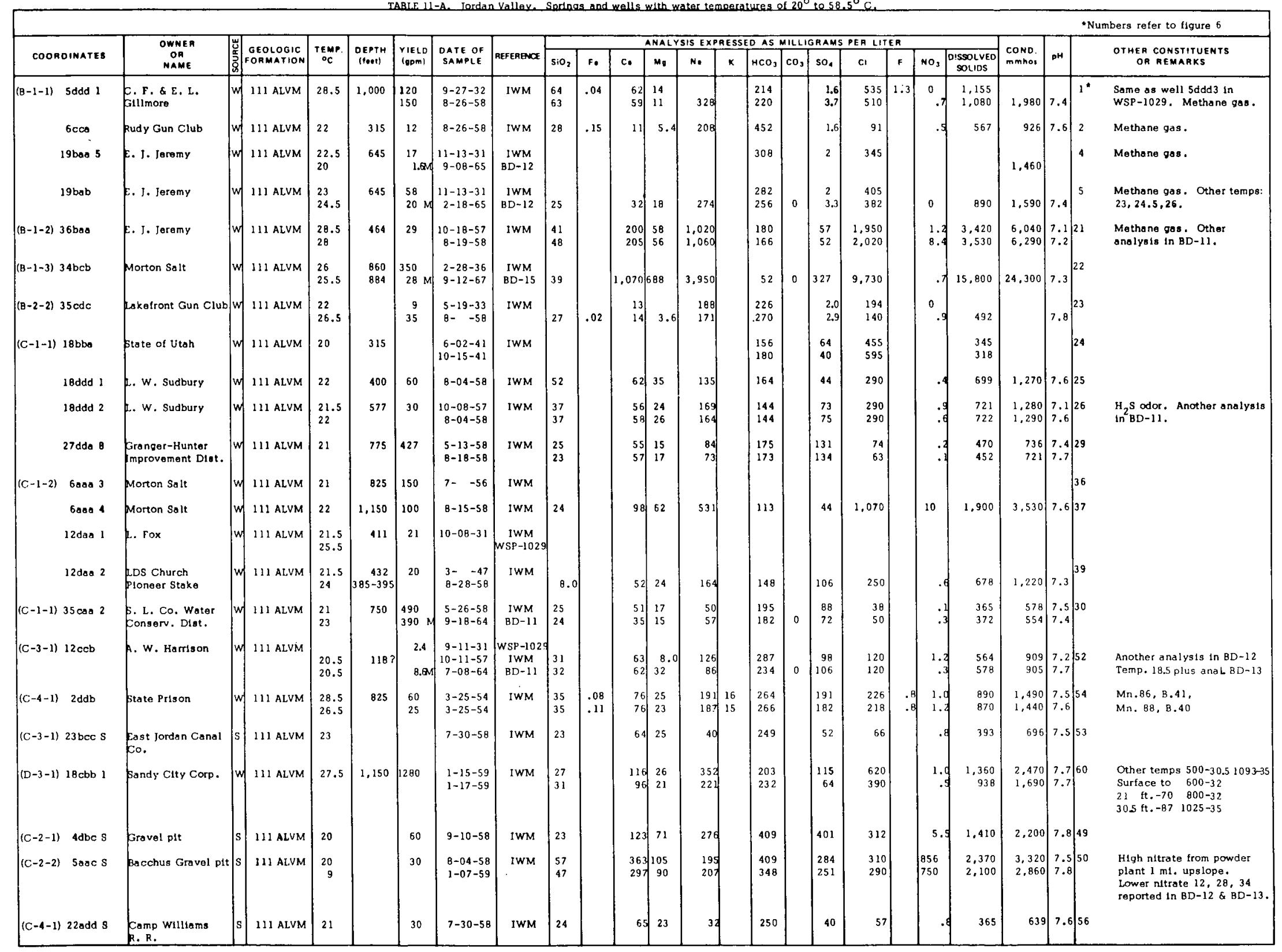


TABLELCL-A. Lordan Valley Springs and wells with water temoeratures of $20^{\circ} 1058.5^{\circ} \mathrm{C}$

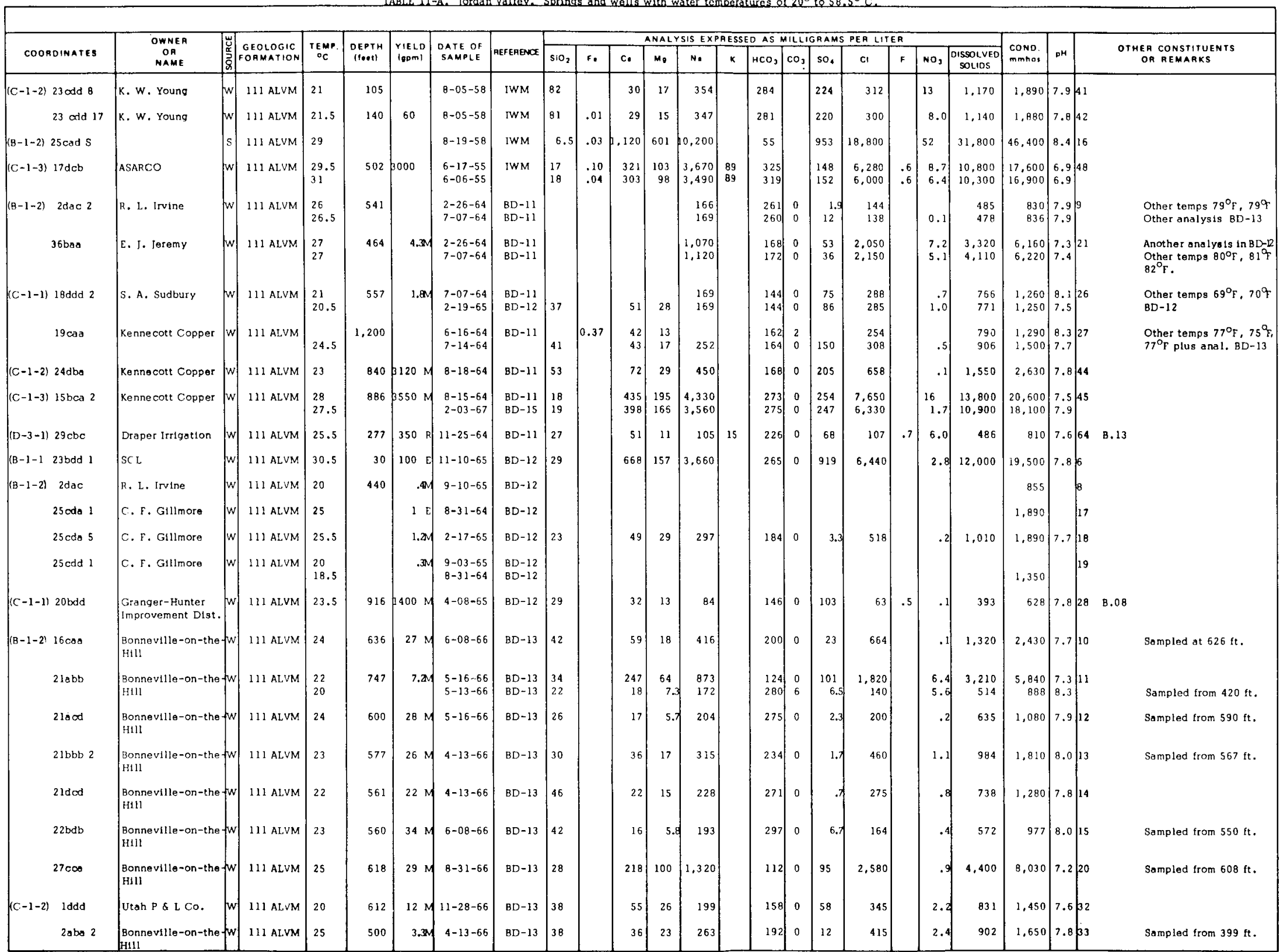


TABLE 11-A. Jordan Valley. Springs and wells with water temperatures of $20^{\circ}$ to $58.5^{\circ} \mathrm{C}$.

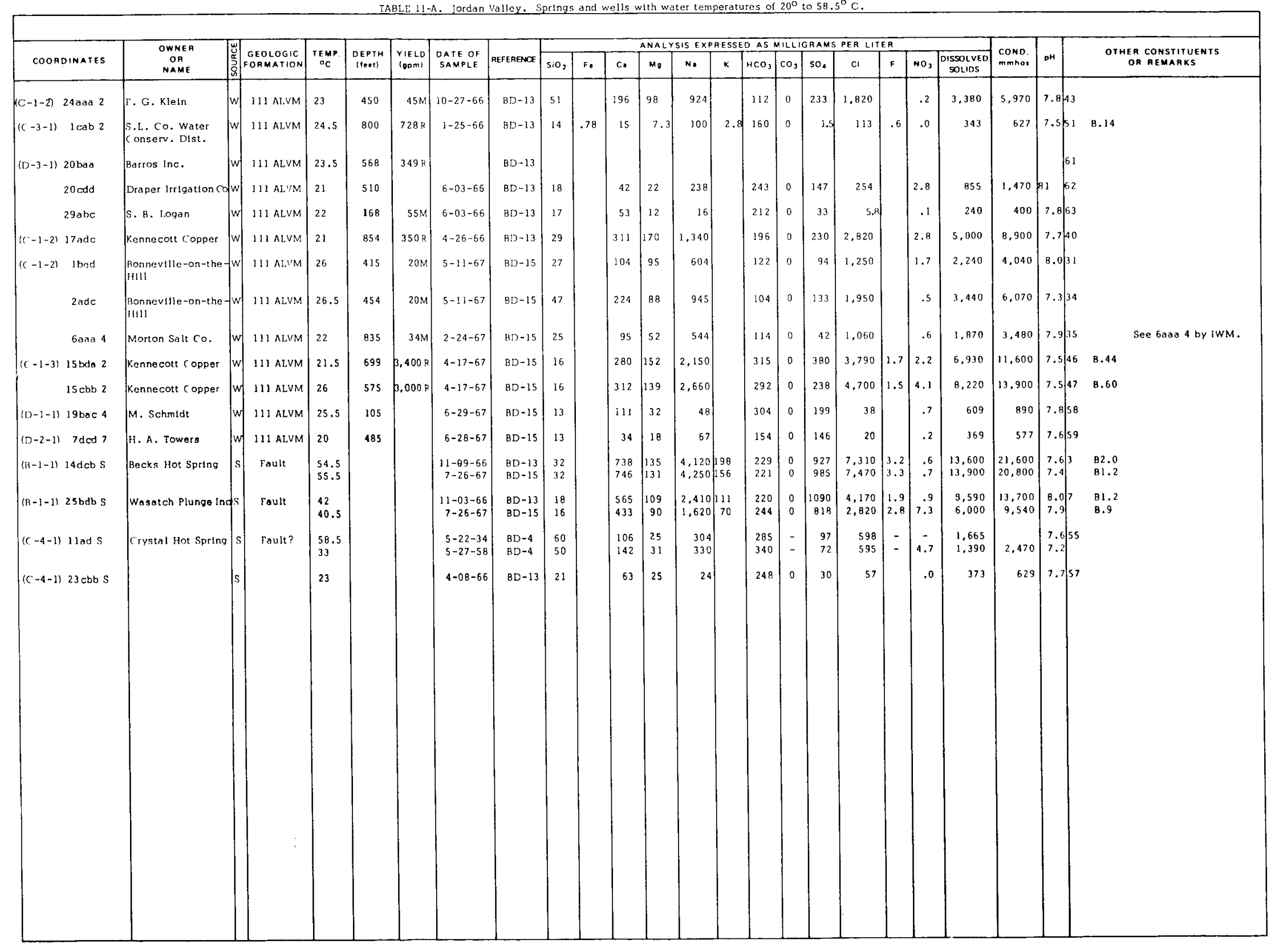


TABLE U-B. Lerdan Vallex. Sorings and wells with watar temperatures of $15.5^{\circ}$ te $12.5^{\circ} \mathrm{C}$.

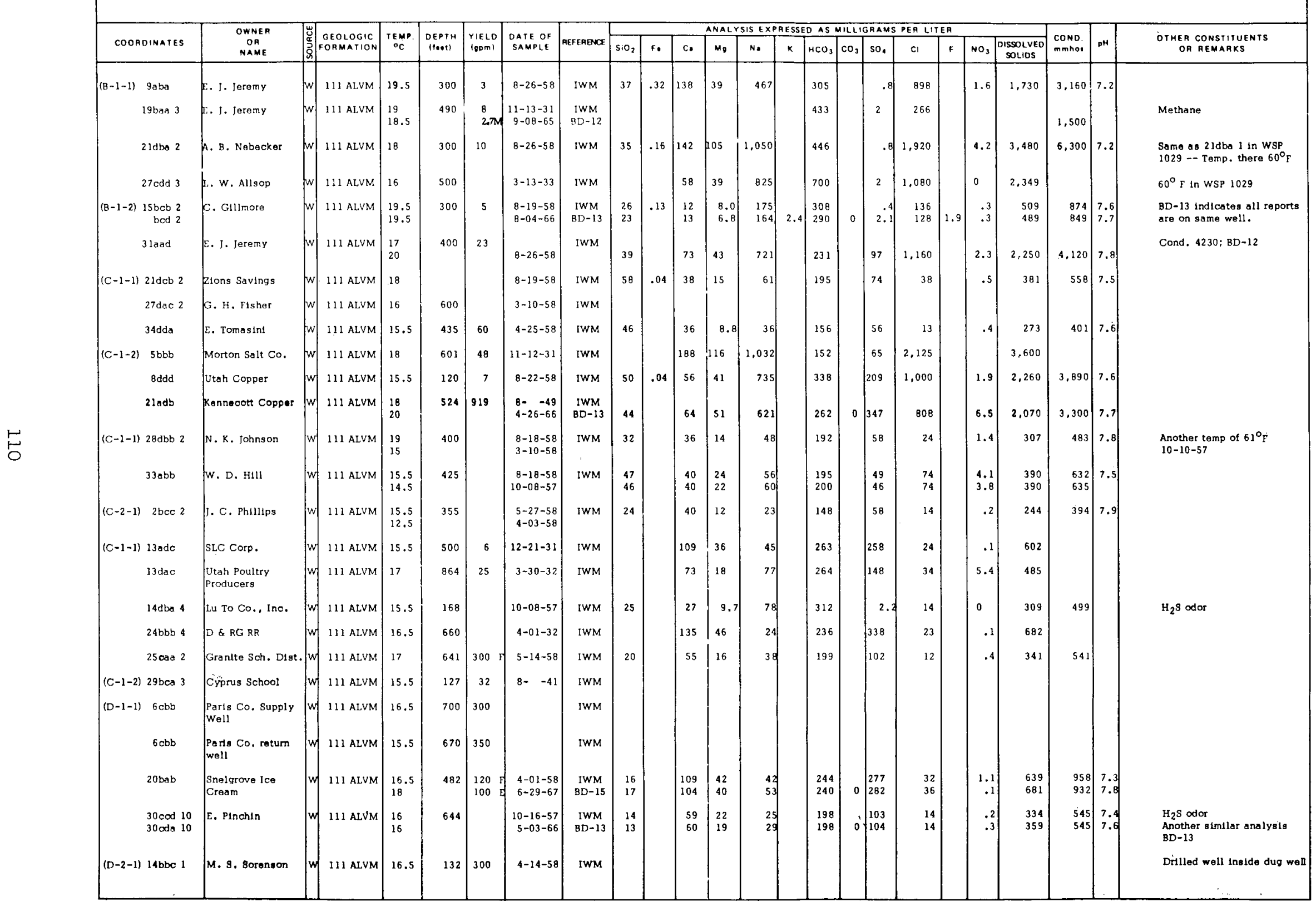


TABLE 11-B. Jordan Valley, Springs and wells with water temperatures of $15.5^{\circ}$ to $19.5^{\circ} \mathrm{C}$.

\begin{tabular}{|c|c|c|c|c|c|c|c|c|c|c|c|c|c|c|c|c|c|c|c|c|c|c|c|c|c|}
\hline \multicolumn{2}{|c|}{ COORDINATES } & \multicolumn{2}{|l|}{$\begin{array}{l}\text { OWNER } \\
\text { OR } \\
\text { NAME }\end{array}$} & 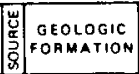 & 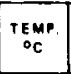 & \begin{tabular}{|l} 
DEPTH \\
(1+owt)
\end{tabular} & \begin{tabular}{|l|} 
YIELO \\
(gom)
\end{tabular} & $\begin{array}{l}\text { DATE OF } \\
\text { SAMPLE }\end{array}$ & REF FRENOE & $\mathrm{SiO}_{2}$ & $\mathrm{Fe}$ & c. & ANAL & $\begin{array}{l}\text { YSIS EXP } \\
\text { No }\end{array}$ & $\frac{1}{k E S:}$ & $\mathrm{HCO}_{3}$ & $\mathrm{cos}_{3}$ & SO. & PEA UT & $F$ & No, & \begin{tabular}{|c|}
$\begin{array}{c}\text { olissolvED } \\
\text { solids }\end{array}$ \\
\end{tabular} & \begin{tabular}{|l|} 
Cono \\
mmhoo: \\
\end{tabular} & $\mathrm{pH}$ & $\begin{array}{l}\text { OTHER CONSTITUENTS } \\
\text { OR REMAAKS }\end{array}$ \\
\hline$(D-2-1)$ & $6 d b b 10$ & $\begin{array}{l}\text { Bi. Co. Water } \\
\text { Eonserv. Dist. }\end{array}$ & $w$ & 111 ALVM & 17 & 855 & $250 \mathrm{~m}$ & $9-18-64$ & 8D-11 & 22 & & 44 & 16 & 32 & & 156 & 0 & 90 & 17 & & .1 & 315 & 469 & 7.7 & \\
\hline & $32 \mathrm{cbb} 2$ & $\begin{array}{l}\text { SL Co. Water } \\
\text { Conserv. Dist. }\end{array}$ & $w$ & 111 ALVM & 18 & 1,007 & $900 \mathrm{M}$ & $9-18-64$ & $B D-11$ & 11 & & 21 & 9.2 & 14 & & 100 & 0 & 20 & 11 & & 1.7 & 152 & 236 & 7.6 & \\
\hline$(B-1-1)$ & $16 \mathrm{ccc}$ & c. F. Gillmore & $w$ & 111 ALVM & 15.5 & 240 & $1.2 \mathrm{~m}$ & & $B D-12$ & 50 & & 28 & 22 & 601 & & 584 & 0 & 6.8 & 695 & & .6 & 1,680 & 3,100 & $7.7 \mid$ & \\
\hline & 19baa 2 & C. F. Gillmore & $w$ & 111 ALVM & 16 & & . 40 & $9-08-65$ & $B D-12$ & & & & & & & & & & & & & & 1.060 & & \\
\hline & 19 baa 3 & c. F. Gillmore & $w$ & $111 \mathrm{ALVM}$ & & 490 & 2.7M & $9-08-65$ & $B D-12$ & & & & & & & & & & & & & & 1,500 & & \\
\hline & $20 \mathrm{bab}$ & S.L.C. & $w$ & 111 ALVM & 15.5 & 274 & $.5 \mathrm{M}$ & $2-18-65$ & $B D-12$ & 20 & & 5.6 & $\begin{array}{l}6 \quad 3.9 \\
\end{array}$ & 309 & & 545 & 0 & 96 & 108 & & 3.2 & 822 & 1,300 & 7.8 & Other temps $60^{\circ} \mathrm{F}, 60^{\circ} \mathrm{F}$ \\
\hline & 23 bdd 2 & S.L.C. & m & 111 ALVM & 18 & 30 & $75 \mathrm{E}$ & & $B D-12$ & 26 & & 587 & 127 & 2,570 & & 313 & 0 & L150 & 4,340 & & 1.7 & 8,960 & 14,800 & 7.9 & \\
\hline$(8-1-2)$ & $7 e c c$ & F. T. Gll Imore & w & 11 ALVM & \begin{tabular}{|l|}
16.5 \\
16.5
\end{tabular} & 389 & $2.5 \mathrm{M}$ & \begin{tabular}{|c|}
$9-02-65$ \\
$7-26-65$
\end{tabular} & $\begin{array}{l}B D-12 \\
B D-12\end{array}$ & 20 & & 84 & 72 & 1,530 & & 215 & 0 & 312 & 2,360 & & .2 & 4,480 & $\begin{array}{l}7,980 \\
8,060\end{array}$ & 7.3 & $\begin{array}{l}\text { Othar tamp, and analysis in } \\
\text { BD- } 13 \text {. }\end{array}$ \\
\hline & $7 \mathrm{dcb}$ & Е. г. Glllmore & w & 111 ALVM & 16.5 & 735 & 4.1M & $9-02-65$ & BD-12 & 20 & & 108 & 100 & 995 & & 201 & 0 & 108 & 1,820 & & .3 & 3,250 & 6.000 & $7.7 \mid$ & \\
\hline & $11 \mathrm{dca} 4$ & Harrison Duck Club & $w$ & iII ALVM & $\begin{array}{l}19 \\
19\end{array}$ & 607 & $3 \mathrm{~m}$ & $\begin{array}{l}2-17-65 \\
9-17-65\end{array}$ & $\begin{array}{l}\mathrm{BD}-12 \\
\mathrm{BD}-12\end{array}$ & 23 & & 11 & 11 & 210 & & 408 & 0 & 1.0 & 138 & & .7 & 612 & $\begin{array}{l}1.020 \\
1.040\end{array}$ & 7.7 & \\
\hline & $13 \mathrm{cca}$ & Harrison Duck Club & 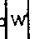 & $111 \mathrm{ALVM}$ & 19 & & $9.1 \mathrm{~m}$ & $9-07-65$ & $\mathrm{BD}-12$ & & & & & & & & & & & & & & 1.240 & & \\
\hline & 15 dao & C. F. Gillmore & (w) & 111 ALVM & 16 & & $1.0 \mathrm{am}$ & $9-10-65$ & $B D-12$ & & & & & & & & & & & & & & 973 & & \\
\hline & $19 \mathrm{aca}$ & a. J. Jeremy & $\omega$ & $111 \mathrm{ALVM}$ & $\begin{array}{l}17 \\
18\end{array}$ & 450 & $11.5 \mathrm{NM}$ & 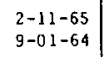 & $\begin{array}{l}B D-12 \\
B D-12\end{array}$ & 21 & & 13 & 5.8 & 471 & & 408 & 20 & 107 & 425 & & .3 & 1,260 & $\begin{array}{l}2,200 \\
2,190\end{array}$ & $8.7 \mid$ & $\begin{array}{l}\text { Other temp and analysis } \\
\text { BD-13. }\end{array}$ \\
\hline & $22 \mathrm{cdb}$ & $\begin{array}{l}\text { C. F. \& E. L. } \\
\text { Gillmoro }\end{array}$ & w & 111 ALVM & $\begin{array}{l}15.5 \\
17\end{array}$ & & $2 \varepsilon$ & $\left|\begin{array}{l}9-03-65 \\
2-02-66\end{array}\right|$ & $\begin{array}{l}8 D-12 \\
B D-13\end{array}$ & 22 & & 14 & 11 & 224 & & 291 & 0 & & 232 & & .9 & 666 & $\begin{array}{l}1,600 \\
1,200\end{array}$ & 7.8 & \\
\hline & $23 \mathrm{bbd}$ & $\begin{array}{l}\text { E. F. \& E. L. } \\
\text { Gillmore }\end{array}$ & w. & $\| 11$ ALVM & $\begin{array}{l}16 \\
15.5\end{array}$ & & $1.5 \mathrm{~m}$ & $\mid \begin{array}{l}9-09-65 \\
2-10-65\end{array}$ & $\begin{array}{l}8 D-12 \\
B D-12\end{array}$ & 22 & & 14 & 11 & 339 & & 388 & 0 & 3.3 & 350 & & 1.4 & 952 & $\begin{array}{l}1,600 \\
1,200\end{array}$ & 7.8 & $\begin{array}{l}\text { BD- } 13 \text { temp } 61^{\circ} \mathrm{F} \text { plus chem } \\
\text { Other temp \& analysis } \\
\text { BD- } 13 \text {. }\end{array}$ \\
\hline & $29 \mathrm{dan} 1$ & $\begin{array}{l}\text { Bonneville-on-tha- } \\
\text { Hill }\end{array}$ & $w$ & $11 \mathrm{ALVM}$ & 19.5 & 420 & $4 \mathrm{E}$ & $9-03-65$ & $B D-12$ & & & & & & & & & & & & & & 1,710 & & \\
\hline & 29daa 2 & $\begin{array}{l}\text { Bonneville-on-the- } \\
\text { H1111 }\end{array}$ & $w$ & 111 ALVM & 19 & 456 & $2.2 \mathrm{M}$ & $9-03-65$ & $\mathrm{BD}-12$ & & & & & & & & & & & & & & 2,190 & & \\
\hline & $30 a b c$ & E. J. Jeremy & w & 111 ALVM & \begin{tabular}{|l|}
18 \\
18.5
\end{tabular} & 450 & $73 \mathrm{M}$ & $\left|\begin{array}{r}2-11-65 \\
9-01-64\end{array}\right|$ & $\begin{array}{l}B D-12 \\
B D-12\end{array}$ & 34 & & 38 & 29 & 626 & & 236 & 0 & 108 & 900 & & .4 & 1,850 & $\begin{array}{l}3,270 \\
3,260\end{array}$ & 7.8 & \\
\hline$(B-1-3)$ & $24 \mathrm{bdd}$ & Morton Salt & w. & 111 ALVM & $\begin{array}{l}19.5 \\
20\end{array}$ & 502 & $27 \mathrm{M}$ & $\mid \begin{array}{l}9-03-65 \\
2-02-66\end{array}$ & $\begin{array}{l}B D-12 \\
B D-13\end{array}$ & 28 & & 174 & 116 & 1,320 & & 162 & 0 & 206 & 2.440 & & .9 & 4,340 & 7,570 & $\theta .1$ & $\begin{array}{l}\text { Other temp. and analysis } \\
B D-13 \text {. }\end{array}$ \\
\hline$(C-1-1)$ & $24 \mathrm{bbd} 2$ & So. S.L.C. & w & 111 ALVM & 16 & 772 & $420 \mathrm{M}$ & $6-08-65$ & $\mathrm{BD}-12$ & 19 & & 82 & 25 & 51 & & 243 & 0 & 177 & 22 & & .5 & 496 & 758 & 7.8 & \\
\hline$(C-1-2)$ & $1 \mathrm{ccc}$ & f. c. Buster & $w$ & 111 ALVM & 15.5 & 170 & $1.1 \mathrm{M}$ & $9-16-65$ & $B D-12$ & & & & & & & & & & & & & & & & \\
\hline & $24 a c d$ & f. c. Bustar & $w$ & 111 ALVM & 17 & & $3.2 \mathrm{~m}$ & $7-14-64$ & $B D-12$ & & & & & & & & & & & & & & 1,630 & & \\
\hline & $24 \mathrm{bdc}$ & . c. Bueter & $w$ & 111 ALVM & $\begin{array}{l}18 \\
18\end{array}$ & 280 & $.2 \times$ & $\mid \begin{array}{r}7-16-64 \\
9-09-65\end{array}$ & $B D-12$ & & & & & & & & & & & & & & $\begin{array}{l}2,360 \\
2,380\end{array}$ & & \\
\hline & 24dad & kenneoott Copper & $|w|$ & $11 \mathrm{ALVM}$ & 17 & 204 & $9.7 \mathrm{M}$ & $9-09-65$ & $B D-12$ & & & & & & & & & & & & & & 1,970 & & \\
\hline & $32 \mathrm{aab}$ & E. G. Whittaker & $w$ & 111 ALVM & 16 & 52 & & $3-07-65$ & $B D-12$ & 36 & & 63 & 115 & 238 & & 458 & 0 & 388 & 258 & & 4.1 & 1,330 & 2,090 & 7.9 & \\
\hline
\end{tabular}




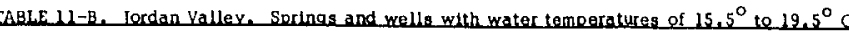

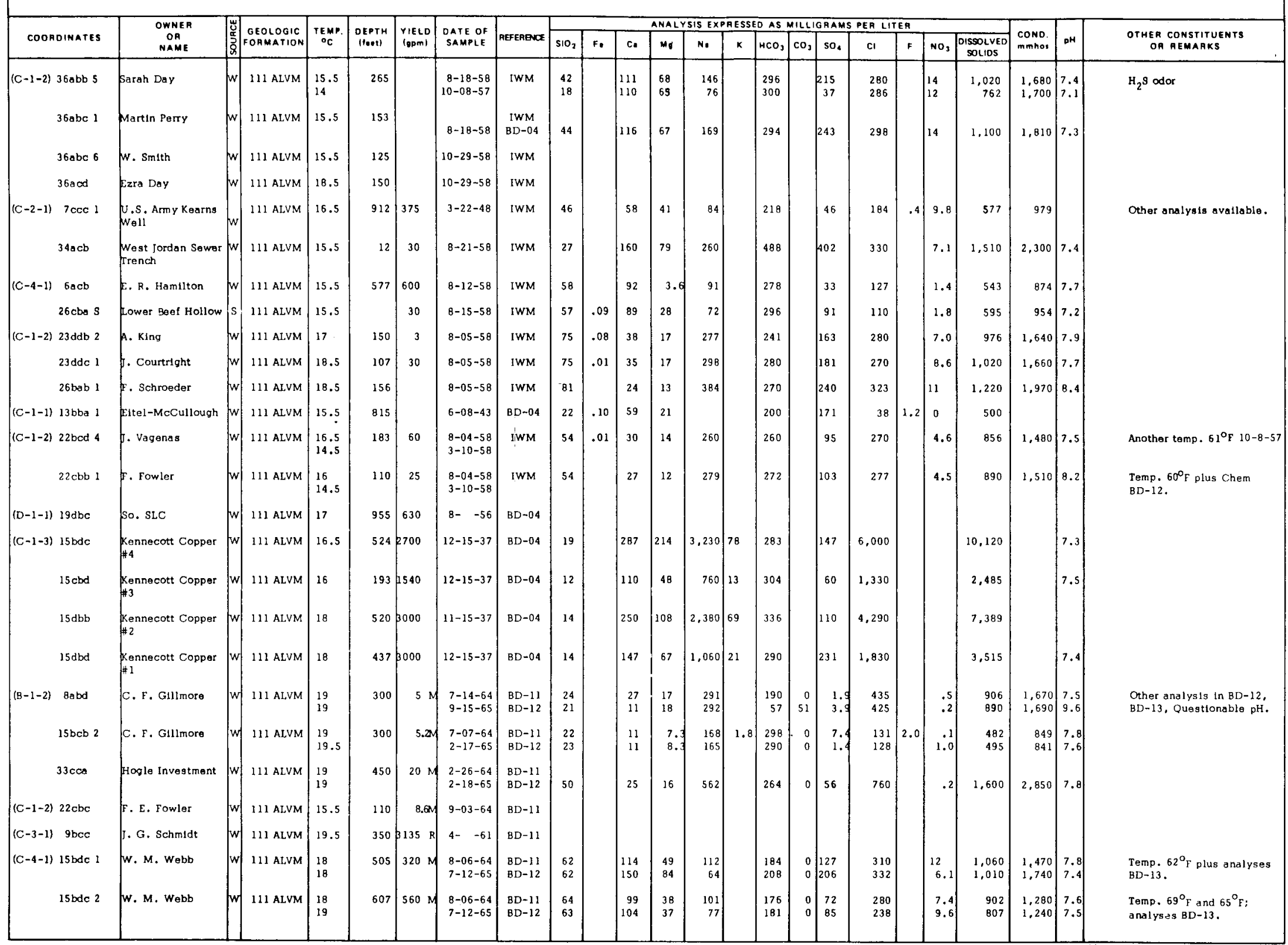




\begin{tabular}{|c|c|c|c|c|c|c|c|c|c|c|c|c|c|c|c|c|c|c|c|c|c|c|c|c|}
\hline \multirow{2}{*}{ COORDINATES } & \multirow{2}{*}{$\begin{array}{l}\text { OWNER } \\
\text { OR } \\
\text { NAME } \\
\end{array}$} & \multirow{2}{*}{\multicolumn{2}{|c|}{ 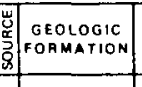 }} & \multirow{2}{*}{\begin{tabular}{|l|} 
TEMP. \\
${ }_{0}$ \\
\end{tabular}} & \multirow{2}{*}{$\begin{array}{l}\text { DEPTH } \\
(1 \mathrm{WeC})\end{array}$} & \multirow{2}{*}{$\mid \begin{array}{l}\text { YIELO } \\
\text { Lgom) }\end{array}$} & \multirow{2}{*}{$\begin{array}{c}\text { DATE OF } \\
\text { SAMPLE } \\
\end{array}$} & \multirow[b]{2}{*}{ REFEAGNCE } & \multicolumn{13}{|c|}{ ANALYSIS EXPRESSED AS MILLIGAMS PER LITER } & \multirow{2}{*}{\begin{tabular}{|c|} 
COND \\
mmnOO \\
\end{tabular}} & \multirow[b]{2}{*}{$\mathrm{OH}$} & \multirow{2}{*}{$\begin{array}{l}\text { OTHER CONSTITUENTS } \\
\text { OF GEMAAKS }\end{array}$} \\
\hline & & & & & & & & & $\mathrm{SiO}_{2}$ & $\mathrm{Fe}$ & c. & $M_{0}$ & N. & $x$ & $\mathrm{HCO}_{3}$ & $\mathrm{CO}_{3}$ & $\mathrm{so}_{4}$ & c & $\mathrm{F}$ & $\mathrm{NO}_{3}{ }^{\circ}$ & $\begin{array}{l}\text { DissoLVED } \\
\text { Solios } \\
\end{array}$ & & & \\
\hline$(C-2-1) 24 b c d$ & $\begin{array}{l}\text { S.L. Co. Wattr } \\
\text { Consarv. Dist. }\end{array}$ & $w$ & 111 ALVM & 18 & 1,000 & 8858 & $8-05-65$ & $B D-12$ & 11 & & 28 & 11 & 61 & & 95 & 0 & 69 & 68 & & 1.5 & 296 & 531 & 7.0 & \\
\hline$(C-4-1) 23 d b b$ & $\begin{array}{l}\text { 5. L. Valley Sand } \\
\text { \& Gravel }\end{array}$ & $w 1$ & 111 ALVM & 15.5 & 262 & $3310 \mathrm{M}$ & $11-08-65$ & $B D-12$ & 27 & & 80 & 41 & 93 & & 290 & 0 & 165 & 115 & & 1.5 & 666 & 1,090 & 7.8 & \\
\hline$(D-1-1) \quad$ ldbd 4 & G. E. Penman & $w 1$ & 111 ALVM & 15.5 & 129 & & 9-10-65 & $8 \mathrm{D}-12$ & 11 & & 86 & 17 & 24 & & 311 & 0 & 44 & 25 & & .3 & 381 & 611 & $7.7 \mid$ & \\
\hline $30 \mathrm{acc} 7$ & South S.L.C. & $w \mid 1$ & 111 ALVM & $\begin{array}{l}16.5 \\
16\end{array}$ & 955 & $510 \mathrm{M}$ & $\mid \begin{array}{r}6-08-65 \\
2-26-64\end{array}$ & $\begin{array}{l}\mathrm{BD}-12 \\
\mathrm{BD}-12\end{array}$ & 15 & & 72 & 23 & 48 & & 222 & 0 & 158 & 23 & & .3 & 454 & $\begin{array}{l}702 \\
646\end{array}$ & 7.8 & \\
\hline$(C-1-2) 21 a b c 2$ & Kennecott & $w:$ & 11I ALVM & 16.5 & 404 & $190 \mathrm{R}$ & $7-14-68$ & $\mathrm{BD}-17$ & & & & & & & & & & & & & & & & \\
\hline$(C-4-1) \quad 14 d$ od & Mut. Jordan Corp. & $w \mid 1$ & $111 \mathrm{ALVM}$ & $\begin{array}{l}16 \\
16\end{array}$ & 845 & $600 \mathrm{R}$ & $\mid$\begin{tabular}{r|}
$4-02-65$ \\
$5-20-68$
\end{tabular} & $\begin{array}{l}B D-17 \\
B D-17\end{array}$ & 25 & & 67 & 38 & 123 & & 234 & 0 & 156 & 127 & & 5.9 & $6 \mathbf{s} 5$ & 1,040 & 7.8 & \\
\hline$(\mathrm{D}-3-1) \quad 7 a b b$ & Sandy City & \begin{tabular}{|l|l}
$w$ & 1
\end{tabular} & 111 ALVM & 17 & 590 & $350 \mathrm{R}$ & $11-15-68$ & $\mathrm{BD}-17$ & & & & & & & & & & & & & & & & \\
\hline$(B-1-2) \quad 7 d b b \quad 1$ & c. F. Glllmore & $w=1$ & 111 ALVM & $\begin{array}{l}16.5 \\
16.5\end{array}$ & 735 & 4.3m & $\mid$\begin{tabular}{r|}
$2-03-66$ \\
$9-01-66$
\end{tabular} & $\begin{array}{l}\mathrm{BD}-13 \\
\mathrm{BD}-13\end{array}$ & 24 & & 92 & 108 & 1.060 & & 190 & 0 & 210 & 1,850 & & .5 & 3,410 & $\begin{array}{l}6.100 \\
6,000\end{array}$ & 8.2 & Sample from $480 \mathrm{ft}$. \\
\hline $27 a c b$ & $\begin{array}{l}\text { Bonneville-on-the- } \\
\text { Mill }\end{array}$ & $w 1$ & 111 ALYM & 17 & & .and & $2-02-66$ & $B D-13$ & 23 & & 77 & .5 & 314 & & 234 & 0 & 20 & 470 & & .0 & 1,020 & 1,850 & 8.0 & \\
\hline$(\mathrm{C}-2-1) \quad 9 \mathrm{ccc}$ & $\begin{array}{l}\text { 5. L. Co. Water } \\
\text { Conserv. Dlat. }\end{array}$ & $w \mid 1$ & 111 ALVM & 18 & 795 & & $3-14-66$ & BD-13 & 24 & & 78 & 23 & 145 & & 234 & 0 & 130 & 340 & & 3.3 & 962 & 1,620 & 7.6 & \\
\hline $26 \mathrm{add}$ & ASARCO & \begin{tabular}{|l|l}
$w$ & 1 \\
&
\end{tabular} & $111 \mathrm{ALVM}$ & 15.5 & & $76 \mathrm{M}$ & $10-20-66$ & $B D-13$ & 11 & & 20 & 9.2 & 28 & & 112 & 0 & 22 & 24 & & .5 & 160 & 291 & 7.5 & \\
\hline$(C-3-1) 330 \mathrm{bd}$ & s. Stefonoff & w 1 & 111 ALVM & 18 & 357 & $620 \mathrm{M}$ & $9-09-66$ & $B D-13$ & 30 & & 152 & 103 & 190 & & 342 & 0 & 385 & 375 & & 8.5 & 1,410 & 2,270 & 7.7 & \\
\hline$(D-1-1) 20 d d d$ & S.L.C. & $w$ & 111 ALVM & \begin{tabular}{|l|}
15.5 \\
15.5
\end{tabular} & .500 & & $\begin{array}{r}7-21-65 \\
7-02-68\end{array} \mid$ & $\begin{array}{l}\mathrm{BD}-13 \\
\mathrm{BD}-17\end{array}$ & $\begin{array}{l}15 \\
17\end{array}$ & & $\begin{array}{l}122 \\
120\end{array}$ & $\begin{array}{l}40 \\
39\end{array}$ & 31 & 2.9 & $\begin{array}{l}254 \\
258\end{array}$ & $\begin{array}{l}0 \\
0\end{array}$ & $\begin{array}{l}289 \\
243\end{array}$ & $\begin{array}{l}27 \\
34\end{array}$ & $\begin{array}{l}.5 \\
.4\end{array}$ & $\begin{array}{l}5.0 \\
6.1\end{array}$ & $\begin{array}{l}691 \\
541\end{array}$ & $\begin{array}{r}936 \\
911\end{array}$ & $\begin{array}{l}7.7 \\
8.0\end{array}$ & \\
\hline 29dbo & Interstote Brick Co & $w \mid 1$ & 111 ALVM & 17 & 480 & & & $B D-13$ & & & & & & & & & & & & & & & & \\
\hline$(D-4-1) \quad 6$ bdd & A. G. HIII & $w \mid 1$ & 111 AIVM & 17 & 28 & & $10-03-36$ & $B D-13$ & 18 & & 64 & 43 & 104 & & 210 & 0 & 176 & 138 & & 13 & 659 & 1.080 & 7.3 & \\
\hline$(C-1-2) 2$ laac 5 & Kennecott Copper & $w \mid 1$ & $111 \mathrm{ALVM}$ & 18.5 & 420 & $400 \mathrm{R}:$ & $\begin{array}{r}12-15-50 \\
4-26-66\end{array}$ & $\begin{array}{l}B D-11 \\
B D-13\end{array}$ & 48 & & 136 & 68 & 822 & & 246 & 0 & 215 & 1,400 & & 9.1 & 2,820 & 4,970 & 7.7 & Ownershlp from BD-11 \\
\hline$(c-2-1) \quad 9 d c c$ & Namba \& Sons & $w 1$ & 111 ALVM & 15.5 & 376 & & $9-08-66$ & $\begin{array}{l}B D-11 \\
B D-13\end{array}$ & 43 & & 116 & 116 & 288 & & 428 & 0 & 422 & 412 & & 35 & 1,630 & 2,420 & 7.7 & \\
\hline$(C-4-1) 11 c a b S$ & & s 1 & 111 ALVM & 15.5 & & & $8-08-66$ & $B D-13$ & 34 & & 102 & 68 & 227 & & 382 & 0 & 333 & 260 & & 2.0 & 1,210 & 1.930 & 7.9 & \\
\hline$(C-1-1) \quad 2 b a c 2$ & $\begin{array}{l}\text { General Brewing } \\
\text { Corp. }\end{array}$ & w. 1 & 111 ALVM & 17 & 870 & $1012 \mathrm{R}$ & $8-24-59$ & $\mathrm{BD}-15$ & & & & & & & & & & & & & & & & \\
\hline Saad 4 & $\begin{array}{l}\text { Utah Wool Pulling } \\
\text { Co. }\end{array}$ & w. & $111 \mathrm{ALVM}$ & 18 & 660 & $61 \mathrm{M}$ & $2-24-67$ & $\mathrm{BD}-15$ & 22 & & 30 & 17 & 144 & & 242 & 0 & 99 & 111 & & .3 & 527 & 888 & 7.7 & \\
\hline $25 \mathrm{bdb} 1$ & South S.L.C. & w & 111 ALVM & \begin{tabular}{|l|}
18 \\
11.5 \\
\end{tabular} & 1,000 & $158 \mathrm{M}$ & $\begin{array}{l}7-25-67 \\
6-20-67\end{array}$ & $\begin{array}{l}\text { BD-15 } \\
\text { BD-15 }\end{array}$ & $\begin{array}{l}19 \\
18\end{array}$ & & $\begin{array}{l}61 \\
46\end{array}$ & $\begin{array}{l}22 \\
19\end{array}$ & $\begin{array}{l}44 \\
37\end{array}$ & & $\begin{array}{l}211 \\
305\end{array}$ & $\begin{array}{l}0 \\
0\end{array}$ & $\begin{array}{r}133 \\
10\end{array}$ & $\begin{array}{l}18 \\
11\end{array}$ & .4 & .1 & $\begin{array}{l}399 \\
285\end{array}$ & $\begin{array}{l}611 \\
497\end{array}$ & $\begin{array}{l}8.0 \\
7.6\end{array}$ & \\
\hline 27 bdd 3 & G. C. Bulls \& Sons & $\mathrm{w}$ & 111 ALVM & 19.5 & 716 & $235 \mathrm{M}$ & $2-21-67$ & BD-15 & & & & & & & & & & & & & & & & \\
\hline $\begin{array}{ll}(\mathrm{C}-2-1) & \text { labc } 1 \\
& \text { 3odd } 4\end{array}$ & $\begin{array}{l}\text { B. T. Helm } \\
\text { Taylorsville- } \\
\text { Bennion Imp. Diat. }\end{array}$ & $w$ & $\begin{array}{l}111 \text { AlVM } \\
111 \text { ALVM }\end{array}$ & 16 & $\begin{array}{l}256 \\
641\end{array}$ & 1530 月 & $\mid \begin{array}{l}6-28-67 \\
2-04-67\end{array}$ & $\begin{array}{l}B D-15 \\
B D-15\end{array}$ & 14 & & 38 & 34 & $\begin{array}{r}19 \\
116\end{array}$ & & $\begin{array}{l}162 \\
128\end{array}$ & 0 & $\begin{array}{r}44 \\
130\end{array}$ & 12 & & 2.5 & 222 & 357 & 7.9 & \\
\hline
\end{tabular}


TABLE $11-8$, Jordan Valloy. Springs ond wolls with watar tomporaturns of $15.5^{\circ}$ to $19.5^{\circ} \mathrm{C}$

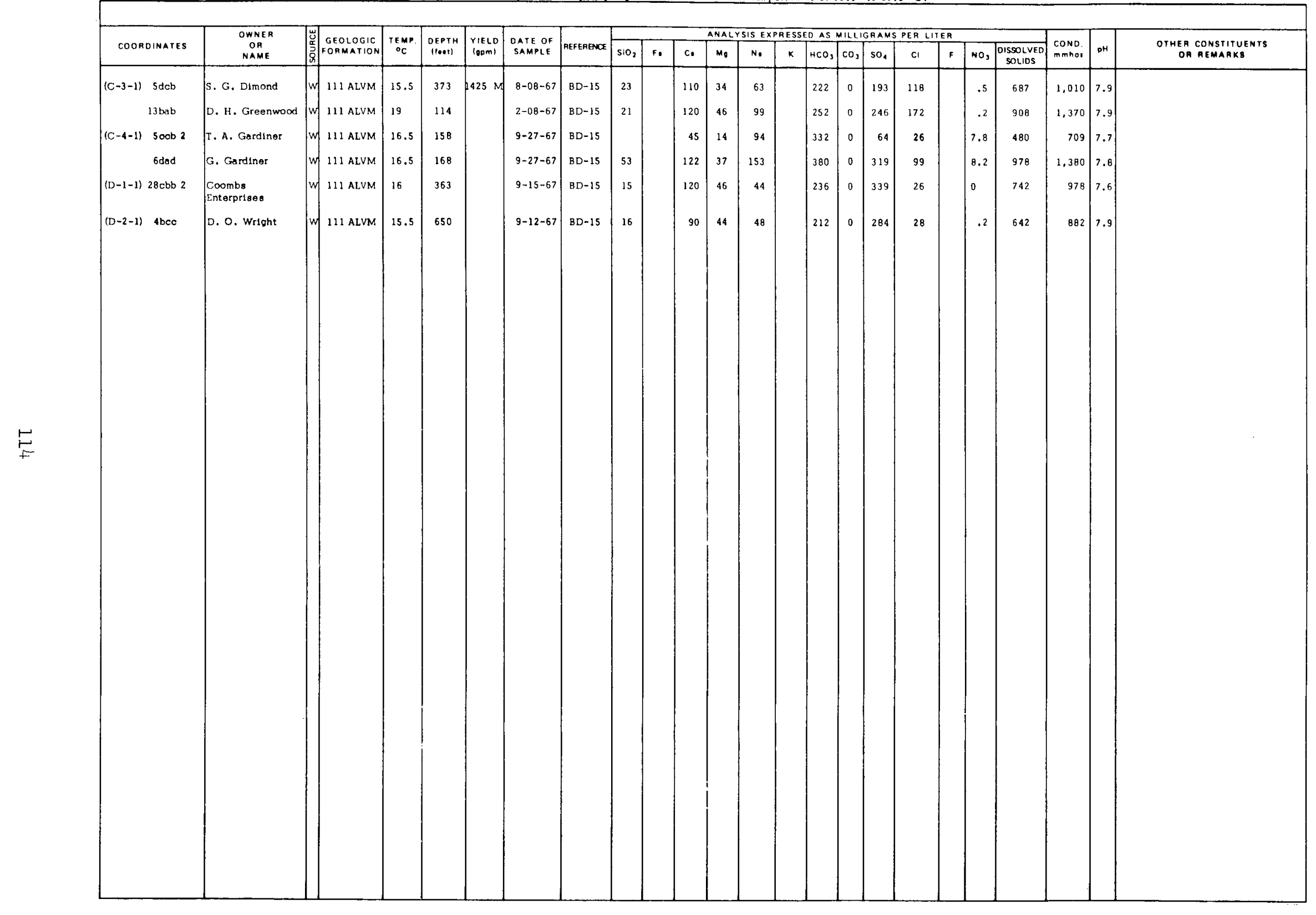


Table 12-A. Pavant Valley - Black Rock Desert. Springs and Wellis With Water Temperatures of $20^{\circ}$ to $67^{\circ} \mathrm{C}$.

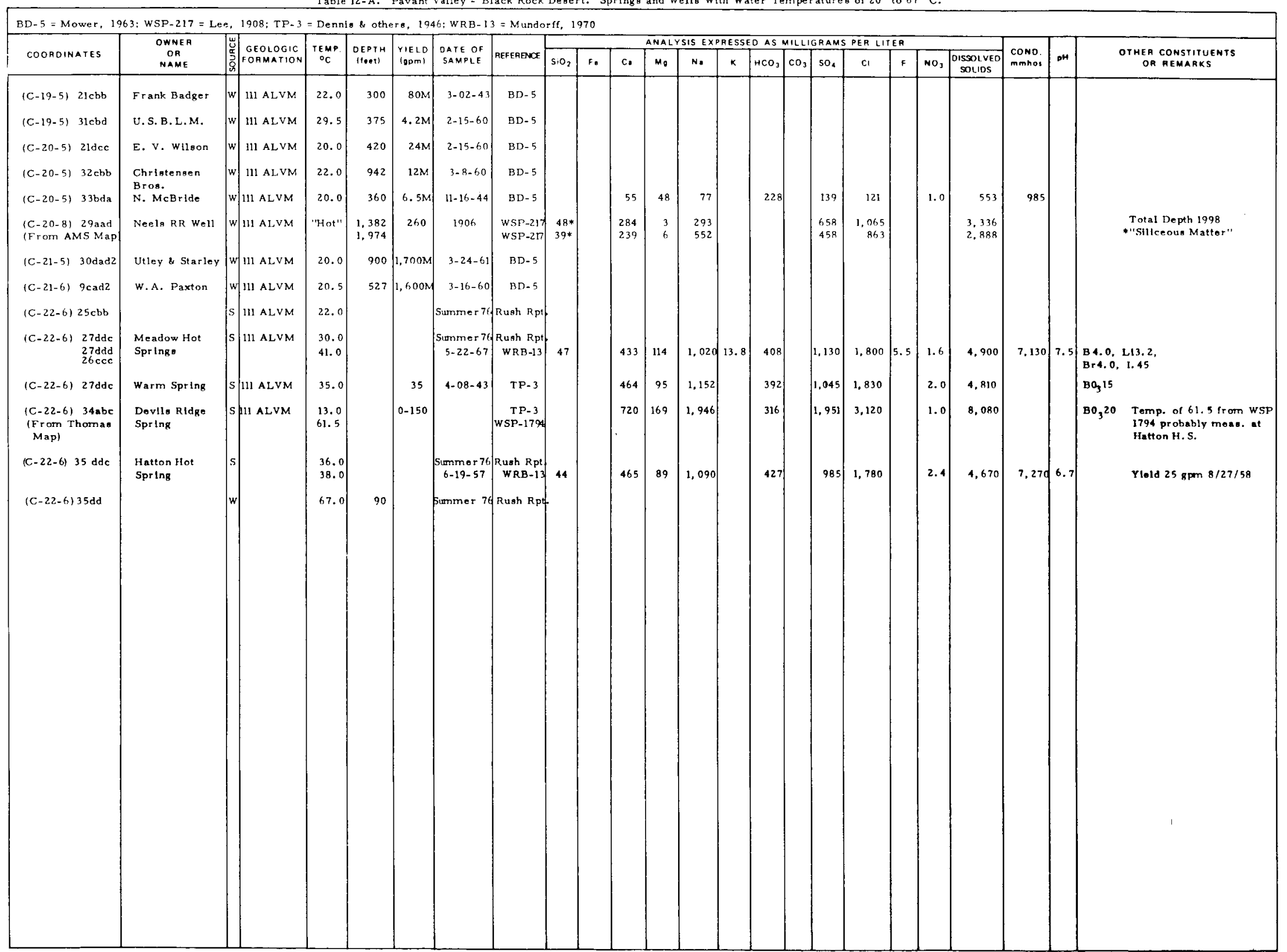


Tablo 12-B. Pavant Valloy. Black Rock Degort. Springe and Wells with Water Temperatures of $15.5^{\circ}$ to $19.5^{\circ} \mathrm{C}$.

\begin{tabular}{|c|c|c|c|c|c|c|c|c|c|c|c|c|c|c|c|c|c|c|c|c|c|c|c|c|}
\hline COOADINATES & $\begin{array}{l}\text { OWNER } \\
\text { OR }\end{array}$ & $\mid$ & GEOLOGIC & TEMP. & DEPTH & YIELD & DATE OF & | REFEAENCF ] & & & & NALL & is Ex: & AESSE & 0 & MILLIG & GAMS & EA LIT & & & & COND. & $\mathrm{DH}$ & OTHER CONSTITUENTS \\
\hline Coomoinges & & & FOAMATION & ${ }^{\circ} \mathrm{C}$ & (mes) & $100 \mathrm{ml}$ & SAMPLE & 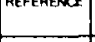 & $\mathrm{SiO}_{2}$ & F. & c. & $m_{0}$ & Ne & $\kappa$ & HCO, & $\mathrm{cos}$ & so. & $c_{1}$ & $\mathbf{F}$ & $\mathrm{NO}_{3}$ & $\begin{array}{c}\text { Dissolver } \\
\text { solios }\end{array}$ & mmhor & pH & ON REMAAKS \\
\hline$(C-18-5) \quad 27 b a b$ & R. T. Knight & $w$ & $111 \mathrm{ALVM}$ & 17.0 & 397 & $1,250 \mathrm{M}$ & $2-04-60$ & $\mathrm{BD}-5$ & & & & & & & & & & & & & & & & \\
\hline$(C-18-5) 27 \mathrm{cba}$ & C. Nleleon & $w$ & $111 \mathrm{ALVM}$ & 16.0 & 495 & $1,150 \mathrm{M}$ & $2-04-60$ & BD- 5 & & & & & & & & & & & & & & & & \\
\hline (C-18-5) 28dde & D. Andersen & $w$ & 111 ALVM & 17.8 & 550 & $2,350 \mathrm{M}$ & $6-07-61$ & $\mathrm{BD}-5$ & & & & & & & & & & & & & & & & \\
\hline (C-18-5) $34 \mathrm{adb}$ & H. Hurat & $\mathrm{w}$ & $111 \mathrm{ALVM}$ & 15.5 & 354 & $650 \mathrm{M}$ & $2-04-60$ & $B D-5$ & & & & & & & & & & & & & & & & \\
\hline$(C-18-5) \quad 34$ bata & L. C. Calliator & $\mathrm{w}$ & $111 \mathrm{ALVM}$ & 16.5 & 667 & $1,750 \mathrm{M}$ & $6-02-61$ & $B D-5$ & 24 & .00 & 136 & 22 & 47 & 1.5 & 358 & & 76 & 116 & & 6. 5. & 605 & 1.010 & 7.7 & $B=.11$ \\
\hline (C-18-5) 34bbs & MeCornlk we:l & $\mathrm{w}$ & $111 \mathrm{ALVM}$ & 16.0 & 502 & $1,300 \mathrm{~m}$ & $2-04-60$ & $\mathrm{BD}-5$ & & & & & & & & & & & & & & & & \\
\hline$(\mathrm{C}-18-5) \quad 34 \mathrm{bca}$ & McCornik Woll & $\mathrm{w}$ & 111 ALVM & 16.0 & 400 & $1,000 \mathrm{M}$ & $2-04-60$ & BD- 5 & & & & & & & & & & & & & & & & \\
\hline$(C-19-5) \quad 28 \mathbf{a a n}$ & H. F. Stovens & $\mathrm{w}$ & 111 ALVM & 18.5 & 200 & 15E & $2-18-60$ & $B D-5$ & & & & & & & & & & & & & & & & \\
\hline$(C-19-5) \quad 28 b d a$ & c. C. Nixon & $|w|$ & $111 \mathrm{ALVM}$ & 19.0 & 220 & $17 \mathrm{M}$ & $2-18-60$ & $B D-5$ & & & & & & & & & & & & & & & & \\
\hline$(C-20-5)$ lbeb & O. T. Hunter & $w \mid$ & 111 ALVM & 16.5 & 430 & $160 \mathrm{M}$ & $2-16-60$ & $\mathrm{BD}-5$ & & & & & & & & & & & & & & & & \\
\hline$(\mathrm{C}-20-5) \mathrm{bbcb}_{2}$ & O. T. Hunter & $\mathrm{w}$ & $111 \mathrm{ALVM}$ & 16.0 & 500 & $150 \mathrm{M}$ & $2-16-60$ & BD- 5 & & & & & & & & & & & & & & & & \\
\hline$(C-20-5)$ 2ddd & G. v. Kennedy & $\mathrm{w}$ & 111 ALVM & 15.5 & 197 & $7 \mathrm{M}$ & $2-18-60$ & $\mathrm{BD}-5$ & & & & & & & & & & & & & & & & \\
\hline$(\mathrm{C}-20-5) 9 \mathrm{daa}$ & w. E. Turner & $|w|$ & $111 \mathrm{ALVM}$ & 16.0 & 330 & $225 \mathrm{M}$ & & $B D-5$ & & & & & & & & & & & & & & & & \\
\hline$(\mathrm{C}-20-5) \quad 10 \mathrm{abb}$ & A. Stevens & $\mathrm{w}$ & 111 ALVM & 16.0 & 35 & $2.7 \mathrm{M}$ & $3-10-60$ & BD. 5 & & & & & & & & & & & & & & & & \\
\hline$(C-18-5) \quad 27 \mathrm{dba}$ & A. Stophenson & $w$ & 111 ALVM & 16.5 & 520 & $1,450 \mathrm{M}$ & $2-04-60$ & BD- 5 & & & & & & & & & & & & & & & & \\
\hline$(C-20-5) \quad 10 d b d$ & s. Wood & $\mathrm{w}$ & $111 \mathrm{ALVM}$ & 16.0 & 196 & $1 . \mathrm{M}$ & $3-04-60$ & BD- 5 & & & & & & & & & & & & & & & & \\
\hline$(C-20-5) \quad 11 \mathbf{a a z}$ & L. D. Andersors & $w$ & $111 \mathrm{ALVM}$ & 16.0 & 198 & $8 M$ & $2-18-60$ & BD- 5 & & & & & & & & & & & & & & & & \\
\hline$(\mathrm{C}-20-5)$ 11aad & L. D. Anderson & $\mathrm{w}$ & $111 \mathrm{ALVM}$ & $16: 0$ & 213 & $18 \mathrm{M}$ & $2-18-60$ & BD- 5 & & & & & & & & & & & & & & & & \\
\hline$(C-20-5)$ Mlbas & c. Wado & $\mathrm{w}$ & $111 \mathrm{ALVM}$ & 16.5 & 595 & . $550 \mathrm{M}$ & $3-04-60$ & BD- 5 & & & & & & & & & & & & & & & & \\
\hline$(C-20-5) \quad 12 b b_{2}$ & C. Johnson & $|\mathrm{w}|$ & 111 ALVM & 16.5 & 203 & $1 \mathrm{E}$ & $8-30-60$ & BD- 5 & & & & & & & & & & & & & & & & \\
\hline$(\mathrm{C}-20-5) \quad 16 \mathrm{dad}$ & B. Stephonaon & $|\mathrm{w}|$ & $111 \mathrm{ALVM}$ & 18.0 & & $22 \mathrm{M}$ & $3-04-60$ & BD- 5 & & & & & & & & & & & & & & & & \\
\hline$(C-20-5) 21 \mathrm{dbd}$ & R. Fuller & $|w|$ & $111 \mathrm{ALVM}$ & 19.5 & 330 & $23 \mathrm{M}$ & $3-04-60$ & $B D-5$ & & & & & & & & & & & & & & & & \\
\hline$(\mathrm{C}-20-5) \quad 22 \mathrm{bcc}$ & J. C. Rowley & $|w|$ & $111 \mathrm{ALVM}$ & 18.5 & 400 & $6 \mathrm{M}$ & $\mid 0-23-57$ & $B D-5$ & 27 & & 111 & 82 & 85 & & 251 & & 430 & 102 & & 3.1 & 963 & 1,460 & 7.1 & \\
\hline$(\mathrm{C}-20-5) \quad 22 \mathrm{cbb}$ & D. D. Hogan & $|w|$ & $111 \mathrm{ALVM}$ & 18.5 & 352 & $4.5 \mathrm{M}$ & $3-04-60$ & BD- 5 & & & & & & & & & & & & & & & & \\
\hline$(C-20-5) 27 b a c$ & Pavant Dev. Co. & $|w|$ & 111 ALVM & 16.5 & 480 & $1,600 \mathrm{M}$ & $3-19-62$ & BD- 5 & & & & & & & & & & & & & & & & \\
\hline$(C-20-5) \quad 27 b c b$ & Rowley & $\mathrm{w}$ & $111 \mathrm{ALVM}$ & 19.5 & 601 & $52 \mathrm{M}$ & $|11-04-43|$ & BD- 5 & & & 178 & 130 & 79 & & 248 & & 687 & 162 & .4 & 2.6 & 7,360 & 1,850 & & $B=.09$ \\
\hline$(\mathrm{C}-20-5) \quad 27 \mathrm{bda}$ & Pavant Dev. Co. & $w$ & $111 \mathrm{ALVM}$ & 15.5 & 475 & $1,200 \mathrm{M}$ & $3-19-62$ & $B D-5$ & & & & & & & & & & & & & & & & \\
\hline$(C-20-5) \quad 27 \mathrm{cbb}$ & H. S. Armstrong & $w$ & $111 \mathrm{ALVM}$ & 17.0 & 286 & $2.3 \mathrm{M}$ & $11-16-44$ & $B D-5$ & & & 45 & 42 & 22 & & 230 & & 70 & 50 & & .4 & 343 & 633 & & \\
\hline$(\mathrm{C}-20-5) 28 \mathrm{acb}$ & E. v. wilson & $w$ & $111 \mathrm{ALVM}$ & 17.0 & 380 & $4.1 \mathrm{M}$ & $2-15-60$ & $B D-5$ & & & & & & & & & & & & & & & & \\
\hline$(C-20-5) 28 \mathrm{cdd}$ & A. Graff & w & $111 \mathrm{ALVM}$ & 18.0 & 354 & $11 \mathrm{M}$ & $2-12-60$ & BD- 5 & & & & & & & & & & & & & & & & \\
\hline (C-20-5) 29abd & E. v. whlson & w & 111 ALVM & 16.0 & 500 & $1.4 \mathrm{M}$ & $|3-10-61|$ & BD- 5 & & & & & & & & & & & & & & & & \\
\hline (C-20.5) 3ldcd & Chrlstensen & $\mathbf{m}$ & $111 \mathrm{ALVM}$ & 18.0 & 508 & $.7 \mathrm{M}$ & $11-16-44$ & BD- 5 & & & 92 & 657 & 60 & & 235 & & 189 & 145 & & 1.5 & 660 & 1,130 & & \\
\hline$(C-20-5) \quad 32.8 \mathrm{AB}$ & Nelson Bros. & $w$ & $111 \mathrm{ALVM}$ & 18.5 & 490 & $10 \mathrm{M}$ & 4-08-43 & $\mathrm{BD}-5$ & & & 34 & 34 & 85 & & 158 & & 52 & 160 & .2 & .2 & 443 & 800 & & $B=.05$ \\
\hline
\end{tabular}


Table 12-B. Pavant Valley. Black Rock Desert. Springs and Wells with Water Temperatures of $15.5^{\circ}$ to $19.5^{\circ} \mathrm{C}$

\begin{tabular}{|c|c|c|c|c|c|c|c|c|c|c|c|c|c|c|c|c|c|c|c|c|c|c|c|c|}
\hline \multirow{2}{*}{ COORDINATES } & \multirow{2}{*}{$\begin{array}{c}\text { OWNER } \\
\text { OR } \\
\text { NAME }\end{array}$} & \multirow{2}{*}{\multicolumn{2}{|c|}{ 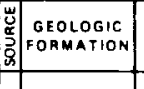 }} & \multirow{2}{*}{\begin{tabular}{|c|} 
TEMP. \\
${ }^{\circ} \mathrm{C}$ \\
\end{tabular}} & \multirow{2}{*}{\begin{tabular}{|l} 
DEPTH \\
$(1 \cdots+1)$
\end{tabular}} & \multirow{2}{*}{\begin{tabular}{|l|} 
YIELD \\
lopml
\end{tabular}} & \multirow{2}{*}{$\begin{array}{l}\text { DATE OF } \\
\text { SAMPLE }\end{array}$} & \multirow[b]{2}{*}{ FEFERENC: } & \multicolumn{13}{|c|}{ ANALYSIS EXPRESSED AS MILLIGAAMS PER LITER } & \multirow{2}{*}{$\begin{array}{l}\text { COND. } \\
\text { mmbor }\end{array}$} & \multirow[b]{2}{*}{$\mathrm{DH}^{\mathrm{DH}}$} & \multirow{2}{*}{$\begin{array}{l}\text { OTMEA CONSTIYUENTS } \\
\text { OR REMARKS }\end{array}$} \\
\hline & & & & & & & & & $\mathrm{SiO}_{2}$ & $\mathrm{Fe}$ & c. & $m_{0}$ & N. & $\kappa$ & $\mathrm{HCO}_{3}$ & $\mathrm{co}_{3}$ & so. & $\mathrm{a}$ & $\mathrm{F}$ & $\mathrm{NO}_{3}$ & $\begin{array}{l}\text { DISSOLVED } \\
\text { SOLIDS }\end{array}$ & & & \\
\hline$(\mathrm{C}-20-5) \quad 33 \mathrm{bbs}$ & L. Stott & $w$ & $111 \mathrm{ALM}$ & 19.0 & 325 & $6 \mathrm{M}$ & $11-16-4$ & BD. 5 & & & 32 & 29 & 78 & & 166 & & 55 & 123 & & 1.0 & 400 & 746 & & \\
\hline$(C-21-5) 5 d b c$ & H. J. Mitcholl & $\mathrm{w}$ & $111 \mathrm{ALVM}$ & 18.0 & 563 & $800 \mathrm{~m}$ & $3-19-62$ & BD. 5 & & & & & & & & & & & & & & & & \\
\hline$(C-21-5) 6 \mathrm{dba}$ & J. Robleon & $\mathrm{w}$ & $111 \mathrm{ALVM}$ & 16.0 & 400 & & $|0-23-5|$ & BD- 5 & 18 & & 48 & 23 & 21 & & 233 & & 24 & 32 & & 2.9 & 284 & 506 & 7.3 & \\
\hline$(C-21-5) 8 b^{2} c_{2}$ & Swallow & $\mu^{\omega}$ & III ALVM & 16.5 & 407 & p.650M & $5-21-62$ & BD- 5 & 20 & .01. & .73 & 20 & 32 & 1.3 & 261 & & 47 & 52 & .2 & 3.8 & 377 & 642 & 7.8 & B. 08 \\
\hline$(C-21-5)^{8 d b b_{2}}$ & J. C. Mooro & $\mathrm{w}$ & 111 ALVM & 16.0 & 400 & , $900 \mathrm{M}$ & & BD- 5 & & & & & & & & & & & & & & & & \\
\hline (C-21-5) 18ada & F. G. Johnzon & $\mathrm{w}$ & $111 \mathrm{ALVM}$ & 16.0 & 453 & & $5-31-43$ & BD- 5 & & & 58 & 28 & 26 & & 234 & & 37 & 59 & & 2.0 & 325 & 605 & & $B=.04$ \\
\hline$(C-21-5) \quad 18 d d d$ & N. Jackuon & $w$ & 111 ALVM & 16.0 & 493 & $35 \mathrm{M}$ & $|10-11-5|$ & BD- 5 & 16 & & 77 & 30 & 108 & & 295 & & 121 & 127 & & 6.9 & 631 & 942 & 7.2 & \\
\hline$(C-21-5) \quad 19 a d a$ & M. J. Palmer & $w$ & $111 \mathrm{ALVM}$ & 16.5 & & & $\mid 11-21-44$ & $B D-5$ & & & 76 & 38 & 64 & & 242 & & 120 & 112 & & 4.8 & 534 & 1.010 & & \\
\hline$(C-21-5)$ 19add & M. J. Palmer & $w$ & $111 \mathrm{ALVM}$ & 18.0 & 670 & $.050 \mathrm{M}$ & $6-01-55$ & BD- 5 & 22 & .04 & 214 & 101 & 183 & 7.2 & 290 & & 561 & 368 & .0 & 2.1 & 1.600 & 2.420 & 6.9 & B.. 91 \\
\hline$(C-21-5) \quad 18 a d d$ & F. G. Johnton & w & $111 \mathrm{ALVM}$ & 16.5 & 508 & & $\mid 11-21-44$ & BD- 5 & & & 61 & 30 & 31 & & 234 & & 60 & 60 & & 4.2 & 362 & 704 & & \\
\hline$(C-27-5) 19 d a a$ & M. J. Palmer & $w$ & $111 \mathrm{ALVM}$ & 17.0 & 403 & 200E & $5-31-43$ & $\mathrm{BD}-5$ & & & 84 & 46 & 104 & & 212 & & 209 & 164 & & 2.5 & 714 & 1,210 & & $8=27$ \\
\hline$(C-21-5) 19 \mathrm{dan}_{2}$ & M. J. Palmor & w & $\because 11 \mathrm{ALVM}$ & 56.5 & 232 & & $5-31-43$ & BD-5 & & & 90 & 45 & 90 & & 256 & & 182 & 145 & & 1.5 & 580 & 1,160 & & $B=.18$ \\
\hline$(\mathrm{C}-21-5) \quad 19 \mathrm{daA}_{3}$ & M. J. Palmer & w & 111 ALVM & 18.0 & 650 & $2.100 \mathrm{M}$ & $3-27-62$ & BD-5 & & & & & & & & & & & & & & & & \\
\hline$(C-21-5) 19 \mathrm{dcd}$ & H. H. Hatton & $|w|$ & 111 ALVM & 16.0 & 330 & & $5-31-43$ & BD-5 & & & 76 & 40 & 88 & & 286 & & 149 & 110 & & 1.5 & 605 & 1,020 & & $B=.27$ \\
\hline$(\mathrm{C}-21-5) 19 \mathrm{dcd}_{2}$ & w. c. Utley & $w$ & $111 \mathrm{ALVM}$ & 15.5 & 334 & & $3-11-60$ & BD-5 & & & & & & & & & & & & & & & & \\
\hline$(\mathrm{C}-21-5) \quad 19 \mathrm{dcd}_{3}$ & H. H. Hatton & $w$ & 111 ALVM & 18.5 & 615 & $220 \mathrm{M}$ & $12-54$ & BD- 5 & 19 & .13 & 138 & 67 & 135 & 5.9 & 314 & & 270 & 268 & & 3.0 & 1,060 & 1,750 & 7.2 & $B=.40$ \\
\hline $\begin{array}{ll}(\mathrm{C}-2 \mathrm{-2}-5) & 20 \mathrm{bba} \\
& 20 \mathrm{bba}_{2}\end{array}$ & J. A. Johnnon & w & $111 \mathrm{ALVM}$ & $\begin{array}{l}15.5 \\
17.0\end{array}$ & $\begin{array}{l}445 \\
480\end{array}$ & & $\left|\begin{array}{|l}11-21-44 \\
12-23-53\end{array}\right|$ & $\begin{array}{l}\text { BD-5 } \\
\text { BD-5 }\end{array}$ & 17 & .48 & $\begin{array}{c}52 \\
104\end{array}$ & $\begin{array}{l}22 \\
45\end{array}$ & $\begin{array}{l}32 \\
91\end{array}$ & 4.6 & $\begin{array}{l}262 \\
292\end{array}$ & & $\begin{array}{r}35 \\
223\end{array}$ & $\begin{array}{r}23 \\
121\end{array}$ & .2 & $\begin{array}{l}9.0 \\
5.6\end{array}$ & $\begin{array}{l}303 \\
755\end{array}$ & $\begin{array}{r}536 \\
1,220\end{array}$ & 7.3 & \\
\hline$(\mathrm{C}-21.5) 20 \mathrm{bdd} 2$ & Maco Bushwoll & $w$ & $111 \mathrm{ALVM}$ & 16.0 & 615 & $950 \mathrm{M}$ & $3-11-60$ & BD- 5 & & & & & & & & & & & & & & & & \\
\hline$(\mathrm{C}-21-5) 20 \mathrm{cbd}$ & Chriotonoen Bro & $w$ & $111 \mathrm{ALVM}$ & 15.5 & 350 & & $3-26-54$ & BD- 5 & & & & & & & & & & & & & & & & \\
\hline$(C-21-5) 20 \mathrm{cc}$ & Chrlotonsen Brop & $w$ & $111 \mathrm{ALVM}$ & 18.0 & 488 & & $5-31-43$ & BD- 5 & & & 126 & 55 & 150 & & 234 & & 316 & 244 & & 2.5 & 1,010 & 1,550 & & $B=.18$ \\
\hline$(\mathrm{C}-21-5) \quad 20 \mathrm{CC} \mathrm{a}_{2}$ & Chriatonaen Bros & $w$ & $111 \mathrm{ALVM}$ & 19.0 & 631 & $600 \mathrm{M}$ & $\mid 22-21-53$ & BD. 5 & 19 & .05 & 202 & 86 & 180 & 10 & 306 & & 455 & 370 & .1 & 3.4 & 1.480 & 2.310 & 7.2 & \\
\hline$(C-21-5) \quad 29 a a c$ & w. C. Utley & $\mathrm{w}$ & $111 \mathrm{ALVM}$ & 16.0 & 315 & $150 \mathrm{M}$ & $11-20-44$ & BD. 5 & & & 54 & 24 & 24 & & 226 & & 44 & 36 & & 3.9 & 297 & 630 & & \\
\hline$(C-21-5) 29 \mathrm{aad}_{2}$ & w. C. Utloy & $\mathrm{w}$ & $111 \mathrm{ALVM}$ & 15.5 & 300 & $65 \mathrm{M}$ & $11-20-44$ & BD- 5 & & & 54 & 20 & 27 & & 253 & & 31 & 22 & & 6.9 & 286 & 530 & & \\
\hline$(\mathrm{C}-21-5) \quad 29 \mathrm{aad}_{3}$ & w. c. Utloy & $w$ & $111 \mathrm{ALVM}$ & 28.0 & 598 & $1.820 \mathrm{M}$ & $1-55$ & $B D-5$ & 18 & .62 & 146 & 60 & 137 & 7.9 & 298 & & 377 & 182 & 0 & 4.6 & 1,080 & 1,650 & 7.1 & $B=.41$ \\
\hline$(C-21-5) \quad 29 \mathrm{baa}$ & w. C. Utley & $w$ & $111 \mathrm{ALVM}$ & 16.0 & 224 & $85 \mathrm{M}$ & $9-05-60$ & BD- 5 & & & & & & & & & & & & & & & & \\
\hline$(C-21-5) 29 \mathrm{bdd}$ & L. Rasmussen & $w$ & $111 \mathrm{ALVM}$ & 16.5 & 207 & & $11-18-44$ & $B D-5$ & & & 63 & 23 & 36 & & 265 & & 48 & 44 & & .6 & 345 & 647 & & \\
\hline$(\mathrm{G}-21-5)^{2} 29 \mathrm{bdd}$ & L. Rasmusen & w & 111 ALVM & 19.0 & 632 & $1,350 \mathrm{M}$ & $6-27-58$ & BD- 5 & 17 & & 305 & 89 & 321 & & 332 & & 756 & 540 & & 2.2 & 2.190 & 3,210 & 7.0 & \\
\hline$(C-21-5) 29 \mathrm{cas}$ & L. Raumuaron & $w$ & $111 \mathrm{ALVM}$ & 15.5 & 314 & $80 \mathrm{M}$ & $3-11-60$ & BD- 5 & & & & & & & & & & & & & & & & \\
\hline$(C-21-5) 29 \mathrm{Cad}$ & L. Rasmusesn & $w$ & $111 \mathrm{ALVM}$ & 17.0 & 440 & $100 \mathrm{M}$ & 5.31 .43 & BD- 5 & & & 109 & 44 & 115 & & 252 & & 228 & 182 & & 2.5 & 805 & 1.350 & & $B=.14$ \\
\hline$(C-21-5) 29 \mathrm{cdd}$ & Chrietienoen Bros & 4 & $111 \mathrm{ALVM}$ & 16.5 & 366 & & $5: 31-43$ & BD- 5 & & & 126 & 42 & 124 & & 280 & & 235 & 200 & & 2.0 & 867 & 1,430 & & $B=.14$ \\
\hline$(C-21-5) 29 \mathrm{edd} 2$ & Chrlettenson Bxol & "x & $13 \mathrm{ALVM}$ & 18.0 & 380 & $2.100 M$ & $3-29-54$ & BD-3 & 17 & .13 & 170 & 34 & 132 & 18 & 288 & & 293 & 280 & .6 & 4.1 & 1,110 & 1.800 & 7.2 & $B=.95$ \\
\hline$(C-21-5) \quad 29 \mathrm{cdd}, 3$ & Rasmuason Bros. & " & 111 ALVM & 16.5 & 357 & $1.000 \mathrm{M}$ & $3-24-61$ & BD- 5 & & & & & & & & & & & & & & & & \\
\hline$(\mathrm{C}-21-5) 29 \mathrm{dce}$ & J. F. Kølly & w & $111 \mathrm{ALVM}$ & 16.5 & 380 & $135 \mathrm{M}$ & $4-08-43$ & BD-5 & & & 181 & 51 & 171 & & 302 & & 362 & 287 & .1 & 3.0 & 1,200 & 1.780 & & $B=.43$ \\
\hline
\end{tabular}


Table 12-B. Pavant Valley. Black Rock Desert. Springr and Wells with Water Temper atures of $15.5^{\circ}$ to $19.5^{\circ} \mathrm{C}$

\begin{tabular}{|c|c|c|c|c|c|c|c|c|c|c|c|c|c|c|c|c|c|c|c|c|c|}
\hline \multirow[b]{2}{*}{ COOROINATES } & \multirow{2}{*}{$\begin{array}{l}\text { OWNEA } \\
\text { OR } \\
\text { NAME }\end{array}$} & \multirow{2}{*}{ 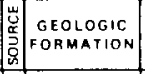 } & \multirow{2}{*}{$\begin{array}{c}\text { TEMP. } \\
{ }^{\circ} \mathrm{C} \\
\end{array}$} & \multirow{2}{*}{\begin{tabular}{|c|} 
DEPTH \\
$1+\cdots+11$
\end{tabular}} & \multirow{2}{*}{\begin{tabular}{|l|}
$Y$ \\
$Y$ IELO \\
Sopm?
\end{tabular}} & \multirow{2}{*}{$\begin{array}{l}\text { DAAE OF } \\
\text { SAMPLE }\end{array}$} & \multirow[b]{2}{*}{ |AEFEREMOE } & \multicolumn{11}{|c|}{ ANALYSIS EXPAESSED AS MILLIGRAMS PER LITER } & \multirow{2}{*}{$\begin{array}{l}\text { COND. } \\
\text { mmhooi }\end{array}$} & \multirow[b]{2}{*}{${ }^{D H}$} & \multirow{2}{*}{$\begin{array}{l}\text { OTHER CONSTITUENTS } \\
\text { OR REMARKS }\end{array}$} \\
\hline & & & & & & & & $\mathrm{SiO}_{2}$ & \begin{tabular}{l|l} 
F. & c.
\end{tabular} & $M_{0}$ & N. & $\kappa$ & $\mathrm{HCO}_{3}$ & \begin{tabular}{l|l|}
$\mathrm{CO}_{3}$ & 50.4 \\
\end{tabular} & $\mathrm{c}_{1}$ & $F$ & $\mathrm{NO}_{3}$ D & $\begin{array}{l}\text { DISSOLVED } \\
\text { SOLIOS }\end{array}$ & & & \\
\hline$(\mathrm{C}-21-5) 29 \mathrm{dcd}$ & J. F. Kelly & $\mathrm{w} \mid 111$ ALVM & 15.5 & 266 & $200 \mathrm{M}$ & $9-05-60$ & BD-5 & & & & & & & & & & & & & & \\
\hline$(\mathrm{C}-21-5) 29 \mathrm{~d} d \mathrm{~d}$ & J. F. Kelly & $\mathrm{w}|111 \mathrm{ALVM}|$ & 15.5 & 277 & $9 \mathrm{M}$ & $5-31-43$ & BD -5 & & 56 & 20 & 47 & & 234 & 51 & 57 & & 4.2 & 352 & 632 & & $B=.14$ \\
\hline$(C-21-5)$ 30ada & W. R. Starley & W| 111 ALVM & 16.5 & 470 & & $5-31-43$ & BD-5 & & 80 & 46 & 101 & & 230 & 181 & 163 & & 1.5 & 686 & 1,170 & & $B=.14$ \\
\hline$(\mathrm{C}-21-5)$ 30bad & Chrtetensen Bros & $\mathrm{w} 111$ ALVM & 15.5 & 365 & & $11-21.44$ & BD- 5 & & 105 & 45 & 118 & & 274 & 221 & 175 & & 1.9 & 801 & 1,340 & & \\
\hline$(C-21-5) 30$ daa & w. c. vtley & \begin{tabular}{|l|l|}
$\mathrm{w}$ & 111 ALVM
\end{tabular} & 16.5 & 437 & & $11-18-43$ & BD- 5 & & & & & & & & & & & & & & \\
\hline$(\mathrm{C}-21.5)$ 30dad & w. C. Utloy & $\mathrm{w}=111 \mathrm{ALVM}$ & 17.0 & 420 & $50 \mathrm{M}$ & $5-31-43$ & $\mathrm{BD}-5$ & & 114 & 52 & 110 & & 282 & 208 & 205 & & 1.0 & 829 & 1,400 & & $B=.14$ \\
\hline$(C-21-5) 30 d b c$ & Chrlatenaer Bros Vy & $w \mid 111$ ALVM & 16.0 & 304 & & & $\mathrm{BD}-5$ & & & & & & & & & & & & & & \\
\hline$(\mathrm{C}-21-5) \quad 30 \mathrm{dbc}{ }_{3}$ & Chrlatonaen Bros & $\begin{array}{lll}\mathrm{w} & 111 & \mathrm{ALVM}\end{array}$ & 19.5 & 787 & $700 \mathrm{M}$ & $5-27-60 \mid$ & BD-5 & 16 & 141 & 67 & 164 & & 229 & 344 & 311 & & 1.0 & 1,160 & 1.860 & 7.6 & $B=.47$ \\
\hline$(C-21-5) 31 \mathrm{cdd} 2$ & J. N. Rogera & 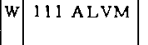 & 17.0 & 800 & $1,150 \mathrm{M}$ & 3-24-59 & BD-5 & 15 & 79 & 23 & 75 & & 305 & 80 & 85 & & 3.1 & 510 & 873 & 7.5 & \\
\hline$(\mathrm{C}-21-5) 32 \mathbf{a a d}$ & J. F. Kelly & $\begin{array}{ll}\mathrm{W} & 111 \\
\end{array}$ & 15.5 & 296 & & $3-11-60$ & $B D-5$ & & & & & & & & & & & & & & \\
\hline$(\mathrm{C}-21-5) \quad 32 \mathrm{acb}$ & J. F. Kelly & 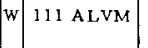 & 15.5 & 266 & & $5-31-43$ & $B D-5$ & & 108 & 35 & 63 & & 212 & 78 & 208 & & 2.5 & 599 & 1,120 & & $B=.13$ \\
\hline$(C-21-5) \quad 32 \mathrm{bb}$ & L. Rasmussen & $\mathrm{W} \mid 111$ ALVM & 18.0 & 600 & $1,100 \mathrm{~m}$ & $4-01-60 \mid$ & ED-5 & & & & & & & & & & & & & & \\
\hline$(\mathrm{C}-21-5) \quad 32 \mathrm{bcb}$ & L. Rasmussen & $w \mid$ I11 ALVM & 15.5 & 285 & & $5-31-43$ & BD- 5 & & 76 & 32 & 72 & & 190 & 98 & 154 & & 2.5 & 528 & 980 & & $B=.11$ \\
\hline$(C-21-5) \quad 32 b c d 2$ & w. C. Utloy & $w \mid 111$ ALVM & 15.5 & 254 & & $11-18-44$ & BD- 5 & & 124 & 46 & 230 & & 238 & 212 & 258 & & 2.7 & 890 & 1,490 & & \\
\hline$(\mathrm{C}-21-5) \quad 32 \mathrm{bcc} 2$ & J. F. Kolly & $w \mid 111$ ALVM & 16.0 & 318 & & $5-31-43$ & $B D-5$ & & 78 & 23 & 70 & & 226 & 107 & 102 & & 1.5 & 493 & 876 & & B.. 05 \\
\hline$(C-22-5) 4 c b d$ & F. P. Roblson & $\begin{array}{lll}\mathrm{W} & 111 & \mathrm{ALVM} \\
\end{array}$ & 15.5 & 276 & $850 \mathrm{M}$ & 5-03-60 & $B D-5$ & & & & & & & & & & & & & & \\
\hline$(C-22-5) 4 c c d$ & F. P. Roblion & $\mathrm{W} / 111 \mathrm{ALVM}$ & 16.5 & 284 & & & $B D-5$ & & & & & & & & & & & & & & \\
\hline$(\mathrm{C}-22-5) 8 \mathrm{aad}$ & w. w. Watts & $W \quad 111$ ALVM & 15.5 & 325 & & $5-31-43$ & BD-5 & & 126 & 36 & 76 & & 256 & 118 & 208 & & 1.5 & 692 & I, 240 & & B.. 05 \\
\hline$(C-22-5) \quad 17 a b d$ & G. Stott & $\begin{array}{lll}W & 111 & \text { ALVM }\end{array}$ & 15.5 & 422 & $290 \mathrm{M}$ & $3-16-60$ & BD- 5 & & & & & & & & & & & & & & \\
\hline$(C-21-5) 30 d b d$ & Chrlutenoon Brod & $w \mid 111$ ALVM & 16.0 & 350 & & $4-11-43$ & BD. 5 & & 131 & 40 & 107 & & 296 & 172 & 178 & .1 & 2.5 & 756 & 1.230 & & \\
\hline$(C-22-6) 3 x d d 2$ & $\begin{array}{l}\text { Edwarda } \\
\text { Hardlng }\end{array}$ & $\mathrm{W}: 112$ PVNT & 17.0 & 339 & $700 \mathrm{M}$ & $7-10-57$ & BD- 5 & 48 & 114 & 41 & 134 & & 276 & 148 & 258 & & 2.3 & 881 & 1,460 & 7.3 & \\
\hline$(\mathrm{C}-23-6) 9 \mathrm{bca}$ & K. Paco & $\begin{array}{ll}\mathrm{W} & 112 \mathrm{PVNT}\end{array}$ & 16.5 & 170 & $3,350 \mathrm{M}$ & $8-27-58$ & BD- 5 & 54 & 405 & 114 & 1,050 & & 486 & 924 & 1,700 & & 5.4 & 4,490 & 6,750 & 6.9 & \\
\hline$(C-23-6) \quad 10 \mathrm{CCC}$ & C. A. Kımbell & $\begin{array}{ll}W & 112 \\
\end{array}$ & 15.5 & 96 & $2.550 \mathrm{M}$ & $6-05-58$ & $B D-5$ & 38 & 265 & 69 & 523 & & 379 & 495 & 885 & & 10 & 2,470 & 3,940 & 7.3 & \\
\hline$(C-23-6) \quad 15 \mathrm{bbd}_{2}$ & G. D. Staplen & $\begin{array}{lll}\mathrm{W} & 112 & \mathrm{PVNT} \\
\end{array}$ & 15.5 & 141 & $3,108 \mathrm{M}$ & $5-25-61$ & BD-5 & 62 & 268 & 59 & 563 & 24 & 262 & 577 & 995 & 1.1 & 3.4 & 2,680 & 4,380 & 7.5 & $B=2.5$ \\
\hline$(C-23-6) \quad 17 c d c$ & L. Bradehaw & $\begin{array}{lll}W & 111 & A L V M\end{array}$ & 16.0 & 440 & $1,700 \mathrm{M}$ & $6-04.58$ & $B D-5$ & 37 & 146 & 74 & 525 & & 287 & 314 & 880 & & 11 & 2,130 & 3.560 & 7.5 & \\
\hline$(C-23-6) 20 c b b$ & N. L. Nielson & $\mathrm{w} 1111 \mathrm{ALVM}$ & 16.0 & 430 & & $8-27-58$ & BD- 5 & 37 & 257 & 136 & 1,140 & & 362 & 533 & 2,000 & & 7.8 & 4,290 & 6.970 & 7.2 & \\
\hline$(C-20-5) 28 d a a$ & & $w \mid 111$ ALVM & 16.5 & 330 & & $\mid 11-16-44$ & TP-3 & & 54 & 44 & 14 & & 244 & 70 & 52 & & .4 & 355 & & & \\
\hline$(C-20-5) 28 \mathrm{ddd}$ & & $\mathrm{W} / 11 \mathrm{ALVM}$ & 16.5 & 309 & & $11-16-44$ & TP-3 & & 49 & 38 & 28 & & 247 & 72 & 43 & & .8 & 352 & & & \\
\hline$(C-21-5) 8 b a b$ & & $w 111$ ALVM & 17.0 & 455 & & $11-22-44$ & TP-3 & & 61 & 28 & 43 & & 260 & 74 & 49 & & .6 & 384 & & & \\
\hline$(C-21-5) 8 b d c$ & & $w \mid 11$ ALVM & 16.5 & 320 & & $5-31-43$ & TP-3 & & 48 & 25 & 28 & & 248 & 32 & 32 & & 1.0 & 288 & & & \\
\hline$(C-21-5) \quad 18 \mathbf{a d d}$ & & $w 111 \mathrm{ALVM}$ & 16.5 & 508 & & $11-21-44$ & TP-3 & & 61 & 30 & 31 & & 234 & 60 & 60 & & 4.2 & 362 & & & \\
\hline$(C-21-5) \quad 18 \mathrm{dad}_{2}$ & & $\mathbf{w} \mid 111 \cdot \mathrm{ALVM}$ & 15.5 & 400 & & Ir-20-44 & TP-3 & & & & & & & 61 & & & & & & & \\
\hline$(C-21.5) \quad 18 \mathrm{dda}$ & & wo 111 ALVM & 16.5 & 448 & & $11-21-44$ & TP-3 & & & & & & & 147 & & & & & & & \\
\hline
\end{tabular}


Table 12-B. Pavant Valley. Black Rock Desert. Springs and Wolls with Water Temperatures of $15.5^{\circ}$ to $19.5^{\circ} \mathrm{C}$.

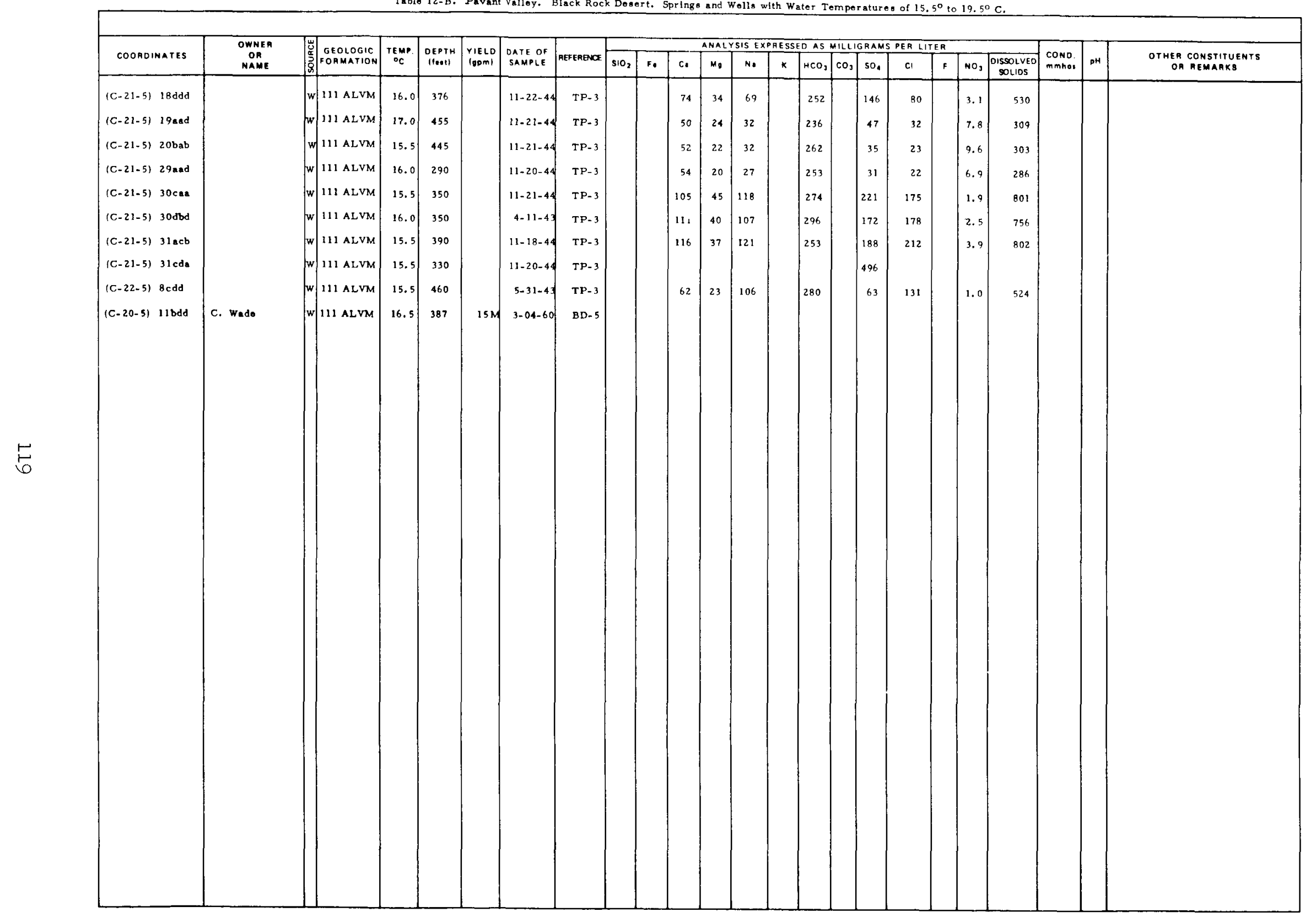


Table 13-A. Sevler Desert. Wells That Yleld Water of $20^{\circ} 1029^{\circ} \mathrm{C}$ and One Spring At $82^{\circ} \mathrm{C}$.

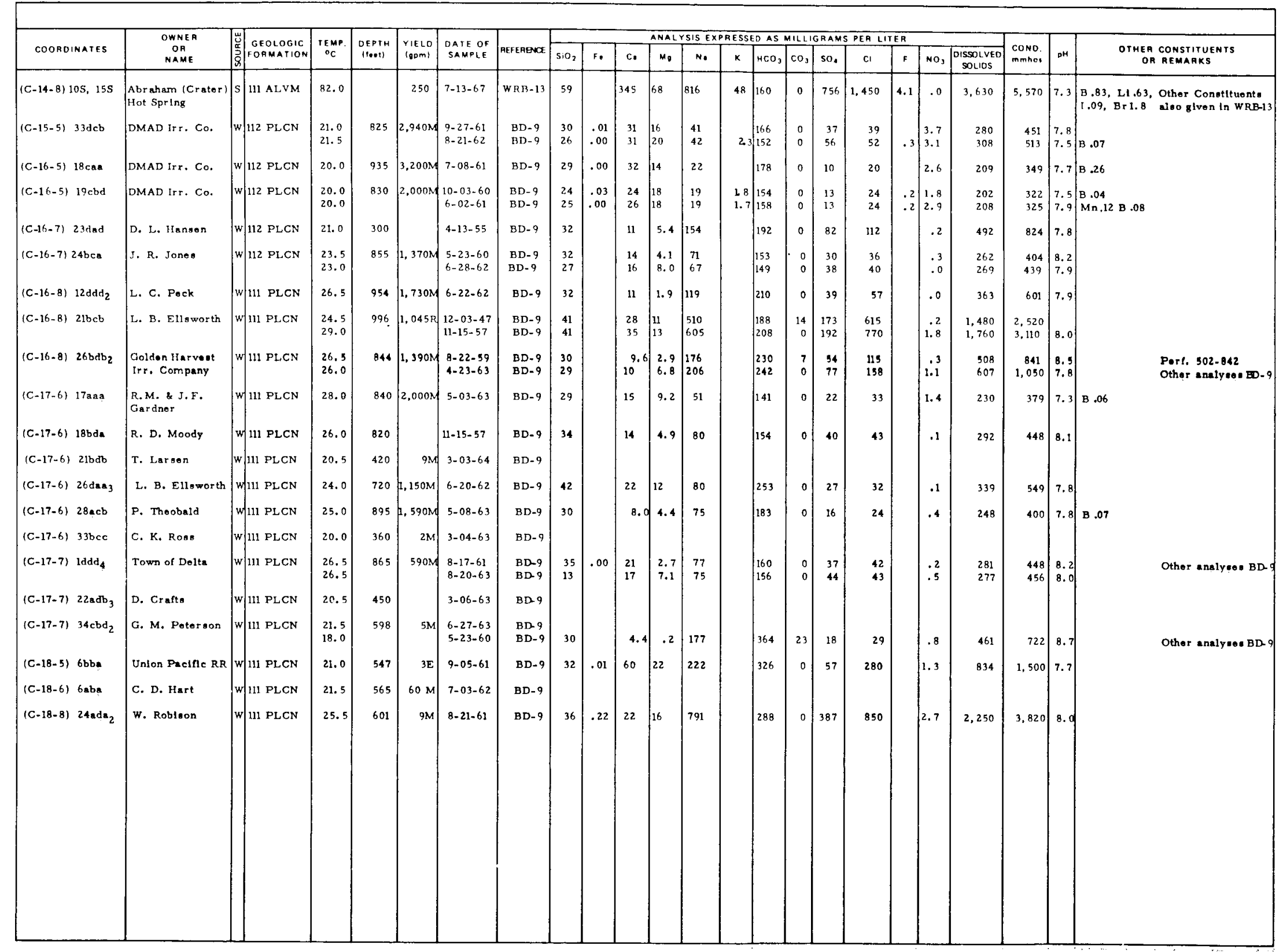


Tabbe 13-B. Sevier Desert. Wolls With Wator Temperatures of $15.5^{\circ}$ to $19.5^{\circ} \mathrm{C}$.

\begin{tabular}{|c|c|c|c|c|c|c|c|c|c|c|c|c|c|c|c|c|c|c|c|c|c|c|c|}
\hline COOHOINATES & $\begin{array}{c}\text { OWNER } \\
\text { OAP } \\
\text { NAME }\end{array}$ & 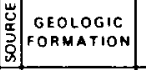 & $\begin{array}{c}\text { Temp. } \\
\text { occ } \\
\end{array}$ & 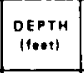 & 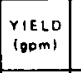 & $\begin{array}{l}\text { DATE OF } \\
\text { SAMPLE }\end{array}$ & AEF EREDVE: & $\mathrm{S}_{1} \mathrm{O}_{2}$ & F. & c. & $\mid$ & 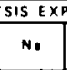 & RESSE & HCO, & 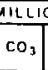 & $\begin{array}{l}\text { GAMAS } \\
\text { so. }\end{array}$ & $\begin{array}{l}\text { PEP LIT } \\
\mathrm{c}_{1}\end{array}$ & ER & $\mathrm{No}^{\mathrm{No}} \mathrm{C}^{\mathrm{C}}$ & 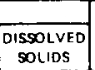 & \begin{tabular}{|c|c|c|} 
cono. \\
mmaoi
\end{tabular} & pr & $\begin{array}{l}\text { OTMER CONSTITUENTS } \\
\text { OR AEARAKS }\end{array}$ \\
\hline$(C-11-8) \quad 33 \mathrm{ccc}$ & G. C. Bennlor & Wf 111 ALVM & 16.5 & 376 & $1250 \mathrm{M}$ & $6-24-63$ & BD-9 & & & & & & & & & & & & & & & & \\
\hline$(c-11-9) \quad$ bca & C. C. Bennton & $\mathrm{W} 111 \mathrm{ALVM}$ & 16.0 & 448 & $640 \mathrm{M}$ & $6-25-63$ & BD-9 & & & & & & & & & & & & & & & & \\
\hline $\mid(C-11-9) \quad 1 c d b$ & a. C. Bennion & $w \mid 111$ ALVM & $\mid 16.0$ & 445 & $800 \mathrm{E}$ & $6-24-63$ & BD -9 & & & & & & & & & & & & & & & & \\
\hline$(C-12-8) 9 b \mathbf{a t}$ & W. H. Potorson & $w 111$ ALVM & 18.0 & 272 & $470 \mathrm{M}$ & $5-02-63$ & BD-9 & 41 & & 68 & 27 & 80 & & 194 & 0 & 36 & 182 & & & 530 & 964 & $7.2 \mid$ & $B-.08$ \\
\hline$(\mathrm{C}-13-6) 26 \mathrm{bac}$ & U.S. B.L.M. & $\mathrm{w}, 11$ ALVM & 16.0 & 175 & $20 \mathrm{R}$ & $8.23-61$ & BD-9 & 61 & .00 & 134 & 113 & 424 & & 238 & 0 & 547 & 675 & & 5. & 2,080 & 3,280 & 7.7 & \\
\hline$(\mathrm{C}-14-5) \quad 35 \mathrm{cdc}$ & J. M. Noloon & W/ $\because 1$ ALVM & 15.5 & 305 & $2040 \mathrm{M}$ & 8.23-61 & BD-9 & & & & & & & & & & 805 & & & & 3,520 & & \\
\hline$(c-14-6) 9 b_{a b}$ & D. Christonoon & $\mathrm{W} \mid 111$ АLVM & 16.0 & 185 & $4 \mathrm{M}$ & $8-23-61$ & $\mathrm{BD}-9$ & & & & & & & & & & & & & & & & \\
\hline$(C-14-6) 9 \mathrm{dda}$ & D. Christensen & $w 11$ ALVM & 16.5 & 143 & $2 \mathrm{M}$ & $8-23-61$ & BD-9 & & & & & & & & & & & & & & & & \\
\hline$(C-14-6) 21 \operatorname{ccc}_{2}$ & E. A. Lyman & $W \mid 111$ АLVM & 15.5 & 185 & $4 M$ & $8-23-61$ & BD. 9 & & & & & & & & & & & & & & & & \\
\hline$(C-14-6) 21 \mathrm{ddd}$ & E. A. Lyman & $\mathrm{W} 111$ ALVM & $\mid$\begin{tabular}{|l|}
$\mid 16.0$ \\
\end{tabular} & 126 & & & BD-9 & & & & & & & & & & & & & & & & \\
\hline$(\mathrm{C}-14-7) 20 \mathrm{ccc}$ & U. S. B. L.M. & $W 111$ ALVM & 16.5 & 194 & & $4-25-63$ & BD-9 & 23 & & 82 & 51 & 322 & & 90 & 0 & 268 & 540 & & 2.1 & 1.330 & 2.340 & 7.0 & \\
\hline$(C-15-4) 17 \mathrm{dab}$ & C. Neteoon & W 111 ALVM & $\mid 16.0$ & 350 & $1,710 \mathrm{M}$ & $6.26 \cdot 63$ & BD-9 & & & & & & & & & & & & & & & & \\
\hline$(C-15-4))_{18 \mathrm{das}}$ & 3. Nlolson & $w \mid 11$ aLVM & 17.0 & 406 & $1,510 \mathrm{~m}$ & 6-23-58 & BD-9 & 28 & & 134 & 68 & 75 & & 224 & 0 & 144 & 308 & & 11 & 878 & 1,540 & 7.7 & \\
\hline$(C-15-4) 26 \mathrm{dcc}$ & Fool Craok & $\mathrm{w} \mid 111$ ALVM & 15,5 & 520 & $1.040 \times 4$ & $9-01-6$ & BD-9 & 15 & .00 & 97 & 25 & 21 & & 194 & 0 & 76 & 81 & & 46 & 456 & 776 & 7.7 & \\
\hline$(C-15-5) 2 d d c$ & J. Nielson & $\mathrm{W} \mid 111$ ALVM & 15.5 & 303 & $1,840 \mathrm{~m}$ & $9-23-58$ & BD-9 & 26 & & 76 & 42 & 68 & & 223 & 0 & 70 & 180 & & 1.0 & 573 & 1,020 & 7.9 & \\
\hline$(C-15-5) 26$ baa & DMAD & $w \mid \cdots$ ALVM & $\left|\begin{array}{l}18.0 \\
18.0\end{array}\right|$ & $8602^{2}$ & $2,520 \mathrm{M}$ & $\mid \begin{array}{l}10-28-58 \\
11-03-\end{array}$ & $\begin{array}{l}\mathrm{BD}-9 \\
\text { BD-9 }\end{array}$ & $\begin{array}{l}32 \\
25\end{array}$ & & $\begin{array}{l}34 \\
35\end{array}$ & \begin{tabular}{|l|}
17 \\
19
\end{tabular} & $\begin{array}{l}23 \\
26\end{array}$ & & $\begin{array}{l}178 \\
182\end{array}$ & $\begin{array}{l}0 \\
0\end{array}$ & $\begin{array}{l}18 \\
26\end{array}$ & $\begin{array}{l}27 \\
31\end{array}$ & & $\begin{array}{l}1.8 \\
2.8\end{array}$ & $\begin{array}{l}241 \\
254\end{array}$ & $\begin{array}{l}382 \\
420\end{array}$ & \begin{tabular}{|l|}
77.8 \\
7.8
\end{tabular} & \\
\hline$(C-15-5) \quad 36 \mathrm{abb}$ & Taylor Flat & $w 111$ ALVM & 18.0 & 935 & $.280 \mathrm{M}$ & $8-22-63$ & BD-9 & & & & & & & & & & & & & & & & \\
\hline (C-15-6) 7ddb & U. S. B. L.M. & $|\mathrm{w}| 111$ ALVM & 15.5 & 336 & $3 \mathrm{M}$ & $8-23-6$ & BD-9 & & & & & & & & & & & & & & & & \\
\hline$(\mathrm{C}-15-7) \quad 18 \mathrm{Cse}$ & W. B. Davle & $\mathrm{W} \mid 111$ ALVM & 18.0 & 795 & $690 \mathrm{M}$ & $8-24-62$ & BD-9 & & & & & & & & & & & & & & & & \\
\hline$(C-15-7) \quad 27 \mathrm{cosb}$ & O. w. Huneaker & $w 111 \mathrm{ALVM}$ & 16.0 & 668 & $90 \mathrm{M}$ & $9-28-66$ & BD-9 & & & & & & & & & & & & & & & & \\
\hline (C-15-7) 30bdd & R. J. Jenseo & $w 111$ ALVM & 15.5 & 170 & $\mathrm{im}$ & $9-06-4$ & BD-9 & 22 & & 12 & 6 & 123 & & 137 & 0 & 76 & 91 & & & 396 & & & \\
\hline$(\mathrm{C}-15-7) 31 \mathbf{a b b} 2$ & Roy Loose & $\mathbf{w} 1111$ ALVM & 16.0 & 380 & $12 \mathrm{M}$ & $3-07-63$ & BD-9 & & & & & & & & & & & & & & & & \\
\hline$(C-15-7) 31 \mathrm{bad}$ & A. M. smith & $\mathrm{W} 1111 \mathrm{ALVM}$ & 16.5 & 405 & $4 \mathrm{M}$ & $9-26-61$ & BD-9 & & & & & & & & & & 104 & & & & 714 & & \\
\hline$(C-15-7) 31 \mathrm{ddd}$ & E. D. Lo000 & $w \mid 111$ ALVM & 16.0 & & $1 \mathrm{M}$ & $9-26-64$ & BD-9 & & & & & & & & & & & & & & & & \\
\hline$(\mathrm{C}-15-7) 36 \mathrm{cbb}$ & Chesley \& Black & $w \mid 111$ ALVM & 15.5 & 420 & & $9-27-66$ & $\mathrm{BD}-9$ & 38 & .00 & 30 & 13 & 62 & & 150 & & 55 & 58 & & & 330 & 524 & 8.2 & \\
\hline$(C-16-4) \quad 18 \mathrm{bda}$ & Stnks Irr. & $\mathrm{w} \mid 111$ ALVM & $\mid 16.5$ & 375 & $790 \mathrm{M}$ & $8-01-64$ & BD-9 & 40 & & 103 & 45 & 89 & & 212 & & 129 & 227 & & 8.9 & 849 & 1,290 & 7.7 & \\
\hline$(C-16-6)$ 18bad & J. A. DeLapp & w| 111 ALVm & $\mid 16.0$ & 225 & $7 \mathrm{M}$ & $3-20-63$ & BD-9 & & & & & & & & & & & & & & & & \\
\hline$(C-16-7)$ lobad & H. Dono & $\mathrm{W} \mid 111 \mathrm{ALVM}$ & $\mid 17.0$ & 919 & $1,920 \mathrm{M}$ & $11-14-62$ & BD-9 & 23 & & 17 & 6.3 & 68 & & 142 & 0 & 41 & 39 & .5 & .5 & 265 & 434 & 7.8 & \\
\hline$(\mathrm{C}-16-7) \quad 12 \mathrm{ecd}$ & A. Barnoy & $\mathrm{W} \mid 111$ ALVM & 16.0 & 582 & $270 \mathrm{M}$ & $4-23-6=$ & BD-9 & & & & & & & & & & & & & & & & \\
\hline$(\mathrm{C}-16-7) \quad 12 \mathrm{dcd}$ & W. E. Black & W| 111 ALVM & $\mid 17.0$ & 704 & $270 \mathrm{M}$ & $5-20-6=$ & BD-9 & & & & & & & & & & & & & & & & \\
\hline$(C-16-7) 13 \mathrm{cad}$ & J. A. DoLapp & $\mathrm{W} \mid 111$ ALVM & 15.5 & 288 & & $4-13-64$ & BD-9 & 25 & & 28 & 20 & 31 & & 132 & & 44 & 45 & & 1.0 & 259 & 438 & 7.5 & \\
\hline$(\mathrm{C}-16-7) \quad 33 \mathrm{bbaz}$ & L. E. Abbott & $w 111$ ALVM & 16.5 & 245 & & $8-16-66$ & BD-9 & 22 & & 84 & 4.4 & 113 & & 168 & & 51 & 66 & & & 348 & 594 & 7.8 & \\
\hline$(\mathrm{C}-16-7) 36 \mathrm{acb}$ & E. A. Lymen & W 111 ALVM & 16.5 & 125 & $4 \mathrm{M}$ & $3-20-6$ & BD-9 & & & & & & & & & & & & & & & & \\
\hline
\end{tabular}


Table 13-B. Sevier Deaert. Wolls with Water Tomporatures of $15.5^{\circ}$ to $19.5^{\circ} \mathrm{C}$.

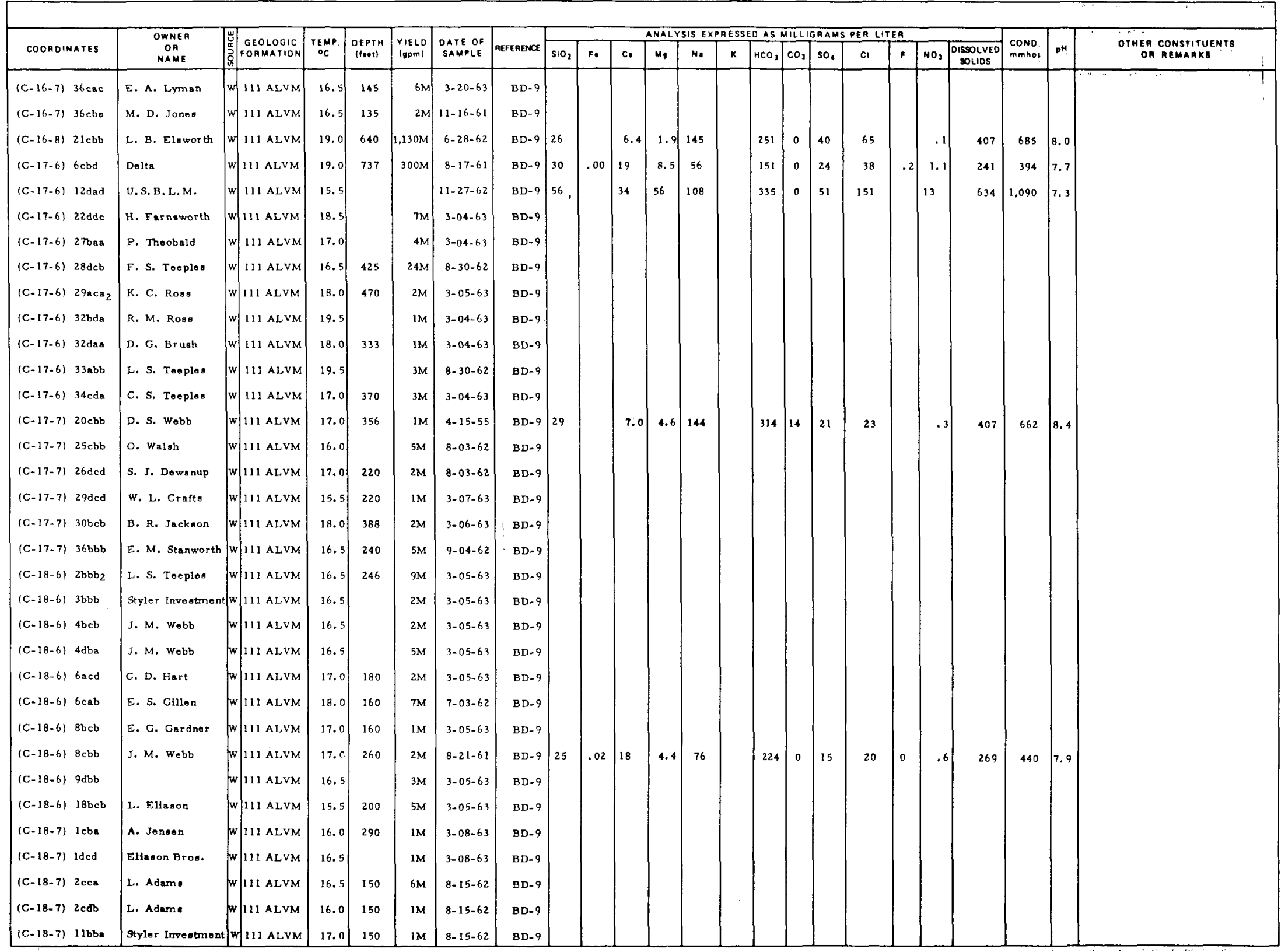


Table 13-B. Sevier Desert. Wells with water Temperatures of $15.5^{\circ}$ to $19.5^{\circ} \mathrm{C}$.

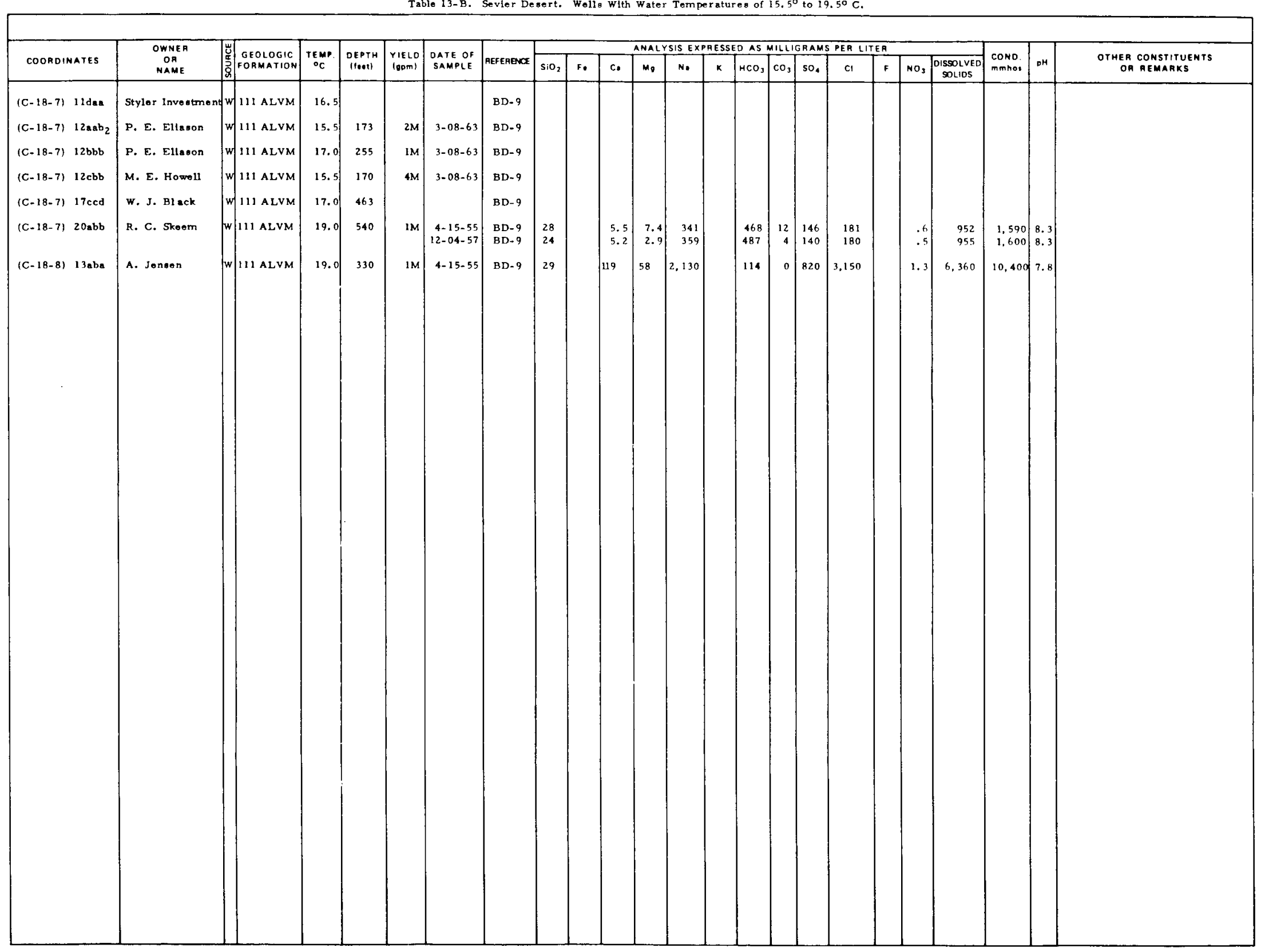


Table 14. Upper Sevier River Valley. Wells and Springs with Water Temperaturea of $15.5^{\circ}$ to $32^{\circ} \mathrm{C}$.

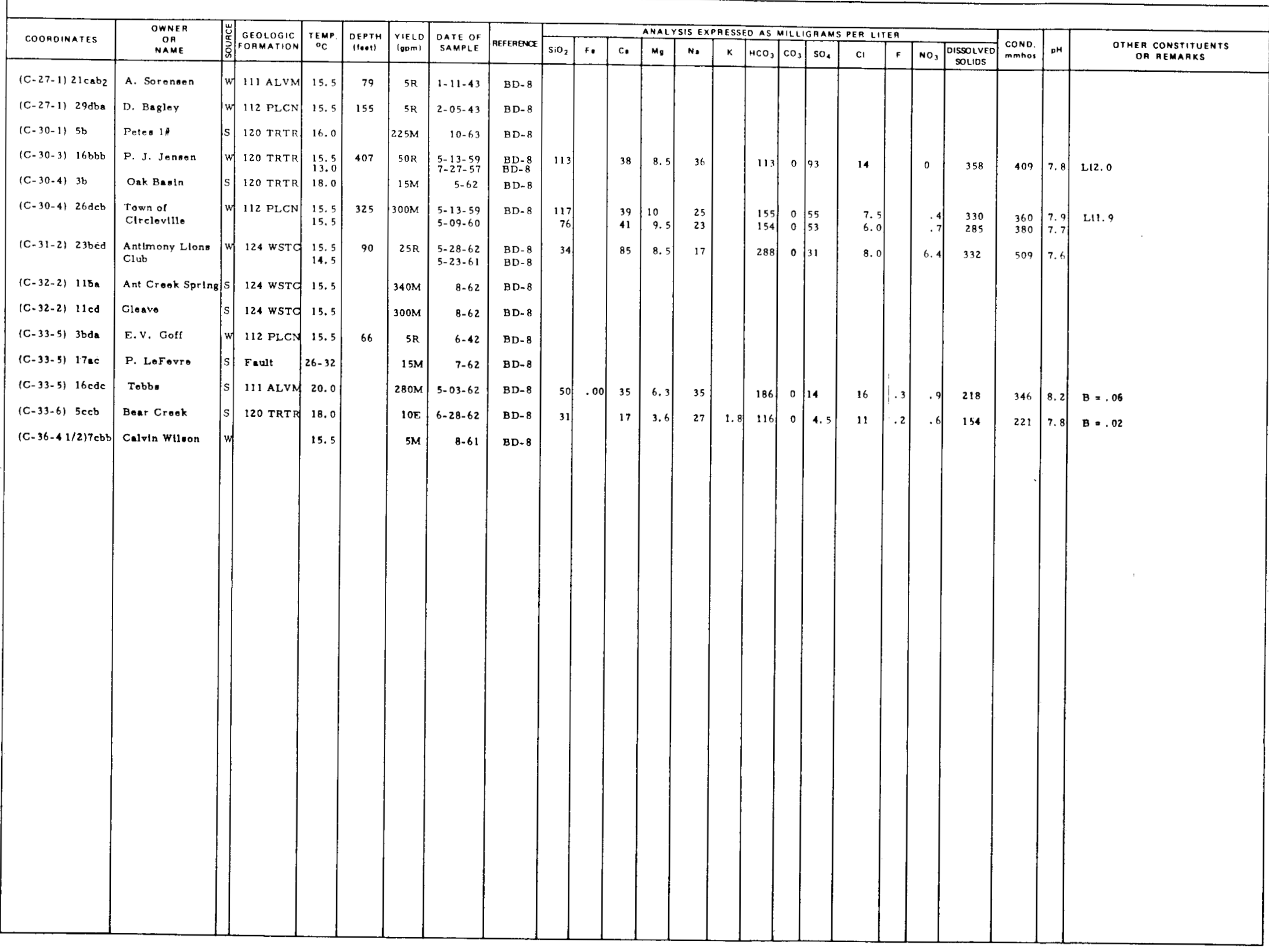




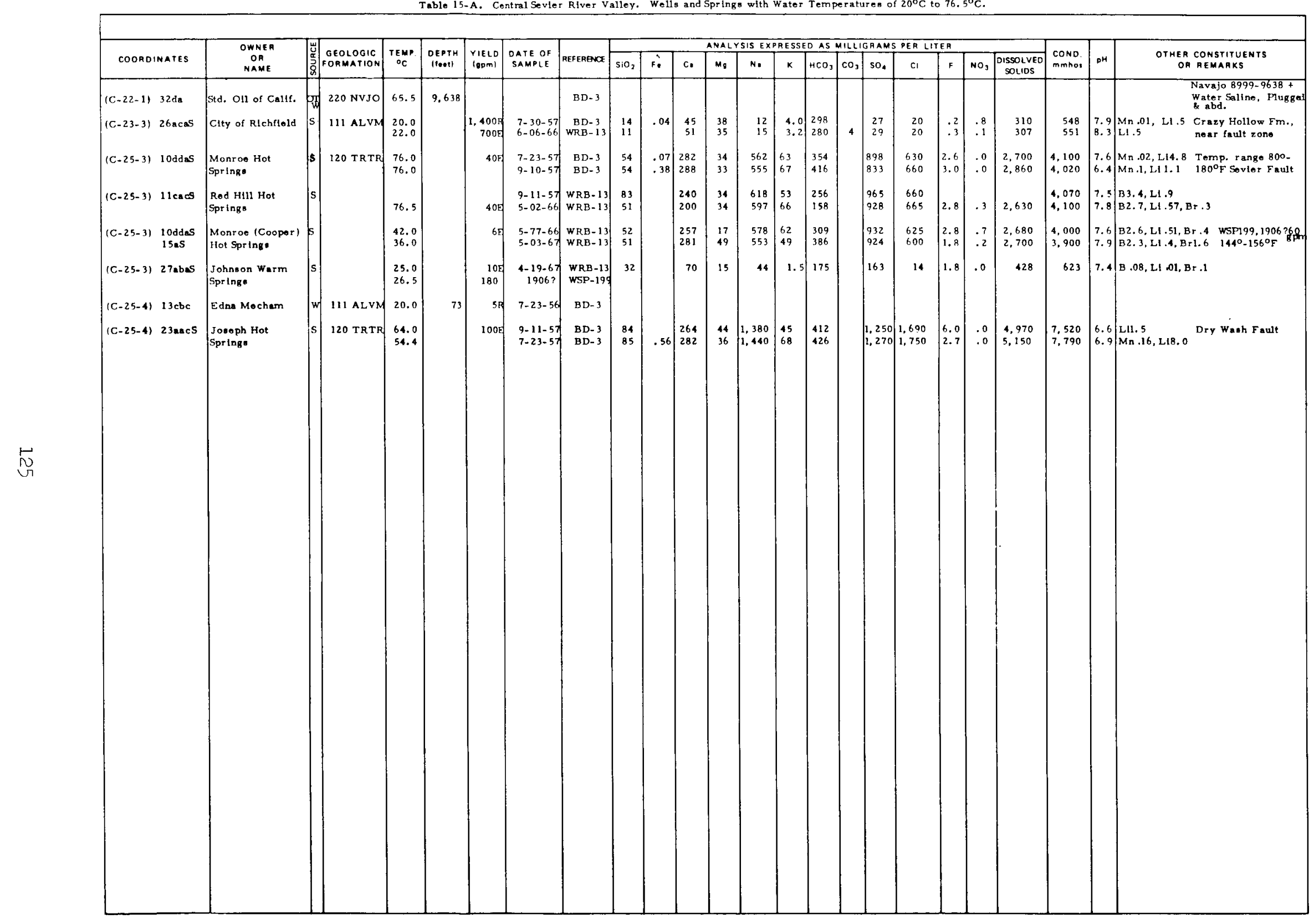


Table 15-B. Central Sovier Rlver Valley. Wolls and Springs with Water Tomporatures of $15.5^{\circ}$ to $19.5^{\circ} \mathrm{C}$.

\begin{tabular}{|c|c|c|c|c|c|c|c|c|c|c|c|c|c|c|c|c|c|c|c|c|c|c|c|}
\hline COOROINATES & $\begin{array}{l}\text { OWNER } \\
\text { Non } \\
\text { NAME }\end{array}$ & 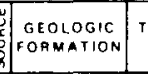 & TEMP. & 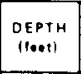 & 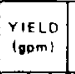 & $\begin{array}{l}\text { OAIE OF } \\
\text { SAMPLIE }\end{array}$ & Reteremere & $\mathrm{SiO}_{2}$ & . & $c$ & MaLY & Ne & ${ }^{2}$ & 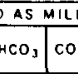 & $\begin{array}{l}\text { LIGRAM } \\
300 .\end{array}$ & $\begin{array}{l}\text { PEALIT } \\
\mathrm{a}^{\text {PI }}\end{array}$ & $F$ & No, $1^{0}$ & $\begin{array}{l}\text { Dissolvet } \\
\text { solios }\end{array}$ & $\begin{array}{l}\text { COND } \\
\text { mmhoo }\end{array}$ & ${ }^{\mathrm{NH}}$ & & $\begin{array}{l}\text { DHFE CONSTITUUN TS } \\
\text { OR AEMARKS }\end{array}$ \\
\hline (C-17-1) 34bca & $\begin{array}{l}\text { Sanpete Fitoh \& } \\
\text { Giame }\end{array}$ & $N 111$ ALVM & 15.5 & 60 & $15 \mathrm{~A}$ & & BD-3 & & & & & & & & & & & & & & & & \\
\hline$(C-17-1) 34 b d b_{1}$ & $\begin{array}{l}\text { Sanpere Fish k } \\
\text { Game }\end{array}$ & 111 ALYM & 15.5 & 60 & 15月 & $9-17-58$ & $\mathrm{BD}-3$ & & & & & & & & & & & & & & & & \\
\hline$(C-17-1) 34 \mathrm{bdb}$ & $\begin{array}{l}\text { Sanpete Flah \& } \\
\text { Ciame }\end{array}$ & 111 ALVM & 15.5 & 60 & 305 & & $\mathrm{BD}-3$ & & & & & & & & & & & & & & & & \\
\hline$(C-17-1) \quad 34 \mathrm{bdb}_{3}$ & $\begin{array}{l}\text { Sanpete Flah \& } \\
\text { Game }\end{array}$ & $N 111$ ALVM & 15.5 & 60 & $2 \mathrm{E}$ & $9-17-58$ & $B D-3$ & & & & & & & & & & & & & & & & \\
\hline$(C \cdot 17-1))_{34 d b}$ & $\begin{array}{l}\text { Sanpete Flsh \& } \\
\text { Giame }\end{array}$ & NII ALVM, & 15.5 & 60 & $2 \mathrm{E}$ & $9-17-58$ & $\mathrm{FD}-3$ & & & & & & & & & & & & & & & & \\
\hline$(C-17-1) 34 \mathrm{cdb}$ & $\begin{array}{l}\text { Sanpete Flsh } \\
\text { Gamo }\end{array}$ & $N \mid 111$ ALVM & $\begin{array}{r}15.5 \\
12.0\end{array}$ & 60 & $2 \mathrm{E}$ & $\begin{array}{l}8-06-56 \\
9-03-57\end{array}$ & $\begin{array}{l}\mathrm{BD}-3 \\
\mathrm{BD}-3\end{array}$ & 34 & .46 & ${ }^{51}$ & 44 & 143 & 8.7 & 227 & 48 & 282 & .5 & 2.5 & 731 & $1,\left.440\right|^{8}$ & 81 & 51.6 & \\
\hline$(C-18-1) \quad 35 \mathrm{aba}_{3}$ & Wesley Johnoon & 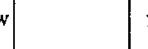 & 16.5 & & $1 \mathrm{E}$ & 8-25-58 & $B D-3$ & & & & & & & & & & & & & & & & Saline Taste \\
\hline$(C-19-1)$ 27dcd & Marlin Sorensen & w & 15.5 & & & & BD-3 & & & & & & & & & 120 & & & & & & & \\
\hline$(C-19-1) \quad 35 a b=$ & L. E. Nleleon & w & 18.5 & 295 & $5 \mathrm{R}$ & & $\mathrm{BD}-3$ & & & & & & & & & 135 & & & & & & & Pert, 55-58, 75-80 \\
\hline$(\mathrm{C}-19-1) \quad 35 \mathrm{bda}$ & J. Sanfilold & 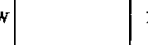 & 18.5 & 274 & $8 \mathrm{R}$ & 1940 & $B D-3$ & & & & & & & & & & & & & & & & \\
\hline$(\mathrm{D}-20-1) 5 \mathrm{~d} \mathrm{ab}$ & Roy Caldwell & $w$ & 16.0 & 93 & 5R & $7-16.58$ & $B D-3$ & & & & & & & & & & & & & & & & \\
\hline$(\mathrm{C}-21-1) \quad 11_{\mathrm{aba}}$ & Town of Redinond & $w 111$ ALVM & $\begin{array}{l}19.0 \\
21.0\end{array}$ & 41 & $12 R$ & $8-22-57$ & $\begin{array}{l}\mathrm{BD}-3 \\
\mathrm{BD}-3\end{array}$ & 40 & .03 & 34 & 19 & 144 & 6.5 & 158 & 95 & 181 & .5 & .7 & 599 & 1,040 & 8.0 & 41.6 & \\
\hline$(C-21-1) 11 \mathrm{ada}_{2}$ & Town of Redmond & & 19.0 & 40 & $1 \mathrm{E}$ & & $B D-3$ & & & & & & & & & & & & & & & & \\
\hline (C-21-1) 13abd & R. E. Noyos & $w \mid 11$ AL,VM & 19.0 & 291 & $50 \mathrm{M}$ & $8-20-58$ & BD-3 & 51 & & 35 & 15 & 104 & & 147 & 94 & 112 & & 1 & 484 & 758 & 7.9 & & \\
\hline$(C-21-1) 26 \mathrm{bdb}$ & Unitod Devel. Co. & of 120 TRTR & 15.5 & 722 & $4 M$ & $7-02.58$ & $B D-3$ & 35 & .03 & 34) & 18 & 86 & & 134 & 92 & 98 & & 1.2 & 430 & 715 & 7.6 & & \\
\hline$(\mathrm{C}-21-1) 33 \mathrm{acc}$ & Roland Crane & & 15.5 & 200 & & $8-08-56$ & BD-3 & & & & & & & & & & & & & & & & \\
\hline$(C-22-1)$ 9add & F. J. Gurney & 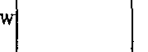 & 15.5 & 300 & & $2-28-58$ & BD-3 & & & & & & & & & & & & & & & & Water highly mineral altoc \\
\hline$(C-23-2) \quad 19 a a c$ & A1 Helquist & w & 15.5 & 190 & & $8-16-57$ & BD-3 & & & & & & & & & 25 & & & & & & & \\
\hline$(\mathrm{C}-23-2) \quad 19 \mathrm{dcc}$ & owen ogden & $\mathrm{w}$ & 16.5 & 88 & $8 \mathrm{M}$ & $8-14-57$ & ${ }^{\mathrm{BD}-3}$ & & & & & & & & & & & & & & & & \\
\hline (C-23-2) 23bdb & $\begin{array}{l}\text { Ventice Pumping } \\
\text { Company }\end{array}$ & & 15.5 & 124 & $50 \mathrm{E}$ & $2-25-58$ & BD-3 & & & & & & & & & 260 & & & & & & & Developed Spring \\
\hline$(C-23-2) \quad 26 \mathrm{bcb}$ & Vorton Oldroyd & $\mathrm{w}$ & 15.5 & 60 & $1 E$ & & ${ }^{B D}-3$ & & & & & & & & & 80 & & & & & & & \\
\hline (C-23-3) 25bab & City of Richfield & & 16.0 & 781 & & $7=06-60$ & BD-3 & 12 & & 52 & 35 & 27 & & 313 & 37 & 29 & & .4 & 341 & 576 & 7.7 & & $\begin{array}{l}\text { Porf. } 212-270,332-398 \\
420-462\end{array}$ \\
\hline$(C-25-4) \quad 13 \mathrm{bdb}$ & w. Wayland & & 16.0 & 70 & $5 \mathrm{R}$ & $7-25-56$ & BD-3 & & & & & & & & & & & & & & & & \\
\hline (C-25-4) 14add & Foon Taylor & & 19.5 & 65 & $5 R$ & 1936 & $B D-3$ & & & & & & & & & & & & & & & & \\
\hline$(\mathrm{D}-22-2) \quad 15 \mathrm{aac}$ & Fallna Irr. Co. & 㖜 & 19.0 & 2,000 & 6758 & $8-27-57$ & BD-3 & 11 & .28 & 26 & 10 & 47 & 5.1 & 196 & 43 & 6.0 & .4 & .1 & 245 & 409 & 8.0 & $\mathrm{L1.4}$ & Plugged below 620 \\
\hline$(\mathrm{D}-18-1) \quad 19 \mathrm{dabS}$ & Fayette Spring & \begin{tabular}{l|l}
$S \mid$ & $124 \mathrm{FLGF}$
\end{tabular} & 18.0 & & $1900 \mathrm{M}$ & $8-27-57$ & $B D-3$ & 13 & .0 & 49 & 43 & 99 & 1.9 & 305 & 43 & 152 & .3 & 1.2 & 553 & 1,020 & 7.6 & L1.3 & \\
\hline$(D-19-2)$ 4das & Clty of Cunnison s & $124 \mathrm{GRRV}$ & 19.5 & & $450 \mathrm{R}$ & & $\mathrm{BD}-3$ & & & & & & & & & & & & & & & & \\
\hline 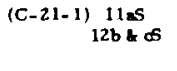 & Town of Rodmond: & $111 \mathrm{AL}, v \mathrm{M}$ & $\begin{array}{l}19.0 \\
21.0\end{array}$ & & $\left|\begin{array}{c}5,000 M \\
131 / 2 \\
1310\end{array}\right|$ & $\begin{array}{l}\text { Aug. } 1959 \\
1906\end{array}$ & $\mid \begin{array}{r}\text { BD-3 } \\
\text { WSP-199 }\end{array}$ & & & & & & & & & & & & & & & & \\
\hline
\end{tabular}


Table 15.B. Central Sevier Rtver Valley. Welle and Springe with Water Temperaturea of $15.5^{\circ}$ to $19.5^{\circ} \mathrm{C}$.

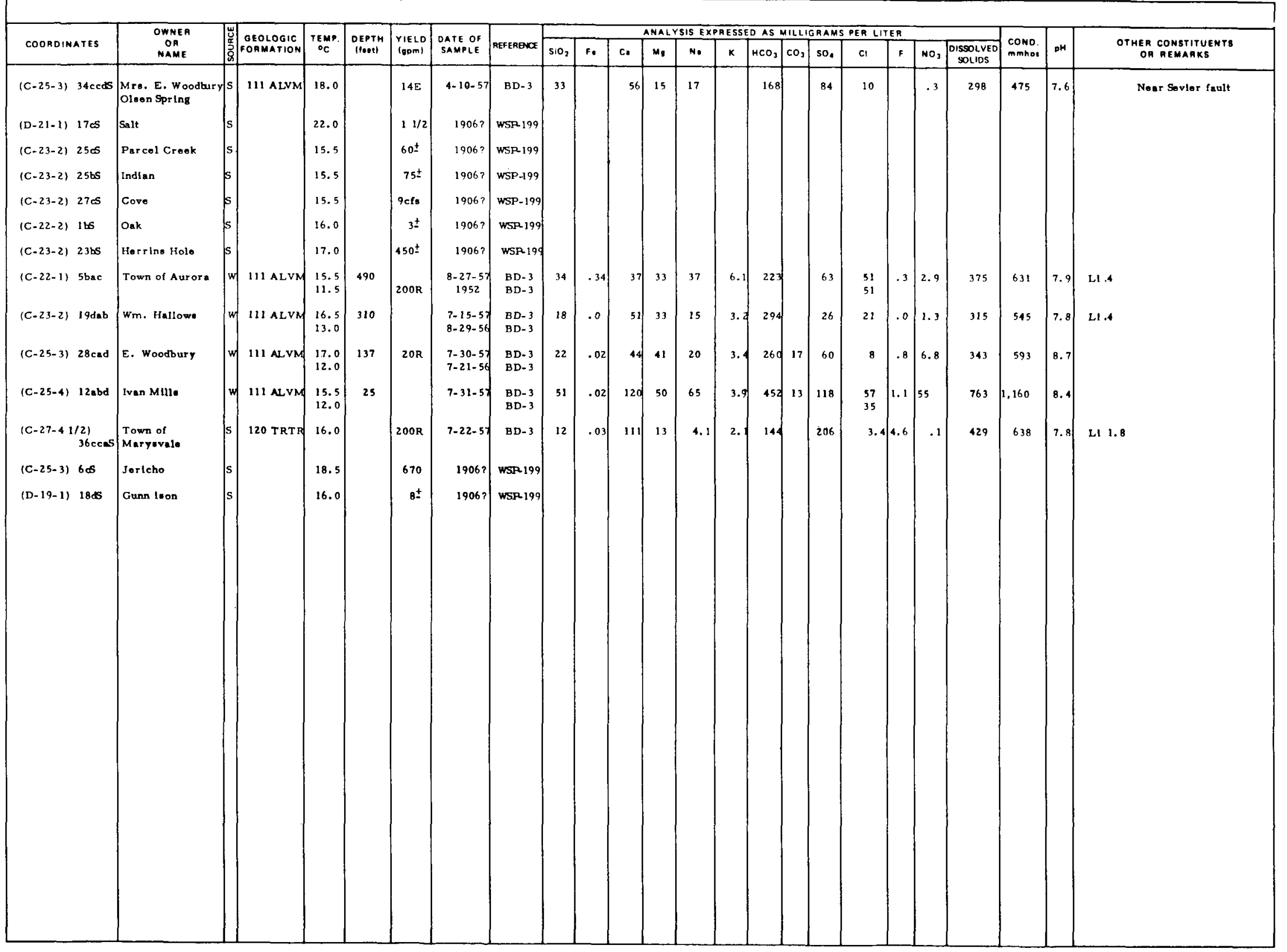


Table 16-A. San Pltch Valley. One Well and Two Springe with water Temperatures of $20^{\circ}$ in $55^{\circ} \mathrm{C}$.

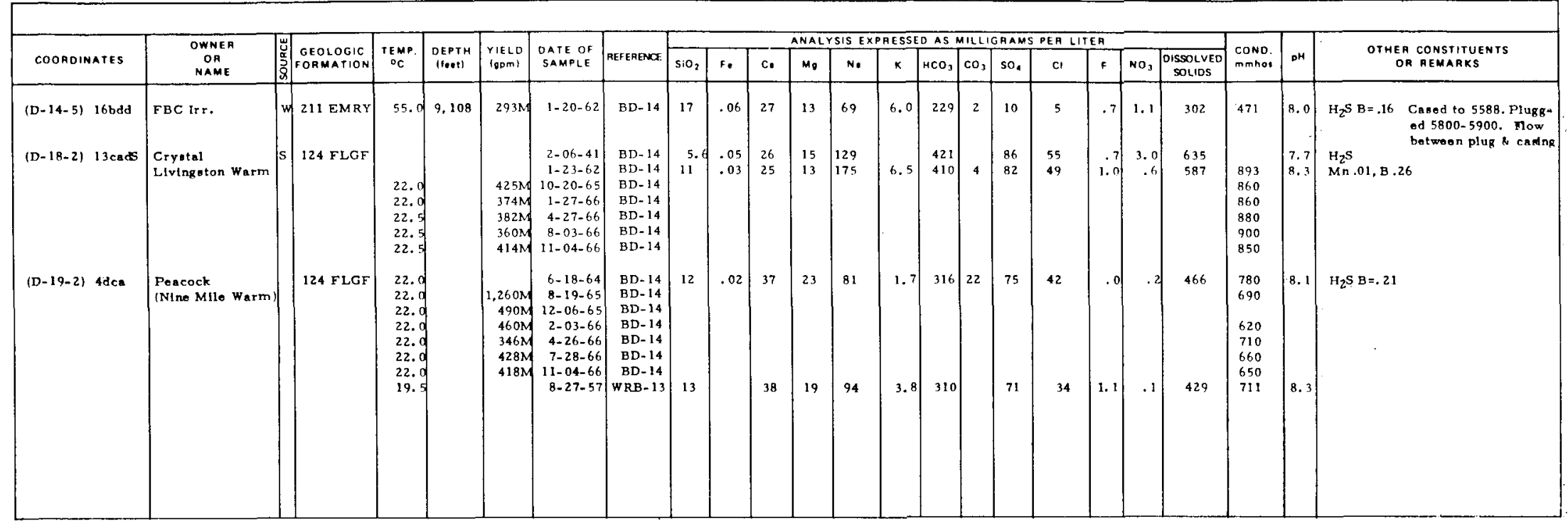

Table 16-B. San Pitch Valley. Wells and Springe with Water Temperatures of $15.5^{\circ}$ to $19.5^{\circ} \mathrm{C}$.

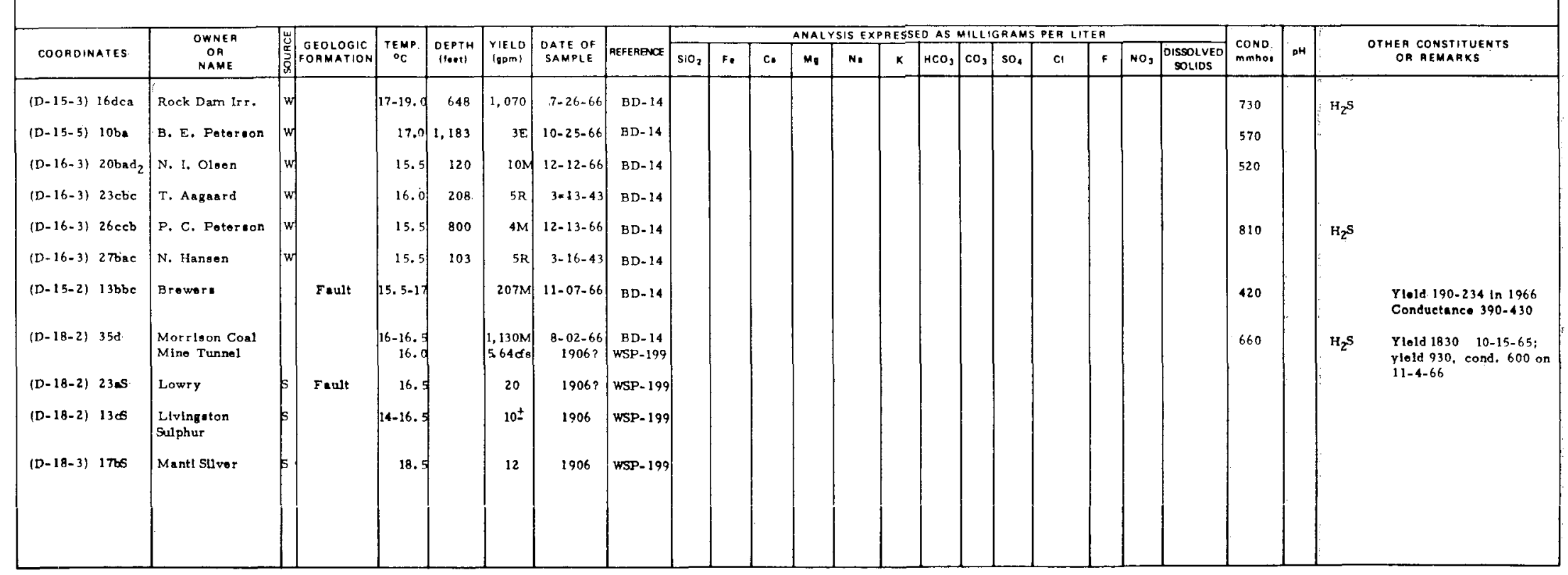


Table 17. Uinta Basin-Ashley Valley. Temperatures of Water from Oll Wells, an Irrigation Ditch, and Ashley Creek.

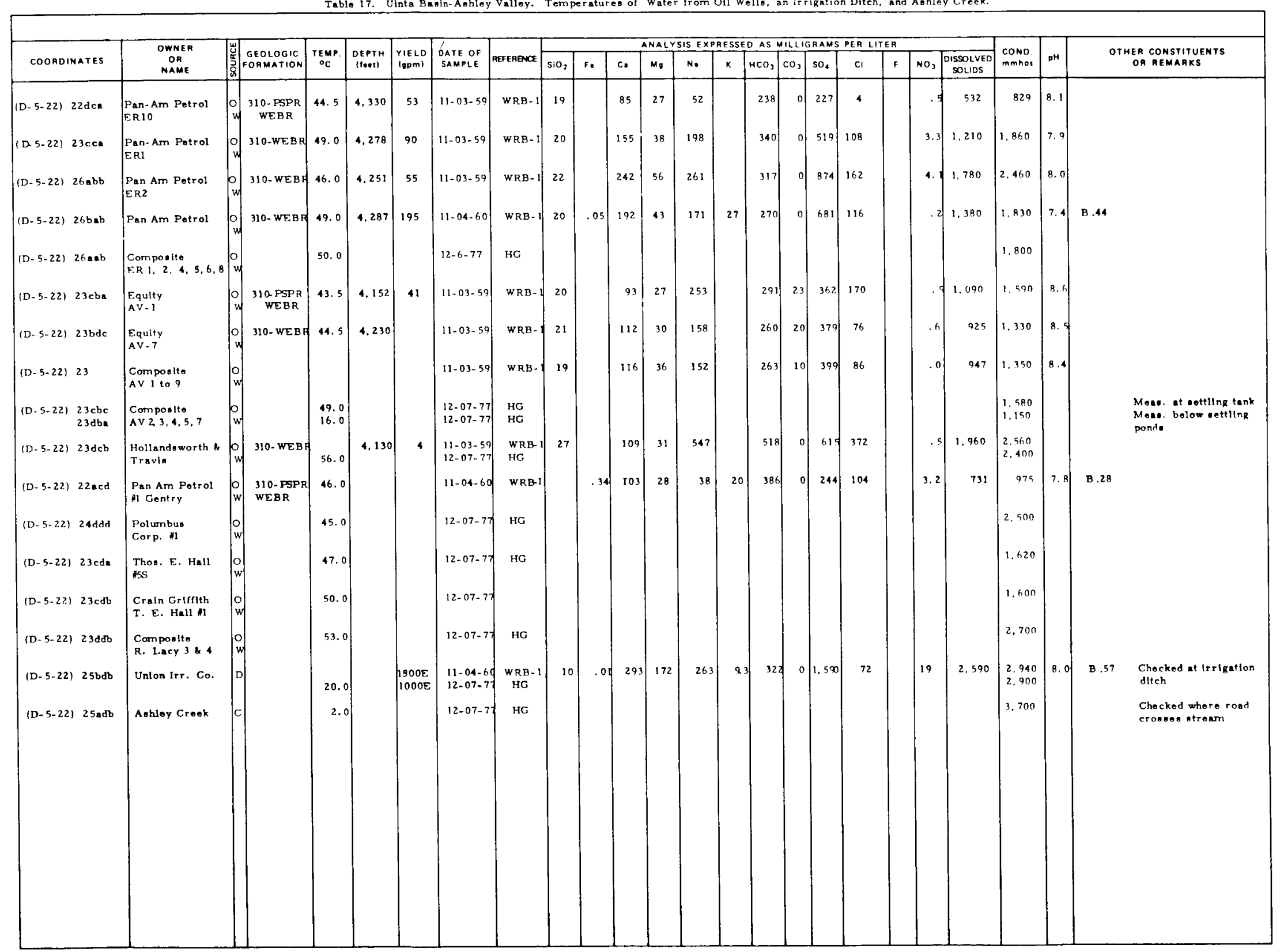


Table 19-A. Uinta Banin. Wellis and Springs with Water Temperatures of $20^{\circ}$ to $57.5^{\circ}$

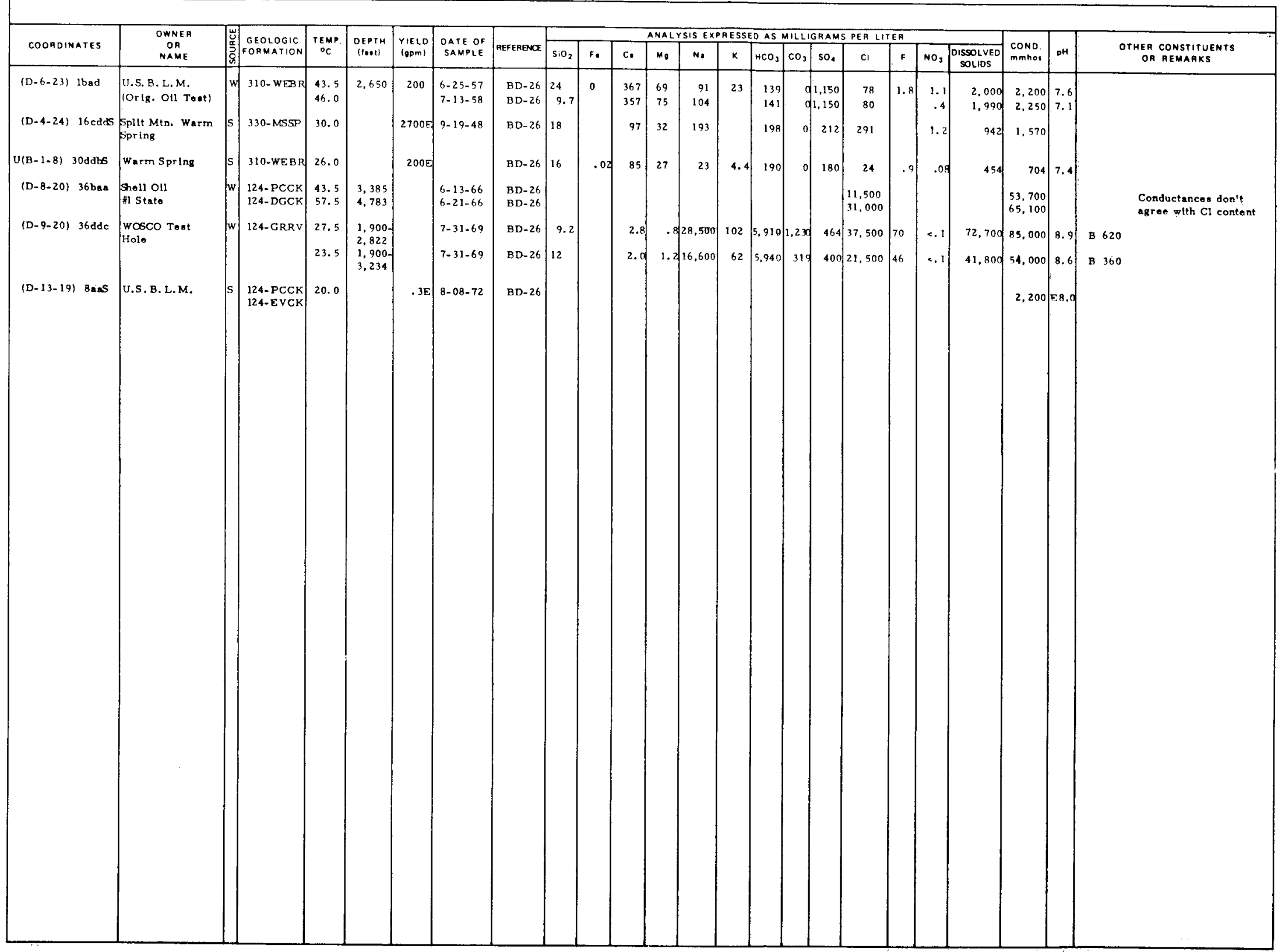


Table I9-B. Uinta Basin. Wells and Springs with Water Temperatures of $15.5^{\circ}$ to $19.5^{\circ} \mathrm{C}$

\begin{tabular}{|c|c|c|c|c|c|c|c|c|c|c|c|c|c|c|c|c|c|c|c|c|c|c|c|c|c|}
\hline \multirow{2}{*}{ COOROTMATES } & \multirow{2}{*}{\multicolumn{2}{|c|}{$\begin{array}{c}\text { OWNEA } \\
\text { OA } \\
\text { NAME }\end{array}$}} & \multirow{2}{*}{ 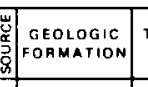 } & \multirow{2}{*}{$\begin{array}{c}\text { TEMP. } \\
{ }^{\circ} \mathrm{C} \\
\end{array}$} & \multirow{2}{*}{\begin{tabular}{|c|} 
DEPTH \\
ifteot
\end{tabular}} & \multirow{2}{*}{\begin{tabular}{|l|}
$Y E L D$ \\
Ispm)
\end{tabular}} & \multirow{2}{*}{\begin{tabular}{|l|} 
OATE OF \\
SAMPLE
\end{tabular}} & \multirow{2}{*}{ REREABNCE } & \multicolumn{13}{|c|}{ ANALYSIS EXPRESSED AS MIILLGRAMS PER LITER } & \multirow{2}{*}{$\begin{array}{l}\text { CONO. } \\
\text { mmhos: } \\
\end{array}$} & \multirow[b]{2}{*}{$\mathrm{pH}$} & \multirow{2}{*}{\multicolumn{2}{|c|}{$\begin{array}{c}\text { OTHER CONSTITUENTS } \\
\text { OR REMARKS }\end{array}$}} \\
\hline & & & & & & & & & $\mathrm{SiO}_{2}$ & $\mathrm{~F} \cdot$ & c. & $M_{0}$ & N. & k & $\mathrm{HCO}_{3}$ & $\mathrm{CO}_{3}$ & so, & a & $F$ & $\mathrm{NO}_{3}$ & $\begin{array}{l}\text { DISSOLVEO } \\
\text { SOLIDS }\end{array}$ & & & & \\
\hline$(D-3-21) \quad 30 d d c_{1}$ & L. Hullinger & $\mathrm{w}$ & 310-WEBR & $\begin{array}{l}17.0 \\
16.5\end{array}$ & 2.715 & 250 & $\left|\begin{array}{c}10-22-57 \\
10-08-58\end{array}\right|$ & $\left.\begin{array}{l}\text { BD-26 } \\
\text { BD-26 }\end{array}\right|_{1}$ & $\begin{array}{c}9.1 \\
10\end{array}$ & & $\begin{array}{l}88 \\
95\end{array}$ & $\begin{array}{l}29 \\
28\end{array}$ & $\begin{array}{c}13 \\
9\end{array}$ & & $\begin{array}{l}224 \\
224\end{array}$ & $\begin{array}{l}0 \\
0\end{array}$ & $\begin{array}{l}174 \\
176\end{array}$ & $\begin{array}{l}2.0 \\
3.5\end{array}$ & & $\begin{array}{l}.2 \\
.1\end{array}$ & $\begin{array}{l}425 \\
432\end{array}$ & $\begin{array}{l}653 \\
654\end{array}$ & $\left|\begin{array}{l}7.3 \\
7.7\end{array}\right|$ & & \\
\hline$(\mathrm{D}-3-21) \quad 30 \mathrm{dd} \mathrm{e}_{2}$ & 2. Hullingor & $w$ & 310. WEBR & 17.0 & 1,230 & & $5-01-73$ & $B D-26$ & 9.7 & 0.13 & 81 & 31 & 6.5 & 3.1 & 220 & 0 & 170 & 1.5 & 1.2 & & 413 & 648 & 7.5 & & \\
\hline$(D-6-25) 36 \mathrm{cab}$ & State of Utah & on & $210-C R C S$ & 17.0 & 1.420 & 0.5 & $9-26-56$ & $B D-26$ & 7.1 & & 491 & 26 & 37 & 7.4 & 335 & 01. & 1.240 & 12 & & .00 & 1.890 & 2.050 & 7.6 & & \\
\hline$(D-11-21) 31 b d d$ & d Golden Hatch & $w$ & $124-G R R V$ & 16.5 & 711 & 2 & $8-31-71$ & $B D-26 / 1$ & 15 & .01 & 0.7 & 0.7 & 370 &. & 562 & 6.5 & 220 & 9.3 & .9 & & 959 & 1.490 & $8.7 \mid$ & & \\
\hline U(C-2+1) $16 \mathrm{bbb}$ & L. E. Allred & $w$ & 123- DCRV & 16.5 & 685 & 10 & $7-06-58$ & $B D-26$ & & $<0.5$ & & & & & 360 & 34 & & 106 & & & & & & & \\
\hline $\mathrm{U}(\mathrm{C}-3.2) 30 \mathrm{cdd}$ & Herbert Murphy & w & 124-UINT & 15.5 & 72 & & $5-11-72$ & $B D-26$ & & & & & & & & & & & & & & 1,950 & & & \\
\hline U(C-4-2) lasa & Chas. Cox & w & 124- UINT & 15.5 & & & $5-09-72$ & BD-26 & & & & & & & & & & & & & & 3.500 & & & \\
\hline$U(C-4-4) 1 d a x$ & D. W. Covlngton & w & $112-\mathrm{OTSH}$ & 16.0 & 43 & 10 & 5.09 .72 & BD.26. & & & & & & & & & & & & & & 720 & & & \\
\hline$(D-11-21) 31 b d d$ & Golden Hatch & $w$ & $124-G R R V$ & $\begin{array}{l}18.0 \\
15.0\end{array}$ & 711 & $\begin{array}{l}2.0 \\
1.4\end{array}$ & $\begin{array}{r}8-20-7 \\
12-24-74\end{array}$ & $\left|\begin{array}{l}\text { BD-29 } \\
\text { BD-29 }\end{array}\right|$ & 17 & .02 & 1.5 & .3 & 340 & 1 & 534 & 62 & 210 & 5. 8 & & & 951 & 1.450 & 9.3 & & Meny trace olomente \\
\hline (D-4-23) $23 \mathrm{ddaS}$ & Dinosaur NM & $s$ & 310-PRKC & 15.5 & & $4 \mathrm{M}$ & $11-18-5$ & BD-26 & 11 & & 140 & 53 & 15 & & 284 & 0 & 345 & 6 & & 2.1 & 712 & 1.000 & 7.5 & & \\
\hline$(D-4-23) \quad 26 \mathrm{cabs}$ & Dinosaur NM & $s$ & 221-ENRD & 17.0 & & & $5-04-50$ & BD-26 1 & 10 & 0 & 78 & 37 & 13 & & 272 & 0 & 124 & 13 & .0 & .3 & 409 & 752 & 7.8 & & \\
\hline$(\mathrm{D}-4-23) \quad 27 \mathrm{bbas}$ & Dinosaur NM & $\mathrm{s}$ & $220-\mathrm{NVJO}$ & 16.0 & & $15 \mathrm{M}$ & $10-01-58$ & BD. 26 & 11 & & 67 & 26 & 11 & & 223 & 0 & 102 & 5.0 & & .6 & 333 & 529 & 7.8 & & \\
\hline$(D-4-23) \quad 27 \mathrm{cbds}$ & Dlnoenur NM & $s$ & 211-FRNR & 15.5 & & & $7+12-58$ & BD-26 & 16 & & 221 & 125 & 426 & & 230 & & 1,700 & 20 & .3 & 2.5 & 2,770 & 3,100 & & & \\
\hline (D-4-25) $31 \mathrm{ccas}$ & Near Dinoa aur & $s$ & 310. WEBR & 19.0 & & & $7-31-68$ & BD-26 & 11 & & 51 & 29 & 3.9 & 1,2 & 248 & 0 & 44 & 2.7 & .1 & 2.7 & 268 & 454 & 7.7 & & \\
\hline$(D-5-24) 32 \mathrm{~s}$ & Morrle Ranch & $\mathrm{s}$ & 310-WEBR & 17.0 & & $10 \mathrm{E}$ & & $T P-15$ & 13 & & & & & & & & 1,220 & BO & & & 1,960 & 2,410 & & & \\
\hline$(D-6-24) \quad 5 \mathrm{acds}$ & Mueket Shot Sp. & $s$ & 310-PRKC & 16.5 & & $\therefore \mathrm{E}$ & $5-11-73$ & $8 D-26$ & 16 & .03 & 240 & 64 & 88 & 27 & 108 & 0 & 910 & 192 & 1.2 & & 1,420 & 1.810 & 7.4 & & \\
\hline$(D-6-24) \circlearrowleft$ & Morrls Ranch & $s$ & 310- WEBR & 18.0 & & $10 \mathrm{E}$ & & $T P-15$ & 13 & & & & & & & & 485 & 51 & & & 911 & 1,260 & & & \\
\hline$(D-7-20) \quad 25 \mathrm{~b} d s$ & SE of Loota & $s$ & III-ALVM & 15.5 & & $40 \mathrm{E}$ & $10-06-48$ & BD. 26 & 24 & & 76 & 35 & 89 & & 342 & 0 & 166 & 46 & & 10 & 614 & 939 & & & \\
\hline (D-9-17) $2 \mathrm{Idca}$ & $\begin{array}{l}\text { U.S. B.L.M. } \\
\text { Southern Basin }\end{array}$ & $\mathrm{w}$ & 124-UINT & 17.5 & 22 & 3 & $9-03-71$ & BD-26 & 11 & .06 & 20 & 16 & 510 & 2.2 & 467 & & 720 & 91 & .2 & & 1,600 & 2,350 & 8. 3 & & $\begin{array}{l}\text { Shallow well. Water } \\
\text { probably warmed by sun }\end{array}$ \\
\hline$(D-10.24) \quad 2 \mathrm{acd}$ & $\begin{array}{l}\text { U.S. B. L.M. } \\
\text { Southern Banin }\end{array}$ & $w$ & 111-ALVM & 18.5 & 12 & & $7-13-58$ & BD-26 & 13 & & 57 & 19 & 44 & & 219 & & 93 & 30 & & .8 & 365 & 6.35 & $7.5 \mid$ & & \\
\hline$(D-12-21) 19 b d \&$ & Sulphur Sp. & 5 & 124-PCCK & 19.5 & & $20 \mathrm{~g}$ & $8-30-71$ & BD-26 & 15 & .02 & 1.6 & .6 & 230 & . & 352 & 32 & 150 & 6.3 & .2 & & 613 & 968 & 8.5 & & Probably rolated to \\
\hline (D-15-20)15bbdS & Flat Rock Moes & 5 & 124-PCCK & 17.0 & 160 & $.2 \mathrm{M}$ & $8-31-71$ & $\mid$\begin{tabular}{|c|}
$B D-20$ \\
$B D-2 A$
\end{tabular} & 16 & .01 & 57 & 16 & 24 & & 242 & 0 & 57 & $\begin{array}{r}7.9 \\
3184\end{array}$ & .1 & & 301 & 478 & 7.6 & $\begin{array}{l}\text { BDR-29 } \\
\text { Reparta }\end{array}$ & $\begin{array}{l}\text { Probably warmed by sur } \\
\text { Tempa. of } 3 \text { to } 12.5^{\circ} \\
\text { flowa. } .75 \text { to } 3 \mathrm{gpm}\end{array}$ \\
\hline $\begin{array}{l}U(C-2-1) \\
U(C-2-1) \\
U(C) c b \\
27 d b b\end{array}$ & So. of Roosovolt & $\mid$ & 112-OTSH & 18.5 & 42 & 7 & $7-06-58$ & BD-26 & 9 & & 4.0 & 1.5 & 147 & & 246 & 0 & 77 & 37 & & 2.3 & 38.3 & 6.39 & & & \\
\hline$U(C-2-6) 14 \mathrm{db} \Phi$ & Ducheene Rlver & $s$ & 123-DCRY & 18.0 & & $5 \mathrm{E}$ & $7-04-58$ & BD-26 & 11 & & 119 & 107 & 16 & & 186 & 0 & 524 & 51 & & .2 & 1,004 & 1,274 & & & \\
\hline$U(C-2-6) 14 d b c$ & Ducheosne Rtver & $\mathrm{w}$ & 112-OTSH & 17.5 & 95 & 20 & $7-04-58$ & BD-26 & 13 & & 90 & 64 & 24 & & 457 & 0 & 138 & 16 & & .2 & 570 & 921 & & & \\
\hline$U(C-2-6) 14 d b \infty$ & Duchesne Rlvar & $s$ & 123-DCRV & 17.5 & & & $7-04-58$ & BD. 26 & & $<0.5$ & & & & & 325 & & & 56 & & & & & & & \\
\hline $\mathrm{U}(\mathrm{C}-3-2) 3 \mathrm{Bbec}$ & SW of Roosevelt & $w$ & $112-\mathrm{OTSH}$ & 15. & 48 & & $5-09-72$ & BD. 2 & & & & & & & & & & & & & & 1,400 & & & $\begin{array}{l}\text { Shallow Well. Water } \\
\text { probably warmed by aur }\end{array}$ \\
\hline$U(D-3-2) \quad 7 d d a$ & At Randlett & w & $112.0 \mathrm{TSH}$ & 15. & 40 & & $7-07-58$ & & 15 & & 128 & 71 & 260 & & 460 & 0 & 652 & 78 & & 11 & 1,470 & 2,010 & & & \\
\hline
\end{tabular}


Table 19-C. Uinta Basin. Gas and Water Welle with Temperatures of $17^{\circ}$ to $34^{\circ} \mathrm{C}$. (Monltorad by USCS).

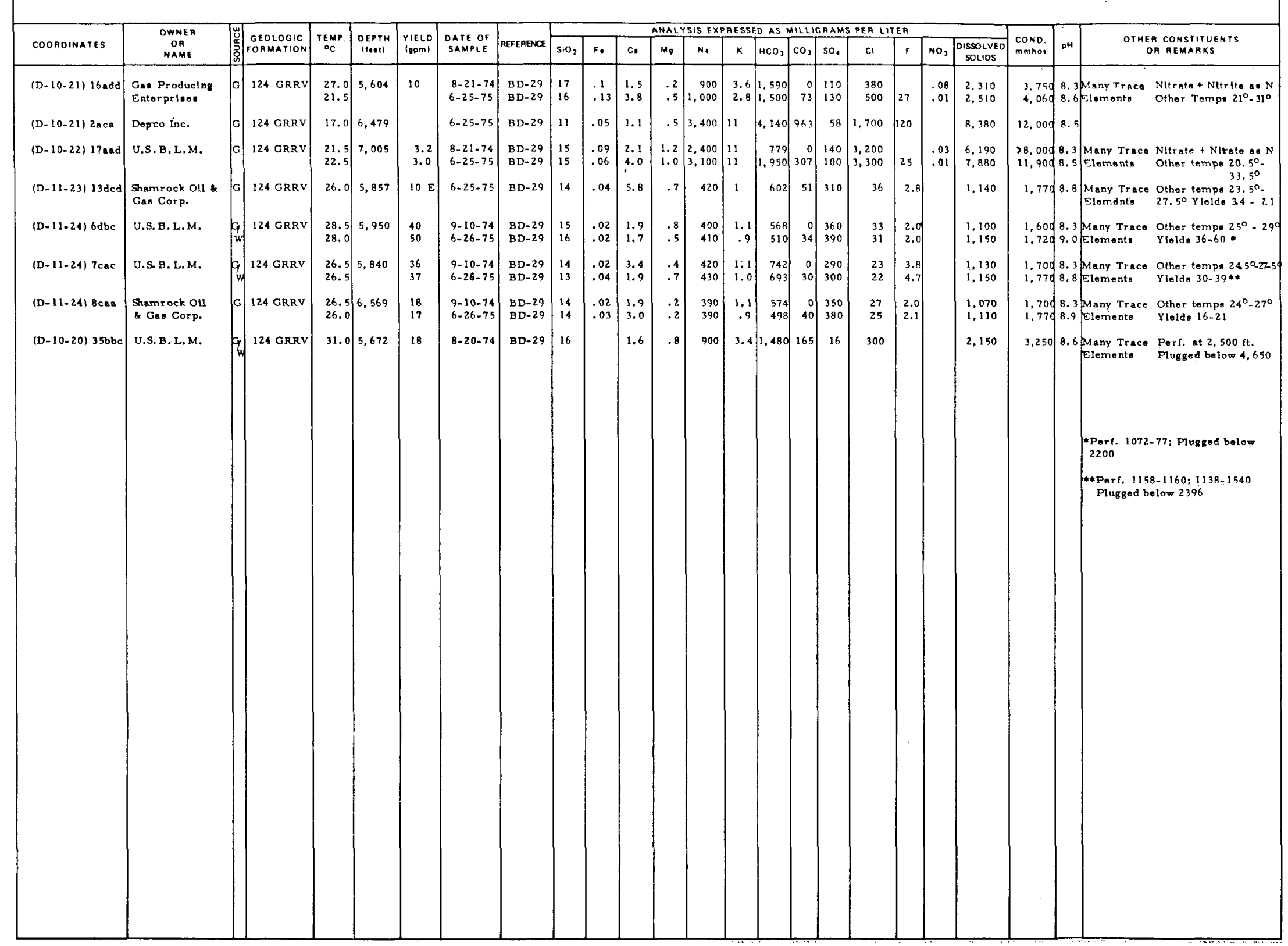


Table 20-A. Northern Utah Valley. Welle and Springs with Water Temperatures of $20^{\circ}$ to $46^{\circ} \mathrm{C}$

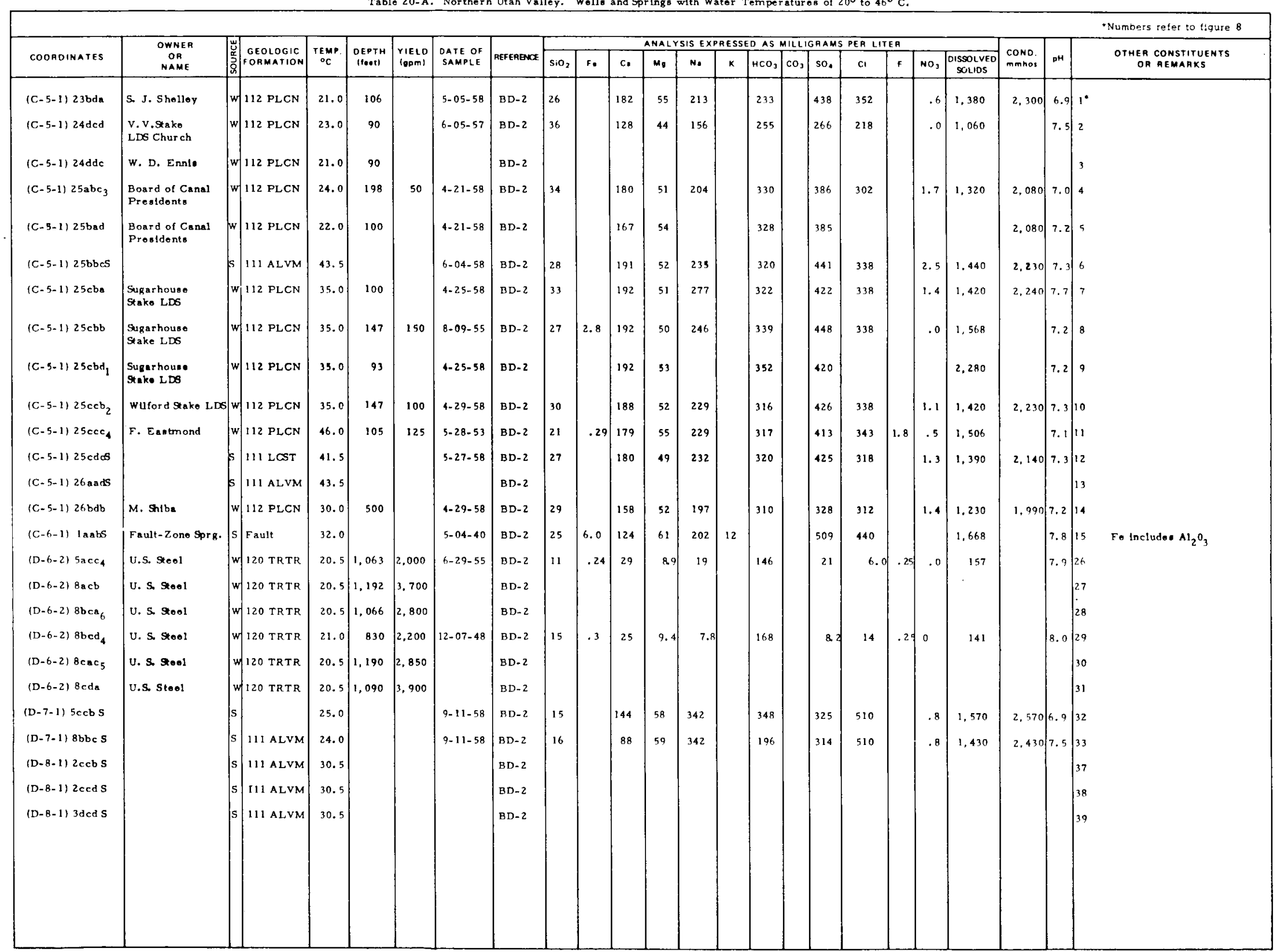


Table 20-B. Northern Utah Valley. Wells with Water Temperatures of $15.5^{\circ}$ to $19.5^{\circ} \mathrm{C}$.

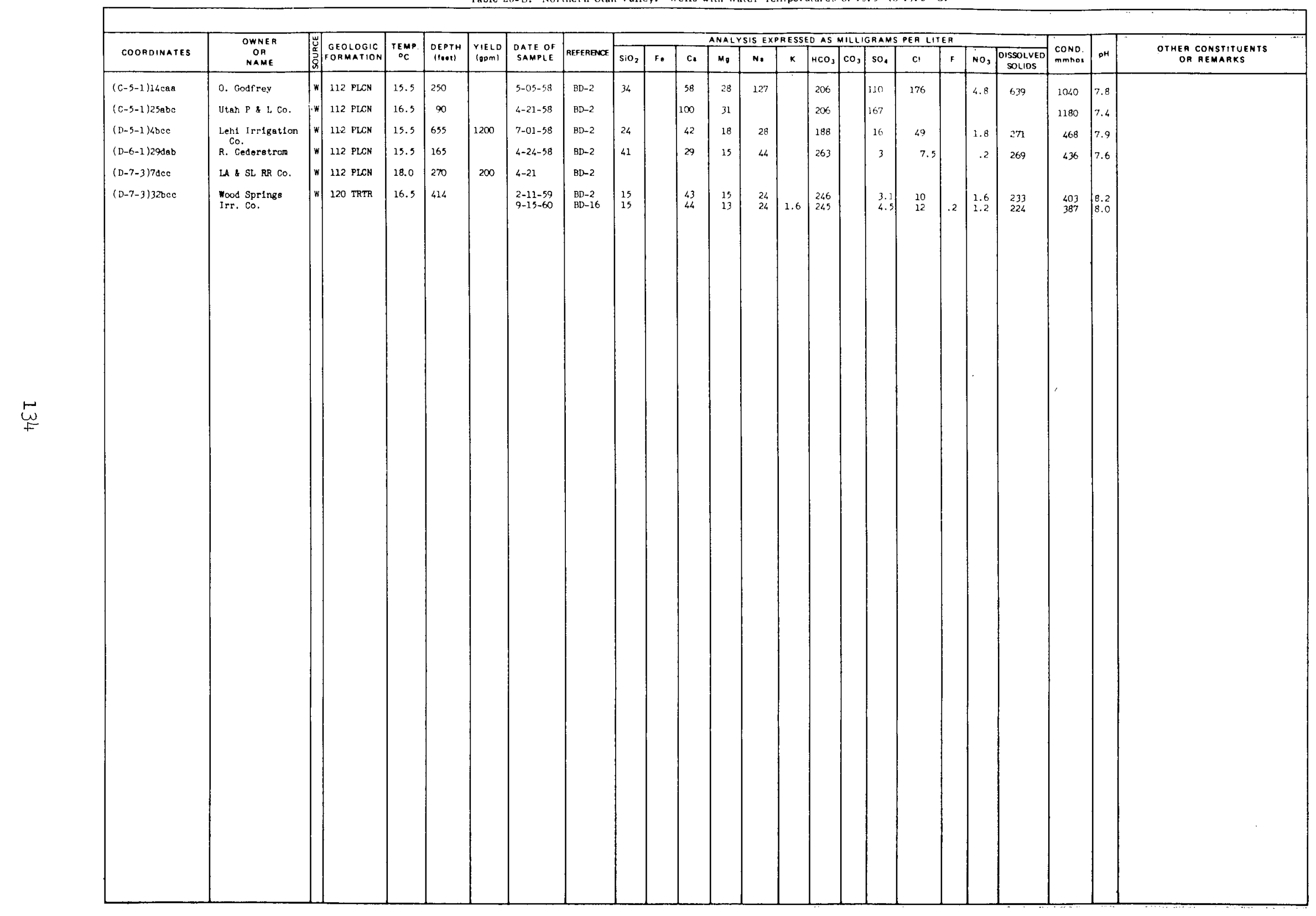


Table 21-A. Southern Utah and Goshen Valleys. Wello with Wator Temperatures of $20^{\circ}$ to $34^{\circ} \mathrm{C}$

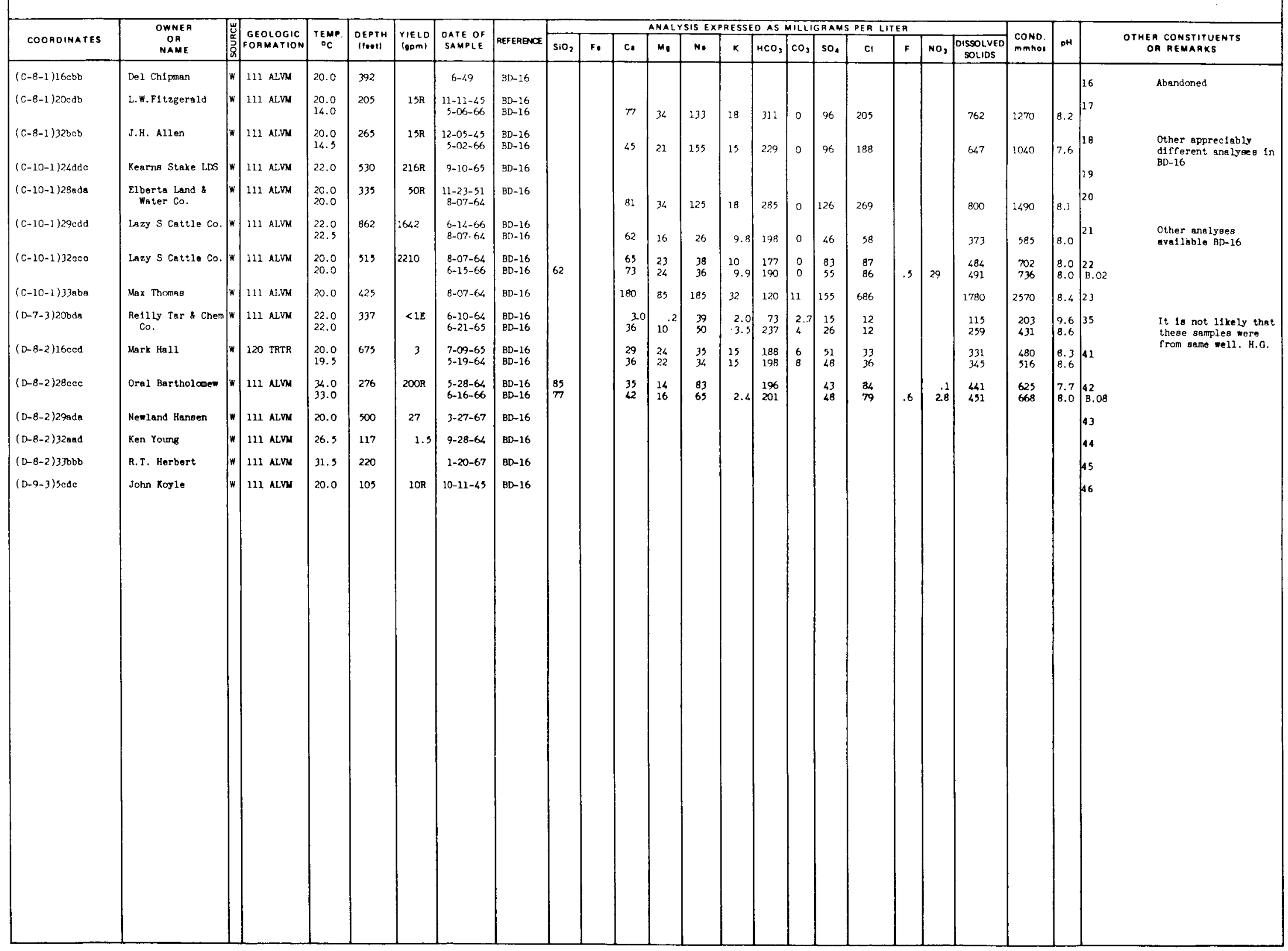


Table 21-8. Southern Utah Valley. Welle with Water Temporatures of $15.5^{\circ}$ to $19.5^{\circ} \mathrm{C}$

\begin{tabular}{|c|c|c|c|c|c|c|c|c|c|c|c|c|c|c|c|c|c|c|c|c|c|c|c|c|c|}
\hline COORDINATES & $\begin{array}{c}\text { OWNER } \\
\text { OR } \\
\text { NAME }\end{array}$ & 然 & $\begin{array}{l}\text { GEOLOGIC } \\
\text { FORMATION }\end{array}$ & TEMP. & $\begin{array}{l}\text { OEPTH } \\
\text { (teet) }\end{array}$ & $\begin{array}{l}\text { YIELO } \\
\text { lopml }\end{array}$ & \begin{tabular}{|l|} 
DATE OF \\
SAMPLE
\end{tabular} & REF EREVCE & $\mathrm{SiO}_{2}$ & $\mathrm{FE}$ & $c_{1}$ & $\begin{array}{l}\text { ANAL } \\
M_{0}\end{array}$ & $\begin{array}{l}\text { SIS E } \\
\text { N. }\end{array}$ & \begin{tabular}{|l|l|} 
PRESSE \\
\end{tabular} & $\begin{array}{l}\text { EOAS } \\
\text { HCO, }\end{array}$ & MILLI & $\begin{array}{l}\text { GRAMS } \\
\text { so. }\end{array}$ & $\begin{array}{c}\text { SEA LI } \\
C^{\prime}\end{array}$ & $\frac{E R}{F}$ & No, & \begin{tabular}{|l} 
Dissolve! \\
solios
\end{tabular} & $\begin{array}{l}\text { cono. } \\
\text { mimhor }\end{array}$ & OH & & $\begin{array}{l}\text { OTMER CONSTITUENTS } \\
\text { OR AEMARKS }\end{array}$ \\
\hline$(\mathrm{D}-7-2) \quad 35 \mathrm{ccd}_{2}$ & Angus Halos & $|s|$ & $111 \mathrm{ALVM}$ & 16.0 & 420 & $90 \mathrm{R}$ & $5-12-64$ & BD- 16 & & & 50 & 17 & 18 & 4.7 & 268 & 0 & 7.2 & 9.9 & & & 258 & 436 & 8.1 & & \\
\hline$(\mathrm{D}-7-2) 36 \mathrm{ccb}$ & w. J. Money & $w$ & 11 ALVM & 18.5 & 504 & 170 & $7-27-64$ & $\mathrm{BD}-16$ & & & & & & & & & & & & & & & & & \\
\hline$(D-7-2) 36 \mathrm{dbc} c_{3}$ & Kolob Farms & $\mathrm{w}$ & 111 ALVM & 15.5 & 450 & 4.3 & $3-23-67$ & BD- 16 & & & & & & & & & & & & & & & & & \\
\hline$(D-7-2) 36 d c c_{4}$ & c. A. Spafford & $w$ & $111 \mathrm{ALVM}$ & 16.5 & 522 & 587 & $\mid 10-27-65$ & BD- 16 & & & & & & & & & & & & & & & & & \\
\hline$(D-7-3) 20 \mathrm{acb}$ & $\begin{array}{l}\text { Utah Co. } \\
\text { Packing Co. }\end{array}$ & $\mathrm{w}$ & 111 ALVM & $\begin{array}{l}15.5 \\
15.5\end{array}$ & 315 & $2 \mathrm{R}$ & $\begin{array}{l}5-19-64 \\
6-21-65\end{array}$ & $\begin{array}{l}\text { BD- } 16 \\
\text { BD-16 }\end{array}$ & & & $\begin{array}{l}54 \\
21\end{array}$ & $\begin{array}{l}16 \\
17\end{array}$ & $\begin{array}{l}35 \\
38\end{array}$ & $\begin{array}{l}3.1 \\
3.5\end{array}$ & $\begin{array}{l}267 \\
171\end{array}$ & \begin{tabular}{|l|}
4.2 \\
8
\end{tabular} & $\begin{array}{l}19 \\
19\end{array}$ & $\begin{array}{l}24 \\
27\end{array}$ & & & $\begin{array}{l}310 \\
228\end{array}$ & $\begin{array}{l}534 \\
425\end{array}$ & $\begin{array}{l}8.4 \\
8.6\end{array}$ & & \\
\hline$(\mathrm{D}-7-3) \quad 20 \mathrm{bcd}$ & $\begin{array}{l}\text { Pacific States } \\
\text { Cast Iron Pipe }\end{array}$ & $w$ & $111 \mathrm{ALVM}$ & 16.0 & 325 & $80 \mathrm{R}$ & $k-10-64$ & BD- 16 & 3.4 & & 46 & 11 & 38 & 3.1 & 273 & 0 & 3.4 & 15 & & & 253 & 476 & 8.0 & & \\
\hline$(\mathrm{D}-7-3) 20 \mathrm{bcd}$ & $\begin{array}{l}\text { Pacific States } \\
\text { Cast Iron Pipe }\end{array}$ & $\mathrm{w}$ & $111 \mathrm{ALVM}$ & 16.5 & 908 & $80 \mathrm{R}$ & $1-22-47$ & BD- 16 & & & & & & & & & & & & & & & & & \\
\hline$(D-7-3)_{20 b c d}$ & $\begin{array}{l}\text { Pacific States } \\
\text { Cast Iron Pipe }\end{array}$ & w & 111 ALVM & 16.5 & 635 & $70 \mathrm{R}$ & $1-15-47$ & BD- 16 & & & & & & & & & & & & & & & & & \\
\hline$(D-7-3) 20 b c d_{4}$ & $\begin{array}{l}\text { Pacific Statos } \\
\text { Cast Iron Pipe }\end{array}$ & w & $111 \mathrm{ALVM}$ & 16.5 & 478 & $75 \mathrm{~F}$ & $1-11-47$ & BD -16 & & & & & & & & & & & & & & & & & \\
\hline$(D-7-3)$ 20bdb & $\begin{array}{l}\text { Rallyy Tar } \\
\text { Chemlcal Co. }\end{array}$ & $\mathrm{w}$ & $111 \mathrm{ALVM}$ & $\begin{array}{l}15.5 \\
14.0\end{array}$ & 560 & $<1 \mathrm{E}$ & $\begin{array}{l}6-10-64 \\
4-20-66\end{array}$ & $\begin{array}{l}\text { BD-16 } \\
\text { BD-16 }\end{array}$ & & & $\begin{array}{l}32 \\
46\end{array}$ & $\begin{array}{l}12 \\
11\end{array}$ & $\begin{array}{l}51 \\
52\end{array}$ & $\begin{array}{l}3.5 \\
3.1\end{array}$ & $\begin{array}{l}210 \\
322\end{array}$ & $\begin{array}{r}15 \\
0\end{array}$ & $\begin{array}{r}28 \\
0\end{array}$ & $\begin{array}{l}13 \\
13\end{array}$ & & & $\begin{array}{l}266 \\
314\end{array}$ & $\begin{array}{l}445 \\
528\end{array}$ & $\begin{array}{l}8.5 \\
8.0\end{array}$ & & \\
\hline (D-7-3) 28bdb & $\begin{array}{l}\text { U.S. Fleh k } \\
\text { Wudd1fo }\end{array}$ & $w$ & $112 \mathrm{PLCN}$ & $\begin{array}{l}17.0 \\
18.0\end{array}$ & 338 & $1200 \mathrm{R}$ & $\begin{array}{l}6-21-63 \\
5-11-64\end{array}$ & $\begin{array}{l}\text { BD-16 } \\
\text { BD- } 16\end{array}$ & 14 & & $\begin{array}{l}188 \\
191\end{array}$ & $\begin{array}{l}63 \\
68\end{array}$ & $\begin{array}{l}69 \\
60\end{array}$ & 5.1 & $\begin{array}{l}258 \\
234\end{array}$ & $\begin{array}{l}0 \\
0\end{array}$ & $\mid \begin{array}{l}537 \\
562\end{array}$ & $\begin{array}{l}78 \\
82\end{array}$ & & .6 & $\begin{array}{l}1,080 \\
1,140\end{array}$ & $\begin{array}{l}1.490 \\
1,470\end{array}$ & $\begin{array}{l}7.5 \\
8.0\end{array}$ & & \\
\hline$(\mathrm{D}-7-3) \quad 28 \mathrm{cab}$ & Park Ro She Corp & w & $111 \mathrm{ALVM}$ & 15.5 & 290 & $30 \mathrm{R}$ & $9-15-64$ & BD-16 & & & & & & & & & & & & & & & & & \\
\hline$(D-8-1) \quad 11 \mathrm{cbd}$ & w. J. McClain & w & $111 \mathrm{PLCN}$ & 16.5 & 151 & .14 & $5-19-64$ & BD-16 & & & 56 & 17 & 48 & 16 & 128 & 5.4 & 48 & 122 & & & 435 & 676 & 8.4 & & \\
\hline$(D-8-1) \quad 12 \mathrm{dda}$ & w. A. Cornaby & $w$ & $\begin{array}{lll}11 & \text { ALVM }\end{array}$ & 15.5 & 196 & .6 & $7-06-64$ & BD-16 & & & & & & & & & & & & & & & & & \\
\hline$(\mathrm{D}-8-1) \quad 13 \mathrm{aaa}$ & R. G. Francls & $|w|$ & 111 ALVM & 16.0 & 358 & 7.3 & $7-06-64$ & $\mathrm{BD}-16$ & & & & & & & & & & & & & & & & & \\
\hline$(D-8-1) \quad 13 d a a_{3}$ & D. F. Meocham & $w$ & 111 ALVM & $\begin{array}{l}19.0 \\
19.0\end{array}$ & 460 & 48 & $\begin{array}{l}5-18-64 \\
6-25-65\end{array} \mid$ & $\begin{array}{l}\text { BD- } 16 \\
\text { BD-16 }\end{array}$ & & & $\begin{array}{l}40 \\
20\end{array}$ & $\begin{array}{l}22 \\
23\end{array}$ & $\begin{array}{l}18 \\
19\end{array}$ & $\begin{array}{l}11 \\
10\end{array}$ & $\begin{array}{l}181 \\
154\end{array}$ & $\begin{array}{l}9.0 \\
5\end{array}$ & $\begin{array}{l}51 \\
40\end{array}$ & $\begin{array}{l}17 \\
16\end{array}$ & & & $\begin{array}{l}313 \\
268\end{array}$ & $\begin{array}{l}431 \\
375\end{array}$ & $\begin{array}{l}8.6 \\
8.4\end{array}$ & & \\
\hline$(\mathrm{D}-8-2) 3 \mathrm{ccd}$ & L. M. Banke & $\mathrm{w}$ & $111 \mathrm{ALVM}$ & $\begin{array}{l}15.5 \\
13.0\end{array}$ & 420 & $40 \mathrm{R}$ & $\begin{array}{r}7-19-65 \\
12-07-61\end{array}$ & $\begin{array}{l}\text { BD- } 16 \\
\text { BD-16 }\end{array}$ & & & 17 & 18 & 23 & 5.5 & 154 & 14 & 13 & 8.2 & & & 195 & 310 & 8.5 & & \\
\hline $\begin{array}{r}(\mathrm{D}-8-2) \\
\text { or } 4 \mathrm{bcb}\end{array}$ & Lakeside Irr. Co. & $w$ & $120 \mathrm{TRTR}$ & $\begin{array}{l}16.5 \\
16.5\end{array}$ & 544 & 36 & $\begin{array}{l}5-12-64 \\
4-20-66\end{array}$ & $\begin{array}{l}\text { BD- } 16 \\
\text { BD-16 }\end{array}$ & & & $\begin{array}{l}24 \\
20\end{array}$ & $\begin{array}{l}10 \\
11\end{array}$ & $\begin{array}{l}51 \\
50\end{array}$ & $\begin{array}{l}3.5 \\
3.1\end{array}$ & $\begin{array}{l}215 \\
246\end{array}$ & $\begin{array}{l}8 \\
0\end{array}$ & $\begin{array}{r}14 \\
0\end{array}$ & $\begin{array}{l}9.2 \\
8.5\end{array}$ & & & $\begin{array}{l}240 \\
246\end{array}$ & $\begin{array}{l}396 \\
381\end{array}$ & $\begin{array}{l}8.4 \\
8.0\end{array}$ & & 1 \\
\hline$(\mathrm{D}-8-2) 4 \mathrm{dad}$ & W. M.Soreneen & $w$ & $120 \mathrm{TRTR}$ & \begin{tabular}{|l|}
18.0 \\
18.0
\end{tabular} & 634 & $70 \mathrm{R}$ & $\begin{array}{l}5-19-64 \\
8-19-64\end{array}$ & $\mid \begin{array}{l}\text { BD-16 } \\
\text { BD-16 }\end{array}$ & 34 & & $\begin{array}{l}31 \\
29\end{array}$ & $\begin{array}{l}13 \\
12\end{array}$ & $\begin{array}{l}37 \\
41\end{array}$ & 3.9 & $\begin{array}{l}204 \\
234\end{array}$ & $\begin{array}{c}13 \\
0\end{array}$ & $\left|\begin{array}{c}15 \\
25\end{array}\right|$ & ${ }_{12}^{7.8}$ & & .3 & $\begin{array}{l}220 \\
230\end{array}$ & $\begin{array}{l}371 \\
354\end{array}$ & $\begin{array}{l}8.6 \\
8.1\end{array}$ & & \\
\hline$(\mathrm{D}-8-2)$ Tbcc & 1. E. Carlson & $|w|$ & 111 ALVM & 17.0 & 370 & $30 \mathrm{E}$ & $6-10-64$ & BD- 16 & & & 35 & 28 & 27 & 9.4 & 200 & 19 & 51 & 16 & & & 316 & 480 & 8.8 & & \\
\hline$(\mathrm{D}-\mathrm{B}-2) 7 \mathrm{cab}$ & H. L. Brooks & $|w|$ & $111 \mathrm{ALVM}$ & 17.0 & 263 & 30 & $8-20-64$ & BD- 16 & & & & & & & & & & & & & & & & & \\
\hline$(\mathrm{D}-8-2) 7 \mathrm{cbd}$ & J. R. Nolson & $w$ & $111 \mathrm{ALVM}$ & 18.0 & 167 & 30 & $8-20-64$ & BD- 16 & & & & & & & & & & & & & & & & & \\
\hline$(D-8-2) 7 d b c$ & Mark Hall & w & $111 \mathrm{ALVM}$ & 15.5 & 550 & 4 & $\mid 10-10-62$ & $B D-16$ & & & 28 & 29 & 25 & 9.0 & 212 & 12 & 31 & 20 & & & 300 & 483 & 8.4 & B. 07 & \\
\hline$(D-8-2) 7 d d a$ & M. E. Hall & $|w|$ & $111 \mathrm{ALVM}$ & 16.0 & 276 & $6 \mathrm{R}$ & $6-03-64$ & BD- 16 & & & 26 & 24 & 19 & 5.9 & 184 & , & 26 & 13 & & & 247 & 391 & 8.5 & & \\
\hline$(D-8-2) 7 d d d$ & M. E. Hall & $|w|$ & 111 ALVM & 16.0 & 520 & 5 & $4-12-40$ & BD- 16 & & & & & & & & & & & & & & & & & \\
\hline (D-8-2) 8a.a. & Elllot Saboy & $|w|$ & $111 \mathrm{ALVM}$ & 16.5 & 131 & 1 & $10-10.62$ & BD- 16 & & & 28 & 30 & 70 & 7.4 & 326 & 29 & 0 & 37 & & & 355 & 641 & 8.7 & B. 18 & \\
\hline (D-B-2) 8Db= & Richard Huntor & $\mathrm{w}$ & $111 \mathrm{ALVM}$ & 15.5 & 400 & 10 & $10-10-62$ & BD-16 & & & 24 & 19 & 27 & 4.7 & 203 & 11 & 2.9 & 12 & & & 209 & 340 & 8.6 & & \\
\hline
\end{tabular}


Table 21-B. Southern Utah Valley. Wolle with Water Temperatures of $15.5^{\circ}$ to $19.5^{\circ} \mathrm{C}$.

\begin{tabular}{|c|c|c|c|c|c|c|c|c|c|c|c|c|c|c|c|c|c|c|c|c|c|c|c|}
\hline COOADINATES & $\begin{array}{l}\text { OWNEA } \\
\text { OR }\end{array}$ & \begin{tabular}{|l|l|}
$\tilde{u}$ & GEOLOGIC \\
\end{tabular} & TEMP. & DEPTH & YYELO & DATE OF & REFEAONE & & & & ANAL & SISEX & RESSEI & DASA & MILLI & GAAMS & PER LIT & & & & cons. & Int & ENTS \\
\hline COOADINATES & $\begin{array}{l}\text { NAME } \\
\text { NAM }\end{array}$ & Dormation & & (16eet) & (8pm) & SAMPLE & REFEREACE: & sio, & $\mathrm{F} \cdot$ & c. & $m_{0}$ & N. & k & $\mathrm{HCO}_{3}$ & $\mathrm{co}_{3}$ & so. & c & $F$ & No, & $\begin{array}{l}\text { DISSOLVED } \\
\text { SOLIDS }\end{array}$ & mmnos & De & ON REMARKS \\
\hline$(D-8-2)$ 8bbb2 & E. L. Otteson & $W 111$ ALVM & 18.0 & 361 & 14 & $5-19-64$ & BD- 16 & & & 34 & 21 & 23 & 7.0 & 220 & 5 & 20 & 14 & & & 249 & 414 & 8.5 & \\
\hline$(D-8-2)$ Bdce & J. c. Bellown & $\mathrm{w} / 111$ ALVM & 16.0 & 294 & 3 & $5-19-64$ & BD- 16 & & & 35 & 21 & 21 & 6.3 & 223 & 0 & 23 & 14 & & & 254 & 414 & 8.0 & \\
\hline$(\mathrm{D}-8-1) 13 \mathrm{aad}$ & 3. A. Sorenen & $\mathrm{W} \mid 111 \mathrm{ALVM}$ & 16.5 & 300 & $5 \mathrm{E}$ & $7-06-64$ & $B D-16$ & & & & & & & & & & & & & & & & \\
\hline (D-8-1) 13add & Joas Shopherd & W 111 ALVM & 16.5 & 291 & 15 & $5-19-64$ & $B D-16$ & & & 34 & 25 & 15 & 8.6 & 196 & 9.3 & 40 & 11 & & & 288 & 415 & $8.5 \mid$ & \\
\hline (D-8-1) 14dad & C. B. Turkey inc. & $\mathrm{W} 111 \mathrm{ALVM}$ & 16.0 & 347 & 25 & $1-03-67$ & BD. 16 & & & & & & & & & & & & & & & & \\
\hline$(D-8-1) 35 b d d$ & Erma Schramm & $W: 111$ ALVM & 16.0 & 300 & & & BD-16 & & & & & & & & & & & & & & & & \\
\hline (D-8-2) 2abd & L. M. Banks & $w 111 \mathrm{ALVM}$ & 16.5 & 350 & & $7-19-65$ & BD- 16 & & & 18 & 20 & 18 & 3.5 & 145 & 10 & 21 & 11 & & & 183 & 308 & 8.5 & \\
\hline$(D-8-2) 2 b c d$ & M. F. NIInen & $w 111$ ALVM & 16.0 & 235 & 15 & $3-17-65$ & BD-16 & & & & & & & & & & & & & & & & \\
\hline$(D-8-2) 2 c a a$ & C. Thomas & $\mathrm{W} 111 \mathrm{ALVM}$ & 15.5 & 377 & 30 & $7-19-65$ & BD- 16 & & & 19 & 20 & 17 & 3.9 & 156 & 7 & 9.1 & 15 & & & 181 & 307 & 8.5 & \\
\hline$(D-8-2) 2 c b c$ & A. E. Evana & W/11 ALVM & \begin{tabular}{|l|}
15.5 \\
14.5
\end{tabular} & 425 & 10 & $6-23-65$ & BD-16 & & & 14 & 20 & 19 & 4. 3 & 156 & 5 & 15 & 8.9 & & & 185 & 299 & 8.5 & \\
\hline$(D-8-2) 2 \mathrm{cda}$ & T. D. Roach & W $111 \mathrm{ALVM}$ & 16.0 & 140 & 15 & $8-06-64$ & BD- 16 & & & & & & & & & & & & & & & & \\
\hline (D-8-2) 2daa & R. D. WL11Lame & $w \mid$ W ALVM & 16.0 & 356 & 72 & $8-06-64$ & BD- 16 & 25 & & 51 & 21 & 22 & & 276 & 0 & 17 & 12 & & & 275 & 454 & 7.7 & \\
\hline$(\mathrm{D}-8-2) 2 \mathrm{ddb}$ & Henry Prlor & w 111 ALVM & 16.0 & 380 & 15 & $8-06-64$ & BD- 16 & & & & & & & & & & & & & & & & \\
\hline (D-8-2) 3aad & Banko Monk & $\mathrm{W} / 111$ ALVM & 16.0 & 413 & 30 & $3-17-65$ & BD-16 & & & & & & & & & & & & & & & & \\
\hline$(D-8-2) 3 a d b$ & J. H. Monk & $w 111$ ALVM & 16.5 & 515 & $1 \mathrm{R}$ & $7-19-65$ & $B \bar{D}-16$ & & & 20 & 15 & 39 & 2.0 & 191 & 9 & 11 & 10 & & & 205 & 348 & 8. 6 & \\
\hline$(D-8-2) 3 d a c$ & Alvln Crump & WW 111 ALVM & 16.0 & 440 & 10 & $8-06-64$ & BD-16 & & & & & & & & & & & & & & & & \\
\hline (D-8-2) 4asb & A. T. Bank: & $W \mid 111$ ALVM & 15.5 & 408 & 33 & $4-03-67$ & BD-16 & & & & & & & & & & & & & & & & \\
\hline$(\mathrm{D}-8-2) 5 \mathbf{A} \mathrm{cd}$ & Dall Argylo & $W \mid 111$ ALVM & \begin{tabular}{|l|}
16.5 \\
14.0
\end{tabular} & 245 & 3 & $\begin{array}{c}7-09-65 \\
8-20-64\end{array} \mid$ & $\begin{array}{l}\text { BD-16 } \\
\text { BD-16 }\end{array}$ & & & 17 & 14 & 64 & 3.5 & 228 & 8 & 12 & 11 & & & 274 & 436 & 8.7 & \\
\hline$(\mathrm{D}-8-2) 9 \mathrm{aad}$ & A. T. Banks & W 111 ALVM & 15.5 & 385 & 35 & $8-24-64$ & BD-16 & & & & & & & & & & & & & & & & \\
\hline$(\mathrm{D}-8-2) 9 \mathrm{dcc}$ & H. E. Anderson & $\mathrm{W} 111 \mathrm{ALVM}$ & 15.5 & 280 & & & BD- 16 & & & & & & & & & & & & & & & & \\
\hline$(D-8-2) 10 a d b$ & Hyrum Ottaben & WIII ALVM & 17.0 & 586 & 80 & $5-31-66$ & BD- 16 & & & & & & & & & & & & & & & & \\
\hline$(D-8-2) 10 b^{2} d_{2}$ & Leo Banka & $\mathrm{w} \mid 111 \mathrm{ALVM}$ & 15.5 & 480 & 15 & B-24-64 & BD-16 & & & & & & & & & & & & & & & & \\
\hline (D-8-2) 10bdd & F. L. Soreneon & WW11 ALVM & 16.0 & 411 & $40 \mathrm{R}$ & $2-19-55$ & BD- 16 & & & & & & & & & & & & & & & & \\
\hline$(\mathrm{D}-8-2) 11 \mathrm{adb}$ & F. R. Hanson & $\mathrm{w}, 111$ ALVM & 17.0 & 204 & $1 \mathrm{E}$ & $8-25-64$ & BD-16 & & & & & & & & & & & & & & & & \\
\hline$(\mathrm{D}-8-2) 11 \mathrm{bcd}_{2}$ & R. R. Hanson & $w 111$ ALVM & 16.0 & 420 & 4 & $8-25-64$ & BD- 16 & & & & & & & & & & & & & & & & \\
\hline$(\mathrm{D}-8-2) 11 \mathrm{cca}_{3}$ & Notdon Nash & $W 111$ ALVM & 16.0 & 492 & $20 \mathrm{E}$ & $6-11-64$ & BD- 16 & & & 36 & 20 & 18 & 3.5 & 228 & 0 & 15 & 11 & & & 219 & 401 & 8.2 & \\
\hline (D-8-2) 12bdc & Nathan Haloo & w| 111 ALVM & $\begin{array}{l}17.0 \\
11.5\end{array}$ & 199 & $<1 \mathrm{E}$ & $5-13-64$ & $\begin{array}{l}\text { BD-16 } \\
\text { BD-16 }\end{array}$ & & & 46 & 28 & 72 & 7.8 & 318 & 7 & 52 & 49 & & & 404 & 697 & 8.3 & \\
\hline$(D-8-2) 13 a b c$ & K. L. John & $\mathrm{W} 112$ PLCN & \begin{tabular}{|l|}
15.5 \\
14.0
\end{tabular} & 378 & 88 & $|5-13-64|$ & $\begin{array}{l}\text { BD-16 } \\
\text { BD-16 }\end{array}$ & & & 49 & 25 & 12 & 2.3 & 220 & 4 & 40 & 17 & & & 266 & 448 & 8.3 & \\
\hline (D-8-2) 13 bdd & R. P. Pace & $w 112$ PLCN & \begin{tabular}{|l|}
16.0 \\
18.0
\end{tabular} & 378 & $135 \mathrm{E}$ & $\begin{array}{l}5-20-64 \\
6.22-65\end{array}$ & $\begin{array}{l}\text { BD-16 } \\
\text { BD-16 }\end{array}$ & & & $\begin{array}{l}46 \\
20\end{array}$ & $\begin{array}{l}23 \\
25\end{array}$ & $\begin{array}{l}12 \\
13\end{array}$ & $\begin{array}{l}2.0 \\
7.0\end{array}$ & $\begin{array}{l}221 \\
140\end{array}$ & $\begin{array}{l}1 \\
7\end{array}$ & $\begin{array}{l}24 \\
31\end{array}$ & $\begin{array}{l}18 \\
16\end{array}$ & & & $\begin{array}{l}261 \\
208\end{array}$ & $\begin{array}{l}433 \\
337\end{array}$ & $\begin{array}{l}8.3 \\
8.4\end{array}$ & \\
\hline$(D-8-2) 14 b b{ }_{3}$ & w. E. Hansen & W. 111 ALVM & 16.0 & 570 & 10.5 & $4-21-64$ & BD- 16 & & & & & & & & & & & & & & & & \\
\hline
\end{tabular}


Tablo 21-B. Southern Utah Valley. Wells with Water Temperaturen of $15.5^{\circ}$ to $19.5^{\circ} \mathrm{C}$

\begin{tabular}{|c|c|c|c|c|c|c|c|c|c|c|c|c|c|c|c|c|c|c|c|c|c|c|c|c|}
\hline \multirow{2}{*}{ COORDINATES } & \multirow{2}{*}{$\begin{array}{c}\text { OWNEA } \\
\text { OP } \\
\text { NAME } \\
\end{array}$} & \multirow{2}{*}{\multicolumn{2}{|c|}{ 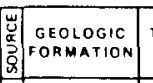 }} & \multirow{2}{*}{$\begin{array}{ll}\text { TEMP. } \\
{ }^{\circ} \mathrm{C} \\
\end{array}$} & \multirow{2}{*}{$\begin{array}{l}\text { DEPTH } \\
(1+\cdots+1)\end{array}$} & \multirow{2}{*}{\begin{tabular}{|c|c|} 
YIELD \\
'gPMI) \\
\end{tabular}} & \multirow{2}{*}{$\begin{array}{c}\text { DATE OF } \\
\text { SAMPLE }\end{array}$} & \multirow[b]{2}{*}{ REFERENGE } & \multicolumn{13}{|c|}{ ANALYSIS EXPRESSED AS MILLIGRAMS PER LITER } & \multirow{2}{*}{$\begin{array}{c}\text { como: } \\
\text { mmhos }\end{array}$} & \multirow[b]{2}{*}{ PH } & \multirow{2}{*}{$\begin{array}{l}\text { OT HER CONSSITUENTS } \\
\text { OA REMAAKS }\end{array}$} \\
\hline & & & & & & & & & $\mathrm{SiO}_{2}$ & $\mathrm{Fe}$ & c. & $m_{0}$ & N. & K & $\mathrm{HCO}_{3}$ & $\mathrm{CO}_{3}$ & so. & $\mathrm{ct}$ & $F$ & $\mathrm{NO}_{3} \mathrm{D}$ & $\begin{array}{l}\text { DISSOLVED } \\
\text { SOLIOS }\end{array}$ & & & \\
\hline$(\mathrm{D}-8-2) 10 \mathrm{abd} 2$ & $\begin{array}{l}\text { Palmyra ward } \\
\text { PDS }\end{array}$ & $w$ & $111 \mathrm{ALVM}$ & $\begin{array}{l}13.5 \\
15.5\end{array}$ & 445 & $25 \mathrm{R}$ & $\begin{array}{r}11-25-53 \\
7-19-65\end{array}$ & $\begin{array}{l}\text { BD- } 16 \\
\text { BD-16 }\end{array}$ & & & 15 & 20 & 18 & 4.7 & 138 & 10 & 19 & 9.9 & & & 185 & 294 & 8.6 & \\
\hline$(D-8-2) 14 b c d$ & Evorett Hanson & $w$ & $111 \mathrm{ALVM}$ & $\begin{array}{l}15.5 \\
17.0\end{array}$ & 424 & $7 \mathrm{R}$ & $7-20-65$ & $\begin{array}{l}\mathrm{BD}-16 \\
\mathrm{BD}-16\end{array}$ & & & 20 & 20 & 17 & 3.1 & 150 & 12 & 15 & 11 & & & 192 & 315 & 8. 7 & \\
\hline$(\mathrm{D}+8-2) 14 \mathrm{dec}$ & w. G. Johns & $\mathrm{w}$ & $111 \mathrm{ALVM}$ & $\begin{array}{l}15.0 \\
15.5\end{array}$ & 377 & 10 & $\begin{array}{l}5-19-64 \\
7-09-65\end{array}$ & $\begin{array}{l}\text { BD-16 } \\
\text { BD-16 }\end{array}$ & & & $\begin{array}{l}53 \\
50\end{array}$ & $\begin{array}{l}21 \\
22\end{array}$ & $\begin{array}{l}14 \\
15\end{array}$ & $\begin{array}{l}2.3 \\
2.0\end{array}$ & $\begin{array}{l}253 \\
262\end{array}$ & $\begin{array}{l}2 \\
0\end{array}$ & $\begin{array}{l}24 \\
20\end{array}$ & $\begin{array}{l}11 \\
9.9\end{array}$ & & & $\begin{array}{l}263 \\
264\end{array}$ & $\begin{array}{l}447 \\
434\end{array}$ & $\begin{array}{l}8.3 \\
7.9\end{array}$ & \\
\hline$(D-8-2) 15 \mathrm{sca}$ & M. J, Hansen & $w$ & $111 \mathrm{ALVM}$ & 15.5 & 403 & $25 \mathrm{R}$ & $5-01-46$ & BD-16 & & & & & & & & & & & & & & & & \\
\hline$(D-8-2) 15 d d b$ & P. A. Johnoon & $\mathrm{w}$ & $111 \mathrm{ALVM}$ & $\begin{array}{l}16.5 \\
16.5\end{array}$ & 468 & 20 & $\begin{array}{l}5-19-64 \\
4-19-66\end{array}$ & $\begin{array}{l}\text { BD- } 16 \\
\text { BD-16 }\end{array}$ & & & $\begin{array}{l}40 \\
37\end{array}$ & $\begin{array}{l}14 \\
14\end{array}$ & $\begin{array}{l}30 \\
29\end{array}$ & $\begin{array}{l}2.7 \\
2.3\end{array}$ & $\begin{array}{l}227 \\
256\end{array}$ & $\begin{array}{l}8 \\
0\end{array}$ & $\begin{array}{r}12 \\
0\end{array}$ & $\begin{array}{l}9.9 \\
9.9\end{array}$ & & & $\begin{array}{l}243 \\
239\end{array}$ & $\begin{array}{l}393 \\
404\end{array}$ & \begin{tabular}{|l|}
8.5 \\
7.8 \\
\end{tabular} & \\
\hline$(D-8-2) 16 b c b$ & Florence Barnoy & $|w|$ & $111 \mathrm{ALVM}$ & 16.5 & 459 & 3 & $5-19-64$ & $B D-16$ & & & 31 & 23 & 26 & 7.0 & 223 & 9 & 21 & 12 & & & 254 & 412 & 8.6 & \\
\hline$(D-8-2) 16 c a a$ & W. G. Foster & $|w|$ & $111 \mathrm{ALVM}$ & 16.5 & 640 & 142 & $9-02-64$ & BD-16 & & & & & & & & & & & & & & & & \\
\hline$(D-8-2) 17 a d a$ & Bert Hanson & $\mathrm{w}$ & $111 \mathrm{ALVM}$ & 18.5 & 466 & 4 & $9-03-64$ & BD- 16 & & & & & & & & & & & & & & & & \\
\hline$(D-8-2) 17 b a a$ & J. w. Blngham & $w$ & $111 \mathrm{ALVM}$ & 15.5 & 380 & 5.6 & $4-05-67$ & $\mathrm{BD}-16$ & & & & & & & & & & & & & & & & \\
\hline$(\mathrm{D}-8-2) 17 \mathrm{ccc}_{2}$ & Allen Clayson & $\mathrm{w}$ & $111 \mathrm{ALVM}$ & $\begin{array}{l}17.0 \\
18.0\end{array}$ & 363 & 60 & $5-19-64$ & $\begin{array}{l}B D-16 \\
B D-16\end{array}$ & & & 37 & 21 & 22 & 7.0 & 234 & 0 & 26 & 12 & & & 278 & 429 & 8.2 & \\
\hline$(D-8-2) 17 d c c$ & B. Shopherd & $\mathrm{w} \mid$ & $111 \mathrm{ALVM}$ & $\begin{array}{l}17.0 \\
18.0\end{array}$ & 340 & 20 & $6-03-64$ & $\begin{array}{l}\text { BD-16 } \\
\text { BD-16 }\end{array}$ & & & 35 & 21 & 29 & 7.4 & 211 & 12 & 33 & 13 & & & 278 & 434 & 8.4 & \\
\hline$(D-8-2) 18 \mathrm{bdc}$ & Lould Then & $\mathrm{w}$ & $111 \mathrm{ALVM}$ & 18.0 & 365 & 12 & $9-03-64$ & $B D-16$ & & & & & & & & & & & & & & & & \\
\hline$(\mathrm{D}-8 \cdot 2) 19 \mathrm{add}$ & A. Beckstrom & $|w|$ & 111 ALYM & 18.0 & 480 & 20 & $9-03-64$ & $B D-16$ & & & & & & & & & & & & & & & & \\
\hline$(\mathrm{D}-8-2) 20_{\mathrm{cad}}$ & Rvan Hawkins & $w$ & $111 \mathrm{ALVM}$ & 16.5 & 450 & 8.8 & $3-28-67$ & BD-16 & & & & & & & & & & & & & & & & \\
\hline$(\mathrm{D}-8=2) 20<\mathrm{ad}_{2}$ & C. E. Hawkln & $|w|$ & 111 ALVM & 16.5 & 420 & 2 & $3-28-67$ & BD-16 & & & & & & & & & & & & & & & & \\
\hline$(\mathrm{D}-8-2) 20 \mathrm{ddd}_{2}$ & A. Becketrom & $|w|$ & 111 ALVM & $\begin{array}{l}18.5 \\
19.5\end{array}$ & 412 & 5 & $\begin{array}{l}5-26-64 \\
6-25-65\end{array}$ & $\begin{array}{l}\text { BD- } 16 \\
\text { BD-16 }\end{array}$ & & & $\begin{array}{l}39 \\
18\end{array}$ & $\begin{array}{l}11 \\
16\end{array}$ & $\begin{array}{l}38 \\
39\end{array}$ & $\begin{array}{l}8.6 \\
8.2\end{array}$ & $\begin{array}{l}206 \\
154\end{array}$ & $\begin{array}{r}13 \\
9\end{array}$ & 28 & $\begin{array}{l}11 \\
12\end{array}$ & & & $\begin{array}{l}286 \\
264\end{array}$ & $\begin{array}{l}434 \\
361\end{array}$ & $\begin{array}{l}8.6 \\
8.5\end{array}$ & $16.5^{\circ}$ BD- 16 \\
\hline$(D-8-2) 21$ aaa & J. M. Argyle & w & $111 \mathrm{ALVM}$ & 16.5 & 498 & $90 \mathrm{R}$ & $7-20-65$ & $B D-16$ & & & 17 & 18 & 29 & 3.5 & 168 & 6 & 16 & 9.6 & & & 187 & 306 & 8.5 & \\
\hline$(D-8-2) 21 a b b$ & Fay Huff & $\mathrm{w}$ & $111 \mathrm{ALVM}$ & 15.5 & 161 & a 1 & $9-22-64$ & BD-16 & & & & & & & & & & & & & & & & \\
\hline$(D-8-2) 21 b^{2} b_{2}$ & Lynn Argyle & $w$ & $111 \mathrm{ALVM}$ & 16.0 & 346 & 6 & $9-14-64$ & $\mathrm{BD}-16$ & & & & & & & & & & & & & & & & \\
\hline$(\mathrm{D}-8-2\rangle) 21 \mathrm{ddd}$ & B. Anderson & w & $111 \mathrm{ALVM}$ & $\begin{array}{l}16.5 \\
16.0\end{array}$ & 347 & 30 & $\begin{array}{l}5-18-64 \\
6-24-65\end{array}$ & $\begin{array}{l}\text { BD-16 } \\
\text { BD- } 16\end{array}$ & & & $\begin{array}{l}37 \\
15\end{array}$ & $\begin{array}{l}15 \\
16\end{array}$ & $\begin{array}{l}28 \\
29\end{array}$ & $\begin{array}{r}3.5 \\
3.5\end{array}$ & $\begin{array}{l}218 \\
156\end{array}$ & $\begin{array}{l}5 \\
7\end{array}$ & $\begin{array}{l}15 \\
17\end{array}$ & $\begin{array}{l}9.9 \\
9.2\end{array}$ & & & $\begin{array}{l}216 \\
189\end{array}$ & $\begin{array}{l}383 \\
287\end{array}$ & $\begin{array}{l}8.4 \\
8.6\end{array}$ & \\
\hline$(D-8.2) 22 \mathrm{cdc}$ & $\begin{array}{l}\text { Utah Hido } \\
\text { \&x Tanjow Co. }\end{array}$ & $\mathrm{w}$ & $111 \mathrm{ALVM}$ & $\begin{array}{l}18.5 \\
16.5\end{array}$ & 620 & $60 \mathrm{R}$ & $\begin{array}{l}5-22-35 \\
5-19-64\end{array}$ & $\begin{array}{l}\text { BD-16 } \\
\text { BD-16 }\end{array}$ & & & 38 & 14 & 28 & 4.3 .2 & 209 & 9 & 16 & 9.6 & & & 203 & 378 & 8.6 & \\
\hline$(\mathrm{D}-8-z) 2 z \mathrm{cdc}_{2}$ & $\begin{array}{l}\text { Utah Hide } \\
\text { \& Tallow Co. }\end{array}$ & wh & $111 \mathrm{ALVM}$ & 17.0 & 385 & $100 \mathrm{R}$ & $5-17-57$ & BD- 16 & & & & & & & & & & & & & & & & \\
\hline $\begin{aligned}(D-8-2) & 23 \mathrm{bdc} \\
23 \mathrm{bdc} & \end{aligned}$ & C. Marcuson & $w$ & 111 ALVM & $\begin{array}{l}16.5 \\
17.0\end{array}$ & 370 & $24 \mathrm{R}$ & $\begin{array}{l}9-15-64 \\
5-20-64\end{array}$ & \begin{tabular}{|l|} 
BD-16 \\
BD-16
\end{tabular} & & & 46 & 19 & 12 & 1.62 & 228 & 0 & 24 & 8 & & & 202 & 400 & 8. 2 & $14^{\circ} 4-19-66 \mathrm{BD}-16$ \\
\hline$(D-8-2) 23 c^{2} b d 2$ & U \& I Sugar Co. & w & $111 \mathrm{ALVM}$ & 16.5 & 390 & 275 & $5-18-64$ & BD-16 & & & 44 & 22 & 13 & 2.0 & 223 & 3 & 27 & 11 & & & 239 & 409 & 8.3 & \\
\hline $\begin{array}{l}(\mathrm{D}-8-2) 23 \mathrm{dca} \\
(\mathrm{D}-8-2) 25 \mathrm{bcc}\end{array}$ & $\begin{array}{l}\text { U a I Suger Co. } \\
\text { E. H. Davis }\end{array}$ & 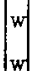 & $120 \mathrm{TRTR}$ & 16.5 & 569 & 82 & $5-27-64$ & BD-16 & 25 & & 46 & 20 & 25 & & 266 & 0 & 16 & 14 & & .1 & 265 & 435 & 7.8 & \\
\hline (D-8-8-2) $25 \mathrm{cdd} 2$ & E. H. Davlo & w & 111 ALVM & 15.5 & 212 & $20 \mathrm{R}$ & $2-26-62$ & BD-16 & & & & & & & & & & & & & & & & \\
\hline
\end{tabular}


Table 21-B. Southern Utah Valley. Wells with water Temperatures of 15.50 to $19.50 \mathrm{C}$.

\begin{tabular}{|c|c|c|c|c|c|c|c|c|c|c|c|c|c|c|c|c|c|c|c|c|c|c|c|}
\hline \multirow{2}{*}{ COOHOINATES } & \multirow{2}{*}{$\begin{array}{l}\text { OWNER } \\
\text { OA } \\
\text { NAME } \\
\end{array}$} & \multirow{2}{*}{ 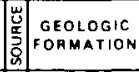 } & \multirow{2}{*}{ TEMP. } & \multirow{2}{*}{$\begin{array}{c}\text { OEPTH } \\
\text { (10.01) }\end{array}$} & \multirow{2}{*}{\begin{tabular}{|l|}
$Y I E L O$ \\
IoDMI
\end{tabular}} & \multirow{2}{*}{$\begin{array}{l}\text { DATE OF } \\
\text { SAMPLE }\end{array}$} & \multirow[b]{2}{*}{ AEF ERENCE } & \multicolumn{13}{|c|}{ ANALYSIS EXPAESSEO AS MILLIGAAMS PER LITER } & \multirow{2}{*}{$\begin{array}{l}\text { COND. } \\
\text { mithos }\end{array}$} & \multirow[b]{2}{*}{ oH } & \multirow{2}{*}{$\begin{array}{l}\text { OTHER CONSTITUENTS } \\
\text { OR REMARKS }\end{array}$} \\
\hline & & & & & & & & $\mathrm{SiO}_{2}$ & F. & c. & $M_{0}$ & N. & к & $\mathrm{HCO}_{3}$ & $\mathrm{CO}_{3}$ & so. & $\mathrm{cl}$ & $\mathrm{F}$ & No, & $\begin{array}{c}\text { DISSOLVED } \\
\text { SOLIDS }\end{array}$ & & & \\
\hline$(\mathrm{D}-8-2) 25 \mathrm{dac}_{3}$ & $\begin{array}{l}\text { California } \\
\text { Packlng }\end{array}$ & $w 111$ ALVM & $\begin{array}{l}16.0 \\
16.5\end{array}$ & 620 & 513 & $9-14-64$ & $\begin{array}{l}\mathrm{BD}-16 \\
\mathrm{BD}-16\end{array}$ & 24 & & 51 & 25 & 8.2 & & 274 & 0 & 1.6 & 13 & & .3 & 282 & 452 & 8.1 & \\
\hline$(\mathrm{D}-8-2)_{26 \mathbf{a a d}_{3}}$ & R. S. Greer & $w \mid 111$ ALVM & 16.5 & 223 & $10 \mathrm{R}$ & $|0-13-61|$ & BD- 16 & & & & & & & & & & & & & & & & \\
\hline$(D-8-2) 26 \mathbf{b a b}_{3}$ & H. S. Thomat & W 111 ALVM & 15.5 & 388 & 2 & $7-20-65$ & $B D-16$ & & & 49 & 20 & 14 & 2.3 & 249 & 0 & 20 & 11 & & & 253 & 435 & 8.0 & \\
\hline (D-8-2) $26 \mathrm{cac}$ & Roy Crear & $|\mathrm{w}| 111$ ALVM & 18.5 & 357 & 14.1 & $3-06-36$ & $B D-16$ & & & & & & & & & & & & & & & & \\
\hline (D-8-2) 27aaa 2 & I. D. Beck & w| 111 ALVM & 16.0 & 348 & $1 \mathrm{E}$ & $9-28-64$ & BD-16 & & & & & & & & & & & & & & & & \\
\hline$(\mathrm{D}-\mathrm{B}-2) 27 \mathrm{bba} \mathrm{a}_{2}$ & R. Anderson & $|w| 11$ ALVM & 15.5 & 275 & 1 & $9-23-64$ & BD- 16 & & & & & & & & & & & & & & & & \\
\hline (D- 8-2) 2Rbars 2 & T. L. Johneon & $|w| 11$ ALVM & $\begin{array}{l}18.0 \\
20.5\end{array}$ & 500 & $4 \mathrm{R}$ & & $\begin{array}{l}\text { BD-16 } \\
\text { BD-16 }\end{array}$ & & & 21 & 16 & 44 & 1.3 & 210 & 13 & 9. I & 18 & & & 285 & $\$ 20$ & 8.6 & \\
\hline (D-8-2) $28 \mathrm{bcc} 5$ & A. G. Hone & $|w| 111$ ALVM & 15.5 & 160 & 1.5 & $9-25-64$ & $B D-16$ & & & & & & & & & & & & & & & & \\
\hline$(\mathrm{D}-8-2) 28 \mathrm{CCA} 2$ & S. L. Thar nton & $W \mid 111$ ALVM & 18.0 & 200 & $<\varepsilon$ & $9-25-64$ & BD-16 & & & & & & & & & & & & & & & & \\
\hline (D-8-2) 28ddd & Ralphy Balzly & $|w| 111$ ALVM & 16.0 & 242 & $\cdot 5$ & $9-25-64$ & $B D-16$ & & & & & & & & & & & & & & & & \\
\hline (D-8-2) 29aan 7 & R. L. HIckmen & W.111 ALVM & 15.5 & 390 & 5 & $9.25-64$ & $B D-16$ & & & & & & & & & & & & & & & & \\
\hline$(D-8-2) 29 \mathbf{a a s}_{\mathbf{B}}$ & Rex Steole & $w 111$ ALVM & 15.5 & 175 & 4 & $9-25-64$ & $B D-16$ & & & & & & & & & & & & & & & & \\
\hline$(\mathrm{D}-8-2) 29 \mathrm{ddd}$ & H. Clayeon & w 111 ALVM & 17.0 & 171 & 6 & $9-28-64$ & BD-16 & & & & & & & & & & & & & & & & \\
\hline$(\mathrm{D}-8-2) 31 \mathrm{cdb} 2$ & $\begin{array}{l}\text { S. Scharror } \\
\text { D. Tannor }\end{array}$ & W 111 ALVM & 19.0 & 230 & 30 & $8-04-64$ & BD-16 & 63 & & 34 & 17 & 40 & & 230 & 0 & 29 & 15 & 0 & .1 & 300 & 428 & 7.7 & \\
\hline (D-8-2) 32da a & $\begin{array}{l}\text { Benjemin } \\
\text { Cematery }\end{array}$ & W. 111 ALVM & 15.5 & 247 & $50 \mathrm{E}$ & $\mid 9-23-64$ & BD-16 & & & & & & & & & & & & & & & & \\
\hline$(D-8-2) 32 d d c$ & $\begin{array}{l}\text { K. Dtxon \& } \\
\text { A. B. Bayor }\end{array}$ & W 111 ALVM & 19.0 & 341 & 2 & $|10-20-64|$ & BD- 16 & & & & & & & & & & & & & & & & \\
\hline$(D-8-2) 33 \mathrm{bdc}$ & Ralph Balzly & W 1111 ALVM & $\begin{array}{l}18.0 \\
17.0\end{array}$ & 185 & 10 & $5-03.65$ & \begin{tabular}{|l|} 
BD-16 \\
BD-16
\end{tabular} & 62 & & 30 & 17 & 59 & & 302 & 0 & 7.4 & 12 & & .1 & 331 & 485 & 8.0 & \\
\hline$(D-8-2) 36 d_{b d}$ & B. E. Cloward & W/111 ALVM & 16.5 & 38 & & & BD- 16 & & & & & & & & & & & & & & & & \\
\hline$(D-8-3) 17 d d a$ & Mark Hansen & Ww 111 ALVM & 15.5 & 125 & $8 \mathrm{P}$ & $5-08-54$ & BD- 16 & & & & & & & & & & & & & & & & \\
\hline$(D-8-3) 18 b d c$ & J. E. Clerk & $W 112$ PLCN & 16.0 & 368 & $200 \mathrm{P}$ & $5-18-54$ & BD-16 & & & 48 & 25 & 11 & 2.3 & 234 & 5 & 28 & 16 & & & 239 & 446 & 8.4 & \\
\hline$(\mathrm{D}-8-3) 20 \mathrm{bab}$ & Nell Bona & $W 111 \mathrm{ALVM}$ & $\begin{array}{l}15.5 \\
15.5\end{array}$ & 295 & 16 & $\begin{array}{l}8-13-64 \\
7-29-65\end{array}$ & $\begin{array}{l}\text { BD-16 } \\
\text { BD-16 }\end{array}$ & & & $\begin{array}{l}55 \\
52\end{array}$ & $\begin{array}{l}21 \\
24\end{array}$ & $\begin{array}{l}53 \\
52\end{array}$ & $\begin{array}{l}5.5 \\
5.5\end{array}$ & $\begin{array}{l}326 \\
362\end{array}$ & $\begin{array}{r}16 \\
7\end{array}$ & $\begin{array}{l}26 \\
13\end{array}$ & $\begin{array}{l}19 \\
18\end{array}$ & & & $\begin{array}{l}349 \\
366\end{array}$ & $\begin{array}{l}609 \\
594\end{array}$ & $\begin{array}{l}8.3 \\
8.4\end{array}$ & \\
\hline$(\mathrm{D}-8-3) 22 \mathrm{cac}$ & J. H. Wootwood & $w 120$ TRTR & $\begin{array}{l}15.5 \\
15 .\end{array}$ & 541 & 1500 & $\begin{array}{l}8-31-64 \\
7-15-64\end{array}$ & \begin{tabular}{|l|} 
BD-16 \\
BD-16
\end{tabular} & 21 & & $\begin{array}{l}69 \\
41\end{array}$ & $\begin{array}{l}23 \\
12\end{array}$ & $\begin{array}{l}49 \\
44\end{array}$ & 3.5 & $\begin{array}{l}268 \\
171\end{array}$ & $\begin{array}{l}0 \\
0\end{array}$ & $\begin{array}{l}84 \\
82\end{array}$ & $\begin{array}{l}48 \\
53\end{array}$ & & .5 & $\begin{array}{l}428 \\
356\end{array}$ & $\begin{array}{l}688 \\
581\end{array}$ & $\begin{array}{l}8.2 \\
8.2\end{array}$ & \\
\hline$(\mathrm{D}-8-3) 32 \mathrm{bba}$ & J. C. Holt & W 111 ALVM & 15.5 & 275 & $25 \mathrm{~F}$ & $\mid 11-25-53$ & BD-16 & & & & & & & & & & & & & & & & \\
\hline$(D-9-1) 14 a d s$ & O. G. Stewart & W/ 111 ALVM & 16.5 & 55 & $10 \mathrm{r}$ & $1-27-45$ & BD- 16 & & & & & & & & & & & & & & & & \\
\hline$(D-9-1) 14 d d d$ & c. W. Nay & W 111 ALVM & 18.5 & 125 & $10 \mathrm{R}$ & $2-04-50$ & BD-16 & & & & & & & & & & & & & & & & \\
\hline$(\mathrm{D}-9-1) 24 \mathrm{cab}$ & Bliso Hyatt & W 111 ALVM & 16.5 & 71 & $10 R$ & $\mid 0-19-61$ & BD-16 & & & & & & & & & & & & & & & & \\
\hline$(D-9-2)$ lbeaz & E. A. TIffany & $W 111$ ALVM & 16.5 & 200 & $4 \mathrm{R}$ & $7-27-65$ & $B D-16$ & & & 66 & 44 & 48 & 11 & 417 & 0 & 70 & 36 & & & 470 & 808 & 8.1 & Also temp. $15.5^{\circ}$ BD -16 \\
\hline (D-9-2) 2bcb & $\begin{array}{l}\text { Spantoh Fork } \\
\text { Stako, LDS }\end{array}$ & W 111 ALVM & $\begin{array}{l}17.0 \\
19.5\end{array}$ & 740 & 480 & $\begin{array}{l}8-13-66 \\
9-02-66\end{array}$ & $\mid \begin{array}{l}B D-16 \\
\text { BD-16 }\end{array}$ & & & $\begin{array}{l}41 \\
29\end{array}$ & $\begin{array}{l}13 \\
13\end{array}$ & $\begin{array}{l}20 \\
39\end{array}$ & $\begin{array}{l}3.5 \\
3.5\end{array}$ & $\begin{array}{l}228 \\
236\end{array}$ & 80 & $\mid \begin{array}{l}5.8 \\
5.8\end{array}$ & $\begin{array}{l}9.9 \\
5.7\end{array}$ & & & $\begin{array}{l}252 \\
220\end{array}$ & $\begin{array}{l}385 \\
390\end{array}$ & $\begin{array}{l}\text { 8. } 1 \\
8.4\end{array}$ & \\
\hline
\end{tabular}


Toblo 21-B. Southern Utah Valley. Wella with Wator Temperatures of $15.5^{\circ}$ to $19.5^{\circ} \mathrm{C}$.

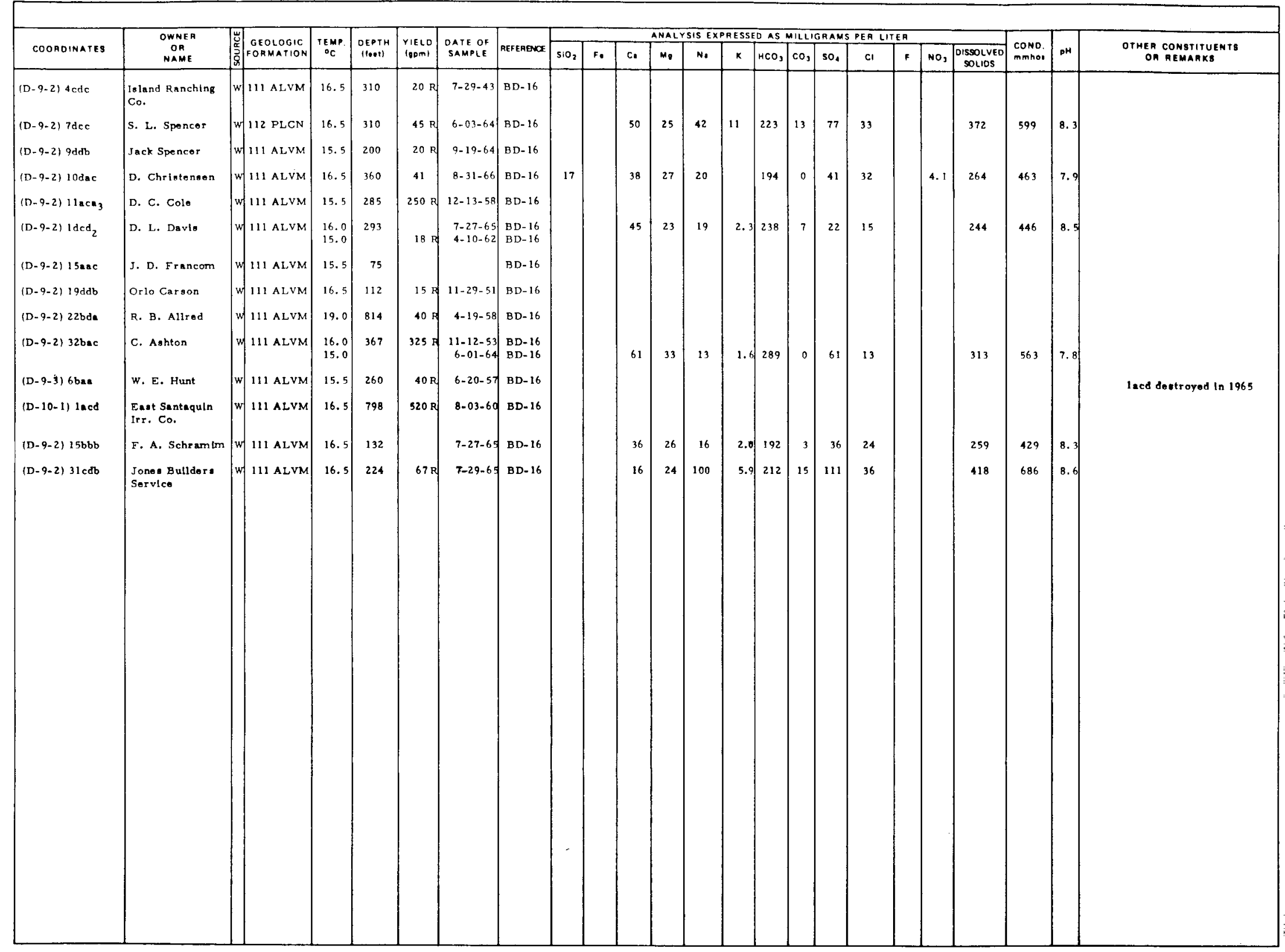

1 
Table 22-A. Southern Utah and Gioghen Valleys

Springe with water Temperatures of $15.5^{\circ}$ to $31.5^{\circ} \mathrm{C}$, and Mine with Water Temperature of $54.5^{\circ} \mathrm{C}$.

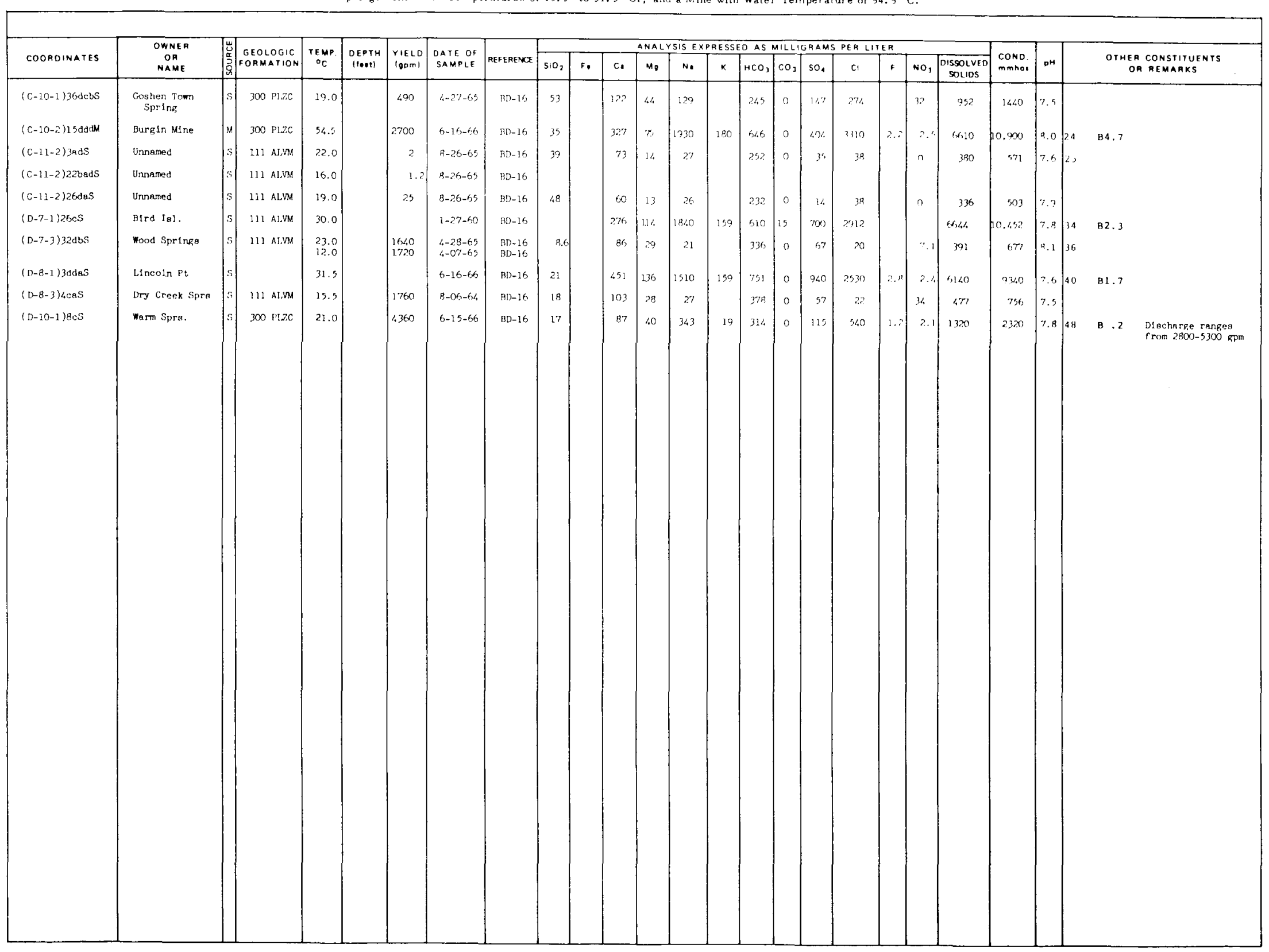


Table 22-B. Goshen Valley. Wells with water Temperatures of $15.5^{\circ}$ to $19.5^{\circ} \mathrm{C}$

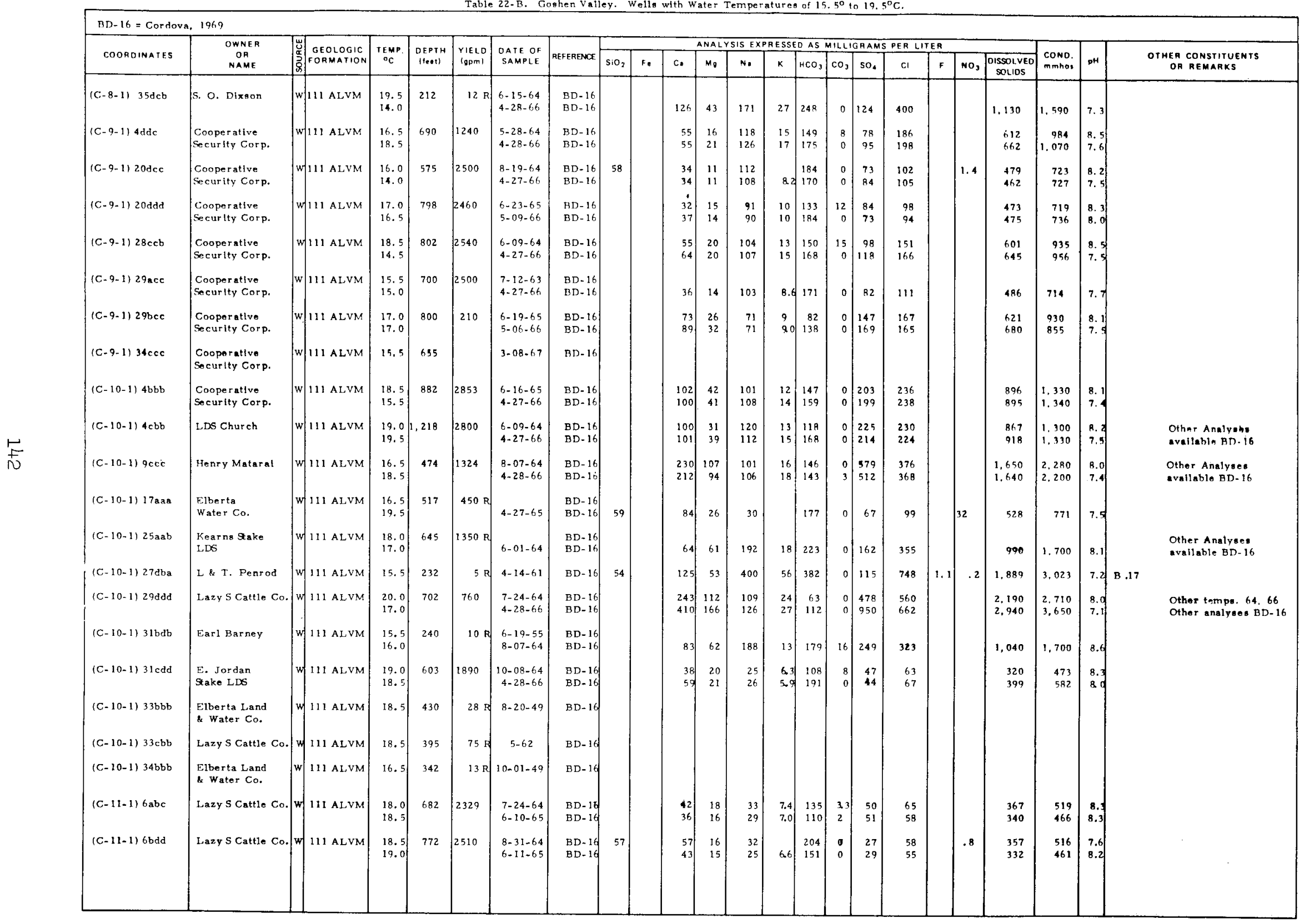

D. 
Table 23-A. Centrat Virgin River Basin. Wella and Springs with water Temperatures of $20^{\circ}$ to $42^{\circ} \mathrm{C}$.

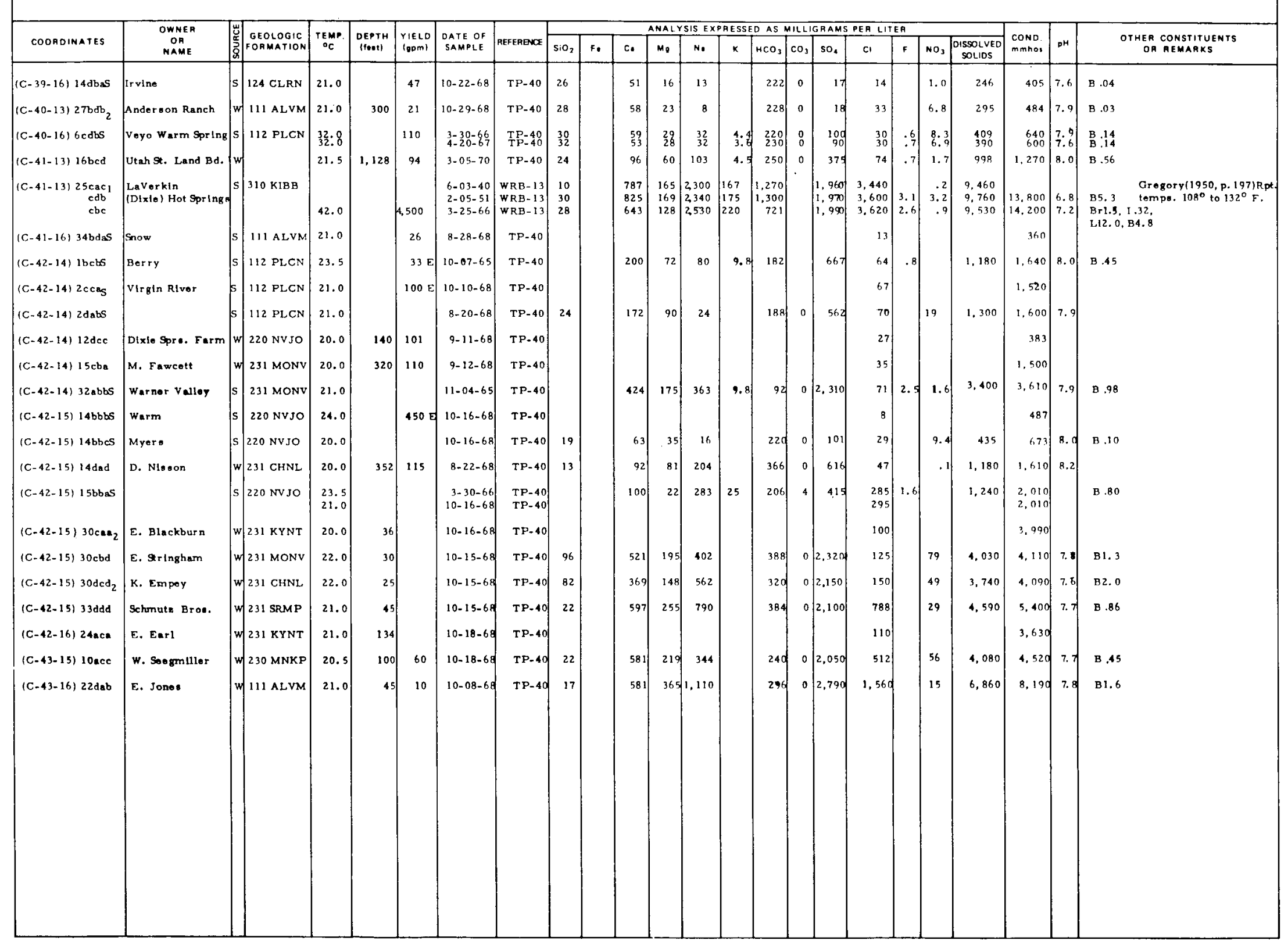


Table 23-B. Contral virgln River Basin. Wolle and Springe with water Tomporatures of $15.5^{\circ}$ to $19.5^{\circ} \mathrm{C}$.

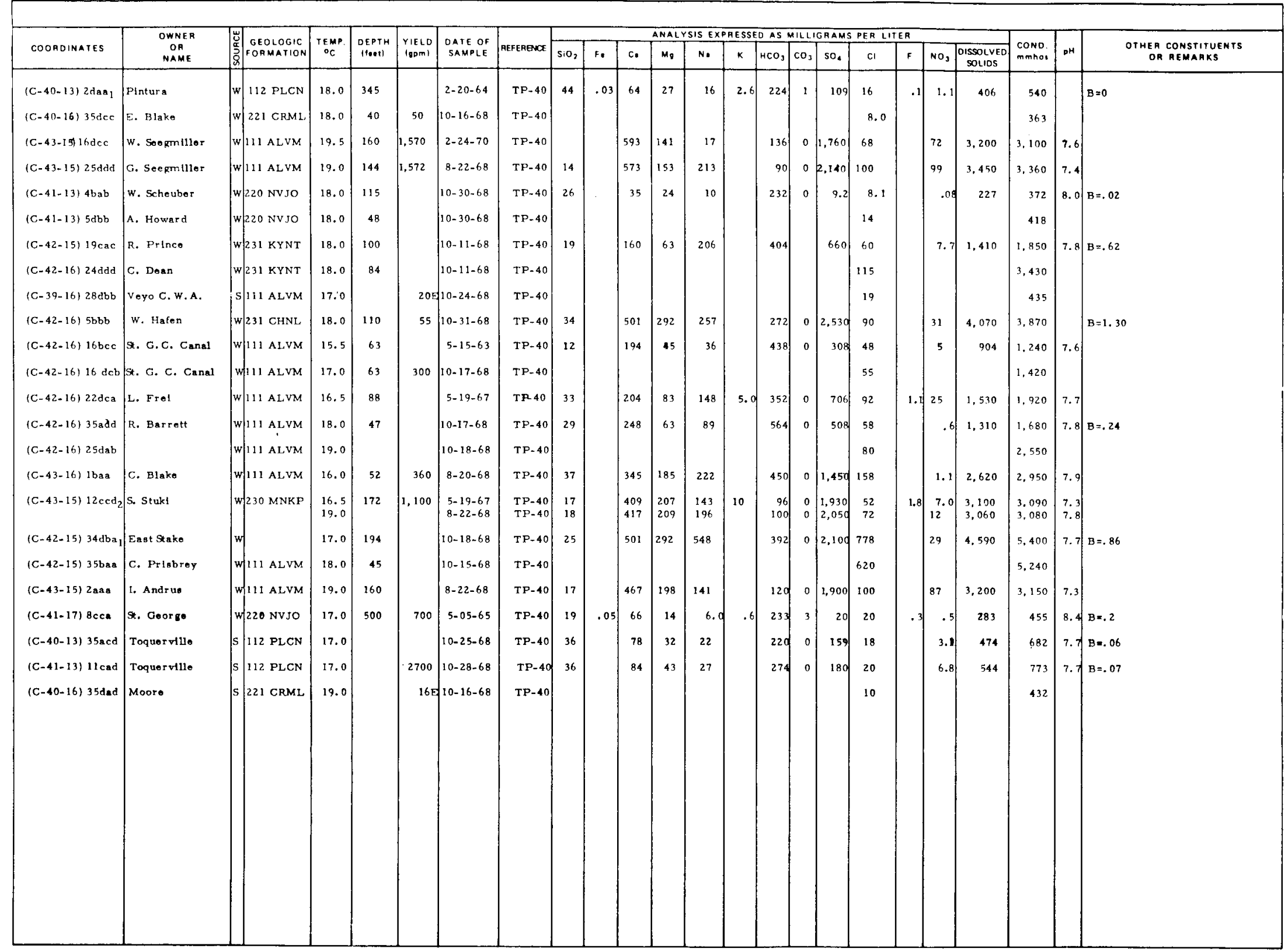


Table 25-A. Blue Creek Valley. Wells and Springs with Water Temporatures of $20^{\circ}$ to $28^{\circ} \mathrm{C}$.

\begin{tabular}{|c|c|c|c|c|c|c|c|c|c|c|c|c|c|c|c|c|c|c|c|c|c|c|c|c|c|}
\hline \multirow[b]{2}{*}{ COOADINATES } & \multirow{2}{*}{$\begin{array}{l}\text { OWNER } \\
\text { OA } \\
\text { NAME }\end{array}$} & \multirow{2}{*}{\multicolumn{2}{|c|}{ 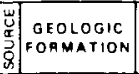 }} & \multirow{2}{*}{$\begin{array}{l}\text { TEMP. } \\
{ }^{\circ} \mathrm{C}\end{array}$} & \multirow{2}{*}{$\begin{array}{l}\text { OEPTH } \\
\text { (feot) }\end{array}$} & \multirow{2}{*}{$\begin{array}{l}\text { VIELO } \\
\text { (spm) }\end{array}$} & \multirow{2}{*}{$\begin{array}{l}\text { DATE OF } \\
\text { SAMPLE }\end{array}$} & \multirow[b]{2}{*}{ REFERENCE } & \multicolumn{13}{|c|}{ ANALYSIS EXPRESSEO AS MILLLGAAMS PEA LITER } & \multirow[b]{2}{*}{$\begin{array}{l}\text { CONO } \\
\text { mmhoo }\end{array}$} & \multirow[b]{2}{*}{$\mathrm{PH}$} & \multirow{2}{*}{\multicolumn{2}{|c|}{$\begin{array}{l}\text { OTHER CONSTITUENTS } \\
\text { OR REMARKS }\end{array}$}} \\
\hline & & & & & & & & & $\mathrm{SiO}_{2}$ & F. & c. & $m_{0}$ & No & k & $\mathrm{HCO}_{3}$ & $\mathrm{CO}_{3}$ & so, & $\mathrm{cl}$ & $F$ & No, & $\begin{array}{l}\text { OISSOLVE: } \\
\text { solids }\end{array}$ & & & & \\
\hline$(B-12-5) 22 \mathrm{dacs}$ & Town of Howell & $\mathrm{s}$ & 310 OORR & 20.0 & & & $7-70$ & TP-37 & & & & & & & & & & & & & & 889 & & & ipe \\
\hline$(B-12-6) 33 \mathrm{dbs}$ & & $\mathrm{s}$ & $310 \mathrm{OORR}$ & 20.5 & & 1 & $7-14-70$ & TP- 37 & & & 81 & 12 & 54 & & 250 & 0 & & 100 & & & 477 & 751 & 8.2 $\mid$ & & $\begin{array}{l}50 \text { ft. be low source } \\
\text { Temp. mease }\end{array}$ \\
\hline$(B-13-5) 295$ & Blue Springe & ${ }^{5}$ & 310 OQRR & 26.5 & & 4,680 & $9-10-64$ & TP-37 & & & 83 & 24 & 540 & 32 & 268 & & 68 & 886 & & & 1,923 & 3,580 & $|8.0|$ & B.2 & 500 ft. below source \\
\hline 298 & & & & & & & $7-07.70$ & TP-37 & 19 & & 56 & 24 & 636 & 22 & 329 & 0 & 84 & 895 & .4 & 1.0 & 2,010 & 3,410 & 7.9 & B 22 & \\
\hline$(B-13-5) 31 \mathrm{daa}$ & L. D. Nesion & w & & 20.5 & 405 & & $7-13-70$ & TP-37 & & & 89 & 41 & 153 & & 343 & 4 & & 274 & & & 1,010 & 1,440 & 8.4 & & \\
\hline$(B+14-6) 9 \mathrm{asb}$ & Delorlu Stokes & $\mathrm{w}$ & & 20.5 & 409 & & 7.07 .80 & TP. 37 & & & 67 & 25 & 213 & & 258 & & & 341 & & & 870 & 1,530 & 8. 3 & & \\
\hline$(\mathrm{B}-15-6) 34 \mathrm{ccc}$ & R. W. Tolman & $\mathrm{w}$ & & 20.5 & 555 & & $7-07-70$ & TP-37 & 41 & & 60 & 25 & 247 & 5.7 & 259 & 0 & 40 & 375 & 1.0 & .3 & 938 & 1,610 & 7.9 & В . 06 & \\
\hline & & & & & & & & & & & & & & & & & & & & & & & & & \\
\hline & & & & & & & & & & & & & & & & & & & & & & & & & \\
\hline & & & & & & & & & & & & & & & & & & & & & & & & & \\
\hline
\end{tabular}

Tablo 25.8. Blue Croek Valley. Wolle and Springe with Water Temperatures of $15.5^{\circ}$ to $19.5^{\circ} \mathrm{C}$

\begin{tabular}{|c|c|c|c|c|c|c|c|c|c|c|c|c|c|c|c|c|c|c|c|c|c|c|c|c|}
\hline \multirow{2}{*}{ COOADINATES } & \multirow{2}{*}{$\begin{array}{l}\text { OWNER } \\
\text { OR } \\
\text { NAME }\end{array}$} & \multirow{2}{*}{\multicolumn{2}{|c|}{ 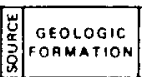 }} & \multirow{2}{*}{$\begin{array}{c}T E M P . \\
{ }^{\circ} \mathrm{C}\end{array}$} & \multirow{2}{*}{$\begin{array}{l}\text { DEPTH } \\
|1+0+1|\end{array}$} & \multirow{2}{*}{\begin{tabular}{|l|}
$r \mid E L O$ \\
Igpmi
\end{tabular}} & \multirow{2}{*}{$\begin{array}{l}\text { DATE OF } \\
\text { SAMPLE }\end{array}$} & \multirow[b]{2}{*}{ REFEAEVKE } & \multicolumn{13}{|c|}{ ANALYSIS EXPRESSSD AS MILLLGRAMS PER LITER } & \multirow{2}{*}{ CONo } & \multirow[b]{2}{*}{$\mathrm{pH}$} & \multirow{2}{*}{$\begin{array}{l}\text { OTHER CONSTIYUENTS } \\
\text { OR REMARKS }\end{array}$} \\
\hline & & & & & & & & & $\mathrm{SiO}_{2}$ & F. & 0. & $\mathrm{Mg}_{\mathrm{g}}$ & N. & k & $\mathrm{HCO}_{3}$ & $\mathrm{Co}_{3}$ & so. & $\mathrm{cl}$ & $\mathrm{F}$ & No, & $\begin{array}{l}\text { DISSOLVED } \\
\text { SOLIDSS }\end{array}$ & & & \\
\hline$(B-11-5) 3 \mathrm{cacs}$ & & $s$ & 310 OQRR & 17.5 & & $\ll$ & $7-70$ & TP-37 & & & & & & & & & & & & & & 76.5 & & \\
\hline$(\mathrm{B}-11-5) 12 \mathrm{ccaS}$ & & $|s|$ & $31000 R R$ & 17. & & & $7-70$ & \begin{tabular}{|l|} 
TP- 37 \\
\end{tabular} & & & & & & & & & & & & & & 631 & & \\
\hline$(\mathrm{B}-12-5) 10 \mathrm{bca}$ & H. C. Kottor & $w$ & & 15.5 & 138 & & $7-14-70$ & TP-37 & & & 66 & 37 & 129 & & 254 & 3 & & 226 & & & 708 & 1,220 & 8.5 & \\
\hline$(\mathrm{B}-12-5) 14 \mathrm{baaS}$ & North Spring & $s$ & 310 OORR & 17.0 & & $<1$ & $7-14-70$ & TP-37 & & & 79 & 15 & 90 & & 243 & 4 & & 140 & & & 543 & 909 & 8.5 & \\
\hline$(\mathrm{B}-12-5) 14 \mathrm{ccc}$ & Dan Douglas & $\mathrm{s}$ & $31000 \mathrm{RP}$ & 18.0 & & $<1$ & $7-14-70$ & $T P-37$ & & & & & & & & & & & & & & 798 & & \\
\hline (B- 12-6) 36ada & O. M. Murk & $w$ & & 16.5 & 212 & & $7-14-70$ & TP-37 & 42 & & 77 & 49 & 67 & 7.7 & 183 & 0 & 54 & 230 & .7 & 2.9 & 644 & 1.100 & R.2 & B. .05 \\
\hline$(\mathrm{B}-13-5) 6 \mathrm{aaa}_{2}$ & 1. M. Turley & $w$ & & 19.0 & 235 & & $7-08-70$ & TP-37 & & & 185 & 70 & 108 & & 144 & 0 & & 591 & & & 1.230 & 2.120 & 7.9 & \\
\hline$(\mathrm{B}-13-5) 16 \mathrm{ccc}$ & E. L. Niolson & $w$ & & 18.5 & & & $7-07-70$ & TP-37 & & & 572 & 245 & 547 & & 142 & 0 & & 2,380 & & & 4,860 & 7.190 & 7.8 & \\
\hline$(\mathrm{B}-13-5) 22 \mathrm{ccc}$ & T. Roberts & $w$ & & 16.5 & 180 & & $7-08-70$ & TP- 37 & & & 65 & 24 & 78 & & 269 & 0 & & 128 & & & 501 & 860 & 8.2 & \\
\hline$(\mathrm{B}-13-5) 33 \mathrm{acc}$ & L. Hawkes & $w$ & & 19.0 & 180 & & $7-14-70$ & TP- 37 & & & 52 & 23 & 101 & & 274 & 3 & & 136 & & & 509 & 901 & 8.6 & \\
\hline$(B-13-6)$ lbdb & R. W. Hentle & $w$ & & 16.5 & 195 & & $7-06-70$ & TP. 37 & & & 149 & 32 & 41 & & 144 & 0 & & 331 & & & 818 & 1,340 & 7.8 & \\
\hline$(B-13-6) 1 \mathrm{dbb}$ & R. W. Henrle & $w$ & $111 \mathrm{ALVM}$ & 19.0 & 704 & $580 \mathrm{R}$ & $7-06-70$ & TP-37 & 47 & & 71 & 19 & 31 & 10 & 160 & 0 & 16 & 127 & .4 & 6.1 & 405 & 701 & 8.2 & 8.04 \\
\hline$(\mathrm{B}-13-6)$ 12aba & R. w. Hienrie & $w$ & & 16.5 & & & $7-07-70$ & TP-37 & & & 325 & 77 & 62 & & 150 & 0 & & 551 & & & 1,700 & 2,470 & 7.9 & \\
\hline (B-13-6) 36acc & A. Manning & $w$ & & 17.5 & 300 & & $7-13-70$ & TP- 37 & & & 447 & 153 & 143 & & 162 & 0 & & 1,340 & & & 3,450 & 4,270 & a.d & \\
\hline
\end{tabular}


Tablo 24. Beaver valley. Welle and Springs with Water Temperatures of $15.5^{\circ}$ to $23.5^{\circ} \mathrm{C}$.

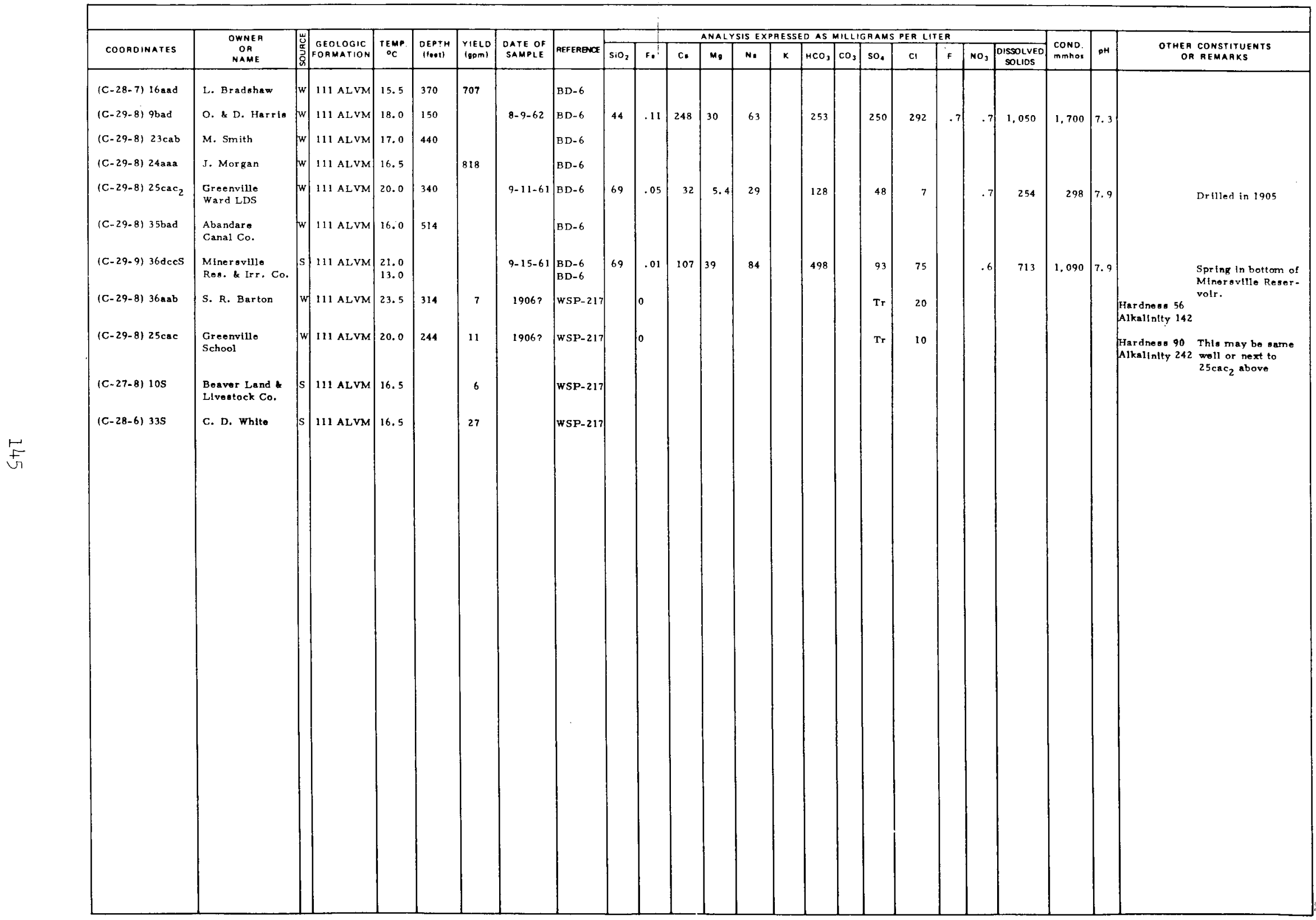


Table 26-A. Cache valley. Wells and One Spring with Water Temperaturee of $20^{\circ}$ to $49^{\circ} \mathrm{C}$.

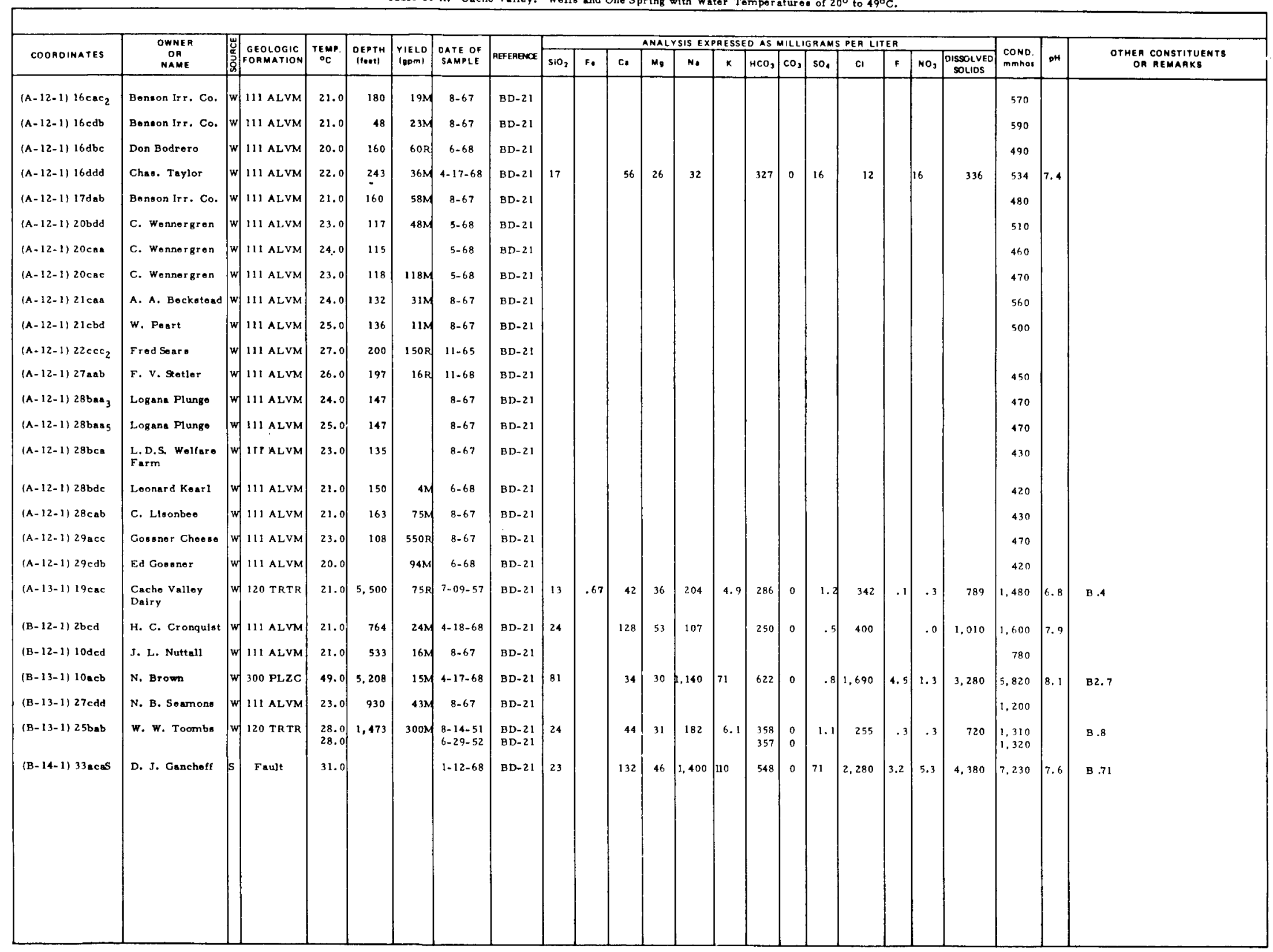


Table 26-B. Cache Valley. Wells and One Spring with Water Temperatures of $16^{\circ}$ to $19^{\circ} \mathrm{C}$.

\begin{tabular}{|c|c|c|c|c|c|c|c|c|c|c|c|c|c|c|c|c|c|c|c|c|c|c|c|}
\hline \multirow{2}{*}{ COORDINATES } & \multirow{2}{*}{$\begin{array}{c}\text { OWNER } \\
\text { OP } \\
\text { NAME }\end{array}$} & \multirow{2}{*}{ 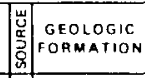 } & \multirow{2}{*}{ TEMP } & \multirow{2}{*}{\begin{tabular}{|c|} 
DEPTH \\
(10et)
\end{tabular}} & \multirow{2}{*}{\begin{tabular}{|l|} 
YIELLO \\
Igpm! \\
\end{tabular}} & \multirow{2}{*}{\begin{tabular}{|c|c|} 
DATE OF \\
SAMPLE \\
\end{tabular}} & \multirow{2}{*}{ AEFEREMCE } & \multicolumn{13}{|c|}{ ANALYSIS EXPAESSED AS MLLIGRAMS PER LITEA } & \multirow{2}{*}{\begin{tabular}{|l} 
cono. \\
amnoos
\end{tabular}} & \multirow{2}{*}{$\mathrm{DH}$} & \multirow{2}{*}{$\begin{array}{c}\text { OTHER CONSTITUENTS } \\
\text { OR FEMARKS } \\
\end{array}$} \\
\hline & & & & & & & & $\mathrm{SiO}_{2}$ & F. & c. & $\mathrm{Mo}$ & N. & k & $\mathrm{HCO}_{3}$ & $\mathrm{cos}_{3}$ & so. & $\mathrm{c}_{1}$ & if & $\mathrm{NO}_{3}$ & 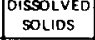 & & & \\
\hline$(A-10-1)$ 16dad & & $W \mid 111$ ALVM & 19.0 & 16 & $80 \mathrm{M}$ & $9-68$ & BD-21 & & & & & & & & & & & & & & 570 & & \\
\hline$(A-10-1) 16 d d b$ & & $\mathrm{w} \mid 111$ ALVM & 16.0 & 18 & $80 \mathrm{E}$ & $9-68$ & $B D-21$ & & & & & & & & & & & & & & 640 & & \\
\hline$(A-12-1) 5 \mathrm{dac}_{2}$ & G. Chamber. & W 111 ALVM & 16.0 & 235 & $4 \mathrm{M}$ & $3-68$ & $\mathrm{BD}-21$ & & & & & & & & & & & & & & 500 & & \\
\hline$(A-12-1) 7 b b b$ & L. Reose & Wh ALVM & 16.0 & 475 & $7 \mathrm{M}$ & $8-67$ & BD-21 & & & & & & & & & & & & & & 820 & & \\
\hline$(A-12-1) 8 d c a$ & R. Gittlns & $\mathrm{w} \mid 111$ ALVM & 16.0 & 189 & $150 \mathrm{M}$ & $6-68$ & $B D-21$ & & & & & & & & & & & & & & 440 & & \\
\hline$(A-12-1) 16$ ada & F. Olnon & $|w| 111$ ALYM & 17.0 & 202 & $9 \mathrm{M}$ & $8-67$ & $\mathrm{BD}-21$ & & & & & & & & & & & & & & 500 & & \\
\hline$(A-12-1) 16 \mathrm{CaC}$ & Beneon Irr. Co. & W| 111 ALVM & 16.0 & 44 & & $2-68$ & $B D-21$ & & & & & & & & & & & & & & 540 & & \\
\hline$(A-12-1) 17 a d a$ & Logan Atrport & $w 111$ ALVM & 18.0 & 145 & $425 \mathrm{R}$ & $\begin{array}{r}5-27-59 \\
7-13-60\end{array}$ & $\begin{array}{l}\text { BD-21 } \\
\text { BD-21 }\end{array}$ & $\begin{array}{l}43 \\
25\end{array}$ & $\begin{array}{l}.03 \\
.02\end{array}$ & $\begin{array}{l}43 \\
55\end{array}$ & $\begin{array}{l}21 \\
15\end{array}$ & $27^{\circ}$ & $\begin{array}{l}8.0 \\
9.2\end{array}$ & $\begin{array}{l}288 \\
281\end{array}$ & $\begin{array}{l}1 \\
1\end{array}$ & $\begin{array}{c}10 \\
6.6\end{array}$ & $\begin{array}{l}11 \\
15\end{array}$ & $\begin{array}{l}.4 \\
.4 \\
\end{array}$ & $\begin{array}{r}4.4 \\
.2\end{array}$ & $\begin{array}{l}309 \\
289\end{array}$ & $\begin{array}{l}463 \\
535\end{array}$ & $\left|\begin{array}{l}7.6 \\
7.7\end{array}\right|$ & $\begin{array}{l}\text { B. } 14 \\
\text { B. } 14\end{array}$ \\
\hline$(A-12-1) 17 d a a$ & Benson Irr. Co. & $w 111$ ALVM & 16.0 & 144 & $10 \mathrm{M}$ & $8-67$ & BD-21 & & & & & & & & & & & & & & 560 & & \\
\hline$(\mathrm{A}-12-1) 17 \mathrm{dcc}$ & s. Hodrero & $\mathrm{w} / 11 \mathrm{ALVM}$ & 17.0 & 53 & $28 \mathrm{M}$ & $5-68$ & $B D-21$ & & & & & & & & & & & & & & 540 & & \\
\hline$(A-12-1) 20 \mathrm{dba}$ & c. Wonnergron & $\mathrm{W} / 11$ ALVM & 17.0 & & $20 \mathrm{M}$ & $5-68$ & $B D-21$ & & & & & & & & & & & & & & & & \\
\hline$(A-12-1) 20 d_{a a_{1}}$ & J. W. Quale & $w \| A L V M$ & 19.0 & & $30 \mathrm{M}$ & $8-67$ & $\mathrm{BD}-21$ & & & & & & & & & & & & & & 570 & & \\
\hline$(\mathrm{A}-12-1) 20 \mathrm{dcb}$ & E. Wuraten & $\mathrm{W} / 111 \mathrm{ALVM}$ & 17.0 & 40 & $120 \mathrm{M}$ & $5-68$ & $B D-21$ & & & & & & & & & & & & & & 440 & & \\
\hline$(A-12-1)$ Zoded & Wm. Kroptlo & W| 111 ALVM & 18.0 & 60 & $33 \mathrm{M}$ & $8-67$ & $B D-21$ & & & & & & & & & & & & & & 490 & & \\
\hline$(A+12-1) 2)_{B a A}$ & L. R. Merrill & $W 111$ ALVM & 19.0 & 50 & $1 \mathrm{M}$ & $8-67$ & $B D-21$ & & & & & & & & & & & & & & 590 & & \\
\hline$(\mathrm{A}-12-1) 21 \mathrm{dca}$ & L. Koorl & $w 111$ ALVM & 17.0 & 57 & $11 \mathrm{R}$ & & $B D-21$ & & & & & & & & & & & & & & & & \\
\hline$(A-12-1) 27 \mathrm{cab}$ & Logan City & $\mathrm{w}: 111$ ALVM & 18.0 & 800 & $4555 \mathrm{R}$ & $1-03-64$ & $B D-21$ & 10 & .01 & 48 & 23 & 5.3 & 1.8 & 245 & 1 & 6.2 & 10 & .1 & .8 & 227 & 405 & 8. 0 & B. 00 \\
\hline$(A-12-1) 28 b c b$ & 5. Bodraro & $w 111$ AL VM & 17.0 & 72 & $21 \mathrm{M}$ & $2-68$ & $B D-21$ & & & & & & & & & & & & & & 480 & & \\
\hline$(\mathrm{A}-12-1) 28 \mathrm{cab} 2$ & L. Andrews & $W 111$ ALVM & 16.0 & 60 & $12 \mathrm{M}$ & $8-67$ & BD-21 & & & & & & & & & & & & & & 510 & & \\
\hline$(A-12-1) 28 c \mathbf{c a} a_{1}$ & M. Bodroro & $w 111$ ALVM & 16.0 & 68 & $100 \mathrm{M}$ & $8-67$ & $B D-21$ & & & & & & & & & & & & & & 510 & & \\
\hline$(\mathrm{A}-12-1) 28 \mathrm{cca}_{2}$ & M. Bodrero & $w 111$ ALVM & 16.0 & 60 & $150 \mathrm{M}$ & $8-67$ & $B D-21$ & & & & & & & & & & & & & & 500 & & \\
\hline$|A-12-1| 29 a_{b a} \mid$ & E. w. Heaton & $w 111$ ALVM & 18.0 & 42 & $16 \mathrm{M}$ & $8-67$ & $8 D-21$ & & & & & & & & & & & & & & 500 & & \\
\hline$(\mathrm{A}-12-1) 29 \mathrm{aba}_{2}$ & E. w. Heaton & $w 111$ ALVM & 18.0 & 51 & $86 \mathrm{M}$ & $8-67$ & $B D-21$ & & & & & & & & & & & & & & 500 & & \\
\hline$(A-12-1) 29 \mathrm{cab}$ & E. Gossner & $\mathrm{W} 11 \mathrm{ALVM}$ & 18.0 & 43 & & $8-40$ & $B D-21$ & & & & & & & & & & & & & & & & \\
\hline$(A-12-1) 29 \mathrm{cba}_{1}$ & E. Gosaner & $w 111$ ALVM & 18.0 & & $3 \mathrm{M}$ & $6-68$ & $B D-21$ & & & & & & & & & & & & & & & & \\
\hline$(\mathrm{A}-12-1) 29 \mathrm{cba}_{2}$ & E. Gosener & $\mathrm{W} 111 \mathrm{ALVM}$ & 18.0 & 158 & $375 \mathrm{R}$ & $6-68$ & BD-21 & & & & & & & & & & & & & & 440 & & \\
\hline$(A-12-1) 31 d_{a b}$ & R.S. Palnter & WII ALVM & $\begin{array}{l}17.0 \\
12.0\end{array}$ & 132 & $273 \mathrm{M}$ & $\begin{array}{l}4-04-61 \\
8-31-62\end{array}$ & $\begin{array}{l}B D-21 \\
B D-21\end{array}$ & $\begin{array}{l}14 \\
7.7\end{array}$ & $\begin{array}{l}.00 \\
.07\end{array}$ & $\begin{array}{l}51 \\
54\end{array}$ & $\begin{array}{l}20 \\
20\end{array}$ & $\begin{array}{l}11 \\
4.5\end{array}$ & $\begin{array}{r}2.0 \\
.9\end{array}$ & $\begin{array}{l}251 \\
250\end{array}$ & $\begin{array}{l}0 \\
0\end{array}$ & $\begin{array}{l}14 \\
14\end{array}$ & $\begin{array}{l}9.0 \\
5.5\end{array}$ & $\begin{array}{l}.4 \\
.1\end{array}$ & $\begin{array}{r}.1 \\
1.9\end{array}$ & $\begin{array}{l}238 \\
220\end{array}$ & $\begin{array}{l}427 \\
411\end{array}$ & $\begin{array}{l}7.7 \\
7.7\end{array}$ & $\begin{array}{l}\text { B. } 1 \\
\text { B. } 02\end{array}$ \\
\hline$(\mathrm{A}-13-1) 31 \mathrm{CCC}_{2}$ & A. C. Roese & W 111 ALVM & 18.0 & 626 & $35 \mathrm{R}$ & $10-68$ & BD-21 & & & & & & & & & & & & & & 930 & & \\
\hline$(A-14-1) 6 c c c$ & Fred Karron & W.111 ALVM & $\begin{array}{r}18.0 \\
7.0\end{array}$ & 20 & $3 \mathrm{M}$ & $4-17-68$ & $\begin{array}{l}\text { BD-21 } \\
\text { BD-21 }\end{array}$ & 13 & & 112 & 112 & 239 & & 722 & 10 & 239 & 268 & & 50 & p. 410 & 2,220 & 7.7 & \\
\hline
\end{tabular}


Tablo 26-B. Cacho Valley. Wells and One Spring with Water Temperatures of $16^{\circ}$ to $19^{\circ} \mathrm{C}$.

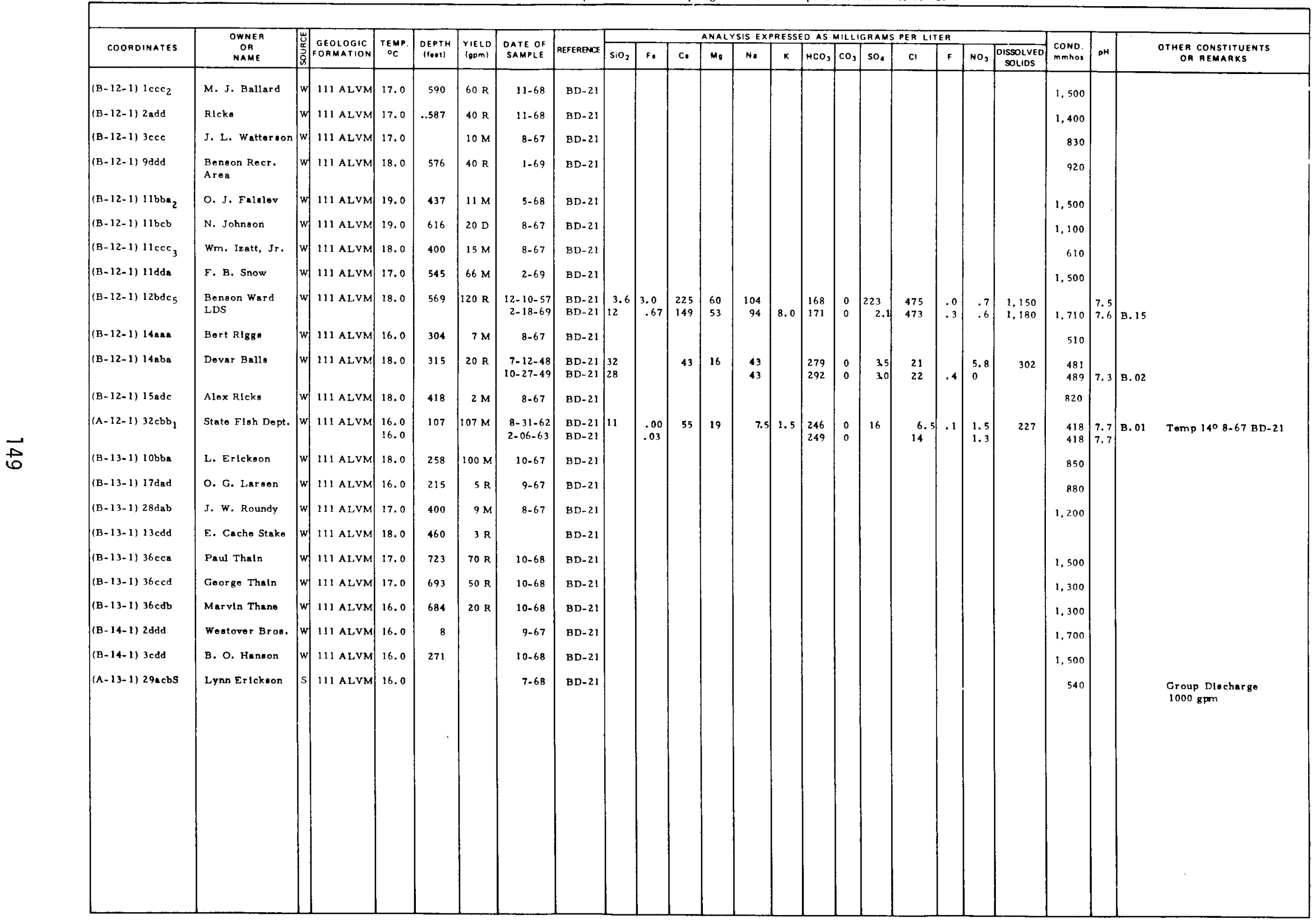


Table 27-A. Canyon Lands. Wells with Water Temperatures of $15.5^{\circ}$ to $28^{\circ} \mathrm{C}$.

\begin{tabular}{|c|c|c|c|c|c|c|c|c|c|c|c|c|c|c|c|c|c|c|c|c|c|c|c|c|}
\hline \multirow{2}{*}{ COORDINATES } & \multirow{2}{*}{$\begin{array}{l}\text { OWNEA } \\
\text { OA } \\
\text { NAME }\end{array}$} & \multirow{2}{*}{\begin{tabular}{|l|l|}
$\begin{array}{l}u \\
\tilde{u}\end{array}$ & GEOLOGIC \\
$\vec{a}$ & FORMATION \\
\end{tabular}} & \multirow{2}{*}{$\begin{array}{c}\text { TEMP. } \\
\text { o } \\
\end{array}$} & \multirow{2}{*}{$\begin{array}{l}\text { DEPTH } \\
\text { (foet) }\end{array}$} & \multirow{2}{*}{\begin{tabular}{|l|l|}
$Y \mid E L D$ \\
Igpm! \\
\end{tabular}} & \multirow{2}{*}{$\begin{array}{l}\text { DATE OF } \\
\text { SAMPLE }\end{array}$} & \multirow[b]{2}{*}{ REFEREACX } & \multicolumn{13}{|c|}{ ANALYSIS EXPRESSED AS MILLIG RAMS PEA LITEA } & \multirow{2}{*}{\begin{tabular}{|l|} 
CONo. \\
mmhoo \\
\end{tabular}} & \multirow[b]{2}{*}{ DH } & \multirow{2}{*}{\multicolumn{2}{|c|}{$\begin{array}{l}\text { OTHER CONSTITUENTS } \\
\text { OA REMAAKS }\end{array}$}} \\
\hline & & & & & & & & $\mathrm{SiO}_{2}$ & $\mathrm{~F} \cdot$ & c. & $\mathrm{Mg}_{\mathrm{g}}$ & N. & $k$ & $\mathrm{HCO}_{3} \mathrm{C}$ & $\mathrm{CO}_{3}$ & so. & c: & $\mathrm{F}$ & $\mathrm{NO}_{3}\left[\begin{array}{ll}\mathrm{OIS} \\
\mathrm{S}\end{array}\right.$ & $\begin{array}{l}15 S O L V E D \\
\text { SOLIDS }\end{array}$ & & & & \\
\hline (D-18-14) 9ded & Roadstde Geyser & $200 \mathrm{MNCS}$ & 28.0 & 180 & & $3-14-47$ & TP-15 & & & 20082 & 288 & 360 & & 2.840 & 0 1. & 540 & 215 & & .0 & 4,710 & 5,640 & & 4B & $\begin{array}{l}\text { Water varmod in long } \\
\text { diecharge pipe }\end{array}$ \\
\hline$(D-21-16)$ 34dda & $\begin{array}{l}\text { G. Ruby Crystal } \\
\text { Goysor }\end{array}$ & 221 ENRD & 18.0 & 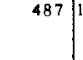 & $1,200 \mathrm{Mg}$ & $3-22-48$ & TP-15 & 13 & & $1,000 / 2$ & 225 & 4.070 & & 4,400 & 02. & $.41 n$ & 4,370 & & & $14,300 \mid 1$ & 19,400 & & & $\begin{array}{l}\text { Abandoned Oll Woll- } \mathrm{CO}_{2} \\
\text { Drive }\end{array}$ \\
\hline$(D-22-14) 28 d$ & F. J. Hat & $W 221$ ENRD & 16.0 & 200 & & $10-28-58$ & $\mathrm{TP}-15$ & 10 & & $\left.321\right|^{2}$ & 246 & 551 & & 2,020 & 0.1. & $.12 n$ & 132 & .00 & .1 & 3.370 & $4,3 4 0 \longdiv { 7 }$ & 7.1 & & \\
\hline$(D-23-21) 27 b c d$ & Nat1. Park Svc. & $W 231$ WNCT & 16.0 & 900 & $4 \mathrm{E}$ & $\mid 0-31-62$ & TP-15 & 5 & & 28 & 18 & 54 & & 163 & 0 & 36 & 62 & & .3 & 283 & 5307 & 7.3 & & \\
\hline$(D-25-12) 14 c$ & T. Marsing & $\begin{array}{lll}\mathrm{w} & 221 & \mathrm{CRMT}\end{array}$ & 16.5 & & & $10-30-58$ & TP-15 & 13 & & 481 & 642 & 339 & & 408 & $\begin{array}{lll}0 & 3 .\end{array}$ & .900 & 105 & .24 & 11 & 6,360 & & 7.0 & & \\
\hline (D-25-21) 20add & National Park & w $220 \mathrm{NVJO}$ & 19.5 & 124 & $8 \mathrm{M}$ & $12-11-58$ & TP-15 & 12 & & 55 & 21 & 75 & & 218 & 0 & 133 & 49 & & 1.6 & 454 & 7627 & 7.4 & & \\
\hline (D-25-21) 2hdce & Suburban Gae & $\begin{array}{ll}\mathrm{W} & 111 \mathrm{ALVM}\end{array}$ & 16.0 & 55 & 25 & $9-05-68$ & $\mathrm{TP}-32$ & 14 & .04 & 46 & 23 & 13 & 2.3 & 220 & 0 & 38 & 14 & .5 & 1.3 & 256 & $\begin{array}{lll}440 & 8\end{array}$ & 8.0 & $B=.04$ & \\
\hline$(D-26-22) 7 \mathrm{bad}$ & Hocls & $\mathrm{w} / 111$ ALVM & 16.0 & 80 & 36 & $9-05-68$ & TP- 32 & 19 & .00 & 112 & 57 & 41 & 2.4 & 312 . & 0 & 300 & 20 & .8 & 9.0 & 749 & 7149 & 7.8 & $B \cdot .07$ & \\
\hline$(\mathrm{D}-26-22) 17 \mathrm{dbc}$ & Garrott Frelght & $\mathrm{W} / 111 \mathrm{ALVM}$ & 16.0 & 153 & 14 & $7-09-68$ & TP- 32 & 10 & 1.3 & 98 & 51 & 44 & 2.1 & 168 & 0 & 370 & 17 & .6 & 2.8 & 701 & 9617 & 7.5 & $8 \cdot .00$ & \\
\hline$(D-26-22) 22 \mathrm{dcd}$ & G. M. white & \begin{tabular}{l|l|l}
$\mathrm{w}$ & $111 \mathrm{ALVM}$
\end{tabular} & 16.0 & 130 & 90 & $7.09-6.8$ & TP. 32 & 14 & .02 & 107 & 38 & 48 & 2.2 & 218 & 0 & 30.3 & 16 & 51 & 12 & 66,4 & 9307 & 7.6 & $B=.00$ & \\
\hline (D-27-2) $26 \mathrm{cda}$ & B. Chapplo & $\begin{array}{ll}\mathrm{W} & 120 \text { TRTR }\end{array}$ & 16.5 & 192 & $450 \mathrm{~F}$ & $9-20.66$ & TP-22 & & & & & & & & & & & & & & 200 & & & \\
\hline$(\mathrm{D}-27-2) 33 \mathrm{dda}$ & Lo Water Worke & $\begin{array}{ll}\mathrm{W} & 120 \mathrm{TRTR}\end{array}$ & 16.5 & 255 & $143 \mathrm{M}$ & 9.20 .66 & TP. 22 & 39 & 01 & 22 & 6.3 & 12 & & 114 & 0 & 30 & 56 & & 1.3 & 141 & 2117 & 7.6 & $\mathrm{Mn}=00$ & \\
\hline (D. -27-2) 34c cb & W. G. Tsylor & $\mathrm{W} 111 \mathrm{ALVM}$ & 16.5 & & $5 E=$ & $10-06-66$ & TP- 22 & & & & & & & & & & & & & & 190 & & & Hlaheot $\mathrm{H}$-ad In Valloy \\
\hline$(\mathrm{D}-27.2) 34 \mathrm{ccc}$ & w. G. Taylor & 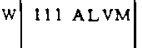 & 16.5 & & $15 \mathrm{M}$ & $9-21-66$ & TP-22 & & & & & & & & & & & & & & 190 & & & \\
\hline$(D-28-2) 3 c b c$ & 5. Recen & \begin{tabular}{|l|l|}
$W$ & $120 \mathrm{TRTR}$
\end{tabular} & 17.0 & 198 & $1,150 \mathrm{M}$ & $8-04-66$ & TP-22 & & & & & & & & & & & & & & 200 & & & \\
\hline$(D-28-2) 3 \mathrm{ccb}$ & $\begin{array}{l}\text { Roads Crook } \\
\text { Water Worke }\end{array}$ & $\mathrm{W}: 120 \mathrm{TRTR}$ & 17.0 & 333 & $1.750 \mathrm{M}$ & $8-04-66$ & TP-22 & 38 & & 24 & 6.1 & 12 & & 124 & 0 & 37 & 34 & & .9 & 152 & 215. & 7.5 & & $\begin{array}{l}\text { Lergest howlng woll } \\
\text { In areas }\end{array}$ \\
\hline$(D-28-2) 3 \mathrm{ccc}_{1}$ & S. Roen & $\mathrm{W} \quad 120 \mathrm{TRTR}$ & 17.0 & 276 & $352 \mathrm{M}$ & $8-04-66$ & TP-22 & & & & & & & & & & & & & & 200 & & & \\
\hline$(D-28-2) 3 \mathrm{ccc}_{2}$ & S. Roos & $\mathrm{w} 120 \mathrm{TRTR}$ & 17.0 & 286 & $386 \mathrm{M}$ & $8-04-66$ & TP-22 & & & & & & & & & & & & & & 210 & & & \\
\hline$(D-28-8) 29 d c b$ & Garkane Power & $w \mid 220$ NVJO & 24.0 & 761 & 3,110 & $10-04-74$ & H. Mtn. & 13 & & 284 & 88 & 494 & 4.4 & & & .070 & 625 & .4 & & 3.746 & 4,200 & 7.8 & & \\
\hline$(\mathrm{D}-28-8) 33 \mathrm{bbb}$ & IPP - Tost & $w \mid 220$ NVJO & 17.5 & 1,685 & 2800 & $8-30-75$ & H. Mtn. & 9.3 & & 95 & 28 & 760 & 3.7 & 289 & & $56 \mathrm{ng}$ & 800 & .7 & .01 & 2,500 & 4,050 & 7.0 & $B=53$ & \\
\hline$(\mathrm{D}-28-8) 33 \mathrm{cdd}$ & IPP - Colt & \begin{tabular}{|l|l|}
$\mathrm{w}$ & $22.0 \mathrm{NVJO}$ \\
\end{tabular} & 17.5 & 1.400 & 200 & 1975 & it. Men. & 9.6 & & 110 & 52 & 130 & 5.6 & 225 & & 380 & 130 & .2 & .07 & 933 & $1,400 / 7$ & 7.0 & $B=60$ & \\
\hline (D-28-12)16ace & Old CCC W•ll & $\mathbf{w} \mid 221$ ENRD & 16.0 & 320 & & $3-16-47$ & TP-15 & & & 15 & 14 & 115 & & 238 & 0 & 130 & 8 & .7 & .1 & 400 & 617 & & & \\
\hline$(D-28-11)$ 16ddb & E. E. Stone & $\mathbf{w} / 221$ ENRD & 18.0 & 340 & 13 & $6-05-59$ & TP-15 & 14 & & 17 & 6.1 & 137 & & 230 & 10 & 144 & 4.5 & .3 & 1.8 & 448 & 688.8 & 8.6 & & $.22 \mathrm{ppm} \mathrm{B}$ \\
\hline $\begin{array}{l}(\mathrm{D}-29-12) 33 \mathrm{acd} \\
(\mathrm{D}-31-7) 36 \mathrm{dad}\end{array}$ & U.S.B.L.M.\$3 & $\mathrm{w} \mid 220$ NVJO & 16.5 & 510 & 200 & $8-09-76$ & H. Mtn. & 11 & & 59 . & 31 & 26 & 7.5 & 239 & & 110 & 15 & .2 &.$\infty$ & 378 & 640 ? & 7.5 & $\begin{array}{l}\mathrm{P}=.00 \mathrm{PO} \\
\mathrm{B}=04, \mathrm{pb} \\
\mathrm{Zn=} \mathrm{n=02} \\
\mathrm{P}=02 \mathrm{PO}\end{array}$ & $\begin{array}{l}4=00 \\
b=01\end{array}$ \\
\hline $\begin{array}{l}(\mathrm{D}-31-7) 36 \mathrm{dad} \\
(\mathrm{D}-31-13) 9\end{array}$ & R. Woaver & $\mid \begin{array}{l}W \\
W \\
W \\
231\end{array}$ & $\begin{array}{l}17.5 \\
18.0\end{array}$ & 6,648 & $\begin{array}{c}55 \\
3 \mathrm{R}\end{array}$ & $\begin{array}{l}8-29-75 \\
6-20-57\end{array}$ & $\mid \begin{array}{l}\text { H. Mtn. } \\
\text { TP. } 15\end{array}$ & $\left|\begin{array}{l}9.6 \\
9.1\end{array}\right|$ & .01 & 25 & $\begin{array}{l}20 \\
28\end{array}$ & 6.5 & $\begin{array}{l}2.0 \\
8.5\end{array}$ & $\begin{array}{l}175 \\
275\end{array}$ & 0 & 27 & $\begin{array}{c}28 \\
12\end{array}$ & $\begin{array}{l}.1 \\
.3\end{array}$ & $\begin{array}{c}.27 \\
3.7\end{array}$ & $\begin{array}{l}188 \\
312\end{array}$ & $\left.\begin{array}{l}350 \\
528\end{array}\right]$ & $\begin{array}{l}7.1 \\
7.4\end{array} \mid$ & $\begin{array}{l}P=.01 P O \\
B .06\end{array}$ & $4=03 \mathrm{~B}=.03$ \\
\hline$(D-33-16) 19$ & & W. 324 HRMS & 16.0 & & $450 \mathrm{R}$ & $10-03-48$ & TP-15 & 8.6 & & 84 & 28 & 12 & & 181 & 0 & 163 & 8 & & 1.0 & 414 & 621 & & & \\
\hline$(\mathrm{D}-33-24) 19 \mathrm{dbd}$ & Hall 1 & $w 221$ ENRD & 15.5 & $\begin{array}{l}1,085 \\
1,256\end{array}$ & $40 \mathrm{R}$ & $10-30-55$ & PP-15 & 21 & & 6.2 & 2.6 & 301 & 5.1 & 500 & 80 & 130 & 7.5 & 1.5 & .5 & 801 & 1,2608 & 8.8 & & \\
\hline & & 220 NVJO & 20.0 & $\begin{array}{l}1,313-1 \\
1,673\end{array}$ & $50 \mathrm{R}$ & $11-22-55$ & PP-15 & 28 & & 19 & 19 & 54 & & 199 & 14 & 46 & 5.5 & & .3 & 284 & 4518 & 8.4 & & \\
\hline (D-35-11) 16cdd & $\begin{array}{l}\text { Shitamartrg } \\
\text { Mlno }\end{array}$ & $w 22.1$ ENRD & 20.0 & 560 & 35 & 1969 & H. Mtn. & 15 & & 21 & 12 & 83 & 5.5 & 177 & & 130 & 8.1 & & .78 & 369 & 6108 & 8.4 & $\begin{array}{l}\mathrm{B}=.07 \mathrm{As} \\
\mathrm{Pb}=.004 \mathrm{I}\end{array}$ & $\begin{array}{l}=005 \\
L=.1\end{array}$ \\
\hline
\end{tabular}


Table 27.A. Canyon Land. Woll, with Water Temporatures of $15,5^{\circ}$ to $28^{\circ} \mathrm{C}$.

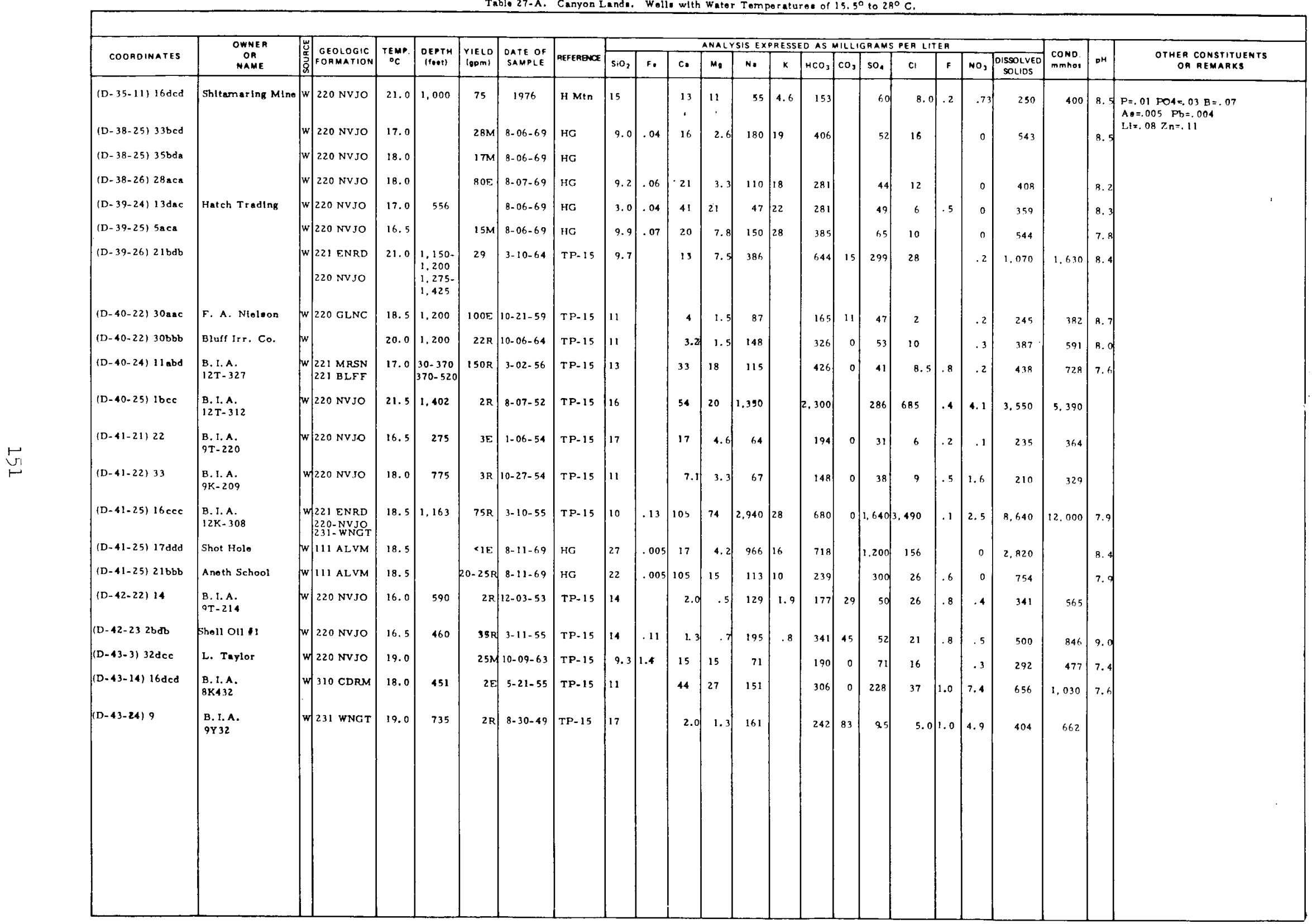


Tablo 27-B. Canyon Lande. Springa with Temperatures of $15.5^{\circ}$ to $31^{\circ} \mathrm{C}$.

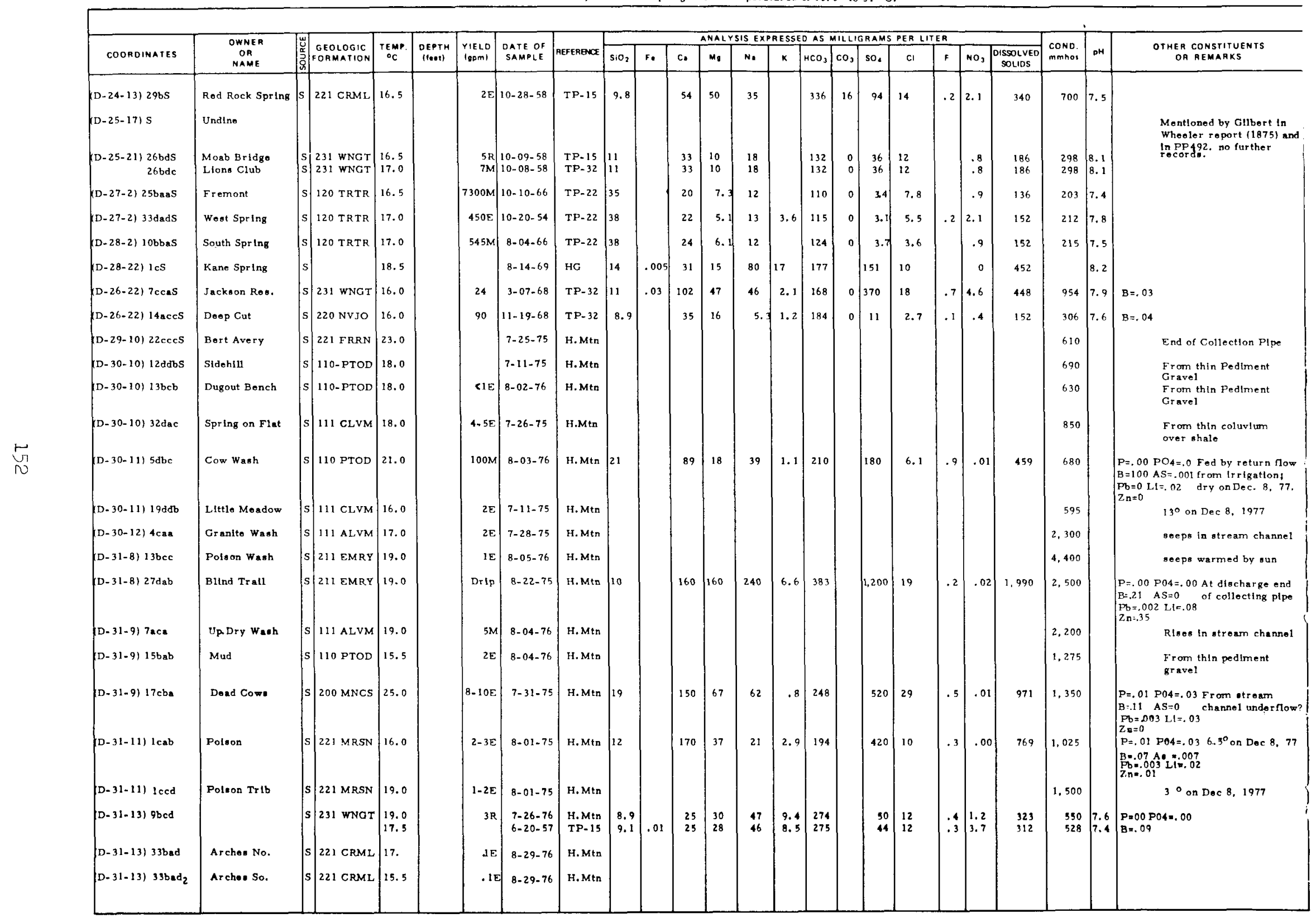


Table 27-B. Canyon Lande. Springs with Temperatures of $15.5^{\circ}$ to $31^{\circ} \mathrm{C}$.

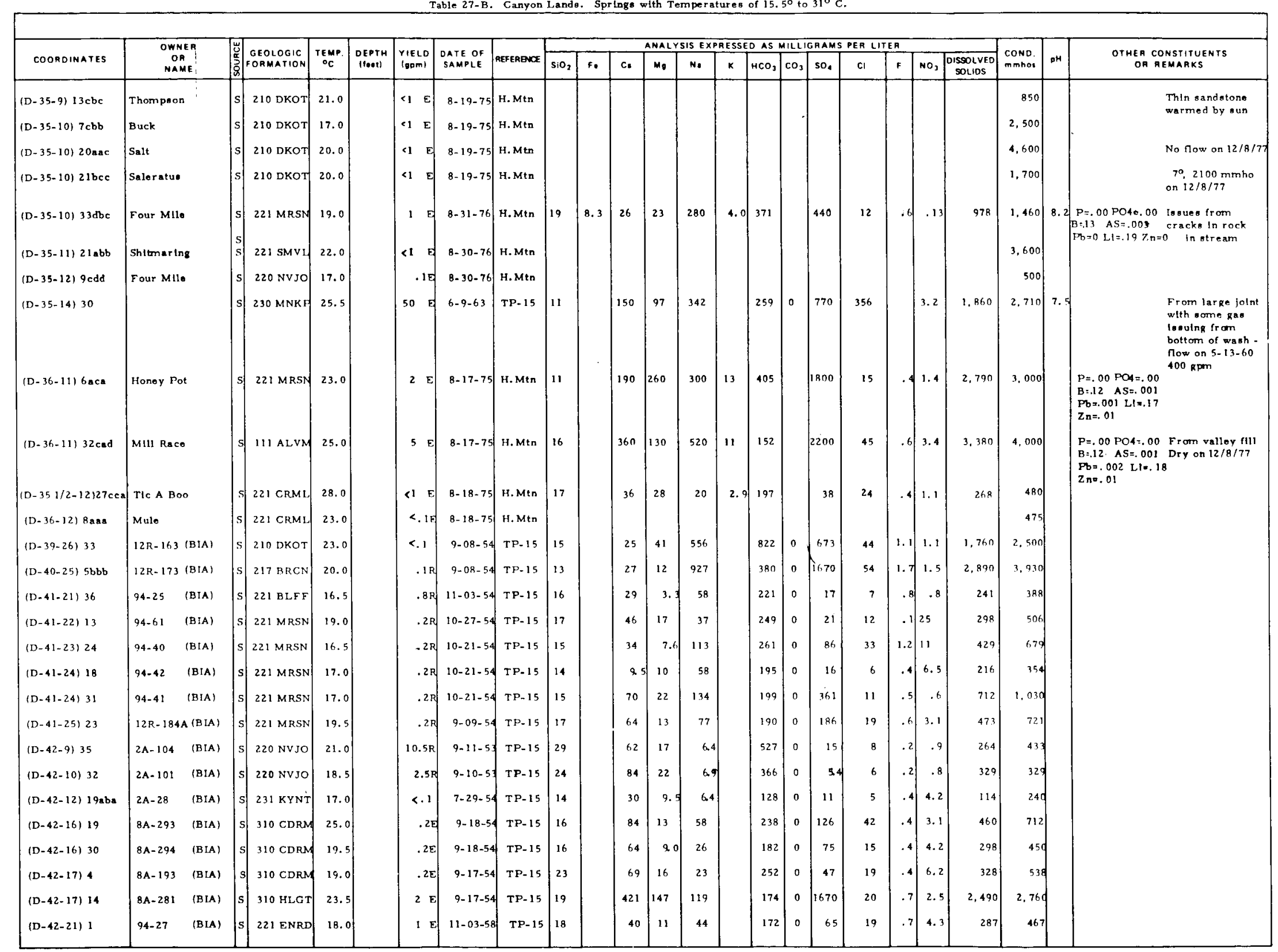


Table 27-B. Canyon Lands. Springs with Temperatures of $15.5^{\circ}$ to $31^{\circ} \mathrm{C}$.

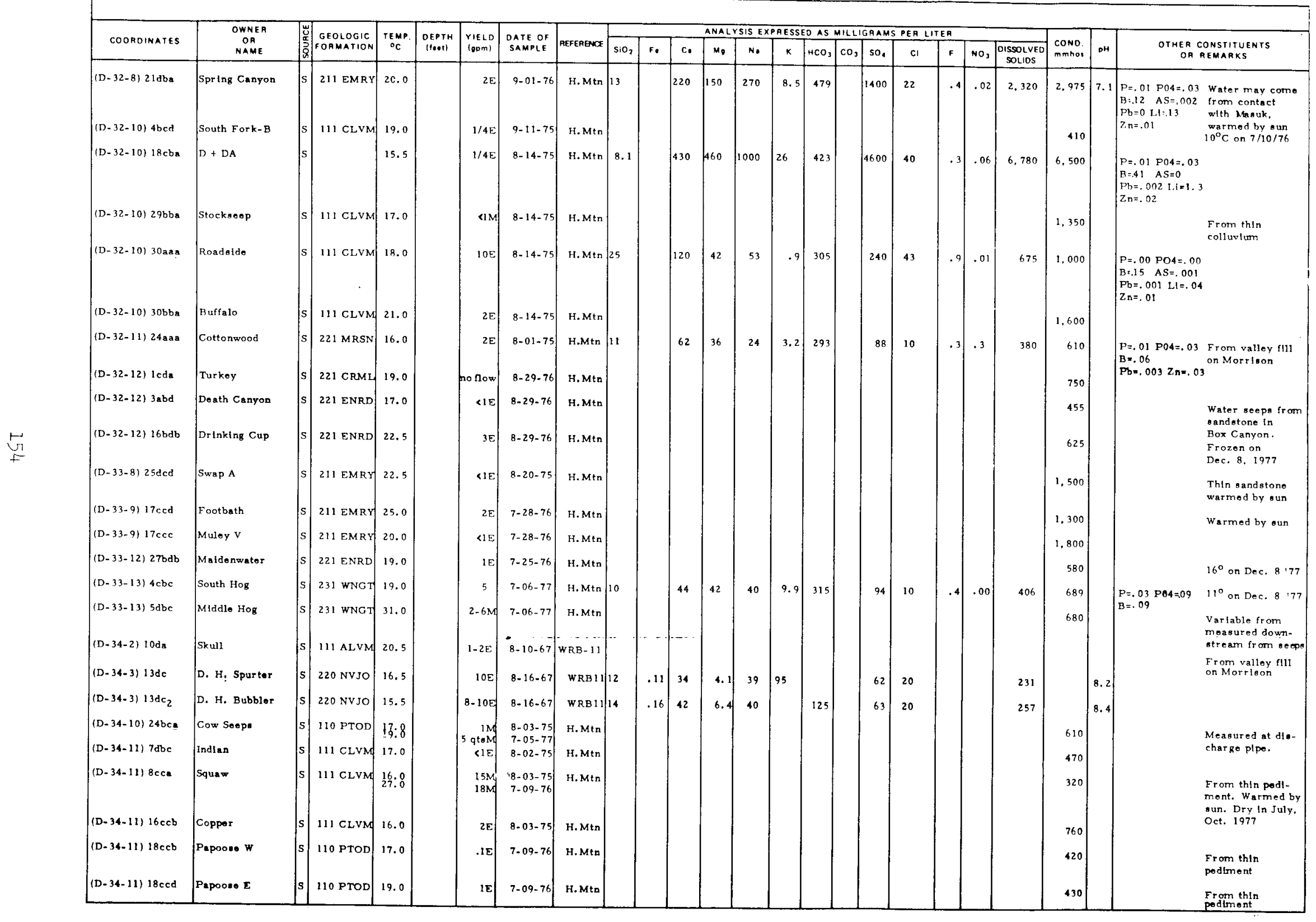


Table 27-B. Canyon Lands. Springs with Temperatures of $15.5^{\circ}$ to $31^{\circ} \mathrm{C}$.

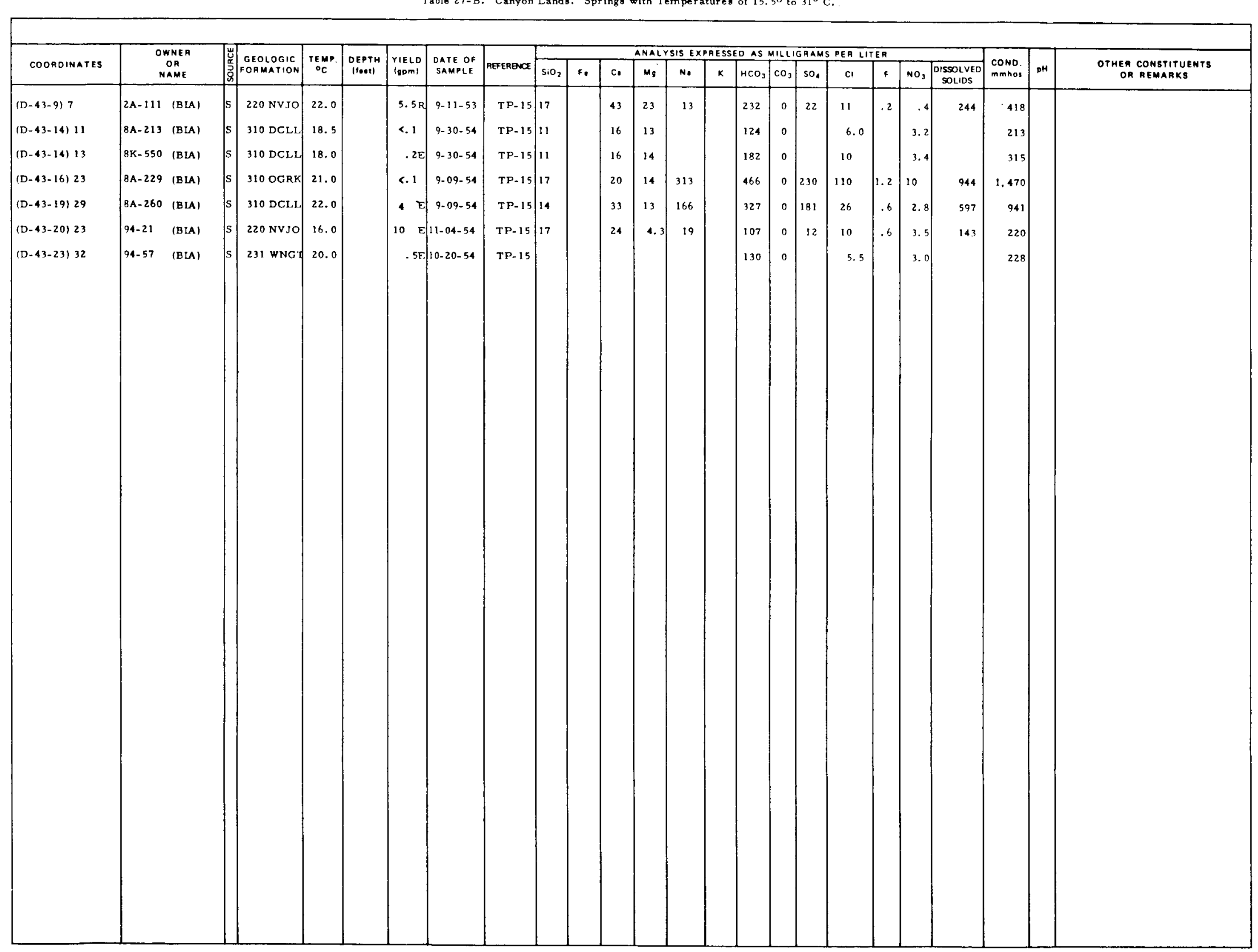


Table 28. Cedat City valley. Wolle with Water Temperatures of $15.5^{\circ}$ to $21^{\circ} \mathrm{C}$

\begin{tabular}{|c|c|c|c|c|c|c|c|c|c|c|c|c|c|c|c|c|c|c|c|c|c|c|c|c|}
\hline \multirow{2}{*}{ COOADINATES } & \multirow{2}{*}{$\begin{array}{c}\text { OWNER } \\
\text { OR } \\
\text { NAME }\end{array}$} & \multirow{2}{*}{ 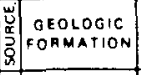 } & \multirow{2}{*}{ TEMP. } & \multirow{2}{*}{$\begin{array}{l}\text { DEPTH } \\
\text { IIETI }\end{array}$} & \multirow{2}{*}{$\begin{array}{l}\text { YIELO } \\
\text { Iopmi } \\
\end{array}$} & \multirow{2}{*}{$\begin{array}{l}\text { DATE OF } \\
\text { SAMPLE }\end{array}$} & \multirow{2}{*}{ REFEAENC: } & \multicolumn{13}{|c|}{ ANALYSIS EXPAESSED AS MILLIGAAMS PER LITER } & \multirow{2}{*}{$\begin{array}{c}\text { cono. } \\
\text { manno: }\end{array}$} & \multirow{2}{*}{$\mathrm{PH}$} & \multirow{2}{*}{\multicolumn{2}{|c|}{$\begin{array}{l}\text { OTHER CONBTITUENTE } \\
\text { OR REMAAKS }\end{array}$}} \\
\hline & & & & & & & & $\mathrm{SiO}_{2}$ & $\mathrm{Fe}$ & c. & $m_{0}$ & N. & к & $\mathrm{HCO}_{3}$ & $\mathrm{CO}_{3}$ & so. & cI & ${ }^{*}$ & No, & $\begin{array}{c}\text { DisSOVIED } \\
\text { solids }\end{array}$ & & & & \\
\hline (C-34-10) 31can & I. Jones & $w \mid 111$ ALVM & 16.0 & 365 & 300 & $5-23-74$ & $B D-28$ & 34 & .01 & 55 & 38 & 57 & 6.4 & 284 & 0 & 67 & 81 & .1 & 2.6 & 490 & 800 & 7.9 9 & в. 09 & \\
\hline$(C-34-11) 36 c^{-1 d d_{2}}$ & D. Clark & $\mathrm{w} 111 \mathrm{ALVM}$ & 19.5 & 128 & 450 & $8.05-60$ & $\mathrm{BD}-6$ & 37 & .01 & 46 & 28 & 26 & 5.1 & 234 & & 67 & 20 & .4 & 1.8 & 346 & 522 & 7.9 & B. 11 & \\
\hline (C-34-12) 36abb & L. C. Jones & $w 111$ ALVM & $\begin{array}{l}19.0 \\
20.0\end{array}$ & & & $9-10.74$ & BD-28 & 26 & .04 & 80 & 52 & 50 & 4.3 & 139 & & 330 & 40 & .2 & .55 & 653 & 1.000 & 7.9 & B. 12 & \\
\hline$(\mathrm{C}-35-10) 7 \mathrm{abc}$ & H. Glbson & W 111 ALVM & 15.5 & 300 & 850 & $8-27-74$ & $\mathrm{BD}-28$ & & & & & & & & & & & & & & 500 & & & \\
\hline$(C-35-11) 24 \mathrm{aab}$ & E. Unton trr. Co. & w 111 ALVM & 15.5 & & 1,100 & $8-15-74$ & $\mathrm{BD}-28$ & & & & & & & & & & & & & & 650 & & & \\
\hline$(\mathrm{C}-37-12) 9 \mathrm{acc}$ & J. A. Watson & W 111 ALVM & $\begin{array}{l}15.5 \\
16.0\end{array}$ & 186 & & $9-11-74$ & $\begin{array}{l}\mathrm{BD}-28 \\
\mathrm{BD}-28\end{array}$ & 54 & .02 & 48 & 5.8 & 14 & 3.8 & 166 & & 12 & 21 & .2 & . 8 . & 245 & 360 & 7.8 & B. 04 & \\
\hline $\begin{array}{r}(\mathrm{C}-37-12) \|_{11 \text { aab }} \\
11 \text { aaa }\end{array}$ & G. Vandenburge & $\mathrm{w} \mid 111 \mathrm{AL} \mathrm{VM}$ & $\begin{array}{l}21.0 \\
21.0\end{array} \mid$ & $\begin{array}{l}365 \\
365\end{array}$ & & $\begin{array}{l}7-13-59 \\
6-14.74\end{array}$ & $\begin{array}{l}\mathrm{BD}-6 \\
\mathrm{BD}-28\end{array}$ & $\begin{array}{l}54 \\
51\end{array}$ & $\begin{array}{l}.02 \\
.02\end{array}$ & $\begin{array}{l}47 \\
47\end{array}$ & $\begin{array}{l}28 \\
30\end{array}$ & $\begin{array}{l}34 \\
31\end{array}$ & 4.1 & $\begin{array}{l}178 \\
180\end{array}$ & 0 & $\begin{array}{l}137 \\
140\end{array}$ & $\begin{array}{l}12 \\
12\end{array}$ & .3 & $\begin{array}{r}3.0 \\
.9\end{array}$ & $\begin{array}{l}403 \\
408\end{array}$ & $\begin{array}{l}586 \\
566\end{array}$ & $\begin{array}{l}7.7 \\
7.8\end{array}$ & B. 14 & $\begin{array}{l}\text { Bi)- } 28 \text { Indicates these } \\
\text { recorda are ame well } \\
\text { llana }\end{array}$ \\
\hline$(C-37-12) \quad 11 d d b$ & Graff Bros. & $w \mid 111$ ALVM & 19.5 & & $1,200 \mathrm{R}$ & $7-24-74$ & $B D-2 B$ & & & & & & & & & & & & & & 550 & & & \\
\hline$(C-37-12) 14 a b c$ & A. L. Graff & W 111 ALVM & $\begin{array}{l}18.0 \\
16.5\end{array}$ & 264 & 600 & $7-23-74$ & $\begin{array}{l}\text { BD-6 } \\
\text { BD- } 28\end{array}$ & & & & & & & & & & & & & & 650 & & & \\
\hline
\end{tabular}

Table 29. Parowan. Spring and Wells with Water Temperatures of $14.5^{\circ}$ to $20^{\circ} \mathrm{C}$.

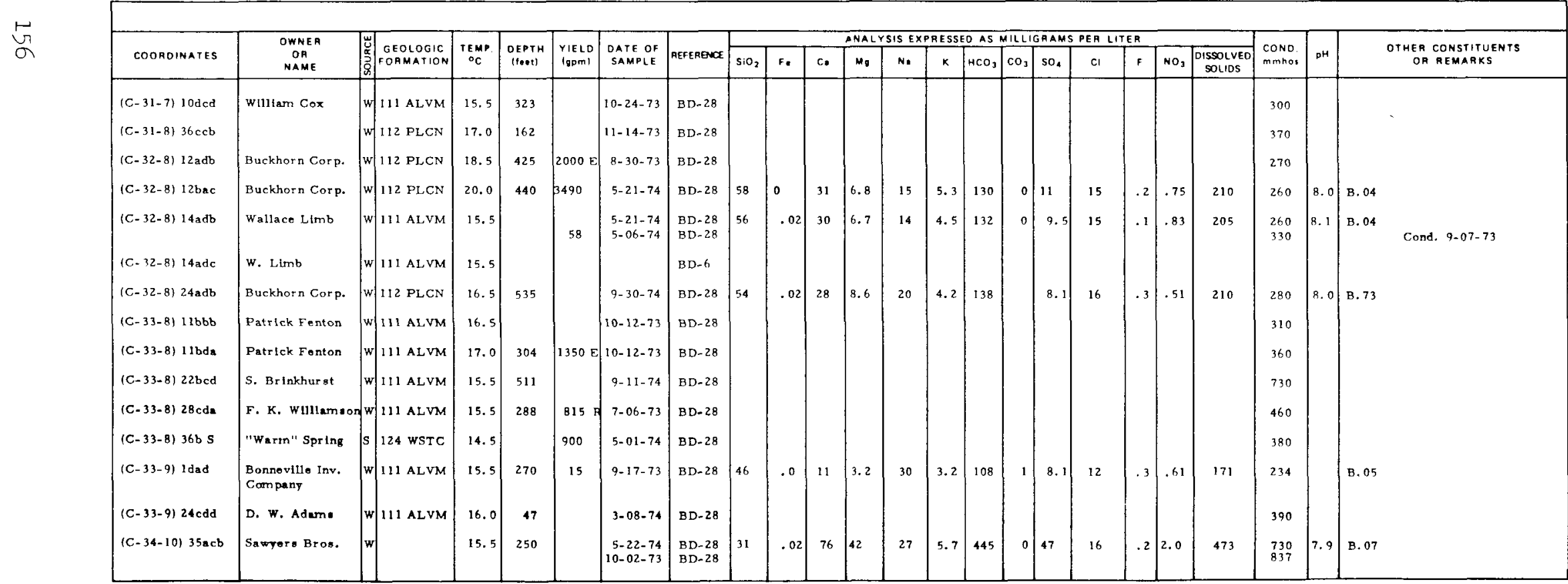


ABLE 30. Codar Valley. Welle with Water Temperatures of $15.5^{\circ}$ to $27^{\circ} \mathrm{C}$.

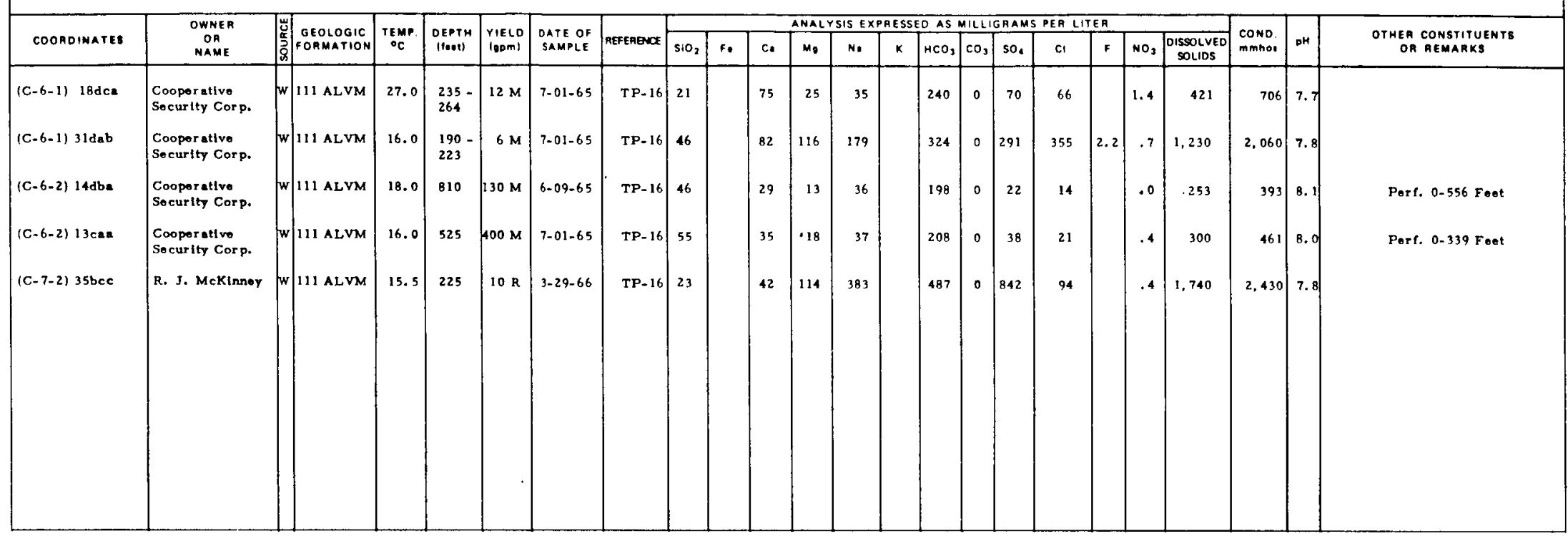

Tablo 31. Northern Juab Valley. Records of a Spring with Temperature of $20^{\circ} \mathrm{C}$ and a
Well with Water Temporature of $15.5^{\circ} \mathrm{C}$. and Chemical Analyoes of Water from Both.

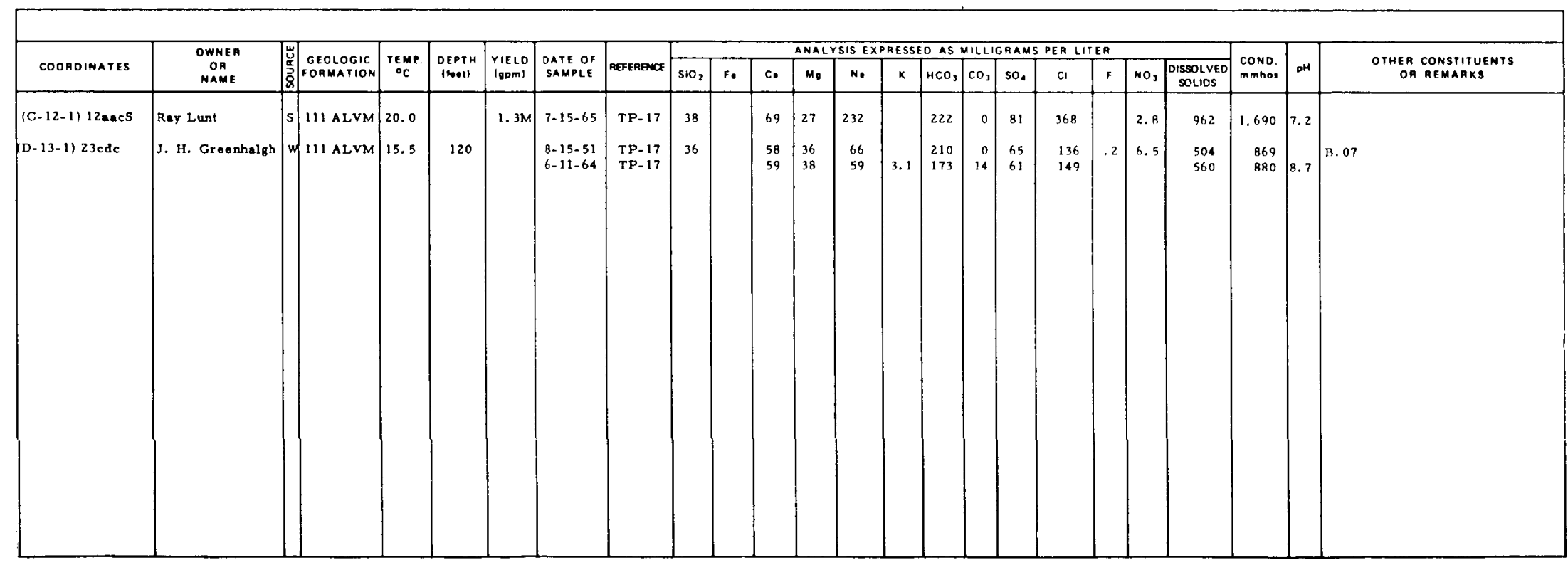


Table 32. Park valley. Recorde of Springs with Water Temperatures of $16^{\circ}$ to $26.5^{\circ} \mathrm{C}$

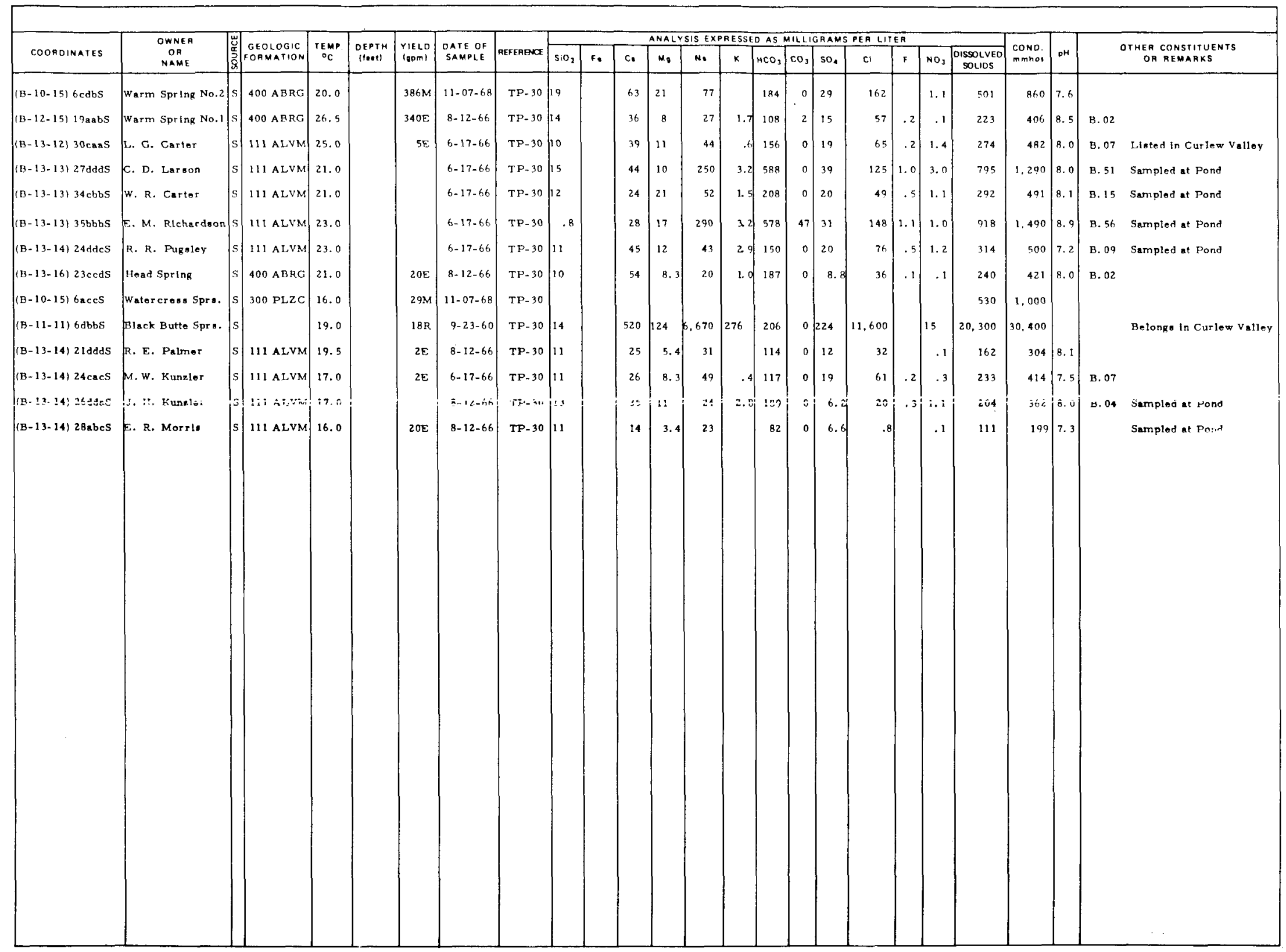


Table 33. Promontory Mountaing. Records of Wella and Springs with Water Temperatures of $15.5^{\circ}$ to $25^{\circ} \mathrm{C}$

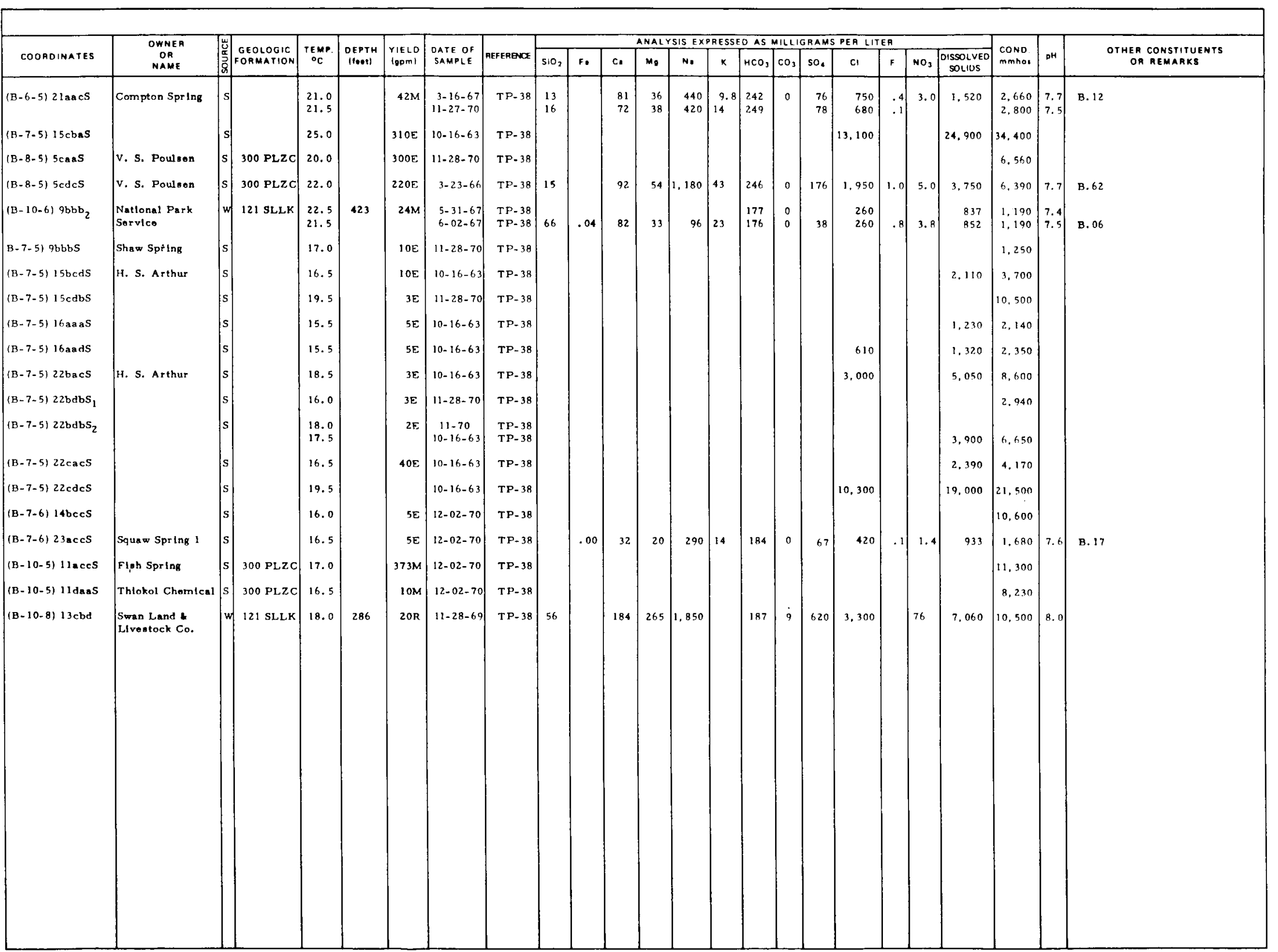


Table 34. Ruah Valley. Records of One well and Three Springs with water Temperatures of $16^{\circ}$ to $26.5^{\circ} \mathrm{C}$
and Chemical Analyaes of $W_{\text {ater from the Well and Springs }}$

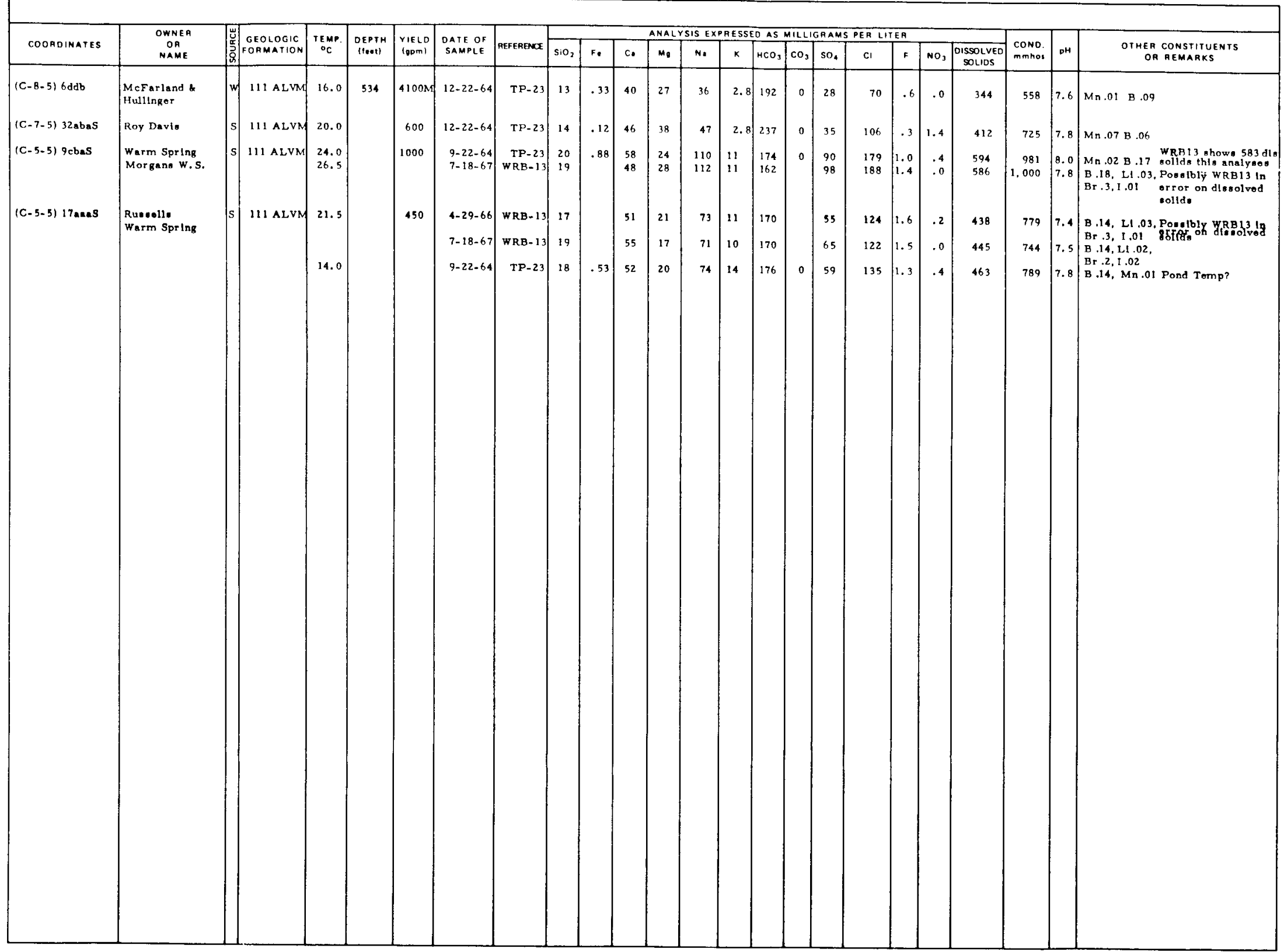


Table 35-A. Skull Valley. Recorda of Wells and Springs with Water Temperatures of $20^{\circ}$ to $26.5^{\circ} \mathrm{C}$

and Chemical Analynes of Water from Some of Those Wella and Springa

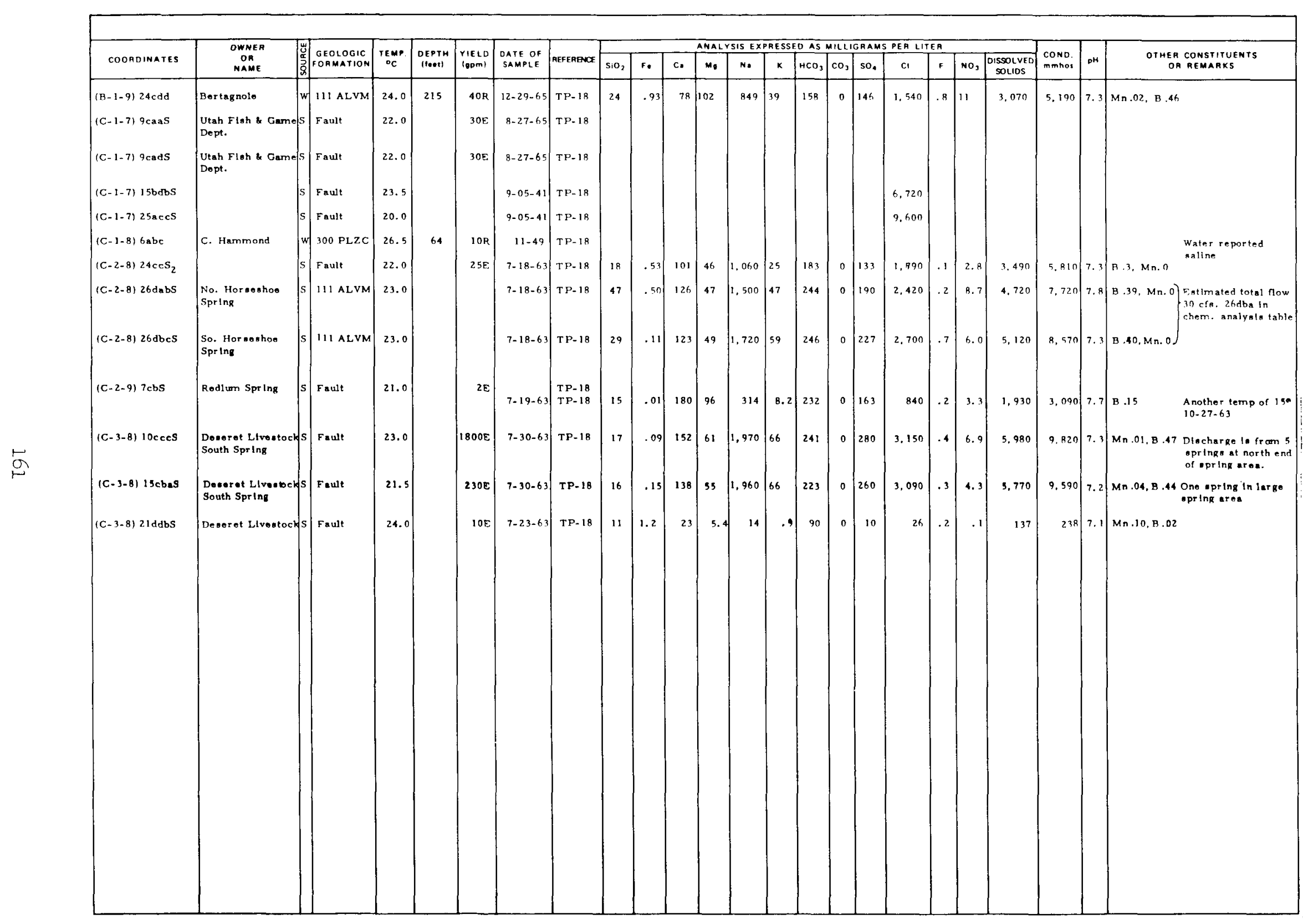




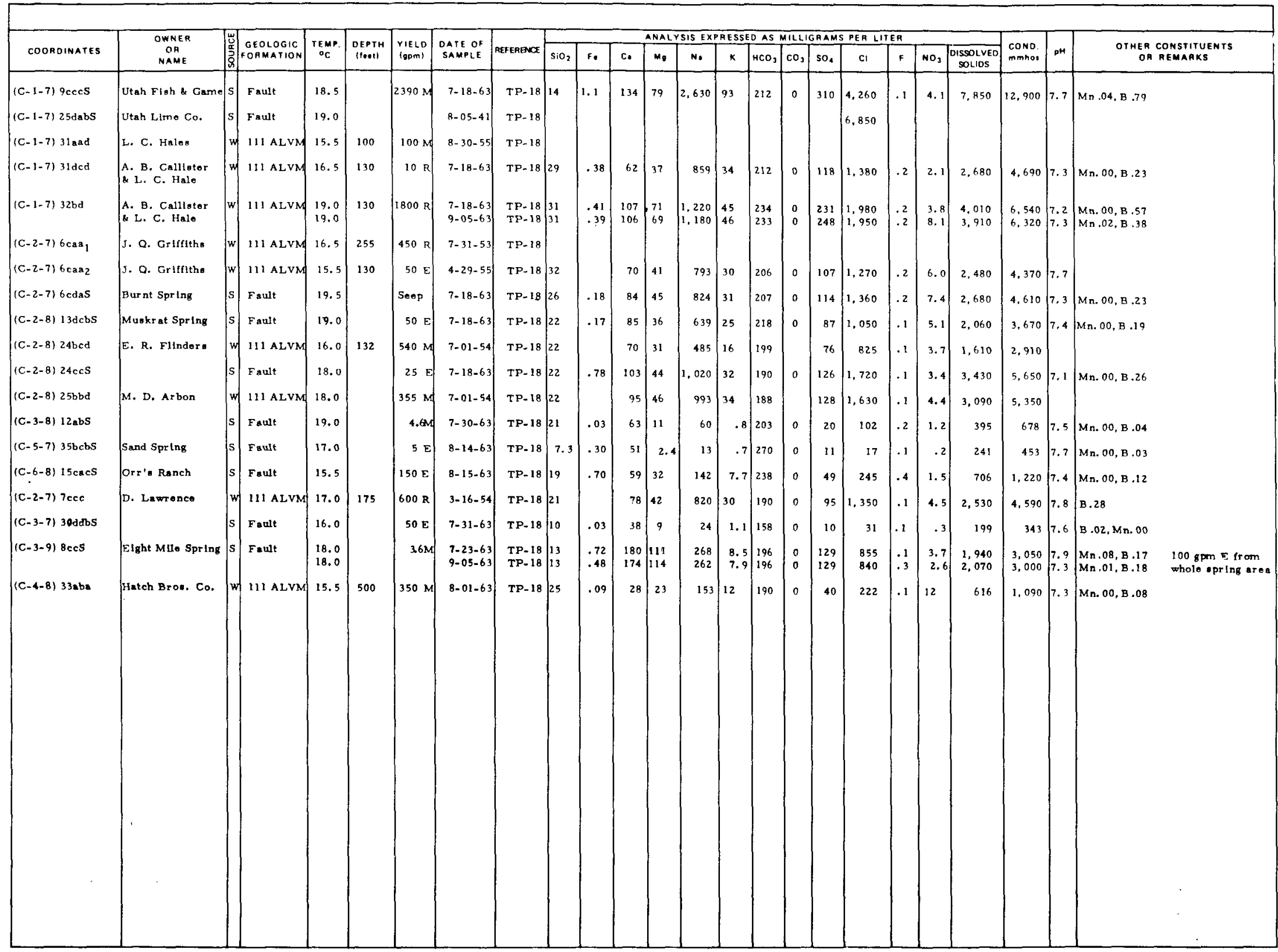


Tabie 36. Snake Valley. Records of Springs and Welle with Water Temperatures of $15,5^{\circ}$ to $270 \mathrm{C}$.

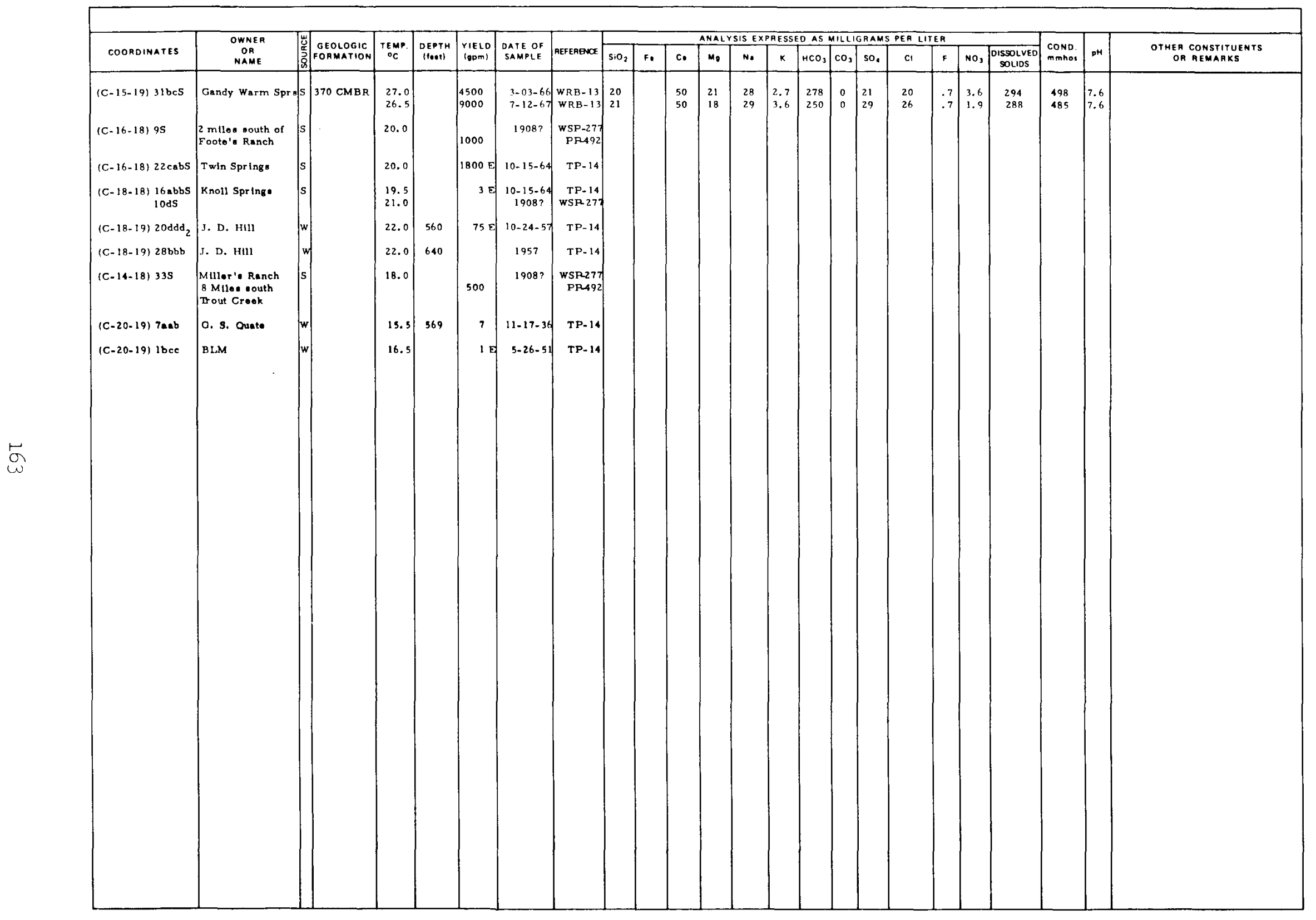


Table 37-A. Tornie Valley. Wollis and Ono Spring with Water Temperatures of $20^{\circ}$ to $30^{\circ} \mathrm{C}$.

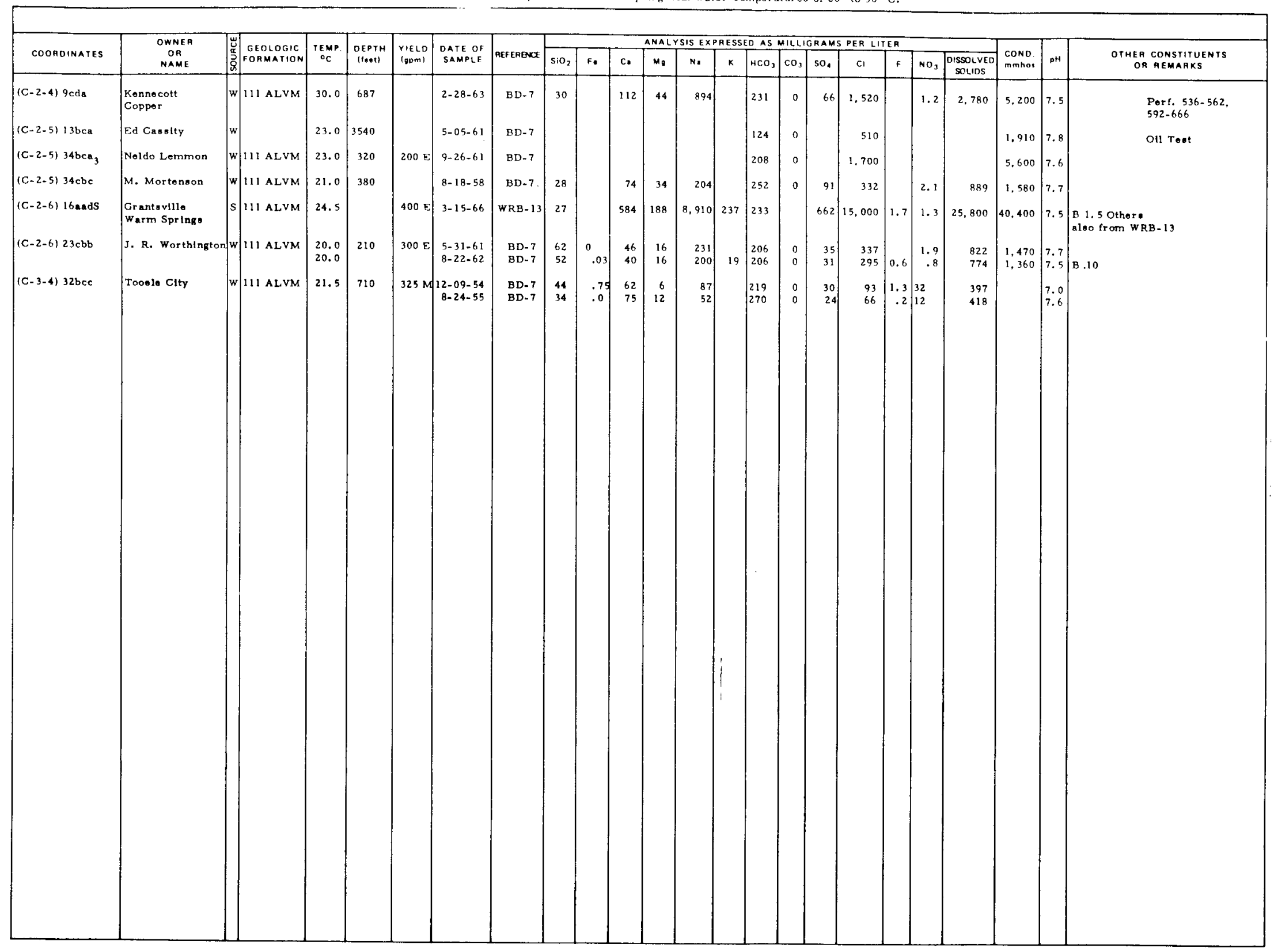

0. 
able 37-B. Tooele Valley. Wells and One Spring with Water Temperatures of $15.5^{\circ}$ to $19.5^{\circ} \mathrm{C}$.

\begin{tabular}{|c|c|c|c|c|c|c|c|c|c|c|c|c|c|c|c|c|c|c|c|c|c|c|c|}
\hline \multirow{2}{*}{ COORDINATES } & \multirow{2}{*}{$\begin{array}{l}\text { OWNER } \\
\text { OA } \\
\text { NAME }\end{array}$} & \multirow{2}{*}{ 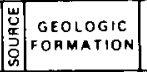 } & \multirow{2}{*}{\begin{tabular}{|c|} 
TEMP. \\
${ }^{\circ} \mathrm{C}$ \\
\end{tabular}} & \multirow{2}{*}{\begin{tabular}{|l|} 
DEPTH \\
(1.o.t) \\
\end{tabular}} & \multirow{2}{*}{\begin{tabular}{|l|}
$\begin{array}{c}\text { YIELD } \\
\text { (gpm) }\end{array}$ \\
\end{tabular}} & \multirow{2}{*}{$\begin{array}{l}\text { OATE OF } \\
\text { SAMPLE }\end{array}$} & \multirow[b]{2}{*}{ AEFEREACE } & \multicolumn{13}{|c|}{ ANALYSIS EXPRESSED AS MILLIGRAMS PER LITER } & \multirow{2}{*}{\begin{tabular}{|l|} 
COND. \\
mmhos \\
\end{tabular}} & \multirow{2}{*}{$\mathrm{OH}$} & \multirow{2}{*}{$\begin{array}{l}\text { OTHER CONSTITUENTS } \\
\text { OA REMARKS }\end{array}$} \\
\hline & & & & & & & & $\mathrm{SiO}_{2}$ & F. & c. & $M_{0}$ & N. & k & $\mathrm{HCO}_{3}$ & $\mathrm{Co}_{3}$ & $\mathrm{so}_{4}$ & $\mathrm{cl}$ & $F$ & $\mathrm{No}_{3}$ & \begin{tabular}{|l|l} 
DISSOLVED \\
soLIDS
\end{tabular} & & & \\
\hline (C-1-4) 26ddd & LeaHe Sait & W. 111 ALVM & 16.0 & 227 & $120 \mathrm{~A}$ & $11-24-61$ & BD-7 & 14 & .01 & 72 & 57 & 533 & 24 & 230 & 0 & 48 & 960 & .2 & 2.3 & 1.820 & 3.550 & 8.1 & $B=.22$ \\
\hline$(C-1-6) 22 d d d$ & Solar Salt & W:11 ALVM & 16.0 & 630 & $40 \mathrm{~A}$ & 1959 & BD-7 & & & & & & & & & & & & & & & & \\
\hline $\begin{aligned} &(\mathrm{C}-2-4) 1 \mathrm{obcd} \\
& 15 \mathrm{cac}\end{aligned}$ & $\begin{array}{l}\mathrm{KCC} \\
\mathrm{KCC}\end{array}$ & 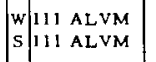 & $\begin{array}{l}16.5 \\
18.0\end{array}$ & 133 & $\left|\begin{array}{r}6 M \\
2600 \mathrm{R}\end{array}\right|$ & $\left|\begin{array}{l}9-06-62 \\
8-22-58\end{array}\right|$ & $\begin{array}{l}\mathrm{BD}-7 \\
\mathrm{BD}-7\end{array}$ & 25 & & 76 & 41 & 288 & & 242 & 0 & 144 & $\begin{array}{l}638 \\
450\end{array}$ & & 4.6 & 1,150 & $\begin{array}{l}2,590 \\
1,990\end{array}$ & 7.6 & \\
\hline$(C-2-4)] 5 c d c$ & s. w. Clark & $\mathrm{w} / 11 \mathrm{ALVM}$ & 16.0 & 305 & $1200 \mathrm{R}$ & $6-27-61$ & BD-7 & 19 & & 122 & 43 & 321 & & 292 & 0 & 277 & 460 & & 2.7 & 1,390 & 2,3307 & 7.5 & \\
\hline$(\mathrm{C}-2-4) 17 \mathrm{dad}$ & E. J. Jeremy & $\mathrm{w} \mid 111 \mathrm{ALVM}$ & 16.5 & & $6 \mathrm{Mg}$ & $\mid 1-29-61$ & BD-7 & & & & & & & & & & 262 & & & & 1,300 & & \\
\hline$(C-2-4) 31 \mathrm{acc}$, & R. Castagno & W 111 ALVM & 17.0 & 180 & & 8. 18.58 & BD-7 & 17 & & 56 & 20 & 135 & & 273 & 0 & 28 & 182 & & 5.8 & 578 & 1.070 & 8. 0 & \\
\hline$(\mathrm{C}-2-4) 31 \mathrm{ada}$ & E. Walters & $|w| 111$ ALVM & 15.5 & 200 & $15 \mathrm{M}$ & $|0-04-60|$ & BD-7 & 14 & .00 & 48 & 18 & 106 & 1.8 & 258 & 0 & 26 & 122 & .2 & 12 & 475 & 836 & $7.9 . \mathrm{B}$ & $B=.08$ \\
\hline$(C-2-4) 31$ add 2 & E. Waltern & $\mathrm{w} 111 \mathrm{ALVM}$ & 15.5 & 202 & & R- $18-58$ & BD-7 & 17 & & 52 & 19 & 96 & & 272 & 0 & 28 & 112 & & 9.7 & 468 & 846 & 7.9 & \\
\hline$(C-2-4)_{31} a_{d d}$ & E. Waltor & $w 111$ ALVM & 16.0 & 271 & $660 \mathrm{~m}$ & $6-05-62$ & BD-7 & & & & & & & & & & & & & & & & \\
\hline$(C-2-4) 31 \mathrm{bcb}$ & F. Hickman & $w / 11$ ALVM & 17.0 & 343 & $80 E$ & $|12-28-60|$ & BD-7 & 17 & .01 & 66 & 25 & 119 & 3.2 & 262 & 0 & 27 & 198 & .1 & 5.9 & 605 & 1,080 & 7.9 & \\
\hline$(C-2-4) 31 b d c_{2}$ & R. Centagno & $\mathrm{W} / 111 \mathrm{ALVM}$ & 17.0 & 260 & & $8=18-58$ & BD.7 & 15 & & 52 & 19 & 136 & & 244 & 0 & 35 & 180 & & 6.0 & 569 & 1,0308 & 8.3 & \\
\hline$(C-2-4) 31 b d c$ & R. Cantagno & $\mathrm{W} 111$ ALVM & 18.5 & 352 & $1200 \mathrm{M}$ & $6-05-62$ & BD-7 & & & & & & & & & & & & & & & & \\
\hline$(\mathrm{C}-2-4) 31 \mathrm{cs} \mathrm{s}_{5}$ & E. Weltor, & $w 111 \mathrm{ALVM}$ & 16.5 & 172 & & B-18-58 & BD-7 & 16 & & 43 & 17 & 168 & & 270 & 0 & 33 & 200 & & 4.8 & 615 & 1,1108 & 8.1 & \\
\hline$(C-2-4) 31 \mathrm{cde} 2$ & E. Waltor, & $w \| A L V M$ & 16.0 & 300 & $1080 \mathrm{M}$ & 9-07.62 & BD-7 & & & & & & & & & & & & & & & & \\
\hline$(\mathrm{C}-2-1) 31 \mathrm{dac}$ & H. C. DHlard & WhII ALVM & 16.0. & 174 & & $8-20-58$ & BD-7 & 15 & & 54 & 19 & 98 & & 280 & 0 & 28 & 112 & & 11 & 475 & 863. & 7.8 & \\
\hline$(C-2-4) 31 \mathrm{dad}$ & H. C. Dullard & $W \| 11$ ALVM & 16.5 & 727 & $300 \mathrm{M}$ & $8-20-58$ & $\mathrm{BD}-7$ & 14 & & 55 & 18 & 107 & & 285 & 0 & 30 & 120 & & 13 & 497 & \begin{tabular}{l|l}
880 & 8
\end{tabular} & 8.0 & \\
\hline$(\mathrm{C}-2-4) 32 \mathrm{cac}$ & R. Boyce & $w 111$ ALVM & 16.0 & 300 & & $9-11.62$ & $B D-7$ & & & & & & & & & & & & & & & & \\
\hline$(\mathrm{C}-2-4) 32 \mathrm{cad}$ & R. Boyce & wh11 ALVM & 16.0 & 400 & $50 \mathrm{M}$ & $9-07-61$ & $B D-7$ & & & & & & & & & & & & & & & & \\
\hline$(C-2-4) 33 \mathrm{anb}$ & J. E. Englend & WI11 ALVM & 16.0 & 403 & $1760 \mathrm{M}$ & \begin{tabular}{|l|}
$7-28-62$ \\
\end{tabular} & $B D-7$ & & & & & & & & & & & & & & & & \\
\hline$(\mathrm{C}-2-5) 5 \mathrm{ccc}_{2}$ & & Wh 11 ALVM & 16.5 & & & $4-19-63$ & BD-7 & & & & & & & & & & 3.620 & & & & 10,400 & & \\
\hline$(C-2-5) \mathrm{Sdcd}_{4}$ & G. S. Higley & $w 11$ ALVM & 15.5 & 417 & & $\mid 0-11-61$ & BD- 7 & & & & & & & & & & 232 & & & & 1.030 & & \\
\hline$(C-2-5)^{6 d d d} 7$ & L. Peasnal & $w 111$ ALVM & 16.5 & 360 & $1.9 \mathrm{M}$ & $|10-10-62|$ & $\mathrm{BD}-7$ & & & & & & & & & & 1,640 & & & & 5.150 & & \\
\hline$(C-2-5) 18 \mathrm{~d} c c$ & E. M. Clark & $w 111$ ALVM & 15.5 & 300 & & $3-08-62$ & $\mathrm{BD}-7$ & & & & & & & & & & & & & & & & \\
\hline$(C-2-5) 27 \mathbf{a d d}$ & E. Cassity & $w / 11$ ALVM & 18.0 & 355 & $150 \mathrm{E}$ & $6-20-62$ & BD-7 & & & & & & & & & & & & & & & & \\
\hline$(C-2-4) 28 b c$ & c. Hlgley & $w \mid \because 1$ ALVM & 15.5 & 335 & $900 \mathrm{E}$ & $|10-16-62|$ & BD-7 & 24 & & 132 & 47 & 152 & & 220 & 0 & 86 & 412 & & 5.1 & 966 & $1,800 ? 7$ & 7.4 & \\
\hline$(C-2-5) 32 d a A$ & J. M. Frasor & $\mathrm{w}: 111$ ALVM & 15.5 & 410 & $200 E$ & $6-19-62$ & BD-7 & & & & & & & & & & & & & & & & \\
\hline$(\mathrm{C}-2-5) 33 \mathrm{dad}{ }_{3}$ & J. C. Palmer & $w \mid 111$ ALVM & 19.5 & 400 & $200 \mathrm{E}$ & $4-11-61$ & $\mathrm{BD}-7$ & 28 & .12 & 91 & 37 & 255 & 6.0 & 247 & 0 & 86 & 454 & .3 & 3.5 & 1,080 & 1.9408 & $8.1 \mathrm{~B}$ & $B=.17$ \\
\hline$(C-2-5) 33 d b a$ & L. A. Bollnder & $W 111$ ALVM & 17.0 & 525 & $200 \mathrm{E}$ & $6-19-62$ & BD-7 & & & & & & & & & & & & & & & & \\
\hline$(C-2-5) 33 d b b$ & R. Fawson & $\mathrm{W} 111 \mathrm{ALVM}$ & 18.5 & 265 & & $3-07-62$ & BD-7 & & & & & & & & & & & & & & & & \\
\hline$(c-2-5) 33 \mathrm{dcd}$ & T. McMichell & $\mathrm{w} \mid 111$ A.LVM & 19.0 & 285 & $535 \mathrm{M}$ & $8-22-58$ & BD-7 & 31 & & 88 & 34 & 190 & & 264 & 0 & 93 & 323 & 4.8 & & 894 & 1,5307 & 7.6 & \\
\hline$(\mathrm{C}-2-3) 34 d d d$ & N. Pentos & $W \mid 11$ ALVM & 18.0 & 440 & & $7-01-59$ & BD-7 & 21 & & 51 & 26 & 202 & & 217 & 0 & 48 & 315 & & .4 & 770 & 1,3907 & 7.8 & \\
\hline$(\mathrm{C}-2.5)^{35 \mathrm{add}_{1}}$ & H. G. Langford & $W 111$ ALVM & 18.5 & 513 & & $6-28-61$ & BD-7 & & & & & & & & & & & & & & 1,460 & & \\
\hline $\mid(C-2-5) 35 a d d_{2}$ & S. A. Lengford & $W \mid 111$ ALVM & 17.0 & 145 & $30 \mathrm{R}$ & $8-18-58$ & BD-7 & 17 & & 93 & 36 & 298 & & 253 & 0 & 39 & 550 & & 5.7 & 1,160 & 2.180 & 7.7 & \\
\hline
\end{tabular}


Teble 37-B. Tooolo Valley. Wells and One Spring with Water Temporatures of 15,50 to $19,50 \mathrm{C}$,

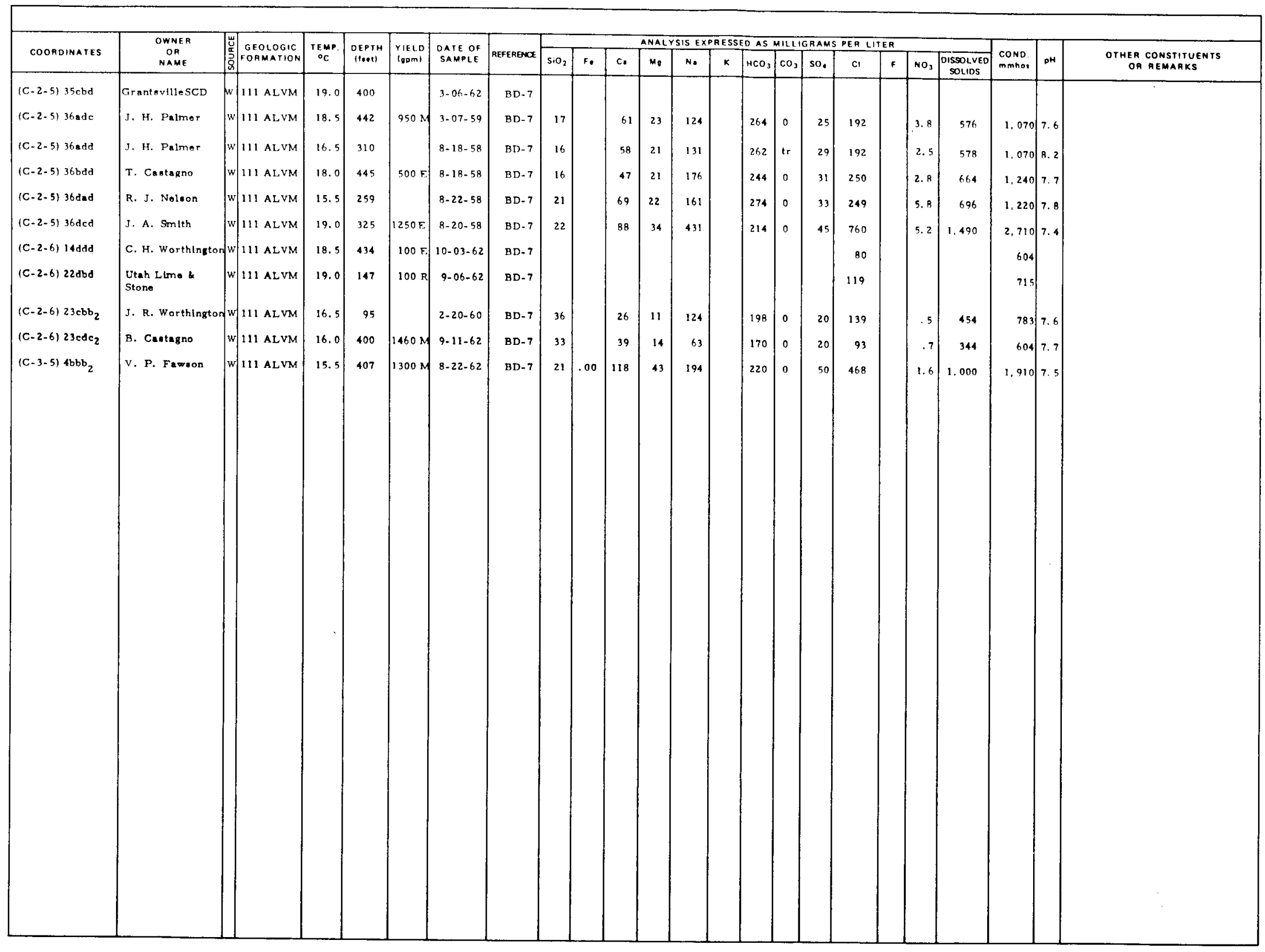


TABLE 38. Tule Valley. Welle and Springs with Water Temperatures of $16^{\circ}$ to $31^{\circ} \mathrm{C}$

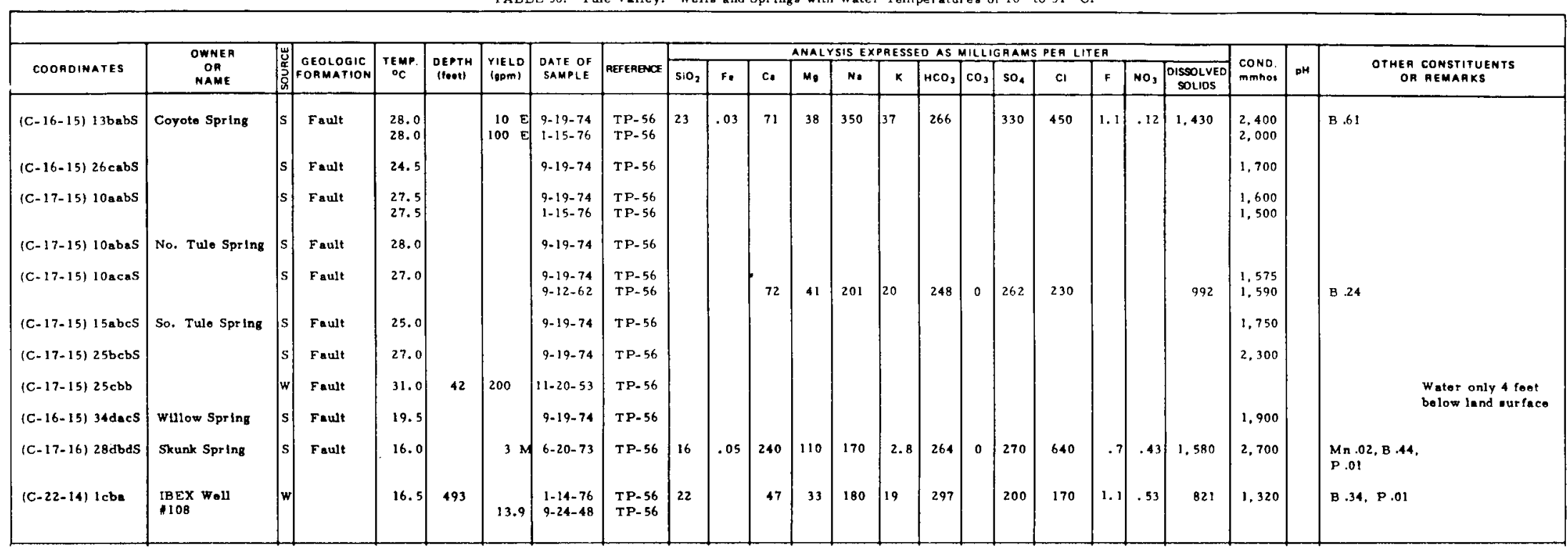

Table 39. Wah Wah Valley. Wells and Springe with Water Temperatures of $15.5^{\circ}$ to $24.5^{\circ} \mathrm{C}$.

\begin{tabular}{|c|c|c|c|c|c|c|c|c|c|c|c|c|c|c|c|c|c|c|c|c|c|c|c|c|c|}
\hline COORDINATES & $\begin{array}{l}\text { OWNEA } \\
\text { OR } \\
\text { NAME }\end{array}$ & \multicolumn{2}{|c|}{\begin{tabular}{|l|l|}
$\mathbf{u}$ & GEOLOOIC \\
$\mathbf{a}$ & FOAMATION \\
\end{tabular}} & $\begin{array}{l}\text { TEMP. } \\
\text { OoC } \\
\end{array}$ & $\begin{array}{l}\text { DEPTH } \\
\text { (1000t) }\end{array}$ & $\begin{array}{l}\text { YIELD } \\
\text { (gpm) } \\
\end{array}$ & $\begin{array}{l}\text { DATE OF } \\
\text { SAMPLE }\end{array}$ & AEFERENCE & $\mathrm{siO}_{2}$ & f. & ANALYSIS EXPAESSEO AS MILLLGRAMS PER LITER & ANALY & $\frac{\text { SISE }}{\text { No }}$ & PESSE & $\mathrm{HCO}_{3}$ & $\begin{array}{ll}M I L L I \\
C O_{3}\end{array}$ & $\begin{array}{l}\text { GRAM } \\
\text { so. }\end{array}$ & $\frac{\mathrm{Cl}}{\mathrm{PEA}}$ & $\begin{array}{ll}E R \\
F\end{array}$ & no, & \begin{tabular}{|l} 
DisSOLVED \\
SOLITS
\end{tabular} & $\begin{array}{l}\text { CONO. } \\
\text { mmnar }\end{array}$ & PH & \multicolumn{2}{|c|}{$\begin{array}{l}\text { OTHER CONSTITUENTS } \\
\text { OA REMARKS }\end{array}$} \\
\hline$(\mathrm{C}-24-13) 34 \mathrm{ccb}$ & $\begin{array}{l}\text { BLM Wah Wah } \\
\text { Woll }\end{array}$ & $\mid \mathrm{w}$ & * & 15.5 & 294 & 30 & $\begin{array}{r}12-17-62 \\
9-25-63\end{array}$ & $\begin{array}{l}\mathrm{TP}-47 \\
\mathrm{TP}-47\end{array}$ & $\begin{array}{l}33 \\
30\end{array}$ & .12 & $\begin{array}{l}77 \\
64\end{array}$ & $\begin{array}{l}29 \\
45\end{array}$ & $\begin{array}{l}366 \\
436\end{array}$ & $\begin{array}{l}15 \\
18\end{array}$ & $\begin{array}{l}160 \\
186\end{array}$ & $\begin{array}{l}0 \\
0\end{array}$ & \begin{tabular}{|l|}
179 \\
205
\end{tabular} & $\begin{array}{l}585 \\
670\end{array}$ & $\begin{array}{l}.5 \\
.4 \\
\end{array}$ & $\begin{array}{l}5.3 \\
4.9\end{array}$ & $\begin{array}{l}1,380 \\
1,600\end{array}$ & $\begin{array}{l}2,380 \\
2,730\end{array}$ & $\begin{array}{r}7.1 \\
7.2\end{array}$ & & - Older Alluvium \\
\hline$(C-28-14) 11$ abb & $\begin{array}{l}\text { Earth Sclonces } \\
\text { Inc. }\end{array}$ & w. & * & 24.5 & 1,472 & & $9.27-73$ & TP-47 & 58 & & 21 & 6.4 & 86 & II & 169 & 0 & 82 & 32 & 1.0 & .85 & 586 & 985 & 7.5 & P. 18, B. 12 & - Older Alluvlum \\
\hline$(C-27-15)_{11 a a d S}$ & $\begin{array}{l}\text { Wah Wah Ranch } \\
\text { No. } 2\end{array}$ & $\mathrm{~s}$ & * & 19.0 & & $10 \mathrm{E}$ & $10-12-72$ & TP-47 & & & & & & & & & & & & & & & & & $\begin{array}{l}\text { * Dlscharge from } \\
\text { tufa depostts }\end{array}$ \\
\hline$(\mathrm{C}-27-15) 11 \mathrm{andS}{ }_{2}$ & $\begin{array}{l}\text { Wah wah Ranch } \\
\text { No. } 3\end{array}$ & $\mathrm{~s}$ & * & 19.0 & & $5 \mathrm{E}$ & $10-12-72$ & TP-47 & & & & & & & & & & & & & & & & & $\begin{array}{l}\text { * Discharge from } \\
\text { tufa deposits }\end{array}$ \\
\hline$(C-27-15) 11 / b_{a s} S_{1}$ & $\begin{array}{l}\text { Wah Wah Rench } \\
\text { No. } 1\end{array}$ & $s$ & $300 \mathrm{PLZC}$ & 19.5 & & $450 \mathrm{E}$ & $\begin{array}{l}9-14-62 \\
5-27-68\end{array}$ & $\begin{array}{l}\mathrm{TP}-47 \\
\mathrm{TP}-47\end{array}$ & $\begin{array}{l}13 \\
13\end{array}$ & & $\begin{array}{l}67 \\
63\end{array}$ & $\begin{array}{l}29 \\
32\end{array}$ & $\begin{array}{l}22 \\
20\end{array}$ & $\begin{array}{l}1.5 \\
1.2\end{array}$ & $\begin{array}{l}316 \\
310\end{array}$ & 0 & \begin{tabular}{|l|}
14 \\
14
\end{tabular} & $\begin{array}{l}37 \\
42\end{array}$ & $\begin{array}{l}.1 \\
.2\end{array}$ & $\begin{array}{l}5.7 \\
6.9\end{array}$ & $\begin{array}{l}340 \\
338\end{array}$ & $\begin{array}{l}624 \\
600\end{array}$ & $\begin{array}{l}7.9 \\
7.8\end{array}$ & $\begin{array}{l}\text { B. } 02 \\
\text { B. } 02\end{array}$ & \\
\hline$(C-27-15) 12 b_{b} s_{1}$ & $\begin{array}{l}\text { Wah wah Ranch } \\
\text { No. } 6\end{array}$ & $s$ & * & 18.0 & & & $10-12-72$ & TP-47 & & & & & & & & & & & & & & & & & $\begin{array}{l}\text { * Dlacharge from } \\
\text { tura dopositte }\end{array}$ \\
\hline$(C-27-15) 12 \mathrm{bbes}_{1}$ & $\begin{array}{l}\text { Wah Wah Ranch } \\
\text { No. } 5\end{array}$ & $\mathrm{~s}$ & * & 18.0 & & $10 \mathrm{E}$ & $10-12-72$ & TP-47 & & & & & & & & & & & & & & & & & $\begin{array}{l}\text { * Dincharge from } \\
\text { tufa depostts }\end{array}$ \\
\hline$(C-27-15) 12 \mathrm{bcds}{ }_{1}$ & $\begin{array}{l}\text { Wah wah Ranch } \\
\text { No. } 4\end{array}$ & $s$ & - & 26.5 & & $20 \mathrm{E}$ & $10-12-72$ & TP-47 & & & & & & & & & & & & & & & & & $\begin{array}{l}\text { "Dlichargo fram } \\
\text { tufa dopostt. }\end{array}$ \\
\hline 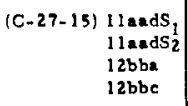 & $\begin{array}{l}\text { Wah wah Ranch } \\
2,3,5 \notin 6\end{array}$ & & & 19.0 & & & $9-14-62$ & TP-47 & 13 & & 60 & 30 & 20 & 1.2 & 298 & 0 & 14 & 36 & .1 & 4.9 & 324 & 592 & 7.9 & B. 02 & $\begin{array}{l}\text { Total Flow wah wah } \\
\text { Springe } 500 \mathrm{gpm} \text { E }\end{array}$ \\
\hline
\end{tabular}


Table 40. Giand Staircase. Springa with Water Temperatures of $15.5^{\circ}$ to $35.5^{\circ} \mathrm{C}$.

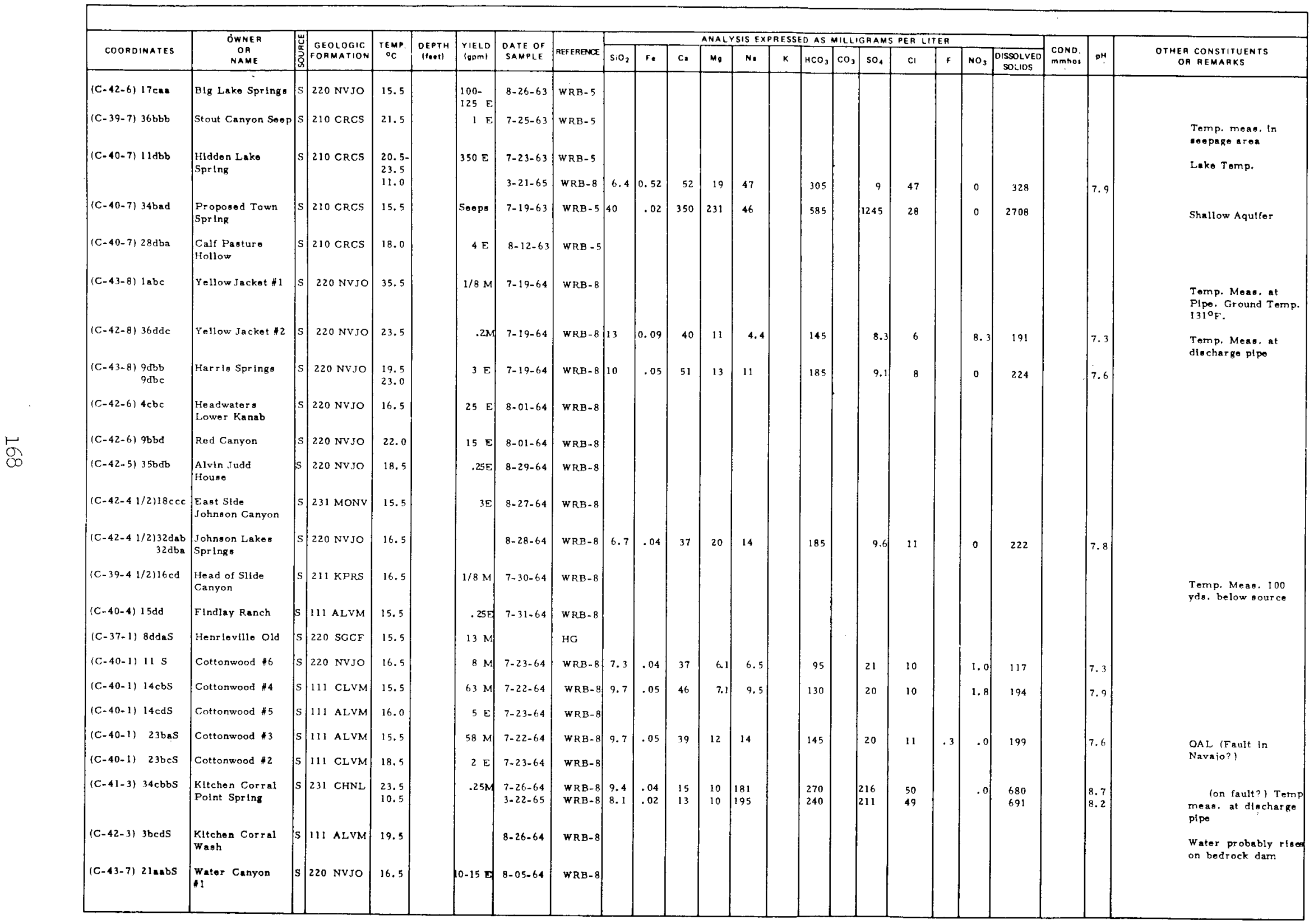


Table 4l. Hansel Valley. Spring and wells with Water Temperatures of $16^{\circ}$ to $18^{\circ} \mathrm{C}$

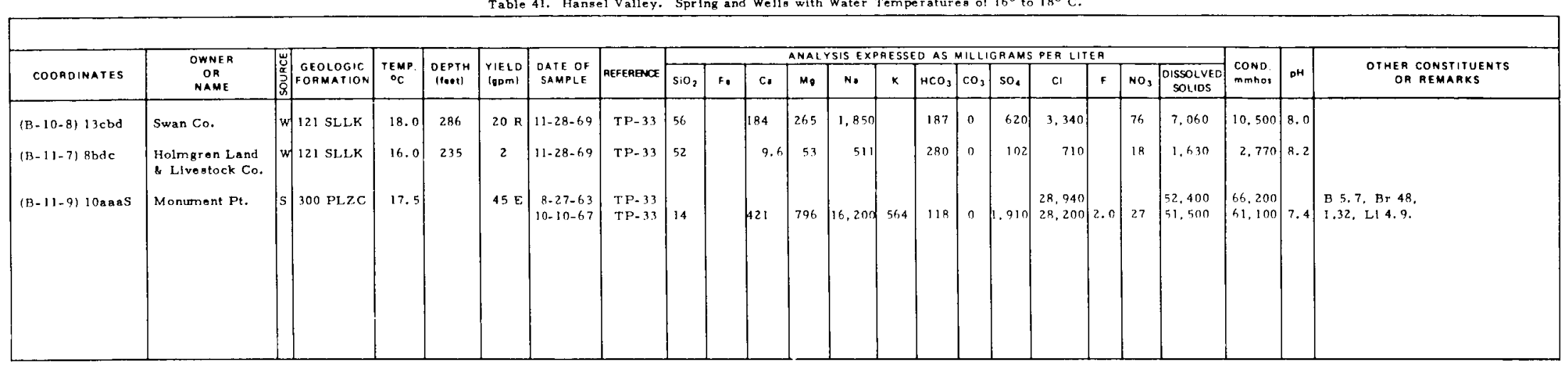

Table 42. Pllot Valley. Well and Springs with Tamporatures of $15.5^{\circ}$ to $16^{\circ} \mathrm{C}$.

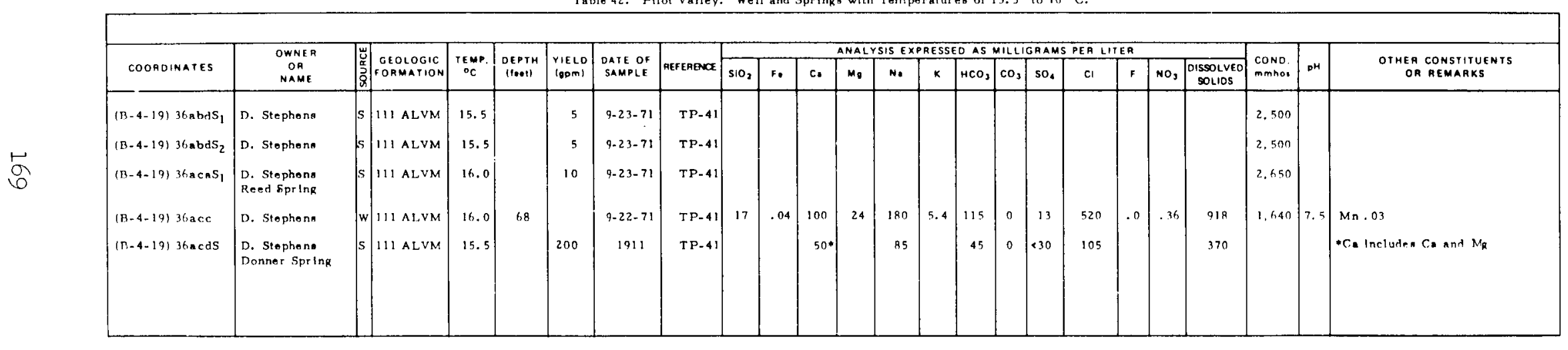

Table 43. Pine Valley. Well with a Water Temperature $o f 16^{\circ} \mathrm{C}$.

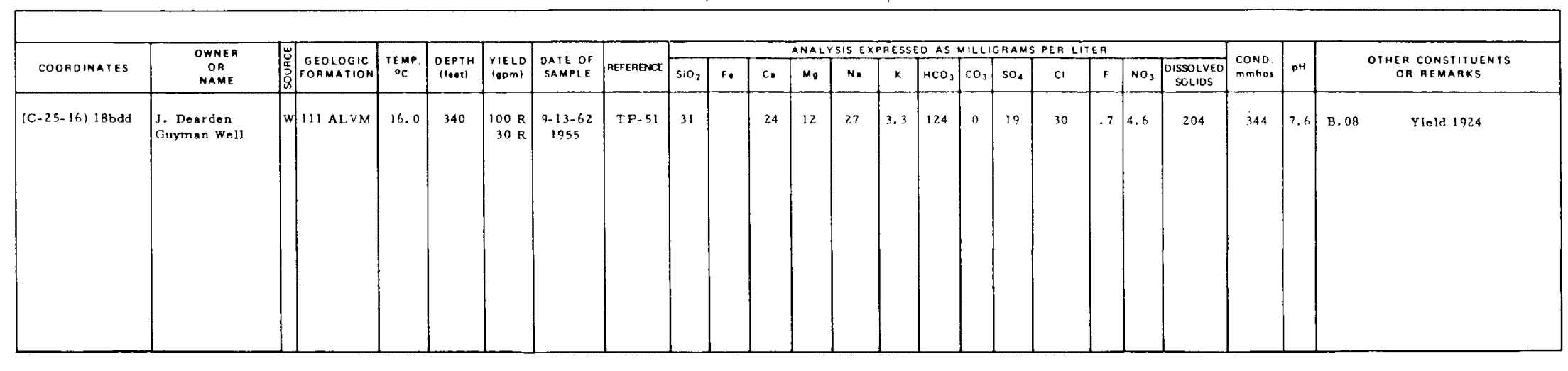


Table 44. Stink Valley. Wells with Water Temperatures of $15^{\circ}$ to $18^{\circ} \mathrm{C}$

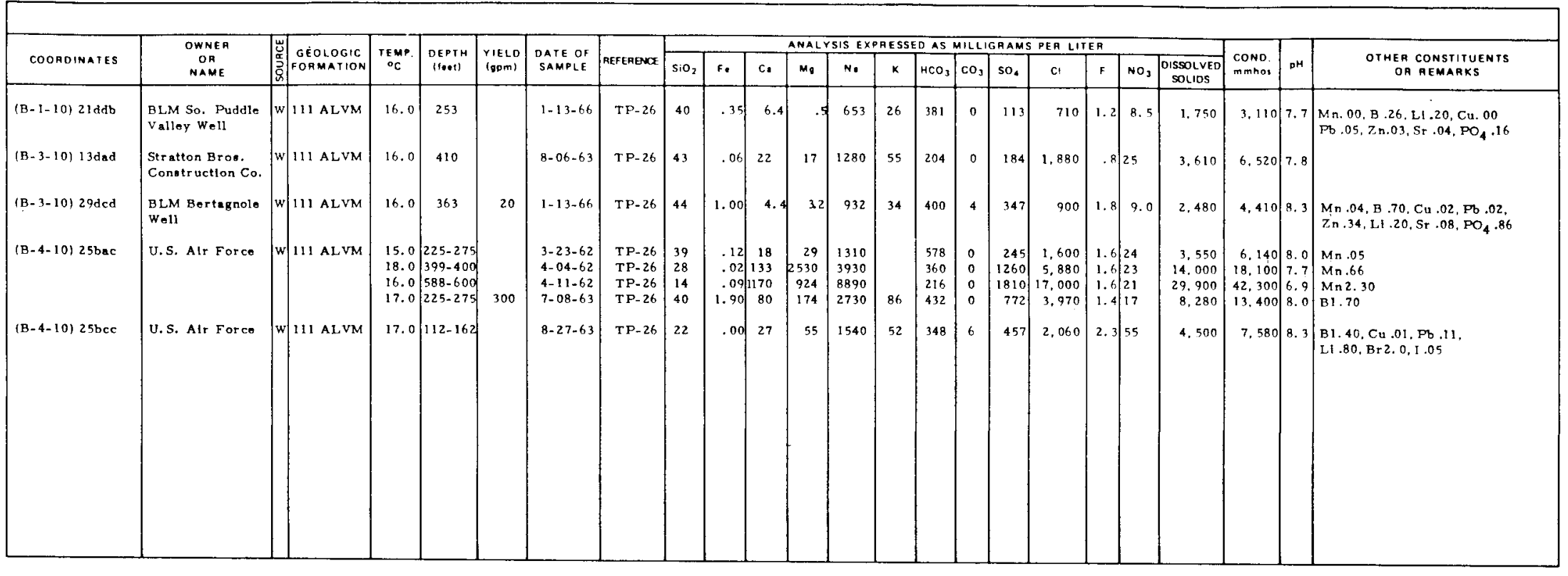

Tab10 45. Yube Dam to Leamington Canyon. Springs in Mills Valley with Temperatures of $16.5^{\circ}$ to $17^{\circ} \mathrm{C}$.

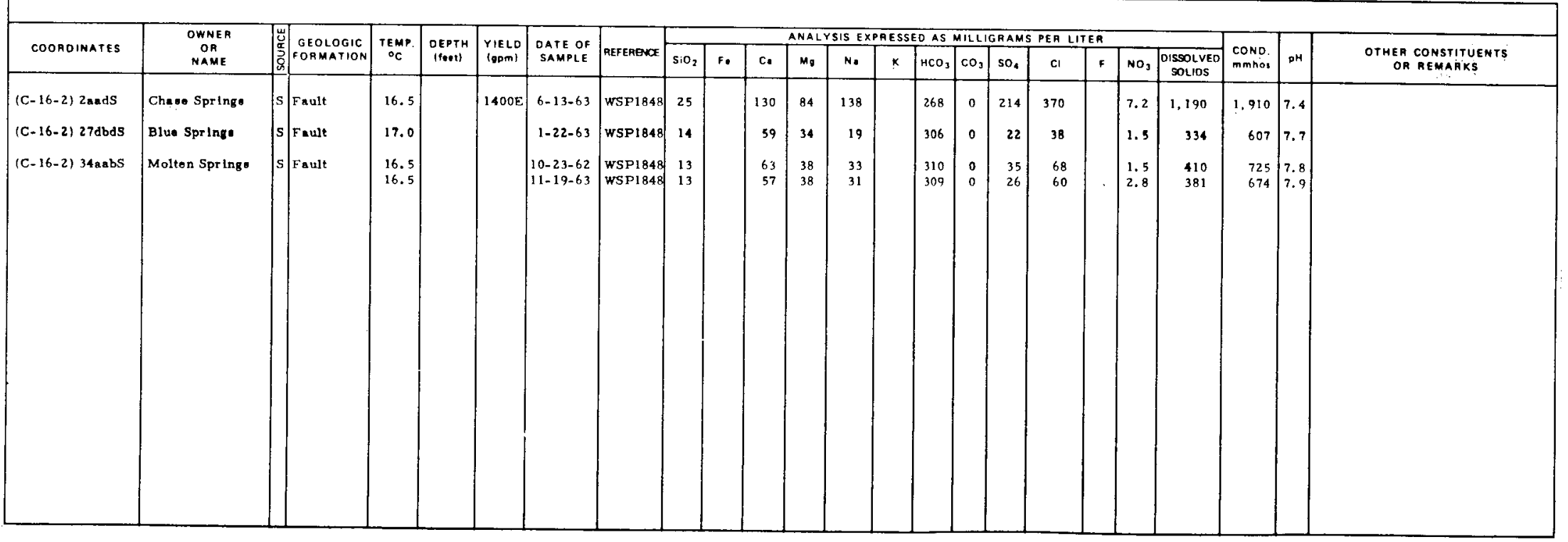


TABLE 46. Records of Castllla, Como, Dlamond Fork, and Patlo thermal springs and of a well in the Great Salt lake Desert.

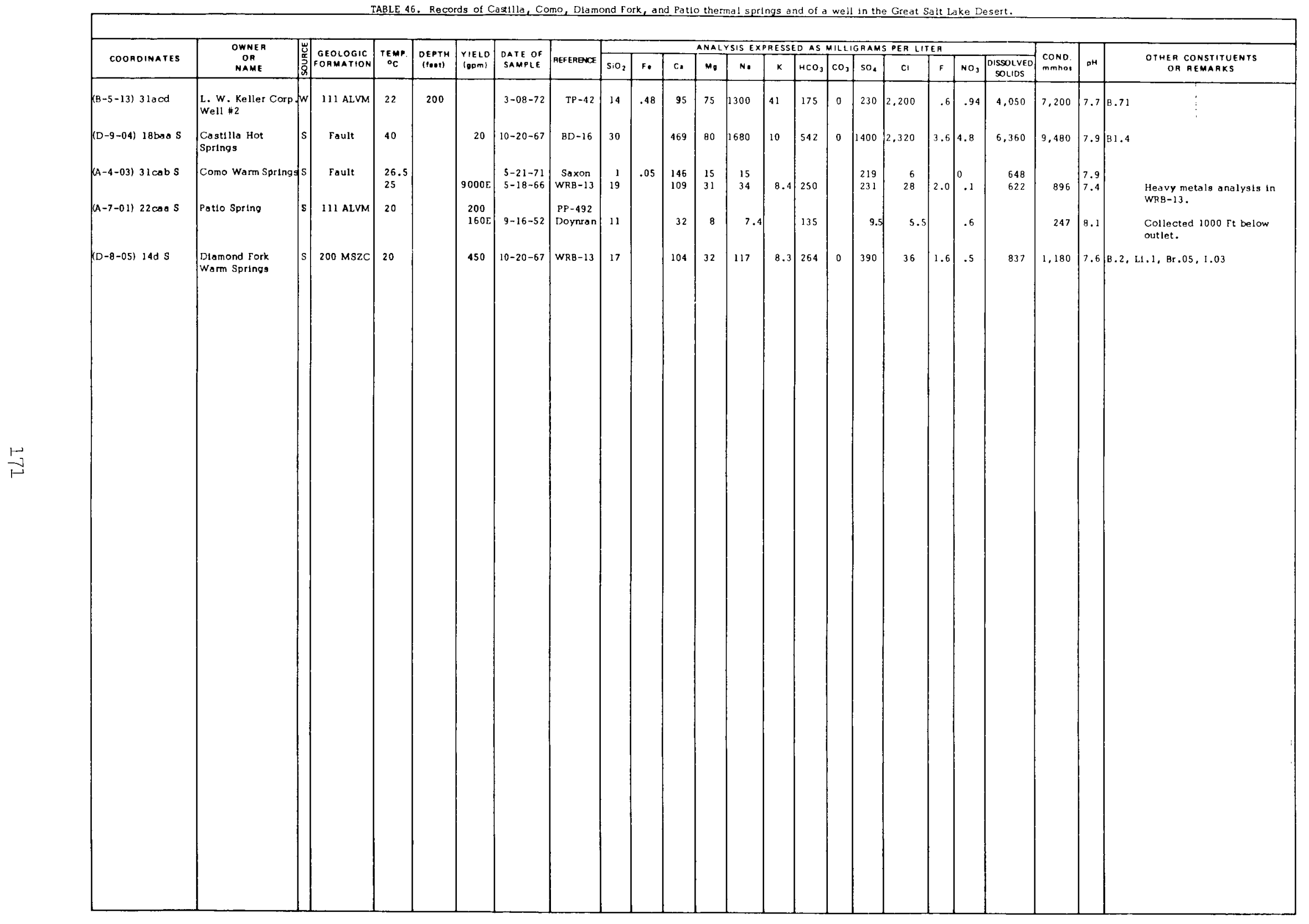




\section{SEIECTED BIBLIOGRAPHY}

This bibliography contains reports on areas covered by the text that have not been cited as well as some general reports on geothermal energy.

Anderson, John J., P.D. Rowley, R.J. Fleck, and A.E.M. Nairn, 1975, Cenozoic geology of southwestern High Plateaus of Utah: Geol. Soc. Amer. Spec. Paper $160,88 \mathrm{p}$.

Beer, L.P., 1967, Ground-water hydrology of southern Cache Valley, Utah: Univ. of Utah PhD Thesis, 203 p.

, 1967, Ground-water hydrology of southern Cache Valley, Utah: Utah State Engineer Inf. Bull. 19.

Boyden, T.A., and F.C. Moulton, 1951, Ground water geology of southern and western Utah Valley: The Compass, v. 29, N. 1, p. 10-20.

Buss, W.R., and N.S. Goeltz, 1974, Bibliography of Utah geology, 1950 to 1970: Utah Geol. and Mineral Survey Bull. 103, 285 p.

Callaghan, Eugene, and R.L. Parker, 1961, Geologic map of the Monroe quadrangle, Utah: U.S. Geol. Survey Geol. Quadrangle Map GQ155.

Carpenter, C.H., G.B. Robinson, Jr., and L.J. Bjorklund, 1964, Selected hydrologic data, upper Sevier River basin, Utah: U.S. Geol. Survey Basic-Data Report N. 8, 29 p.

, 1967, Ground-water conditions and geologic reconnaissance of the upper Sevier River basin, Utah: U.S. Geol. Survey Water-Supply Paper 1836, $91 \mathrm{p}$.

Carpenter, Everett, 1913, Ground water in Boxelder and Tooele Counties, Utah: U.S. Geol. Survey Water-Supply Ppaper 333, 90 p.

Connor, J.G., C.G. Mitchell, and others, 1958, A compilation of chemical quality for ground and surface waters in Utah: Utah State Engineer Tech. Pub. 10, 276 p.

Cook, K.L., and E. Hardman, 1967, Regional gravity survey of the Hurricane fault area and Iron Springs district, Utah: Geol. Soc. America Bul1., v. 78, p. 1063-1076.

Davis, G.H., and L.A. Wood, 1974, Water demands for expanding energy development: U.S. Geol. Survey Circ. 703, 14 p.

Dutcher, L.C., W.F. Hardt, and W.R. Moyle, Jr., 1972, Preliminary appraisal of ground water in storage with reference to geothermal resources in the Imperial Valley, area, California: U.S. Geol. Survey Circ. 649, 57 p. 
Eardley, A.J., 1944, Geology of the north-central Wasatch Mountains, Utah: Geol. Soc. Amer. Bull. v. 55.

Emmons, S.F., 1877, Wahsatch Range in Descriptive Geology: U.S. Geol. Explor. 40th Parallel (King) v. 2, p. 340-392.

Feltis, R.D., and H.D. Goode, 1961, Production and use of fresh water from the Ashley Valley oil field, Uintah County, Utah: in Geological Survey Research 1961, U.S. Geol. Survey Prof. Paper 424-C, p. C90-C93.

Fix, P.E., W.B. Nelson, B.E. Lofgren, and R.G. Butler, 1950, Ground water in the Escalante Valley, Beaver, Iron, and Washington Counties, Utah: Utah State Engineer Tech. Pub. No. 6, $100 \mathrm{p}$.

Gates, J.S., 1962, Geohydrologic evidence of a buried fault in the Erda area, Tooele Valley, Utah: U.S. Geological Survey Research 1962, Prof. Paper 450D, p. D78-D80.

Gilbert, G.K., 1890, Lake Bonneville: U.S. Geol. Survey Mon. 1, 438 p.

Goode, H.D., 1958, The geology and distribution of aquifers in the southeastern part of San Juan County, Utah: U.S. Geol. Survey Open-file Rept. 9 p. 9 figs.

, 1969, Reconnaissance appraisal of the water resources near Escalante, Garfield County, Utah: Utah Geol. and Mineralog. Survey Water-Resources Bul1. 11, $38 \mathrm{p}$.

Hague, Arnold, 1877, Northern Wasatch Region in Descriptive Geology: U.S. Geol. Exploration 40th Parallel (King) v. 2, p. 393-419.

Heylmun, E.B., 1966, Geothermal power potential in Utah: Utah Geol. and Mineralog. Survey Special Studies 14, $18 \mathrm{p}$.

Hintze, L.F., 1973, Geologic history of Utah: Brigham Young Univ. Geol. Studies, v. 20, part 3, $181 \mathrm{p}$.

Hood, J.W., 1976, Characteristics of aquifers in the northern Uinta Basin area, Utah and Colorado: Utah Dept. Nat. Resources Tech. Pub. n. 53, 63 p.

, 1977, Hydrologic evaluation of Ashley Valley, northern Uinta Basin area, Utah: Utah Dept. Nat. Resources Tech. Pub. n. 54, 17 p.

, 1977, Hydrologic evaluation of the upper Duchesne River Valley, Northern Uinta Basin, area, Utah: Utah Dept. Nat. Resources Tech. Pub. n. 57,26 p.

Hood, J.W., and K.M. Waddell, 1969, Hydrologic reconnaissance of Deep Creek Valley, Tooele and Juab Counties, Utah, and Elko and White Pine Counties, Nevada:

Utah Dept. Nat. Resources Tech. Pub. n. 24, 49 p. 
Huddle, J.W., and F.T. McCann, 1947, Pre-Tertiary geology of the Duchesne River area, Wasatch and Duchesne Counties, Utah: U.S. Geol. Survey Oil and Gas Inv. Prelim. Map OM75.

Iorns, W.V., C.H. Hembres, and G.L. Oakland, 1965, Surface-water resources of the San Juan Division: U.S. Geological Survey Prof. Paper 44I-E, p. 299-364.

James, A.H., W.H. Smith, J.E. Welsh, and others, 1971, Surface geology map of the Bingham District, Salt Lake and Tooele Counties, Utah: Kennecott Copper Corp. map.

King, Clarence, 1878, Systematic Geology: U.S. Geol. Explor. 40th Parallel (King) v. $1,803 \mathrm{p}$.

Lee, W.T., Stone, R.W., Gale, H.S., and others, 1915, Guidebook of the western United States, Part B. The overland route with a side trip to Yellowstone Park: U.S. Geol. Survey Bull. 612, 244 p.

Lines, G.C., 1977, Hydrology and surface morphology of the Bonneville Salt Flats and Pilot Valley playa, Utah: U.S. Geol. Survey Open-File Report 78-18, 196 p., 47 figs.

Lipman, P.W., and I. Friedman, 1975, Interaction of meteoric water with magma, an oxygen-isotope study of ash-flow sheets from southern Nevada: Geol. Soc. America Bull., v. 86, p. 695-702.

Lovering, T.S., and H.D. Goode, 1963, Measuring geothermal gradients in drill holes less than 60 feet deep, East Tintic district, Utah: U.S. Geol. Survey Bull. $1172,48 \mathrm{p}$.

Mabey, D.R., M.D. Crittenden Jr., H.T. Morris, R.J. Roberts, and E.W. Tooker, 1964, Aeromagnetic and generalized geologic map of part of north-central Utah: U.S. Geol. Survey Geophysical Investigations Map GP 422.

Moore, W.J., 1973, Preliminary geology map of the western Traverse Mountains and Northern Lake Mountains, Salt Lake and Utah Counties, Utah: U.S. Geol. Survey Misc. Field Studies Map MF-490.

Morey, G.W., R.O. Fournier, and J.J. Rowe, 1962, The solubility of quartz in water in the temperature interval from $25^{\circ}$ to $300^{\circ} \mathrm{C}$ : Geochim, et Cosmochim, Acta, v. 26, p. 1029-1043.

O'Connell, M.F., and R.F. Kaufman, 1976, Radioactivity associated with geothermal waters in the western United States: U.S. Environmental Protection Agency, Las Vega, Nev., Tech. Note ORP/LY-75-8A, 25 p.

Olmstead, F.H. and others, 1975, Preliminary hydrogeologic appraisal of selected hydrothermal systems in northern and central Nevada: U.S. Geol. Survey OpenFile Rept. 75-56, $267 \mathrm{p}$. 
Peterson, D.L., 1974, Bouguer gravity map of part of the northern Lake Bonneville basin, Utah and Idaho: U.S. Geol. Survey Misc. Field Studies Map MF-627.

Peterson, D.L., and S.S. Oriel, 1970, Gravity anomalies in Cache Valley, Cache and Box Elder Counties, Utah, and Bannock and Franklin Counties, Idaho, in Geological Survey Research 1970: U.S. Geol. Survey Prof. Paper 700-C, p. C114-C118.

Peterson, Wm., 1946, Ground water supply in Cache Valley, Utah, available for domestic use and irrigation: Utah State Agr. Coll. Ext. Service N.S. 133, $101 \mathrm{p}$.

Price, Don, and L.L. Miller, 1975, Hydrologic reconnaissance of the southern Uinta Basin, Utah and Colorado: Utah Dept. Nat. Resources Tech. Pub. n. 49, $59 \mathrm{p}$.

Raspet, Rudolph, J.H. Swartz, M.E. Lillard, and E.C. Robertson, 1966, Preparation of thermistor cables used in geothermal investigations: U.S. Geol. Survey Bull. 1203-C, p. Cl-Cll.

Robertson, E.C., Rudolph Raspet, J.H. Swartz, and M.E. Lillard, 1966, Properties of thermistors used in goethermal investigations: U.S. Geol. Survey Bull. 1203-B, p. BI-B34.

Rowley, P.D., J.J. Anderson, and P.L. Williams, 1975, A summary of the Tertiary volcanic stratigraphy of the southwestern high plateaus and adjacent Great Basin, Utah: U.S. Geol. Survey Bull. 1405-B, p. B1-B20.

Stewart, J.H., 1977, East-west patterns of Cenozoic igneous rocks, aeromagnetic anomalies, and mineral deposits, Nevada and Utah: Geol. Soc. America Bull., v. 88, p. $67-77$.

Sumsion, C.T., 1971, Geology and water resources of the Spanish Valley area, Grand and San Juan Counties, Utah: Utah Dept. Nat. Resources Tech. Pub. n. $32,40 \mathrm{p}$.

Swanberg, C.A., 1974, The application of the Na-K-Ca geothermometer to thermal areas of Utah and the Imperial Valley, California: Geothermics, v. 3, n.2, p. 53-59.

Tanner, A.B., 1966, Natural radio-activity of ground water in Feth, J.H., D.A. Barker, and others, Lake Bonnevil],e: Geology and hydrology of the Weber Delta district, including Ogden, Utah: U.S. Geol. Survey Prof. Paper 518, p. 63-66.

Thomas, H.E., and W.B. Nelson, 1948, Ground water in the East Shore area, Utah: Part I, Bountiful district, Davis County: Utah State Engineer Tech. Pub. no. $5,152 \mathrm{p}$.

Thomas, H.E., W.B. Nelson, B.E. Lofgren, and R.G. Butler, 1952, Status of development of selected ground-water basins in Utah: Utah State Engineer Tech. Pub. n. 7, 96 p. 
Thomas, H.E., and G.H. Taylor, 1946, Geology and ground-water resources of Cedar City and Parowan Valleys, Iron County, Utah: U.S. Geol. Survey Water-Supply Paper 993; 210 p.

Truesde11, A.H., and R.0. Fournier, 1977, Procedure for estimating the temperature of a hot-water component in a mixed water by using a plot of dissolved silica versus enthalpy: U.S. Geol. Survey Jour. Research, v. 5, n.1, p. 49-52.

Waite, H.A., W.B. Nelson, B.E. Lofgren, R.L. Barnell, R.G. Butler, and J.H. Feth, 1954, Progress report on selected ground-water basins in Utah: Utah State Engineer Tech. Pub. n. 9, $128 \mathrm{p}$.

White, D.E., 1957a, Thermal waters of volcanic origian: Geol. Soc. America Bull. v. 68 , p. $1637-1658$.

- 1957b, Magmatic, connate, and metamorphic waters: Geol. Soc. America Bull. v. 68, p. 1659-1682.

White, D.E., and W.W. Brannock, 1950, The sources of heat and water supply of thermal springs, with particular reference to Steamboat Springs, Nevada: Am. Geophys. Union Trans., v. 31, p. 566-574.

White, D.E., W.W. Brannock, and K.J. Murata, 1956, Silica in hot spring waters: Geochim, et Cosmochim. Acta, v. 10, p. 27-59.

White, D.E., and D.L. Williams, [editors], 1975, Assessment of geothermal resources of the United States - 1975: U.S. Geol. Survey Circ. 726, $155 \mathrm{p}$.

Williams, J.S., 1962, Lake Bonneville: Geology of southern Cache Valley, Utah: U.S. Geol. Survey Prof. Paper 257-C, p. 131-152.

Young, R.A., and C.H. Carpenter, 1965, Ground-water conditions and storage in the central Sevier Valley, Utah: U.S. Geol. Survey Water Supply Paper 1787, 95 p.

Zietz, Isidore, Ralph Shuey, and J.R. Kirby Jr., 1976, Aeromagnetic map of Utah: U.S. Geol. Survey Geophys. Invest. Map GP-907. 
DISTRIBUTION RECORD FOR DOE/ET/28393-7

\section{Internal Distribution}

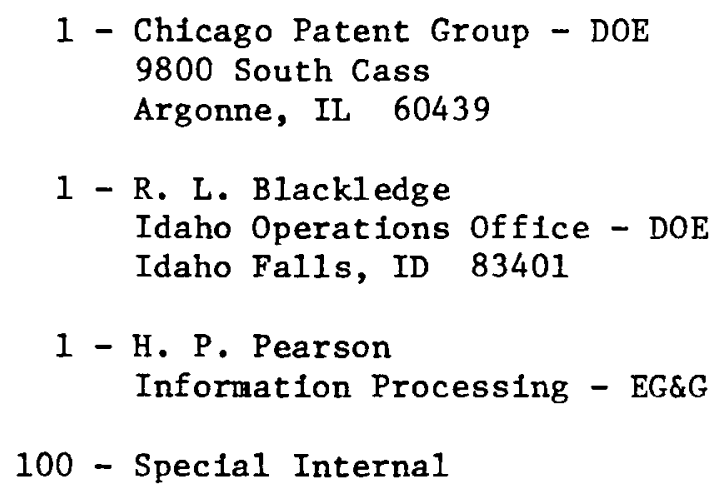

External Distribution

2 - Technical Information Center - DOE Box 62

Oak Ridge, TN 37830

Total Copies Printed: 105 